LUIZ CARLOS DE ANDRADE JÚNIOR

\title{
A SIMULAÇÃO NO CÓDIGO CIVIL
}

Tese de Doutorado

Orientador: Custódio da Piedade Ubaldino Miranda

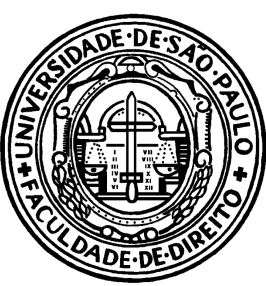

UNIVERSIDADE DE SÃO PAULO

FACULDADE DE DIREITO

São Paulo - 2014 
LUIZ CARLOS DE ANDRADE JÚNIOR

\section{A SIMULAÇÃO NO CÓDIGO CIVIL}

Tese apresentada como requisito para habilitação ao título de Doutor em Direito, sob a orientação do Professor Associado Custódio DA PIEDAdE UBALDINO MirANDA, na subárea de Direito Civil, integrada ao Departamento de Direito Civil da Faculdade de Direito da Universidade de São Paulo.

\section{UNIVERSIDADE DE SÃO PAULO}

\section{FACULDADE DE DIREITO}

São Paulo - 2014 
À Natalia, com amor e gratidão. 


\section{RESUMO}

A simulação encontra-se disciplinada no artigo 167 do Código Civil. Trata-se de um instituto milenar, cuja compreensão desafiou gerações de autores e até hoje oferece grandes dificuldades ao jurista. No decorrer do século XX, assistiu-se à ascendência e à decadência de diversas teses relativas à configuração do fenômeno simulatório. As teses voluntaristas, declaracionistas e causalistas duelaram por décadas, sem abrirem qualquer espaço para a formação de um consenso. A doutrina contemporânea, preocupada com a superação do apriorismo conceitual que reduziu a dogmática da simulação a mero reflexo da teoria geral do negócio jurídico, procurou descrever o negócio simulado como uma manifestação de autonomia privada. Esta concepção desloca a exegese do artigo 167 do Código Civil para um plano banhado por novas luzes. O negócio não se torna simulado porque é deficiente; não lhe falta vontade, nem válida declaração e muito menos causa. $\mathrm{O}$ que dá origem à simulação é a vontade que o anima e a função que desempenha: a criação da ilusão negocial. Cumpre diferenciar a aparência que os simuladores criam (o "negócio aparente"), do negócio simulado, que dela se reveste. A apreensão da essência da simulação pressupõe a assimilação do mecanismo próprio da ilusão negocial. Os simuladores criam determinados índices de significação que, confrontados "a olho nu", justificam a formação de uma incorreta convicção sobre a natureza ou a titularidade subjetiva da relação jurídica. Quando, contudo, os índices que se mostram aos olhos dos terceiros são contrapostos a outros, deliberadamente ocultados pelos simuladores, aqueles passam a ostentar um sentido diferente. A inverdade do negócio simulado decorre da incongruência de dois juízos formulados, respectivamente, pelos simuladores - que conhecem todo o quadro negocial - e pela comunidade - que somente pode ver uma parcela do agir dos contraentes. Bem se entende, assim, que o legislador considera nulo o negócio simulado não por conta de um defeito estrutural - do qual não é lícito cogitar -, mas em virtude de uma incompatibilidade - não natural, pois que afirmativamente decretada pela norma - entre todo o comportamento dos simuladores e as diretrizes que informam a ordem jurídico-normativa vigente. Nesse cenário, várias e complexas questões surgem, relacionadas aos limites da simulação, aos desdobramentos da declaração de nulidade do negócio simulado, à eventual validade do negócio dissimulado, à proteção dos interesses de terceiros de boa-fé etc. $\mathrm{O}$ exame destes temas, além de levar em consideração uma precisa descrição do fenômeno simulatório, não pode dar-se ao largo da orientação metodológica que inspira o Código Civil, e, consequentemente, o artigo 167. No limiar do século XXI, o artigo 167 assume o papel de mediador de conflitos e apaziguador de tensões intersubjetivas. O dever de uma doutrina inspirada pela jurisprudência de valoração, mais que conceber cânones fundados na lógica formal, é o de identificar soluções que dialoguem com a concretude da vida de relação e, desse modo, permitam aflorar os juízos de valor sobre os quais o legislador fez repousar a sua obra.

Palavras-chave: negócio jurídico, autonomia privada, simulação, dissimulação, acordo simulatório, aparência, ilusão negocial, interposição de pessoa, nulidade. 


\section{RIASSUNTO}

La simulazione è disciplinata dall'articolo 167 del Codice Civile. Si tratta di un istituto millenario, la cui comprensione ha sfidato generazioni di autori e fino ad oggi crea grandi difficoltà per il giurista. Lungo il secolo XX, si è assistito all'ascendenza e alla decadenza di diverse tesi riguardanti la configurazione del fenomeno simulatorio. Le teorie della volontà, della dichiarazione e della causa hanno combattuto durante decenni, senza cedere spazio per la formazione di un consenso. La dottrina contemporanea, preoccupata con il superamento dell'apriorismo concettuale che ha ridotto la dogmatica della simulazione ad un semplice riflesso della teoria generale del negozio giuridico, ha cercato di descrivere l'operazione simulata come una manifestazione di autonomia privata. Questa concezione orienta l'esegesi dell'articolo 167 del Codice Civile verso un piano bagnato da nuove luci. L'operazione non diventa simulata perché è deficiente; non gli manca volontà, né valida dichiarazione e molto meno causa. Il che dà origine alla simulazione è la volontà che la ravviva e la funzione che disimpegna: la creazione dell'illusione negoziale. È il nostro obbligo differenziare l'apparenza che i simulatori creano (il negozio apparente), dal negozio simulato, che si riveste di quella apparenza. L'apprensione dell'essenza della simulazione presuppone l'assimilazione del meccanismo stesso dell'illusione negoziale. I simulatori creano determinati indici di significazione che, confrontati "a occhio nudo", giustificano la formazione di un'incorretta convinzione riguardo alla natura o titolarità soggettiva della relazione giuridica. Quando, tuttavia, gli indice che si presentano agli occhi di terzi sono contrapposti ad altri, deliberatamente occultati dai simulatori, quelli passano ad ostentare un senso diverso. La falsità dell'atto simulato deriva dall'incongruità di due giudizi formulati, rispettivamente, dai simulatori - che conoscono tutto il quadro del negozio giuridico - e dalla comunità - che può solo vedere una particella dell'agire dei contraenti. Rimane ben inteso, così, che il legislatore ritiene nullo il negozio simulato non a causa di un difetto strutturale - su cui non è licito cogitare -, ma in virtù di un'incompatibilità - non naturale, giacché affermativamente decretata dalla norma - fra tutto il comportamento dei simulatori e le direttive che informano l'ordine giuridiconormativa vigente. In questo scenario, diverse e complesse questioni appaiono, legate ai limiti della simulazione, agli sdoppiamenti della dichiarazione di nullità dell'atto simulato, all'eventuale validità dell'atto dissimulato, alla protezione degli interessi di terzi di buona fede, ecc. L'esame di questi temi, oltre a prendere in considerazione una precisa descrizione del fenomeno simulatorio, non può svolgersi che alla luce dell'orientamento metodologico che ispira il Codice Civile, e, conseguentemente, l'articolo 167. Alla soglia del secolo XXI, l'articolo 167 assume il ruolo di mediatore di conflitti e pacificatore di tensioni intersoggettive. Il dovere di una dottrina ispirata dalla giurisprudenza dei valori, più che concepire canoni fondati sulla logica formale, è quello di identificare soluzioni che dialogano con la concrezione della vita di relazione e, in questo modo, consentono di affiorare i criteri sui quali il legislatore ha fatto la sua opera riposare.

Parole-chiave: negozio giuridico, autonomia privata, simulazione, dissimulazione, accordo simulatorio, apparenza, illusione negoziale, interposizione di persona, nullità. 


\section{RÉSUMÉ}

La simulation est disciplinée dans l'article 167 du Code Civil. Il s'agit d'un institut millénaire, dont la compréhension a défié des générations d'auteurs et qui procure jusqu'à aujourd'hui de grandes difficultés au juriste. Tout au long du $20^{\text {ème }}$ siècle, on a assisté à l'ascendance et décadence de plusieurs thèses concernant la configuration du phénomène simulatoire. Les thèses de la volonté, de la déclaration et de la cause se sont combattues durant des décennies, sans céder d'espace pour la formation d'un consensus. La doctrine contemporaine, se souciant de la maîtrise de l'apriorisme conceptuel qui a réduit la dogmatique de la simulation à un simple reflexe de la théorie générale de l'acte juridique, a cherché de décrire l'acte simulé comme étant une manifestation d'autonomie privée. Cette conception oriente l'exégèse de l'article 167 du Code Civil vers un plan inondé de nouvelles lumières. L'acte ne devient pas un acte simulé parce qu'il est déficient; il ne lui manque ni volonté, ni déclaration valide et bien moins cause. Ce qui mène à la simulation c'est la volonté qui l'anime et la fonction qu'il exerce: la création de l'illusion de l'acte. Il est de notre devoir de ne pas confondre l'apparence que les simulateurs créent (l'acte apparent), de l'acte simulé. L'appréhension de l'essence de la simulation présuppose l'assimilation du propre mécanisme de l'illusion de l'acte. Les simulateurs créent des indices déterminés de signification lesquels, confrontés "à l'œil nu", justifient la formation d'une conviction incorrecte sur la nature ou la propriété subjective de la relation juridique. Quand ils sont, toutefois, contrastés à d'autres indices, délibérément occultés par les simulateurs, ceux qui se présentent aux regards des tiers passent à arborer un sens différent. La contre-vérité de l'acte simulé découle de l'incongruité de deux décisions formulées, respectivement, par les simulateurs - qui connaissent tout le cadre de l'acte - et par la communauté - qui ne peut voir qu'une parcelle de l'action des contractants. Il est bien entendu, ainsi, que le législateur considère nul l'acte simulé, non au titre d'un défaut structurel - sur lequel il n'est pas licite de cogiter -, mais en vertu d'une incompatibilité non naturelle, vu que décrétée affirmativement par la norme - entre tout le comportement des simulateurs et les directives qui informent l'ordre juridique-normative en vigueur. Dans ce décor, surgissent plusieurs questions complexes, rattachées aux limites de la simulation, aux dédoublements de la déclaration de nullité de l'acte simulé, à l'éventuelle validité de l'acte dissimulé, à la protection des intérêts de tiers de bonne foi, etc. L'examen de ces thèmes, en plus de prendre en considération une description précise du phénomène simulatoire, ne peuvent pas ignorer l'orientation méthodologique qui inspire le Code Civil, et, en conséquence, l'article 167. À l'aube du $21^{\text {ème }}$ siècle, l'article 167 assume le rôle de médiateur de conflits et conciliateur de tensions intersubjectives. Le devoir d'une doctrine inspirée de la jurisprudence de l'évaluation, plus que concevoir des canons fondés sur la logique formelle, est celui d'identifier des solutions qui dialoguent avec la concrétion de la vie de relation et, de cette façon, permettent d'affleurer les critères sur lesquels le législateur fait reposer son œuvre.

Mots-clés: acte juridique, autonomie privée, simulation, dissimulation, accord simulatoire, apparence, illusion de l'acte, interposition de personne, nullité. 


\section{AGRADECIMENTOS}

Este trabalho não é obra apenas de seu autor. Não fosse pelas valiosas contribuições que diversas pessoas ofertaram no decorrer de sua elaboração, ele jamais teria sido concluído. É, pois, o momento de agradecer aos que, de alguma maneira, colaboraram com o sucesso desta empreitada.

Agradeço aos meus pais, Luiz Carlos e Conceição, por, amorosamente e energicamente, determinarem minha formação pessoal e tornarem possível minha formação acadêmica. Obrigado por existirem em minha vida e por serem a razão de tudo para mim.

Agradeço à minha esposa, Natalia, pelo apoio incondicional e pela inabalável paciência nestes anos em que me tornei ausente e distraído quanto a tudo que não tivesse a ver com este trabalho. Obrigado por ser meu porto seguro, minha fonte de inspiração, minha constante motivação.

Agradeço à Velha, mas Sempre Nova Academia, por me acolher tão ternamente desde a graduação e me fazer experimentar as benesses e as agruras de ser um dos seus. Obrigado por permitir que eu repousasse sob suas Arcadas e ali colhesse a essência do mais importante fundamento do direito: a convivência.

Agradeço ao Professor Custódio da Piedade Ubaldino Miranda por ter sido meu mentor durante toda a jornada que conduziu à conclusão do meu estudo sobre a simulação. Obrigado pela confiança, pelo amparo, pela orientação precisa e esclarecedora, e, sobretudo, por ter-me dado a honra de elaborar, sob a sua orientação, um estudo sobre o tema que, há mais de 30 anos, tem como referência uma obra sua.

Agradeço aos Professores Heleno Taveira Tôrres e Alcides Tomasetti Júnior pelas importantes críticas e sugestões apresentadas durante o exame de qualificação a que me submeti durante a elaboração do presente trabalho. Suas contribuições foram essenciais para o melhor desenvolvimento da árdua pesquisa que me dispus a realizar. 
Agradeço aos colegas do Koury Lopes Advogados, especialmente a Henrique Lopes e Victor Polizelli, pela compreensão e pelo apoio, sem os quais, não tenho dúvidas, jamais teria concluído o presente trabalho.

Agradeço a Alex Barreto e Claudia Brito Marzagão pelo importante estímulo e pelas ideias que me ajudaram a tornar este trabalho mais completo.

Agradeço a todos que me ajudaram a tentar atingir o objetivo de me tornar doutor em direito, e que, por imperdoável injustiça de minha parte, não tiveram seus nomes expressamente mencionados nestas breves linhas.

Agradeço, enfim, a Deus, por ter querido que tudo fosse como foi. 


\section{ÍNDICE GERAL}

\section{INTRODUÇÃO}

1. Escopo do presente estudo 11

2. Orientação metodológica 13

3. Plano de trabalho 16

CAPÍtULO I - A SIMULAÇÃO

§ 1. A tradição doutrinária $r$

$\begin{array}{lr}\text { 4. A tese voluntarista } & 20\end{array}$

$\begin{array}{ll}\text { 5. A tese declaracionista } & 25\end{array}$

6. A tese causalista $r$

§ 2. A simulação no quadro da autonomia privada $\quad 35$

7. O problema da definição legal de simulação 35

8. Esclarecimento terminológico $\quad 44$

9. O caráter instrumental do negócio simulado 45

10. A perfeição estrutural do negócio simulado $\quad 53$

11. A simulação e a função social do contrato $r$

$\begin{array}{ll}\text { § 3. O acordo simulatório } & \mathbf{7 6}\end{array}$

$\begin{array}{ll}\text { 12. Simulação e reserva mental } & 78\end{array}$

13. A natureza e a autonomia do acordo simulatório 85

$\begin{array}{ll}\text { § 4. A ilusão negocial } & 91\end{array}$

14. Uma releitura da tese declaracionista 92

15. O ponto de relevância hermenêutica do negócio simulado 97

16. A dupla valoração do negócio simulado 103

17. A composição da ilusão negocial $r$

$\begin{array}{ll}\text { §. As fronteiras sistemáticas da simulação } & 118\end{array}$

18. Falsidade 119

$\begin{array}{lr}\text { 19. Falsa qualificação } & 123\end{array}$

\begin{tabular}{lr}
20. & Fraude à lei \\
\hline & 130
\end{tabular}

21. Abuso de direito 138

22. Negócio indireto e negócio fiduciário 141

CAPÍTULO II - AS MANIFESTAÇÕES DA SIMULAÇÃOO 146

§ 6. As classes de simulação $\quad 146$

23. Absoluta e relativa $r$

\begin{tabular}{ll}
24. & Inocente e nocente \\
\hline
\end{tabular}

25. Total e parcial $\quad 147$

$\begin{array}{lr}\text { § 7. As hipóteses típicas de simulação } & 150\end{array}$

26. O negócio simulado como tipo $r$

27. Simulação subjetiva 157

28. Declaração, confissão, condição ou cláusula não verdadeira 167

\begin{tabular}{lr}
29. & Antedata e pós-data \\
\hline
\end{tabular}

§ 8. Os limites da simulação $r$

30. A “disponibilidade dos efeitos" e a "forma interna" 173

$\begin{array}{ll}31 . & \text { Atos formais } \\ 32.777\end{array}$

32. Títulos de crédito 178

33. Atos não negociais $r$

34. Negócios unilaterais 186

35. Sociedade: o debate em torno da simulabilidade 195 
36. Sociedade: simulação e desconsideração 201

37. Atos familiares 214

CAPÍTULO III - O REGIME JURÍDICO DA SIMULAÇÃO 216

§ 9. A nulidade do negócio simulado $r$

38. A existência do negócio simulado 216

39. A nulidade especial prevista no artigo 167

40. Os desdobramentos da nulidade do negócio simulado 230

41. A nulidade parcial do negócio simulado 234

§ 10. A legitimidade para alegar a nulidade do negócio simulado $\quad 234$

42. O debate sob a vigência do Código Civil de 1916

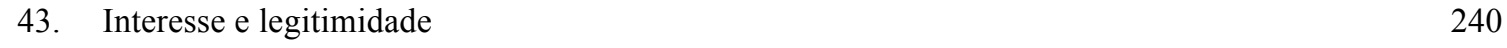

44. O interesse dos simuladores $\quad 245$

45. O interesse dos terceiros 246

46. Declaração ex officio $r$

§ 11. Prescrição e decadência $r$

47. A inaplicabilidade da regra de decadência 253

48. O regime excepcional do artigo $48 \quad 255$

49. Prescrição e decadência quanto ao negócio dissimulado 256

$\begin{array}{ll}\S \text { 12. A validade do negócio dissimulado } & 257\end{array}$

$\begin{array}{ll}\text { 50. A unidade da simulação relativa } & 258\end{array}$

51. A extraversão do negócio dissimulado 264

§ 13. Os direitos de terceiros de boa-fé $\quad 276$

52. A condição de terceiro 276

53. As bases dogmáticas da tutela aos direitos de terceiros de boa-fé 278

54. O requisito da boa-fé 286

55. Os direitos assegurados aos terceiros de boa-fé 288

$\begin{array}{ll}\text { 56. Conflitos entre terceiros de boa-fé? } & 291\end{array}$

CONCLUSÕES $\quad 294$

REFERÊNCIAS $\quad 299$ 


\title{
INTRODUÇÃO*
}

\author{
El gran Rey calla y suspira, \\ y dice: - Acabemos ya; \\ la belleza sólo está \\ en los ojos de quien mira.
}

(Don Ramón de Campoamor, Creencias)

Relembre-se da Condition Humaine de Magritte. Um quadro retrata outro quadro que jaz em frente a uma janela; no quadro retratado, uma paisagem contendo uma árvore. O único sujeito capaz de afirmar se a árvore retratada no quadro em frente à janela existe é o seu autor; nem o próprio Magritte saberia responder esta pergunta. $\mathrm{O}$ artista imaginário tem uma visão privilegiada, que o permite interpretar a realidade e a pintura diante de si de modo a precisar com exatidão a correspondência entre ambos. Já Magritte, assim como o público em geral, encontra-se aprisionado a um ângulo visual que revela uma única realidade: a de um quadro diante de uma janela.

O que é o negócio jurídico, senão um quadro, pintado a tantas mãos quantas sejam as das partes, contendo o desenho de uma ideia? O negócio jurídico, enquanto expressão de um dever-ser, representa a si próprio. O seu referencial existencial não jaz fora da tela; materializa-se na riqueza de suas cores.

\footnotetext{
* Nas notas de rodapé inseridas neste trabalho, quando uma obra for citada mais de uma vez, a primeira ocorrência conterá a sua referência completa; as seguintes, por seu turno, conterão menção ao nome do autor, com a indicação do local em que foram citadas pela primeira vez. Em geral, a menção a nomes de juristas realizada no corpo do texto consistirá da apresentação apenas dos sobrenomes; nas notas de rodapé, além dos sobrenomes, em maiúsculas pequenas (versaletes), serão apresentados os prenomes abreviados. Excepcionalmente, no caso da citação de juristas brasileiros, referir-se-á ao prenome por extenso, sempre que assim forem eles conhecidos na comunidade científico-jurídica.

No decorrer do texto e das notas de rodapé, as referências a dispositivos do Código Civil serão realizadas apenas com a menção ao número do artigo e suas subdivisões, se houver. Remissões a dispositivos de outros diplomas dar-se-ão com a identificação da norma a que pertencem.

A respeito das principais diretrizes metodológicas adotadas para a elaboração deste trabalho, v. E. C. Silveira MArchi, Guia de Metodologia Jurídica - Teses, Monografias, e Artigos, 2a ed., São Paulo, Saraiva, 2009, passim. Note-se, porém, que, atendendo às recomendações do próprio autor, algumas regras dispostas em sua obra foram adaptadas, para adequar o presente trabalho aos padrões seguidos pela maioria dos textos consultados, sobretudo, de origem brasileira, portuguesa, italiana e francesa.
} 
Todo aquele que observa um negócio jurídico fá-lo como quem aprecia a obra de Magritte; visualiza uma realidade tal qual a retratada pelo quadro em frente à janela, que somente pode ser apreendida nos limites da moldura que a cerca. Seria inútil buscar comparar a imagem criada pelos contraentes com o mundo por detrás da tela. A ideia que ela representa pertence apenas ao plano do direito; uma dimensão que se capta somente através dos inúmeros quadros que a representam.

De nada adiantaria ao observador, portanto, indagar se o artista imaginário teria "querido" produzir o quadro empostado diante da janela. Tal indagação em nada esclareceria a relação entre a pintura dentro da pintura e o mundo a sua volta. A árvore retratada na composição caprichosamente repousada sobre o cavalete é o que parece ser, embora não necessariamente seja uma representação fiel da realidade. A questão sobre a realidade ou irrealidade da obra do artista imaginário não tem, portanto, nada que ver com a vontade deste.

Dir-se-ia, então, que o quadro colocado em frente à janela não desempenharia a sua função. Seria correto dizê-lo? Para que serve um quadro, senão para retratar algo que se confunde consigo próprio? A fidelidade entre a ideia estampada na tela e o seu modelo, à evidência, não é determinada pela funcionalidade do quadro, que, a todo momento, limita-se a transmitir uma mensagem. Se esta é verdadeira ou falsa é um problema que tem que ver com a qualidade da mensagem, não com a utilidade do quadro.

Poder-se-ia, enfim, dizer que o trabalho do artista imaginário desnaturaria ou neutralizaria a realidade. Mas, haveria sentido em tal conjectura? Se, por detrás daquela pintura, existisse uma árvore, ela continuaria sendo a mesma coisa, independentemente do quadro colocado à frente da janela. Do mesmo modo, se não existisse árvore alguma, isto já não resultaria do fato de um tal objeto ter sido representado em uma composição artística, mas de outras razões, absolutamente alheias à atuação do artista imaginário, como, por exemplo, a circunstância de aquela jamais ter sido plantada.

A simulação submete, ao jurista, questões semelhantes às acima referidas. Os particulares, assim como Magritte, projetam-se como artistas imaginários, e deixam uma parte de sua obra encoberta; ao fazê-lo, induzem os observadores a reconhecerem uma ideia que, por ventura, pode ser a errada. Durante as décadas do século XX, a doutrina duelou ferozmente com este misterioso instituto. Defenderam que a vontade seria a chave 
de sua compreensão, sem, porém, darem-se conta de que aquela nada influenciaria a criação da aparência descrita e disciplinada pelo direito. Os que discordavam desta abordagem, tentaram, sem definitivo sucesso, relacionar a essência da simulação ao conflito de declarações e ao abuso da causa. Tais tentativas, embora cobertas de méritos, não assimilaram a circunstância de que a simulação não é produto, exclusivamente, do agir dos simuladores, pois depende, como o simulacro platônico, do aprisionamento do terceiro observador a um ponto de vista desprivilegiado.

O mais grave pecado da dogmática da simulação, no entanto, parece ter sido o de assentar-se sobre a crença de que aquela seria explicável a partir da descrição categorial do negócio jurídico. Acreditou-se que bastaria identificar os elementos que comporiam o negócio jurídico para, supondo a falta de alguns destes, identificar-se a essência do fenômeno simulatório. Assim, se o negócio jurídico fosse vontade, esta faltaria; se fosse declaração, esta seria insubsistente; e assim por diante.

Ocorre, todavia, que o defeituoso e o incompleto não são equivalentes ao meramente aparente. A falta de algo decorre da omissão ou da destruição, mas a aparência, que a lei descreve e disciplina ao tratar da simulação, é resultante de uma construção. A simulação não é o não ser, mas um ser aparente; o seu exame, portanto, somente pode ser referir ao modo como seja possível (melhor dizendo, o legislador entende que seja possível) a produção da ilusão capaz de subjugar a razão alheia.

É necessário uma mudança de perspectiva; tal mudança, aliás, já pode ser notada nas obras mais recentes dedicadas ao estudo do tema. Os simuladores usam da autonomia privada para perpetrar o engano. É deste peculiar emprego da autonomia privada que nos ocuparemos nas páginas que seguem.

\section{Escopo do presente estudo}

Os aspectos gerais da disciplina jurídica da simulação encontram-se definidos no artigo 167, cuja redação é a seguinte:

Art. 167. É nulo o negócio jurídico simulado, mas subsistirá o que se dissimulou, se válido for na substância e na forma.

$\S 1^{\circ}$ Haverá simulação nos negócios jurídicos quando:

I - aparentarem conferir ou transmitir direitos a pessoas diversas daquelas às quais realmente se conferem, ou transmitem;

II - contiverem declaração, confissão, condição ou cláusula não verdadeira; 
III - os instrumentos particulares forem antedatados, ou pós-datados.

$\S 2^{\circ}$ Ressalvam-se os direitos de terceiros de boa-fé em face dos contraentes do negócio jurídico simulado.

O instituto da simulação tem acompanhado a experiência jurídica há séculos. Os romanos $^{1}$ dela trataram, embora de maneira não tão aprofundada como fizeram os glosadores medievais ${ }^{2}$. Uma riquíssima produção doutrinária foi-lhe dedicada a partir de meados do século XIX, e, sobretudo, durante todo o século XX. Nada obstante, em pleno século XXI, precisar os seus contornos categoriais continua sendo tarefa de árdua consecução. Não à toa, "rios de tinta correram, e ainda correrão", , sobre este que é um dos mais tormentosos problemas do direito civil.

Este estudo é dedicado ao exame da simulação à luz dos parâmetros normativos estabelecidos pelo Código Civil. Mais especificamente, abordaremos os aspectos materiais do fenômeno simulatório. Não se ignora que a simulação pode acarretar complexos desdobramentos processuais, muitos dos quais, aliás, foram examinados pelos autores que se debruçaram sobre o assunto. A despeito disso, os notáveis desenvolvimentos observados, nos últimos tempos, no campo da ciência processual, requereriam um aprofundamento teórico tão ou mais intenso que aquele necessário ao estudo do artigo 167. Levando isto em conta, e, comprometidos com o rigor metodológico que deve orientar a elaboração de todo trabalho acadêmico, preferimos limitar o escopo do presente trabalho à disciplina civilística do instituto. Por idênticas razões, não abordaremos os reflexos que a disciplina da simulação pode produzir em outros ramos do direito, como, por exemplo, o tributário e o trabalhista. Para não corrermos o risco de apresentar observações superficiais ou mal fundamentadas, preferimos reservar a análise interdisciplinar do instituto da simulação para uma oportunidade futura. A única exceção a este critério será a da exposição atinente à legitimidade e ao interesse para alegar a simulação, e se justifica por razões de ordem histórico-evolutiva: deveras, como o Código Civil de 1916 abordava esta matéria em um dos dispositivos dedicados ao regramento da simulação, parece-nos

\footnotetext{
${ }^{1}$ Para um abordagem compreensiva da simulação no direito romano, v. G. PUGLIESE, La simulazione nei negozi giuridici - Studio di diritto romano, Padova, CEDAM, 1938; N. DUMONT-KISLIAKOFF, La simulation en droit romain, Paris, Cujas, 1970.

${ }^{2}$ V. a respeito da simulação no âmbito da glosa medieval, v. F. MANCUSO, La teorica della simulazione nell'esperienza dei glossatori, Bologna, Monduzzi, 2004.

${ }^{3}$ V. Andrioli, Profili processuali della nuova disciplina della simulazione in Studi in onore di Enrico Redenti, v. II, Milano, Giuffrè, 1951.
} 
pertinente examinar o impacto que a transição para o Código Civil de 2002 teria impactado esta disciplina.

Não temos - é bom dizer com clareza - a expectativa de, por meio deste trabalho, exaurir o estudo da simulação. Também não pretendemos apresentar soluções definitivas aos problemas que serão enfrentados. Anima-nos a oportunidade de contribuir com o debate sobre este apaixonante tema, cuja importância prática cresce a cada dia; quanto mais complexas as relações econômicas travadas entre os particulares, e quanto mais incisiva a intervenção do Estado nos domínios da autonomia privada, mais recorrente e multifacetada se torna a simulação.

\section{Orientação metodológica}

A recente reformulação dos fundamentos do direito civil reflete a historicidade da consciência jurídica brasileira e consubstancia na evolução dos paradigmas individualistas do Código Beviláqua - permeados pelas diretrizes da jurisprudência dos conceitos - à matriz ético-social - conformada aos ditames da jurisprudência de valoração. Esta evolução não pode ser ignorada pelo estudioso da simulação.

O regime jurídico atribuído à simulação pelo Código Civil de 2002 rompe completamente com o modelo do Código Civil de 1916. A nulidade do negócio simulado, o mecanismo de proteção dos direitos de terceiros de boa-fé e a excepcional validade do negócio dissimulado merecem ser examinados com rigor dogmático. Mais que simples mudança nos textos legais, os desdobramentos que o artigo 167 vincula à simulação são expressão de juízos de valor formulados pelo legislador com vistas à solução de conflitos de interesses.

Segundo a exposição de motivos do Código Civil, este seria orientado pelas diretrizes da concreção e realizabilidade ${ }^{4}$. Tais diretrizes remetem aos ideais da jurisprudência de valoração - a "terceira fase do direito moderno", como a denomina Miguel Reale ${ }^{5}$.

\footnotetext{
${ }^{4}$ Miguel Reale, História do Novo Código Civil, São Paulo, Revista dos Tribunais, 2005, p. 72; 80.

${ }^{5}$ Miguel Reale, Nova Fase do Direito Moderno, $2^{a}$ ed., São Paulo, Saraiva, 1998, p. 95-129.
} 
Embora não seja possível demarcar, com exatidão, os períodos em que teriam vigorado cada uma das "fases do direito moderno", pode-se dizer que, em termos gerais, nos últimos dois séculos, a experiência jurídica continental observou os seguintes momentos decisivos:

(a) entre a revolução francesa e o início da vigência do Código Civil alemão preponderou o movimento da jurisprudência dos conceitos (“Begriffsjurisprudenz");

(b) na passagem do século XIX para o século XX, e nas primeiras décadas deste, o conflito entre o liberalismo predominante e as classes sociais oprimidas impulsionou a reação contra o excessivo formalismo então observado e propugnou a injeção de um conteúdo sociológico mais saliente à experiência jurídica, surgindo a jurisprudência dos interesses ("Interessenjurisprudenz"); e

(c) em meados do século XX, sobretudo, após o fim da Segunda Guerra Mundial, como natural evolução da jurisprudência dos interesses, desenvolveu-se a jurisprudência de valoração ("Wertungsjurisprudenz"), segundo a qual os preceitos normativos deveriam ter o seu conteúdo preenchido segundo uma orientação axiológica ${ }^{6}$.

Característica da jurisprudência dos conceitos é a dedução de soluções jurídicas por meio da operação de subsunção, de acordo com a qual um determinado fato corresponderia a um conceito segundo os ditames da lógica formal. Isto pressuporia que o conceito viesse delimitado de maneira detalhada e rígida na norma, de modo a permitir uma comparação precisa entre a previsão abstrata e o fato concreto. A operação de subsunção autorizaria a formulação de um único raciocínio binário, do gênero sim ou não ${ }^{7}$.

Já para os defensores da jurisprudência dos interesses, as leis resultariam de embates dialéticos travados entre os diversos interesses da sociedade, os quais lutariam

\footnotetext{
${ }^{6}$ Miguel Reale, Direito Natural/Direito Positivo, São Paulo, 1984, p. 37.

${ }^{7}$ A. KAUFMANN - W. HASSEMER (orgs.), Einfürung in Rechtsphilosophie und Rechtstheorie der Gegenwart, 1994, trad. por. de M. Keel - M. S. Oliveira, Introdução à Filosofia do Direito e à Teoria do Direito Contemporâneas, Lisboa, Calouste Gulbenkian, 2002, p. 166-170.
} 
constantemente por reconhecimento e proteção $^{8}$. Mediante o achamento da solução jurídica ("Rechtsfindung”), partir-se-ia do pressuposto de que toda norma jurídica conteria um juízo subjetivo de autoria do legislador acerca da solução de um conflito de interesses. Por conseguinte, para os seguidores desta corrente metodológica, os direitos subjetivos corresponderiam a mecanismos para a satisfação de interesses particulares contemplados em normas jurídicas pelo ato de vontade do legislador ${ }^{9}$. O objetivo da Ciência do Direito, mais que proceder a uma série de operações lógico-racionais, consistiria na identificação do pano de fundo que teria levado o legislador a tomar sua decisão política, o que significaria, por outro modo, rastrear o conflito de interesses que teria dado causa à criação da $l \mathrm{i}^{10}$.

A jurisprudência de valoração é uma evolução da jurisprudência dos interesses. O seu desenvolvimento associa-se à crise de legitimidade do positivismo jurídico ${ }^{11}$. Para os defensores desta concepção jusfilosófica, as categorias jurídicas seriam “apenas um meio auxiliar de visionação dirigido à compreensão das valorizações gerais dos interesses e das opções do legislador nos casos de conflito"12. Ao contrário da jurisprudência dos interesses, esta forma de encarar o fenômeno jurídico não mira na solução do conflito de interesses em si, mas no valor que o legislador teria prestigiado ao tomar as suas decisões $^{13}$. O dado axiológico impregnado no conteúdo da norma seria relacionado a um elemento suprapositivo do ordenamento jurídico ${ }^{14}$.

${ }^{8}$ K. LARENZ, Methodenlehre der Rechtswissenschaft, 1991, trad. port. de José Lamego, Metodologia da Ciência do Direito, $5^{\text {a }}$ ed., Lisboa, Calouste Gulbenkian, 2009, p. 65

9 F. WIEACKER, Privatrechtsgeschte der Neuzeit Unter Besonderer Berücksichtigung der Deutschen Entwicklung, 1967, trad. port. de A. Botelho Hespanha, História do Direito Privado Moderno, $4^{\mathrm{a}}$ ed., Lisboa, Calouste Gulbenkian, 2010, p. 666.

${ }^{10}$ K. LARENZ, Metodologia... cit. (nota 8), p. 666.

${ }^{11}$ Como salienta N. BobBio (Il positivismo giuridico - Lezioni di filosofia del diritto, 1996, trad. port. de M. Pugliesi, E. Bini e C. Rodrigues, O Positivismo Jurídico - Lições de Filosofia do Direito, São Paulo, Ícone, 2006 , p. 15-23), a expressão "positivismo" não possui, no campo jurídico, o mesmo sentido que no campo filosófico. O direito positivo é conceituado em oposição ao direito natural. Esta antítese não é unívoca, tendo sido demonstrada de maneiras diversas, em distintos momentos históricos. Numa acepção clássica, abstraída da filosofia aristotélica, o direito natural corresponderia ao universal, enquanto o direito positivo representaria o parcial. A versão moderna da dicotomia, que deve informar o sentido do termo aludido no texto, dá conta de que o direito natural é aquele apreendido por meio da razão, sendo, portanto, passível de demonstração a priori (autônomo), enquanto o direito positivo provém de um ato de imposição (heterônomo).

${ }^{12}$ F. WIEACKER, História cit. (nota 9), p. 666.

${ }^{13}$ K. LARENZ, Metodologia ... cit. (nota 8), p. 164; 172.

14 J. BAPTISTA MACHADO, Introdução ao direito e ao discurso legitimador, Coimbra, Almedina, 1983, p. $307 \mathrm{ss}$. 
A aproximação do Código Civil à jurisprudência de valoração é reforçada pela presença, em diversos dos seus dispositivos, de tipos, conceitos indeterminados e cláusulas gerais. A jurisprudência de valoração permite-nos abrir mão de um compromisso irrestrito para com a lógica formal que orienta a subsunção; impõe-nos, contudo, a tarefa de investigar os valores aglutinados no conteúdo normativo do artigo 167. Tais valores sintetizam a tomada de posição, positivada pelo legislador, a respeito dos pontos de tensão (núcleos de conflito) captados a partir da observação da vida social.

O negócio simulado dá origem a um notável conflito de interesses, decorrente do choque entre as posições jurídicas ocupadas, de um lado, pelos simuladores, e do outro, pela comunidade. A atenção dedicada, pela norma, à apreciação deste conflito de interesses, é evidenciada pela estrutura normativa do artigo 167 . O $\S 2^{\circ}$ deste dispositivo trata especificamente da proteção dos direitos de terceiros de boa-fé. Já a nulidade do negócio simulado, cominada no caput daquele artigo, conquanto equalize a tensão estabelecida entre os interesses dos simuladores - que poderão alegar a simulação quando seja necessário salvaguardar a intenção comum plasmada no negócio jurídico -, é sobremaneira relevante para a tutela dos interesses dos terceiros prejudicados pela simulação.

O protagonismo do conflito entre interesses dos simuladores e da comunidade evidencia que a compreensão do fenômeno simulatório pressupõe a adoção de um particular ponto de relevância hermenêutica. Demais disso, esta abordagem metodológica consente um enfrentamento especializado dos diversos aspectos do regime jurídico do negócio simulado, ao final do qual será possível visualizar as peculiaridades que a nulidade do negócio simulado apresenta em contraposição com a disciplina geral das nulidades.

Cremos, enfim, que a jurisprudência de valoração oferece, além de uma orientação jusfilosófica, ferramentas técnicas, das quais pretendemos nos aproveitar para a condução de nossas investigações em torno da simulação.

\section{Plano de trabalho}

O presente trabalho dividir-se-á em três capítulos.

No Capítulo I, investigaremos o noção de simulação, à luz do artigo 167. A primeira etapa a ser cumprida neste desiderato será o investigação em torno de uma 
definição legal de simulação. Constatada a inexistência de tal definição, passaremos a reconstruir a categoria da simulação com base no reconhecimento de que esta se insere no conjunto dos atos de autonomia privada. Estudaremos criticamente a tradição doutrinária de modo a extrair subsídios para a identificação dos contornos característicos do instituto, passando, na sequência, a identificar o modo como se opera o mecanismo da ilusão negocial. Por fim, para conferir maior precisão às conclusões esboçadas, trataremos de distinguir a simulação de figuras próximas, como a fraude à lei, o negócio indireto, a fraude à lei e o abuso de direito.

O Capítulo II tratará das manifestações da simulação. Cuidaremos de aspectos ligados às classes, às hipóteses típicas, e aos limites do fenômeno simulatório. As classes de simulação são aquelas elaboradas pela doutrina: simulação absoluta e relativa; inocente e nocente; total e parcial. As hipóteses típicas de simulação são descritas na lei: simulação subjetiva, simulação objetiva, e antedata e pós-data. Os limites da simulação são impostos pela natureza peculiar de certos atos, a qual impede que os particulares disponham integralmente quanto à produção de seus efeitos; examinaremos, neste particular, a simulabilidade dos negócios formais, dos negócios unilaterais, dos atos familiares, dos títulos de crédito e do contrato de sociedade.

O Capítulo III será dedicado ao regime jurídico da simulação. Abordaremos, em linha de partida, a nulidade do negócio simulado e os desdobramentos da sua disciplina. Estudaremos, ainda, as condições às quais se subordina a validade do negócio dissimulado e a operatividade da extraversão. Também abordaremos a fundamentação dogmática e as regras específicas atinentes à proteção dos direitos de terceiros de boa-fé.

Por último, passaremos, em revista, as principais conclusões expostas no decorrer da obra, com vistas a fixar nossos pontos de vista sobre as questões examinadas e oferecer, ao leitor, uma síntese de nosso pensamento. 


\section{CAPÍTULO I - A SIMULAÇÃo}

\section{§ 1. A TRADIÇÃo DOUTRINÁRIA}

No campo das ciências do espírito, a elaboração do conhecimento novo pressupõe um diálogo com a tradição, uma vez que a aspiração última do estudioso é sempre a de juntar-se àquela ${ }^{15}$. Conquanto não seja aconselhável adotar, sic et simpliciter, formulações teóricas concebidas em contextos histórico-culturais já superados, seria igualmente inadequado fechar os olhos para as valiosas contribuições legadas pelos autores do passado.

Nos países filiados ao sistema do direito romano-germânico, a simulação foi disciplinada por dispositivos legais de conteúdos distintos.

Apenas para citar alguns exemplos, as normas em vigor na França (artigo 1321 do Código Civil francês ${ }^{16}$ ), na Itália (artigo 1414 do Código Civil italiano ${ }^{17}$ ), e na Alemanha

${ }^{15}$ H.-G. GADAMER, Wahrheit und methode, 1960, trad. port. de F. P. Meurer, Verdade e Método, v.1, 12ª ed., Petrópolis, Vozes, 2012, p. 372 ss. Um grupo peculiar de preconceitos, originado de uma autoridade que se tornou anônima com o passar do tempo, que oferece fundamento de validade para seus próprios preceitos, independentemente de qualquer fundamentação racional, é a tradição. A tradição é uma manifestação preconceituosa que habita o âmago mais profundo das ciências do espírito, permitindo diferenciá-las das ciências da natureza. Para um estudioso de matemática, analisar o momento histórico ou o progresso teórico havido entre diversas gerações para a elaboração de um estudo presente não passa de uma preocupação secundária. Para um estudioso do direito, sucede bem o inverso. Como salienta H.-G. GADAMER, "o que satisfaz nossa consciência histórica é sempre uma pluralidade de vozes nas quais ressoa o passado. O passado só aparece na diversidade dessas vozes. É isso que constitui a essência da tradição da qual participamos e queremos participar". A mediação da tradição, segundo ensina o autor, a partir das ideias de Heidegger, opera-se de fórmula circular. O intérprete parte de seus preconceitos (tradição), faz uma primeira leitura da realidade, que resulta num projeto prévio. Este projeto prévio deve ser revisto, ante a verificação da coisa em $s i$, ou ante a verificação da arbitrariedade da opinião prévia. Neste movimento de sucessivas idas e vindas, acertos e erros, o intérprete vai paulatinamente ajustando a afinação do sentido de sua opinião, como um violinista faz com cada uma das cordas de seu instrumento. Concluído o processo, o intérprete terá separado os verdadeiros preconceitos - i.e. a tradição "validada", que fundamenta a compreensão -, dos falsos preconceitos (a tradição "rejeitada"), que leva a mal entendidos.

16 "Artigo 1321. As contradeclarações podem ter efeito apenas entre as partes contratantes; elas não têm efeito contra terceiros". Tradução livre; no original: “Article 1321. Les contre-lettres ne peuvent avoir leur effet qu'entre les parties contractantes; elles n'ont point d'effet contre les tiers".

17 “Art. 1414. O contrato simulado não produz efeito entre as partes. Se as partes quiseram concluir um contrato diferente daquele aparente, tem efeito entre estas o contrato dissimulado, desde que subsistam os seus requisitos de substância e de forma. As disposições precedentes se aplicam também aos atos unilaterais destinados a uma pessoa determinada, que sejam simulados por acordo entre o declarante e o destinatário". Tradução livre; no original: "Art. 1414. Il contratto simulato non produce effetto tra le parti. Se le parti hanno voluto concludere un contratto diverso da quello apparente, ha effetto tra esse il contratto dissimulato, purché 
(§ 117 do Código Civil alemão ${ }^{18}$ ) representam três paradigmas completamente diferentes. O modelo francês concentra-se na inoponibilidade, perante terceiros, dos efeitos da "contre-lettre". A norma italiana dispõe, a seu turno, que o negócio simulado não produz efeitos entre as partes, valendo, entre elas, o que secretamente se convencionou. O sistema alemão comina a sanção de nulidade ao negócio simulado, ressalvando a vigência do disciplina aplicável ao negócio dissimulado.

Diante desse mosaico normativo, surgiram variadas teorias sobre a simulação. As principais teses defendidas sobre a natureza jurídica do instituto dividiram-se entre voluntaristas, declaracionistas e causalistas.

Tais teses compartilham de um postulado metodológico comum: o apriorismo conceitual. Em razão desta abordagem, os contornos categoriais da simulação foram definidos em função de uma prévia tomada de posição a respeito da teoria do negócio jurídico. Para a parcela da doutrina que via na vontade o cerne da atividade negocial, a simulação consistiria num vício da manifestação de vontade; aqueles que atribuíam papel determinante à declaração a conceberiam como o resultado da oposição de declarações contraditórias; e, por fim, os adeptos da concepção objetivista do negócio jurídico a associariam a uma disfunção do regulamento de interesses. Em síntese, qualquer que fosse o ponto de vista adotado, o negócio simulado negaria a própria essência ${ }^{19}$.

A principal consequência do apriorismo conceitual foi a redução da autonomia dogmática da simulação. Esta situação faria com que os desenvolvimentos havidos no campo da teoria do negócio jurídico gerassem consequências diretamente relacionadas ao modo de conceber e explicar o fenômeno simulatório.

ne sussistano i requisiti di sostanza e di forma. Le precedenti disposizioni si applicano anche agli atti unilaterali destinati a una persona determinata, che siano simulati per accordo tra il dichiarante e il destinatario".

18 “§ 117. (1) Se uma declaração de vontade, que é para ser emitida a outrem, for consensualmente emitida apenas por aparência, então ela é nula. (2) Se um negócio simulado ocultar outro negócio jurídico, as disposições relativas ao negócio oculto se aplicam” Tradução livre; no original: “§ 117. (1) Wird eine Willenserklärung, die einem anderen gegenüber abzugeben ist, mit dessen Einverständnis nur zum Schein abgegeben, so ist sie nichtig. (2) Wird durch ein Scheingeschäft ein anderes Rechtsgeschäft verdeckt, so finden die für das verdeckte Rechtsgeschäft geltenden Vorschriften Anwendung".

${ }^{19}$ A. AURICCHIO, La simulazione nel negozio giuridico - Premesse generali, Napoli, Eugenio Jovene, 1957, p. 4-6. 


\section{A tese voluntarista}

Segundo a tese voluntarista, a simulação derivaria de uma deliberada divergência entre vontade e declaração. Esta definição, que remonta à pandectística germânica e à doutrina dominante na Itália anteriormente à entrada em vigor do Código Civil italiano de 1942, foi acolhida por um grande número de autores ${ }^{20}$.

De acordo com a teoria da vontade ("Willenstheorie"), vontade e declaração nasceriam, geralmente, unidas, como um só fenômeno; mas somente a vontade deveria ser considerada "o único elemento importante e eficaz"21. A vontade obrigaria o particular desde que devidamente exteriorizada. Por conseguinte, a declaração não se prestaria a nada além de revelar a existência do consentimento ${ }^{22}$.

Normalmente, vontade e declaração concordariam. Poderiam, porém, ocorrer situações em que esta ordem harmoniosa se perturbasse, notadamente a formação de um querer que não fosse manifestado, ou uma manifestação à qual não correspondesse uma intenção sincera. No primeiro caso, a vontade seria um fenômeno arcano e misterioso, pelo qual o direito não se interessaria; o ato seria, pois, inexistente ${ }^{23}$. No segundo caso, o negócio jurídico celebrado seria tido, em geral, como nulo ${ }^{24}$.

${ }^{20}$ Cf. dentre outros: F. Ferrara, Della simulazione dei negozi giuridici, 1922, trad. port. de A. Bossa, A Simulação dos Negócios Jurídicos, São Paulo, Saraiva, 1939, p. 59 ss; F. PeSTALOzZA, La simulazione nei negozi giuridici, Milano, Società Editrice Libraria, 1919, p. 8-9; H. LEHMANN, Allgemeiner Teil des Bürgerlichen Gesetzbuches, 1922, trad. esp. de J. M. Navas, Parte General, v. 1, Madrid, Revista de Derecho Privado, 1956, p. 361; N. Coviello, Manuale di diritto civile italiano - Parte generale, $3^{\mathrm{a}}$ ed., Milano, Società Editrice Libraria, 1924, p. 370; A. BUTERA, Della simulazione nei negozi giuridici e degli atti "in fraudem legis", Torino, UTET, 1936, p. 1-5; G. STOLFI, Teoria del negozio giuridico, 1947, trad. esp. de Jaime Santos Briz, Teoria del Negocio Jurídico, Madrid, Revista de Derecho Privado, 1959, p. 154-158; A. Trabucchi, Istituzioni di diritto civile, $8^{\mathrm{a}}$ ed., Padova, CEDAM, 1954, p. 130; J. BelezA Dos SAnTOS, $A$ Simulação em Direito Civil (1955), 2a ed., São Paulo, Lejus, 1999, p. 47-52; H. CoRTÉS, La simulación como vicio jurídico, Buenos Aires, Araujo, 1939, p. 10-13; H. CÁMARA, Simulación en los actos jurídicos, Buenos Aires, Depalma, 1944, p. 35-48; M. CARCABA FERnANDEZ, La simulación en los negocios jurídicos, Barcelona, Bosch, 1986, p. 31-33; M. A. D. ANDRADE, Teoria Geral da Relação Jurídica, v. II, Coimbra, Almedina, 2003 (reimpressão), p. 168-169; M. AlBALADEJO GARCíA, La simulación, Madrid, Edisofer, 2005, p. 17-18; e E. RopPO, Il contratto, trad. port. de A. Coimbra e M. Gomes, O Contrato, Coimbra, Almedina, 2009, p. 161-162.

${ }^{21}$ F. C. SAVIGNY, System des heutigen römischen Rechts, trat. it. de V. Scialoja, Sistema del diritto romano atuale, v. 3, Torino, UTET, 1900, p. 342.

${ }^{22}$ J. BelezA dos SAntos, A Simulação... cit. (nota 20), p. 9.

${ }^{23}$ A. BUTERA, Della simulazione... cit. (nota 20), p. 3.

${ }^{24}$ A. ButerA, Della simulazione... cit. (nota 20), p. 11. 
Se a desconformidade entre vontade e declaração fosse deliberada pelas partes, surgiria a simulação, uma espécie de vício do consentimento ${ }^{25}$. "O negócio jurídico simulado dá origem a um vício de consentimento. Este vício (...) ofende ao mesmo tempo o elemento interno e o elemento externo do consentimento, e faz com que, acompanhados um do outro, não correspondam mais à verdade. O negócio simulado é a falsa imagem do verdadeiro" ${ }^{, 26}$. No embate entre a vontade e a declaração, a primeira deveria preponderar ${ }^{27}$.

Vale notar, entretanto, que a tese voluntarista da simulação não seguiria à risca os ditames da teoria da vontade. A doutrina não tardaria a perceber que esta formulação teórica apresentava imperfeições. Com efeito, a teoria da vontade privilegiava o querer psicológico, descuidando-se do elemento material da declaração, o qual, muitas vezes, era considerado idôneo a produzir consequências jurídicas. Esta teoria mostrava-se, pois, insatisfatória ao atendimento das exigências da vida social, porquanto a sua aplicação incondicional eliminava a segurança das relações contratuais ${ }^{28}$.

No movimento de reavaliação dos paradigmas voluntarísticos, surge a teoria da responsabilidade. De acordo com esta, embora a vontade fosse o fundamento do negócio

${ }^{25}$ H. LehmanN, Parte General cit. (nota 20), p. 357-371.

${ }^{26}$ A. ButERA, Della simulazione... cit., (nota 20), p. 3. Tradução livre; no original: "Il volontario dissidio tra l'interno volera e la dichiarazione fa sorgere il negozio simulato. Il negozio simulato mette capo a un vizio di consenso. Questo vizio (...) offende nel medesimo tempo l'elemento interno e l'elemento esterno del consenso, e fa che scompagnati l'uno dall'altro non rispondano più alla verità. Il negozio simulato è la falsa immagine del vero".

${ }^{27}$ F. C. SAVIGNY, Sistema .. cit. (nota 21), p. 347-350: "Finalmente, deve-se aqui incluir também o caso, que geralmente é o único mencionado, da simulação. Com isto se entende uma declaração de vontade, na qual concorrem mais de uma pessoa, as quais estejam de acordo em atribuir às suas declarações um sentido diferente do comum. Ora, aqui o princípio fundamental é que deva valer a verdadeira intenção, não aquela aparentemente expressa nas palavras. Isto ocorre nas diversas aplicações que seguem: 1) quando não se quis nenhum negócio jurídico, embora as palavras exprimam o contrário; 2) quando o negócio jurídico querido seja diverso daquele expresso com as palavras; 3) quando as pessoas, entre as quais deverá surgir a relação jurídica, sejam diferentes daquelas que sustentariam a declaração de vontade. Conquanto possam ser diversos os casos aqui enumerados, constata-se, em todos, a característica comum acima notada, de que a contradição entre a vontade e a declaração não permaneça restrita ao simples pensamento do declarante, mas possa ser reconhecida por aquele que estabeleça relação diretas com ele". Tradução livre; no original: "Finalmente è qui da annoverarsi anche il caso, che spesso è il solo menzionato, della simulazione. Con ciò s'intende una dichiarazione di volontà, nella quale concorrono più persone, che si sono data l'intesa di attribuire alle loro dichiarazioni un senso diverso dall'ordinario. Ora qui il principio fondamentale è che debba valere la vera intenzione, non quella apparentemente espressa nelle parole. Esso ricorre nelle diverse applicazioni seguenti: 1) Quando non si è voluto alcun negozio giuridico, sebbene le parole esprimano il contrario. 2) Quando il negozio giuridico voluto è diverso da quello espresso con le parole. 3) Quando le persone, tra le quali dovrà sorgere il rapporto, sono diverse da quelle che porterebbero le parole della dichiarazione di volontà. Per quanto possano esser diversi anche i casi qui enumerati, tuttavia ricorre in tutti il comune carattere sopra notato, che la contraddizione tra la volontà e la dichiarazione non resta chiusa nel semplice pensiero del dichiarante, ma può essere riconosciuta da coloro che entrano con lui in rapporto immediato".

${ }^{28}$ A. BUTERA, Della simulazione... cit. (nota 20), p. 13. 
jurídico, ela cederia espaço à valoração autônoma da declaração sempre que o declarante fosse responsável (i.e. culpado) pela discordância entre o querer interno e a respectiva manifestação. Cumpriria mitigar os perigos decorrentes da extensão da teoria da vontade às últimas consequências; a vontade deveria contar com a proteção do direito apenas na medida em que a sua aplicação não atentasse contra a estabilidade do tráfico jurídico ${ }^{29}$. A teoria da responsabilidade é, então, concebida como alternativa que contemplaria os imperativos da justiça e da confiança, uma vez que não se fundaria exclusivamente sobre a vontade, atribuindo certa relevância à boa-fé que o público deposita na declaração.

Seguindo esta tendência, Ferrara descreve a falta de vontade como uma espécie de elemento negativo do negócio jurídico. Sozinha, a vontade não justificaria quaisquer efeitos; porém, quando faltasse, o negócio jurídico tornar-se-ia deficiente ${ }^{30}$. O direito protegeria apenas determinações sérias de vontade, não a malícia ou os caprichos da autonomia privada. "[A] lei atende às circunstâncias em que se realiza a determinação da vontade, e se considera que esta não é digna de protecção jurídica, retira-lhe"31.

Para o autor, o procedimento da simulação seria complexo e envolveria, ao menos, três requisitos ${ }^{32}$ :

(a) o conflito entre a vontade e a declaração, que deveria ser proposital (pois do contrário surgiriam outras figuras, como o erro);

(b) o acordo sobre a não realidade do negócio jurídico, que diferenciaria a simulação da reserva mental; e

(c) a intenção de enganar, que distinguiria a simulação que ocorre no mundo jurídico daquela que ocorre nos palcos do teatro, nas salas de aula e em quaisquer outras declarações não sérias feitas por brincadeira.

Nem todos os autores voluntaristas, porém, aceitaram a vinculação da simulação a um conflito entre vontade e declaração. Stolfi, por exemplo, defende que o negócio simulado decorreria da manifestação de uma vontade aparente; os seus pressupostos

\footnotetext{
${ }^{29}$ A. BUTERA, Della simulazione... cit., (nota 20), p. 18.

${ }^{30}$ F. FERrarA, $A$ simulação... cit. (nota 20 ), p. 30

${ }^{31}$ F. Ferrara, $A$ simulação... cit. (nota 20), p. 45-47.

${ }^{32}$ F. Ferrara, A simulação... cit. (nota 20), p. 52 ss.
} 
seriam, exclusivamente, a inteligência (ou o acordo) entre as partes e a estruturação de um ato cumprido apenas em aparência. Nenhuma das partes manifestaria uma vontade em contraste com o ânimo interno; diversamente, ambas concordariam em atribuir à vontade expressa uma forma diversa da verdadeira, mediante a criação de dois atos antitéticos: de um lado, declarariam querer em aparência, de outro, declarariam que em realidade nada quereriam, ou quereriam algo diverso ${ }^{33}$.

Já Cariota Ferrara sugere que seria possível querer a declaração (enquanto fato), mas não querer o conteúdo correspondente. Nestes termos, a simulação surgiria não simplesmente como conflito entre vontade e declaração, mas como específica ausência da vontade de conteúdo. O divórcio entre o negócio jurídico e a realidade operar-se-ia na medida em que as partes pudessem, por meio do próprio arbítrio, transformar sua declaração em mero fato, impondo-lhe a perda da condição de ato jurídico ${ }^{34}$.

No Brasil, a tese voluntarista da simulação mostraria mais uma de suas facetas.

Ao propor a distinção entre os vícios da vontade (erro, dolo e coação) e os vícios sociais (simulação e fraude contra credores), Beviláqua deixa claro que, no caso destes, a vontade dos sujeitos manifestar-se-ia de maneira absolutamente normal; atuaria, porém, uma circunstância de natureza diversa, consistente num desvio da boa-fé e da honestidade. O comportamento dos simuladores não seria capaz de determinar a "desarmonia entre o que se passa no recesso da alma e o que se exterioriza em palavras ou fatos"; diversamente, apenas tornaria a manifestação de vontade juridicamente inoperante.

Nessa esteira, seria simulado o ato fictício que simula a existência de uma declaração que não se fez, ou que simula a existência de uma declaração que não se fez; de maneira menos tautológica, o autor descreveria a simulação como "declaração enganosa da vontade, visando a produzir efeito diverso do ostensivamente indicado" $" 35$.

É de se assinalar que, muito embora, à época de Beviláqua, fossem conhecidas teses que pudessem ser manejadas para explicar a dissociação entre o querido e o declarado pelas partes (como a própria teoria da vontade), o autor não recorreu

${ }^{33}$ G. STOLFI, Teoria del Negocio Jurídico cit. (nota 20), p. 155-156.

${ }^{34}$ L. CARIOTA FERRARA, Il negozio giuridico nel diritto privato italiano, Napoli, Morano, 1949, p. 421; 524.

${ }^{35}$ C. BeviláQua, Teoria Geral do Direito Civil, $2^{\mathrm{a}}$ ed. (1928), Campinas, Servanda, 2007, p. 298;310-311. 
explicitamente a qualquer delas para estruturar seu raciocínio; preferiu elaborar uma explicação baseada na boa-fé: "[d]omina a matéria da simulação a regra formulada pelo direito romano: acta simulata veritatis substantiam mutare non potest; mas para que a simulação constitua um vício do ato jurídico, há de ser empregada de má-fé, no intuito de prejudicar alguém ou fraudar a lei. A simulação de boa-fé, sem prejuízo de terceiros nem ofensa à lei, é tolerada",36.

Como se vê, Beviláqua não faz qualquer referência ao conflito entre vontade e declaração. Nem por isso, contudo, deixaria de inspirar as gerações futuras, que, inusitadamente, mesclariam as suas lições com os ditames da tese voluntarista, tal qual preconizada em outros países. Surgiria, assim, um voluntarismo sincrético: a dissociação entre vontade e declaração seria elemento da simulação, mas não macularia o aspecto psicológico do negócio jurídico, quer quanto à sua formação, quer quanto à sua comunicação exterior ${ }^{37}$.

Mais recentemente, já durante a vigência do Código Civil de 2002, a concepção voluntarista da simulação seria retomada por Humberto Theodoro Júnior, para quem a simulação implicaria uma "mentira no suporte fático do negócio jurídico, que torna ilícito o seu objeto" ${ }^{38}$. O autor associou a transição, da anulabilidade prevista no Código Civil de 1916 para a nulidade cominada no Código Civil de 2002, a uma revaloração da divergência volitiva pressuposta pela simulação. "Agora" - diz - "o novo Código considera nulo o negócio (e não mais anulável) e o faz simplesmente porque produto de simulação, ou seja, declaração que não corresponde à vontade real dos sujeitos do negócio. Nada se exigiria,

${ }^{36}$ C. BeviláQua, Teoria Geral... cit. (nota 35), p. 311.

37 Silvio Rodrigues, Curso de Direito Civil, v. 1 - Parte Geral, 32 a ed., São Paulo, Saraiva, 2002, p. 183;197. No mesmo sentido: M. M. Serpa Lopes, Curso de Direito Civil, v. I - Introdução, Parte Geral e Teoria dos Negócios Jurídicos, 8 a ed., Rio de Janeiro, Freitas Bastos, s.d., p. 457 ss.; M. GARCEZ, Nulidades dos Actos Jurídicos, $2^{\text {a }}$ ed., v. 1, Rio de Janeiro, Jacintho Ribeiro dos Santos, 1910, p. 240 ss; San Tiago Dantas, Programa de Direito Civil - Aulas Proferidas na Faculdade Nacional de Direito, Rio de Janeiro, Rio, 1979, p. 281 ss.; A. ChAves, Antônio, Tratado de Direito Civil, v. I - Parte Geral, t. II, $3^{\text {a }}$ ed., São Paulo, Revista dos Tribunais, 1982, p. 1434 ss.; e V. RÁo, Vicente, Ato Jurídico, 4ª ed., São Paulo, Revista dos Tribunais, 1997, p. 186-187.

${ }^{38}$ Humberto TheOdORo JúnIOR, Comentários ao Novo Código Civil, v. III, t. I (arts. 138 a 184), 4ª ed., Rio de Janeiro, Forense, 2008, p. 470. Após a entrada em vigor do Código Civil de 2002, também seguiram a tese voluntarista da simulação: Washington de BArros Monteiro, Curso de Direito Civil, v. 1 - Parte Geral, atual. por A. C. B. M. França Pinto, 44a ed., São Paulo, Saraiva, 2012, p. 272-273; Caio Mário da Silva PereIRA, Instituições de Direito Civil, v.1 - Introdução ao Direito Civil e Teoria Geral de Direito Civil, atual. por M. C. Bodin Moraes, 25 a ed., Rio de Janeiro, Forense, 2012, p. 535; Arnaldo RizzARdo, Parte Geral do Código Civil, $7^{\mathrm{a}}$ ed., Rio de Janeiro, Forense, 2011, p. 493. 
para ter-se a simulação, no plano dos objetivos anteriores ou posteriores à declaração, a não ser a aparência não verdadeira da declaração"39.

\section{A tese declaracionista}

De acordo com esta corrente teórica, os simuladores ajustariam a criação de duas realidades, duas declarações: uma (oculta) destinada a fixar o regulamento dos seus interesses; outra (ostensiva) destinada a criar, perante terceiros, uma aparência negocial desprovida de qualquer potencialidade no plano da eficácia ${ }^{40}$.

Como reação à teoria da vontade, surge a teoria da declaração (“Erklärungstheorie") propugna que a vontade interna não possuiria significado enquanto não fosse declarada; por isso, o direito deveria atribuir eficácia apenas à declaração, um fenômeno do mundo exterior. As pessoas se vinculariam por meio de suas palavras; os destinatários da declaração possuiriam o direito de confiar naquilo que lhes fosse declarado. Assim, um negócio jurídico jamais poderia ser considerado nulo sob o pretexto de não ter sido querido aquilo que se declarou ${ }^{41}$.

A teoria da declaração, em sua feição moderna, busca proteger a boa-fé do destinatário da declaração, orientando-se, pois, segundo o princípio da confiança. A declaração somente deveria prevalecer quando o destinatário da declaração estivesse agindo de boa-fé, ou seja, não conhecesse ou não tivesse como conhecer o eventual defeito da manifestação volitiva do declarante ${ }^{42}$. Flume narra que Bähr teria sido um dos primeiros a defender a teoria da declaração, em 1875, quando escreveu o seguinte: "[q]uien al contratar suscite la apariencia externa de su voluntad de una manera que le pueda ser imputada, de modo que el otro contratante de buena fe crea y pueda creer haber adquirido derechos por ello, no será oído en su alegación de que en realidad le ha faltado la

${ }^{39}$ Humberto THEODORO JÚNIOR, Comentários... cit. (nota 38), p. 472.

${ }^{40}$ Cf. G. Messina, La simulazione assoluta in Scritti giuridici (1907-1908), v. V, Milano, Giuffrè, 1948 ; F. Santoro-Passarelli, Dottrine generali del diritto civile, 9a ed. (1966), Napoli, Eugenio Jovene, 1983, p. 151; N. DistASO, La simulazione dei negozi giuridici, Torino, UTET, 1960, p. 151 ss.; A. GENTILI, Simulazione dei negozio giuridi in Digesto delle Discipline Privatistiche - Sezione Civile, v. XVIII, Torino, UTET, 1998, p. 511-524; e M. C. DIENER, Il contratto in generale - Manuale e applicazioni pratiche dalle lezioni di Guido Capozzi, Milano, Giuffrè, 2002, p. 711.

${ }^{41}$ N. Coviello, Manuale... cit. (nota 20), p. 366.

${ }^{42}$ M. A. Domingues De Andrade, Teoria Geral... cit. (nota 20), p. 158-159. 
correspondiente voluntad. Responde por la apariencia externa de su voluntad precisamente como si efectivamente hubiera querido" 43 .

A partir deste embasamento dogmático, Köhler ${ }^{44}$ sustenta que a simulação surgiria em razão do neutralizar-se de duas declarações antitéticas que, contudo, guardariam unidade entre si. O autor não admite a existência de uma contrariedade entre vontade e declaração. Seria inexato, segundo ele, representar tais elementos como distintos; daí a impossibilidade de vislumbrar um conflito que os envolvesse. A declaração não seria o anúncio de um estado psíquico preexistente, senão um dos lados de um só fenômeno. Portanto, a declaração, mais que manifestação, seria uma encarnação do querer.

Quem assinasse um documento, pelo qual se obrigasse a dada prestação e, concomitantemente, declarasse não se obrigar, na verdade não se obrigaria a nada. Fá-lo-ia do mesmo modo que o comediante quando encena, ou o professor quando ensina. Porém, os dois fragmentos da declaração, o "sim, obrigo-me" e o "não, não me obrigo", formariam um fato único, de expressão neutra; amalgamar-se-iam, resultando no estabelecimento de nenhuma relação jurídica. $\mathrm{O}$ negócio jurídico simulado seria um não negócio ("Nichtgeschäft") pois, a rigor, sequer chegaria a se formar concretamente.

Conforme destaca Messina, a teoria da declaração não conduziria a um primitivo formalismo jurídico, mas à valorização do complexo comportamental das partes como indicação de uma intenção real e objetiva. Assim, embora fosse admissível a unidade de ação que Köhler vislumbrara no procedimento simulatório (i.e. a unidade de sentido da intenção, ainda que desdobrada em duas declarações), esta não teria seus termos reduzidos

43 W. Flume, Allgemeiner Teil des Bürgerlichen Rechts. Zweiter Band, Das Rechtsgeschäft. Vierte, unveränderte Auflage Enzyklopädie der Rechts-und Staatswissenschaft, 1992, trad. esp. de J. M. M. González e E. G. Calle, El negocio jurídico, Madrid, Fundación Cultural Del Notariado,1998, p. 84. Também a exposição de motivos do segundo projeto do Código Civil alemão, elaborada após levar em consideração as formulações de Röver, Bähr, Hartmann, Isay, dentre outros declarativistas, aproxima, explicitamente, a teoria da declaração ao princípio de proteção à confiança. Confira-se: "Después de una exposición introductoria del ponente y del ponente general, hubo acuerdo, en primer lugar, acerca de que ni el dogma de la voluntad ni la máxima de la confianza (teoría de la declaración) opuesta a él, se pueden seguir sin restricciones, y que por eso era necesario esaminar separadamente los casos concretos que se presenten, sin tomar partido positivamente por una o por otra teoría" (p. 85). Cf., a respeito, L. ENNECCERUS - H. C. NIPPERDEY, Allgemeiner Teil des Bürgerlichen Rechts, trad. esp. de Blas Péres González e José Alguer, Derecho Civil (Parte General), v. II, Primeira Parte, Barcelona, 1981, p. 309-312.

44 KÖHLER, Studien über Mentalreservation und Simulation, conforme relatado por N. DISTASO, La simulazione... cit. (nota 40), p. 9-11, nota 3. 
à antítese de duas declarações, que se neutralizariam; melhor dizendo, tais declarações conspirariam em prol de um contratar aparentemente ${ }^{45}$; desse modo, o negócio simulado representaria uma espécie de ato de execução de um prévio acordo ${ }^{46}$.

Mais recentemente, a tese declaracionista da simulação passaria por um processo de renovação metodológica, sob inspiração da teoria da linguagem e da semiótica jurídica. Nessa toada, Gentili afirma que as declarações de vontade das partes, quando dirigidas à formação do negócio jurídico, constituiriam normas jurídicas (o autor distingue o modelo de análise fática - em que a declaração seria vista como suporte fático do negócio jurídico - do modelo de análise semântica - em que a declaração caracterizaria um juízo dispositivo, isto é, o próprio regulamento de interesses) $)^{47}$.

Por meio desta mudança de perspectiva, que o autor admite não ser dogmática, mas fruto de uma alternativa metodológica que permitiria eliminar o problema da falácia naturalista $^{48}$ (i.e. a tentativa de explicar-se o dever-ser a partir do ser), ele conclui que a simulação seria o fenômeno derivado da produção, pelas partes, de um juízo normativo contraditório. As partes estabeleceriam uma norma que se destinaria a valer entre elas, e, ao mesmo tempo, colocariam em ação uma norma cuja função seria a de vigorar perante terceiros. Porquanto tais normas não fossem compatíveis entre si, a simulação resultaria deste embate ${ }^{49}$.

É importante, por fim, distinguir as teses declaracionistas de ascendência alemã e italiana da teoria das contre-lettres, surgida sob a égide do Código de Napoleão. O legislador francês não disciplinou a simulação diretamente, mas a eficácia da contradeclaração. Esta seria eficaz entre as partes, mas não poderia produzir efeitos perante terceiros. Seriam dois atos distintos: o ato ostensivo e o ato oculto. Ainda que se pudesse dizer que existe, entre tais atos, uma forte relação temporal, motivacional, e até psicológica, não se poderia dizer que a simulação seja um fenômeno unitário ${ }^{50}$.

${ }^{45}$ G. MESSINA, La simulazione assoluta cit. (nota 40), p. 86.

${ }^{46}$ G. MESsinA, La simulazione assoluta cit. (nota 40), p. 91-92.

47 A. GENTILI, Il contratto simulato - Teorie della simulazione e analisi del linguaggio, Milano, Giuffrè, 1982, p. 221-254.

${ }^{48}$ A. GENTILI, Il contratto simulato... cit. (nota 47), p. 255-259.

49 A. GENTILI, Il contratto simulato... cit. (nota 47), p. 276-280.

${ }^{50}$ Isto foi bem notado, aliás, pelo próprio F. FERRARA ( $A$ simulação... cit., nota 20, p. 61), quando criticava a teoria declaracionista dos alemães: "Mas é curioso notar que esta teoria, extremamente subtil, corresponde ao 
No Brasil, a tese declaracionista da simulação teve pequena aceitação. A manifestação mais relevante parece ser a de Custódio da Piedade Ubaldino Miranda, que ao examinar o fenômeno simulatório pelo prisma da estrutura, conclui que "mediante uma só intenção, as partes emitem duas declarações: uma destinada a permanecer secreta e a outra com o fim de ser projetada para o conhecimento de terceiros, isto é, do público em geral. A declaração, destinada a permanecer secreta, consubstanciada numa contradeclaração ou ressalva, constata a realidade subsistente entre os simuladores"

São dignas de nota, ademais, as proposições de Heleno Tôrres. Embora se possa dizer que a opinião deste autor transite entre a tese declaracionista modernizada (normativista) e a tese causalista, a ideia geral de que as partes da simulação criariam duas realidades paralelas, uma efetiva e outra aparente, pode ser claramente identificada em sua construção.

Após apresentar comentários de ordem metodológica, voltados à teoria da linguagem, o autor aduz que, por meio de um ato de autonomia privada, as partes estabeleceriam uma norma jurídica com a finalidade de predispor, perante terceiros de boafé, uma aparência de negócio jurídico. Paralelamente, as partes criariam outra norma jurídica destinada a vigorar intra pars, cujo objeto remeteria a uma declaração contrária ao ato aparente ${ }^{52}$.

\section{A tese causalista}

A infrutífera dialética entre os voluntaristas e os declaracionistas levaria parte da doutrina a procurar uma via alternativa. Emergiria, nesse contexto, a tese causalista da simulação, a qual busca explicar o instituto referindo-o a um vício da causa. No negócio

conceito material que, da simulação, têm os escritores franceses. Também eles se ocupam de lettres et contrelettres e concebem o negócio simulado como aquele que se modifica e suprime por outro negócio jurídico contemporâneo do primeiro e destinado a permanecer secreto. Só os escritores alemães falam dum negócio único, cujo conteúdo neutraliza, ao passo que os franceses falam de dois negócios que se neutralizam reciprocamente. A diferença não é grave". Confirma este ponto de vista M. DAGOT (La simulation en droit privé, Paris, LGDJ, 1965, p. 58-59), segundo o qual o "élément apparent" (ato simulado) é um contrato modificado, totalmente ou parcialmente, pelo "acte secret" (contradeclaração).

51 Custódio da Piedade Ubaldino Miranda, Teoria Geral do Negócio Jurídico, $2^{\mathrm{a}}$ ed., São Paulo, Atlas, 2009 , p. 159.

${ }^{52}$ H. T. TôRres, Simulação de Atos e Negócios Jurídicos - Pactos Simulatório e Causa do Negócio Jurídico in Junqueira de Azevedo, Antônio, Tôrres, Heleno Taveira, Carbone, Paolo (coords.), Princípios do Novo Código Civil Brasileiro e Outros Temas - Homenagem a Tullio Ascarelli, 2a ed., São Paulo, Quartier Latin, 2010, p. 318-319. 
simulado, a forma negocial (suporte fático) seria manejada com vistas à persecução de uma finalidade prática incompatível os respectivos efeitos ${ }^{53}$.

Causa é um dos termos mais plurívocos do Direito Civil ${ }^{54}$.

Na França, a doutrina contemporânea concebe a causa a que alude o artigo 1108 do Código Civil francês como causa final, objetivo que leva o particular a se obrigar ${ }^{55}$. Em sua feição objetiva (mais conhecida como causa da obrigação), a causa é entendida como a contrapartida convencionada, configurada a partir da integração dos motivos determinantes ao conteúdo da relação contratual. Em sua dimensão subjetiva (geralmente relacionada à causa do contrato), a causa coincide com os motivo determinantes. A causa objetiva presta-se à verificação da existência do sinalagma, assim como para a interpretação da relação jurídica; já causa subjetiva serve como parâmetro para a formação de um juízo sobre a licitude da operação jurídica ${ }^{56}$.

Na Itália, floresceu a teoria da causa típica, descrita como a "função econômicosocial do negócio inteiro, considerada digna de tutela jurídica, na síntese dos seus elementos essenciais, como totalidade e unidade funcional em que se explica a autonomia privada" ${ }^{57}$.

É praticamente lugar comum atribuir a concepção da causa típica a Scialoja. Este fato foi, porém, recentemente desmentido. Ferri relata que, conquanto o termo "função" houvesse sido empregado por Scialoja para descrever a causa nas célebres Lezioni romane dell'anno 1892-1893, este autor o empregara sem adjetivações, para referir-se ao tipo negocial legalmente estabelecido. Para Scialoja, a causa correspondente à finalidade do negócio jurídico seria a causa subjetiva; para descrevê-la, o autor não teria feito qualquer

\footnotetext{
${ }^{53}$ Figuram, dentre os expoentes desta vertente doutrinária: F. CARnELUTTI, Sistema del diritto processuale civile, v. II, Padova, CEDAM, 1938, p. 403-405; E. BETTI, Teoria generale del negozio giuridico, $3^{\mathrm{a}}$ ed. (1960), Napoli, Edizioni Scientifiche Italiane, 2002. p. 393 ss.; S. PUGLIATTI, La simulazione dei negozi giuridici unilaterali in Diritto civile - Metodo - Teoria - Pratica, Milano, Guffrè, 1951; S. RomANO, Contributo esegetico allo studio della simulazione (L'art. 1414 c.c.) in Rivista trimestrale di diritto e procedura civile, Milano, 1954.

${ }^{54}$ Sobre a diversidade das noções de causa no direito romano, v. G. GorLA, Il contratto - Problemi fontamentali trattati con il metodo comparativo e casistici, v. I - Lineamenti generali, Milano, Giuffrè, 1954 , p. 296-298.

55 D. Bonnet, Cause et condition dans les actes juridique, Paris, LGDJ, 2005, p. 3-4.

${ }^{56}$ J. GHestin, Causa de l'engagement et validité du contrat, Paris, LGDJ, 2006, p. 79.

${ }^{57}$ E. BETTI, Teoria generale... cit. (nota 53), p. 180.
} 
menção à função, aludindo apenas à apreciação que o ânimo do agente formula sobre a causa objetiva.

O pioneiro da teoria da causa como função econômico-social teria sido Betti. As suas ideias teriam revolucionado ${ }^{58}$ a teoria da causa, servindo aos propósitos do regime corporativista. "A causa surge, portanto, no sistema do Código Civil de 1942, não como valor que exprime, como se disse, o ponto de vista do contraente (como era na tradição do instituto), mas aquele do ordenamento jurídico"; desempenha "um papel de controle, para estabelecer se os fins privados, perseguidos pelos contraentes, sejam coerentes com aqueles gerais, fixados pelo ordenamento"59. A noção de causa típica seria um reflexo dos princípios do estado fascista ${ }^{60}$.

Com o passar do tempo e a restauração do Estado Democrático de Direito, o negócio jurídico voltaria a ser visto como um instrumento genuinamente privado ${ }^{61}$; fonte de valor capaz de produzir efeitos que, ao ordenamento jurídico, não caberia autorizar, mas recepcionar ou rejeitar ${ }^{62}$. Nesse movimento, a causa típica passaria a ser considerada insatisfatória, caindo em profundo descrédito, sobretudo, por não justificar a legitimidade e a eficácia dos negócios atípicos ${ }^{63}$.

${ }^{58}$ G. B. Ferri, Il Negozio Giuridico, 2a ed., Padova, CEDAM, 2004, p. 115-116: “Com a introdução, na teoria da causa, do termo função, não se opera apenas uma reforma terminológica, de todo extrínseca e formal, mas se muda a perspectiva e o próprio papel que a causa destina-se a desempenhar na teoria do negócio jurídico" (tradução livre).

59 G. B. FERRI, Il Negozio Giuridico cit. (nota 58), p. 116.

${ }^{60}$ G. B. FERRI, Il Negozio Giuridico cit. (nota 58), p. 117-118.

${ }^{61}$ G. B. FERRI, Il Negozio Giuridico cit. (nota 58), p. 123: "Com a queda da ideologia dirigista e o advento de uma Constituição liberal-democrática, também o negócio volta a ser um instrumento para a realização de interesses eminentemente privados, e a causa torna-se, novamente, elemento do negócio; não como instrumento e mecanismo de controle do agir autônomo dos particulares, como nas intenções do legislador [italiano] de 1942; mas como (...) objeto de controle, que permite constatar, concretamente, a existência e o grau de compatibilidade entre aqueles valores que o negócio exprime e aqueles, por outro lado, expressos pelo ordenamento estatal". Tradução livre; no original: "Con la caduta dell'ideologia dirigista e l'avvento di una Costituzione liberal-democratica, anche il negozio torna ad essere uno strumento per la realizzazione di interessi eminentemente privati e la causa ridiventa un elemento del negozio; non quale strumento e meccanismo di controllo dell'agire autonomo dei privati, come nelle intenzioni del legislatore del 1942; semmai (...) quale oggetto di controllo, che consente di costatare, in concreto, l'esistenza e il grado di compatibilità tra quei valori che il negozio esprime e quelli, invece, espressi dall'ordinamento statuale".

${ }^{62}$ C. B. N. CiOfFI, Classe, concetto e tipo nel percorso per l'individuazione del diritto applicabile ai contratti atipici, Torino, Giappichelli, 2008, p. 60.

${ }^{63}$ C. M. BiancA, Diritto Civile, v. III - Il Contratto, $2^{\mathrm{a}}$ ed. (2000), Milano, Giuffrè, 2007, p. 452. 
Abrir-se-ia, assim, espaço ao desenvolvimento da teoria da causa concreta, entendida como função prático-individual ${ }^{64}$. Esta concepção da causa parte do pressuposto de que cada negócio jurídico seria a expressão objetivada de finalidades subjetivas. A regra negocial não vale, pois, apenas em função de sua objetividade, mas também em razão daquelas finalidades subjetivas das quais é portadora, e que nela se objetivam; esta realidade complexa, na sua composição de aspectos subjetivos e aspectos objetivos, tem como amálgama, precisamente, a causa ${ }^{65}$. Nessa ordem de ideias, a causa coordenaria a operação privada como um todo, em seus aspectos subjetivos e objetivos ${ }^{66}$.

Registre-se, por pertinente, que a preponderância da concepção concreta da causa não imporia o completo abandono da ideia de função econômico-social. Apenas deixaria claro que a causa propriamente dita seria concreta, apreendida pela perspectiva dos particulares, pois a ela corresponderia a orientação finalística imposta ao negócio jurídico. A causa típica pertenceria ao plano abstrato; seria um esquema funcional resumido, uma súmula de notas características que, abstratamente, descreveria a classe a que pertenceriam os arranjos de interesses concretamente estabelecidos pelos particulares ${ }^{67}$.

A tese causalista da simulação, dado o momento em que se desenvolveu, não levou em consideração a evolução da noção de causa, acima relatada. Assim, buscou explicar o fenômeno simulatório com base na abstração da causa típica ${ }^{68}$, à qual se oporia 0 escopo prático.

Carnelutti foi um dos que primeiro enveredou por este caminho. Para o autor, a causa seria o interesse objetivo que o sujeito nutriria em relação a um objeto e o levaria a valer-se dos meios necessários a alcançá-lo. Assim, entre a forma e a vontade estaria a causa: a forma corresponderia ao elemento físico, e a vontade ao elemento psicológico; a causa, por seu turno, seria o elemento econômico. A simulação ensejaria uma inadequação da causa ${ }^{69}$.

${ }^{64}$ G. B. FerRI, Il Negozio Giuridico cit. (nota 58), p. 124; F. CARRESI, Il contratto, t. 1, Milano, Giuffrè, 1987, p. 251-252.

${ }^{65}$ G. B. FERRI, Il Negozio Giuridico cit. (nota 58), p. 124.

${ }^{66}$ G. B. FerRI, Causa e tipo nella teoria del negozio giuridico, Milano Giuffrè, p. 355-375, especialmente p. 370-371.

${ }^{67}$ G. B. FERRI, Causa e tipo... cit. (nota 66), p. 349.

${ }^{68} \mathrm{O}$ diagnóstico é S. PugliatTI, La simulazione... cit., (nota 53), p. 559.

${ }^{69}$ F. CARNELUTTI, Sistema... cit. (nota 53), p. 396-399. 
Poderia a forma de um ato ser querida para o atendimento a interesse diverso ou incompatível os seus efeitos jurídicos. $\mathrm{O}$ agente desejaria que uma declaração de vontade produzisse apenas os seus efeitos naturais, não os seus efeitos jurídicos característicos, a fim de que se criasse uma aparência, não uma realidade ${ }^{70}$. Eis o que se daria com o negócio simulado: os contraentes o celebrariam sem o interesse da produções dos efeitos próprios de sua forma.

Betti sustenta, em sentido semelhante, que a simulação seria o resultado de um conflito insanável entre o escopo prático típico e a causa típica; ele expressaria um abuso da função instrumental do negócio jurídico ${ }^{71}$.

Já Romano propõe o exame da simulação a partir de uma concepção dinâmica da causa típica, como se pressentisse as transformações a que esta noção se submeteria nos anos vindouros. Segundo o autor, a causa deveria ser definida levando-se em conta todo o procedimento colocado em prática pelos particulares ${ }^{72}$. Revestir-se-ia de relevância causal não apenas a determinação do tipo ao qual pertencesse o negócio jurídico, como também toda a cadeia de atos praticados pelas partes, desde as tratativas até a execução das prestações convencionadas $^{73}$. Em vista disso, a deliberada inexecução do escopo negocial desnaturaria a causa do negócio simulado, o qual seria válido, mas ineficaz ${ }^{74}$. A simulação acarretaria uma fratura no procedimento negocial ${ }^{75}$; os seus requisitos seriam, portanto, $\mathrm{o}$ negócio simulado, a sua deliberada inexecução e o acordo simulatório ${ }^{76}$.

Vale citar, por fim, a radical formulação de Pugliatti, segundo a qual o negócio simulado não passaria de um negócio jurídico normal cuja causa seria eliminada ou distorcida pelo acordo simulatório. Segundo o autor, a “qualificação 'simulado' não

\footnotetext{
${ }^{70}$ F. CARNELUTTI, Sistema... cit. (nota 53), p. 403-405

${ }^{71}$ E. BETTI, Teoria generale... cit. (nota 53), p. 400.

${ }^{72}$ S. Romano, Contributo esegetico... cit. (nota 53), p. 35.

${ }^{73}$ S. Romano, Contributo esegetico... cit. (nota 53), p. 36.

${ }_{75}^{74}$ S. Romano, Contributo esegetico... cit. (nota 53), p. 34; 45-53.

75 S. Romano, Contributo esegetico... cit. (nota 53), p. 42 . O negócio jurídico surgiria com a produção do respectivo suporte fático; nesta etapa, o tipo seria determinado (e, consequentemente, a causa típica), e a produção dos correspondentes efeitos jurídicos tornar-se-ia indisponível (criado o suporte fático, a incidência da norma jurídica não mais se sujeitaria a qualquer tipo de controle a cargo dos particulares). As partes poderiam, porém, dispor da atuação negocial, deixando de dar cumprimento ao avençado (i.e. não atuação do negócio jurídico), ou o fazendo de modo incompatível com a causa típica (i.e. atuação de um negócio jurídico diferente). Quando preordenada, a inexecução seria capaz de romper o ciclo causal mediante inserção de uma conduta inconciliável com a função típica do negócio jurídico.

${ }^{76}$ S. RoMANO, Contributo esegetico... cit. (nota 53), 1954, p. 41.
} 
encontra suas raízes dentro do esquema do negócio, mas fora deste, e, precisamente, no acordo simulatório"77. Sob esta perspectiva, Pugliatti elevaria o acordo simulatório à condição de eixo central do fenômeno simulatório.

A tese causalista ecoaria nas páginas da dogmática civilística brasileira, ainda durante a vigência do Código Civil de 1916.

Seguindo esta tendência, Orlando Gomes sustenta que a simulação dependeria da presença do acordo simulatório - que a diferenciaria da reserva mental - e do propósito de enganar terceiros. Note-se que a palavra propósito não vem utilizada, aí, a esmo. A simulação poderia vincular-se a variadas razões de ordem subjetiva, que motivariam a adoção deste expediente; tais razões corresponderiam à causa simulandi, isto é, aos motivos determinantes da simulação ${ }^{78}$. A causa simulandi, contudo, não haveria de confundir-se com o fim da simulação, isto é, com a causa concreta ${ }^{79}$ do procedimento levado a efeito pelas partes. Este corresponderia ao propósito negocial viciado, indigno de tutela jurídica porquanto teria por escopo a criação do engano mediante a instauração de uma aparência negocial ${ }^{80}$. Logo, o negócio seria simulado porque o propósito negocial que não se poderia dizer inexistente - consistiria na criação de uma imagem irreal. Esta causa concreta contrastaria com a causa abstrata ${ }^{81}$.

${ }^{77}$ S. Pugliatti, La simulazione... cit., (nota 53), p. 543.

${ }^{78}$ Orlando GoMeS, Introdução ao Direito Civil, 6 a ed., Rio de Janeiro, Forense, 1979, p. 516.

${ }^{79}$ Orlando GOMES, Introdução... cit. (nota 78), p. 445-447; 515. O autor denomina causa abstrata aquela que determina o tipo negocial, e causa concreta a que diz respeito ao fim, à função típica do negócio jurídico. A causa concreta também é designada, em algumas passagens, propósito negocial. Ambos os perfis da causa seriam passíveis de valoração pela norma jurídica, para fins de atribuição de validade e eficácia aos negócios privados Esta bivalência da causa a converteria em fator de justificação do negócio jurídico, na medida em que revelaria a importância dos interesses sociais nele plasmados e, concomitantemente, atestaria a idoneidade do fim prático almejado pelas partes.

${ }^{80}$ Orlando GOMES, Introdução... cit. (nota 78), p. 411; 516.

81 Deve-se ter em vista, contudo, que, muito embora Orlando GOMES atribuísse relevância à causa, não chegou a negar, completamente, a importância da vontade para a caracterização da simulação. Isto se torna evidente quando se examinam as intrincadas linhas ao longo das quais o autor diferencia o negócio simulado das figuras do negócio fiduciário e do negócio indireto.

A princípio, afirma o autor (Introdução cit., nota 78, p. 403), as três classes de negócio jurídico poderiam ser associadas ao emprego de um dado tipo negocial com vistas à obtenção de resultados contrastantes com a sua causa abstrata.

O negócio fiduciário não poderia ser confundido com o negócio simulado pois, embora o primeiro envolvesse uma extrapolação do meio sobre o fim (i.e. o meio negocial utilizado se desdobraria em diversas fases), os negócios jurídicos celebrados seriam todos reais e queridos; isto, porém, não ocorreria na simulação, em que o negócio ostensivamente praticado não corresponderia ao querer da partes. "Ora, não há simulação quando as partes querem realmente o efeito do negócio. Inadmissível identificá-lo [o negócio fiduciário] ao negócio simulado, porque este é o que tem aparência contrária à realidade. No negócio 
Já sob a vigência do Código Civil de 2002, Tércio Sampaio Ferraz Jr. defenderia que a previsão da nulidade do negócio seria um reflexo de uma valoração causalista da simulação, pela qual esta figuraria como questão afeita à causa do negócio jurídico ${ }^{82}$. De maneira semelhante, Mattietto sustentaria que "a simulação não é vício do consentimento, mas defeito em que há incompatibilidade entre a causa típica do negócio e o intento prático das partes" $" 83$.

Por fim, registre-se que Custódio da Piedade Ubaldino Mirando, a despeito de acolher a tese declaracionista para descrever a estrutura da simulação, aproximar-se-ia da tese causalista ao abordar a qualificação jurídica do fenômeno simulatório.

Para o autor, a simulação implicaria uma desvirtuação da causa. Os interesses perseguidos pelos simuladores seriam divergentes dos escopos práticos tipicamente

fiduciário, nenhuma divergência há entre a vontade real e a vontade declarada" (Introdução cit., nota 78, p. 445-447; 515, p. 409).

Semelhantemente, o negócio indireto não se identificaria com o negócio simulado, pois, conquanto pudessem divergir o meio e o fim do negócio (pois a transcendência poderia ser do meio sobre o fim, ou do fim sobre o meio), os negócios jurídicos eventualmente celebrados seriam sempre conforme a real intenção das partes. "Para haver negócio indireto é preciso que, através de negócio típico, que as partes quiserem realmente realizar, seja visado fim diverso do que lhe corresponde. O negócio seria querido pelas partes; por isso não se poderia identificar o negócio indireto com o negócio simulado. Há quem os assimile, mas sem razão. Neste, como se sabe, ou o negócio não existe ou é aparente. No negócio indireto, a vontade é real" (Introdução cit., nota 78 , p. 409; 445-447; 515).

Na esteira do acima exposto, o autor especifica a hipótese inicial, segundo a qual o negócio simulado implicaria o emprego do negócio jurídico com vistas ao alcance de um fím divergente da função típica do negócio. Isto se daria por obra da vontade; esta circunstância seria, pois, a que diferenciaria a simulação de institutos afins. Assim, o negócio simulado acarretaria a aparência do real; no caso da simulação absoluta, haveria a pura aparência; no caso da simulação relativa, os efeitos jurídicos produzidos decorreriam de outro negócio (o negócio dissimulado), o qual diversamente do que sucede com o negócio indireto, exerceria função típica.

${ }^{82}$ Tércio Sampaio FerRaz JR., Simulação e negócio jurídico indireto: no direito tributário e à luz do novo Código civil in Revista Fórum de Direito Tributário, v. 48, 2010, p. 9-26: “O novo Código altera o enquadramento da simulação. Não se trata, necessariamente, de um defeito (da vontade, maliciosa ou inocente), mas da presença de um requisito de validade aparentemente consistente com as regras de validade, mas, na verdade, inconsistente. Por exemplo, o objeto é lícito (requisito de validade), mas contém um dado impossível: apõe-se ao documento uma data anterior àquela em que é firmado, violando o tempo cronológico. Embora possa haver aí vontade maliciosa (intuito de enganar), mais relevante é a presença de uma data que 'faz' do negócio firmado no presente um negócio realizado no passado. O negócio, assim, não é inválido porque mentiroso, mas porque a 'causa temporal' do negócio (quando foi realizado) é apenas aparente (simul, semelhante a uma condição temporal possível). Por isso, pelo novo Código, é nulo e não anulável'.

${ }^{83}$ L. MATtietTo, Negócio jurídico simulado (notas ao art. 167 do Código Civil) in Delgado, Mario Luiz, Alves, Jones Figueirêdo (coords.), Questões Controvertidas - Parte Geral do Código Civil, Série Grandes Temas de Direito Privado - v. 6, São Paulo, Método, 2007, p. 466-480: “A escolha legislativa, passando a simulação de causa de anulabilidade para de nulidade, é respaldada na ideia de que tal figura, mais que restrita a atingir interesses privados, ofende o interesse público de correção e veracidade na relações negociais. A questão não é puramente volitiva, de solução com base na vontade das partes, mas, muito pelo contrário, liga-se à causa do negócio jurídico, pois como ensina Pugliatti, 'o acordo simulatório priva o negócio de sua causa"”. 
associados à forma negocial criada. "Quer isso dizer que existe, na simulação, um desvio da causa: na simulação absoluta, as partes lançam mão do tipo, sem qualquer propósito negocial, mais precisamente, lançam mão de uma forma negocial, correspondente a um determinado tipo, sem o conteúdo correspondente (...) $\mathrm{Na}$ simulação relativa, subsiste o negócio dissimulado, se válido for na substância e na forma (art. 167, parte II), mas o negócio simulado, cuja função é encobrir o negócio dissimulado, continua sendo um negócio com desvio da causa, porque as partes não pretendem alcançar, com a sua celebração, os efeitos que lhe são próprios, correspondentes ao tipo negocial escolhido, mas, sim, os efeitos próprios do negócio dissimulado. Não visam à função econômicosocial própria do negócio simulado, mas a do dissimulado" ${ }^{\Perp 4}$.

\section{§ 2. A SIMULAÇão NO QUADRO DA AUTONOMIA PRIVAdA}

Neste parágrafo, buscaremos identificar os principais traços característicos da simulação enquanto categoria do direito civil. Como veremos, a ausência de uma definição legislativa sugere que se investigue a essência do fenômeno simulatório a partir do conteúdo mínimo comum aos suportes fáticos descritos nos incisos do $\S 1^{\circ}$ do artigo 167.

No desenvolvimento deste estudo, a correspondência entre a simulação e o negócio simulado revelará que a norma não disciplina um vício ou defeito do negócio jurídico, mas uma particular manifestação da autonomia privada. Esta constatação, por fim, abrirá caminho para que passemos a examinar, nos parágrafos seguintes, a materialidade do agir simulado, sobretudo o modo pelo qual este atenta contra a confiança da comunidade e suscita a reação do ordenamento jurídico.

\section{O problema da definição legal de simulação}

É corriqueiro principiar-se o estudo da simulação buscando defini-la com base no sentido ordinário deste vocábulo. Ferrara, por exemplo, chega a afirmar que a simulação não perderia sua natureza ao deslocar-se para o plano normativo ${ }^{85}$. Já Distaso postula que a

\footnotetext{
${ }^{84}$ Custódio da Piedade Ubaldino MiRAndA, Teoria Geral... cit. (nota 51), p. 116-117.

${ }^{85}$ F. FERRARA, A simulação... cit. (nota 20 ), p. 50.
} 
simulação disciplinada pelo direito civil guardaria perfeita correspondência com aquela descrita nos dicionários; simular, portanto, equivaleria a imitar, fingir, falsear etc. ${ }^{86}$

A abordagem empírica ao instituto da simulação, todavia, tem sido duramente criticada. Auricchio destaca que a elaboração de uma noção metajurídica de simulação com recurso ao bom senso ou à tradição seria um esforço em vão. Segundo o autor, a suposição, baseada no senso comum, de que o negócio simulado é um negócio "fingido", afastaria o intérprete de uma elaboração científica relativa aos traçar os limites entre realidade e aparência. ${ }^{87}$ No mesmo sentido, Messineo observa que a noção empírica de simulação não poderia transpor-se para o campo do direito; neste, aquela assumiria um significado próprio, totalmente distinto do indicado nos dicionários ou apreensível a partir da experiência comum ${ }^{88}$.

A nosso juízo, a fixação de um ponto de partida extrajurídico para o desenvolvimento do estudo da simulação (como, aliás, para qualquer categoria jurídica) deve ser evitada. De fato, não seria improvável que o intérprete que pretendesse examinar o negócio simulado com base em dicionários (da linguagem corrente) chegasse a conclusões distorcidas ou incoerentes.

${ }^{86}$ N. DistASO, La simulazione... cit. (nota 40), p. 58-64.

${ }^{87}$ A. AURICCHIO, La simulazione... cit. (nota 19), p. 21-22: "O primeiro problema, preliminar a um estudo sobre a simulação, é a precisa individualização do objeto desta pesquisa; as discussões da doutrina, de fato, versam não apenas sobre a valoração da atividade dos simuladores, mas antes, sobre a atividade material que vem valorada para uma exata reconstrução do instituto. Anunciada esta questão, revela-se logo inadequado o método de adotar um conceito empírico de simulação, ainda que de modo provisório, com a intenção de sucessivamente atribuir-lhe noções jurídicas. Para ilustrar com um exemplo significativo os perigos de tal método, considere-se que da adoção do significado vulgar de simulação deriva, a guisa de corolário, um primeiro princípio: negócio simulado é negócio fingido. Ora, longe de negar ao instituto qualquer relação com o fenômeno da aparência, pode-se bem dizer, pelo contrário, que o escopo da pesquisa sobre o assunto é precisamente o de traçar os limites entre realidade e aparência, e, portanto, de elaborá-los de modo científico: mas é exatamente por isto que parece duvidoso considerar já resolvido o problema assinalado a partir do significado comum do termo "simulação"”. Tradução livre; no original: "Primo problema, preliminare ad uno studio sulla simulazione, è la precisa individuazione dell'oggetto stesso dell'indagine; i dissensi della dottrina, infatti, vertono non solo sulla diversa valutazione dell'attività dei simulanti ma ancor prima sull'attività materiale che va valutata per una esatta ricostruzione dell'istituto. Sollevata questa questione, si rivela subito inadeguato il metodo di adottare un concetto empirico di simulazione, sia pure in modo provvisorio, con intenzione di corredarlo successivamente di nozioni giuridiche. Per illustrare, con esempio significativo, i pericoli di un simile metodo, si consideri che dall'adozione del significato volgare di simulare deriva, a guisa di corollario, un primo principio: negozio simulato è negozio finto. Ora, lungi dal negare all'istituto della simulazione ogni rapporto con il fenomeno dell'apparenza, si può ben dire invece che scopo di un'indagine sul l'argomento è proprio quello di tracciare i limiti tra realtà ed apparenza e quindi di elaborarli in modo scientifico; ma è proprio per questo che sembra dubbio considerare già risolto il problema segnalato nel significato comune del termine "simulazione"".

${ }^{88}$ F. MESSINEO, Il contratto in genere, t. $2^{\circ}$, Milano, Giuffrè, 1972, p. 436. 
Dentre as diversas definições dadas a "simulação" por um certo dicionário, encontram-se, por exemplo, as seguinte: "[r]epresentação do funcionamento de um sistema, processo ou fenômeno para treinamento (esp. para enfrentar situações de perigo) ou diversão (simulação de voo/incêndio)"; "[e]nsaio, teste ou experiência (simulação eleitoral/de vestibular) ${ }^{89}$. Em outro dicionário, a palavra simulação vem definida, dentre outras coisas, como: "Disfarce, dissimulação" 90 . Ora, o vestibulando realiza um exame simulado com o objetivo de preparar-se para o teste de ingresso à universidade, e o aspirante a piloto submete-se a treinamentos em simuladores de voo; seria possível associar este significado à simulação jurídica? Seria a simulação disciplinada pelo direito civil o produto de um treinamento ou ensaio para a celebração futura de um negócio jurídico? Evidentemente que não. E quão grave não seria se o intérprete confundisse simulação e dissimulação, como sugerido em um dos léxicos; a interpretação do caput do artigo 167 tornar-se-ia impossível.

Pensamos, pois, que a definição do termo "simulação" deve ser buscada em um único e específico lugar: na lei. Trata-se de um termo técnico-jurídico, não empírico ${ }^{91}$.

\footnotetext{
89 Simulação (verbete) in Dicionário on line Caldas Aulete, disponível em $<$ http://aulete.uol.com.br/simulação> (acesso em 05/01/2014).

90 Simulação (verbete) in Michaelis Moderno Dicionário da Língua Portuguesa, disponível em $<$ http://michaelis.uol.com.br > (acesso em 05/01/2014).

${ }^{91}$ De fato, a aproximação entre a simulação jurídica e a empírica não é capaz de refletir a "transformação teleológica" mediante a qual o direito capta os dados da experiência. A atividade legislativa é de segundo grau, ou seja, lida com redefinições (A. BELVEDERE, Il problema delle definizione nel codice civile, Milano, Giuffrè, 1977, p. 67 ss.). Neste mister, G. RADBRUCH (Rechtsphilosophie, $8^{\mathrm{a}}$ ed., 1993, trad. port. de M. Holzhausen, Filosofia do Direito, $2^{\mathrm{a}}$ ed., São Paulo, Martins Fontes, 2010, p. 176) refere-se ao conceito de "filoxera", o qual, aparentemente, seria igualmente abrangente, para o direito e a zoologia; uma análise mais cuidadosa, contudo, mostraria que o termo apresentaria alcances distintos para as duas ciências: "seu caráter daninho para os vinhedos, essencial para a ciência jurídica, é totalmente inessencial para a zoologia".

Em vista disso, cabe assinalar que a simulação a que alude o artigo 167 somente pode ser concebida mediante uma operação conjectural. É, sobretudo, com a construção de tipos jurídico-estruturais que se concretiza o chamado pensamento conjectural. A conjectura tem lugar sempre que o legislador vê-se forçado a abandonar a lógica que normalmente orienta nossa compreensão sobre a realidade, abrindo espaço para a configuração de modelos funcionais (Miguel REALE, O Direito como Experiência (Introdução à Epistemologia Jurídica), São Paulo, Saraiva, 1968, p. 177-178). A preterição da causalidade natural (poder-se-ia dizer: a maquinação de uma nova causalidade, peculiar ao direito) deve-se ao fato de a norma destinar-se, em última instância, a conferir realizabilidade a certos valores. $\mathrm{O}$ ato de conjecturar presta-se a superar aquilo que não se pode apreender do real. A razão, aliada à imaginação criadora, visa a ir além da experiência, formulando suposições plausíveis lastreadas na experiência, mas sem o compromisso de refleti-la com fidelidade. Sobre o tema, Miguel ReAle (Verdade e Conjetura, São Paulo, Nova Fronteira, 1983, p. 48-49) ensina: “[e]nganamse, pois, aqueles que reduzem o pensamento conjetural a um jogo quimérico ou arbitrário de imagens: o seu domínio não é o dos conceitos, é certo, mas é o das idéias. O termo do discurso conjetural não são formas imediatas ou mediatas de categorização do real, mas são perspectivas ou vetores de sentido que compõem o leque das idéias, aptas a atuar como coordenadas sistemáticas ou reguladoras das experiências das quais partimos por julgá-las insuficientes a apagar nossa natural ansiedade de compreensão total”.
} 
Tome-se, como exemplo, a pessoa jurídica. Esta não pode ser apreendida diretamente da experiência; não há um conceito que a sintetize a partir da realidade. Há, porém, uma ideia plausível de pessoa jurídica - a conjectura. A pessoa jurídica, ao contrário do que defendem os adeptos da corrente nominalista, não apresenta caráter artificial, ilusório, ou arbitrário. Ela capta o teor funcional intrínseco a toda atividade humana mediante um esquema regulativo de um sistema de relações sociais (centro de interesses socialmente estruturados) ${ }^{91}$. Existe, pois, uma correspondência remota entre o modelo da personalidade jurídica (fato jurídico) e os centros de interesses socialmente estruturados (fato social) (Miguel REALE, O Direito... cit., supra, p. 150-157).

O caráter conjectural da simulação jurídica pode ser confirmado por meio de um exemplo trivial de uso da palavra "simulação" em seu sentido ordinário: simula-se um incêndio em um edifício a fím de realizar-se o treinamento da evacuação dos diversos pavimentos, para o caso de uma concreta emergência. Seria possível conceber o emprego do termo "simulação" com idêntico sentido ao deste exemplo, porém, reportando-se ao negócio jurídico?

A resposta é negativa. Isto decorre do caráter alográfico do negócio jurídico. Não há como simular o negócio jurídico do modo como se simula um incêndio em um edifício. Pela via reversa, se a simulação de incêndio ocorresse como a de um negócio jurídico, o edifício seria efetivamente consumido por chamas.

Eros Roberto GRAU (Ensaio e discurso sobre a interpretação/aplicação do Direito, $5^{\mathrm{a}}$ ed., São Paulo, Malheiros, 2009, p. 30-31; 81-82) diz que o direito é alográfico porque o texto normativo não se completa apenas com o sentido nele impresso pelo legislador. É necessária a intervenção do intérprete, que, desvencilhando a norma do seu invólucro, opera a sua inserção na vida. A circunstância de o direito ser alográfico traz outra consequência: não pode ser imitado, fingido ou falsificado.

Para chegar à conclusão de que o direito é alográfico, Eros Roberto GRAU estabelece a distinção entre artes alográficas e autográficas. Este tema foi examinado detidamente por N. GoODMAN (Languages of Art, $2^{\mathrm{a}}$ ed., Indianapolis, Hackett, 1976, p. 116) que se propôs a solucionar o seguinte dilema: por que seria possível falsificar um quadro de Rembrandt, mas seria impossível falsificar uma sinfonia de Haydn? A resposta residiria no fato de as artes alográficas (como a música) fundarem-se em uma linguagem definida, que permite identificar o original simplesmente confrontando cada elemento da sua notação (letra, nota, número) com aqueles presentes no exemplar avaliado. Se uma suposta cópia apresentasse um desvio com relação ao original, tratando-se de uma arte alográfica, não se diria estar-se diante de uma imitação; quando muito, deparar-se-ia com uma cópia errada, ou, então, de um novo original. As artes autográficas não se encontram nesta situação, pois não se expressam em uma notação definida. A identidade da obra de arte somente pode precisar-se com recurso ao fato histórico da sua criação. Lucrécia não seria, pois, apenas o quadro que retrata a jovem romana que tragicamente se suicidara, mas a obra criada por Rembrandt em dado e específico momento histórico. Esta referência espaço-temporal não apenas seria necessária para tornar o trabalho único, como implicaria a possibilidade da sua falsificação ou imitação.

A manifestação de vontade negocial não perde sua natureza, nem se despe de relevância jurídica, em razão de as partes intencionarem fingi-la. Na tentativa de simular o negócio jurídico (em termos empíricos), os particulares infalivelmente dão-lhe vida. Encarar a simulação jurídica empiricamente é, por isso, uma tarefa inviável, que esbarra numa necessária imbricação entre o fictício e o real ${ }^{91}$. J. BAUDRILLARD (Simulacres et simulation, 1981, trad. port. de M. J. Costa Pereira, Simulacros e Simulação, Lisboa, Relógio d'Água, 1991, p. 30) contribui com a compreensão desta ideia ao cogitar da hipótese de um assalto simulado: "Por exemplo: seria interessante ver se o aparelho repressivo não reagiria mais violentamente a um assalto simulado que a um assalto real. (...) A simulação é infinitamente mais perigosa, pois deixa sempre supor, para além do seu objecto, que a própria ordem e a própria lei poderiam não ser mais que simulação. Mas a dificuldade está à altura do perigo. Como fingir um delito e prová-lo? Simule-se um roubo numa grande loja: como convencer o serviço de segurança de que se trata de um roubo simulado? Nenhuma diferença "objetiva": são os mesmos gestos, os mesmos signos que para um roubo real, ora os signos não pendem nem para um lado nem para o outro. Para a ordem estabelecida são sempre do domínio do real. Organize-se um falso assalto. Verifique-se bem a inocência das armas e faça-se o refém mais seguro que nenhuma vida humana fique em perigo (pois aí cai-se sob a alçada do direito penal). Exija-se um resgate e proceda-se de maneira que a operação tenha toda a repercussão possível - em suma, imite-se o mais possível a "verdade" a fím de testar a reacção do aparelho a um simulacro perfeito. Não será possível: a rede de signos artificiais vai-se imbricar inextrincavelmente com os elementos reais (um policial vai realmente disparar à vista; um cliente do banco vai desmaiar e morrer de ataque cardíaco; vai ser realmente pago o resgate fingido), em suma, ser-se-á devolvido imediatamente, sem o querer, ao real, uma das funções do qual é precisamente devorar toda a tentativa de simulação, reduzir tudo a real - a ordem estabelecida é mesmo isso, bem antes da entrada em cena das instituições da justiça”. 
A resolução de recorrer-se ao texto normativo para buscar o significado de simulação vem, contudo, acompanhada por ulteriores complicações. É que, a bem se ver, o artigo 167 não define a simulação. O caput do dispositivo estabelece que o negócio simulado é nulo; por seu turno, o $\S 1^{\circ}$ do referido artigo, ao dizer que "[h]averá simulação nos negócios jurídicos quando (...)", não enuncia os caracteres da simulação, enquanto categoria jurídica, mas suportes fáticos aos quais deve ser aplicada a disciplina descrita no artigo; são eles: [os negócios jurídicos que] aparentarem conferir ou transmitir direitos a pessoas diversas daquelas às quais realmente se conferem, ou transmitem (inciso I); [os negócios jurídicos que] contiverem declaração, confissão, condição ou cláusula não verdadeira (inciso II); e [os negócios jurídicos cujos] instrumentos particulares forem antedatados, ou pós-datados (inciso III). Tais suportes fáticos, logo se nota, são espécies (melhor dizer, como veremos, tipos) de negócios simulados; a simulação, em si, seria uma qualidade comum àqueles três suportes fáticos, a qual, no entanto, a norma não chega a definir.

É elucidativa, neste mister, a comparação do artigo 167 com o $\mathrm{n}^{\circ} 1$ do $\operatorname{artigo} 240^{\circ}$ do Código Civil português, o qual, a pretexto de definir o negócio simulado, traça os contornos característicos da própria simulação: "Se, por acordo entre declarante e declaratário, e no intuito de enganar terceiros, houver divergência entre a declaração negocial e a vontade real do declarante, o negócio diz-se simulado". A partir desta dicção legal, não se mostraria despropositado vislumbrar a definição de simulação como divergência entre vontade e declaração resultante de um acordo entre declarante e destinatário da declaração. No direito brasileiro, diversamente, esta dedução não se mostra viável, razão pela qual a simulação, citada no $\S 1^{\circ}$ do artigo 167 , assume a feição de ferramenta de apresentação.

Como explica Ross, trata-se, a ferramenta de apresentação, do conceito jurídico que, conquanto desprovido de referencial semântico, desempenha um papel importante na estruturação do sistema normativo, interligando fatos condicionantes a consequências jurídicas $^{92}$. O tema foi explorado com desenvoltura num simpático artigo que o autor intitulou $T \hat{u}$-Tĥ. Esta seria uma expressão utilizada pelos integrantes da tribo Aisat-Naf, instalada nas Ilhas Oasuli, para se referir à circunstância (ao estado de coisas) surgida

92 A. Ross, On law and justice (1958), trad. port. de E. Bini, Direito e Justiça, São Paulo, Edipro, 2003, p. 203-212. 
quando um determinado tabu fosse violado (e.g. um homem tivesse um encontro com a sogra, ou alguém matasse um animal totêmico). Quem se investisse em th-tĥu seria considerado ameaçado por uma força sobrenatural perigosa, e por isso haveria de submeter-se a um ritual de purificação ${ }^{93}$. Tomando esta interessante história como inspiração, Ross sugere que dois tipos de proposição poderiam ser elaborados com relação a $t \hat{u}-t \hat{u}^{94}$ :

(a) proposição descritiva: quem quebra um tabu está $t \hat{u}$-th; e

(b) proposição prescritiva: quem está th-tĥu deve submeter-se ao ritual de purificação.

Em nenhuma de tais proposições, porém, tĥu-tĥu teria um sentido próprio. Para apreender com maior clareza as conclusões de Ross, reproduzamos o seu raciocínio tomando como exemplo a suposta definição legal de simulação. Partindo-se do disposto, por exemplo, no caput e no inciso III do $\S 1^{\circ}$ do artigo 167 , seria possível formular duas diferentes proposições:

(a) proposição descritiva: sempre que houver antedata em instrumento particular de um negócio jurídico, haverá simulação; diga-se, haverá th-th-doravante, "fato 1"; e

(b) proposição prescritiva: se o negócio jurídico contém th-tĥ, deve ser declarado nulo - doravante, "fato 2 ".

No cenário que se descortina, o que significaria $t \hat{u}-t \hat{u}$ ? Após algumas tentativas e erros, descobrir-se-ia que a única resposta não absurda seria obtida substituindo fato 1 por fato 2 nas proposições antes elaboradas ${ }^{95}$. O resultado seria algo do tipo: sempre que houver antedata em instrumento particular de um negócio jurídico $\rightarrow$ o negócio jurídico deve ser nulo.

Como se nota, ao tentar-se descobrir o significado de $t \hat{u}$-tĥ, constatar-se-ia que esta expressão não possui qualquer importância que não a realização da cópula entre o

\footnotetext{
${ }^{93}$ A. Ross, Th-Tû (1957), trad. port. de E. Bini, Tĥ-Tĥ, São Paulo, Quartier Latin, 2004, p. 13-14.

${ }^{94}$ A. Ross, Th-Tû cit. (nota 93), p. 17-20.

${ }^{95}$ A. Ross, Th-Tû cit. (nota 93), p. 23-29.
} 
fato 1 e o fato 2. Com este raciocínio, Ross demonstrou que diversos conceitos utilizados pelo legislador são desprovidos de significação própria. Poderiam ser descartados, não fosse sua inegável utilidade como ferramenta de apresentação, isto é, como meio de correlação entre fatos condicionantes e consequências jurídicas ${ }^{96}$. O conceito de propriedade, por exemplo, não passaria de um aparato conceitual oco, embora fosse útil; tal qual um organizador, enfeixaria certos fatos em torno das consequências jurídicas correspondentes, facilitando a aplicação da norma. Algo semelhante parece suceder com a simulação a que faz referência o $\S 1^{\circ}$ do artigo 167 .

Contra esta linha de argumentação, poder-se-ia defender que o legislador brasileiro teria formulado uma definição denotativa (ou extensiva) de simulação. Por meio desta técnica, a delimitação do definendum dá-se mediante a enumeração dos objetos, ou de exemplos de objetos, por ele denotados ${ }^{97}$. A palavra metal, por exemplo, poderia ser definida, denotativamente, aludindo-se a ferro, cobre, prata, manganês, mercúrio, etc.

Deve-se observar, contudo, que a definição denotativa requer que os termos que definem as espécies sejam notáveis, isto é, possuam significado unívoco e facilmente apreensível $^{98}$. Assim, para definir a palavra compositor, poder-se-ia mencionar nomes como os de Mozart, Beethoven, Tchaikovsky e Mahler; ficaria evidente, neste caso, o traço em comum entre os diversos elementos do definens. Isto, porém, não sucede com as supostas instâncias denotativas contidas nos incisos do $\S 1^{\circ}$ do artigo 167 , pois cada uma delas descreve um suporte fático complexo, cujas semelhanças não são óbvias. Além disso, a definição denotativa não pode ser adotada quanto a termos que não possuam referencial denotativo, como unicórnio ${ }^{99}$. Se a ferramenta de apresentação é identificada exatamente

\footnotetext{
${ }^{96}$ Confira-se o que o autor diz a respeito (Tĥ-Tû cit., nota 93, p. 32-34): "Dessa maneira - é preciso admiti-lo - nossa terminologia e nossas idéias apresentam uma considerável semelhança estrutural com o pensamento mágico primitivo, com respeito à invocação de potências sobrenaturais, as quais, por sua vez, são convertidas em efeitos fáticos. (...) Creio que esse é o caso, e tomarei como ponte de partida o conceito de propriedade. As normas jurídicas que dizem respeito à propriedade podem, sem dúvida, ser expressas sem necessidade de empregar essa palavra. Em tal caso haveria de formular um grande número de normas, que ligam diretamente as consequências jurídicas individuais com os fatos jurídicos individuais. Por exemplo: Se uma pessoa adquiriu licitamente uma coisa mediante compra, deverá ser acolhida a ação que, para obtenção de sua entrega, essa pessoa instaure contra outros que a retêm em seu poder. Se uma pessoa herdou uma coisa, deverá ser acolhida a ação por perdas e danos que essa pessoa mova contra outros que, por negligência, causaram danos à coisa".

${ }^{97}$ I. M. COPI, Introduction to Logic, trad. port. de A. Cabral, Introdução à Lógica, $2^{\mathrm{a}}$ ed., São Paulo, Mestre Jou, 1978, p. 123-124.

98 A. BELVEDERE, Il problema delle definizione... cit. (nota 91), p. 92.

${ }^{99}$ Cf. I. M. CopI, Introdução à Lógica cit. (nota 97), p. 124.
} 
por carecer de um referencial semântico, logo não há como defender que ela poderia ser objeto de uma definição denotativa.

$\mathrm{Na}$ realidade, mais adequado que cogitar-se de uma definição denotativa seria buscar vislumbrar, no artigo 167 uma definição condicional, assim entendida aquela que alude ao definendum por intermédio do emprego de condições impostas à utilização de uma determinada qualificação. Dessa feita, a caracterização de um dos suportes fáticos descritos no $\S 1^{\circ}$ do dispositivo acima citado seria a condição para a manifestação da simulação, isto é, o pressuposto da qualificação do negócio jurídico como simulado. Esta constatação, todavia, somente viria a confirmar que a simulação figura, no texto legal, como ferramenta de apresentação (ou termo qualificador), e que não existe uma definição legislativa que lhe seja correlata, pois apenas os fatos condicionantes são definidos ${ }^{100}$.

As considerações acima apresentadas levam-nos a concluir que, diante da omissão legislativa, a tarefa de definir a simulação incumbe à doutrina. Tal constatação não deve ser entendida como atributiva de discricionariedade ao intérprete, o qual, tanto quanto possível, deve buscar fundamentos no direito positivo para amparar suas construções. Mais especificamente, deve, o jurista, buscar identificar o conteúdo mínimo comum às espécies delineadas nos incisos do $\S 1^{\circ}$ do artigo 167, pois, do contrário, seria inviável interpretar-se os próprios suportes fáticos ali descritos, os quais, bem se nota, apresentam contornos fluidamente demarcados.

Outro aspecto a ser notado refere-se à identidade que esta postura hermenêutica estabelece entre a simulação e o negócio simulado. Sendo certo que a norma não disciplina os efeitos da simulação, mas do negócio simulado, é acertado afirmar que tais figuras constituem o âmago de uma questão unitária. Seria, com efeito, inadmissível perguntar, em primeiro lugar, sobre o que seria a simulação, para apenas depois indagar a respeito do que seria o negócio simulado.

\footnotetext{
${ }^{100}$ A. BELVEDERE, Il problema delle definizione... cit. (nota 91), p. 86-87. O autor afirma que a definição condicional seria por demais complexa para ser empregada pelo legislador e que dela se valeria apenas a doutrina, para eliminar termos qualificadores empregados na norma por motivo de brevidade ou simplicidade. Não parece, contudo, que o legislador brasileiro tenha se intimidado por tal complexidade, pois descreveu as condições à qualificação do negócio jurídico como simulado sob a forma de tipos jurídicoestruturais, como teremos oportunidade de expor (v. tópico 26).
} 
Entre simulação e negócio simulado existe, não se nega, uma relação de resultado, mas apenas no sentido em que tal relação também se instaura relativamente à atividade negocial e o contrato. Pense-se num contrato de compra e venda: as partes conduzem uma fase de tratativas, no curso da qual ajustam o propósito de celebrar a avença; na sequência, firmam o acordo, tendo por objeto a troca da coisa pelo preço. Não faria sentido cogitar-se, neste caso, de um "acordo compravenditório" autônomo, tendo por objeto colorir o contrato com os atributos próprios da compra e venda. A relação jurídica forma-se como um todo, ainda que no curso de um progressivo processo deliberativo, cujo momento finalístico é a formação do enlace contratual. Analogamente, a simulação não é mais que a atividade desenvolvida pelas partes para determinar o surgimento do negócio simulado. Aquela constitui um fato com sua própria disciplina, mas não difere, enquanto fenômeno jurídico, do negócio simulado, que nada mais é que o instrumento que lhe confere expressão na caso concreto.

Desse modo, ao contrário do que se costuma afirmar, o negócio simulado não é um "elemento da simulação"; a simulação, enquanto "ação do simular", e o negócio simulado, como "ato simulado", são faces de um só fenômeno, apreendido em sua dimensão dinâmica (procedimental) - no caso daquela -, e estática - no que tange a este. Consequentemente, é de se negar a existência de dois problemas distintos, o da simulação e o do negócio simulado ${ }^{101}$.

Isto posto, passaremos a investigar o conteúdo mínimo que aproxima as hipóteses discriminadas nos incisos do $\S 1^{\circ}$ do artigo 167, o qual, a um só tempo, caracteriza a simulação e condiciona a atribuição, ao negócio jurídico, da qualificação "simulado". Como o leitor poderá notar, empregaremos, no decorrer da exposição, as expressões "simulação" e "negócio simulado" para nos referir o fenômeno a que se dirige a disciplina do artigo 167. Antes, contudo, de partir para um exame mais aprofundado da matérias, um esclarecimento terminológico mostra-se necessários.

${ }^{101}$ Conclusões análogas foram sustentadas, na Itália, por A. AURICCHIO, La simulazione... cit. (nota 19), p. $24 ; 46 ; 47$. 


\section{Esclarecimento terminológico}

Costuma-se estabelecer uma identidade entre o negócio simulado e a aparência que ele ostenta. Segundo esta abordagem, uma compra e venda simulada seria, a princípio, uma compra e venda, embora apresentasse uma imperfeição estrutural que a tornaria meramente aparente. No entanto, este raciocínio apresenta falhas: a compra e venda aparente não deve ser confundida com o negócio (dito "simulado") que se reveste desta aparência. A situação jurídica aparente não coincide com o suporte fático da relação jurídica real $^{102}$.

Para tornar esta ideia mais clara, recorramos ao singelo exemplo do peixe-pedra (Synanceia verrucosa), um dos inúmeros animais dotados da habilidade se camuflar-se dentre rochas ou corais presentes no fundo do mar. Acaso se adotasse o raciocínio segundo o qual a aparência se confunde com aquilo que dela se reveste, dir-se-ia que o peixe-pedra seria uma pedra defeituosa; no lugar de estruturas cristalinas ou sedimentares, a imperfeita rocha seria composta de carne e osso. O peixe pareceria uma pedra, e por conta disso, seria uma pedra.

Haveria algum sentido nesta insólita formulação? Certamente não.

$\mathrm{Na}$ descrição da simulação, há de se distinguir, de um lado, a aparência, e de outro, a realidade negocial. Tradicionalmente, esta distinção estabelece uma oposição entre o negócio simulado e o negócio dissimulado. Tal dicotomia tem levado a pensar que na simulação absoluta haveria apenas um negócio jurídico, enquanto na simulação relativa seriam dois. Quem assim pensa, todavia, não se dá conta do fato de que, na simulação, há sempre um único negócio jurídico, cujo propósito é, na simulação absoluta, exclusivamente o de criar uma aparência negocial, e, na simulação relativa, o de revestir a operação negocial de uma aparência anormal, camuflando-a, tal qual faz a pele do peixepedra. "Simular é criar esta falsa aparência negocial"103. Desse modo, é mister ter em mente que o negócio simulado é uma coisa, e a aparência que ele estabelece é outra, completamente diferente. Deve-se, pois, distinguir o negócio simulado do "negócio aparente".

\footnotetext{
${ }^{102}$ R. Moschella, Contributo alla teoria dell'apparenza giuridica, Milano, Giuffrè, 1973, nota, p. 37.

${ }^{103}$ P. PAis De VAsconcelos, Teoria Geral do Direito Civil, 6 a ed., Coimbra, Almedina, 2010, p. 682-683.
} 
A própria tese causalista, que prometia superar as limitações apresentadas pelas teorias da vontade e da declaração, não dá a devida importância à distinção entre a causa do negócio simulado e a causa que este aparenta possuir. Tal deslize é comparável ao do sujeito que, indagado sobre a função de um objeto, responde, pensando ser uma caneta, que ela serviria como instrumento de escrita; diria isto, porém, sem notar que o objeto em questão seria um espelho que reflete uma caneta, e que a resposta correta seria: "sua função é refletir tudo o que jaz à sua frente”. Dizer que o negócio simulado exerce uma função incompatível com aquela atribuível à sua aparência é tão absurdo quanto assumir que a função do espelho seria a de escrever, e que esta, circunstancialmente, deixaria de ser cumprida. O fato de o espelho criar um reflexo que pode, sob certas circunstâncias, enganar o observador (pense-se nos jogos de espelhos explorados por ilusionistas em atrações de parques de diversão), em nada prejudica a sua perfeita funcionalidade, qual seja, a de refletir a todo momento o que seja colocado à sua frente.

No decorrer deste trabalho, passaremos a nos referir ao negócio simulado, seguindo a dicção da lei, como aquele que "aparenta", isto é, o que, contendo declaração não verdadeira, produz a aparência negocial. Por outro lado, quando aludirmos ao "negócio aparente", teremos em vista a imagem que o negócio simulado transmite. A oposição é muito clara: o negócio simulado é o instrumento, o "negócio aparente" é o resultado; o negócio simulado é produzido pelas partes, o "negócio aparente" é uma construção da razão do público ${ }^{104}$. Com efeito, não existe aparência entre os simuladores; somente o ponto de vista dos terceiros faz surgir a equivocada representação da realidade correspondente à aparência.

\section{O caráter instrumental do negócio simulado}

A percepção de que o negócio simulado não é o que aparenta ser (assim como o peixe-pedra não é uma pedra, mas um peixe) leva-nos, acompanhados da doutrina contemporânea, a inseri-lo no quadro da autonomia privada. Afinal de contas, a aparência é uma realidade juridicamente relevante que pode ser voluntariamente produzida ${ }^{105}$. O negócio simulado, portanto, institui um programa pelo qual as partes buscam reproduzir a

\footnotetext{
${ }^{104}$ F. DURAND, L'apparence en droit fiscal, Paris, LGDJ, 2009, p. 19.

${ }^{105}$ U. MAJELLO, Il contratto simulato: aspetti funzionali e strutturali in Rivista di Diritto Civile, Padova, n. 5 , Settembre-Ottobre, 1995, p. 643.
} 
eficácia de um contrato queridamente desprovido de eficácia ${ }^{106}$; por outras palavras, ele é um instrumento de que se utilizam os contraentes para obter a representação, aos olhos dos terceiros, de um dado efeito jurídico (um ato translativo, o nascimento ou a extinção de uma obrigação etc.) $)^{107}$.

Um dos marcos na tentativa de superação da insuficiência das teses tracionais da simulação dá-se com a publicação da obra de Auricchio. O autor salienta que a redução da autonomia privada a um problema de simples correspondência entre o suporte fático e a respectiva previsão legislativa deixaria sem explicação a eficácia jurídica do regulamento de interesses contido no negócio jurídico. Seria, assim, compreensível que a moderna literatura jurídica tentasse suplantar a concepção pandectística segundo a qual toda eficácia resultaria da produção do suporte fático, buscando identificar os reais contornos da autonomia privada não mais no aspecto estrutural, mas sim no perfil dinâmico e funcional das relações jurídicas ${ }^{108}$.

O fenômeno da simulação colocaria em evidência esta dupla dimensão da autonomia privada, uma vez que as partes criam um título ou documento típico, apto a assumir relevância enquanto suporte fático estruturalmente perfeito, embora a este não correspondesse um regulamento efetivo. Por outras palavras, a autonomia privada comportaria duas diferentes valorações normativas: "Uma, que nesta sede se considera condicionada à perfeição do suporte fático legislativo, consiste na valoração operada pelo legislador sobre o comportamento das partes. A outra, ao invés, interna à primeira, é propriamente a valoração que as partes formulam quanto aos próprios interesses e encontra a sua expressão em termos de eficácia negocial”"109.

\footnotetext{
${ }^{106}$ U. MAJELLO, Il contratto simulato... cit. (nota 105), p. 645.

107 N. Cipriani, La simulazione di effeti giuridici. Appunti sulla fattispecie, 2012, disponível em $<$ http://www.giurisprudenza.unisannio.it>, p. 8.

${ }^{108}$ A. AURICCHIO, La simulazione... cit. (nota 19), p. 11. Tradução livre; no original: "Posta la questione in questi termini, ben si comprende che la letteratura giuridica contemporanea tenti di superare quella tipica posizione pandettistica attraverso il superamento dello stesso concetto di fattispecie negoziale; conseguentemente, si cerca di cogliere le reali dimensioni del fenomeno dell'autonomia privata non più sotto l'aspetto strutturale, ma piuttosto nel suo profilo dinamico e funzionale".

109 A. AURICCHIO, La simulazione... cit. (nota 19), p. 15. Tradução livre; no original: "L'una, che in questa sede si ritiene condizionata alla perfezione della fattispecie legislativa, corrisponde alla valutazione operata dal legislatore sul comportamento delle parti. L'altra invece, interna alla prima, è proprio la valutazione che le parti fanno dei propri interessi e trova la sua espressione in termini normativi dell'efficacia negoziale".
} 
Auricchio defende que a relevância normativa da vontade poderia ser de dois tipos: em certos casos, aquela constituiria o pressuposto de fato de efeitos jurídicos predeterminados; em outras situações, teria o condão de determinar a extensão dos próprios efeitos jurídicos. Instaurar-se-ia, neste termos, uma oposição entre a dinâmica do suporte fático e a do regulamento de interesses. Esta dúplice relevância justificaria a circunstância de uma declaração preceptiva, como, por exemplo, o casamento, ser valorada, pela ordem jurídica, como mero ato legítimo. No caso do negócio simulado, a ausência de vontade de conteúdo - configurada na dimensão pré-jurídica - seria reconhecida, pela norma, como determinante do seu modo de ser, isto é, como fator apto a excluir a operatividade do regulamento de interesses, sem, porém, prejudicar a integridade do suporte fático ${ }^{110}$.

O negócio simulado, segundo o autor, não pareceria perfeito, mas efetivamente o seria. As partes não criariam um negócio fingido; a aparência referir-se-ia exclusivamente aos efeitos finais, que na verdade faltariam, conquanto os terceiros acreditassem no contrário. A referência à eficácia negocial, para além da dinâmica do suporte fático, seria confirmada pelo fato de que, na simulação, o regulamento de interesses estabelecido pelas partes - não o suporte fático - seria aparente ${ }^{111}$.

A teoria de Auricchio funda-se, como deixamos entrever, na suposição de que o regulamento de interesses seria um pacto $n u$, isto é, uma convenção não formalizada caracterizadora de um núcleo de pura eficácia ${ }^{112}$. O negócio jurídico, portanto, não consistiria num regulamento de interesses revestido por uma forma, mas na soma de um suporte fático - com base no qual se processaria o juízo de validade ou invalidade - e um pacto nu, responsável por atribuir operatividade ao suporte fático no plano da eficácia. Daí a definição da simulação como alteração patológica de um negócio jurídico capaz de excluir a sua eficácia ${ }^{113}$.

A doutrina, em geral, não tem acolhido esta segregação entre o suporte fático e o regulamento de interesses. Pelo contrário, prepondera o entendimento de que o regulamento de interesses integra o próprio suporte fático; e nisto, precisamente, consistiria

\footnotetext{
${ }^{110}$ A. AURICCHIO, La simulazione... cit. (nota 19), p. 77.

${ }_{111}$ A. AURICCHIO, La simulazione... cit. (nota 19), p. 87.

${ }^{112}$ A. AURICCHIO, La simulazione... cit. (nota 19), p. 12.

${ }^{113}$ A. AURICCHIO, La simulazione... cit. (nota 19), p. 57.
} 
a diferença entre o negócio jurídico e o ato jurídico em sentido estrito ${ }^{114}$. De todo modo, as proposições de Auricchio chamam a atenção para o fato de que a simulação não deve ser concebida como uma deficiência (quantitativa ou qualitativa), mas como um particular modo de ser do negócio jurídico enquanto ato de autonomia privada.

Neste sentido, Ceroni sugere que o negócio simulado equivaleria a uma espécie de manifestação oblíqua da autonomia privada. A simulação, por si, seria indiferente para o direito; apenas se ela viesse acompanhada de um motivo determinante ilícito associado caberia uma reação contrária do ordenamento jurídico ${ }^{115}$. Já Majello identifica no negócio simulado uma manifestação anômala de autonomia privada ${ }^{116}$. O autor propõe a distinção entre a simulação juridicamente irrelevante e a simulação juridicamente relevante ${ }^{117}$. Pertenceriam ao primeiro grupo as declarações de vontade jocandi causa, docendi causa ou teatrais. No segundo grupo, estariam as simulações de negócios jurídicos propriamente ditas. Enquanto a simulação juridicamente irrelevante acarretaria a inexistência do negócio jurídico, por falta de elementos essenciais do suporte fático (a vontade, o acordo, o consenso etc.), isto não se daria com o negócio jurídico submetido à simulação juridicamente relevante, que não deixaria de viabilizar a composição entre os interesses dos contraentes.

A esta altura do discurso, poder-se-ia objetar que tais desenvolvimentos teóricos, observados no âmbito da doutrina italiana ${ }^{118}$, não poderiam servir de inspiração ao trabalho de interpretação do artigo 167. Deveras, os autores antes aludidos chegam à conclusão de que o negócio simulado seria válido, embora relativamente ineficaz ${ }^{119}$. Diversamente, o Código Civil de 2002 teria cominado, ao negócio simulado, a sanção de nulidade, o que deveria, supostamente, descartar a possibilidade de aquele integrar a esfera da autonomia privada.

Vale notar, porém, que a inclinação dogmática acima examinada também se faz presente em outros países. Na Espanha, por exemplo, Coderch sustenta que o direito civil

\footnotetext{
114 R. Scognamiglio, Contributo ala teoria del negozio giuridico, $2^{\mathrm{a}}$ ed. (1969), Napoli, Jovene, 2008, p. 103 .

${ }_{115}$ C. CERONI, Autonomia privata e simulazione, Padova, CEDAM, 1990, p. 22.

${ }^{116}$ U. MAJELLO, Il contratto simulato... cit. (nota 105), p. 642.

${ }^{117}$ U. MAJELLO, Il contratto simulato... cit. (nota 105), p. 641-656.

${ }^{118}$ V., também, A. Luminoso, Il mutuo dissenso, Milano, Giuffrè, 1980, p. 220.

${ }^{119}$ F. Galgano, Il negozio giuridico, $2^{\mathrm{a}}$ ed., Milano, Giuffrè, 2002, p. 368 ss.; F. MessineO, Il contratto in genere cit. (nota 88), p. 487 ss.
} 
espanhol não proibiria, em caráter geral, a simulação absoluta ou relativa, razão pela qual inexistiria um dever geral de abster-se de simular negócios jurídicos ${ }^{120}$. Na França, Dagot assevera que a simulação expressaria a necessidade humana de manter certos negócios em segredo; em alguns casos, a intenção das partes poderia até ser reprovável, por envolver a prática de fraude, contudo, nada autorizaria a suposição da existência de uma regra geral segundo a qual estaria proibida a prática da simulação ${ }^{121}$.

Vem, contudo, da Alemanha a confirmação da relação entre simulação e autonomia privada, a despeito da nulidade do negócio simulado. Como se sabe, o $§ 117$ do Código Civil alemão reputa nulo o negócio simulado. Em vista disso, vários autores afirmam que o artigo 167 teria reproduzido o paradigma normativo do direito alemão ${ }^{122}$. Neste contexto, o paralelo entre o Código Civil de 2002 e o Código Civil alemão não se mostra despropositado.

Deve-se notar que numa obra mais recente que aquelas geralmente citadas pelos autores brasileiros que se valem do direito alemão como modelo para a interpretação do artigo 167, Kallimopoulos assevera, incisivamente, que a simulação não deveria ser explicada com base nas teorias da vontade ou da declaração, mas a partir do princípio da autonomia privada. "O regramento do $\S 117$, seções 1 e 2, do Código Civil alemão deve ser tido como indissociável do princípio da autonomia privada, de modo que o apelo às teorias da declaração, da vontade e da validade ${ }^{123}$ se mostra descabido, e a problemática,

${ }^{120}$ P. S. CODERCH, Simulación Negocial, Deberes de Veracidad y Autonomía Privada in P. S. CODERCH - J. M. S. SÁnchez, Simulación e deberes de veracidad - Derecho civil e derecho penal: dos estudios de dogmática jurídica, Madrid, Civitas, 1999, p. 19-20.

${ }^{121}$ M. DAGOT, La simulation... cit. (nota 50), p. 10. Neste contexto, afirma-se que o legislador francês teria adotado uma abordagem juridicamente neutra com relação à simulação (Cf. F. DEBOISSY, La simulation en droit fiscal, Paris, LGDJ, 1997, p. 2). Eventual sanção jurídica somente tornar-se-ia aplicável em razão de uma causa superveniente e independente (e.g. fraude, dolo), mas não da simulação, em si. Os particulares, diz M. DAGOT, teriam o direito de manter certos negócios em segredo; logo, a simulação nada mais seria que um instrumento jurídico legítimo, corolário da autonomia, o qual, em princípio, não induz a ilicitude do contrato, nem tampouco implica qualquer prática proibida (p. 10).

${ }^{122}$ Por exemplo: I. GAINO, A Simulação dos Negócios Jurídicos, $2^{\mathrm{a}}$ ed., São Paulo, Saraiva, 2012, p. 46-47; R. Senise LisboA, Manual de Direito Civil, v. 1 - Teoria Geral do Direito Civil, 6 a ed., São Paulo, Saraiva, 2010, p. 468; Humberto THEODORO JÚNIOR, Comentários... cit. (nota 38), p. 469.

${ }^{123} \mathrm{O}$ recurso às teorias da vontade e da declaração, no âmbito do estudo da simulação, houvera sido questionado pela doutrina alemã. K. LARENZ (Allgeimeiner Teil des deutschen Bürgerlichen Rechts, 1975, trad. esp. de M. Izquierdo y Macías-Picavea, Derecho Civil - Parte General, Madrid, EDERSA, 1978, p. 450) defendia a adoção, pelo Código Civil alemão, de uma concepção ojetiva do negócio jurídico, fundada na pretensão de validez: "[e]n realidad, la declaración de voluntad jurídico-negocial es no sólo una comunicación, sino una manifestación de validez, y, como tal, es en los casos una realización de la voluntad que se dirige a producir efectos jurídicos, la cual se hace valer en ella. La voluntad meramente interna nada puede producir. Si hago saber a otro únicamente que quiero (actualmente) esto o aquello, no por eso se me 
suscitada pela discussão completamente supérflua destas teorias contribuirá mais para tornar as questões obscuras que para esclarecê-las"124.

Dando um passo além, Kallimopoulos postula que a ausência de pretensão de validade seria apreendida, pela ordem jurídica, como uma particular concretização da autonomia privada: o lado negativo da autonomia privada. Inspirado em Kant, o autor distingue duas dimensões da autonomia privada: a positiva e a negativa. A autonomia privada positiva seria aquela concretizada com a produção de atos que vinculariam os particulares, com vistas à efetiva produção de efeitos jurídicos; a autonomia privada negativa consistiria na atuação destinada à não obtenção de efeitos jurídicos, isto é, à criação da simples aparência negocial ${ }^{125}$.

Para Kant, toda grandeza negativa (inclusive o lado negativo da liberdade) seria, na verdade, uma grandeza positiva, com a peculiaridade de se colocar, circunstancialmente, em oposição com outra grandeza. Não haveria, porém, de se confundir a grandeza negativa com a ausência de qualquer grandeza ${ }^{126}$.

impide querer otra cosa acto seguido. Por el contrario, si digo: 'Me comprometo a hacer esto o aquello', esta declaración tiene carácter definitivo. El declarante - en tanto que no se reserve la revocación - renuncia a la posibilidad de alegar una modificación de su voluntad; se ha 'vinculado' mediante la declaración. Así considerada, la declaración de voluntad - no de otro modo que una ley o una sentencia firme - es un acto determinante. Este tiene por fin no sólo dar a conocer un hecho exterior a él mismo, sino inmediatamente la producción del efecto jurídico en él señalado, al manifestar que éste (con la declaración y desde ahora) debe tener validez". Em sintonia com este entendimento, ENNECCERUS - H. C. NiPPERDEY (Derecho Civil... cit., nota 43, p. 314) enfatizam que interpretação diversa poderia conduzir a situações de perplexidade: o $§ 117$, que rege a simulação, por exemplo, poderia ser bem explicado e interpretado, indistintamente, segundo a teoria da vontade ou a teoria da declaração; a redação do parágrafo não permitiria chegar a conclusão alguma, em favor de uma, ou outra abordagem dogmática. Em vista disso, melhor que concluir que o legislador alemão teria adotado uma solução de compromisso entre as teorias antagônicas, seria atestar a eleição de uma opção legislativa alternativa aos dogmas da vontade e da declaração (Derecho Civil... cit., nota 43, p. 315). Nesse contexto, ao negócio simulado de que trata o $\S 117$ do Código Civil alemão faltaria a pretensão de validade; as partes o estipulariam com o objetivo exclusivo de criar uma aparência enganadora (K. LARENZ, Derecho Civil... cit., supra, p. 500).

${ }^{124}$ G. D. Kallimopoulos, Die Simulation im bürgerlichen Recht - Eine rechtsdogmatische Untersuchung, München, Verlag, 1966, p. 20-21. Tradução livre; no original: "Die Regelung des $\S 117$ Abs. 1 und 2 BGB ist unmittelbar mit dem Grundsatz der Privatautonomie zu bregünden, so da $\beta$ eine Heranziehung der Willens, Erklärungs- und Geltungstheorien fehl am Platze ist, und die Problematik durch einen durchaus entbehrlichen Theorienstreit eher getrübt als gelöst wird"'

${ }^{125}$ G. D. Kallimopoulos, Die Simulation... cit. (nota 124), p. 21.

${ }^{126}$ Para chegar a esta conclusão, I. KANT (Versuch den Begriff der negativen Grössen in die Weltweisheit eizuführen, 1763, trad. port. de Jair Barboza, Ensaio para introduzir a noção de grandezas negativas em filosofia in Ensaios pré-críticos, São Paulo, UNESP, 2005, p. 57-58) parte da diferença entre oposições lógicas e reais. "A primeira oposição, vale dizer, a lógica, é a única para a qual se dirigiu a atenção. Ela consiste no seguinte: de uma única e mesma coisa, afirma-se e nega-se algo ao mesmo tempo. A conseqüência dessa conexão lógica é absolutamente nada". Na oposição, lógica, a oposição entre dois predicados dá-se em razão do princípio da contradição; isto, contudo, não ocorreria no caso da oposição real. 
A ideia de duas grandezas que se opõem, em sentidos opostos, acarretando o repouso - que não se confundiria com o nada - encontra-se claramente representada na interpretação dada por Kallimopoulos ao $§ 117$ do Código Civil alemão: “[v]ista a questão do ponto de visto jurídico de terceiros não participantes, as relações de simulação correspondem exatamente ao caso em que as partes envolvidas na relação jurídica permanecem imóveis e, por isso, permanecem na mesma situação jurídica. No suporte fático do $\S 117$, seção 1 do Código Civil alemão, as partes estão de acordo que todo seu curso de ação deixará a conjuntura jurídica atual inalterada"127.

Os mais céticos poderiam, neste passo, arguir que uma atuação dos particulares voltada à criação de nenhum vínculo jurídico seria irrelevante, logo, não guardaria qualquer relação com a autonomia privada. Esta preocupação, porém, não se justificaria.

Em primeiro lugar, como se sabe, há negócio jurídico ainda que as partes não desejem vincular-se, uma perante a outra. $\mathrm{O}$ ato praticado é, ao mesmo tempo, meio e fim da atividade privada, porquanto o seu escopo coincide com o ato da sua celebração. Tratase, aí, de uma concreta manifestação de autonomia negocial, calcada na exclusão do significado jurídico que, de outro modo, atribuir-se-ia ao comportamento privado ${ }^{128}$.

Ao examinar esta questão, Cariota Ferrara, curiosamente, admite a função ou relevância negativa da autonomia privada (qualquer semelhança com a terminologia empregada por Kallimopoulos é mera coincidência...). As partes não poderiam - ressalva o autor - criar ou forjar os efeitos de um negócio jurídico, pois isto seria contra a ordem pública. Nada impediria, contudo, que excluíssem a vinculatividade do comportamento

\footnotetext{
"Aqui também se suprime algo que é posto pelo outro; contudo, a conseqüência é algo (cogitabile). A força motriz de um corpo que se dirige a uma região, bem como um esforço igual do mesmo corpo na direção oposta, não se contradizem e, como predicados, são possíveis ao mesmo tempo num mesmo corpo. A conseqüência disso é o repouso, que é algo (repraesentabile)".

${ }^{127}$ G. D. KAllimopoulos, Die Simulation... cit. (nota 124), p. 21. Tradução livre; no original: "Sieht man zunächst noch von der Rechtsstellung unbeteiligter Dritter ab, so entsprechen die Verhältnisse bei der Simulation genau dem Fall, in dem die Rechtsgenossen untätig bleiben und dadurch an der bestehenden Rechstlage festhalten. Bei dem Tatbestand des $\S 117$ Abs. 1 BGB die Parteien in Einverständnis darüber, da $\beta$ ihr ganzes Vorgehen die bisherige Rechtslage unverändert lassen wird".

${ }^{128}$ R. ScOGnAmiglio, Contributo... cit. (nota 114), p. 213. Tradução livre; no original: "Si tratta insomma, nel caso in esame, di una esplicazione concreta dell'autonomia delle parti, la cui efficacia si spiega appunto in virtù del riconoscimento nel nostro diritto della libertà negoziale; si realizza in definitiva un negozio che ha per contenuto l'esclusione del significato giuridico che altrimenti competerebbe al comportamento privato".
} 
negocial, desde que esta vontade fosse clara e perfeitamente recognoscível pelo destinatário da declaração ${ }^{129}$.

Em segundo lugar, deve-se atentar que, por meio do negócio simulado, as partes não se limitam a excluir a vinculatividade do regulamento de interesses; fazem exatamente aquilo que, segundo Cariota Ferrara, seria censurável: forjam os seus efeitos. O negócio simulado encerra uma precisa e complexa regulamentação de interesses ${ }^{130}$, mediante a qual as partes adotam condutas capazes de suscitar, no público, a convicção (incorreta) sobre a vigência de uma determinada relação jurídica. Desse modo, a simulação extrapola o lado negativo da autonomia privada pois se fundamenta no ajuste de um particular regramento aplicável aos interesses dos simuladores, direcionado ao alcance de um determinado resultado jurídico ${ }^{131}$.

O escopo dos simuladores consiste em determinar a exterioridade de uma operação negocial que, a qualquer observador, possa parecer eficaz ${ }^{132}$. Logo, ao realizar a operação simulada, as partes definem metas que pretendem implementar mediante condutas logicamente e finalisticamente articuladas, imprimindo, de tal maneira, uma direção unitária aos vários momentos que integram a operação perseguida ${ }^{133}$. O negócio simulado, portanto, assume uma feição instrumental quanto a interesses mais amplos compartilhados pelos contraentes ${ }^{134}$.

A construção aqui empreendida amolda-se ao direito positivo. No artigo 167, encontra-se expressa referência à aparência (inciso $I$ do $\S 1^{\circ}$ ). Ademais, a menção à (ausência) de verdade (inciso II do $\S 1^{\circ}$ ) remete ao engano de terceiros (pois somente estes a desconheceriam). O inciso II do $\S 1^{\circ}$ do artigo 167 preceitua concretizar-se a simulação diante da inserção, no negócio jurídico, de declaração não verdadeira; não seria descabido parafrasear as hipóteses descritas incisos I e III do $\S 1^{\circ}$ em termos análogos: haveria

\footnotetext{
${ }^{129}$ L. CARIOTA FERRARA, Il negozio giuridico... cit. (nota 34), p. 55.

${ }^{130}$ G. CONTE, La simulazione del matrimonio nella teoria del negozio giuridico, Padova, CEDAM, 1999, p. 380 .

${ }^{131}$ U. MAJELLO, Il contratto simulato... cit. (nota 105), p. 642.

${ }^{132}$ F. ANELLI, Simulazione e interposizione in M. COSTANZA (cur.), Vincenzo Roppo - Trattato del contrato, v. III - Effeti, Milano, Giuffrè, 2006, p. 571.

${ }^{133}$ G. CONTE, La simulazione del matrimonio... cit. (nota 130), p. 381.

${ }^{134}$ F. ANELLI, Simulazione e interposizione cit. (nota 132), p. 572; U. MAJELLO, Il contratto simulato... cit. (nota 105), p. 646; A. VALENTE, Nuovi profili della simulazione e della fiducia - Contributo ad un superamento della crisi della simulazione, Milano, Giuffrè, 1961, p. 168.
} 
simulação quando o negócio jurídico contivesse uma atribuição não verdadeira de direitos a determinado sujeito, ou, quando o respectivo instrumento particular lhe assinalasse marcos temporais de vigência não verdadeiros.

Ao descrever a simulação nestes termos, o artigo 167 acolhe a concepção segundo a qual a simulação decorre de um procedimento negocial que visa a induzir uma incorreta apreciação da realidade por parte da comunidade. Tal situação não se afere pela perspectiva pessoal, de cada terceiro em particular, mas sob o enfoque pelo qual a generalidade dos terceiros apreende o negócio simulado. A simulação possui a habilidade, objetivamente aferível, de difundir um erro coletivo ${ }^{135}$. Este resultado não se produz por brincadeira, nem constitui obra do acaso. Enganar o público mediante a criação de uma relação jurídica "não verdadeira" é algo que interessa aos simuladores; é, pois, o conteúdo substancial de um regulamento de interesses instrumental cuja identificação demanda a inclusão do negócio simulado no quadro da autonomia privada.

\section{A perfeição estrutural do negócio simulado}

Como vimos ${ }^{136}$, há uma distinção ontológica entre o negócio simulado e o “negócio aparente". A aparência, como indica o $\S 1^{\circ}$ do artigo 167, é um atributo do negócio jurídico, que o faz ser simulado. Diante disso, é importante diferenciar a estrutura do "negócio aparente" - ou seja, aquela que se torna externamente recognoscível - da estrutura do negócio simulado - isto é, aquela pertinente ao regulamento de interesses que ser como instrumento à criação da aparência. Levando em conta esta distinção, torna-se possível atestar que, ao contrário do que supunha a doutrina mais antiga, o negócio simulado apresenta-se estruturalmente perfeito. Não reside, pois, num suposto vício estrutural, a gênese e a justificação do fenômeno simulatório.

De fato, o artigo 104 descreve os requisitos de validade do negócio jurídico: a capacidade dos sujeitos, a idoneidade do objeto e a forma prescrita ou não defesa. Já o artigo 166 estabelece as hipóteses gerais de nulidade: a incapacidade dos sujeitos, a inidoneidade do objeto, a ilicitude do motivo comum determinante, a preterição de forma ou solenidade legal, a fraude à lei, e a proibição taxativa do ato. Tendo-se em vista este

\footnotetext{
${ }^{135}$ N. Distaso, La simulazione... cit. (nota 40), p. 443.

${ }^{136}$ V. tópico 8.
} 
arcabouço normativo, é imperioso assinalar que, se o negócio simulado possuísse uma imperfeição estrutural, seria nulo independentemente de qualquer disposição normativa específica. Com maior rigor, na verdade, poder-se-ia até mesmo concluir que aquele seria inexistente, acaso se considerasse que a declaração não conteria nenhuma vontade ou que a declaração ostensiva, contrariada por outra, perderia a condição de veículo da vontade privada (como sugeria Köhler, que descrevia o negócio simulado como um "nichtgeschäft").

A bem se ver, se o legislador entendeu ser necessário a sua expressa intervenção com vistas a cominar a sanção de nulidade ao negócio simulado, isto somente pode ter uma explicação: o negócio simulado seria, a princípio, válido; para romper com este natural estado de coisas, fez-se necessário uma intervenção explícita na ordem normativa, determinando-se a nulidade como consequência arbitrária apta a proporcionar a solução ótima aos conflitos de interesse que girassem em torno da simulação. $\mathrm{O}$ raciocínio orientado a valores permite concluir que não fosse pelo artigo 167, o negócio simulado seria válido. A validade originária e a nulidade arbitrária são expressões de juízos de valor que o legislador comunica mediante o modo como abordou a disciplina da simulação.

Esta interpretação demonstra, ainda, que a lei brasileira encontra-se em plena harmonia com o posicionamento predominante na doutrina contemporânea. Já na década de 1960, Auricchio esclarece que o negócio simulado seria estruturalmente perfeito. O acordo, entendido como fato histórico da formação do contrato, não se poderia considerar ausente, pois neste não se manifestaria o desacordo, ou seja, o dissenso sobre a declaração ${ }^{137}$. A causa também estaria presente pois o negócio simulado assumiria, perante o público, a sua relevância típica. A forma seria certamente atendida pois, sem ela, a criação da aparência enganadora afigurar-se impossíve ${ }^{138}$. E, por fim, a existência do objeto, entendido como matéria do regulamento de interesses seria um pressuposto lógico da aplicação da norma sobre a simulação, pois um negócio sem objeto não poderia dar origem a uma relação jurídica aparente ${ }^{139}$.

${ }^{137}$ A. AURICCHIO, La simulazione... cit. (nota 19), p. 85.

${ }^{138}$ A. AURICCHIO, La simulazione... cit. (nota 19), p. 86.

${ }^{139}$ A. AURICCHIO, La simulazione... cit. (nota 19), p. 86. 
A percepção da perfeição estrutural do negócio simulado coloca em xeque as teses tradicionais da simulação, amparadas, todas elas, na equivocada premissa de que a aparência seria um resultado da inadequada formação da relação negocial.

A tese voluntarista, como relatamos ${ }^{140}$, pretende descrever a simulação a partir da falta da regular declaração da vontade. No entanto, a superação do dogma da vontade exclui a subsistência desta abordagem dogmática ${ }^{141}$. O negócio simulado é querido ${ }^{142}$, assim como os seus efeitos, especificamente no que diz respeito à criação da aparência ${ }^{143}$. Precisamente porque as partes declaram o que querem, também não é pertinente falar-se de um conflito entre a vontade e a declaração ${ }^{144}$. A vontade transcendental (vontade real), tal qual o númeno kantiano, é ininteligível; a norma capta e valora um único fenômeno, qual seja, a manifestação de vontade. Por conseguinte, o único confronto de que caberia cogitar seria o da manifestação de vontade com ela própria, e do qual, à evidência, não haveria como decorrer qualquer discrepância ${ }^{145}$. A bem da verdade, a experiência mostra que raramente as partes têm tanta consciência sobre a vontade que manifestam e os resultados que perseguem, quanto a que mostram possuir quando celebram o negócio simulado ${ }^{146}$.

É oportuno notar que a associação da simulação à ausência de vontade assume a premissa de que o negócio simulado e o "negócio aparente" seriam fenômenos equivalentes. Por esse prisma, mostrar-se-ia consistente a afirmação de que as partes não quereriam os efeitos do negócio simulado. A doutrina mais recente, ao se insurgir contra o paradigma voluntarista, esforçou-se em demonstrar que o procedimento simulatório seria animado por uma específica vontade, a vontade de simular ${ }^{147}$. Esta formulação, porém, somente passa a apresentar a consistência pretendida na medida em que se reconheça que o negócio simulado é ontologicamente distinto do "negócio aparente"; enquanto o primeiro instrumentaliza a simulação (sendo, pois, animado pela vontade de simular), o segundo é o

\footnotetext{
${ }^{140}$ V. tópico 4.

${ }^{141}$ R. SACCO, Simulazione (verbete) in Enciclopedia giuridica, v. XXXIII, Roma, Istituto della Enciclopedia Italiana, 1992, p. 1. Tradução livre; no original: "Ma, quando poi la dottrina del negozio come volontà fu abbandonata, la simulazione non potè più essere presentata come una divergenza fra volontà e dichiarazione".

${ }^{142}$ J. A. S. Del Nero, Conversão Substancial do Negócio Jurídico, Rio de Janeiro, Renovar, 2001, p. 397.

${ }^{143}$ E. BETTI, Teoria generale... cit. (nota 53), p. 397-398.

${ }^{144}$ G. FURGIUELE, Della simulazione di effetti negoziali, Padova, CEDAM, 1992, p. 37-38.

145 A. Gentili, Simulazione in M. Bessone (dir.), Trattato di diritto privato, t. V - Il contratto in generale, Torino, Giappichelli, 2002, p. 521.

${ }^{146}$ G. CONTE, La simulazione del matrimonio... cit. (nota 130), p. 366.

${ }^{147}$ M. DAGOT, La simulation... cit., p. 30 ss. G. A. NUTI, La simulazione... cit. (nota 173), p. 51 ss.
} 
fim da simulação, materializando-se na medida em que o engano ultime-se instalado. Realmente, a vontade de simular não pode ser vista como inspiração volitiva do "negócio aparente", o qual não deixa de remeter a vontade diversa (e.g. a vontade de comprar e vender, de prestar e tomar serviços, de locar e alugar um bem). A vontade relativa ao “negócio aparente", com efeito, não é manifestada pelos contraentes; mas nem deveria ser. A aparência enganadora limita-se a revestir, ab externo, o complexo regulamento de interesses estabelecido entre os simuladores (i.e. o negócio simulado, que "aparenta" ou “contém declaração não verdadeira), o qual, por seu turno, não carece, em absoluto, de uma vontade devidamente formada e manifestada.

Poder-se-ia arguir, contrariamente ao que acabamos de defender, que o artigo 404, inciso I, do Código de Processo Civil chancelaria a tese voluntarista porquanto disponha ser lícito à parte inocente provar com testemunhas, nos contratos simulados, a "divergência entre a vontade real e a vontade declarada"148. Tal alegação, contudo, mostrar-se-ia frágil; aliás, ainda durante a vigência do Código Civil de 1916, foi cabalmente refutada por Custódio da Piedade Ubaldino Miranda: "[e]mbora se empreguem nesse texto legal as palavras clássicas com que a doutrina tradicional conceitua a simulação, não se pode ver em um dispositivo isolado da lei adjetiva, concernente à prova testemunhal, fundamento bastante para a construção de um conceito do fenômeno simulatório" ${ }^{\text {"149 }}$.

O autor sustenta que o referido dispositivo da lei processual teria um escopo bastante limitado, a saber, o de validar uma corrente jurisprudencial que vinha admitindo a alegação e a prova da simulação por iniciativa da parte economicamente mais fraca nos negócios simulados que dissimulavam a violação à lei da usura ${ }^{150}$. Desse modo, o artigo 404, inciso I, do Código de Processo Civil prestar-se-ia a evidenciar a inadequação da aplicação irrestrita do artigo 104 do Código Civil de 1916, o qual vedava a alegação da simulação pelos contraentes do negócio simulado ${ }^{151}$.

\footnotetext{
${ }^{148}$ H. T. TÔRRES, Simulação... cit. (nota 52), p. 320-321.

${ }^{149}$ Custódio da Piedade Ubaldino Miranda, A Simulação no Direito Civil Brasileiro, São Paulo, Saraiva, 1980 , p. 39.

${ }^{150}$ Custódio da Piedade Ubaldino MirandA, A Simulação... cit. (nota 149), p. 39.

${ }^{151}$ Custódio da Piedade Ubaldino Miranda, A Simulação... cit. (nota 149), p. 40.
} 
A tese declaracionista, como vimos ${ }^{152}$, tende a identificar na simulação uma discrepância entre declarações. O acolhimento deste ponto de vista, se fosse o caso, não deveria implicar a conclusão de que a estrutura do negócio simulado seria imperfeita. Deve-se notar, antes de mais, que a simulação não se mostra apta a instaurar um conflito entre declarações, mas entre fragmentos de uma só de declaração. A declaração ostensiva e a oculta, ainda que formalizadas em instrumentos distintos, formam uma unidade.

O fragmento mostrado ao público, na verdade, é uma não declaração. "Declaração simulada não é mais real que declaração imaginária (...). Declaração simulada, imaginária, falsificada, não são espécies do gênero declaração, se declaração quer dizer 'declaração existente, verdadeira e real'(...)"153. Nada distingue aquilo que se diz ostensivamente, daquilo que se dispõe veladamente; o que se simula não é jamais uma declaração inteira, mas um fragmento que, embora não o sendo, parece uma declaração completa $^{154}$. Entre o fragmento ostensivo e o oculto não há contradição, pois a incompatibilidade entre os seus sentidos não surge na instância das partes, mas na dos terceiros. A harmonia que caracteriza o comportamento total dos simuladores é uma imposição lógica, semelhante à coerência que se observa no confronto entre a elaboração de um projeto e a sua fiel execução ${ }^{155}$.

Nessa esteira, ainda que se considere que a contradeclaração exclui os efeitos do fragmento aparente ${ }^{156}$, a declaração, em sua totalidade, não perde a habilidade de exteriorizar a vontade dos contraentes (mesmo que esta vontade não seja imediatamente recognoscível pelo público). Por conseguinte, não se mostra adequado supor que o negócio simulado careça de uma declaração íntegra; precisamente porque a declaração e a contradeclaração afiguram-se incindivei ${ }^{157}$, formam um todo unitário e orgânico cuja relevância jurídica não pode ser questionada.

\footnotetext{
${ }^{152} \mathrm{~V}$. tópico 5 .

${ }^{153}$ R. SACCO - G. DE Nova, Il contratto, t. 1, 3a ed., Torino, UTET, 2004, p. 647. Tradução livre; no original: “[U]n aggetivo, aggiunto ad un nome, può essere incompatibile con l'esistenza e la realtà dell'entità indicata dal nome. Dichiarazione simulata non è più reale che dichiarazione immaginaria (...). Dichiarazione simulata, immaginaria, falsificata non sono specie del genere dichiarazione, se dichiarazione vuol dire 'dichiarazione esistente, vera e reale'."

${ }^{154}$ R. SACCO - G. DE NOVA, Il contratto cit. (nota 153), p. 646.

${ }^{155}$ G. FURGIUELE, Della simulazione... cit. (nota 144), p. 41.

${ }^{156}$ R. SACCO - G. DE NOVA, Il contratto cit. (nota 153), p. 646.

${ }^{157}$ R. SACCO - G. DE NOVA, Il contratto cit. (nota 153), p. 653.
} 
Questão mais complexa refere-se à causa do negócio simulado. Embora o Código Civil de 2002 - a exemplo de seu antecessor - não aponte a causa dentre os elementos essenciais do negócio jurídico, não a ignora completamente. O artigo 166, inciso III, "quando se refere ao motivo determinante, comum a ambas as partes, reconhece a inadmissibilidade de causa ilícita, distinguindo-a do objeto ilícito, vedado no inciso II do mesmo artigo" 158 . Tem-se defendido, ademais, com fundamento no artigo 421 - que consagra a cláusula geral da função social do contrato - que "a posição anticausalista torna-se ainda mais inadequada"159.

Consoante expusemos anteriormente ${ }^{160}$, a noção de causa passou por sensíveis transformações, especialmente no período sucessivo à queda dos regimes totalitários europeus. Ao dessa evolução dogmática, constata-se que a causa propriamente dita, ou seja, a causa concreta, não integra o suporte fático do negócio jurídico, como elemento adicional; trata-se, na realidade, do concreto modo de expressão do regulamento de interesses, que orienta a qualificação e a valoração do negócio jurídico. O negócio jurídico apresenta duas diferentes, mas inseparáveis dimensões: a estrutura e a regra. É a primeira, consistente no conjunto de acontecimentos, fatos, atividades, comportamentos, declarações etc., que as partes criam e organizam para dar um válido direcionamento aos seus interesses, vale dizer, para "poder por a regra"161 . A estrutura determina a regra; mas é a operabilidade desta que demarca a função prático-individual perseguida pelos contraentes. Já a função econômico-social extraída da previsão legal abstrata, geralmente denominada “causa típica", não caracteriza, propriamente, o perfil funcional do negócio jurídico, mas o esquema normativo (o modelo regulativo) que notabiliza o "tipo".

A tese causalista da simulação desenvolveu-se com base na noção de causa típica. No entanto, para concluírem que a causa típica do negócio simulado seria viciada, os autores forçosamente recorreram ao confronto entre esta e outro elemento, de caráter mais concreto, o qual representaria (como faz a causa concreta) a pontual funcionalidade de cada negócio jurídico singular. Betti, por exemplo, tentou explicar a simulação com base na contraposição entre causa típica e escopo prático. Para o autor, na simulação, o escopo

\footnotetext{
${ }^{158}$ Custódio da Piedade Ubaldino MiRAndA, Teoria Geral... cit. (nota 51), p. 115.

${ }^{159}$ M. C. Bodin De Moraes, A Causa dos Contratos in Revista Trimestral de Direito Civil, Rio de Janeiro, v. 21, 2005, p. 96 .

${ }^{160}$ V. tópico 6.

${ }^{161}$ G. B. Ferri, Causa e tipo... cit. (nota 66), p. 373.
} 
prático (que também mereceria a qualificação de "típico") seria incompatível com a causa típica.

Nada obstante, o próprio Betti reconhece que o escopo prático seria responsável pela determinação causal normal do querer $^{162}$; seria a dimensão subjetiva da causa, que refletiria um interesse individual ${ }^{163}$ e se imbricaria com a função econômica típica, formando com esta uma só cadeia psicológica ${ }^{164}$. A causa, entendida como síntese funcional dos elementos essenciais do negócio jurídico, integraria a estrutura do ato ${ }^{165} \mathrm{e}$ seria determinada por uma vontade final direcionada à causa ${ }^{166}$, cuja expressão consubstanciar-se-ia no escopo prático.

Em vista dessas premissas, é impossível não indagar: qual a efetiva diferença entre o escopo prático, a que alude Betti, e a vontade real, em que se funda a tese voluntarista? Se a causa é determinada por uma "vontade final", onde reside a novidade deste ponto de vista? Diante de tão desconcertantes questões, mostra-se oportuna a crítica de Scognamiglio no sentido de que o preceito concebido por Betti não se distinguiria da vontade enquanto fato pré-jurídico criador do direito; por meio de um jogo de palavras, Betti teria simplesmente proposto uma oposição entre preceito (no lugar da vontade) e declaração ${ }^{167}$.

Não há como deixar passar que a construção bettiana segundo a qual a simulação seria capaz de excluir toda verdadeira correspondência entre a causa típica do negócio e a determinação causal ${ }^{168}$ entra em choque com seus próprios fundamentos. Ora, se entre o escopo prático e a causa há uma relação de implicação, como poderia existir uma

\footnotetext{
${ }^{162}$ E. BETTI, Teoria generale... cit. (nota 53), p. 393.

${ }^{163}$ E. BETTI, Teoria generale... cit. (nota 53), p. 174.

${ }^{164}$ E. BETTI, Teoria generale... cit. (nota 53), p. 386.

${ }^{165}$ G. CONTE, La simulazione del matrimonio... cit. (nota 130), p. 564.

${ }^{166}$ E. BETTI, Teoria generale... cit. (nota 53), p. 184. Em outra passagem (p. 67), o autor esclarece: "E é que o regulamento pré-escolhido pelas partes deve, tanto quanto possível, responder à sua conveniência privada: conveniência de que é índice a determinação causal daquelas, dirigida a um resultado prático, o seu intento prático. Se tal intento, no caso específico, é viciado, pode-se arguir que o regulamento pré-escolhido não responde à concreta conveniência, assim como vem, por essas partes, valorada". Tradução livre; no original: "Ed è che il regolamento prescelto dalle parti deve per quanto è possibile rispondere alla loro convenienza privata: convenienza, di cui è indice la loro determinazione causale rivolta a un risultato pratico, il loro intento pratico. Se tale intento nel caso specifico è viziato, ciò fa arguire che il regolamento prescelto non risponde alla concreta convenienza, così come venne da esse parti valutata".

167 R. Scognamiglio, Contributo... cit. (nota 114), p. 69-72. Em sentido semelhante: G. CONTE, La simulazione del matrimonio... cit. (nota 130), p. 357; 360.

${ }^{168}$ E. BETTI, Teoria generale... cit. (nota 53), p. 393-396.
} 
incompatibilidade entre estes termos? Por imperativo lógico, a consideração de que a "vontade final" determinaria a causa somente poderia resultar na perfeita harmonização entre esta e o escopo prático ${ }^{169}$.

Os sucessores de Betti buscariam aprimorar os seus ensinamentos, cada qual à sua maneira. De acordo com Pugliatti, a causa típica seria destruída ou modificada pelo acordo simulatório; em vista disso, a simulação continuaria sendo um vício ligado à estrutura do negócio jurídico, merecendo, indiscriminadamente, a qualificação de inexistente e nulo ${ }^{170}$. Romano, por seu turno, conceberia a causa em sua acepção dinâmica; por conseguinte, o problema da simulação não mais diria respeito à estrutura negocial - que permaneceria íntegra - mas à possibilidade de conservação de uma relação jurídica incompatível com o comportamento executivo dos contraentes ${ }^{171}$.

Muito embora tais teorias representem valiosas contribuições ao estudo da simulação, elas não levam em consideração que, considerado em bloco, o negócio simulado possui causa (concreta), e, ademais, reconduz-se a um tipo (i.e. apresenta causa típica). Como bem observa Conte, ao se perceber que a causa, mais que um esquema subsuntivo de perfil abstrato, relaciona-se a uma função prático-individual, torna-se difícil sustentar que o negócio simulado dela careceria ${ }^{172}$. Disso decorre que, se o negócio simulado possui causa concreta, não haveria razões para não possuir uma específica causa típica; bastaria, para tanto, que a lei descrevesse a operação simulatória como um tipo, ou seja, mediante uma descrição sumária de seus traços essenciais.

O "negócio aparente" certamente não tem causa, mormente porque não possui nada além da própria aparência; mas o negócio simulado, que desta aparência se reveste, tem uma clara - e por que não dizer, óbvia - função: a de criar a aparência. Aqui se vê que intuição de Pugliatti representou, na história da dogmática da simulação, um importante avanço; se o acordo simulatório poderia ser dotado de uma peculiar causa típica, por que não dizer o mesmo do próprio negócio simulado? Porquanto, como demonstramos acima, o acordo simulatório ultima-se absorvido pelo negócio simulado, a operação típica que o

\footnotetext{
${ }^{169}$ U. LA PORTA, Il problema della causa del contratto - I. La causa ed il trasferimento dei dirrito, Torino, Giapicchelli, 2000, p. 25-26.

${ }^{170}$ S. Pugliatti, La simulazione... cit., (nota 53), p. 546.

${ }^{171}$ S. Romano, Contributo esegetico... cit. (nota 53), p. 39.

${ }^{172}$ G. CONTE, La simulazione del matrimonio... cit. (nota 130), p. 366.
} 
legislador capta e disciplina não é a transformação de um negócio real em aparência, mas a criação da própria aparência, que já nasce como tal.

Nestes termos, a função de autonomia privada desempenhada pelo negócio simulado - a "causa simulandi em sentido estrito" - dirige a vontade de declarar a constituir, do contrato, apenas a forma enganadora. Por isso, não é correto considerar o negócio simulado carente de causa, uma vez que este irradia a imagem da voluntária conclusão - apenas formal, logo enganadora - do negócio jurídico. Nisto consiste a causa típica do negócio simulado ${ }^{173}$.

Não é difícil perceber que o artigo 167, a pretexto de definir a simulação, enuncia os caracteres de tipos negociais, assim como fazem, por exemplo, os dispositivos que descrevem os diversos tipos contratuais. A referida norma não se limita, como o $\mathrm{n}^{\mathrm{o}} 1$ artigo $240^{\circ}$ do Código Civil português ("Se, por acordo entre declarante e declaratário, e no intuito de enganar terceiros, houver divergência entre a declaração negocial e a vontade real do declarante, o negócio diz-se simulado"), a indicar os caracteres de um vício do negócio jurídico; no direito brasileiro, o negócio se torna simulado por dar azo a uma das operações enumeradas nos incisos do $\S 1^{\circ}$ do artigo 167: aparentar conferir ou transmitir direitos a pessoas diversas daquelas às quais realmente se conferem, ou transmitem; conter declaração, confissão, condição ou cláusula não verdadeira; informar, por meio de instrumento particular, data diversa daquela em que tenha sido celebrado.

O Código Civil, ao relacionar a simulação a situações típicas, reconhece e disciplina a causa simulandi em sentido estrito. Trata-se de uma causa peculiar, a qual se resolve na forma da sua existência fenomênica ${ }^{174}$. A simulação, a teor do artigo 167, não é a imitação de uma forma pressuposta como real, mas uma forma de realidade ${ }^{175}$. As partes acordam sobre a oportunidade de ofertar aos terceiros um ou mais índices com base nos quais sejam induzidos a considerar que determinados efeitos negociais tenham sido produzidos. A simulação funda-se, pois, sobre a atuação conjunta das partes em prol da manifestação destes índices ${ }^{176}$.

\footnotetext{
${ }^{173}$ G. A. NUTI, La simulazione del contratto nel sistema del diritto civile, Milano, Giuffrè, 1986, p. 64-65.

${ }^{174}$ A. PELliCANÒ, Il problema della simulazione nei contratti, Padova, CEDAM, 1988, p. 54-55.

${ }^{175}$ A. PELliCANÒ, Il problema... cit. (nota 174), p. 6-8.

${ }^{176}$ G. FURGIUELE, Della simulazione... cit. (nota 144), p. 59.
} 
Nessa linha de raciocínio, deve-se investigar a simulação a partir da causa concreta do negócio jurídico ${ }^{177}$. Isto não significa, em absoluto, que o negócio simulado seria caracterizado por um descompasso entre a causa típica e a causa concreta. A causa concreta identifica a vocação do negócio jurídico; presta-se a sintetizá-lo em sua globalidade $^{178}$, e ao assim fazê-lo, determina a causa típica ${ }^{179}$. Em razão disso, há, no negócio simulado, perfeita correspondência entre a causa concreta e a causa simulandi em sentido estrito.

Diante das ponderações precedentes, concluímos que o negócio simulado apresenta-se estruturalmente perfeito, razão pela qual o quid da simulação não deve ser associado a um atributo (estático) da relação negocial, mas ao dinamismo de sua peculiar funcionalidade. Reitera-se, desse modo, a consideração do negócio simulado como instrumento de autonomia privada do qual os simuladores se valem para a persecução de bem definidos interesses.

\section{A simulação e a função social do contrato}

A proposição segundo a qual o negócio simulado configura uma manifestação de autonomia privada deve, ainda, ser testada em face de outro potencial obstáculo ao seu acolhimento: a função social do contrato.

O artigo 421 estabelece que "[a] liberdade de contratar será exercida em razão e nos limites da função social do contrato". A doutrina tem-se ocupado, prioritariamente, de examinar o conteúdo programático da norma, afirmando que se trata de um comando que subordina a liberdade de contratar à promoção de determinados valores ${ }^{180}$. Esta liberdade, ademais, vem sendo associada a duas subespécies: a liberdade de decidir a respeito da celebração do contrato e a liberdade de estipular o conteúdo contratual. Ainda que seja questionável a possibilidade de a primeira destas sofrer limitações, parece indubitável que

\footnotetext{
${ }^{177}$ F. Di MARZIO, Interposizione reale di persona, simulazione, frode alla lege nei contratti in Giustizia civile, Milano, v. LI, Ottobre, 2001, p. 440.

${ }^{178}$ G. B. FERrI, Causa e tipo... cit. (nota 66), p. 371.

${ }^{179}$ C. M. BiAnCA, Diritto Civile cit. (nota 63), p. 472-473.

${ }^{180}$ Ver, dentre outros: H. TheOdoro Júnior, O Contrato e sua Função Social, $3^{\mathrm{a}}$ ed., Rio de Janeiro, Forense, 2008, p. 73 ss.; M. Y. BIERWAGEN, Princípios e Regras de Interpretação dos Contratos no Novo Código Civil, $3^{\mathrm{a}}$ ed., São Paulo, Saraiva, 2007, p. 59 ss.; C. L. Bueno DE Godoy, Função Social do Contrato, $4^{a}$ ed., São Paulo, Saraiva, 2012, p. 169 ss.; ARruda Alvim, A Função Social dos Contratos no Novo Código Civil in Revista dos Tribunais 815, São Paulo, 2003, p. 11 ss.; C. SAlomão FILHo, Função Social Primeiras Anotações in Revista dos Tribunais 823, São Paulo, 2004, p. 67 ss.
} 
a função social do contrato, tal qual positivada pelo Código Civil, figura como condicionante do exercício da autonomia privada ${ }^{181}$.

Particularmente interessante ao estudo da simulação se mostra a questão sobre o sentido da limitação prevista no artigo 421. Mais especificamente, discute-se a respeito do seu caráter endógeno ou exógeno. Do ponto de vista endógeno, a função social seria o fundamento constitutivo da autonomia privada; quanto ao aspecto exógeno, ela representaria uma restrição ao alcance, predeterminado, da autonomia privada. Tais antagônicas perspectivas são bem sumarizadas por Judith Martins-Costa, com base nos ensinamentos de Canotilho ${ }^{182}$ :

(a) limite endógeno: os direitos e respectivos limites seriam imanentes a qualquer posição jurídica; o conteúdo definitivo de um direito seria, precisamente, o conteúdo que resultasse dessa compreensão do direito "nascido" com limites;

$\mathrm{e}$

(b) limite exógeno: os direitos e as restrições seriam dimensões separadas; as restrições seriam desvantagens impostas externamente aos direitos; o âmbito de proteção de um direito seria mais extenso do que a garantia efetiva, pois

\footnotetext{
${ }^{181}$ Tem-se afirmado que o artigo 421 não seria aplicável a todos os negócios jurídicos, senão apenas aos contratos. G. L. Branco (Função Social dos Contratos - interpretação à luz do Código Civil, São Paulo, Saraiva, 2009, p. 276) sustenta, a respeito, que o legislador não teria criado uma regra sobre a função social dos atos de autonomia privada, em geral; a funcionalização dos negócios jurídicos, distintos dos contratos, não decorreria daquele dispositivo, mas da aplicação de outras normas (como os artigos 50 e 187), segundo as quais o exercício dos direitos, em geral, deveria obedecer finalidades socialmente típicas. Este entendimento se mostra questionável, não apenas por conta de tratar-se, o artigo 421, de uma cláusula geral, como, ainda, da possibilidade de obter-se, por esta via interpretativa, uma solução inconciliável com a integridade sistemática do Código Civil. De fato, a depender do sentido que se atribua à expressão "liberdade de contratar", e considerando-se os valores que se encontram à base da codificação vigente (eticidade, socialidade e operabilidade), seria indefensável a tese de que o legislador teria restringido a obrigação de exercer a autonomia privada, segundo a função social, a apenas certa categoria de atos (contratos). Uma discriminação deste gênero somente seria passível de acolhimento se fosse possível identificar uma (boa) razão que a justificasse. Entre adotar uma concepção anti-isonômica, e outra isonômica, poderia, o intérprete, preferir a primeira, certificando-se de que a desigualdade seria meramente nominal; isto é, se a atribuição de tratamentos distintos a situações que, sob um particular ponto de vista, fossem equivalentes (não há como negar que o contrato é uma espécie de ato de autonomia privada, dentre tantas outras), tendesse a privilegiar outros valores prestigiados pela ordem jurídica, a quebra de isonomia não seria efetiva, mas meramente instrumental (um meio para a consecução de um fim legítimo; o "tratar desigualmente os desiguais"). O problema aqui enfrentado consiste em que, inclinando-se a doutrina a identificar, no artigo 421, uma limitação à autonomia contratual, entendida como manifestação da autonomia privada, não parece existir qualquer explicação racional à suposição de que o legislador teria decidido submeter apenas o contrato à disciplina disposta neste artigo.

182 Judith Martins-Costa, Reflexões sobre o Principio da Função Social do Contrato in Revista Direito $G V$, v. 1, n.1, São Paulo, maio-2005, p. 48.
} 
aos direitos sem restrições seriam apostos limites que diminuem o âmbito inicial de proteção.

Logo se nota que, acaso se acolhesse o entendimento de que a função social do contrato define internamente os limites da autonomia privada, seria forçoso concluir que o negócio simulado não pertenceria àquele domínio. Daí a necessidade de examinarmos a questão de maneira detida.

As poucas opiniões já manifestadas sobre o tema parecem buscar uma solução de compromisso, segundo a qual os limites derivados da cláusula geral da função social do contrato não seriam meramente exógenos. Afirma-se, neste sentido, que a norma do artigo 421 veicularia, mais que uma restrição externa à operatividade da autonomia privada, um dado estruturante, que determinaria, ab interno, o teor e o alcance daquela, de modo a prevenir que o negócio jurídico fosse desvirtuado enquanto instrumento empregado para a satisfação de interesses socialmente apreciáveis ${ }^{183}$.

Ao dissertar sobre o tema, Custódio da Piedade Ubaldino Miranda deduz a ambivalência (normatividade endógena/normatividade exógena) da cláusula geral da função social do contrato a partir da oposição das expressões "em razão" e "nos limites", ambas constantes do artigo 421.

Segundo o autor, a norma, ao estatuir que a liberdade de contratar seria exercida em razão da função social do contrato, teria estabelecido uma imposição de caráter positivo, atinente aos dois sentidos da liberdade de contratar, a saber, a iniciativa de contratar e a liberdade de estruturar o conteúdo do contrato. No que se refere ao primeiro destes sentidos, a expressão "em razão" indicaria que a função social do contrato deve orientar a formação da relação negocial; desse modo, o contrato que não apresentasse, em sua expressão, mínima função social, haveria de ser rejeitado pela ordem jurídica. Relativamente ao segundo dos aludidos sentidos, a função social, enquanto razão determinante da atividade contratual, deveria levar os particulares a promoverem interesses socialmente relevantes, como o melhoramento do meio ambiente, a instauração da livre concorrência e um melhor atendimento ao consumidor. Não bastaria, para o atendimento

${ }^{183}$ G. L. BRAnCO, Função Social dos Contratos... cit. (nota 181), p. 235. 
do comando legal em comento, abster-se de contrariar interesses socialmente relevantes; seria necessário efetivamente contribuir com a realização destes ${ }^{184}$.

Especificamente quanto aos contratos empresariais, Custódio da Piedade Ubaldino Miranda explica que o exercício da liberdade de contratar em razão da função social do contrato pressuporia a lembrança de que, embora o objetivo primordial da sociedade capitalista seja o lucro, a busca deste resultado não pode dar-se em prejuízo do impulso ao desenvolvimento social. Tal exigência, no entanto, deveria ter aplicação mitigada no terreno dos contratos que visam primordialmente a consecução de interesses privados, como, por exemplo, a locação de bem móvel ou imóvel; ainda que tais contratos pudessem, por vias reflexas, afetar negativamente interesses mais amplos de um grupo social, a sua razão determinante naturalmente residiria no âmbito de uma relação intersubjetiva $^{185}$.

A seu turno, a previsão de que a liberdade de contratar deveria exercitar-se nos limites da função social do contrato visaria a prevenir a estipulação de cláusulas que de algum modo, direta ou indiretamente, viessem a conflitar com interesses socialmente relevantes. Neste caso, a limitação aplicar-se-ia a todos os contratos, inclusive aqueles destinados primordialmente ao atendimento de interesses privados. Não se trataria, neste caso, de restringir a formação do vínculo contratual, mas de disciplinar o alcance de seu conteúdo e a sua operatividade concreta, isto é, o modo como as partes dariam cumprimento às obrigações contraídas e exerceriam os diretos obtidos em razão do contrato $^{186}$.

Para Custódio da Piedade Ubaldino Miranda, o preceito positivo correspondente à expressão "em razão", sobretudo no que se refere ao estabelecimento e cláusulas que promovam interesses socialmente relevantes, revelaria a normatividade endógena da cláusula geral da função social do contrato. Em nota de rodapé inserta exatamente na passagem em que comenta o citado preceito positivo, o autor diz: "[n]esta medida, nos parece também que tanto quanto uma 'funcionalidade exógena' haverá uma 'normatividade endógena' na exigência da função social do contrato, não se limitando tal

\footnotetext{
${ }^{184}$ Custódio da Piedade Ubaldino Miranda, Comentários ao Código Civil, v. 5 - Dos Contratos em Geral (Arts. 421 a 480), São Paulo, Saraiva, 2013, p. 32-34.

${ }^{185}$ Custódio da Piedade Ubaldino MiRANDA, Comentários... cit. (nota 184), p. 35-36.

${ }^{186}$ Custódio da Piedade Ubaldino MiRANDA, Comentários... cit. (nota 184), p. 38-48.
} 
normatividade aos princípios de boa-fé e de autonomia privada. (...) A jurisprudência temse valido, em larga medida, para integrar os contratos de prestação de serviços de saúde, médico-hospitalar com cláusulas não previstas neles, ou até em contrário das previstas, obrigando as prestadoras de tais serviços a fornecer tratamento e/ou equipamento médicohospitalar necessário, recorrendo à norma da função social do contrato". Por outro lado, o autor identifica um limite exógeno à liberdade de contratar a partir da expressão "nos limites", a qual incidiria sobre o momento da vigência do contrato: "[a] função social do contrato constitui-se também, para além da razão de contratar, em um limite externo, 'exógeno', à liberdade de contratar. Ela aparece assim, no espírito da lei, com um duplo objetivo: o de presidir à formação dos contratos e o de limitá-los na irradiação de seus efeitos (...)"187.

Vale notar, todavia, que o autor estabelece, relativamente à abrangência da normatividade endógena da cláusula geral da função social do contrato, uma distinção entre as classes dos contratos que envolvem interesses institucionais e aqueles que se reportam a interesses eminentemente privados. Nesse diapasão, somente os primeiros, assim como, em certa medida, os contratos empresariais, estariam sujeitos à observância da regra derivada da expressão "em razão"

Em vista da solidez das conclusões formuladas por Custódio da Piedade Ubaldino Miranda, não nos resta alternativa senão subscrevê-las, ressalvando, contudo uma possível divergência quanto ao sentido da normatividade endógena atribuída à cláusula geral da função social do contrato, da qual devemos tratar por interessar ao estudo que ora desenvolvemos.

Conforme se depreende da leitura das páginas escritas pelo eminente Professor da Academia de Direito do Largo de São Francisco, a chamada "funcionalidade endógena" não chegaria a excluir o ato privado do plano da autonomia privada. Tanto assim que a consequência da infração ao artigo 421, por ato imputável às partes, seria, “in extermis a

\footnotetext{
${ }^{187}$ Custódio da Piedade Ubaldino MiRAndA, Comentários... cit. (nota 184), p. 33, nota 24; p. 36.

${ }^{188}$ Custódio da Piedade Ubaldino MiRAndA, Comentários... cit. (nota 184), p. 36. Confira-se, in verbis, como se expressou o autor, neste particular: "Mais precisamente, quando a lei fala, sucessivamente, na primeira parte do dispositivo, em liberdade de contratar em razão da função social do contrato e, na segunda parte, em exercer essa liberdade nos limites impostos pela função social do contrato, deve o intérprete encarar a função social como referida a diferentes tipos de contratos. Naquele primeiro sentido, estarão em linha os contratos que envolvem interesses institucionais e, em certa medida, os contratos empresariais (...). No segundo sentido, estarão todos os contratos, incluindo os que têm a ver com interesses meramente privados".
} 
nulidade do contrato, nos termos do art. 166, VII, in fine, que considera nulo o negócio jurídico cuja prática a lei proíbe sem cominar sanção (...)"189. O autor, com efeito, não chega a cogitar da inexistência do contrato em decorrência da aplicação da cláusula geral da função social do contrato.

Em vista dessas considerações, parece-nos oportuno precisar a abrangência que a ideia de normatividade endógena assuma no campo de estudo do artigo 421. Cumpre distinguir, de um lado, a autonomia privada como liberdade social, e de outro, a liberdade de contratar como poder jurídico.

A doutrina tem defendido, recorrentemente, que a autonomia privada corresponde a uma poder pré-jurídico.

A noção de autonomia da vontade, fortemente influenciada pelos ideais pandectistas, tendia a atribuir, ao ânimo psíquico do particular, a capacidade de criar o direito. Este discurso se colocava acima do mecanismo suporte fático/efeito, com base no qual, até hoje, costuma-se explicar a incidência da norma jurídica. A vontade determinaria e produziria os efeitos, não enquanto elemento do suporte fático legalmente prescrito, mas como força originária, apta a regular e extinguir relações jurídicas ${ }^{190}$.

Este vocabulário, predominante na passagem do direito comum ao direito codificado, sofreria severas críticas, entrando em decadência a partir de 1935, quando os autores principiam a cogitar de outras fórmulas, como regulamento de interesses, ato preceptivo, ato de autonomia privada. Destacam-se, neste contexto, as contribuições de Betti $^{191}$.

Segundo o autor, o negócio surgiria como fato social, em razão do exercício de um poder pré-jurídico. Os interesses que o direito privado disciplina existiriam na vida social independentemente da intervenção do direito; os particulares, em suas relações recíprocas, estabeleceriam diretrizes aptas a satisfazerem suas necessidades, elegendo, termos sob os quais dar-se-ia a troca de bens e de serviços ${ }^{192}$. Os atos pelos quais se

\footnotetext{
${ }^{189}$ Custódio da Piedade Ubaldino MiRANDA, Comentários... cit. (nota 184), p. 45-46, nota 51.

${ }^{190}$ N. IRTI, Letture bettiane sul negozio giuridico, Milano, Giuffrè, 1991, p. 6.

191 Autor este, aliás, citado por Custódio da Piedade Ubaldino MiRANDA, Comentários... cit. (nota 184), p. 32-33.

${ }^{192}$ E. BETTI, Teoria generale... cit. (nota 53), p. 42.
} 
expressaria a iniciativa privada, gênese social do negócio jurídico, permitiriam, por si, que os indivíduos regulassem suas atividades, e por conseguinte compusessem os seus interesses da maneira que melhor lhes aprouvesse. Seriam atos de autonomia privada, isto é, instrumentos de autodeterminação e autorregulamentação ${ }^{193}$.

O cerne desta teoria consiste, precisamente, na descrição da interação que se estabeleceria entre o ato de autonomia privada e a ordem jurídico-positiva. Para Betti, a passagem do plano social para o jurídico dar-se-ia mediante uma operação de reconhecimento da regulamentação privada, à qual se conferiria tutela jurídica (como algo adicionado e logicamente posterior). Em virtude de tal reconhecimento, os negócios da vida privada assumiriam a condição de negócios jurídicos, e se tornariam instrumentos que o direito colocaria à disposição dos particulares para disciplinar os próprios interesses na vida de relação ${ }^{194}$.

A característica essencial do negócio jurídico seria o conteúdo preceptivo da declaração ou do comportamento. As condutas reguladas pelo direito privado poderiam ter conteúdos variados; todavia, somente seria negócio jurídico o ato que tivesse por conteúdo um preceito de autonomia privada, o qual, uma vez reconhecido (ou recepcionado) pelo ordenamento estatal, tornar-se-ia imediatamente operativo dos efeitos jurídicos correspondentes à sua função econômico-social ${ }^{195}$. Seria, a eficácia jurídica, um produto da lei; isto, porém, não prejudicaria a circunstância de a vinculatividade do ato de autonomia privada mostrar-se atuante desde o terreno social. O preceito de autonomia privada figuraria, pois, como o pressuposto fático de incidência da norma jurídica ${ }^{196}$.

$\mathrm{Na}$ fase de recepção, o direito poderia impor restrições ao alcance das finalidades miradas pelas partes. Instaurar-se-ia, assim, um controle da autonomia privada, operada por meio da valoração da função prática que caracteriza o tipo. Com este crivo, a ordem normativa poderia considerar que os interesses particulares não demandariam tutela, ignorando-os; identificar, naqueles, uma função socialmente relevante, que justificaria a concessão da proteção jurídica legalmente prevista; ou, por fim, reputar o regulamento de interesses reprovável, sujeitando-o a consequências contrárias ao escopo visado pelas

\footnotetext{
${ }^{193}$ E. BETTI, Teoria generale... cit. (nota 53), p. 46.

${ }^{194}$ E. BETTI, Teoria generale... cit. (nota 53), p. 47.

${ }^{195}$ E. BETTI, Teoria generale... cit. (nota 53), p. 154-155.

${ }^{196}$ E. BETTI, Teoria generale... cit. (nota 53), p. 50-51.
} 
partes. Em qualquer destes casos, o controle da autonomia privada seria externo; o que estaria em jogo, neste momento, não seria a caracterização do ato de autonomia privada, mas a possibilidade do seu reconhecimento pela ordem jurídica ${ }^{197}$.

Em vista disso, é necessário ter cautela ao interpretar-se a proposição de Betti segundo a qual os particulares seriam titulares de uma competência dispositiva. Segundo o autor, competiria aos indivíduos determinar, nas relações entre eles, os escopos práticos a perseguidos e a via a seguir para ordenar os próprios interesses; seria de competência da ordem jurídica distinguir e valorar as categorias de interesses e os escopos práticos visados pelos indivíduos, prescrevendo aos seus atos a modalidade e os requisitos de validade e de eficácia ${ }^{198}$. Isto, porém, não significaria que a competência dos particulares seria concedida pelo direito, ou neste encontraria o seu fundamento. Betti di-lo com todas as letras: "Mas o ponto saliente é que, com respeito à iniciativa privada, a ordem jurídica exerce uma função apenas negativa, limitadora e disciplinadora"199 . A competência dos particulares não seria jurídica, mas social, e, como tal, não seria concedida, mas simplesmente reconhecida pelo direito.

Tais construções dogmáticas seriam acolhidas e aprimoradas por Scognamiglio, para quem o substrato real do negócio jurídico seria o fenômeno da autonomia privada ${ }^{200}$. A afirmação, embora pareça singela, possui um significado mais profundo, que o autor logo destacaria: a autonomia privada, vista como atitude do indivíduo tendente a impor regras aos próprios interesses, seria confrontada e disciplinada pelo direito posto; consistiria, por assim dizer, no substrato material sobre o qual a norma jurídica incidiria ${ }^{201}$.

Os indivíduos poderiam impor-se regras em variados campos da vida: religioso, moral, profissional, cultural etc. Sempre que isto ocorresse, estaria em evidência a autonomia. Contudo, a autonomia privada propriamente dita - autonomia negocial - teria, como terreno fértil, exclusivamente o plano das relações econômico-sociais. Poder-se-ia

\footnotetext{
${ }^{197}$ E. BETTI, Teoria generale... cit. (nota 53), p. 47-54.

${ }^{198}$ E. BETTI, Teoria generale... cit. (nota 53), p. 85-86.

${ }^{199}$ E. BETTI, Teoria generale... cit. (nota 53), p. 86. Tradução livre; no original: "Ma il punto saliente é che, rispetto all'iniziativa privata, l'oirdine giuridico non ha che una funzione negativa, limitatrice e disciplinatrice".

${ }^{200}$ R. SCOGNAMiglio, Contributo... cit. (nota 114), p. 83.

${ }^{201}$ R. SCOGNAMiglio, Contributo... cit. (nota 114), p. 83-84.
} 
dizer, então, que a autonomia privada assume o seu significado próprio na realidade social $^{202}$.

A premissa de que o ato de autonomia privada seria um fenômeno extrajurídico ${ }^{203}$ conduziria, naturalmente, à discussão sobre o intercâmbio estabelecido entre a realidade social e aquela própria do direito. A este propósito, Scognamiglio explica que o ordenamento jurídico reconheceria o ato de autonomia privada em sua essência real. A autonomia negocial, apreendida em sua dimensão dinâmica, operaria no mundo do direito do mesmo modo que o faria no plano social. $O$ direito não conferiria, aos particulares, uma liberdade, ou um poder novo; nem poderia, porque esta capacidade de agir, regulando os seus próprios interesses, já lhes competiria em virtude da consciência social. A lei, portanto, limitar-se-ia a atribuir relevância jurídica ao ato de autonomia privada, consentindo o surgimento, na esfera normativa, de um fenômeno dotado, mutatis mutandis, de natureza idêntica àquele. Disso derivaria a noção de negócio jurídico como ato de autonomia privada dotado de relevância jurídica ${ }^{204}$.

A nosso ver, a concepção da autonomia privada como poder pré-jurídico encontra guarida no Código Civil. A prova disso encontra-se no artigo 166, que, ao descrever as hipóteses de nulidade, em momento algum dá e entender que o negócio poderia ser inexistente em razão da gravidade do vício que o acometesse. Pense-se no caso do negócio com objeto impossível; a impossibilidade ali referida abrange não apenas a física, como a também jurídica. Caio e Tício ajustam a compra e venda de um terreno na lua. Tal contrato, evidentemente, não cumpriria qualquer função socialmente relevante, e, mesmo assim, seria apenas nulo, não inexistente. O que dizer, então, do negócio animado por motivo comum determinante ilícito? Diga-se que Caio tenha contratado Tício para cometer um crime, por exemplo, furtar destruir determinado bem do patrimônio de Mévio. A ilicitude, em tais circunstâncias, viria acompanhada da imoralidade e da ofensa aos bons costumes; além disso, sem dúvida alguma, o contrato não desempenharia uma função social legítima (nem mesmo sob a perspectiva eminentemente social). A despeito disso

\footnotetext{
${ }^{202}$ R. SCOGnamiglio, Contributo... cit. (nota 114), p. 89. Tradução livre; no original: "Questa constatazione, che trova pieno conforto nell'esperienza storica, ci fa vedere insomma che l'autonomia negoziale rileva essenzialmente, come fattore della vita sociale; risultato, questo, che appare sin da ora decisivo per un esatto orientamento ai fini della conoscenza del negozio".

${ }^{203}$ R. SCOGNAMigLio, Contributo... cit. (nota 114), p. 98.

${ }^{204}$ R. SCOGNAMiglio, Contributo... cit. (nota 114), p. 140.
} 
tudo, a limitação à autonomia privada consistente na cominação da nulidade não retiraria, do ato praticado, a sua característica de negócio jurídico. A lei é expressa, neste mister, ao adotar a premissa de que o negócio nulo é ato de autonomia privada, tanto que assim se expressa: “É nulo o negócio jurídico quando (...)”.

A interpretação do artigo 421, no nosso entendimento, deve distinguir a valoração social da valoração normativa do ato (e da sua função). Para que fique bem claro como o descasamento entre o juízo de valor puramente social e aquele fundado na ordem jurídico positiva, é válido lançar mão de um exemplo. Tem-se tornado cada vez mais comum em nossa sociedade a comercialização de mídias, contendo obras fonográficas ou cinematográficas, produzidos sem a autorização dos titulares dos respectivos direitos autorais. Trata-se do fenômeno da "pirataria", que, embora cause prejuízos às grandes gravadoras musicais, assim como às distribuidoras de filmes e aos estúdios de cinema, propicia, a grande parte da população, especialmente aos que integram as classes menos elevadas da pirâmide social, acesso ao lazer e a bens culturais. Registre-se, neste passo, que o lazer é direito social assegurado pela Constituição Federal (artigo $6^{\circ}$ ), e a cultura deve ser assegurada pelo Estado e pela própria sociedade a todos, sobretudo à criança, ao adolescente e ao jovem (artigos 215 e 227).

Nesse contexto, ousaríamos defender que a compra e venda de obras audiovisuais "piratas" desempenha, inegavelmente, uma função socialmente relevante. Num país como o nosso, deve existir uma parcela da população que reprove este tipo de contratação; no entanto, embora não disponhamos de dados estatísticos, parece-nos inegável que uma expressiva parcela da sociedade concorda com tal prática ${ }^{205}$.

\footnotetext{
${ }^{205} \mathrm{O}$ diagnóstico coincide com aquele que inspirou a absolvição de indivíduo acusado de cometer o crime de violação de direito autoral, tipificado no artigo 184, § $2^{\circ}$, do Código Penal (Decreto-Lei $n^{\circ} 2.848 / 1940$ ), nos autos do processo $\mathrm{n}^{\mathrm{o}} 003 / 2.10 .0009449-0$, julgado pela $2^{\text {a }}$ Vara Criminal e de Infância e Juventude da Comarca de Alvorada/RS em 02/03/2012. Na sentença, o magistrado adota das seguintes razões de decidir (transcrita no que interessa ao desenvolvimento do texto): "Sucede que, o acusado confessou espontaneamente que adquiriu os DVDs com ele apreendidos pelo valor de $\mathrm{R} \$ 2,00$, sendo que os expunha a venda no momento da abordagem por $\mathrm{R} \$ 5,00$. Sustentou, inclusive, ter ciência da ilegalidade de sua conduta. De outra banda, o policial militar Israel de Moura Lorenzato foi taxativo no sentido de que o réu efetivamente patrocinava a venda de mídias falsificadas em via pública, as quais foram objetas de apreensão. Diante deste contexto, não pairam dúvidas de que o acusado efetivamente perpetrou o fato que lhe é imputado na exordial acusatória. Pende de análise, contudo, a adequação típica deste agir, isto é, se a comercialização de cópias não autorizadas CDs/DVDs caracteriza infração penal, mormente considerada a sua nítida aceitação social. (...) Ao desate da presente contenda, inexorável a aplicação do princípio da adequação social. Como é cediço, tal princípio foi desenvolvido sob a premissa de que uma conduta
} 
Apesar disso tudo, não há dúvidas de que a violação de direito autoral constitui ato ilícito, sujeito, inclusive, a sanções civis (Lei nº 9.610/1998, artigos 101 ss.). A compra e venda de mídias piratas, portanto, é negócio jurídico ilícito e proibido por lei, logo, absolutamente nulo, ex vi dos incisos II e VII do artigo 166). Nada obstante, dúvidas remanesceriam a respeito da aplicação, a um contrato desse jaez, do artigo 421; seria a compra e venda de mercadorias "piratas" também nula em virtude da inobservância da cláusula geral da função social do contrato.

Ao que nos parece, a resposta é afirmativa. É que, embora a norma faça expressa referência à função social do contrato, ela não se vale da valoração social dos atos privados, mas os submete a uma valoração normativa, a qual, todavia, é inspirada pelo modo como o direito positivo capta a função social do contrato. Opera-se, também nesta sede, a segregação entre o plano social e o plano normativo que justificou o surgimento da teoria da causa concreta e a sua distinção para com o tipo; como vimos em outra passagem, a causa concreta emana da relação jurídica individual, e o tipo (sintetizado pela função econômico-social) corresponde ao arquétipo abstrato formulado pelo legislador com base nas relações jurídicas comumente observadas no tráfico social. É certo que, ao apreciar um caso singular, o juiz terá em conta a operação concretamente perpetrada pelas partes; porém, para predicar o atendimento ou desatendimento ao artigo 421, ele deverá confrontar a relação jurídica individual com uma construção racional erigida a partir do ponto de vista do ordenamento jurídico, tendente a, por assim dizer, "internalizar", no seio do sistema jurídico, uma esquema abstrato consistente naquilo que, supostamente, seria a "voz" da consciência social. O julgador, inegavelmente, não poderia efetivamente "psicografar" a opinião da sociedade, até porque não disporia de dons sobrenaturais nem dados estatísticos para tanto; desse modo, restar-lhe-ia formular uma conjectura, a qual, na medida em que passasse a orientar a produção de uma norma jurídica individual (a sentença), assumiria a mesma abstração que qualquer outro elemento do direito positivo. Justifica-se, assim, que um negócio jurídico que possa, eventualmente, desempenhar uma função socialmente relevante no plano da socialidade in concreto (como a compra e venda de produtos A conduta perpetrada pelo agente é flagrantemente aceita pela sociedade e, por tal motivo, impassível de coerção pela gravosa imposição de reprimenda criminal. (...)". Não temos a pretensão, nesta sede, de emitir qualquer avaliação sobre a aplicação da norma penal ao caso acima colacionado; pretendemos, tão somente, destacar que a aceitabilidade social da "pirataria" já foi reconhecida pelo Judiciário. 
“piratas"), seja reputado ilegítimo, carente de função social, no plano da socialidade in abstracto, tomada como elemento normativo de decisão sob os auspícios do artigo 421.

Ao final desta não tão breve digressão, constatamos que a função social do contrato normativa - que não se confunde com a função social do contrato concreta, assim como a causa típica não se confunde com a causa concreta - somente pode limitar a autonomia privada ab externo. Quer dizer, o negócio jurídico deve ter como razão determinante de sua formação, assim como da estruturação do seu conteúdo, a função social sintetizada a partir do olhar do direito (a liberdade de contratar será exercida em razão da função social do contrato); deve, ainda, vigorar de modo a promover fins que, segundo a consciência social apreendida pelo aplicador da norma, sejam socialmente relevantes (a liberdade de contratar será exercida nos limites da função social do contrato). Se qualquer destas condições deixar de ser cumprida, o ato de autonomia privada, formado no plano social, deixa de ser recepcionado pela ordem jurídico-positiva, e, por conseguinte, considera-se nulo ${ }^{206}$.

A função do contrato, e a função social do contrato a que alude o artigo 421, situam-se em planos distintos. A primeira - prático-individual - se coloca no âmbito da autonomia privada; a segunda pertence ao universo do direito. A função social do contrato a que se refere o artigo 421 é fruto de uma tradução que a norma realiza com base na experiência; é o modo como o direito enxerga a vida de relação, uma síntese abstrata de inumeráveis funções prático-individuais. Dessa feita, a verificação da compatibilidade entre o regulamento de interesses privado e seus efeitos dá-se apenas ex post, e - frise-se ab externo ${ }^{207}$.

Quando o legislador impõe a necessidade de se exercitar a liberdade de contratar "em razão" da função social do contrato, não está conferindo, aos particulares, uma liberdade limitada (i.e. não há liberdade de contratar para além ou ao arrepio da função social do contrato), mas estabelecendo um parâmetro para o reconhecimento da relevância

\footnotetext{
${ }^{206}$ Nesta ordem de ideias, logra-se compreender o porquê de a função social do contrato a que alude o artigo 421 jamais poder ser contrária às diretrizes legais afeitas à atividade contratual. Ainda que o negócio jurídico desempenhasse uma função aprazível à ordem social, na concretude da vida de relação, a função social considerada pelo juiz somente poderia ser aquele obtida após o trespasse da realidade social pelo filtro normativo; dessa operação somente poderia resultar uma construção abstrata conforme o sistema, pois seria, ela própria, um produto do sistema.

${ }^{207}$ G. B. FERRI, Il Negozio Giuridico cit. (nota 58), p. 62.
} 
jurídica do ato de autonomia privada. Não nos afigura procedente, pois, o ponto de vista de Judith Martins-Costa segundo o qual "se a esse papel de 'previsão de limite externo negativo' se resumisse o princípio da função social do contrato, o art. 421 seria virtualmente inútil, uma vez que o exame de casos já decididos pela jurisprudência demonstra que, ou as hipóteses já estão apanhadas pela regra do art. 187 do Código Civil (consagradora da ilicitude de meios), ou não se trata de caso de incidência do princípio da função social, mas hipóteses de interpretação favorável ao aderente, integração segundo a boa-fé, ou casos já regulados em leis especiais, como o Código de Defesa do Consumidor ou o Estatuto da Terra" ${ }^{\text {208 }}$. Como bem destaca Custódio da Piedade Ubaldino Miranda, a limitação da liberdade de contratar pode consistir numa imposição positiva de colocar a relação jurídica estabelecida privadamente a serviço de determinados fins, como a promoção da concorrência e a contribuição com a eficiência das relações de consumo.

Além disso, consoante destaca a própria autora da tese acima criticada, o artigo 421 legitima a eficácia transubjetiva em razão da qual os efeitos do contrato exorbitariam a esfera de direitos das partes, assumindo relevância sob a perspectiva de determinados terceiros (como, por exemplo, nos casos de interferência de terceiros e redes contratuais), ou de terceiros indeterminados (tal qual sucede nos casos em que o contrato é examinado com vistas à defesa da concorrência ou do meio ambiente). Aderimos, sem ressalvas, ao entendimento de que é "na geração de eficácias transubjetivas que reside (...) a função que mais de perto está ligada no 'em razão da' e a que mais fundamente poderá inovar a teoria do contrato". Entendemos, porém, que a modulação subjetiva da eficácia contratual, ao contrário de criar a liberdade de contratar, limita-se a definir o regime jurídico ao qual os atos de autonomia privada devem submeter-se. Frise-se mais uma vez: não convém confundir a liberdade, que emana do tráfico social, com a validade que provém do direito. A operatividade do artigo 421 é externa à autonomia privada, seja quando amplie a eficácia subjetiva do contrato, ou, ainda, quando delimite a eficácia intersubjetiva deste (e.g. nos contratos que instrumentalizem prestações essenciais à pessoa humana, "o princípio da função social deve atuar como norte à interpretação das regras, contratuais ou legais, no sentido que melhor garanta a 'carga de existencialidade"”) $)^{209}$.

\footnotetext{
${ }^{208}$ Judith MARTINS-COSTA, Reflexões... cit. (nota 182), p. 49-50.

${ }^{209}$ Judith MARTINS-COSTA, Reflexões... cit. (nota 182), p. 53.
} 
A corroborar a conclusão acima exposta, adicione-se que a suposição de que um único elemento (a função social) poderia ser o fundamento estruturante da autonomia privada, e, ao mesmo tempo, postar-se fora dela, como um fator externo capaz de restringir a sua abrangência, enfrenta dificuldades lógicas. Tal construção buscaria justificar a autonomia e a heteronomia sobre bases idênticas, o que, inevitavelmente, denunciaria uma inconsistência. Além disso, uma determinação endógena da liberdade contratual jamais poderia constar de uma norma jurídica, a qual, por definição, constitui um comando heterônomo. Tal raciocínio somente faria algum sentido acaso se adotasse a premissa de que, a priori, o particular não possuiria qualquer liberdade (conforme a lógica do tudo proibido $^{210}$ ), podendo atuar exclusivamente dentro dos limites que a ordem jurídica permitisse. Se assim fosse, a autonomia privada seria concebida por um viés exclusivamente positivo; logo, seria uma categoria de liberdade de segundo grau, fundada num direito subjetivo supostamente conferido, ao particular, pela ordem jurídica.

Ante o exposto, a cláusula geral da função social do contrato não obsta à inclusão do negócio simulado no rol dos atos de autonomia privada; conforme demonstramos em momento anterior ${ }^{211}$, este desempenha uma função no plano pré-jurídico. Tal função pode, inclusive, ser socialmente aplaudível: o benfeitor milionário deseja doar uma geladeira nova à jardineira da escola de seus filhos, mas ciente de que esta sentir-se-ia profundamente envergonhada se recebesse um presente de um homem solteiro com tantas posses, pede ao porteiro, que trabalha na mesma escola de seus filhos, que dê a ela o eletrodoméstico, sem mencionar o seu nome. A única intenção do doador é a de ajudar a pobre moça, mãe de 6 filhos, que teve a última geladeira danificada em razão de uma queda abrupta no fornecimento de energia elétrica. O negócio seria simulado, porém, queremos crer, ninguém o ousaria considerar socialmente inútil ou pernicioso. O contrato seria nulo, mas exclusivamente por ser alvo de uma reprovação legal, não social.

A função social in concreto não se poderia dizer desatendida, muito embora a função social in abstracto houvesse de ser considerada preterida. Com efeito, até nos parece que todo negócio simulado deixe de observar o artigo 421 - o que confirmaria o caráter de cláusula geral deste dispositivo, cuja aplicação poderia dar-se concorrentemente

\footnotetext{
${ }^{210}$ N. BoBBIO, Teoria della norma giuridica (1993), trad. port. de F. Pavan Baptista e A. Bueno Sudatti, Teoria da Norma Jurídica, 2ª ed., São Paulo, Edipro, 2003, p. 127.

${ }^{211} \mathrm{~V}$. tópico 11.
} 
com a do artigo 167. Não se deve deixar de notar, contudo, que a função social que lhe faltaria seria aquela informada pela abstração realizada pelo julgador, o qual não pode observar a vida de relação senão através da lente do direito positivo.

\section{§3. O ACORDO SIMULATÓRIO}

A suposição de que o negócio simulado seria, a princípio, o próprio "negócio aparente", deu origem a um processo de glorificação do acordo simulatório. Este teria o efeito de transformar o negócio jurídico em mera aparência (seria algo equivalente a um ato divino capaz de transformar uma pedra em um peixe que parece uma pedra). Nas linhas seguintes, veremos que o acordo simulatório é responsável por conferir, ao negócio jurídico, a qualificação de "simulado", no entanto, ao fazê-lo, não difere do conteúdo convencional que demarca a específica formatação de qualquer outro negócio típico.

Um aguerrido defensor da proeminência do acordo simulatório foi Pugliatti. Para o autor, haveria congruência ${ }^{212}$ entre o negócio simulado e o acordo simulatório; por conseguinte, este último deveria reputar-se um genuíno negócio jurídico, dotado de estrutura e função (causa típica) próprias. O acordo simulatório assumiria a feição de negócio jurídico bilateral, com causa absolutamente típica, a qual poderia operar-se de duas maneiras distintas, destruindo ou de ordem modificando da causa do "negócio aparente",213.

O autor deixa claro que a inspiração de sua teoria seria o texto do artigo 1414 do Código Civil italiano, o qual, explicitamente, menciona o acordo entre os simuladores. Nem todos, contudo, demonstraram tamanha sensibilidade a esta referência constante da norma. Romano, por exemplo, defende que o acordo simulatório não passaria de um motivo comum determinante de indole negativa ${ }^{214}$; Auricchio o reduz a mera preliminar de

\footnotetext{
${ }^{212}$ S. PugliatTi, La simulazione... cit., (nota 53), p. 561-562.

${ }^{213}$ S. Pugliatti, La simulazione... cit., (nota 53), p. 571. Tradução livre; no original: "Trattasi, cioè, di un atto che ha sempre struttura bilaterale, sia che tenda a preparare la simulazione di un negozio bilaterale, sia che tenda a predisporre la simulazione di un negozio unilaterale (fondato su dichiarazione recettizia). Specificando ulteriormente, si può dire che l'accordo simulatorio sia da configurare un negozio bilaterale, con una sua causa assolutamente tipica, che può assumere due aspetti: o di ragione distruttrice o di ragione modificatrice della causa (materiale) del negozio posto in essere (negozio simulato). Questa costruzione gode del crisma della legge: l'accordo che costituisce il fulcro della simulazione è espressamente menzionato dall'art. 1414 cpv. ult. e disciplinato, con gli altri elementi del fenomeno simulatorio, da questa e successive disposizioni. $\mathrm{E}$ - si direbbe - un negozio nominato".

${ }^{214}$ S. ROMANO, Contributo esegetico... cit. (nota 53), p. 44.
} 
fato, integrante da fase de tratativas precedente à celebração do negócio simulado ${ }^{215}$; e Messina, por fim, não via no acordo simulatório algo mais que um fato jurídico em sentido estrito, que teria por objeto a preordenação da aparência enganadora destinada a produzir a ficção ${ }^{216}$.

Outros doutrinadores, ainda preocupados em assegurar alguma autonomia dogmática ao acordo simulatório, o concebem como negócio declarativo ${ }^{217}$ (cujo objeto seria a indicação do sentido da declaração simulada); ato preparatório da futura simulação ${ }^{218}$; ou convenção interpretativa, capaz de traduzir a linguagem convencional empregada pelas partes ${ }^{219}$.

O Código Civil de 2002, ao contrário do Código Civil italiano e do Código Civil alemão, não alude ao acordo. Esta situação, aliás, já se observava quando estava em vigor o Código Civil de 1916, teria levado Pontes de Miranda a defender a prescindibilidade deste elemento para a configuração do suporte fático da simulação ${ }^{220}$. Ao assim se manifestar, todavia, o autor isolou-se no contexto da doutrina brasileira; de fato, a maioria $^{221}$ entendia que o acordo simulatório seria o fator que diferenciaria a simulação da reserva mental ${ }^{222}$. Este estado de coisas manteve-se com a entrada em vigor do Código Civil de $2002^{223}$.

\footnotetext{
${ }^{215}$ A. AURICCHIO, La simulazione... cit. (nota 19), p. 38-40.

216 G. MESSINA, La simulazione assoluta cit. (nota 40), p. 92.

${ }^{217}$ L. CARIOTA FERRARA, Il negozio giuridico... cit. (nota 34), p. 524.

${ }^{218}$ F. MESSINEO, Il contratto in genere cit. (nota 88), p. 453.

${ }^{219}$ E. BETTI, Teoria generale... cit. (nota 53), p. 399; 404-405.

${ }^{220}$ F. C. Pontes De Miranda, Tratado de Direito Privado, v. 4, atual. por M. Bernardes de Melo e Marcos Ehrhardt Jr., São Paulo, Revista dos Tribunais, 2012, p. 521: "Sobre o acôrdo como elemento essencial da simulação, há: a) doutrina que tem como tal; b) doutrina, que, a despeito de textos legais alusivos a entendimentos entre figurantes, se satisfaz com a recepticiedade e o conhecimento da manifestação de vontade pelo destinatário (e.g. ...); e c) doutrina que admite simulação nos atos jurídicos em geral (Teixeira de Freitas, Esbôço, art. 521), desde que se trate de manifestações de vontade suscetíveis de simulação. O Código Civil brasileiro seguiu essa doutrina. O que simula promessa de recompensa para doar está exposto a que o interessado no objeto da recompensa, que satisfaça o que se exigiu, promova a anulação; e.g., trata-se de executor testamentário que tinha de fazer promessa ao público em que a recompensa seria quadro célebre, e em verdade doou a alguém que instruiu para se utilizar da simulação, ou apenas, sem acôrdo, fêz ser o único beneficiável".

${ }^{221}$ Cf., por todos, Custódio da Piedade Ubaldino Miranda, A Simulação... cit. (nota 149), passim, especialmente p. 43 ss.

${ }^{222}$ F. Ferrara, A simulação... cit. (nota 20), p. 52-53; G. MEssina, La simulazione assoluta cit. (nota 40), p. $86 ; 91$.

${ }^{223}$ V., por todos, I. GAINO, A Simulação... cit. (nota 122), p. 52 ss.
} 
Neste terreno, pensamos ser necessário separar a discussão em dois diferentes momentos. Em primeiro lugar, cumpre verificar se a simulação é um fenômeno convencional (o acordo, aqui, deve ser entendido como convergência de intencionalidades). Em segundo lugar, se atestada a convencionalidade, deve-se examinar a natureza e a autonomia do acordo.

\section{Simulação e reserva mental}

Com relação ao primeiro dos aspectos acima destacados, a opinião majoritária tem sido a de que o acordo simulatório distinguiria a simulação da reserva mental. Parece, pois, oportuno colocar os dois institutos em perspectiva, com vistas a verificar se o caráter convencional seria responsável por conferir uma identidade própria ao fenômeno simulatório.

O termo reserva mental é geralmente utilizado para fazer referência à divergência voluntária entre a vontade determinada mas não manifestada pelo declarante e aquela efetivamente consubstanciada na declaração ${ }^{224}$. O Código Civil dela trata no artigo 110, estabelecendo que a reserva mental, salvo quando conhecida pelo destinatário da declaração, não prejudica a validade desta.

Diz-se que o declarante que age com reserva mental não quer aquilo que se encontra declarado, com o intuito de enganar a contraparte. Não seria, a reserva mental, coincidente com a simples mentira, pois o declarante pretenderia que o destinatário da declaração tomasse as suas palavras como sérias, embora nutrisse a esperança de que o negócio celebrado não produzisse quaisquer efeitos. $O$ propósito de engano que caracterizaria a reserva mental poderia ser exemplificado pelas seguintes situações hipotéticas: um amigo empresta dinheiro a outro que ameaçava se suicidar para dissuadi-lo desta medida (o mutuante não queria emprestar, mas salvar a vida do mutuário); um homem, querendo manter conjunção carnal com uma mulher, diz que a toma por esposa (o cônjuge varão não queria se casar, mas apenas manter conjunção carnal com a cônjuge mulher); um autor de obra literária diz que os fundos obtidos com a venda desta seriam

${ }^{224}$ G. A. NuTI, La simulazione... cit. (nota 173), Giuffrè, 1986, p. 135. 
destinados à caridade (o escritor não queria promover a filantropia, mas impulsionar a venda de seu livro) $^{225}$.

A consideração dos exemplos acima aludidos causa perplexidade; se aquelas circunstâncias fossem caracterizadoras da reserva mental, então grande parte dos atos humanos seriam dela eivados. O jovem indolente não quer trabalhar; apenas ganhar dinheiro para poder sair da casa dos pais. O namorado não quer comprar flores para presentear a namorada (pois não tem dinheiro sobrando e acha esse tipo de agrado frívolo), mas vai à floricultura e adquire um buquê de rosas para a companheira. Seriam, estes, casos de reserva mental?

Em face destas desconcertante questões, não nos parecem despropositadas as críticas de Köhler, segundo as quais precisamente porque a declaração seria efetivamente emitida, não poderia ser contrária a uma vontade espiritual, pressuposta como existente no interior recôndito da mente. $\mathrm{O}$ autor ilustra seu pensamento dizendo que um homicida não poderia portar e não portar, ao mesmo tempo, a vontade de matar; analogamente, quem, em modo consciente, dissesse "compro", concluiria uma ação de vontade juridicamente relevante, mostrando-se absolutamente descabida a conjectura sobre a existência de um querer transcendental em sentido contrário ${ }^{226}$. Seguindo a mesma linha de ideias, Messina assinala que a reserva mental, entendida como um dizer "sim" pensando "não", deveria ser tida como juridicamente impossível, permanecendo cogitável tão somente aos autores dos tratados de teologia moral ${ }^{227}$.

Não podemos, em vista da positivação de uma norma especificamente dedicada à reserva mental, concluir, como Messina, que ela seria impossível. Nada obstante, também não conseguimos admitir que o legislador ter-se-ia dado ao trabalho de disciplinar uma situação que poderia ser resumida, em última instância, no fazer algo a contra gosto. O modo como se fala do engano perpetrado pela reserva mental, ou seja, o "fazer algo apenas para ..." evidencia que o fenômeno tem sido tratado como concernente ao plano dos motivos. O motivo que induziria o sujeito a emitir a declaração não seria de todo harmonioso com tal conduta uma vez que a negociação seria um meio (inconveniente

\footnotetext{
${ }^{225}$ N. Nery JúnIOR, Vícios do Ato Jurídico e Reserva Mental, São Paulo, Saraiva, 1983, p. 20-21. Exemplos semelhantes são referidos por A. VON TUHR, Derecho Civil... cit. (nota 431), p. 498.

${ }^{226}$ KÖHLER apud N. DisTASO, La simulazione... cit. (nota 44).

${ }^{227}$ G. MEssinA, La simulazione assoluta cit. (nota 40), p. 88.
} 
mas necessário) à obtenção de um ulterior resultado de ordem prática. Mas se os motivos são, em regra, irrelevantes para o direito, qual seria o propósito do artigo 110 ?

Não é esta a sede para empreender mais aprofundadas investigações sobre os contornos categoriais da reserva mental. Devemos, no entanto, adotar algumas premissas sobre este instituto de modo a tornar-se possível a sua contraposição à simulação. Ao que nos parece, a inserção de um dispositivo como o artigo 110 no Código Civil é inspirada pela necessidade de disciplinar a reserva mental conhecida. O declarante diria "A" com a ressalva de que isto significaria "B" ou "não A", e o declaratário teria conhecimento disto. A reserva mental, portanto, consistiria na unilateral modificação do sentido dos termos empregados ${ }^{228}$. Neste contexto, a primeira parte do artigo 110 não faz mais que ratificar o que estabelece o artigo 112, ou seja, que a declaração interpreta-se segundo a vontade nela "consubstanciada". A irrelevância da reserva mental é referida, pelo legislador, não porque se mostra necessária a sua determinação ${ }^{229}$, mas com o objetivo de tornar evidente, por oposição, a relevância da reserva mental na hipótese de ela ser conhecida do destinatário da declaração.

O ser conhecida a reserva mental do destinatário da declaração não significa que ela também o seja pelos demais terceiros. Em vista disso, a norma impõe uma restrição à aplicação do comando do artigo 112 segundo a qual a vontade consubstanciada na declaração, na hipótese de reserva mental conhecida, deve ser precisada sob a perspectiva do declaratário, não pelo ponto de vista do público ${ }^{230}$. A questão que surge, neste passo, diz respeito ao sentido da relevância atribuída pela norma à reserva mental conhecida: seria, o negócio jurídico celebrado em tais circunstâncias, simulado ou inexistente?

A opinião segundo a qual a reserva mental conhecida seria equiparável à simulação parte do pressuposto de que a simples ciência da ressalva seria suficiente para criar a aparência enganadora. Nesse sentido, Pugliese nega que a simulação dependeria de um efetivo acordo para ultimar-se caracterizada. Segundo o autor, a simulação poderia

\footnotetext{
${ }^{228}$ Como sugerem: G. MESsina, La simulazione assoluta cit. (nota 40), p. 88; W. FLuME, El negocio jurídico cit. (nota 43), p. 481; K. LARENZ, Derecho Civil... cit. (nota 123), p. 498.

${ }^{229}$ Sobre o caráter supérfluo da previsão legal da irrelevância da reserva mental, cf. A. VON TUHR, Derecho Civil... cit. (nota 431), p. 497.

${ }^{230} \mathrm{O}$ acerto político-legislativo deste tipo de prescrição foi objeto de debate entre W. FLuME (El negocio jurídico cit., nota 43, p. 481) e K. LARENZ (Derecho Civil... cit., nota 123, p. 497), opinando o primeiro em favor da conveniência da relevância da reserva mental conhecida, e o segundo em sentido contrário.
} 
derivar de uma declaração não séria emitida por uma das partes (reserva mental aberta) cujo sentido fosse inequivocamente compreendido pela contraparte ${ }^{231}$. O conhecimento sobre a não seriedade da declaração não equivaleria a um acordo tácito entre as partes pois, ao deixar entrever a reserva, o declarante nutriria, quando muito, a expectativa de que a outra parte a compreendesse como tal; ademais, o fato de a contraparte comportar-se conforme o sentido disforme atribuído à declaração não implicaria a certeza de que ela terlhe-ia aderido ${ }^{232}$.

A propósito do tema, Del Bono sustenta que a simulação seria, assim como a reserva mental, sempre unilateral. Para o autor, o que diferiria uma figura da outra seria o simples conhecimento do destinatário da declaração. Por conseguinte, a simulação não seria, em si, bilateral, pois a irrealidade das declarações resultaria de atos materiais individuais das partes. O acordo sobre a simulação limitar-se-ia, segundo esta abordagem, à ciência do verdadeiro sentido atribuído a cada uma das manifestações de vontade emitidas pelos contraentes ${ }^{233}$.

Embora bem fundamentados, os entendimentos acima descritos parecem assumir uma premissa que não se mostra correta na totalidade dos casos, qual seja, a de que o declaratário que conhece da reserva mental também declara com reserva mental. De fato, não necessariamente aquele que sabe que a declaração da contraparte foi reservada pretende tê-la como ineficaz. Desse modo, é possível, por exemplo, que o doador declare com reserva mental, fazendo esta circunstância chegar ao conhecimento do destinatário, o qual, a despeito da reserva, pretenda tornar-se dono da coisa pretensamente doada. Em tal situação, o negócio jurídico seria inexistente ${ }^{234}$, faltando, assim, o pressuposto lógico da regra veiculada no artigo 167 . É conveniente, ademais, não confundir a reserva aberta com a reserva descoberta. Se um terceiro, que não age em nome do declarante, alerta o declaratário sobre a reserva mental do terceiro, então o negócio jurídico poderia ser válido ou inexistente, a depender de a reserva mental ser descoberta antes ou depois do

\footnotetext{
${ }^{231}$ G. PUGLIESE, La simulazione... cit. (nota 1), p. 19. "Ora, se a não seriedade da manifestação é realmente reconhecida pela outra parte, parece-me que nada mais se requer para que surja um negócio simulado". Tradução livre; no original: "Ora, se la non verità della manifestazione è realmente riconosciuta dall'altra parte, a me pare che null'altro occorra, perché trovi luogo un negozio simulato".

${ }_{232}$ G. PUGLIESE, La simulazione... cit. (nota 1), p. 18-19.

${ }^{233}$ F. Del Bono, Dichiarazione riproduttiva - Contributo alla dottrina del documento contrattuale, Milano, Giuffrè, 1948, p. 151 ss.

${ }^{234}$ J. SCHAPP, Einführung in das Bürgeliche Recht (2003), trad. port. de M. G. L. Rurack e K.-P. Rurack, Introdução ao Direito Civil, Porto Alegre, Sergio Antonio Fabris, 2006, p. 262-263.
} 
intercâmbio de declarações ${ }^{235}$. Nenhum destes casos de reserva mental conhecida, porém, seriam equivalentes à simulação ${ }^{236}$.

Deve-se, pois, diferenciar as situações em que a reserva mental é conhecida, mas ignorada pelo destinatário da declaração, daquelas em que este lhe adere, ainda que por meio do comportamento concludente. No primeiro caso, haveria puro, dissenso, em vista do qual o negócio jurídico haveria de predicar-se inexistente ${ }^{237}$. Se "A" declara com reserva mental e "B", embora sabendo disso, declara sem reserva mental, não se forma o acordo de vontades de que depende a construção do suporte fático do negócio jurídico. A vontade oculta deixa de sê-lo, e, portanto, reduz-se a uma não vontade declarada por "A"238. A declaração realizada com reserva conhecida tornar-se-ia uma declaração de ciência, descritiva do conteúdo prescritivo que lhe poderia ser atribuído ${ }^{239}$.

Já no segundo caso, a adesão do destinatário da declaração forçosamente daria origem a um acordo, parecendo-nos artificiosa a proposição de que o comportamento do destinatário da declaração, em conformidade com os desígnios do declarante, não evidenciaria a formação tácita de uma convenção; de fato, somente acolhendo-se paradigmas hermenêuticos baseados no mais primitivo dos voluntarismos seria possível atribuir tamanha importância à vontade psicológica em detrimento da face socialmente recognoscível da declaração exteriorizada por meio do comportamento concludente. $\mathrm{O}$ declaratário, dir-se-ia, também agiria com reserva mental; adote-se com cautela, contudo, a descrição da formação do acordo entre as partes como dupla reserva mental, pois apenas quando o declarante pudesse conhecer (a) da reserva mental da contraparte; e (b) do fato de a sua própria reserva mental ser conhecida pela contraparte (i.e. saber que o outro sabe)

235 J. SCHAPP, Introdução cit. (nota 234), p. 262; G. D. KAllimopoulos, Die Simulation... cit. (nota 124), p. 42.

${ }^{236}$ G. D. Kallimopoulos, Die Simulation... cit. (nota 124), p. 40.

${ }^{237}$ Quanto a esta hipótese, podemos acolher a opinião de J. C. MoreIRA Alves (A Parte Geral do Projeto de Código Civil (Subsídios Históricos para o Novo Código Civil Brasileiro), 2a ed., São Paulo, Saraiva, 2003, p. 109), o qual, no entanto, não traça a distinção que acima propusemos entre o dissenso e adesão.

${ }^{238}$ G. A. NUTI, La simulazione... cit. (nota 173), p. 136.

${ }^{239}$ A Gentili, Simulazione cit. (nota 145), p. 551. O caso, adicione-se, é semelhante ao das declarações não sérias, emitidas em representações teatrais, jocosas ou didáticas. Sobre estas, R. ScoGNAMIGLIO (Contributo... cit., nota 114, p. 200) assevera ser inexato qualquer tentativa de explicar a ausência de efeitos jurídicos com base na falta ou no vício de algum dos elementos do suporte fático do negócio jurídico. Tais declarações não concorreriam, de maneira alguma, para o regulamento de interesse privados, para a criação de direitos e obrigações, para a modificação de esferas jurídicas; a vocação dessas manifestações de vontade seria tão distante daquela minimamente requerida para o surgimento do negócio jurídico que a inexistência deste afigurar-se-ia imediatamente apreensível. 
poder-se-ia concluir ter-se estabelecido uma relação negocial simulada. Por outras palavras, o simples fato de existir dupla reserva mental conhecida não significa que tenha havido dupla adesão, logo, tenha surgido o acordo. É possível, portanto, que a dupla reserva mental não prejudique a validade do negócio jurídico, diante da irrelevância de ambas as reservas.

Bem se entende, assim, porque o direito brasileiro não repetiu a fórmula do $\mathrm{n}^{\mathrm{o}} 2$ do artigo $244^{\circ}$ do Código Civil português ${ }^{240}$, e porque não é correta a afirmação de que a reserva mental conhecida sempre deve ser equiparada à simulação ${ }^{241}$. O artigo 167 somente se aplica diante da existência do negócio jurídico, logo, da formação de um acordo. Mesmo quando referente a ato unilateral, a simulação é bilateral, pois unilateral é apenas a aparência criada ${ }^{242}$. É possível, por exemplo, que um negócio unilateral receptício como o mandato torne-se simulado, mas isto requererá desde logo a colaboração do mandatário aparente. Situação análoga seria verificável quanto a um negócio unilateral não receptício, como a promessa de recompensa; sem a adesão, ao procedimento simulatório, de um beneficiário aparente previamente identificado, seria impossível a criação de uma realidade externa que pudesse reputar-se distinta da eficácia real. Enfim, se o sujeito pretendesse simular o ato unilateral sozinho, não conseguiria ir além da reserva mental cerrada, a qual não se mostraria nem mesmo pensável como fenômeno jurídico relevante, à luz do que dispõe o artigo 112.

A interpretação acima defendida parece ser confirmada pelo exame da evolução a que se submeteu a disciplina da simulação no curso da história do direito brasileiro. Consoante narra Custódio da Piedade Ubaldino Miranda, o Esbôço de Teixeira de Freitas distinguia a simulação dos atos jurídicos em geral (artigo 521, incisos $1^{\circ}$ e $2^{\circ}$ ) da simulação dos atos entre vivos (artigo 522, incisos $1^{\circ}$ e $2^{\circ}$ ). Os projetos de Coelho Rodrigues e o Projecto primitivo de Clóvis Beviláqua, por seu turno, não se referiam à simulação dos atos jurídicos em geral, aludindo apenas à simulação dos atos entre vivos. O Projecto primitivo, no entanto, distinguia a simulação da reserva mental, na seção denominada "Da

\footnotetext{
240 “Artigo $244^{\circ}$ (Reserva mental)

1. Há reserva mental, sempre que é emitida uma declaração contrária à vontade real com o intuito de enganar o declaratário. 2. A reserva não prejudica a validade da declaração, excepto se for conhecida do declaratário; neste caso, a reserva tem os efeitos da simulação".

${ }^{241}$ P. S. Gagliano - R. PAMPlona Filho, Novo Curso de Direito Civil-Parte Geral, vol. I, 13 ed., p. 412.

${ }^{242}$ V. também o tópico 34.
} 
simulação e reserva mental", a qual abarcava o artigo 105, redigido de maneira muito semelhante ao artigo 110 do Código Civil de 2002: “A declaração de vontade subsiste válida ainda que o declarante haja feito a reserva mental de não querer o que declara, salvo se a pessoa, a quem for dirigida, tiver conhecimento da reserva",243.

A comissão revisora rejeitaria a proposição de Clóvis Beviláqua, por considerá-la omissa quanto à simulação dos atos causa mortis e à simulação inocente. Opinou, em vista disso, em favor da substituição dos artigos do Projecto primitivo dedicados à simulação pelos respectivos dispositivos do Esbôço. Na sequência, a comissão especial do Senado alterou o projeto em tramitação, incluindo e suprimindo disposições de modo a definir os termos que se ultimariam, mais tarde, positivados nos artigos 102 a 105 do Código Civil de $1916^{244}$.

Para Custódio da Piedade Ubaldino Miranda, eram improcedentes as críticas da comissão revisora no sentido de que o Projecto primitivo era omisso ao tratar apenas da simulação dos atos entre vivos. Segundo o autor, a simulação stricto sensu, exigindo como elemento do seu conceito o acordo entre as partes, só nos atos inter vivos poderia ocorrer. Nos demais atos, como, por exemplo, no testamento, destinado a surtir os efeitos por morte do declarante, poderia dar-se apenas a reserva mental. De todo modo, com a supressão da figura da reserva mental, resultante da emenda do Projecto primitivo mediante a incorporação dos dispositivos do Esbôço, ter-se-ia atribuído à simulação uma dimensão mais abrangente, incluindo-se aí os casos de reserva mental conhecida. A expressão "atos em geral" abrangeria, segundo o autor, os atos inter vivos e mortis causa, e a simulação, tal qual positivada pelo legislador de 1916, englobaria a reserva mental aberta ${ }^{245}$.

Volvendo os olhos ao Código Civil de 2002, nota-se ter o legislador adotado uma posição diferente, no que se refere à reserva mental. Entendeu que seria pertinente incluir um artigo dedicado à reserva mental, assim como entendera Teixeira de Freitas. Ora, se a supressão do dispositivo dedicado à reserva mental, quando da tramitação do Código Civil de 1916, teria significado a ampliação do raio de abrangência da simulação, qual seria a consequência da mudança de critério operada pelo legislador de 2002? Ao que nos parece,

\footnotetext{
${ }^{243}$ Custódio da Piedade Ubaldino MiRAndA, A Simulação... cit. (nota 149), p. 50-51.

${ }^{244}$ Custódio da Piedade Ubaldino MIRANDA, A Simulação... cit. (nota 149), p. 51.

${ }^{245}$ Custódio da Piedade Ubaldino MiRANDA, A Simulação... cit. (nota 149), p. 51-52.
} 
somente há uma resposta: o tratamento da reserva mental aberta em uma norma destacada do artigo 167 implica a redução da amplitude do instituto da simulação, a qual, ao contrário do que sucedia durante a vigência do Código Civil de 1916, não mais abrange a figura da reserva mental aberta.

Diante desta ordem de considerações, entendemos que a previsão, contida na segunda parte do artigo 110 aplica-se apenas aos casos de reserva mental conhecida, mas ignorada pela contraparte. Neste caso, o negócio jurídico deve reputar-se inexistente, não simulado, em razão da alteridade entre o conhecimento da reserva mental e o consenso sobre a produção de uma relação jurídica aparente.

\section{A natureza e a autonomia do acordo simulatório}

Confirmado o caráter convencional da simulação, cabe perquirir a respeito da natureza do acordo.

Antes de mais, é importante esclarecer que o objeto de tal avença não pode ser a destruição ou modificação do negócio simulado (mais precisamente, do "negócio aparente"). Lembre-se que a aparência somente pode ser assim descrita se corresponder a uma imagem carente de realidade, um simulacro que somente surge em razão de uma equivocada apreciação dos fatos por parte do observador. O "negócio aparente" jamais é celebrado pelos simuladores; a aparência já surge, como tal, em razão do programa negocial estabelecido entre eles $^{246}$. Com efeito, seria contrário à realidade das coisas conceber que as partes teriam querido, num primeiro momento, o negócio cuja validez rechaçariam logo depois, ao celebrar o acordo simulatório (os momentos aqui referidos são logicamente, não temporalmente distintos). Também seria contrário à economia do negócio supor que existiria um outro negócio quando, na realidade, o primeiro não fosse querido desde o começo ${ }^{247}$. Uma compra e venda simulada não é real antes de se tornar aparente; é

\footnotetext{
${ }^{246}$ F. MARANI, La simulazione negli atti unilaterali, Padova, CEDAM, 1971, p. 143.

${ }^{247}$ P. S. CoDERCh, Simulación Negocial... cit. (nota 120), p. 49; G. D. KAllimopoulos, Die Simulation... cit. (nota 124), p. 41. Para ilustrar seu entendimento, este último autor vale-se do seguinte exemplo: o empresário "A" quer demitir seus funcionários do escritório, com exceção de sua secretária "B", e contratar nova força de trabalho; antes da demissão, ele conta a "B" sua intenção e, a fim de evitar potenciais comentários por parte dos funcionários demitidos, conta-lhe que ela também receberá uma carta demissional; a demissão será apenas encenada, "B" deixará temporariamente o cargo, mas receberá um salário completo e o tempo até sua "readmissão" será computado como férias. "B" declara sua concordância com o que lhe fora exposto e tudo corre conforme planejado. Nesso exemplo, depara-se com um caso típico de declaração de vontade simulada,
} 
um negócio real que se reveste da aparência de compra e venda (por isto, simulado). O acordo simulatório, portanto, visa a criar a aparência, não a destruir a realidade.

Isto posto, vê-se que o acordo simulatório encerra o momento em que as partes estabelecem a simulação positivamente ${ }^{248}$. Aquele, portanto, necessariamente possui conteúdo negocial, sobretudo porque, como demonstramos linhas acima, o negócio simulado instaura um complexo regulamento de interesses.

A conclusão diversa não se chegaria à luz das ponderações da mais recente doutrina alemã sobre o tema. Na Alemanha, o $§ 117$ do Código Civil, embora não faça menção ao acordo simulatório ("Simulationsabrede"), cita expressamente o consentimento da contraparte da declaração ("Einverständnis"). Em vista disso, tem-se reconhecido que a simulação pode surgir em razão do intercâmbio de consentimentos (hipótese em que surgiria um contractus de simulando), mas isto não seria obrigatório. Seria suficiente, à caracterização da simulação, que o declaratário ofertasse o "de acordo" em face das intenções do declarante, ainda que tal conduta se restringisse a aceitá-las sem manifestar qualquer oposição ${ }^{249}$. Note-se bem: consentimento não seria sinônimo de mera ciência. Nesse estado de coisas, ainda que não fosse requerido um contrato específico para a perpetração da simulação, parece inegável que a vontade de um simulador teria de ser acolhida pela vontade de outro sujeito, o qual, aderindo àquela, também se tornaria simulador. A concordância, nestes termos, não deixaria de ter caráter negocial, ainda que o ato fosse unilateral, pois o anuente não se restringiria a autorizar a simulação, mas prestaria imprescindível colaboração à concretização desta.

Deveras, a causa da simulação ${ }^{250}$ é associativa $^{251}$; tal qual ocorre num contrato de sociedade, os simuladores reúnem esforços para a consecução de um objetivo comum.

de cuja nulidade não se pode duvidar. A concordância de "B" foi expressada antes da demissão, através da carta demissional, de modo que, não se pode falar de um acordo posterior do caráter simulado. Se "A" tivesse obtido a concordância de B só após a realização da demissão através da carta demissional, aí a demissão seria sem dúvida válida, e a concordância posterior de "B" levaria a uma anulação posterior da demissão, demissão esta ex tunc. Nesse caso não se trataria de uma simulação, mas sim de uma reserva mental cerrada (caso "A", com a carta demissional, quisesse confundir temporariamente "B"), ou de uma declaração de vontade inteiramente normal, que mais tarde seria revogada retroativamente através de um acordo entre os interessados.

${ }^{248}$ L. CARIOTA Ferrara, Il negozio giuridico... cit. (nota 34), p. 524-525.

${ }^{249}$ G. D. KAllimopoulos, Die Simulation... cit. (nota 124), p. 41-43.

${ }^{250} \mathrm{~V}$. tópico 10 . 
Seria ingênuo crer que, durante o iter simulatório, os contraentes manter-se-iam absolutamente desvinculados, no que tange à empreitada conjuntamente assumida. A experiência mostra que quem se dispõe a assumir a condição de simulador espera contar com a adesão da contraparte; entre os partícipes da simulação surge, portanto, uma relação de mútua confiança ${ }^{252}$. Assim, ao ajustarem o regulamento de interesses voltado à criação da ilusão negocial, as partes assumem obrigações; não se trata da promessa de celebrar o "negócio aparente" 253 (como a que decorreria de um negócio preliminar), mas do dever de cumprir o negócio simulado como tal (levando a efeito a difusão dos índices de que depende a disseminação da ilusão negocial) ${ }^{254}$.

É precisamente daí que decorre a impossibilidade de se atribuir autonomia ao acordo simulatório, pois, em última instância, ele se confunde com o regramento privado estabelecido pelos simuladores, sendo, portanto, descabida a sua valoração isolada ${ }^{255}$. Admitir-se o contrário seria equivalente a ver algum sentido, quanto a um contrato de compra e venda, em cogitar-se de um autônomo "acordo compraveditório"; tal suposição, além de redundante e inócua, não possuiria qualquer fundamento técnico.

Em sintonia com esta leitura, Furgiuele defende que o acordo simulatório seria fruto de uma abstração do comportamento concludente das partes, as quais, no decorrer de um procedimento, criariam os índices necessários a enganar os terceiros, assim como atestariam a sua condição de parte de um aparato criador da aparência negocial. $\mathrm{O}$ acordo simulatório, segundo o autor, seria uma fusão simbiótica de motivo comum determinante e convenção: aquele relacionar-se-ia à realização de uma atividade - a simulação; esta, por sua vez, reconduziria os atos praticados a um sentido compatível com a atividade que os originaria. Enquanto o motivo comum determinante geralmente precederia a simulação, a convenção deveria ser duradoura, pois dela dependeria a permanência do sentido da simulação enquanto tal ${ }^{256}$.

\footnotetext{
${ }^{251}$ Sobre a distinção entre causa de troca e causa associativa, v. F. GALGANO, Il negozio giuridico cit. (nota 119), p. 199 ss.

${ }^{252}$ F. MESSineO, Il contratto in genere cit. (nota 88), p. 454; S. PUGLIATTI, La simulazione... cit., (nota 53), p. 548.

${ }_{253}$ Bem observa S. PUGliatTi, La simulazione... cit., (nota 53), p. 548.

${ }^{254}$ F. ANELLI, Simulazione e interposizione cit. (nota 132), p. 582; F. MESSINEO, Il contratto in genere cit. (nota 88), p. 454.

${ }^{255}$ G. CONTE, La simulazione del matrimonio... cit. (nota 130), p. 387.

${ }^{256}$ G. FURGIUELE, Della simulazione... cit. (nota 144), p. 72 ss.
} 
A associação da dimensão volitiva da simulação ao motivo comum determinante, como destacamos acima, já houvera sido prenunciada por Romano. Ocorre, porém, que, na medida em que o motivo comum determinante insere-se no regulamento de interesses estabelecido pelas partes, assume especial relevância jurídica, passando a identificar-se com a finalidade negocial ${ }^{257}$. Demais disso, a pactuação quanto ao sentido das declarações emitidas não parece ser mais que um natural desdobramento da conversão daquele impulso pré-jurídico em conteúdo do quadro negocial.

Por conta disso, não é possível restringir o acordo simulatório ao entendimento firmado na fase pré-negocial, como fez Auricchio. Embora as tratativas possam orientar a interpretação do negócio jurídico e dar origem a deveres colaterais ou anexos em virtude da incidência do princípio da boa-fé objetiva, estas não perdem a condição de situação de fato; por conseguinte, não se mostram capazes de determinar o cerne da regra posta pelo negócio jurídico. Se o negócio é simulado, isto não resulta de uma preliminar de fato, mas do próprio teor da relação jurídica colocada em vigor.

O programa da futura simulação ultima-se absorvido pelo ajuste convencional próprio do negócio simulado. Nessa linha de raciocínio, Majello chega a sugerir que o acordo simulatório não passaria de um cláusula acessória do negócio simulado, com estrutura semelhante à da condição ${ }^{258}$. A intuição é feliz, mas imperfeita, pois a intenção comum de simular integra-se ao núcleo dispositivo do negócio simulado, determinando-lhe a causa concreta ${ }^{259}$. Mais precisa é a afirmação do autor de que a simulação ter fonte no acordo somente pode significar que ela encerra a função total do negócio jurídico, quando absoluta, e a função parcial deste, quando relativa ${ }^{260}$.

A tese acima defendida poderia ser alvo de objeções. Uma delas extrair-se-ia de um desafiador exemplo narrado por Cipriani: o proprietário de um bem ajusta, com outrem, a transferência deste; combina, ainda, com a contraparte, que a avença deveria ser mantida em sigilo, de modo que não fosse possível identificar-se a mudança de titularidade ocorrida. "Em um suporte fático do gênero, embora a situação final criada não fosse diferente daquela decorrente de um ato translativo absolutamente simulado, o que se

\footnotetext{
${ }^{257}$ J. GHESTIN, Causa de l'engagement... cit. (nota 56), p. 127.

${ }^{258}$ U. MAJELLO, Il contratto simulato... cit. (nota 105), p. 647.

${ }^{259}$ N. CIPRIANI, La simulazione di effeti giuridici... cit. (nota 107), p. 7.

${ }^{260}$ U. MAJELLO, Il contratto simulato... cit. (nota 105), p. 645.
} 
simula é um 'não efeito', enquanto a operação translativa, querida pelas partes, é dissimulada” ${ }^{, 261}$. Outro possível questionamento poderia decorrer da arguta observação de Furgiuele de que a simulação poderia persistir a despeito da resolução do negócio simulado. Poderia existir simulação - adverte o autor - no caso em que as partes resolvessem resilir um contrato de maneira sigilosa, embora ajustassem, entre si, continuar comportando-se como se o contrato ainda estivesse em vigor ${ }^{262}$.

As situações acima relatadas poderiam insinuar que, ao menos sob certas condições, o reconhecimento da autonomia do acordo simulatório seria inevitável.

Não se deve ignorar, contudo, que o exemplo ventilado por Cipriani não chega a guardar identidade com a simulação. Causaria espécie, de fato, associar-se a este instituto a representação de um "não efeito"; a aparência negocial, por imperativo da norma, é elemento necessário do fenômeno. A ocultação de uma relação jurídica efetiva corresponderia, acaso se acolhesse o ponto de vista do autor, a uma dissimulação pura, hipótese que não foi contemplada pelo legislador, a uma, porque não haveria negócio jurídico a ser declarado nulo, e, a duas, porque os eventuais interesses de terceiros preteridos pela eficácia do contrato confidencial seriam protegidos pelas normas relacionadas à inoponibilidade ${ }^{263}$, nos limites em que esta se encontra prevista.

\footnotetext{
${ }^{261}$ N. CIPRIANI, La simulazione di effeti giuridici... cit. (nota 107), p. 11.

${ }^{262}$ G. FURGIUELE, Della simulazione... cit. (nota 144), p. 69-70.

${ }^{263}$ Cite-se, por exemplo, o artigo 129 da Lei $n^{\circ}$ 6.015/73:
}

“Art. 129. Estão sujeitos a registro, no Registro de Títulos e Documentos, para surtir efeitos em relação a terceiros:

$1^{\circ}$ ) os contratos de locação de prédios, sem prejuízo do disposto do artigo $167, \mathrm{I}, \mathrm{n}^{\circ} 3$;

$2^{\circ}$ ) os documentos decorrentes de depósitos, ou de cauções feitos em garantia de cumprimento de obrigações contratuais, ainda que em separado dos respectivos instrumentos;

$3^{\circ}$ ) as cartas de fiança, em geral, feitas por instrumento particular, seja qual for a natureza do compromisso por elas abonado;

$4^{\circ}$ ) os contratos de locação de serviços não atribuídos a outras repartições;

$5^{\circ}$ ) os contratos de compra e venda em prestações, com reserva de domínio ou não, qualquer que seja a forma de que se revistam, os de alienação ou de promessas de venda referentes a bens móveis e os de alienação fiduciária;

$6^{\circ}$ ) todos os documentos de procedência estrangeira, acompanhados das respectivas traduções, para produzirem efeitos em repartições da União, dos Estados, do Distrito Federal, dos Territórios e dos Municípios ou em qualquer instância, juízo ou tribunal;

$7^{\circ}$ ) as quitações, recibos e contratos de compra e venda de automóveis, bem como o penhor destes, qualquer que seja a forma que revistam;

$8^{\circ}$ ) os atos administrativos expedidos para cumprimento de decisões judiciais, sem trânsito em julgado, pelas quais for determinada a entrega, pelas alfândegas e mesas de renda, de bens e mercadorias procedentes do exterior.

$9^{\circ}$ ) os instrumentos de cessão de direitos e de créditos, de sub-rogação e de dação em pagamento". 
O exame da afirmação de Furgiuele, por seu turno, deve dar-se com atenção ao correto ângulo de apreciação do fenômeno simulatório. Conforme demonstramos, o negócio simulado não corresponde ao parecer, mas ao instrumento negocial que dá origem à aparência (ou melhor, que dela se reveste). Como consequência disso, a resolução de um negócio não simulado, acompanhada da manutenção da aparência da relação jurídica preexistente, não significa que o negócio simulado tenha perdido vigência, permanecendo eficaz apenas o acordo simulatório, pois o ajuste de interesses surgido nestes termos corresponde, ele próprio, à totalidade do negócio simulado: uma relação jurídica dotada de aparência ilusória. Por outras palavras, o negócio não simulado extinto cederia lugar ao negócio simulado, não a um isolado acordo simulatório; a criação da aparência enganadora a partir da resolução de um negócio jurídico preexistente, portanto, não é mais que uma das maneiras pelas quais poder-se-ia desenrolar o procedimento simulatório. O exemplo de Furgiuele, ao contrário de justificar a concepção do acordo simulatório como negócio autônomo, reforça o entendimento de que aquele identifica-se com a conteúdo dispositivo do negócio simulado.

Vale, por fim, registrar que o acordo simulatório não se confunde com a chamada contradeclaração. Enquanto o primeiro possui caráter dispositivo, a segunda veicula uma declaração de ciência (declaração de verdade), servindo tão somente como prova préconstituída da simulação ${ }^{264}$.

Ante o exposto, apenas para fins didáticos conseguimos atribuir valor próprio à figura do acordo simulatório. Certamente o enlace volitivo dos simuladores consiste no momento decisivo, característico e indefectível do procedimento simulado, no qual se dá a preordenação da aparência ${ }^{265}$. Isto não difere, porém, do que ocorre com qualquer contrato: na compra e venda, por exemplo, o enlace volitivo das partes consiste no momento decisivo, característico e indefectível da atividade contratual, no qual se dá a preordenação da iminente troca da coisa pelo preço; mas não há - repita-se - um "acordo compravenditório" autônomo.

${ }^{264}$ G. BIANCHI, La simulazione, Padova, CEDAM, 2003, p. 201-202.

${ }^{265}$ N. DistAso, La simulazione... cit. (nota 40), p. 200. 


\section{§ 4. A ILUSÃo NEGOCIAL}

O resultado ao qual chegamos após a exposição precedente permite-nos visualizar o fenômeno simulatório por uma perspectiva mais concreta e menos dependente dos preconceitos impostos pelos diferentes dogmas da teoria geral do negócio jurídico. A concepção do negócio simulado como manifestação de autonomia privada põe em relevo o seu significado global; os particulares que se predispõem a realizar uma operação simulada dedicam-se à condução da atividade negocial que lhes parece mais adequada à consecução das finalidades que perseguem ${ }^{266}$. A compreensão do fenômeno simulatório não requer mais que a devida reconstrução do sentido da atividade das partes ${ }^{267}$.

Na sequência, passaremos a examinar de maneira mais aprofundada o mecanismo da simulação, ou seja, a operatividade do regulamento de interesses que caracteriza o negócio simulado. Como veremos, o interesse dos simuladores é o de enganar o público, disseminando, desse modo, a ilusão negocial. Para alcançar este objetivo, as partes se valem de um jogo de perspectivas, permitindo que o público tome conhecimento de apenas parte de seu comportamento. Este artifício leva os terceiros a interpretar e a qualificar incorretamente aquilo que percebem, atribuindo um sentido inadequado à conduta dos contraentes do negócio jurídico.

O modo como a simulação se desenrola é singelo, e poderia ser exemplificado da seguinte maneira. Considere-se que um leitor encontre, diante de si, a palavra "cavalo"; esta palavra poderia ser associada a alguns significados, como, por exemplo, o mamífero da família dos equídeos, ou a peça de xadrez capaz de movimentar-se em "L". Poderia ocorrer, porém, de esta palavra não representar a totalidade de um vocábulo, mas somente parte dele; poderia suceder, ainda, que o restante da palavra fosse mantida em sigilo por quem a tivesse escrito. Nesse cenário, imagine-se que enquanto o leitor ordinário pudesse ler apenas "cavalo", o autor do escrito pudesse visualizar "cavalo-marinho". A omissão do complemento "-marinho", capaz de alterar completamente o significado do vocábulo, e os possíveis sentidos que este poderia assumir quando utilizado, induziria o leito ordinário a um erro de apreciação sobre o signo em exame. "Cavalo", quando associado a "-marinho",

\footnotetext{
${ }^{266}$ G. CONTE, La simulazione del matrimonio... cit. (nota 130), p. 386. Tradução livre; no original: "I soggetti privati che si ripropongono di realizzare una operazione simulata si impegnano a compiere quell'attività negoziale che più appare idonea ai loro occhi a far conseguire quelle determinate finalità cui mirano".

${ }^{267}$ G. CONTE, La simulazione del matrimonio... cit. (nota 130), p. 388.
} 
não teria nada que ver com o mamífero ou a peça de xadrez; na realidade, o "cavalo" que integra o substantivo composto "cavalo-marinho" não possui significado próprio, pois é um componente de uma unidade de sentido mais ampla.

Com este singelo exemplo, podemos conceber com maior clareza o modo de ser da simulação. A ilusão negocial, como teremos oportunidade de expor mais detalhadamente, funda-se sobre a ocultação de determinados atos ou fatos que, se fossem conhecidos pelo público, ensejariam uma diversa interpretação ou uma diferente qualificação do negócio jurídico.

\section{Uma releitura da tese declaracionista}

Dentre as diversas teses da simulação, a declaracionista é, de fato, a que se mostra menos suscetível a críticas. Nessa esteira, Conte conclui, após seguir um itinerário semelhante ao traçado nas páginas anteriores, que o sentido da complexa regulamentação criada pelas partes residiria na predisposição de um regulamento de interesses articulado em dois planos: um externo, a ser ostentado perante os olhos de terceiros, e outro interno, em que se concretizaria o regulamento de interesses estabelecido pelas partes ${ }^{268}$.

Pensamos, contudo, que alguns aspectos da tese declaracionista poderiam ser mais bem precisados, sobretudo a concepção de que a declaração ostensiva "valeria perante terceiros", ao passo que a declaração oculta "valeria entre as partes". Segundo nos parece, não é bem assim que as coisas funcionam no âmbito da simulação.

Vejamos um exemplo que pode servir como fio condutor da análise da questão: Caio e Tício comparecem perante o cartório de notas e celebram uma escritura pública, pela qual o primeiro declara obrigar-se a determinada prestação em favor do segundo. No mesmo dia, as partes formalizam, mediante instrumento particular, uma ressalva pela qual Caio declara que, a despeito do disposto na primeira avença, ele não se obriga a qualquer prestação. Seria correto, em vista destes fatos, afirmar que a escritura pública valeria perante terceiros e o instrumento particular valeria entre as partes? Não conseguimos responder afirmativamente esta indagação. No exemplo proposto, ambas as declarações, a pública e a particular, valeriam entre as partes assim como poderiam, igualmente,

${ }^{268}$ G. CONTE, La simulazione del matrimonio... cit. (nota 130), p. 388. 
repercutir sobre a esfera de direitos de terceiros (destinatários indiretos da declaração). A duplicidade de declarações (ou fragmentos de declaração) não seria suficiente para demarcar a instauração do fenômeno simulatório.

Uma prova dessa constatação poderia ser obtida por meio da inclusão, no referido exemplo, de um dado até então não mencionado: a cognoscibilidade das declarações.

Assuma-se, numa primeira aproximação, que o instrumento particular que formalizasse a ressalva fosse recognoscível pelos terceiros (em razão de, por exemplo, ter sido levado a registro perante o oficial de títulos e documentos), assim como a escritura pública (presumivelmente apreensível pelo público em virtude da publicidade do registro). Em tal situação, o "cidadão médio" estaria diante de duas declarações pretensamente conflitantes, mas de maneira alguma poderia concluir que, entre o "sim, me obrigo" e o "na verdade, não me obrigo", apenas o primeiro fragmento de declaração seria eficaz, do ponto de vista de sua particular posição jurídica. A conclusão a que naturalmente se chegaria, neste quadro fático, seria a de que as partes não teriam celebrado qualquer negócio jurídico, ou, quando muito, teriam firmado um acordo e sucessivamente o teriam resilido. Não haveria, pois, espaço para se cogitar de simulação ${ }^{269}$.

Considere-se, então, numa segunda aproximação, que a ressalva constante de instrumento particular fosse mantida em absoluto segredo por Caio e Tício. Se assim fosse, a declaração aparente poderia ser tida como aparente, não porque valeria apenas perante terceiros (pois, potencialmente, continuaria a vigorar entre as partes), mas porque não valeria para ninguém, nem entre os simuladores nem perante o público. Na realidade, a única declaração a valer seria a "resultante" (a alusão às grandezas vetoriais da física se mostra útil nesta sede) da interação entre os dois fragmentos, o oculto e o ostensivo. Mais especificamente, no exemplo em apreço, valeria a declaração por meio da qual as partes ajustariam criar uma aparência negocial, embora, a par disso, mantivessem suas posições jurídicas inalteradas. Vê-se, pois, que a aparência não resultaria da simples oposição de fragmentos de declaração, nem da atribuição, a estes, de âmbitos subjetivos de validade diversos. Seria, diversamente, o produto do engano, ou seja, da apresentação, ao público,

\footnotetext{
${ }^{269}$ Uma aguda e precisa crítica à tese fundada na "anulação" ou "neutralização" de declarações conflitantes é desenvolvida por S. PugliatTI, La simulazione... cit., (nota 53), p. 543-545. O autor sustenta que o fato de as partes emitirem duas declarações, ou fragmentos de declaração não seria suficiente a caracterizar a simulação, pois cada uma das manifestações de vontade apresentaria plena autonomia estrutural e funcional.
} 
de uma conduta que pudesse ser considerada como negocial, mas que, se fosse analisada à luz da totalidade do comportamento das partes, não seria predicada como tal. De fato, apenas a partir do momento em que incluímos o engano generalizado no exemplo em tela podemos atestar a presença da simulação.

É, portanto, muito feliz a proposição de Köhler segundo a qual, para que a simulação se completasse, não bastaria a oposição de declarações, pois seria necessário que o fragmento com aparência de validade fosse exposto ao público para que pudesse ser reconhecido e incitasse o engano. Assim, como o público teria uma visão apenas parcial do fato único produzido pelas partes, interpretaria mal o nada criado, acreditando tratar-se de algo efetivo. Destarte, a essência do fenômeno simulatório não reside na paralisação de uma declaração pela contradeclaração, nem na simples intenção de enganar ${ }^{270}$, mas na consumação do engano.

A propósito, Messina concebe a consumação do engano como uma declaração de ciência que incutiria nos terceiros uma equivocada representação da realidade. Deve-se assinalar, contudo, que, o autor abordava este elemento da simulação do ponto de vista dos contraentes. Ele acreditava que, uma vez celebrados o acordo simulatório e o negócio simulado, as partes poderiam, a qualquer momento, desistir do seu plano original. Se assim ocorresse, o negócio jurídico celebrado não passaria de um negócio celebrado por brincadeira. Assim, para que a simulação se manifestasse em sua plenitude, seria necessário que os figurantes emitissem, cada um por si, uma declaração atestadora dando conhecimento do ocorrido aos terceiros. Esta declaração, de cunho unilateral, não possuiria conteúdo dispositivo (i.e. configuraria simples declaração de ciência); seria o último anel do procedimento simulado, uma declaração informativa cuja emissão tornaria defeso, às partes, voltar atrás no curso da simulação. A consumação engano, assim concebida, justificaria a distinção entre a simulação e as demais declarações não sérias ${ }^{271}$.

A intuição de Messina, conquanto correta, deixa pairar a sensação de que a simulação seria um fenômeno dependente exclusivamente da conduta das partes: ela seria uma coisa aos olhos destas (i.e. a emissão de declarações contraditórias), e outra aos olhos dos terceiros (i.e. o engano decorrente da aparência). Tanto assim que os críticos do autor

${ }^{270}$ P. S. CODERCH, Simulación Negocial... cit. (nota 120), p. 39; 50.

${ }^{271}$ G. MESSINA, La simulazione assoluta cit. (nota 40), p. 95-98. 
diriam que a consumação do engano não importaria ao sucesso da empreitada dos simuladores (a qual se exauriria com a emissão de fragmentos de declaração contraditórios entre si), mas apenas como condição à proteção dos direitos de terceiros ${ }^{272}$.

É de assinalar, no entanto, que a simulação não apresenta configurações distintas para os simuladores e para os terceiros; é, diversamente, um fenômeno unitário que pressupõe a participação destes. O sutil equívoco que macula a tese declaracionista parece consistir na suposição de que o negócio engana porque é aparente (i.e. torna-se aparente em razão da duplicidade de declarações, para então enganar). Em nossa opinião, contudo, é bem o contrário que ocorre: o negócio é aparente porque engana (i.e. o engano é condição lógica da aparência). A fragmentação da declaração é um pressuposto material do engano, mas não o conflito entre os fragmentos, do qual, a rigor, não se pode cogitar. O conflito entre declarações jamais se caracteriza sob a perspectiva das partes, pois para estas, o "sim, me obrigo" e o "na verdade, não me obrigo" formam uma única manifestação de vontade, coerente e capaz de acomodar os seus interesses da maneira desejada. É necessário distinguir a diversidade de declarações (ou fragmentos de declaração) da contradição entre $\operatorname{elas}^{273}$ : o negócio simulado pressupõe a emissão de uma declaração complexa, passível de se tornar apenas parcialmente ostensiva; não implica, contudo, um conflito entre os fragmentos da declaração, os quais, considerados conjuntamente, formam uma unidade de sentido harmoniosa. Acaso se quisesse vislumbrar alguma contradição, dever-se-ia opor, de um lado, a estrutura negocial criada pelas partes, e de outro, a declaração negocial reconhecida pela comunidade. Na simulação, divergem os sentidos que as partes e o público atribuem à relação negocial.

Este ponto de vista parece ter sido compartilhado por Distaso, o qual afirma que a atividade material a que se reporta a simulação se identifica como um procedimento cujo resultado não é recognoscível pela comunidade, o qual se direciona a suscitar no mundo exterior a confiança legítima quanto à realidade de um autorregulamento que, na realidade das relações dos simuladores, não existe (simulação absoluta), ou apenas parcialmente se conforma com o regulamento de interesses que se fez aparecer (simulação relativa) ${ }^{274}$. O autor defende que o procedimento simulatório seria composto de dois momentos distintos,

\footnotetext{
${ }^{272}$ R. SACCO - G. DE NOVA, Il contratto cit. (nota 153), p. 650.

${ }^{273}$ S. PugliatTi, La simulazione... cit. (nota 53), p. 542.

${ }^{274}$ N. Distaso, La simulazione... cit. (nota 40), p. 62.
} 
porém teleologicamente conexos e coordenados: o da preordenação da aparência e o da atuação da aparência. O "ato aparente", enquanto falsa assinalação da realidade, contradir-se-ia em sua essência; isto ocorreria por obra do acordo simulatório, que, ao mesmo tempo, preordenaria a aparência e tornaria simulado o negócio firmado entre as partes. A unívoca direção da intenção das partes se concretizaria pela duplicidade de declarações, uma preordenante e outra atuante da aparência. Estas declarações se contradiriam no plano da relação entre os contraentes, e, deste modo, acarretariam a dissociação entre a realidade e a ficção ${ }^{275}$.

Se pudéssemos sugerir um único reparo à formulação de Distaso, incluiríamos a participação do público no momento da atuação da aparência. É intuitiva a percepção de que não há aparência se esta não engana, e não há engano se não há quem se possa dizer enganado. Sem a vítima do engano, qualquer preordenação da aparência seria inócua. $\mathrm{O}$ que torna o "negócio aparente", isto é, o que permite a dissociação entre o real e o irreal é precisamente a comunicação, ao público, de uma realidade (que surge como representação ideal formada pela razão diante dos dados conhecidos) diferente daquela que os simuladores criam e conhecem.

Como bem assinala Platão nO Sofista, o simulacro incorpora o ponto de vista do observador; uma escultura de uma figura humana de grandes dimensões, esculpida propositalmente com uma desproporção entre os membros inferiores e a parte superior à cintura, somente poderia parecer equilibrada se captada de um particular ângulo visual (i.e. a partir da sua base); do contrário, se alguém a olhasse de cima para baixo (como poderia fazê-lo o escultor, do alto de um andaime), não se depararia com a aparência pretendida, pois tal ponto de vista seria inadequado à instalação do engano ${ }^{276}$.

O negócio simulado, portanto, decorre de um circuito que obrigatoriamente requer a interação com o público para que se possa reputar fechado. A atuação dos simuladores tem por objeto a predisposição de um aparato fático capaz de motivar os terceiros a

\footnotetext{
${ }^{275}$ N. Distaso, La simulazione... cit. (nota 40), p. 145 ss.

276 Platão, $O$ Sofista, trad. port. de J. D. Rodrigues, UFB, 1980 (disponível em $<$ http://www.ebooksbrasil.org/eLibris/sofista.html>, XIII:

"Estrangeiro - E então? E o que dá a impressão de belo, por ser visto de posição desfavorável, mas que, para quem sabe contemplar essas criações monumentais em nada se assemelha com o modelo que presume imitar, por que nome designaremos? Não merecerá o de simulacro, por apenas parecer, sem ser realmente parecido? Teeteto - Sem dúvida”.
} 
formularem um juízo sobre o seu comportamento. Eles têm "como objetivo da sua atuação os terceiros, e, em particular, a formação, nestes últimos (...) de um convencimento incorreto, contudo - acerca da verificação de uma alteração na situação de direito preexistente" 277 . Por conseguinte, o traço característico da simulação não é o choque de declarações (ou fragmentos de declaração), mas o conflito entre duas percepções: a comunidade, presa a um limitado ponto de vista, visualiza apenas parte do comportamento dos contraentes, atribuindo-lhe um sentido diferente daquele que as partes atribuem à totalidade da operação negocial; um sentido, ademais, incongruente com aquele que os próprios terceiros atribuiriam ao comportamento dos simuladores se tivessem acesso à sua integralidade.

\section{O ponto de relevância hermenêutica do negócio simulado}

Para que um comportamento privado seja objeto de interpretação jurídica, é necessário que ele apresente a forma requerida à sua qualificação como negócio jurídico. Seria inútil pretender interpretar, juridicamente, um comportamento que sequer remetesse a um ato dotado de relevância normativa. Mas, se ao menos a imagem do negócio subsiste, sujeita-se à interpretação o comportamento privado exteriormente recognoscível no mundo social, não a vontade psicológica que não tenha sido adequadamente objetivada. Quando se fala de recognoscibilidade social, deve-se entender que o negócio jurídico seja recognoscível por aqueles em face dos quais ele deve ser tido como juridicamente relevante. Em geral o negócio jurídico deve tornar-se recognoscível à contraparte do declarante, ou à comunidade que o cerca, quando não haja uma contraparte. Existe, portanto, um ponto de relevância para o tratamento interpretativo - ponto de relevância hermenêtica -, a qual o hermeneuta deve investigar com vistas a identificar a sede em que deve assentar-se a eficácia do negócio jurídico ${ }^{278}$.

Relativamente ao negócio simulado, existe, por certo, uma dimensão do comportamento negocial que interessa às partes, notadamente a convenção associativa que tem por objeto a difusão da aparência enganadora. Nada obstante, o ponto de relevância hermenêutica a ser considerado para o diagnóstico da simulação não se limita à

\footnotetext{
277 G. FURGIUELE, Della simulazione... cit. (nota 144), p. 58.

${ }^{278}$ E. BETTI, Interpretazione della legge e degli atti giuridici (teoria generale e dogmatica), 2a ed., Milano, Giuffré, 1971, p. 386 ss.
} 
recognoscibilidade, pela contraparte, da declaração simulada emitida pelo declarante. Como vimos acima, a dissociação entre o irreal e o irreal depende do engano do público; consequentemente, a investigação em torno do fenômeno simulatório deve levar em conta, igualmente, a (não) recognoscibilidade, pelos terceiros, do efetivo conteúdo do regulamento de interesses estabelecido entre os contraentes. Dizendo de outro modo, a interpretação do negócio simulado, direcionada a atestar esta sua qualidade, deve se orientada, de um lado, pela recognoscibilidade, pelos figurantes, do programa simulatório entre eles convencionado; e, de doutro lado, pela não recognoscibilidade, pelo público, deste mesmo programa.

A relevância do ponto de vista dos terceiros para a qualificação do engano que caracteriza a simulação é confirmada pelo direito positivo. $\mathrm{O}$ artigo 167 descreve o negócio simulado como não verdadeiro. No negócio simulado, o juízo deôntico formulado pelas partes se afigura descolado da verdade ${ }^{279}$.

Tem-se assinalado, contudo, que o negócio jurídico, enquanto expressão de um dever-ser, não se sujeita ao tribunal da verdade. Isto é, o negócio jurídico não expressa

${ }^{279}$ A verdade, numa conpeção nominal, consiste no acordo do conhecimento com o objeto (I. KANT, LogikEin Handbuch zu Vorlesungen, trad. port. de F. Castilho, Manual dos cursos de Lógica Geral, $2^{\mathrm{a}}$ ed., Campinas, Unicamp, 2002, p. 101 ss.) Esta dimensão da verdade denomina-se material, pois depende das notas particulares do objeto, ou seja, de sua essência real. É impossível formular enunciados universais sobre a verdade material, a qual deve ser sempre verificada e testada caso a caso. Entende-se por essência real, pois, o conjunto de notas características que se extrai e se conjuga em confronto com a experiência.

A verdade material (adaequatio rei et intellectus) é estabelecida por um juízo, mas pode derivar da conformidade da mente ao objeto (adaequatio intellectus ad rem), ou da conformidade das coisas à mente (adaequatio rei ad intellectus). Na primeira hipótese, o pensamento amolda-se ao existente; o ideal acopla-se ao real, de modo que a inteligência torne-se apta a descrever que o que é é, e o que é assim é assim. Na segunda hipótese, depara-se com uma modelação da realidade ao pensamento; esta, igualmente, docorre da razão, porém, o caminho é inverso ao pressuposto pela concepção clássica, antes descrito. A inteligência possui uma precompreensão acerca da realidade, e, posteriormente, compara-a com o objeto particular; a conformidade surgirá se a coisa for aquilo que dela se tiver pensado. Este encontro leva o sujeito a afirmar que a coisa é verdadeira, e.g. um verdadeiro amigo, um verdadeiro heroi, um verdadeiro gênio. A primeira verdade poder-se-ia denominar gnoseológica; a segundo, ontológica. (A. JUNQUEIRA DE AZEVEDO, Negócio Jurídico e Declaração Negocial (Noções gerais e formação da declaração negocial), Tese (Titularidade) Faculdade de Direito da Universidade de São Paulo, São Paulo, 1986, p. 169-170).

Condição de todo conhecimento, inclusive daquele fundado na verdade material, é a verdade formal. É desta, que abstrai completamente o conteúdo do objeto, que trata a Ciência Lógica, e seus enunciados universais, como os princípios da identidade, da razão suficiente, e do terceiro excluído (I. KANT, Manual... cit., supra, p. 105). "No campo da Lógica formal, o que importa é a consequência rigorosa das proposições entre si, e não a adequação de seus enunciados com os objetos a que se referem" (M. REALE, Filosofia do Direito, 20 ed., São Paulo, Saraiva, 2002, p. 28). Tanto a verdade formal, quanto a verdade material, a princípio, consistem em uma relação da qual faz parte o conhecimento; relação com ele próprio (verdade formal), ou com o objeto (verdade material). Não é a verdade, portanto, um juízo de valor, mas a expressão de uma relação objetiva. 
uma relação objetiva passível de ser qualificada como verdadeira ou falsa ${ }^{280}$. Não são poucos - reconheça-se - os esforços realizados em prol da submissão do direito aos ditames da lógica modal deôntica ${ }^{281}$. Nada obstante, o fato de a norma jurídica não comunicar um estado de coisas (i.e. não conter uma asserção), mas estabelecer uma prescrição, em geral, sob a forma de um juízo hipotético ( $\operatorname{Se} A$ é, $B$ deve ser), tem frustrado a pretensão da maioria dos lógicos, que, até o presente, esbarram nos óbices impostos pela lei de Hume ${ }^{282}$ e pelo dilema de Jørgensen ${ }^{283}$. A lógica das normas, apesar

${ }^{280}$ A. GENTILI, Il contratto simulato... cit. (nota 47), p. 257: "Longe de ser um contrato aparente (rectius uma aparência de contrato), o negócio simulado é, como todo juízo dispositivo, insuscetível de verificação (verdadeira ou falsa potendo ser a asserção da sua realidade histórica, mas não ou valor que lhe é atribuído, catalogável apenas em termos de validade). A sua pretensa 'aparência', em corretos termos lógicos e jurídicos, não exprime mais que um vício subjacente ao valor específico do contrato, ou melhor, e mais precisamente, a inadequação que aquele juízo revela com respeito aos interesses das partes. O engano implícito na feliz fórmula do contrato aparente cai tão logo a aparência se refira à realidade incontroversível do juízo". Tradução livre; no original: "Lungi dall'essere un contratto apparente (rectius un'aparenza di contratto) il negozio simulato è, come ogni giudizio dispositivo, insuscettibile di verificazione (vera o falsa potendo essere l'asserzione della sua realtà storica, ma non il valore attribuitole, catalogabile solo in termini di validità). La sua pretesa 'apparenza', in corretti termini logici e giuridici non esprime altro che un vizio sotteso al valore specifico del contratto, ovvero e più precisamente, l'inadeguatezza che quel giudizio dispositivo rivela rispetto agli interessi delle parti. L'inganno implicito nella fortunata formula del contratto apparente cade subito, solo che l'apparenza si riferisca alla realtà incontrovertibile del giudizio".

Assinala, ainda, a propósito, R. SCHREIBER, Logik des Rechts (1962), trad. esp. de E. Valdés, Lógica del Derecho, Fontamara, Ciudad de México, 1991, p. 121-122: "Las normas jurídicas, sin embargo, no pueden ser valoradas de la misma manera que las proposiciones indicativas, es decir como verdaderias o falsas. Las normas jurídicas no puden ser verificadas recurriendo directamente a la realidad. Para saber si una proposición es jurídicamente debida, habrá que tener en cuenta el procedimiento especial según el cual las normas jurídicas obtienes validez".

No mesmo sentido, A. Ross, Directives and Norms, trad. esp. de J. S.-P. Hierro, Lógica de las normas, Madrid, Tecnos, 1971, p. 98: "Es obvio, y hasta donde alcanza mi conocimiento aceptado, que los directivos carecen de valor de verdad (no son verdaderos ni falsos), en la mayoría de los casos con seguridad. No puedo imaginar que alguien diga que la orden 'Pedro, cierra la puerta' o la regla de ajedrez 'En un solo movimiento el rey sólo puede moverse un puesto' puede ser verdadera o falsa. De la regla de ajedrez puede decirse que existe (o está vigente) en una cierta comunidad de dos jugadores; esta afirmación será verdadera o falsa. Pero, como es obvio, esto no es lo mismo que adscribir valores de verdad a las normas mismas, igual que no puede decirse que los cisnes negros tengan un valor de verdad simplemente porque la afirmación de que existen cisnes negros tenga un valor de verdad".

${ }^{281}$ Sobre o tema, v. T. MAZZARESE, Logica deontica e linguaggio giuridico, Padova, CEDAM, 1989, passim; G. KALINOWSKI, La logique des normes (1972), trad. esp. de J. R. Capella, Logica del discurso normativo, Madrid, Tecnos, 1975, passim, especialmente p. 20 ss.

${ }^{282}$ D. Hume, A Treatise of Human Nature (1739), trad. port. de D. Danowiski, Tratado da Natureza Humana - Uma tentativa de introduzir o método experimental de raciocínio nos assuntos morais, $2^{\mathrm{a}}$ ed., São Paulo, UNESP, 2009, p. 498; 509: “A razão é a descoberta da verdade ou da falsidade. A verdade e a falsidade consistem no acordo e no desacordo seja quanto à relação real de idéias, seja quanto à existência e aos fatos reais. Portanto, aquilo que não for suscetível desse acordo ou desacordo será incapaz de ser verdadeiro ou falso, e nunca poderá ser objeto de nossa razão. Ora, é evidente que nossas paixões, volições e ações são incapazes de tal acordo ou desacordo, já que são fatos e realidades originais, completos em si mesmos, e não implicam nenhuma referência a outras paixões, volições e ações. É impossível, portanto, declará-las verdadeiras ou falsas, contrárias ou conforme à razão. (...) Em todo sistema de moral que até hoje encontrei, sempre notei que o autor segue durante algum tempo o modo comum de raciocinar, estabelecendo a existência de Deus, ou fazendo observações a respeito dos assuntos humanos, quando, de repente, surpreendo-me ao ver que, em vez das cópulas proposicionais usuais, como é e não é, não encontro uma só 
dos notáveis avanços observados no campo da lógica jurídica, parece não ter ido muito além da lógica das proposições normativas, como profetizara o último Kelsen ${ }^{284}$.

Dessa feita, quanto ao negócio jurídico, expressão de um dever-ser, não se pode estabelecer qualquer relação de verdade - ou inverdade -, seja formal ou material. Nada obsta, porém, a que se formule um juízo descritivo sobre o negócio jurídico, segundo o qual se possa afirmar tratar-se, por exemplo, de um verdadeiro contrato de compra e venda ou de um falso contrato de compra e venda. Esse tipo de proposição seria o que, normalmente, o público formularia diante de um negócio jurídico, e, como tal, poderia ser verdadeiro ou falso. Enquanto as partes diriam que deve-ser, o público diria que $e^{285}$.

A distinção entre o negócio jurídico tomado pela perspectiva das partes e do público coincide, de certo modo, com a diferenciação traçada por Kelsen entre norma e

proposição que não esteja conectada a outra por um deve ou não deve. Essa mudança é imperceptível, porém da maior importância. Pois como esse deve ou não deve expressa uma nova relação ou afirmação, esta precisaria ser notada e explicada; ao mesmo tempo, seria preciso que se desse uma razão para algo que parece totalmente inconcebível, ou seja, como essa nova relação pode ser deduzida de outras inteiramente diferentes".

283 Sobre o tema, v. A. Ross, Lógica... cit. (nota 280), p. 130-131: “Por una parte, se concibe tradicionalmente que la lógica se ocupa de sentencias en la medida en que expresan proposiciones, y especialmente de la relación entre los valores de verdad de las diferentes proposiciones. Las conectivas lógicas se definen por medio de tablas de verdad que determinan sin ambigüedad el valor de verdad de una expresión molecular como función de sus expresiones atómicas constituyentes. Por tanto, inferir lógicamente significa poner en relación el valor de verdad de una sentencia con el valor de verdad de otra u otras sentencias. (Por simplicidad, y puesto que es usual aunque no correcto, hablaré de 'sen- tencias' en lugar de 'proposiciones', expresadas por sentencias.) Inferir lógicamente $S_{2}$, a partir de $S_{1}$, significa que si $S_{1}$ es verdadera, $S_{2}$ también es verdadera. Cualquier inferencia lógica puede formularse como un juicio hipotético de la forma: Si las premisas $P_{1}, P_{2}, \ldots, P_{n}$, son verdaderas, entonces la conclusión $C$ también es verdadera. De lo que se sigue que una secuencia de sentencias puede considerarse como una inferencia lógica solamente a condición de que las premisas consistan exclusivamente en sentencias que posean valor de verdad, y que, por tanto, sean o verdaderas o falsas. Puesto que los directivos no tienen valor de verdad (...), tal condición no se cumple si entre las premisas hay sentencias que expresen directivos, lo que significa que las inferencias deónticas quedan excluidas. Ciertamente, es posible construir reglas de transformación según las cuales se pueda decir que un directivo $\mathrm{D}_{2}$ se ha inferido a partir de otro directivo $D_{1}$. Pero, puesto que $D_{1}$ y $D_{2}$ son sentencias que carecen de valor de verdad, no es posible interpretar esas reglas ni explicar qué quiere decir que $D_{2}$ se sigue de $\mathrm{D}_{1}$. (...) Dicho brevemente, el dilema consiste en esto: por el modo como tradicionalmente se entiende el concepto 'inferencia lógica', parece que no tiene sentido hablar de 'inferencia deóntica'; pero, por otra parte, parece obvio que tales inferencias tienen lugar".

${ }^{284}$ H. KELSEN, Allgemeine Theorie der Normen (1979), trad. port. de J. F. Duarte, Teoria Geral das Normas, Porto Alegre, Sergio Antonio Fabris, 1986, p. 207.

${ }^{285}$ Precisas, a respeito desta questão, são as palavras de A. Ross (Lógica... cit., nota 280, p. 99): "La cuestión de si un directivo puede tener valor de verdad es independiente de la cuestión de si es posible tener un conocimiento de las cualidades de validez morales. Que un directivo no puede tener valor de verdad se sigue analíticamente del significado de 'directivo' y de 'valor de verdad'. La diferencia fundamental entre una proposición y un directivo se halla, como hemos visto, a nivel semántico. Ambos describen un tema (en el caso del directivo, una ideacción) que la proposición concibe como real ('así es') y el directivo presenta como forma de conducta ('así debe ser'). Decir de una expresión que es verdadera es, precisamente, aceptar que 'así es'. Por tanto, sólo las proposiciones pueden ser verdaderas”. 
enunciado. Tal discriminação parte da separação entre a significação de um ato de vontade e a significação de um ato de pensar. "A proposição cuja significação é um enunciado, descreve alguma coisa. É verdadeira ou falsa; quer dizer: corresponde ou não ao que ela descreve. A proposição cuja significação é uma norma pre-screve alguma coisa. Nem é verdadeira nem falsa". A função do enunciado é a de transmitir um saber; a da norma é a de submeter a vontade ${ }^{286}$.

Embora pensar e querer sejam funções diferentes, podem encontrar-se interligados. Toda proposição cujo sentido é uma norma (um dever-ser) precisa, antes de ser estabelecida, ser pensada. $O$ ato de pensamento é anterior ao ato de vontade ${ }^{287}$. Do mesmo modo, um ato de pensamento surge na esfera psíquica do destinatário da norma, que, antes de aderir àquela (reconhecendo sua validade), deve entender a sua específica significação normativa. "[Q]uando recebo uma ordem posso constatar, por autoobservação, que percebo interiormente a declaração de outrem a mim dirigida, i.e. escuto certas palavras pronunciadas, vejo um gesto ou caracteres impressos ou escritos, e que, além disso, acontece algo em mim que é diferente desse ouvir e desse ver, a saber: entendo a declaração ouvida ou vista, e precisamente entendo como ordem e não como enunciado; isto significa que apreendo o sentido que foi expresso como o enunciado, o sentido: que eu devo conduzir-me de um determinado modo" ${ }^{288}$.

Ocorre que, para o destinatário da norma, o enunciado, fruto do ato de pensar, dá origem a uma prescrição autônoma (“devo fazer isto”). Este processo psíquico, porém, não poderia ser observado quanto àqueles que, não sendo destinatários diretos da norma, limitassem-se a formar uma representação mental acerca da significação da declaração emitida. Assim parece suceder com os que ocupam a posição de terceiro com relação a um específico negócio jurídico, os quais, tomando conhecimento da declaração formulada por outrem, identificam o seu caráter deôntico mediante a formulação de um enunciado, isto é, um ato de pensamento, não de vontade. Concluem, assim, que "Caio e Tício celebraram um contrato de compra e venda". Esta proposição, de sentido meramente indicativo, é um juízo da ordem do ser dirigido à existência ideal do juízo deôntico estabelecido entre Caio

\footnotetext{
${ }^{286}$ H. KELSEN, Teoria Geral... cit. (nota 284), p. 208.

${ }^{287}$ H. KELSEN, Teoria Geral... cit. (nota 284), p. 211.

${ }^{288}$ H. KELSEN, Teoria Geral... cit. (nota 284), p. 45.
} 
e Tício. Aquele enunciado, embora tenha por objeto a validade do negócio jurídico, pretende ser verdadeiro, não válido.

A verdade, enfatiza Kelsen, é uma qualidade do enunciado; não se equipara, pois, à validade da norma, que não é uma qualidade desta, mas a sua própria existência. Um enunciado pode ser falso, e, mesmo assim, não deixar de ser enunciado. Isto não ocorre com a norma, que, sem validade, perde sua juridicidade. $\mathrm{O}$ enunciado sobre uma norma é verdadeiro se a norma vale; será falso se não valer $^{289}$; aquele pode, pois, ser verificado, na medida em que se disponha de provas de que a norma foi posta e não teve sua validade cessada por um ato de derrogação.

Em vista do exposto, a inverdade que o artigo 167 atribui ao negócio simulado pode ser concebida da seguinte maneira: é falso o enunciado formulado pelo público acerca da existência ideal do negócio jurídico. Não será falso o negócio simulado em si, porque não pode ser predicado como tal; nem faltará verdade ao enunciado formulado pelos simuladores, previamente à prática do ato de vontade, pois este corresponderá precisamente ao estabelecimento de um dever-ser direcionado à criação da aparência negocial, i.e. à promoção de uma incorreta representação da realidade na dimensão psíquica do público. Em face disso, uma vez celebrado o negócio jurídico, a significação deôntica que ele encerra não corresponderá ao sentido indicativo que o correlato enunciado, formulado pelo público, expressa.

Neste passo, percebe-se que a tese declaracionista de viés semiótico, defendida sobretudo por Gentili ${ }^{290}$, requer um adendo. Tal construção baseia-se na suposição de que, no negócio simulado, coexistiriam duas regras, uma destinada a valer entre as partes, outra destinada a valer perante terceiros. Seria equivocado, contudo, admitir que o negócio jurídico pudesse ser fonte de regras que, conquanto compartilhassem de um só âmbito interno de validade (a relação jurídica entre as partes), afigurassem-se antagônicas. Nem seria correto conceber que uma regra pudesse ser criada para valer apenas perante terceiros, pois o que vale para estes (rectius: influencia a sua esfera de direito) é sempre

\footnotetext{
${ }^{289}$ H. KELSEN, Teoria Geral... cit. (nota 284), p. 228: "Se um manual que descreve o Direito Penal do Estado $\mathrm{X}$ contém a proposição: 'Se um homem prometeu casamento a uma mulher, e não cumpriu sua promessa, e se além do não-cumprimento da promessa não reparou os prejuízos causados à mulher, segundo o Direito do Estado X, deve ser dirigida execução forçada (...)", então esta proposição é verdadeira se vale uma norma deste conteúdo, e ela vale se foi estabelecida pela via legislativa ou do Costume".

${ }^{290}$ V. tópico 5.
} 
aquilo que vale para os contraentes. A eficácia externa do negócio jurídico não é mais que um desdobramento da sua eficácia interna, pois os terceiros são destinatários indiretos da declaração.

Em face disso, as regras criadas pelos simuladores não seriam dos tipos $R_{1}=S_{1}$ não deve a $S_{2}$ e $R_{2}=S_{1}$ deve a $S_{2}$, mas apenas perante terceiros, em que "R" significa regra, e "S" significa sujeito; mas dos tipos tipo $R_{1}=S_{1}$ não deve a $S_{2}$ e $R_{2}=S_{1}$ deve aparentar dever a $S_{2}$. Entre estas regras não haveria antinomia, pois possuiriam conteúdos distintos, que não se contraporiam, mas se complementariam ${ }^{291}$. No curso da simulação, porém, surgiria uma terceira proposição, não mais uma regra, mas um enunciado: $E=E$ É fato que $S_{1}$ deve a $S_{2}$. Tal enunciado seria formulado pelo público, com base no material interpretativo trazido ao seu conhecimento, e, precisamente por não coincidir com o sentido de $R_{l}$, demarcaria a concretização da simulação.

O direito, portanto, reconhece que o negócio simulado sujeita-se a uma dupla valoração - não duas valorações realizadas pelos contraentes, mas uma de autoria destes e outra imputável aos terceiros - e, ao aludir à inverdade do negócio jurídico, assume esta dialética hermenêutica como essência da simulação.

\section{A dupla valoração do negócio simulado}

Embora tenhamos empregado, até aqui, a expressão aparência enganadora, existe outra que poderia substituí-la, e seria mais apropriada. Aparência, enquanto imediatidade do $\operatorname{ser}^{292}$, é algo que todo negócio jurídico possui. Por outro lado, a aparência que induz a um engano melhor se denominaria ilusão $o^{293}$.

A ilusão pode ser concebida de maneiras diferentes. Freud diz que ela decorre do desejo; o que não significa, necessariamente, a irrealidade. A jovem pode iludir-se crendo que um dia encontrará um príncipe encantado; não se exclui, porém, a possibilidade de que

\footnotetext{
${ }^{291}$ S. PUGLIATTI, La simulazione... cit. (nota 53), p. 542.

${ }^{292}$ Esta percepção remete-nos a Platão, O Sofista cit (nota 276), XIII:

"Estrangeiro - E a arte que produz simulacros, não imagens, não seria mais acertado denominá-la ilusória? Teeteto - Certíssimo".

${ }^{293}$ G. W. F. HeGEL, Wissenschaft der Logik (1816), trad. port. de M. A. Werle, Ciência da Lógica (excertos), São Paulo, Barcarolla, 2011, p. 115.
} 
isto venha a ocorrer, eventualmente ${ }^{294}$. Já Kant a descreve de modo diverso: corresponde (a ilusão transcendental) a uma percepção equivocada da realidade em si, que persiste ainda que se conheça a circunstância de tratar-se de um erro ${ }^{295}$. Um graveto que estivesse pela metade dentro de uma tigela cheia d'água pareceria angulado, aos olhos do observador; mesmo que este soubesse que tal efeito deriva da refração da luz, não haveria meios de enxergar o graveto em sua configuração correta enquanto permanecesse em tal condição. É neste segundo sentido que adotamos o termo ilusão, referindo-nos à simulação. Aquela ludibria a razão, e somente deixa de enganar quando o intérprete altera o ângulo pelo qual observa o negócio jurídico.

Na simulação, a criação voluntária da ilusão negocial torna-se possível em vista da consideração, pelas partes e pelos terceiros, respectivamente, de materiais interpretativos mais amplos (os quais aderem com maior intensidade aos fatos históricos e às circunstâncias concretas que subjazem ao estabelecimento da relação jurídica) e mais restritos (declarações e comportamentos dotados de maior aderência ao aspecto formal). $\mathrm{O}$

${ }^{294}$ S. FreUd, Die Zukunft einer Illusion (1927), trad. port. de J. Salomão (dir.), O Futuro de Uma Ilusão in Edição Standard Brasileira das Obras Psicológicas Completas de Sigmund Freud, v. XXI, São Paulo, Imago, 2006, p. 39-40: "Quando digo que todas essas coisas são ilusões, devo definir o significado da palavra. Uma ilusão não é a mesma coisa que um erro; tampouco é necessariamente um erro. A crença de Aristóteles de que os insetos se desenvolvem do esterco (crença a que as pessoas ignorantes ainda se aferram) era um erro; assim como a crença de uma geração anterior de médicos de que a tabes dorsalis constitui resultado de excessos sexuais. Seria incorreto chamar esses erros de ilusões. Por outro lado, foi uma ilusão de Colombo acreditar que descobriu um novo caminho marítimo para as Índias. O papel desempenhado por seu desejo nesse erro é bastante claro. Pode-se descrever como ilusão a asserção feita por certos nacionalistas de que a raça indo-germânica é a única capaz de civilização, ou a crença, que só foi destruída pela psicanálise, de que as crianças são criaturas sem sexualidade. O que é característico das ilusões é o fato de derivarem de desejos humanos. (...) As ilusões não precisam ser necessariamente falsas, ou seja, irrealizáveis ou em contradição com a realidade. Por exemplo, uma moça de classe média pode ter a ilusão de que um princípie encantado aparecerá e se casará com ela. Isto é possível, e certos casos assim já ocorreram”.

${ }^{295}$ I. KANT, Kritik der reinen Vernunft (2 $2^{\mathrm{a}}$ ed., 1787), trad. port. de V. Rohden e U. B. Moosburger, Crítica da Razão Pura, São Paulo, Nova Cultural, 1999, p. 231: “A ilusão lógica, que consiste na simples imitação da forma da razão (a ilusão dos silogismos sofísticos), surge unicamente de uma falta de atenção à regra lógica. Por isso, tão logo esta é concentrada sobre o caso em questão, a ilusão desaparece completamente. A ilusão transcendental, ao contrário, não cessa, embora tenha já sido descoberta e sua nulidade tenha sido claramente discernida pela crítica transcendental. (por exemplo, a ilusão na proposição: o mundo tem que ter um começo no tempo). A causa disso é que em nossa razão (considerada subjetivamente como uma faculdade cognitiva humana) encontram-se regras fundamentais e máximas do seu uso, as quais possuem completamente o aspecto de princípios objetivos e pelos quais possuem completamente os apecto de princípios objetivos e pelos quais acontece que a necessidade subjetiva de uma certa conexão de nossos conceitos em benefício do entendimento é tomada por uma necessidade objetiva de determinação das coisas em si mesmas. Trata-se de uma ilusão que de modo algum pode ser evitada, assim como tampouco podemos evitar que o mar pareça mais alto no meio que na praia porque no primeiro caso vemo-lo mediante raios luminosos mais altos que no segundo, ou mais ainda, assim como o próprio astrônomo não pode evitar que a lua ao surgir pareça maior, se bem que ele não seja enganado por esta ilusão.

A dialética transcendental contentar-se-á, portanto, em descobrir a ilusão dos juízos transcendentes e ao mesmo tempoimpedir que ela engane (...)". 
suporte fático ostensivo constitui-se de um conjunto de índices de uma realidade inexistente. Tomados em conjunto, portanto, formam um signo cujo sentido isolado contrasta com o sentido global $^{296}$ do agir negocial. A característica da simulação, precisamente, é esta dúplice e separada relevância da aparência que ilude e da aparência (que se mantém velada) do real ${ }^{297}$.

A aparência jurídica ${ }^{298}$, em termos gerais, é o resultado de uma pesquisa em torno do sentido da declaração negocial orientada pela boa-fé que o público nela deposita. É necessário interpretar e qualificar o negócio, reconduzindo-o a uma das categorias legalmente previstas. Esta operação se processa com base no exame de comportamentos e circunstâncias consideradas relevantes pelo direito, e resulta na determinação dos efeitos jurídicos recognoscíveis por um terceiro de boa-fé, objetivamente imputáveis aos declarantes. A adoção do ponto de vista de um terceiro de boa-fé de normal diligência ${ }^{299}$ permite a reconstrução do suporte fático concreto, reconduzível a um dos esquemas abstratos contemplados pelo ordenamento normativo ${ }^{300}$.

No que tange à ilusão negocial, as partes deliberadamente criam a aparência com o propósito de ludibriar a razão da comunidade. Estabelecem uma estrutura negocial complexa, constituída de declarações verbalizadas e não verbalizadas (comportamento

\footnotetext{
${ }^{296}$ M. CASElla (Simulazione (diritto privato) (verbete) in Enciclopedia del diritto, v. XLII, Milano, Giuffrè, 1990, p. 599) cogita de divergência entre significado e sentido.

${ }^{297}$ M. CASElLA, Simulazione cit. (nota 296), p. 599.

${ }^{298}$ Sobre o tema, v. F. CARnelutTI, Teoria generale del Diritto (1951), trad. port. de A. C. Ferreira, Teoria Geral do Direito, São Paulo, LEJUS, 1999, p. 392. Tem-se considerado a aparência como fonte de legitimação formal dos direitos. É um simulacro criado pela própria ordem jurídica, consistente na forma sensível da realidade jurídica, ou seja, o modo como ela se manifesta exteriormente (R. MoschELLA, Contributo... cit., nota 102, p. 37). Funda-se no princípio de publicidade, o qual fundamenta a relevância do direito como efetivamente se realiza nas relações usuais, não no modo como ele deveria ser, segundo uma abordagem puramente ideal (R. Moschella, Contributo..., cit., nota 102, p. 39). Com base neste princípio, defende-se que aquele que age negocialmente, confiando em um fato exterior que, por força da lei ou da opinião pública, representa a forma de manifestação de determinada situação jurídica, merece ser protegido, mormente quando a confiança tenha sido depositada na situação de fato criada por quem a proteção desta não interessa.

É complexa a estrutura da aparência, que, mais que um parecer, pressupõe um transaparecer algo diverso do que é. "A aparência não é um parecer opaco, um puro fato que revela apenas a si próprio, uma vez que um fenômeno que se limita a revelar a si próprio não pode nunca ser aparente: isso se dá por aquilo que é; somente quanto um fenômeno, além de si próprio, faz aparecer um outro fenômeno, e o faz aparecer como real enquanto seja irreal, surge a aparência" (A. FALZEA, Apparenza in Enciclopedia del diritto, v. II, Milano, Giuffrè, 1958, p. 685).

${ }^{299}$ M. CASElla, Simulazione cit. (nota 296), p. 599. Conforme observa A. FAlzEA (Apparenza... cit., nota 298, p. 697), a aparência não pode ser recognoscível como tal. A ausência da escusabilidade do erro exclui a aparência. $\mathrm{O}$ erro é capaz de dar azo à aparência quando, segundo os usos e costumes vigentes, não possa ser evitado pela normal diligência do "cidadão médio".

${ }^{300}$ M. CASELla, Simulazione cit. (nota 296), p. 598.
} 
concludente). Mantêm, porém, uma parcela de suas condutas em sigilo, prevenindo, assim, a recognoscibilidade social de determinados atos e fatos. Os simuladores criam um signo que somente pode ser adequadamente compreendido se considerado em sua totalidade. Ilustrativamente, dizem "estrela", remetendo, assim, ao corpo celeste assim denominado, mas omitem um complemento. A palavra "estrela" passa a ter um sentido completamente diferente se inserida no vocábulo composto "estrela-do-mar"; e assume um sentido diverso se empregada na frase "Elizabeth Taylor foi uma estrela". A estrela-do-mar e a estrela do cinema não se confundem com o corpo celeste denominado "estrela"; esta palavra, porém, é fatalmente interpretada incorretamente se os elementos que permitiriam precisar o ser correto sentido e o seu adequado sentido são excluídos da relação comunicacional estabelecida entre o locutor e o interlocutor ${ }^{301}$.

${ }^{301}$ Uma interessante concepção sobre o mecanismo de ocultação de parte do comportamento negocial que notabiliza a simulação é a proposta por J. A. S. DEL NERO (Conversão Substancial... cit., nota 142, p. 58 ss.; 396-397). Para compreendermos as proposições do autor, é importante passarmos, em revista, o seu ponto de vista sobre a formação gradual da relação jurídica com base em um processo deliberativo, o qual seria composto das seguintes etapas: (a) conhecimento dos fatos e do direito; (b) eleição do fim que pretende alcançar-se; e (c) escolha do meio adequado para atingir o fim almejado.

J. A. S. DEL NERo esclarece que nada impediria, porém, que houvesse processos deliberativos parciais e sucessivos, integrados em um único processo deliberativo total. Em cada processo deliberativo parcial haveria um fim e um meio, sendo certo que este fim constituiria o meio do processo deliberativo parcial seguinte. Para ilustrar este raciocínio, que o autor considera inspirado pela "lógica da análise funcional", ele enuncia a seguinte situação hipotética: "Suponha-se que: a) Tício tenha interesse em adquirir o direito subjetivo de propriedade (...) que recai sobre uma coisa, pertencente a Mévio, com todas as outras consequências, não puramente jurídicas, senão, também, econômicas e sociais, associadas a tal aquisição, satisfazendo, assim, tal interesse; b) Mévio tenha interesse em adquirir a disponibilidade jurídica (...) de uma quantia em dinheiro, pertencente a Tício, com todas as outras consequências, não puramente jurídicas, senão, também, econômicas e sociais, associadas a tal aquisição, satisfazendo, assim, tal interesse; c) Tício e Mévio conheçam o artigo 1.122 do Código Civil, que trata de um certo modelo jurídico-negocial denominado 'contrato de compra-e-venda', e o sentido jurídico de 'obrigação' (...). Buscando satisfazer tais interesses e conhecendo o modelo jurídico do contrato de compra-e-venda, aquela norma jurídica e o sentido jurídico de obrigação, Tício 'assegura' a Mévio que lhe pagará o preço, em dinheiro, e Mévio 'assevera' a Tício que lhe transferirá o domínio da coisa. Posteriormente, Tício paga o preço, em dinheiro, a Mévio, e Mévio transfere o domínio da coisa a Tício, satisfazendo-se os interesses de ambos".

Diante do exemplo acima descrito, seria possível constatar a cisão do processo deliberativo total de Caio e Tício em quatro processos deliberativos parciais e sucessivos (relações entre meios e fins), a seguir indicados:

(a) processo deliberativo parcial I:

i. fim: instituição de um ente jurídico-negocial correspondente ao contrato de compra e venda;

ii. meio: intercâmbio de declarações cujo conteúdo consistiria em comprar e vender;

(b) processo deliberativo parcial II:

i. fim: estabelecimento de obrigações de pagar o preço e transferir o domínio da coisa;

ii. meio: instituição de um ente jurídico-negocial correspondente ao contrato de compra e venda (fim do processo deliberativo I);

(c) processo deliberativo parcial III:

i. fim: cumprimento das obrigações de pagar o preço e de transferir o domínio da coisa;

ii. meio: estabelecimento de obrigações de pagar o preço e transferir o domínio da coisa (fim do processo deliberativo II); 
A construção acima apresentada aproxima-se, de certa maneira, do pensamento de Segrè, segundo o qual a declaração simulada seria emitida em uma linguagem convencional. A partir do texto de D. $34,5,3^{302}$, o autor afirma que quem diz algo diverso daquilo que quer não diz o que a voz significa, porque não o quer, nem o que quer, porque a voz não o diz ${ }^{303}$. Em vista disso, a simulação não poderia ser explicada com base em um conflito entre vontade e declaração, pois resultaria, na verdade, de uma divergência de interpretação decorrente do emprego, pelas partes, de uma linguagem convencional: "[s]e as partes A e B concordaram em declarar a compra e venda das árvores da floresta de A, substituindo sob este nome os cavalos de seu estábulo, estes usaram uma linguagem

(d) processo deliberativo IV:

i. fim: aquisição do direito subjetivo de propriedade relativo à coisa (Tício), e aquisição da disponibilidade jurídica da quantia correspondente ao preço (Caio);

ii. meio: cumprimento das obrigações de pagar o preço e de transferir o domínio da coisa (fim do processo deliberativo III).

Em vista da análise das conclusões extraídas do exemplo acima colacionado, seria possível constatar, com J. A. S. DEL NERO, que a satisfação dos interesses jurídico-privados dependeria do desenvolvimento de quatro processos deliberativos sucessivos, os quais se articulariam no bojo de um processo deliberativo total. $\mathrm{O}$ processo deliberativo parcial I teria como fim a instituição de um ente que correspondesse a um modelo jurídico-negocial, e como meio a ação que correspondesse a tal modelo jurídico-negocial; o processo deliberativo parcial II teria como fim a determinação de consequências jurídicas, e como meio a instituição do modelo jurídico negocial; o processo deliberativo parcial III teria como fim a concretização das consequências jurídicas, e como meio a determinação destas; e, por fim, o processo deliberativo parcial IV teria como fim a satisfação do interesse, e como meio a concretização das consequências jurídicas.

Em tal contexto, denominar-se-iam: (a) "declaração jurídico-negocial”, a ação que corresponde a algum modelo jurídico-negocial; (b) "negócio jurídico", o ente correspondente ao modelo jurídico-negocial; (c) "fim prático", a satisfação do interesse posto ou aceito como último; (d) "fim jurídico", a determinação das consequências jurídicas típicas do modelo jurídico-negocial; (e) "meio jurídico", o negócio jurídico; (f) "eficácia jurídica", a idoneidade do negócio jurídico para, por si, determinar as consequências jurídicas típicas do modelo jurídico-negocial; (f) "efetividade" e "inefetividade" do negócio jurídico, respectivamente, a satisfação e a não satisfação do interesse, isto é, a consecução, ou não, do fim prático.

Nos negócios simulados, ou se elegeria um só fim prático, ou não se elegeria nenhum. Eleito um só fim prático, as partes escolheriam, porém, dois meios jurídicos diversos: (a) um, em que todos os fins e todos os meios das etapas "I", "II", "III" e "IV" estariam fundados no processo deliberativo, mas o meio da etapa "I" não se exteriorizaria e não se tornaria recognoscível pelo público, embora fosse conhecido pelas partes seria o negócio dissimulado; e (b) outro, em que apenas o meio da etapa "I" se exteriorizaria e seria recognoscível por terceiros, permanecendo todos os fins das etapas "I", "II", "III" e "IV" alheios ao processo deliberativo - seria o negócio dissimulado. "Nessas circunstâncias, na simulação relativa, ao contrário do que usualmente se afirma, as partes ‘querem' ambos os negócios jurídicos - o simulado e o dissimulado -, justamente para que um, o simulado, encubra o outro, o dissimulado; as partes não 'querem' a eficácia jurídica e a efetividade dos dois, mas apenas a de um - a do negócio jurídico dissimulado - e, portanto, no tocante ao negócio jurídico simulado, embora 'querendo-o', não 'querem' nem a instituição das suas conseqüências jurídicas (eficácia jurídica) nem a concretização delas (efetividade do negócio jurídico simulado)".

302 "In ambiguo sermone non utrumque dicimus, sed id dumtaxat quod volumus: itaque qui aliud dicit quam vult, neque id dicit quod vox significat, quia non vult, neque id quod vult, quia id non loquitur".

303 G. SEgRÈ, In matéria di simulazione nei negozi giuridici in Temi Emiliana, 1924, agora in Scritti Giuridici, vol. 1' ${ }^{\circ}$, Arezzo, Cortona, 1930, p. 423. 
convencional”304. A simulação implicaria, nestes termos, uma incompatibilidade entre o dois possíveis sentidos da declaração, de modo que o sentido correto somente poderia ser apreendido após uma operação de tradução: onde se lia "árvore", passa-se a ler "cavalo".

Mas a recondução da simulação ao emprego de uma linguagem convencional não exaure a descrição do fenômeno, pois, como bem aponta Carresi, nem sempre decorre deste expediente a criação de uma aparência ${ }^{305}$. Nada obstante, este pensamento tem o mérito de vincular a simulação a um defeito de recognoscibilidade ${ }^{306}$.

Desta ideia, aliás, valer-se-ia Betti ao afirmar que, no caso do negócio simulado, a valoração que acompanha a consciência do significado do ato (que não se confundiria com a vontade de conteúdo) não se reportaria ao significado objetivo da declaração, mas a outro significado, convencionado secretamente pelas partes. A declaração simulada submeter-se-ia a uma dupla e incongruente valoração: uma objetiva, e outra subjetiva. A conclusão do negócio jurídico viria acompanhada de uma duplex interpretatio, de um lado, fundada nos pressupostos da ordem jurídico-positiva, e de outro, dependente do sentido subjetivo atribuídos, pelas partes, ao regulamento de interesses entre si estabelecido ${ }^{307}$.

Para Betti, o emprego de uma linguagem convencional permitiria, aos simuladores, decifrar o verdadeiro sentido do comportamento negocial, em um procedimento análogo à interpretação autêntica ${ }^{308}$. A declaração simulada deveria, pois, ser apreciada à luz do intento simulatório como se fosse uma proposição indicativa ou alusiva cujo significado seria esclarecido através de uma conexa convenção interpretativa $^{309}$.

Ao defender que a simulação pressupõe um problema hermenêutico derivado do reconhecimento, pelo público, de um significado incompatível com o sentido da declaração negocial, Betti tangencia o quid do fenômeno simulatório; é curioso notar, porém, que,

\footnotetext{
304 "Se le parti A e B hanno d'accordo dichiarato di comprare e vendere gli alberi della foresta di A., sottintendendo sotto questo nome i cavalli della sua scuderia (...)esse hanno usato un linguaggio convenzionale" (G. SEGRÈ , In matéria di simulazione... cit., nota 303, p. 427).

${ }^{305}$ F. CARRESI, Apparenza e realtà del contratto in Rivista trimestrale di diritto e procedura civile, Milano, 1963, p. 499.

${ }^{306}$ E. BETTI, Teoria generale... cit. (nota 53), p. 402.

${ }^{307}$ E. BETTI, Teoria generale... cit. (nota 53), p. 399-400.

${ }^{308}$ E. BETTI, Teoria generale... cit. (nota 53), p. 400; 405.

${ }^{309}$ E. BETTI, Teoria generale... cit. (nota 53), p. 399.
} 
para fazê-lo, ele se distancia dos paradigmas de uma teoria baseada na inadequação da causa. A recognoscibilidade do negócio jurídico é um elemento que concerne menos à interação entre causa e intento prático que à avaliação acerca da legitimidade daquele, sob a perspectiva da sociedade.

A importância desta passagem da teoria bettiana (cuja peculiaridade não seria ignorada pela doutrina ${ }^{310}$ ) encontra o seu ápice no momento em que o autor afirma que a incompatibilidade entre a causa e o escopo prático típico não seria exteriormente constatável $^{311}$. Por conta disso, apenas quando o intento simulatório fosse descoberto, ou revelado, seria possível extirpar o elemento discrepante (como um ramo seco), retificá-lo ou substituí-lo; tudo isto se operaria com base em um procedimento de interpretação corretiva ${ }^{312}$.

O público não tem acesso à totalidade do negócio jurídico; é por isso que ele se torna simulado. "Caracteriza o fenômeno simulatório o defeito de recognoscibilidade (...) é própria da simulação, de fato, a antítese entre a não realidade inter partes do negócio simulado, e a valoração objetivamente apreciável deste como ato verdadeiro e real"313. Levando em conta os índices de significação ${ }^{314}$ manifestados pelos simuladores, a comunidade forma uma convicção errada sobre o sentido jurídico do comportamento negocial; assim, o interpreta e/ou o qualifica inapropriadamente.

\section{A composição da ilusão negocial}

A ilusão negocial decorre da disseminação de um erro coletivo, semelhante ao error communis a que se referiam os glosadores. Por ser este erro atinente ao sentido e/ou ao enquadramento típico do negócio jurídico, mostra-se salutar identificar os elementos com base nos quais, normalmente, operam-se as operações de interpretação e a qualificação. Atualmente, a doutrina tende a admitir que o efetivo sentido do regulamento

\footnotetext{
${ }^{310}$ S. Pugliatti, La simulazione... cit., (nota 53), p. 560.

${ }^{311}$ E. BETTI, Teoria generale... cit. (nota 53), p. 394.

${ }^{312}$ E. BETTI, Teoria generale... cit. (nota 53), p. 399.

${ }^{313}$ N. DistASO, La simulazione... cit. (nota 40), p. 85. Tradução livre; no original: "Caratterizza il fenomeno simulatorio il difetto di riconoscibilità (...) è propria della simulazione, infatti, l'antitesi fra la non realtà, inter partes, del negozio simulato e la valutazione oggettivamente apprezzabile di questo come atto vero e reale".

${ }^{314}$ M. CASELlA, Simulazione cit. (nota 296), p. 599.
} 
de interesses seja investigado na concretude da experiência ${ }^{315}$. Betti, aliás, já dizia que a interpretação deveria fundar-se no exame de todo o complexo comportamental das partes, neste se incluindo a fase de tratativas e as condutas executivas ${ }^{316}$.

A verdade do negócio jurídico (i.e. aquilo que subjaz à aparência) não emana apenas de uma declaração verbalizada. O comportamento negocial, mais que a simples declaração escrita ou falada, é o que determina o seu sentido e a sua qualificação. Desse modo, a interpretação e a qualificação são orientados pela causa $\operatorname{concreta}^{317}$, a qual, enquanto função prático-individual, expressa o valor que as partes atribuem à operação em sua globalidade ${ }^{318}$. O negócio jurídico vem apreciado em bloco $^{319}$, sem perder-se de vista

${ }^{315}$ G. B. FERRI, Il Negozio Giuridico cit. (nota 58), p. 64-65.

316 Nisto consistiria o cânone da totalidade da interpretação do negócio jurídico. Cf. E. BETTI, interpretazione... cit. (nota 278), p. 384-385.

${ }^{317}$ C. M. BIANCA, Diritto Civile cit. (nota 63), p. 454; 472-473. A doutrina tradicional tendia a determinar o tipo ao qual o negócio jurídico deveria ser reconduzido com base nos essentialia negotii. De acordo com esta abordagem dogmática, operações necessárias e suficientes à qualificação do negócio jurídico seriam a determinação dos elementos essenciais do tipo e a verificação da presença destes na relação concreta em exame. Os negócios jurídicos teriam elementos próprios, legalmente determinados, constitutivos da sua essência, que os caracterizariam e o distinguiriam entre si. Os essentialia negotii, compondo o conteúdo do negócio jurídico, constituiriam a sua organização típica e lhe confeririam identidade. Dos essentialia negotii distinguir-se-iam os naturalia negotii e os accidentalia negotii. Os primeiros seriam as regras que o ordenamento jurídico estabelece como complemento da regulamentação jurídico-negocial; os segundos, por sua vez, seriam os pactos aditivos que não influiriam sobre a constituição do esquema típico previsto na lei, como as regras sobre prazos e as condições (sobre o tema, v. W. FLUME, El negocio jurídico cit., nota 43, p. 112 ss.). Tem-se acentuado, mais recentemente, a insuficiência deste mecanismo para definição da tipicidade das relações negociais. R. PINTO DuARTE (Tipicidade e Atipicidade dos Contratos, Coimbra, Almedina, 2000 , p. 89 ss.) assinala, neste particular, que a doutrina dos essentialia negotii não basta à aplicação do direito porque o sentido unitário da norma jurídica não pode ser captado através da consideração, ainda que conjunta, de diversos componentes, enunciados isoladamente. Ademais, a separação entre os essentialia negotii e os naturalia negotii é artifical, logo reprovável, pois os primeiros, embora qualificativos, também contribuiem com a determinação da disciplina aplicável à relação jurídica concreta. A qualificação dos negócios jurídicos com base nos supostos elementos essenciais enfrenta, ainda, o obstáculo da alteridade entre tipos e conceitos, em vista da qual os primeiros não são delimitáveis a partir de critérios classificatórios. "Por outras palavras: a doutrina dos essentialia pode, nalguns casos, servir para a delimitação do conceitos qualificativos, mas não é nunca critério bastante para o relacionamento destes com os factos".

${ }_{318}$ G. B. Ferri, Causa e tipo... cit. (nota 66), p. 371.

${ }^{319}$ G. B. FERrI, Causa e tipo... cit. (nota 66), p. 256: "No caso concreto, o negócio jurídico, no seu conjunto de elementos essenciais e não essenciais, forma um bloco unitário e como tal, isto é, unitariamente, deverá ser valorado pelo ordenamento jurídico: apenas por esta maneira, de fato, pode-se colher o sentido e o alcance da operação econômica que o negócio jurídico exprime. Certamente se pode aceitar a classificação e as distinções em elementos que a doutrina (e, em parte, também o legislador) costuma fazer, sob a condição de que, a tais distinções em elementos se atribua não mais que um valor descritivo, util a uma visão articulada de todo o fenômeno negocial; e que deve conduzir, no caso concreto, a um melhor enquadramento de toda a operação econômica contida no negócio, não já a um artificioso fracionamento desta". Tradução livre; no original: "Nel caso concreto il negozio giuridico, nel suo insieme di elementi essenziali e non essenziali, forma un blocco unitario e come tale, unitariamente, cioè, dovrà essere valutato dall'ordinamento giuridico: soltanto in questa maniera, infatti, si può cogliere il senso e la portata dell'operazione economica, che il negozio giuridico esprime. Certamente si può accettare la classificazione e le distinzione in elementi che la dottrina (e, in parte, anche il legislatore) è solita fare, a patto che, a dette distinzioni in elementi si attribuisca non più che un valore descrittivo, utile cioè ad una visione articolata di tutto il fenomeno 
que os seus elementos, por mais heterogêneos que sejam (declarações escritas, atos materiais, e, até mesmo, o silêncio), coordenam-se em direção a um finalidade unitária. Não à toa tem-se tornado cada vez mais frequente a investigação da substância econômica da operação negocial, a qual, ao lado do conjunto de condutas das partes, torna-se determinante à interpretação e à qualificação.

Tem-se defendido que os simuladores reproduziriam a eficácia do negócio jurídico $^{320}$, agindo como se o tivessem efetivamente celebrado. A aparência difundida pelo negócio simulado somente poderia remeter aos efeitos deste, pois embora ele existisse realmente, a sua eficácia pareceria diversa daquela efetivamente produzida ${ }^{321}$. Segundo esta abordagem, a simulação instalaria um descompasso entre a aparência negocial e a realidade eficacial ${ }^{322}$.

Sendo procedente este entendimento, a simulação pressuporia a produção de um conjunto de sinais capaz de fazer as vezes daqueles elementos em que se funda a interpretação e a qualificação do negócio jurídico ${ }^{323}$. O surgimento da ilusão negocial vincular-se-ia à manifestação do grupo de circunstâncias que, em situações normais, acompanharia a existência do ato. Isto porque a aparência somente poderia ser irradiada por um complexo fático que, apreendido imediatamente, desse conta da normal incidência de um dado esquema regulativo ${ }^{324}$. Nessa esteira, não bastaria, aos simuladores, criar a forma do "negócio aparente", pois seria de se esperar que o público reconhecesse, por si, a causa concreta e os demais fatores relevantes à definição da realidade negocial. Por conseguinte, se as partes não criassem, ao lado do índice formal, outros índices de significação atinentes às circunstâncias materiais indicativas da operatividade da relação negocial aparente, o público jamais seria enganado, ou seja, não se configuraria a ilusão negocial.

negoziale; e che deve condurre, nel caso concreto, ad un miglior inquadramento di tutta l'operazione economica contenuta nel negozio, non già ad un suo artificioso frazionamento".

${ }^{320}$ G. FURGIUELE, Della simulazione... cit. (nota 144), p. 58-59.

${ }^{321}$ U. MAJELlO, Il contratto simulato... cit. (nota 105), p. 649. Segundo A. FAlzEA (Apparenza... cit., nota 298, p. 697), a aparência poderia apenas relacionar-se a um aspecto da eficácia, não a um dado constitutivo. Não se emanaria da declaração que não fosse capaz de manifestar qualquer realidade jurídica. Decorreria de um complexo comportamental capaz de fazer o público cometer um erro objetivamente escusável.

${ }^{322}$ U. MAJELLO, Il contratto simulato... cit. (nota 105), p. 645.

${ }^{323}$ A. FAlZEA, Apparenza... cit. (nota 298), p. 689.

${ }^{324}$ A. FAlZEA, Apparenza... cit. (nota 298), p. 689. 
Vale observar, porém, que não é comum que a generalidade do público obtenha acesso às circunstâncias fáticas posteriores à criação do instrumento que permitem precisar a causa concreta que anima o negócio jurídico. Por exemplo, celebrado um contrato de locação, não seria razoável supor que qualquer terceiro, por sua própria capacidade, pudesse atestar a efetiva ocorrência dos pagamentos dos aluguéis. Sobretudo se os pagamentos ocorressem por meio de transferências bancárias, a própria garantia do sigilo bancário impediria que eles viessem à tona, tornando-se fatos notórios. Se a eventual falta reiterada de pagamentos fosse imediatamente recognoscível, o "cidadão médio" poderia, ou melhor, deveria dar-se conta de que o contrato em questão seria de comodato, não locação. No entanto, a normal diligência que se exige do público quanto às situações de aparência jurídica não chega a impor a realização de ulteriores investigações.

A bem da verdade, hoje, parece ser pacífico que o grau de diligência dos sujeitos é variável, uma vez que depende das possibilidades econômicas destes. Levando-se isto em conta, é pertinente notar que os terceiros podem apreciar as relações estabelecidas entre os particulares de maneiras distintas: a diligência daqueles que exercem o comércio profissionalmente tende a considerar com maior percuciência os riscos envolvidos nas diversas transações; por outro lado, aqueles que, em virtude de seus escassos meios econômicos, não conseguem, ou melhor, não devem informar-se sobre todos os riscos envolvidos nas diversas transações, obtêm acesso a um nível mais superficial de informações $^{325}$. De todo modo, seja qual for a condição do terceiro, não se chega a esperar que este comporte-se com zelo maior que o requerido pela diligência normal do bom pai de família $^{326}$.

Nesse estado de coisas, é necessário distinguir dois modos pelos quais o negócio jurídico pode tornar-se socialmente recognoscível:

(a) é possível, em primeiro lugar, que as partes limitem-se a adotar determinadas condutas que evidenciem, por si, a eficácia da relação jurídica; a relação jurídica expressa-se exclusivamente por meio de circunstâncias fáticas colaterais ou sucessivas à celebração do (presumido) negócio jurídico (e.g. atos de execução de obrigações e comportamento concludente); surgem, 
titularidades aparentes que não necessariamente correspondem a equivalentes titularidades formais;

(b) é também possível, em segundo lugar, que as partes formalizem declarações negociais, por meio de instrumentos públicos ou particulares, ou até mesmo manifestações verbais emitidas perante testemunhas, das quais o público pode tomar conhecimento e aferir a existência do negócio jurídico; isto pode ocorrer, é claro, sem prejuízo de, adicionalmente, as partes adotarem condutas ulteriores, como as mencionadas no item anterior.

No primeiro dos casos acima enumerados, a criação da ilusão negocial requer que os índices de significação criados pelos simuladores aludam à eficácia do regulamento de interesses cuja existência se pretende comunicar ao público. Deveras, se o único meio pelo qual o negócio jurídico torna-se socialmente recognoscível consiste no complexo comportamental das partes, seria impossível a perpetração do programa simulatório sem que as condutas atinentes à própria operatividade da relação negocial fossem comunicadas ao público, embora se ultimassem neutralizadas ou modificadas por outras condutas empreendidas secretamente pelas partes. O exemplo da sociedade de fato $^{327}$ (sociedade em comum) simulada mostra-se, neste particular, esclarecedor. As partes apresentam-se, perante terceiros, como sócios, suscitando a crença de que desempenham uma atividade econômica comum; sigilosamente, contudo, acordam que devem conduzir os negócios da pretensa sociedade na condição de empresários individuais. A bem se ser, para incutir no público a convicção de que a sociedade em comum existiria, os simuladores haveriam de comportar-se como verdadeiros sócios, reproduzindo, desta maneira, os traços característicos da eficácia do contrato de sociedade. Tais comportamentos, porém, seriam mal interpretados e indevidamente qualificados pois não corresponderiam à integralidade do agir negocial dos contraentes. Fosse levado em conta o conjunto de condutas mantido em segredo, seria possível constatar que uma sociedade de fato não existiria.

No segundo dos aludidos casos, contudo, parece-nos que a simples criação da forma negocial (e.g. declaração escrita) seria suficiente para despertar a confiança do público, que somente poderia questionar a substancialidade do negócio jurídico acaso se

${ }^{327}$ V. tópico 36. 
pusesse a investigar a causa concreta para além do disposto na declaração levada a termo. Esta situação configura-se, naturalmente, nas situações em que o negócio simulado sujeitase a exigências de forma. Em tais hipóteses, a ilusão negocial não pode prescindir da forma da relação negocial aparente ${ }^{328}$. De fato, a perfeição formal do "negócio aparente" é pressuposto de sua capacidade de criar uma situação de confiança apta a induzir terceiros ao engano ${ }^{329}$. Se o "negócio aparente" apresentasse uma imperfeição formal, não haveria espaço para qualquer engano; a própria aparência implicaria a conclusão quanto a tratar-se de um negócio nulo.

A formalização do "negócio aparente" poderia ser suficiente para a criação da ilusão negocial também no caso de negócios não sujeitos a requisitos formais. A título de exemplo, considere-se que Caio e Tício celebrem, mediante instrumento particular, contrato de comodato. A simples apresentação do instrumento particular poderia justificar a confiança do público quanto à efetividade desta operação negocial. De fato, terceiros não saberiam - nem se poderia exigir que soubessem -que, veladamente, Tício pagaria um valor mensal a Caio como contraprestação pelo uso da coisa emprestada, razão pela qual o contrato em questão haveria de qualificar-se como de locação. Dessa feita, a simples criação da forma negocial seria hábil a servir como índice de significação suficiente ao estabelecimento do "negócio aparente".

Colocada a questão nestes termos, podemos seguir adiante, passando a examinar o mecanismo mais profundo da ilusão negocial. Como dissemos, as partes mantêm algo em segredo; uma parcela do seu comportamento que não é exteriormente constatável. Se tais elementos fossem conhecidos de antemão, os índices de significação ostensivamente manifestados passariam a revestir-se de um sentido diferente; não surgiria qualquer aparência, porquanto a essência da relação jurídica poderia ser identificada mediante simples interpretação ${ }^{330}$ ou requalificação ${ }^{331}$, as quais, reportando-se à causa concreta e à substância econômica, permitiriam corrigir eventual impropriedade atinente ao sentido gramatical dos termos da declaração (verbalizada), segundo a máxima falsa demonstratio

\footnotetext{
${ }^{328}$ G. FURGIUELE, Della simulazione... cit. (nota 144), p. 59.

${ }^{329}$ N. DistASO, La simulazione... cit. (nota 40), p. 434.

${ }^{330}$ P. PAIS DE VASCONCELOS, Teoria Geral... cit. (nota 103), p. 683; G. CRICENTI, Frode alla lege, $2^{\mathrm{a}}$ ed., Milano, Giuffrè, 2008, p. 27.

${ }^{331}$ C. M. BiAnCA, Diritto Civile cit. (nota 63), p. 698.
} 
non nocet ${ }^{332}$. O fato, portanto, de os terceiros terem conhecimento de apenas parte do comportamento dos simuladores fazem-nos atribuir, à relação negocial, uma causa concreta equivocada - logo, ilusória.

O negócio simulado possui a habilidade de ocultar, total ou parcialmente, a própria função prático-individual. A substância econômica de que depende a adequada interpretação e a correta qualificação do negócio jurídico não emana do conjunto de condutas e declarações ostensivamente manifestadas ${ }^{333}$. A significação global do comportamento dos simuladores é a de não se produzir qualquer resultado, jurídico ou econômico; ou a de produzir-se resultados, jurídicos ou econômicos, distintos daqueles que a feição externa da declaração negocial sugere ${ }^{334}$.

Isto conduz o público, inevitavelmente, a formar uma convicção incorreta sobre o enquadramento típico do negócio jurídico. Dizendo de outro modo, na simulação, a interpretação corretiva de que depende o restabelecimento da coerência entre aquilo que se vê e aquilo que as partes fazem não se torna disponível, ao público, em linha de partida. Diversamente, se fosse possível acessar, diretamente, dados que permitissem aferir a incongruência entre o sentido global da manifestação de vontade e aquele suscitado pelos índices de significação criados pelas partes, qualquer terceiro poderia aduzir o cabimento da interpretação corretiva do regulamento de interesses, fundada na causa concreta.

Nesse passo, fica claro o relevo da intuição de Romano de que a premeditada e preordenada inexecução do regulamento negocial desnaturaria a sua causa ${ }^{335}$. O descumprimento deliberado das obrigações pela parte, associado à injustificada inércia da contraparte, evidencia a estranheza da prestação à função prático-individual. Esta circunstância, acaso fosse notória, imediatamente recognoscível pelo "cidadão médio", daria ensejo à adequada qualificação do negócio jurídico, com desprezo ao nomen juris ou quaisquer termos inadequadamente declarados pelos contraentes; se, todavia, não fosse exteriormente constatável, não haveria dúvidas: o negócio seria simulado.

\footnotetext{
${ }^{332}$ W. Flume, El negocio jurídico cit. (nota 43), p. 367 ss.

${ }^{333}$ U. Morello, Frode alla legge, Milano, Giuffrè, 1969, p. 218-219; F. Di MARZIO, Interposizione... cit. (nota 177), p. 446-447.

${ }^{334}$ E. DANZ, Die Auslegung der Rechtsgeschäfte: Zugleich ein Beitrag zur Rechts- und Thatfrage (1897), trad. esp. de W. Roces, La interpretacion de los negocios jurídicos - Estudio sobre la cuestion de derecho e la cuestion de hecho, Madrid, Victoriano Suarez, 1926, p. 26-27.

${ }^{335}$ S. Romano, Contributo esegetico... cit. (nota 53), p. 36.
} 
De tudo o que se disse, fica a constatação de que o negócio torna-se simulado na medida em que, aos índices de significação tornados públicos pelos simuladores oponhamse outros índices, igualmente reais, porém socialmente irreconhecíveis, que, fossem levados em consideração, permitiriam que a situação jurídica das partes fosse interpretada e qualificada de maneira diversa. O desenrolar da função prático-individual do negócio simulado assenta-se, precisamente, na manipulação do material fático subjacente à relação negocial, de maneira que índices aparentes comuniquem sentidos diversos daqueles que assumiriam se fossem considerados à luz do comportamento total dos contraentes.

Para que esta dinâmica possa ser mais bem visualizada, considere-se o exemplo, talvez o mais comum nos manuais escolares, da venda fantástica. A depender de como a situação seja descrita, como veremos, pode-se, ou não, considerar caracterizada a simulação.

Vejamos uma primeira versão deste exemplo: o cônjuge pretende doar um bem à concubina, porém, deseja ocultar a liberalidade; "simula", então, com aquela, uma compra e venda, atribuindo ao bem valor irrisório.

Haveria, nesta hipótese, negócio simulado? A resposta, claramente, é negativa. De fato, qualquer terceiro de boa-fé que se deparasse com aparência da venda fantástica, nos termos acima narrados, poderia concluir que o tipo de referência eleito pelas partes compra e venda - não refletiria o conteúdo e o sentido - a causa concreta - do negócio jurídico concretamente celebrado. Haveria, não se nega, falsa qualificação; não surgiria, contudo, a ilusão negocial.

A falsa qualificação não engana. Não se justificaria, num caso destes, a intervenção normativa do instituto da simulação; o legislador estabeleceu uma barreira de proteção à confiança legítima ${ }^{336}$, não ao negligente ou imprudente. $O$ direito não protege os que dormem. A velha parêmia informa a delimitação categorial da simulação por imperativo da isonomia. Ainda que as partes tivessem agido intencionalmente, o legislador não poderia dar, àqueles que tivessem crido na falsa qualificação por descuido ou despreparo, a mesma proteção que se reserva aos que nela tivessem crido por não terem condições de aperceber-se da inverdade negocial perpetrada pelos simuladores.

${ }^{336}$ F. DURAND, L'apparence... cit. (nota 104), p. 23-25. 
Passemos, agora, a examinar uma segunda formatação do exemplo.

Assuma-se que, em 20/05/2013, João e Maria tenham celebrado contrato de compra e venda tendo por objeto um automóvel novo, cujo valor de mercado, auferido por órgãos especializados, girasse em torno de $\mathrm{R} \$ 52.000,00$. No referido contrato, as partes fixaram o preço de $\mathrm{R} \$ 55.000,00$. No dia 21/05/2013, Maria efetua o pagamento do preço a João, mediante emissão de cheque nominal. João deposita o referido cheque no mesmo dia, em sua conta bancária. No dia 24/05/2013, João acompanha Maria até o Departamento Estadual de Trânsito, e efetua a transferência da titularidade do veículo. No instrumento particular produzido com vistas a formalizar a relação jurídica, e levado a registro perante o competente oficial de registro de títulos e documentos, as partes consignam a ocorrência do pagamento, anexam cópia do cheque e do respetivo comprovante de compensação bancária, e João dá quitação a Maria.

Estes são os fatos que as partes tornaram públicos. $O$ que os terceiros não poderiam saber, contudo, é que no dia 27/05/2013, Maria recebera uma transferência bancária, no valor de R \$55.000,00. O autor do depósito? João.

O "desfazimento" do pagamento, ou seja, a neutralização do sentido deste índice de significação, associado ao esforço das partes em manter tal circunstância em sigilo, evidenciariam a irrelevância jurídica da conduta publicamente manifestada, neste particular. Nesse cenário, o diagnóstico da ilusão negocial seria positivo. A interpretação segundo a qual as partes teriam concretizado uma troca onerosa mostrar-se-ia inadequada, assim como a qualificação do contrato como compra e venda. O público, porém, não teria condições de dar-se conta disto, pois todos os índices de significação de que disporia para interpretar e qualificar a intenção comum das partes revelariam a celebração de um perfeito contrato de compra e venda. É neste ponto que cai como uma luva a feliz proposição de Betti: apenas quando caísse a ilusão proceder-se-ia à interpretação corretiva do negócio simulado $^{337}$. No momento em que fosse descoberta a secreta devolução do preço, capaz de excluir a onerosidade da avença, seria possível examinar a relação jurídica das partes em bloco, isto é, contemplando-se a totalidade do regulamento de interesses entre elas estabelecido.

${ }^{337}$ E. BETTI, Teoria generale... cit. (nota 53), p. 398-400. 
À guisa de conclusão, concebemos a ilusão negocial como um estado de fato ${ }^{338}$ revestido de relevância jurídica (logo, objeto de uma questão de direito ${ }^{339}$ ) - porque fruto de um negócio jurídico típico. O negócio simulado se alicerça sobre um jogo de pontos de vista. As partes decidem quais comportamentos tornam públicos, e, desse modo, influenciam a formação de juízos de confiança por parte da comunidade. A difusão de um erro coletivo sobre a essência do regulamento de interesses caracteriza a simulação. Fosse, enfim, o Rei das Creencias de Campoamor resumir tudo isto, possivelmente diria que a simulação "está em los ojos de quien mira".

\section{§ 5. AS FRONTEIRAS SISTEMÁTICAS DA SIMULAÇ̃̃o}

Até aqui, buscamos definir a simulação por um viés positivo, ou seja, destacando suas características constitutivas e a configuração que o direito positivo lhe atribui. Agora, com vistas a obter a confirmação das constatações a que chegamos, passaremos a examinar o modo como a simulação interage com outros institutos do direito civil, que com ela guardam alguma similitude.

Por meio deste exercício, esperamos tornar ainda mais claros os contornos categoriais da simulação, em consonância com o que prescreve o artigo 167.

338 S. Romano, Ordinamento sistematico del diritto privato, v. II - L'azione - Il potere, $3^{\text {a }}$ ed., Napoli, Morano, s.d., p. 321; F. DURAND, L'apparence... cit. (nota 104), p. 29.

339 A questão de fato relaciona-se, num primeiro momento, com a "determinação do âmbito de relevância jurídica a reconhecer à situação histórico-concreta problemática", e, num segundo momento, com a "comprovação dos elementos específicos dessa relevância e dos seus efeitos". O primeiro momento resulta no pressuposto objetivo da realização do direito, isto é, na "situação histórica em que o problema jurídico concreto se situa,o âmbito e o conteúdo da relevância jurídica dessa problemática”. O segundo momento relaciona-se ao problema da prova, ou seja, à probabilidade-frequência objetiva da qual deriva a dedução de uma verdade prática, que não coincide com a verdade teorético-científica. "É uma verdade em si mesma função da intenção especificamente jurídica, i. é, dos objectivos práticos que o direito se propõe na consideração e resolução dos seus problemas normativos". Isto não significa que a verdade jurídica seja menos exigente que a verdade teorético-científica; é apenas distinta, na medida em que admite o desempenho de um papel marcantemente argumentativo (persuasivo) pela prova (A. CASTANHEIRA NEVES, Metodologia jurídica-Problemas fundamentais, Coimbra, Coimbra, 1993, p. 163).

A questão de direito, por seu turno, desdobra-se em abstrata e concreta. A primeira tem por escopo a determinação do critério jurídico que deve orientar a solução do problema concreto; a segunda é o próprio juízo concreto que se impõe como decisão deste problema

Por outras palavras, a questão de direito abstrata diz respeito à identificação da norma que se deve aplicar ao caso concreto, enquanto a questão de direito concreta representa a solução jurídica encontrada em sua manifestação acabada, quer seja decorrente de uma mediação entre a questão de fato e a questão de direito abstrata (realização do direto por mediação da norma), quer seja decorrente de uma ação integrativa conduzida pelo decididor, diante da impossibilidade de identificar-se uma norma diretamente aplicável ao problema jurídico (realização do direito por autônoma constituição normativa) (A. CASTANHEIRA NEVES, Metodologia... cit., supra, p. 165 ss.). 


\section{Falsidade}

A doutrina não hesita ao distinguir a simulação da falsidade material. Nesta, o documento original é fisicamente manipulado. Pense-se num cheque emitido pelo valor de $\mathrm{R} \$ 100,00$, o qual, vindo a ser adulterado, passe a indicar o valor de R\$1.000,00. A atuação do adulterador, neste caso, faria a feição atual do documento contrastar com a original. Não se estabeleceria, a rigor, um descasamento entre o documento e o fato por ele representado, mas entre o documento e ele próprio, em suas versões original e falsificada. A discussão em torno da materialidade do documento, à evidência, não tangencia o tema da simulação, limitando-se à prova sobre o fato da adulteração ${ }^{340}$.

Mais complexo, contudo, é o confronto entre a simulação e a falsidade ideológica. Neste caso, a informação contida no documento não se reputa verdadeira; a atuação do falsificador não se volta, pois, apenas contra o meio, mas, também, contra a mensagem.

Sobre o tema, Ferrara defende que a simulação disfarçaria o consentimento, ou seja, o elemento subjetivo, ao passo que a falsidade ideológica alteraria a verdade material das declarações emitidas. Nesse contexto, somente poderia ser falsa a escritura lavrada perante o tabelião, e apenas na medida em que ela atestasse fatos históricos que não tivessem ocorrido. Desse modo, se o oficial público permitisse constar, da escritura, que Caio e Tício estiveram em sua presença, quando, na verdade, isto jamais ocorrera, o evento da declaração seria inverídico, e a escritura, por conseguinte, encontrar-se-ia maculada pela falsidade ideológica ${ }^{341}$.

Beleza dos Santos estatui, a propósito, que a simulação de um negócio jurídico não implicaria, forçosamente, a falsidade do documento que o traduzisse; este deveria reputar-se verdadeiro se retratasse, fielmente, todos os fatos ocorridos, o teor das declarações emitidas, e as formalidades realizadas no ato de sua produção. Em face disso, somente haveria falsidade ideológica se o documento falhasse em relatar a realidade histórica das declarações nele inscritas. A simulação, diversamente, macularia a gênese da

\footnotetext{
${ }^{340}$ V., a propósito, F. FERrARA, A simulação... cit. (nota 20), p. 117-118. A distinção aludida no texto é assim traçada por J. BELEZA DOS SANTOS, A Simulação... cit. (nota 20), p. 75: "Entre a falsidade material e a simulação a diferença é evidente: aquela consiste ou na suposição do documento ou na viciação da data, contexto ou assinaturas (...) e supõe, por isso, a viciação material da parte do documento, da sua data, do seu contexto, das suas assinaturas ou a sua falsificação total; a simulação nada tem, evidentemente, com a materialidade do documento, mas sim com aformação do ato jurídico que ele traduz".

${ }^{341}$ F. FERRARA, A simulação... cit. (nota 20), p. 118-120.
} 
declaração, e, por conta disso, seria anterior ao próprio documento; o consentimento faltaria, pois as declarações, conquanto verdadeiras, seriam insinceras ${ }^{342}$.

Pestalozza observa, ao abordar o tema, que a simulação recairia sobre o conteúdo volitivo do negócio jurídico e se operaria mediante a inserção, no documento, de uma vontade que os contraentes não nutririam. Como consequência disso, a simulação não se confundiria com a falsidade ideológica, a qual atingiria o documento enquanto atestação de uma ordem de fatos. A declaração emitida pelas partes seria verdadeiramente aquela que aparece no documento, o qual atestaria um fato verdadeiro; os declarantes, no entanto, esconderiam a verdadeira vontade, fazem, assim, aparecer uma vontade não verdadeira ${ }^{343}$.

As posições doutrinárias acima descritas parecem consistentes se observadas à luz da premissa que as inspira: a de que o fato atestado no documento seria a atividade material da declaração, não o sentido desta. Por outras palavras, o instrumento narraria um fato natural ("A" disse "X" para "B"), não a própria qualificação do quanto dito enquanto vontade negocial. Seria como se o documento, ao narrar a declaração negocial, se limitasse a estatuir que "o declarante disse querer algo", não chegando a atestar que "algo seria querido pelo declarante". Os pontos de vista que seguem esta tendência, à evidência, encontram-se fortemente comprometidos com certas concepções do negócio jurídico, e da própria simulação, as quais, atualmente, não se mostram inteiramente sustentáveis.

Um importante aprimoramento teórico relativo ao tema ora examinado pode ser encontrado na obra de Carnelutti. O autor propõe a distinção entre declarações de verdade e declarações de vontade. "[M] ente-se quando se narra, simula-se quando se declara o querer". Em vista disso, a falsidade ideológica somente poderia acometer os documentos narrativos, não os dispositivos.

Sendo dispositivo o documento, o contraste entre o seu conteúdo e a realidade configuraria a simulação, não uma mentira ${ }^{344}$. O documento dispositivo poderia, quando muito, ser alvo de contrafação ${ }^{345}$. Desse modo, a falsidade de tal espécie de documento haveria de resolver-se mediante a constatação quanto a ter sido produzido por pessoas

\footnotetext{
${ }^{342}$ J. BeleZA dos SANTOS, A Simulação... cit. (nota 20), p. 75-76.

${ }^{343}$ F. PeStalozZa, La simulazione... cit. (nota 20), p. 7.

${ }^{344}$ F. CARnElutTi, Teoria del falso, Padova, CEDAM, 1935, p. 49.

${ }^{345}$ F. CARNELUTTI, Teoria del falso cit. (nota 344), p. 157.
} 
diversas das que figuram como seus signatários, ou em lugar ou data diversos daqueles nele $\operatorname{assinalados}^{346}$. A contrafação, segundo Carnelutti, referir-se-ia à identidade do documento, de modo a fazê-lo parecer um outro. Os aspectos de tal identidade seriam o quem o produziu, o onde e o quando isto ocorreu. As três espécies de contrafação, ora referidas, apresentariam as seguintes características ${ }^{347}$ :

(a) contrafação de autoria: a subscrição é falsa quando composta por um nome diferente daquele pertencente a quem a apõe; ainda que o nome alheio viesse inscrito com a anuência do seu titular, a contrafação não poderia ser negada;

(b) contrafação de lugar e data: consiste na falsa informação sobre o lugar e o tempo em que o documento é formado.

Que o documento dispositivo não possa ser falsificado é algo que, a nosso ver, decorre do próprio caráter deôntico do negócio jurídico. A ausência de uma atestação, ou, caso se prefira, de uma declaração de verdade, impede que tal documento seja predicado como verdadeiro ou falso. Se o público interpreta e qualifica equivocadamente o negócio jurídico, falsas serão a interpretação e a qualificação que lhe forem atribuídas. A falsidade, nesta sede, parece limitar-se, como entendia Ferrara, aos termos da escritura pública que se referem, exclusivamente, a acontecimentos históricos que circundam a realização do ato (e.g. “ aqui comparecem as partes...”).

Somente seria possível adotar um raciocínio distinto do acima exposto acaso adotássemos, como os autores mais antigos, a distinção entre o fato da declaração e o conteúdo desta. Esta segregação, contudo, não se mostraria conciliável com a concepção do negócio jurídico como estrutura de sentido destinada a estabelecer um regulamento de interesses autônomo. O negócio jurídico não é o produto articulado de fatos naturais (e.g a declaração, a vontade, o documento, a entrega da coisa etc.), mas um esquema conceitual, capaz de expressar o regulamento vinculante de interesses estabelecido pelos particulares no campo de suas relações econômico-sociais ${ }^{348}$. Se o instrumento, público ou particular, diz que "Caio promete doar a Tício", sendo o ato dispositivo, a declaração se incorpora ao suporte material que o formaliza (já o diz o artigo 112). O que o documento retrata (ou

\footnotetext{
${ }^{346}$ F. CARNELUTTI, Teoria del falso cit. (nota 344), p. 157.

${ }^{347}$ F. CARNELUTTI, Teoria del falso cit. (nota 344), p. 155.

${ }^{348}$ R. SCOGNAmiglio, Contributo... cit. (nota 114), p. 98-99; 102-103.
} 
melhor, dispõe) não é a sequência material de fatos naturais (e.g. Caio abriu a boca e pronunciou as seguinte palavras: "prometo"; "doar"; "a"; "Tício"), mas um sentido completo, apreensível como comportamento negocial. O negócio jurídico, portanto forma uma unidade com o documento em que é disposto.

Esta constatação, porém, não resolve o problema das fronteiras entre a simulação e a falsidade ideológica. Isto ocorre porque o legislador brasileiro não restringiu a simulação às declarações dispositivas. Prova disto encontra-se nos incisos II e III do $\S 1^{\circ}$ do artigo 167, em que vem indicada, explicitamente, a simulabilidade da confissão e da data, espécimes de declaração de ciência. Aliás, o próprio Carnelutti afirma que constituem hipóteses de falsidade documental por contrafação as chamadas antedata e pós-data de uma escritura privada ${ }^{349}$. Antedata e a pós-data são, inequivocamente, hipóteses de simulação ${ }^{350}$.

Em vista do exposto, concluímos que a distinção entre simulação e falsidade ideológica merece temperamentos. No que tange aos documentos dispositivos, a separação dos fenômenos se mostra convincente. Contudo, relativamente às declarações de ciência e às circunstâncias negociais que dão identidade à escritura (como a data, o local, e a identidade das partes), a falsidade ideológica, ou melhor, a contrafação, insere-se no procedimento simulatório $^{351}$. A distinção entre tais figuras e a simulação, portanto, não pode ir além daquela traçada entre meios e fins.

${ }^{349}$ F. CARNELUTTI, Teoria del falso cit. (nota 344), p. 155.

${ }^{350}$ Nem se cogite, neste ponto, da suposição de que a antedata e a pós-data não seriam casos de simulação. Tal interpretação não se justifica à luz do inequívoco sentido da norma.

${ }^{351}$ Esta interpretação concilia-se com a inspiração romanística presente no texto do $\S 1^{\circ}$ do artigo 167 , o qual, em última instância, provém do Esbôço de Teixeira de Freitas. De fato, o direito romano concebia a simulação como uma espécie de falsidade.

Ao examinar os textos do código de Justiniano relativos à simulação (C. 4, 22: plus valere quod agitur, quam quod simulate concipitur; C. 4, 22, 1: In contractibus rei veritas potius quam scriptura prospici debet; C. 4, 22, 2: Acta simulata, velut non ipse, sed eius uxor comparaverit, veritatis substantiam mutare non possunt. questio itaque facti per praesidem examinabitur provinciae), G. PUGLIESE (La simulazione... cit., nota 1, p. 174 ; 223-225) demonstra que a simulação (que não fora objeto de um tratamento sistemático, pelos romanos, senão durante o período justinianeu) não correspondia a um fenômeno amplo. Diversamente, os textos tratavam, especificamente, da situação em que existia uma divergência entre a declaração contida em um negócio jurídico e a declaração contida em um documento. A veritas rei ou a veritatis substatantiam corresponderiam ao negócio jurídico celebrado; a simulação, por seu turno, seria concretizada por meio do documento. O autor destaca que o documento não tinha, em Roma - como ocorre no direito moderno função dispositiva. Servia, portanto, como mero meio de prova. Disso decorria o caráter limitado da simulação, que não passava da falsa atestação de um fato. O verbo concipitur significaria, na fórmula da rubrica que encabeça o título C, 22, "exprimire", "pronunciare", "proferre". Segundo o autor, teria ocorrido uma relevante deturpação do sentido original da simulação em virtude de interpolações ocorridas durante a 


\title{
19. Falsa qualificação
}

\author{
A simulação não se confunde com a falsa qualificação. ${ }^{352}$
}

Pais de Vasconcelos, ao debruçar-se sobre o tema da qualificação ${ }^{353}$, assinala que a vontade das partes possui uma relevância autônoma como "índice do tipo", mormente quando aquelas estipulam uma concreta qualificação ao negócio jurídico. O autor narra

fase do direito comum; de todo modo, o simulare original somente compreenderia a falsa informação sobre um estado de coisas.

Em sentido semelhante, N. DUMONT-KISLIAKOFF (La simulation... cit., nota 1, p. 15-28; 202), após realizar uma extensa pesquisa sobre o uso das palavras simulare e fingere na época romana, conclui que estes eram empregados com o sentido de fingir, imitar, falsear a realidade, imaginar, inventar, fraudar, encenar. Para a autora, a simulação concebida pelos romanos remeteria à criação de uma aparência mediante a simples afirmação de fatos falsos.

${ }^{352}$ A distinção entre a falsa qualificação e a simulação fora notada já por A. BUTERA (Della simulazione... cit., nota 20, p. 50): “A eventual errônea denominação não deve ser confundida com o negócio simulado. Por isso, as partes, com os seus atos, miram a escopos práticos, e o verdadeiro nomen iuris é dado sempre pelo juiz. Ainda que estas denominem o negócio, durante a fase de execução, como relação de locação transformável em compra e venda após o pagamento da última parcela do preço, tudo isto não exclui que o ato seja, desde a sua origem, uma venda. (...) O error in nomine negotii não é simulação pois o erro na permanece completamente estranho à relação simulada". Tradução livre; no original: "L'eventuale erronea denominazione, non deve essere confusa col negozio simulato. Per altro, le parti, con i loro atti, mirano a scopi pratici e il vero nomen iuris è dato sempre dal giudice. Se pure le medesime denomino il negozio, durante lo stato di esecuzione, un rapporto locatizio, trasformabile, dopo pagata l'ultima rata di prezzo, in una compra-vendita, tutto ciò non esclude che l'atto sia, sin dalla sua origine, una vendita (...). L'error in nomine negotii, non è simulazione, perché l'errore nel rapporto simulato rimane completamente estraneo".

${ }^{353}$ A qualificação corresponde ao raciocínio indutivo que permite reconduzir um negócio jurídico à previsão típica abstratamente descrita na norma. Trata-se de "um juízo predicativo que tem como objecto um contrato concretamente celebrado e que tem como conteúdo a correspondência de um contrato a um ou mais tipos, bem como o grau e o modo de ser dessa correspondência”. Dizer que o a qualificação encerra um juízo predicativo implica reconhecer que ela desenrola-se como um processo de tentativas e erros, o que, aliás, notabiliza o ato de interpretar em sua correlação com o círculo, ou espiral hermenêutico. "O contrato é qualificado através do reconhecimento nele de uma qualidade que é a qualidade de corresponder a este ou àquele tipo, a este ou aquele modelo típico. A qualificação legal traz consigo sempre um processo de relacionação entre a regulação contratual subjectiva estipulada e o ordenamento legal objectivo onde o catálogo de tipos contratuais legais se contém. Este relacionamento traduz-se num movimento espiral e hermenêutico, assente numa pré-compreensão que se traduz em pré-qualificações experimentais precárias feitas com apoio na cultura jurídica e na 'experiência do mundo' de que qualifica". A qualificação assume como ponto de partida uma pré-compreensão sobre o negócio jurídico, uma "antecipação de sentido na expetativa de um resultado". Esta pré-compreensão, por ser provisória, poderá ser modificada, aprimorada, complementada, conforme o processo espiral, indo do negócio ao tipo, e voltando deste àquele, sob a incidência da luminosidade da experiência e da racionalidade jurídicas, confiram maior esclarecimento a que empreende o ato de qualificar. O conteúdo do negócio jurídico deve ser conciliado com o modelo regulativo; isto suscita duas ordens de questões, a primeira delas, afeita à eleição do tipo candidato à qualificação, e a segunda atinente à vinculação entre o caso concreto e o tipo selecionado. A escolha do tipo candidato à qualificação é uma etapa problemática do processo. Embora a experiência e o saber jurídico possibilitem, geralmente, ao autor da qualificação, restringir os tipos elegíveis a um grupo limitado, faz-se necessário experimentar todas as possibilidades vislumbradas, de modo a se poder, diante das circuntâncias concretas do caso, excluir as impertinentes, e, por fim, identificar a mais adequada. No que tange à questão da vinculação entre o negócio jurídico in concreto e o tipo legal, esta não necessariamente decorrerá de exata e completa correspondência entre ambos. O juízo predicativo da qualificação, dado o seu teor tipológico, estrutura-se a partir de uma relação de semelhança (P. PAIS DE VASCONCElos, Contratos Atípicos, Coimbra, Almedina, 1995, p. 161-167). 
que, na maioria das vezes, as partes estipulam, nos negócios que celebram, o tipo a que este deve ser reconduzido. A formação da vontade e do acordo acerca do tipo negocial ocorreria já na fase pré-contratual, quando as partes entender-se-iam sobre o quadro regulativo com base no qual pretenderiam contratar. As partes poderiam indicar um tipo ao qual o futuro negócio jurídico deveria reconduzir-se (se objetivassem celebrar um negócio típico); poderiam, outrossim, escolher um tipo de referência (se quisessem celebrar um negócio de tipo modificado); por fim, poderiam até mesmo afastar completamente um determinado tipo (se a sua intenção fosse a de estabelecer uma relação negocial absolutamente atípica) ${ }^{354}$.

A autonomia privada, diz o autor, não se reduz à escolha do tipo contratual, mas também permite a designação desse mesmo tipo. A estipulação do tipo, que não possui caráter meramente declarativo, integrando o conteúdo da relação jurídica, pode ser expressamente clausulada, constar do preâmbulo do instrumento, ou simplesmente ser constituída pelo seu título ${ }^{355}$. Nesse estado de coisas, nota-se que a afirmação de que o ato de qualificação incumbe apenas ao juiz não procede. As partes também qualificam o negócio jurídico, embora de maneira não definitiva ${ }^{356}$.

A despeito de ser um índice do tipo, a qualificação empreendida pelos contraentes não é absolutamente determinante para a qualificação ${ }^{357}$. Embora, normalmente, exista harmonia entre a estipulação realizada pelas partes e os demais índices do tipo, bem pode ocorrer de aquela não se conciliar com estes. A estipulação do tipo pode corresponder a uma falsa qualificação sempre que a escolha do tipo não corresponda, verdadeiramente, ao tipo reclamado pela disciplina efetiva a que se submete a relação jurídica estabelecida pelas partes $^{358}$.

Pais de Vasconcelos identifica uma semelhança entre a falsa qualificação e a simulação relativa. Para ele, os negócios relativamente simulados seriam caracterizados

\footnotetext{
${ }^{354}$ P. Pais de Vasconcelos, Contratos Atípicos cit. (nota 353), p. 129.

355 P. PAis De VASCONCElos, Contratos Atípicos cit. (nota 353), p. 130.

${ }^{356}$ P. PAIS DE VASCONCElos, Contratos Atípicos cit. (nota 353), p. 131-132.

${ }^{357}$ Isto, ademais, já era destacado por E. BETTI (Teoria generale... cit., nota 53, p. 86), segundo o qual a eleição do regime legal ao qual se deveria sujeitar o negócio jurídico, quando realizada pelas partes, mediante a aposição de uma denominação, não teria mais que valor indicativo. Seria, quando muito, um "índice de valoração" dos efeitos jurídicos, os quais, em última instância, seriam determinados exclusivamente pela ordem jurídico-positiva.

${ }^{358}$ P. PAIS De VASCONCELOS, Contratos Atípicos cit. (nota 353), p. 133.
} 
pela intencional estipulação de um tipo falso. Na simulação relativa, a falsa qualificação "é feita para enganar terceiros"; ali, "não subsiste (...) uma vontade contratual que funde a estipulação do tipo, que não merece, assim, juridicidade"359.

Esta opinião, conquanto parcialmente correta, não atribui o devido relevo que a imediatidade da requalificação assume na distinção entre a falsa qualificação e a simulação. Embora a simulação relativa envolva, de fato, uma falsa qualificação, a inadequação do tipo estipulado pelos simuladores somente se revela à luz de elementos estranhos ao instrumento que formaliza o negócio jurídico. Como bem assinala Butera, "[n]a simulação, em regra, ressalta o sigilo: as partes que se exprimem abertamente, em

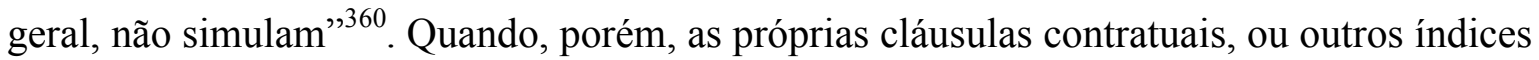
do tipo constantes da forma ostensivamente produzida (e.g. objeto, qualidade das partes, a contrapartida etc.) permitem identificar, diretamente, a incorreção do rótulo atribuído pelas partes, caracteriza-se a falsa qualificação stricto sensu. Com efeito, a possibilidade de o intérprete requalificar o negócio jurídico, valendo-se de dados colhidos diretamente da situação aparente, exclui a relevância da aparência negocial, logo descaracteriza a ilusão negocial. A requalificação evidencia a ausência de simulação precisamente porque "as partes não ocultam uma realidade diferente daquela que aparece"361.

Não cabe, pois, confundir a simulação com a "falsa demonstração". Com base no princípio falsa demonstratio non nocet, assegura-se que o efetivo e concorde sentido atribuído pelas partes à declaração determine o seu conteúdo válido, com absoluta independência do teor literal da fórmula pronunciada ${ }^{362}$. Assim, caso as partes atribuam, ao negócio jurídico, um nomen juris errado, incompatível com a sua natureza (e.g. intitulam, por exemplo, como "comodato", a "locação"), o intérprete não se encontra vinculado à incorreta denominação empregada pelos contraentes; nem esta prejudica a validade da avença conforme a sua adequada designação.

\footnotetext{
${ }^{359}$ P. PAIS De VASCONCElos, Contratos Atípicos cit. (nota 353), p. 129.

${ }^{360}$ A. ButerA, Della simulazione... cit. (nota 20), p. 51-52. Tradução livre; no original: "Nella simulazione, di regola, campeggia sempre la segretezza: le parti, che si esprimono apertamente, in generale, non simulano. Comunque sia, il certo è questo che l'atto simulato è sempre dichiarato nullo e di niun effetto (...), mentre rispetto all'atto oscuramente compilato, opera l'interpretazione integrativa del negozio lacunoso (...)".

${ }^{361}$ C. M. BIANCA, Diritto Civile cit. (nota 63), p. 698.

${ }^{362}$ W. FLuME, El negocio jurídico cit. (nota 43), p. 364.
} 
Segundo Flume, a alteridade deste fenômeno para com a simulação derivaria da circunstância de o enquadramento do negócio jurídico concreto em um dos tipos legalmente previstos ser uma questão de valoração normativa, a qual permaneceria, a todo tempo, indiferente à qualificação realizada pelas partes ${ }^{363}$. Esta explicação, contudo, não se afigura completa, pois também no que tange ao negócio simulado a qualificação da relação jurídica estabelecida entre as partes dá-se com base na lei, especialmente no momento posterior à descoberta do procedimento ilusório. Em vista disso, a diferença qualitativa entre a simulação e a falsa qualificação consiste na ilusão que a primeira cria, e que a segunda não implica. Na simulação, a superação do nomen iuris depende da identificação de elementos que, a princípio, são mantidos em segredo pelos contraentes; descobertos tais elementos, a (re)qualificação do negócio simulado dá-se de maneira idêntica ao do negócio falsamente qualificado, segundo a máxima falsa demonstratio non nocet.

Vale notar, ademais, que também nos países filiados à tradição do common law, onde vigora a chamada "sham doctrine",364, é clara a distinção entre a simulação ("sham")

${ }^{363}$ W. Flume, El negocio jurídico cit. (nota 43), p. 484.

364 A doutrina da simulação começou a se desenvolver, na Inglaterra, no final do século XIX (R. B. STAFFORD, A legal-comparative study of the interpretation and application of the doctrines of the sham and the alter-ego in the context of south african trust law: the dangers of translocating company law principles into trust law, Tese (Masters of Law) - Rhodes University, 2010, p. 70). Esta elaboração, contudo, não se deu de maneira uniforme, surgindo, em razão de precedentes diversos, três diferentes doutrinas: "sham doctrine", a "pretence doctrine" e a "alter-ego doctrine". Estas doutrinas referem-se, em termos gerais, à irrealidade ou falsidade da relação jurídica, ou de um de seus aspectos, derivada do documento contratual firmado pelas partes.

Os traços fundamentais da "sham doctrine" encontram-se delineados no caso Snook v. London and West Riding Investments Ltd. (1967). No julgamento deste importante precedente, o Lord Justice Diplock afirmou o seguinte: "As regards the contention of the plaintiff that the transactions between himself, Auto Finance and the defendants were a "sham", it is, I think, necessary to consider what, if any, legal concept is involved in the use of this popular and pejorative word. I apprehend that, if it has any meaning in law, it means acts done or documents executed by the parties to the "sham" which are intended by them to give to third parties or to the court the appearance of creating between the parties legal rights and obligations different from the actual legal rights and obligations (if any) which the parties intend to create. But one thing, I think, is clear in legal principle, morality and the authorities... that for acts or documents to be a "sham", with whatever legal consequences follow from this, all the parties thereto must have a common intention that the acts or documents are not to create the legal rights and obligations which they give the appearance of creating".

A fórmula acima adquiriu força de cânone, passando a ser repetida em diversos julgamentos posteriores, em vários países filiados à tradição do common Law (R. B. STAFFORD, A legal-comparative study... cit., supra, p. 71).

Outro caso, julgado pela Câmara dos Lordes, pode ajudar a esclarecer a visão dos ingleses a respeito da "sham doctrine". Trata-se de Hilton v. Plustitle Ltd. (1988). A elucidativa narrativa que segue foi elaborada por S. BRIGHT (Beyond Sham and into Pretense in Oxford Journal of Legal Studies, v. 11, Oxford, 1991, p. 137-138): "Mr. Hilton let a number of high quality flats in London, all of which were advertised as being available only as company lets. An actress, Miss Rose, decided to take one of these flats and was told by Mr. Hilton that his accountant could provide her with a company. In fact, through her solicitors, she bought an off-the shelf company called Plustile Ltd. and became a shareholder and director. Before the letting was completed Mr. Hilton obtained a banker's reference for Miss Rose and not the company that would be paying 
e a requalificação ("categorization" ou "relabelling"). Como assinala Conaglen, não deve existir, entre o negócio simulado ("sham transaction") e o negócio não simulado, qualquer diferença notória. Se existisse uma imperfeição aparente no contrato, que fosse perceptível por um observador terceiro, ocorreria simples requalificação, em nada coincidente com a aplicação da "sham doctrine" 365 .

Nesta esteira, não se trata de falsa qualificação, mas de verdadeira simulação, a construção da relação negocial a partir de elementos estranhos ao instrumento que a formaliza, sobretudo a causa concreta e o conteúdo econômico que esta revela.

De fato, como sublinha Gabriellii ${ }^{366}$, o "contrato do terceiro milênio" deve ser entendido como operação jurídico-econômica, independentemente dos contornos formais que apresente externamente. Conquanto o contrato não seja redutível à operação econômica subjacente, aquele é sempre um instrumento para a satisfação e a tutela de interesses concretos; por conta disso, a relação jurídica deve ser integrada mediante uma disciplina legal que seja apropriada à causa concreto, e, portanto, à economia do negócio ${ }^{367}$.

the rent. The rent was paid throughout Miss Rose on personal cheques [sic], the company not having a bank account. On one of the renewals dates for the lease Mr. Hilton tried to increase the rent, Miss Rose objected and the landlord sought possession. The order was granted at first instance and upheld onn appeal. The argument put forward by Miss Rose was that the letting to the company was a sham".

S. BRIGHT conta que os juízes rejeitaram a alegação de simulação formulada por Miss Rose em razão de os direitos e obrigações atribuídos à pessoa jurídica locatária realmente existirem, diante do consenso estabelecido entre as partes: "as both parties knew and undertand that the company was the tenant and not Miss Rose personally the lease did not give an appearance of creating rights not intended to exist and so was not a sham" (Beyond Sham... cit., supra, p. 138).

No direito contratual do common law, a interpretação dos contratos deve dar-se desconsiderando-se tanto a prévia intenção das partes (tratativas), como o comportamento executivo. Logo, para se aferir o conteúdo do contrato, não podem ser levados em conta o antes e o depois da sua celebração. A "sham doctrine" constitui uma exceção a esta regra: presentes os seus requisitos, o juiz pode investigar aqueles fatores em busca da "real truth of the matter" (M. Conaglen, Sham Trusts in The Cambridge Law Journal, v. 67, Cambridge, 2008, p. 186).

${ }^{365}$ M. ConAGLen, Sham Trusts cit. (nota 364), p. 186: “This relates to the point made earlier regarding the conceptual difference between categorization of transactions on the one hand and application of the sham doctrine so as to ignore those transactions on the other. If it is objectively clear that the parties did not intend a transaction of type- $X$ and in fact, as a matter of law, intended rights and obligations which constitutes a type- $Y$ transaction, then the courts are capable of treating the transaction as one of type- $Y$ without need of any sham doctrine: they can simply categorise it as type- $Y$. Only where the objective appearance of the transaction is type- $X$ do the courts need a justification to look behind the objective appearance in order to get at "the real truth of the matter".

${ }^{366}$ E. GABRIELli, Il contratto e le sue classificazioni in P. RESCIGNO - E. GABRIELLi (cur.), Tratatto dei contratti, t. I - I contratti in generale, $2^{\mathrm{a}}$ ed., Torino, UTET, 2008, p. 59.

${ }^{367}$ C. M. BIANCA, Diritto Civile cit. (nota 63), p. 29; E. DANZ, La interpretacion... cit. (nota 334), p. 19 ss.; S. PIMONT, L'economie du contrat, Aix-en-Provence, PUAM, 2004, p. 64 ss. 
No contexto da sociedade de massa, a recondução do negócio jurídico aos esquemas típicos previstos em lei passa a dar-se com base no significado da operação econômica que aquele tende a $\operatorname{aperfeiçoar~}^{368}$. A noção de operação econômica identifica uma sequência unitária e composta que compreende o regulamento de interesses, todos os comportamentos que com este se relacionam para o alcance dos resultados queridos, e a situação objetiva na qual o complexo de regras e os outros comportamentos se colocam ${ }^{369}$. A economia do negócio é um todo, o conjunto e a ordem dos elementos necessários à persecução de um resultado. Ela enseja um exame abrangente da coerência do ato jurídico. O seu elemento central é a função que o ato desempenha em prol dos interesses das partes, a qual deve ser apreendida globalmente e concretamente. Tecnicamente, a determinação da causa com base no aspecto econômico repousa sobre uma interpretação finalística da declaração de vontade. Nestes termos, a economia do negócio configura poderosa ferramenta da qual dispõe o intérprete para interpretar e qualificar a relação jurídica concretamente estabelecida pelos particulares ${ }^{370}$.

É imperioso, contudo, distinguir o sentido econômico que se atribui à transação com base nas próprias declarações formalizadas e publicizadas pelas partes ${ }^{371}$, daquele que se apreende mediante ulteriores e mais aprofundadas investigações, voltadas à identificação de circunstâncias anteriores e posteriores à celebração do negócio jurídico.

\footnotetext{
${ }^{368}$ Sobre o tema, são esclarecedoras as palavras de E. GABRIELLI (Il contratto... cit., nota 366, p. 59-60): “As constantes transformações das concretas formas dos regulamentos de interesse deve, portanto, direcionar cada investigação sobre o contrato a uma perspectiva hermenêutica de horizonte mais amplo e sistematicamente mais arejada: aquela da operação econômica. A ideia de que o contrato possa continuar a viver no mundo dos fatos juridicamente relevantes como uma mônada isolada parece já um resquício daquele tipo de romantismo jurídico que remete ao dogma da vontade de oitocentista memória. (...) Em tal contexto, a noção de contrato - tal qual puro esquema formal, e, portanto, insuficiente a exprimir os comportamentos multiformes dos interesses em jogo e a variabilidade das soluções através das quais aqueles podem comporse - mostra-se às vezes inapta a colher a relevância que, em concreto, em cada fattispecie singular, a função do ato assume e da qual o conceito de operação econômica, ao invés, pode fornecer uma mais ampla e compreensiva expressão". Tradução livre; no original: "Il continuo mutare delle concrete forme dei regolamenti d'interesse deve dunque indurre ad indirizzare ogni indagine sul contratto verso una prospettiva ermeneutica di più largo respiro sistematico: quella dell'operazione economica. L'idea che il contratto possa continuare a vivere nel mondo dei fatti giuridicamente rilevanti come una monade isolata appare oramai un retaggio di quella sorta di romanticismo giuridico riconducibile al dogma della volontà di ottocentista memoria. (...) In tale contesto, la nozione di contratto - quale puro schema formale, e quindi insufficiente ad esprimere il multiforme atteggiarsi degli interessi in gioco e la variabilità delle soluzioni attraverso le quali gli stessi possono comporsi - risulta a volte inidonea a cogliere la rilevanza che in concreto, in ogni singola fattispecie, la funzione dell'atto assume e di cui il concetto di operazione economica, invece può fornire una più ampia e comprensiva espressione"

${ }^{369}$ E. GABRIELLI, Il contratto... cit. (nota 366), p. 60.

${ }^{370}$ S. PIMONT, L'economie du contrat cit. (nota 367), p. 63 ss.; 191 ss.; 202 ss.

${ }^{371}$ E. DANZ (La interpretacion... cit., nota 334, p. 107 ss.) reporta-se aos fins econômicos "notórios".
} 
Como enfatizamos linhas acima ${ }^{372}$, não se mostra razoável exigir do público o conhecimento de todas as circunstâncias práticas que envolvem uma determinada operação negocial. A substância econômica que a comunidade reconhece, segundo a normal diligência do "cidadão médio", limita-se à que exsurge das declarações que as partes formalizam (exceção feita aos casos em que o negócio jurídico se manifesta, exclusivamente, com base no comportamento concludente das partes).

Sobre o tema, Pimont explica que a requalificação do contrato pode dar-se, em alguns casos, com base em um cláusula que exclua ou modifique um dos elementos essenciais do tipo negocial eleito pelas partes. Em outras situações, no entanto, o juiz pode atuar contrariamente ao sentido consubstanciado na declaração formalizada, dando proeminência à vontade “encarnada" em uma operação econômica ${ }^{373}$. No primeiro caso, segundo pensamos, não haveria nada que pudesse depor contra a validade do negócio jurídico; no segundo caso, porém, se a contrariedade ao sentido literal possível da declaração levasse em conta circunstâncias atinentes a uma operação econômica socialmente não recognoscível, entendemos que aquela situação ilusória que caracteriza a simulação estaria presente.

Desse modo, se o sentido econômico que se pode extrair do conjunto de comportamentos precedentes e sucessivos à celebração do negócio jurídico desmente a estipulação de tipo realizada pelas partes, deve-se ter como positivo o diagnóstico da simulação, pois terá surgido a ilusão negocial ${ }^{374}$. Se, diferentemente, o sentido econômico considerado relevante para a requalificação encontra-se plasmado no instrumento, ou nos diversos instrumentos produzidos pelas partes (o que se dá, sobretudo, nos casos de redes contratuais e contratos coligados), não cabe cogitar-se de simulação.

Para ilustrar esse entendimento, considere-se o elucidativo exemplo proposto por Bianca: um alienante transfere um bem a uma sociedade por um certo preço, mediante o acordo de que o pagamento efetuado deveria compensar o débito decorrente da subscrição, por ele efetuado, de ações representativas do capital social desta mesma sociedade. Segundo o sentido literal das declarações formalizadas pelas partes, estas teriam celebrado

\footnotetext{
${ }^{372}$ V. tópico 17.

${ }^{373}$ S. PIMONT, L'economie du contrat cit. (nota 367), p. 237-238.

${ }^{374}$ Em sentido semelhante, J. ABEILle, De la simulation dans le droit des sociétés, Paris, LGDJ, 1938, p. 144.
} 
uma compra e venda e, sucessivamente, ajustado a compensação da obrigação de pagar o preço (a cargo da sociedade) com a obrigação de integrar o capital subscrito (a cargo do vendedor). A despeito disso, não seria necessário investigar nenhuma circunstância prática colateral, antecedente ou sucessiva à emissão das declarações, para, com base no parâmetro da causa concreta, atestar que os negócio jurídicos praticados teriam sido mal qualificados. Em realidade, as partes não teriam realizado compra e venda alguma, mas ajustado a integralização de capital por meio da conferência de um bem, sujeita, portanto, à obrigação de avaliação do bem entregue pelo acionista, segundo a legislação pertinente ${ }^{375}$. Não caberia, aí, falar-se de simulação, pois o regime jurídico adequado a este quadro negocial seria identificado, sem maiores dificuldades, por meio da adequada valoração do propósito econômico veiculado pelas declarações emitidas pelos particulares envolvidos.

\section{Fraude à lei}

A simulação também não se confunde com a fraude à $l e i^{376}$. A primeira evidência da distinção encontra-se explícita no direito positivo. O artigo 166, inciso VI, comina a sanção de nulidade ao negócio que "tiver por objetivo fraudar lei imperativa". O fato de um dispositivo normativo ter sido dedicado, especificamente, à disciplina da fraude à lei, prenuncia a necessidade de assentar em termos precisos a distinção entre este instituto e a simulação, de que trata o artigo 167. Do contrário, o intérprete chegaria à assistemática conclusão de que um mesmo fenômeno jurídico encontrar-se-ia disciplinado, de maneira idêntica, por duas normas de um só diploma.

Com base nos textos legados pelos romanos ${ }^{377}$, os autores modernos conceberam a fraude à lei como o comportamento das partes que, do ponto de vista formal e estritamente jurídico, não infringiria a letra da lei, mas a contradiria substancialmente, no

${ }^{375}$ C. M. BIANCA, Diritto Civile cit. (nota 63), p. 475.

${ }^{376}$ M. A. Domingues De ANDRADE, Teoria Geral... cit. (nota 20), p. 180-181.

${ }^{377}$ Sobretudo, os seguintes fragmentos de Paulo e Ulpiano:

D. 1, 3, 29 - PAULUS, libro singolari ad legem Cinciam: Contra legem facit, quid id facit quod lex prohibet, in fraudem vero, qui salvis verbis legis sententiam eius circumvenit.

D. h.t., 30 - UlpIANUS, libro IV ad edictum: Fraus enim legi fit, ubi quod (lex) fieri noluit, fieri autem non

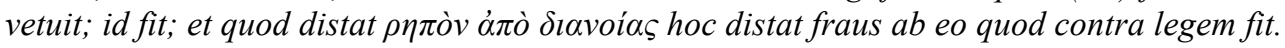


sentido e no escopo ${ }^{378}$. A partir desta noção geral, a doutrina dividiu-se entre a teoria objetiva e a teoria subjetiva.

Para os adeptos da teoria objetiva, no negócio fraudulento haveria uma divergência entre os efeitos jurídicos e os efeitos econômicos. Desse modo, a utilização de um negócio por si lícito tornar-se-ia ilícita na medida em que este viesse a produzir resultados econômicos incompatíveis com o a disciplina do respectivo tipo, os quais, circunstancialmente, fossem proibidos ou rejeitados pela ordem normativa ${ }^{379}$.

Segundo a teoria subjetiva, o negócio fraudulento não poderia, a princípio, ser reprimido pois isto se daria com base na aplicação analógica de uma norma excepcional (i.e. a norma proibitiva). Em vista disso, o combate à elisão seria normativamente autorizado em função do intento elusivo, ou seja, a intenção das partes de legitimamente se valerem de um esquema típico alternativo àquele vedado pela lei com o objetivo precípuo de furtar-se à incidência de uma disciplina jurídica mais restritiva. O intento elusivo seria o motivo determinante do ato, ou seja, o movimento volitivo que conduziria as partes a adotarem uma estrutura negocial em detrimento de outra ${ }^{380}$.

Ambas as teorias, contudo, apresentam fragilidades. No que se refere à teoria objetiva, assinala-se que esta aproximaria a fraude à lei, sobremaneira, à figura do negócio indireto, de modo que, a rigor, o negócio fraudulento não passaria de um negócio atípico ilícito. Nessa esteira, não haveria sentido em cogitar-se de infração indireta ou oblíqua a norma imperativa, pois o negócio indireto, reconhecida a sua carência de autonomia dogmática $^{381}$, infringiria diretamente o comando legal ${ }^{382}$. Já quanto à teoria subjetiva, temse afirmado que ela pressuporia uma indevida distinção entre o intento prático e o intento jurídico; no âmago do negócio jurídico, os dois seriam equivalentes, e, por conseguinte,

\footnotetext{
${ }^{378}$ U. MORELlo, Frode alla legge cit. (nota 330), p. 19. F. FERRARA (A simulação... cit., nota 20, p. 91-92), expõe o seguinte: "Há um ponto em que estão de acôrdo todos os escritores: que a fraude constitue uma violação indirecta da lei, não segundo o seu conteúdo literal, mas segundo o seu espírito. Aquele que defrauda não contradiz as palavras da lei, pelo contrário, cinge-se respeitosamente à sua letra, mas, na realidade, vai contra o sentido da disposição, vem a frustrar a finalidade a que tendia o princípio jurídico (...)".

${ }^{379}$ G. CRICENTI, Frode alla lege cit. (nota 330), p. 29-30.

${ }^{380}$ G. CRICENTI, Frode alla lege cit. (nota 330), p. 32.

${ }^{381} \mathrm{~V}$. tópico 22.

${ }^{382}$ G. CRICENTI, Frode alla lege cit. (nota 330), p. 30-32.
} 
não seria possível atribuir específica relevância ao intento elusivo com vistas a identificar o quid da fraude à lei ${ }^{383}$.

A dificuldade do tema da fraude à lei torna-se ainda mais saliente diante da opinião segundo a qual, em muitas ocasiões, seria possível controlar a elusão pretendida pelas particulares com base em procedimentos hermenêuticos, tais como a interpretação extensiva e a analogia. Diante da volubilidade que estas abordagens imporia aos contornos característicos da fraude à lei, pretendeu-se desenvolver uma teoria unitária na tentativa de captar a essência peculiar do instituto.

Um autor que se destacou nessa vertente teórica é Morello. Segundo o autor, uma elaboração dogmática unitária da fraude à lei requereria o enfrentamento concomitante das questões suscitadas pelas teorias objetiva e subjetiva, de modo a identificar-se critérios que pudessem formar um conjunto orgânico de diretrizes. Tais questões relacionar-se-iam ${ }^{384}$ :

(a) à interpretação da lei eludida para além do seu conteúdo literal, de forma a estender sua aplicação à materialidade das transações, complementando, assim o sentido dos negócios jurídicos concretos, mediante verdadeira integração;

(b) ao controle dos negócios jurídicos efetivamente concluídos, ou dos pressupostos de aplicação da norma eludida; e

(c) ao aspecto subjetivo do procedimento, o chamado intento elusivo.

No que se refere ao âmbito de aplicação das normas eludidas, o principal aspecto a se observar seria aquele afeito à necessidade de identificar normas que não comportariam interpretação extensiva, vigentes em áreas de strictum jus. Como a infração, no caso da fraude à lei, seria indireta e oblíqua, a impossibilidade de recorrer a instrumentos como a interpretação analógica ou teleológica, com vistas a ampliar o raio de incidência da norma eludida, poderia tornar a interpretação jurídica insuficiente para eliminar os inconvenientes acarretados pela malitia dos particulares, surgindo espaço à adoção da técnica da fraude à lei. Dois tipos de quesitos deveriam, segundo o autor, orientar a avaliação da rigidez do liame entre a norma e o correspondente texto ${ }^{385}$ :

${ }^{383}$ G. CRICENTI, Frode alla lege cit. (nota 330), p. 33-36.

${ }^{384}$ U. MORELLO, Frode alla legge cit. (nota 330), p. 259-260.

${ }^{385}$ U. MORELLO, Frode alla legge cit. (nota 330), p. 321. 
(a) critérios hermenêuticos legais, voltados à indicação das circunstâncias sob as quais se poderia recorrer à analogia, interpretação teleológica etc. (tais como, para citar alguns exemplos do direito brasileiro, os artigos $4^{\circ}$ e $5^{\circ}$ da DecretoLei n ${ }^{\circ} 4.657 / 1942$ - Lei de Introdução às normas do Direito Brasileiro; e o artigo 111 do Código Tributário Nacional, que impõe a adoção de "interpretação literal" quanto a normas que estabelecem a suspensão ou exclusão do crédito tributário, a isenção de tributos ou a dispensa do cumprimento de deveres tributários instrumentais); e

(b) princípios gerais orientadores da ordem jurídica em vigor, com base nos quais o intérprete deveria examinar o equilíbrio estabelecido entre o ideal de certeza do direito (previsibilidade das decisões) e a busca da justiça substancial (aderência à realidade socioeconômica).

De acordo com Morello, a fraude à lei implicaria a superação das formas de direito privado empregadas pelos particulares em favor da elucidação da relação econômica subjacente ao negócio jurídico. Contudo, em atenção à tradição reinante nos países filiados à civil law, este expediente somente poderia ser empregado excepcionalmente, desde que atendidos os seguintes pressupostos ${ }^{386}$ :

(a) a constatação, a partir das próprias cláusulas do negócio jurídico, pactos acessórios ou negócios coligados, de inconsistências que apontariam um descasamento entre a forma de direito privado e o nomen juris ou a substância econômica da transação;

(b) a presença de elementos econômicos de fácil verificação e indubitável relevância no contexto dos interesses em jogo, capazes de evidenciar a artificialidade da convenção firmada entre os particulares;

(c) a caracterização do intento elusivo a partir de indícios objetivos, notadamente os seguintes:

i. sub-rogabilidade em sentido econômico do procedimento adotado pelas partes com aquela que constitui objeto da norma eludida: a apreciação deste pressuposto deveria ter como referência preponderante a dimensão econômica; porém, não se deveria ignorar o aspecto jurídico-formal, porquanto importaria aferir se a forma jurídica empregada não corresponderia a mero artifício para a produção de específicos resultados práticos; e

ii. falta de interesse econômico ou empresarial: o intérprete deveria verificar se existiria uma base econômica que legitimasse o negócio jurídico, ou se, contrariamente, a estrutura negocial montada não se prestaria a qualquer outro fim que não a elusão de norma imperativa; tal análise deveria levar em conta não apenas os interesses concretos das partes, mas, também, o

${ }^{386}$ U. MORELLO, Frode alla legge cit. (nota 330), p. 304 ss. 
ponto de vista do "cidadão médio", ou seja, a opinião vigente na comunidade a respeito da concretude de certo arranjo negocial, assim como sobre a recorrência do emprego deste como instrumento elusivo.

Passando a limpo as formulações de Morello, constata-se que, segundo este autor, a fraude à lei caracterizar-se-ia quanto a normas imperativas que prescrevessem determinada disciplina a um resultado prático, não a uma dada forma de direito privado. Apenas quanto a normas ditas "materiais", ou seja, aquelas que disciplinam um específico resultado, não uma determinada conduta, seria possível atribuir relevo à razão da proibição, passando a buscar-se, no comportamento concreto dos particulares, a infração indireta ou oblíqua à lei. Do ponto de vista subjetivo, a fraude à lei dependeria da constatação, por meio de índices sintomáticos, de que, mediante o emprego de determinada estrutura negocial, as partes não estariam a perseguir objetivos dignos de tutela jurídica. Observadas estas premissas, seria possível desconsiderar o aspecto nominal da operação negocial, sancionando-a em razão de seu caráter fraudulento.

A tese acima exposta, no entanto, tem sido alvo de críticas por parte da doutrina mais recente. Afirma-se, neste mister, que a fraude à lei não se fundaria sobre a construção ou correção da relação negocial, nem ensejaria a superação das formas de direito privado empregadas pelos particulares, pois tais operações coincidiriam com a requalificação do negócio jurídico. O intérprete não estaria vinculado à qualificação eleita pelas partes, ou seja, ao nomen juris atribuído ao negócio jurídico; poderia, portanto, atribuir um rótulo adequado ao negócio jurídico com base na causa concreta, e, eventualmente, atestar a sua ilicitude imediatamente (não por via oblíqua) ${ }^{387}$. Diz-se, ainda, que o chamado intento elusivo não integraria o suporte fático da fraude à lei. Além de a norma não lhe fazer qualquer referência, se fosse compreendido como estado psicológico do particular, naturalmente deveria ser tido como irrelevante, a não ser que se caracterizasse como motivo comum determinante; neste caso, porém, a nulidade decorreria da ilicitude do motivo comum determinante, não da fraude à lei. Ademais, se concebido como vontade objetivada no negócio jurídico, o intento elusivo não seria mais que um componente da causa concreta deste ${ }^{388}$. Sustenta-se, por fim, que a fraude à lei não poderia configurar-se quanto a um único negócio jurídico, mas apenas no contexto de uma cadeia de negócios

${ }^{387}$ G. CRICENTI, Frode alla lege cit. (nota 330), p. 24-25.

${ }^{388}$ F. Di MARZIO, La nullità del contratto, Padova, CEDAM, 1999, p. 326. 
jurídicos coligados, os quais, em sua unidade funcional, expressariam uma operação econômica legalmente vedada ${ }^{389}$.

Diante da vexata quoestio relativa à qualificação jurídica da fraude à lei, parece oportuno recobrar a intuição, já manifestada por Morello ${ }^{390}$, e recentemente resgatada por Cricenti $^{391}$, segundo a qual a fraude à lei configuraria verdadeira cláusula geral. Melhor dizendo, ela manifestar-se-ia em virtude da combinação de uma norma imperativa com uma cláusula geral. A norma imperativa definiria um determinado regime jurídico, restritivo, que não poderia ser aplicado mediante a interpretação extensiva ou a analogia a fatos distintos daqueles nela enumerados. A cláusula geral (i.e. a norma que sanciona a fraude à lei), por seu turno, autorizaria, em caráter de exceção, o emprego da interpretação extensiva ou da analogia, de maneira a fazer incidir aquela disciplina legal a outros atos capazes de proporcionar resultados práticos idênticos ou análogos ao sancionado pelo comando legal $^{392}$.

Nestes termos, é possível reconhecer a autonomia dogmática da fraude à lei, reputando-a aplicável sobretudo nos casos em que a requalificação do negócio jurídico não seja possível (porque há permutabilidade em sentido econômico entre o negócio típico celebrado pelas partes e o vedado pela norma imperativa, ou porque as partes se valem de uma série de negócios jurídicos que não se poderia reconduzir a uma única estrutura negocial), e nas situações em que não existe um fundamento autônomo, de natureza jurídica ou econômica, que justifique a adoção, pelas partes, de um esquema negocial em detrimento daquele objeto da norma eludida. Para proceder ao desvelamento da fraude à lei, o intérprete deve partir da identificação do âmbito de aplicação da norma imperativa, ou seja, identificar se esta disciplina uma modalidade de comportamento ou um resultado econômico. Neste segundo caso, a norma diz-se material, sendo, portanto, fraudável. Na sequência, cumpre examinar a substância econômica do negócio posto em prática, com vistas a valorar se esta equivale ao resultado econômico descrito na norma. Ao fim desta operação interpretativa torna-se possível dizer se o negócio jurídico atende, ou não, a uma

\footnotetext{
${ }^{389}$ S. NARDI, Frode alla legge e collegamento negoziale, Milano, Giuffrè, 2006, p. 68 ss.

${ }^{390}$ U. MORELLO, Frode alla legge cit. (nota 330), p. 299 ss.

${ }^{391}$ G. CRICENTI, Frode alla lege cit. (nota 330), p. 38-41.

${ }^{392}$ F. Di MARZIO, La nullità... cit. (nota 388), p. 322-324.
} 
finalidade vedada pelo ordenamento; se a resposta for afirmativa, está-se diante da fraude à $1 \mathrm{ei}{ }^{393}$.

Como se vê, mesmo esta última formulação apoia-se, em certa medida, sobre a consideração de uma dimensão subjetiva da fraude lei. Deveras, se a requalificação do negócio jurídico não é possível, a princípio, porque há uma sub-rogabilidade em sentido econômico que não permite precisar, de maneira definitiva, qual estrutura negocial deveria prevalecer (a adotada explicitamente pelas partes ou aquela que fosse vedada pela norma imperativa), a caracterização da fraude à lei passa a depender da inexistência de um interesse autônomo quanto ao tipo negocial eleito pelo contraentes, mais precisamente, um interesse que transcendesse a mera elusão da lei. Assim, se as partes podem valer-se, igualmente, de dois diferentes meios para chegar a um resultado, e o direito rejeita este resultado fazendo alusão a apenas um destes meios, deve-se indagar se o meio alternativo (não proibido expressamente) empregado possui uma justificativa econômico-social autônoma. Se a resposta for negativa, ou seja, se a escolha do meio tiver sido orientada pelo objetivo de descaracterizar o pressuposto de aplicação da norma proibitiva ou restritiva, não se poderá negar ter-se manifestado uma intenção de fraudar, ainda que não se chegue ao ponto de atribuir a esta intenção um caráter autônomo.

No cenário que se descortina, a distinção entre a fraude à lei e a simulação passa a ser dogmaticamente justificável (em confirmação, portanto, ao dado apontado já pela literal alteridade verificada no confronto entre o inciso VI do artigo 166 e o artigo 167). Nesta sede, permanecem atuais a lições de Ferrara, segundo as quais o negócio fraudulento não seria, em absoluto, aparente, mas perfeitamente sério. As partes o quereriam tal qual ele se realizasse, com todas as consequências derivadas da forma jurídica escolhida ${ }^{394}$. A fraude mudaria o estado de fato regulado pela lei, de modo que ela se tornaria inaplicável $^{395}$. Poderia dar-se a fraude à lei mediante o emprego de um negócio diferente,

\footnotetext{
${ }^{393}$ F. Di MARZIO, La nullità... cit. (nota 388), p. 325-326: Tradução livre; no original: "Tirando le fila del discorso: la norma che, a un'attenta lettura, si rivela non formale, ma materiale va interpretata con riguardo non al comportamento contrattuale che sanziona ma al risultato economico che vieta: il contratto o l'insieme di contratti collegati vanno analizzati non per la veste formale che assumono ma per il risultato pratico che consentono di raggiungere. Se quest'ultimo corrisponde a quello vietato, dovendosi escludere che le parti abbiano un interesse meritevole alle forme adottate, il contratto (si reputa, nel senso che) è illecito".

${ }^{394}$ F. FERrARA, A simulação... cit. (nota 20), p. 91.

${ }^{395}$ F. FERrARA, $A$ simulação... cit. (nota 20), p. 93: "Estas imagens dão uma ideia bastante exacta da fraude: os contratantes propõem-se fugir à aplicação duma norma jurídica, conformando a sua conduta de tal modo que não possa ser diretamente reprovada e que, com o conjunto de meios oblíquos empregados, venha a
} 
ou da combinação de negócios; a modificação de condições de fato indicadas como pressupostos de incidência da norma; ou pela interposição ${ }^{396}$. Diante dessas premissas, a distinção entre a simulação e a fraude a lei seria enunciada da seguinte maneira ${ }^{397}$ :

A ocultação nem põe nem tira nada ao negócio realizado: afastando o véu enganador, aparece o negócio na sua verdadeira essência, na sua realidade nua e crua; e se este negócio se encontrar em contradição com uma lei proibitiva, tem-se um contra legem agere, não um in fraudem legis agere. Contra legem escondido, velado, oculto; circunstância que não altera a sua natureza.

(...)

Se eu desdobrar um véu sobre um facto realizado; se cobrir com um disfarce uma transgressão real, nem por isso a transgressão deixa de o ser: ficará coberta, escondida, mascarada, mas será sempre uma transgressão, uma colisão contra o conteúdo verbal da norma jurídica.

A simulação não é um meio para iludir a lei, mas sim ocultar a sua violação.

Vê-se, nestes termos, que a denominação "simulação em fraude à lei"; melhor seria referir-se a "simulação ilícita" ou "simulação nocente" (como preferimos), a não ser que o adjetivo "fraudulenta" fosse associado ao "dano", em sentido amplo ${ }^{398}$. A simulação, quando nocente, não tem o objetivo de violar diretamente uma disposição legal, mas o de ocultar uma ilegalidade ${ }^{399}$. É claro que, em vista da cominação da sanção de nulidade ao negócio simulado, este torna-se, por si, ilegal; na simulação nocente, portanto, há uma dupla ilegalidade, uma das quais presta-se a esconder a outra. Em suma, a simulação e a fraude à lei operam em planos distintos ${ }^{400}$, sendo certo que um negócio simulado pode, inclusive, ser empregado de modo a ocultar um negócio fraudulento; ambos, contudo, não chegam a confundir-se.

conseguir-se o resultado que a lei queria impedir. É, pois, um elemento de conduta fraudulenta a intenção das partes de se subtraírem à força coactiva do direito, mas não é essenciala consciência de que se tenta alcançar um fim proibido".

${ }^{396}$ F. FERRARA, A simulação... cit. (nota 20), p. 93-94.

${ }^{397}$ F. FERrARA, A simulação... cit. (nota 20), p. 95-96.

${ }^{398}$ F. FerrarA, A simulação... cit. (nota 20), p. 96. V. também N. DistASO, La simulazione... cit. (nota 40), p. 131 ss.

${ }^{399}$ G. CRICENTI, Frode alla lege cit. (nota 330), p. 26.

${ }^{400}$ S. NARDI, Frode alla legge... cit. (nota 389), p. 43. 


\section{Abuso de direito}

A associação entre simulação e abuso de direito possui evidente inspiração na concepção bettiana da simulação como abuso da função instrumental do negócio jurídico. Vale notar, porém, que, o próprio Betti diferencia o abuso de direito do abuso do negócio. Para o autor, o negócio jurídico não se confundiria com o exercício de um direito subjetivo, pois tais figuras assentar-se-iam sobre postulados diversos. O negócio jurídico pressuporia interesses a regular nas relações com outros, mas não necessariamente relações jurídicas preexistentes a modificar. Assim, poderia haver negócio jurídico sem direito subjetivo a se exercer, como no caso da assunção de dívida. Por outro lado, o exercício de um direito subjetivo relacionar-se-ia a uma situação previamente criada; realizaria o estado de fato correspondente a uma preexistente proteção legal, com ou sem a cooperação de outrem. Em face disso, o abuso do direito não se confundiria com o abuso do negócio, ainda que se entendesse por "direito" qualquer "poder", em sentido genérico ${ }^{401}$.

A esta opinião poder-se-ia contrapor o entendimento de que o abuso de direito, por constituir verdadeira cláusula geral, abrangeria, além dos direitos subjetivos, outras classes de poderes e liberdades ${ }^{402}$. Ao examinar o artigo 187, Boulos aduz que o instituto ali disciplinado seria um dos vetores da socialidade e, por isso, deveria ser interpretado da maneira mais ampla possível. Segundo o autor, o artigo 187 abrangeria os direitos subjetivos patrimoniais (direitos de crédito e direitos reais), os denominados direitosdeveres (poderes-deveres) ou poderes funcionais, as liberdades, os ônus jurídicos, os direitos potestativos, os poderes, as exceções, enfim, qualquer situação jurídica ativa ou permissão genérica de atuação ${ }^{403}$. De modo que, à luz do direito vigente, não seria absurdo cogitar-se de um abuso do negócio como sinônimo de abuso de direito.

Deve-se atentar, contudo, que o abuso de direito somente pode configurar-se quando o sujeito invoca um poder que, formal ou aparentemente, lhe pertence ${ }^{404}$. Por outras palavras, o particular somente logra abusar de um direito cuja titularidade tenha adquirido, muito embora não esteja autorizado a exercê-lo como bem entenda.

\footnotetext{
${ }^{401}$ E. BETTI, Teoria generale... cit. (nota 53), p. 75; 383.

402 A. Menezes Cordeiro, Tratado de Direito Civil, v. V, Coimbra, Almedina, 2011, p. 372-374.

${ }^{403}$ D. M. Boulos, Abuso do Direito no novo Código Civil, São Paulo, Método, 2006, p. 150-155.

${ }^{404}$ D. M. Boulos, Abuso do Direito... cit. (nota 403), p. 162. Também H. E HöRSTER, A parte Geral do Código Civil Português - Teoria Geral do Direito Civil, Coimbra, Almedina, 1992, p. 282.
} 
A temática da titularidade do direito sempre foi problemática nos marcos da teoria do abuso. Afirmou-se que, se o exercício abusivo de um direito seria repelido pela ordem normativa, a situação que o caracterizaria já não constituiria um direito. Nestes termos, a figura do abuso de direito configuraria verdadeira contradictio in terminis ${ }^{405}$. Com vistas a superar este impasse, a doutrina passou a sustentar que a abusividade decorreria do exercício do direito de modo a colocá-lo em confronto com as diretrizes informativas do sistema jurídico. Seria um exercício assistemático - disfuncional ${ }^{406}$ - de uma posição jurídica $^{407}$. Esta abordagem programática, de jaez teleológico, teria o mérito de conciliar o direito com o abuso, uma vez que a assistematicidade não implicaria a desnaturação do direito, mas o choque deste com os princípios regentes da ordem jusprivatística.

Nesse contexto, parece ser ainda defensável a distinção, traçada por Josserand, entre os atos ilegais, ilícitos e excessivos. No caso dos primeiros não haveria direito a se exercer, pois o ato seria intrinsecamente incorreto. Quanto aos segundos, os particulares seriam titulares de posições jurídicas inicialmente legítimas a quais, no entanto, tornar-seiam reprováveis em razão dos objetivos concretos a que fossem direcionadas; haveria, no caso dos atos ilícitos, uma desvirtuação do direito caracterizada pelo respeito à letra da lei, mas a infração ao seu espírito. Por fim, relativamente aos atos excessivos, não haveria nem ilegalidade nem ilicitude, mas uma externalidade negativa anormal, da qual poderia, eventualmente, decorrer a responsabilidade objetiva do agente. No âmbito deste sistema tripartite, o abuso de direito situar-se-ia entre os opostos representados pelos atos ilegais e pelos atos excessivos; a ilicitude atinente à abusividade resultaria da infração à finalidade da lei, não à sua literalidade ${ }^{408}$.

Levando em conta esta ordem de considerações, a aproximação entre o abuso de direito e a simulação somente poderia ser admitida acaso esta última fosse encarada por um ângulo que, como temos nos esforçado em demonstrar, não é o mais adequado. Se o procedimento simulatório pressupusesse a celebração do "negócio aparente", e a simulação fosse um efeito decorrente de uma anomalia deste, bem se poderia crer que os simuladores

\footnotetext{
${ }^{405}$ V., a propósito de um exame crítico das teorias internas e externas do abuso, as ponderações de A. MENEZES CORDEIRO, Tratado... cit. (nota 402), p. 351 ss.

${ }^{406}$ A. MenEZes Cordeiro, Tratado... cit. (nota 402), p. 366-369.

${ }^{407}$ P. RoUBIER, Droits subjectifs et situations juridiques (1963), Paris, Dalloz, 2005, p. 47 ss.

${ }^{408}$ L. Josserand, De l'esprit des droits et leur relativitè - Théorie dite de l'abus des droits (1939), 2a ed., Paris, Dalloz, 2006, p. 357-363.
} 
abusariam da liberdade negocial, exercendo-a de maneira assistemática, contrariamente aos postulados basilares do ordenamento jurídico. Contudo, conforme buscamos evidenciar, o negócio simulado não se confunde com o "negócio aparente"; é a ilusão negocial um efeito da simulação, não o contrário ${ }^{409}$.

O negócio simulado é aquele que cria a aparência ou contém declaração não verdadeira; é a fonte da ilusão negocial, e, como tal, é intrinsecamente incorreto - logo, ilegal. Este o juízo de valor contido no artigo 167, o qual sanciona da simulação com a nulidade. Não é possível sujeitar o negócio simulado à disciplina do artigo 187 porque este dispositivo aplica-se sobre o ato a princípio legítimo ${ }^{410}$, que se torna ilícito em virtude do abuso. Não é este, contudo, o caso dos negócios nulos, ou daqueles taxativamente ilícitos, os quais, ainda que pudessem decorrer de um abuso cometido no momento pré-jurídico, são imediatamente captados pela ordem normativa como antijurídicos.

A confirmar este entendimento, é salutar notar que o abuso de direito pressupõe a existência de situações em que não há abuso. Com efeito, a ideia de abuso de direito pressupõe que a lei reconheça a relevância de uma posição jurídica, mas não admita que ela seja exercida para além de certos limites. Por conseguinte, somente poderia tornar-se ilícito, por força do artigo 187, o ato dotado da potencialidade de ser realizado legalmente e licitamente. Se esta potencialidade não existisse, o abuso tornar-se-ia simplesmente inimaginável, pois não existiria a posição jurídica de que se poderia abusar. E é isto, precisamente, o que sucede com o negócio simulado; é logicamente inconcebível o abuso, quanto a este, pois não há como celebrá-lo legalmente. O abuso e o não abuso são irrelevantes para o negócio simulado, que será sempre nulo; é, assim, impossível cogitar-se do abuso de direito em tal âmbito.

Percebe-se, assim, que a noção de abuso da autonomia privada deve ser concebida com temperamento. Como tivemos oportunidade de demonstrar ${ }^{411}$, a autonomia privada é um poder pré-jurídico, cujas manifestações o direito se limita a valorar, positivamente ou

\footnotetext{
${ }^{409}$ Considere-se um empréstimo simulado; em vista deste, poder-se-ia indagar se os particulares teriam o direito de celebrar um empréstimo, o qual, por conta de características que lhe fossem adicionadas (e.g. a falta de vontade, ou uma correlata contradeclaração). Responder-se-ia, então, que sim, os particulares têm o direito de contratar empréstimos; seria abusivo, porém, torná-lo simulado. Este ponto de vista não se apercebe de que os simuladores não celebram qualquer empréstimo; celebram um negócio jurídico que se reveste da aparência de empréstimo.

${ }^{410}$ D. M. Boulos, Abuso do Direito... cit. (nota 403), p. 162.

${ }^{411} \mathrm{~V}$. tópico 11.
} 
negativamente. $\mathrm{O}$ abuso de uma posição jurídica somente poderia ter por objeto um ato reconhecido e acolhido pela ordem jurídica, não uma conduta dotada, a priori, de relevância exclusivamente social. Por este motivo, não nos parece sustentável a suposição de que um ato de autonomia privada nulo ${ }^{412}$, como o negócio simulado, o qual se submete a uma imediata valoração negativa pela ordem jurídica, seja associado a um abuso da autonomia privada (assim como, analogamente, não se justificaria a alegação de que um negócio ilícito - e.g. compra e venda de entorpecentes - seria abusivo).

\section{Negócio indireto e negócio fiduciário}

Majoritariamente, define-se o negócio indireto como o negócio típico do qual as partes se utilizam com vistas a atingir resultados atípicos, ou pertencentes a outro tipo. Segundo Ascarelli, no negócio indireto, “as partes recorrem a um determinado negócio jurídico, mas o escopo prático visado não é, afinal, ao normalmente realizado através do negócio adotado, mas um escopo diverso, muitas vezes análogo àquele de outro negócio ou sem forma típica própria no sistema jurídico"413. Para Rubino, o negócio indireto proporciona um resultado jurídico alheio ao negócio utilizado, o qual substitui no todo ou em parte o efeito típico daquele ${ }^{414}$. Seriam exemplos de negócios indiretos o mandato para fins de cessão, doação o venda; a representação para fins de associação em participação ou arrendamento; o negotium mixtum cum donatione; a venda, permuta ou transação entre coerdeiros para fins de divisão; a liquidação para fins de fusão, e, no mais, todas as "sociedades anômalas"415.

\footnotetext{
412 Por outro giro, diríamos que o abuso da autonomia privada somente poderia ser constatado quanto aos negócios jurídicos que, sob todos os aspectos, fossem considerados inicialmente válidos. Quanto a estes, a invalidade não seria imanente, mas decorreria do abuso de direito. Pensando deste modo, logra-se compatibilizar o conteúdo do artigo $187 \mathrm{com}$ as regras dedicadas à disciplina das invalidades, as quais careceriam de toda utilidade se atribuíssemos envergadura mais ampla àquele dispositivo. Nessa esteira, o exercício da posição jurídica dos simuladores não se mostra assistemático - logo, abusivo - pois, num momento logicamente anterior a norma lhe retira a validade.

${ }^{413}$ T. AsCarelli, Problemas das Sociedades Anônimas e Direito Comparado (1945), Campinas, Bookseller, 2001, p. 156.

${ }^{414}$ D. RuBINO, Il negozio giuridico indiretto (1937), trad. esp. de L. Rodriguez-Arias, El Negocio Jurídico Indireto, Madrid, Revista de Derecho Privado, 1953, p. 25.

${ }^{415}$ D. RUBINO, Il negozio giuridico indiretto cit. (nota 414), p. 19.
} 
Também se incluem na classe dos negócios indiretos os chamados negócios fiduciários ${ }^{416}$. Com o negócio fiduciário, as partes celebram, além do negócio jurídico, um pacto adjeto ("pactum fiducice") que vincula a sua eficácia à consecução de uma finalidade específica. Os elementos caracterizantes da fidúcia são a efetividade da transmissão e a possibilidade do abuso do fiduciário $^{417}$. Ajusta-se, por exemplo, que a transmissão da propriedade deve servir como instrumento a que o adquirente realize atos de administração no interesse do alienante; ou, ainda, que a propriedade permaneça sob a titularidade do adquirente apenas enquanto perdurar a sua relação creditícia com o alienante ${ }^{418}$. A característica distintiva do negócio fiduciário é a de que este acarreta uma transmissão de propriedade cujo efeito é parcialmente neutralizado por uma convenção entre as partes ${ }^{419}$. As partes pretendem alcançar um determinado resultado prático que não decorreria, naturalmente, dos instrumentos formais empregados; os contraentes convencionam subtrair-se da eficácia coercitiva do negócio jurídico, dando voluntário cumprimento a obrigações que não decorreriam da sua estrutura típica ${ }^{420}$. Este contraste entre a dimensão funcional e a estrutural reflete uma excedência do meio sobre os fins ${ }^{421}$.

Tradicionalmente, a distinção doutrinária entre a simulação e o negócio indireto é estabelecida com base na vontade. Diz-se, neste particular, que, no caso do negócio indireto, as partes realizariam o que querem, pois não deixariam de submeter-se à disciplina típica do negócio celebrado. Os contraentes não desdenhariam os efeitos típicos do negócio jurídico adotado, pois a produção destes seria pressuposta à realização dos

\footnotetext{
416 T. ASCARElli, Problemas... cit. (nota 413), p. 159. Contra: L. CARIOTA FERRARA, I negozi fiduciari trasferimento cessione e girata a scopo di mandato e di garanzia. Processo fuiduciario (1933), Padova, CEDAM, 1978, p. 40; N. DisTASO, La simulazione... cit. (nota 40), p. 118-120.

${ }^{417}$ C. M. BiAnCA, Diritto Civile cit. (nota 63), p. 712. Ocorrendo o abuso do fiduciário, não restaria, ao fiduciante, outra solução que não o pleito da reparação pelas perdas e danos (L. CARIOTA FERRARA, I negozi fiduciari... cit., nota 416, p. 17).

${ }^{418}$ A fidúcia, assim descrita, é a de ascendência romana; caracteriza-se por uma limitação do escopo prático a que se presta a transmissão do direito mediante um vínculo obrigacional. Distancia-se, assim, da fidúcia germânica, caracterizada pela transmissão de um direito que, por si, já seria limitado (limitação real), por força de uma condição resolutiva. Como explica L . CARIOTA-FERRARA (I negozi fiduciari... cit., nota 416, p. 10-17), a concepção germânica do negócio fiduciário não poderia ser acolhida, pois se funda numa presunção de que toda operação desta espécie submete-se a uma condição resolutiva. Por conseguinte, deverse-ia preferir a formulação romana, de base obrigacional. No direito brasileiro, diferentemente, a fidúcia germânica parece ter se tornado possível a partir da positivação do direito real de propriedade fiduciária (artigos $1361 \mathrm{ss}$.)

419 T. ASCARELLI, Problemas... cit. (nota 413), p. 159.

${ }^{420}$ N. LiPARI, Il negozio fiduciario, Milano, Giuffrè, 1971. p. 176.

${ }^{421}$ L. CARIOTA FERRARA, I negozi fiduciari... cit. (nota 416), p. 40.
} 
efeitos indiretos ${ }^{422}$. "Na simulação as partes, para alcançar o fim visado, declaram o que não corresponde à vontade delas, regulando, no entanto, clandestinamente, as próprias relações jurídicas de modo conforme à vontade real; no negócio indireto, ao contrário, o fim prático visado pelas partes é alcançado justamente por meio do negócio adotado e declarado" 423 . Sustenta-se, ademais, que a simulação não se prestaria a explicar a frequente extralegalidade (atipicidade) do escopo indireto; no que tange às hipóteses em que o resultado indireto fosse dotado de tipicidade (i.e. correspondesse aos efeitos de outro negócio típico), não haveria razões para crer-se que o negócio-meio não seria querido, pois quem quisesse os resultados indiretos também haveriam de querer os meios necessários alcançá-10 ${ }^{424}$.

Relativamente ao negócio fiduciário, a doutrina diverge. Para alguns, o negócio fiduciário seria uma espécie de negócio simulado, uma vez que a limitação imposta à transmissão efetuada evidenciaria que ele jamais teria sido querido ${ }^{425}$. Em sentido oposto, postula-se que a diferença entre o negócio fiduciário e o negócio simulado residiria na vontade, presente no primeiro, mas ausente no segundo; o negócio fiduciário seria real, porque querido, ao passo que o negócio simulado seria irreal, pois carente de vontade ${ }^{426}$. Do ponto de vista da teoria da declaração, o confronto em tela dar-se-ia com fulcro no momento em que ocorreria a "destruição" da declaração ostensiva; enquanto na simulação esta se daria ab initio - excluindo toda a efetividade da transmissão ajustada -, no negócio fiduciário ela se processaria em momento posterior, assumindo a feição de uma modificação ex nunc dos termos convencionados ${ }^{427}$. Aduz-se, ainda, que a alteridade do negócio fiduciário em face do negócio simulado decorreria da irrelevância externa do "pactum fiducice", o qual não impediria a efetividade da transmissão efetuada em favor do fiduciário, o qual tornar-se-ia, erga omnes, titular do direito real atinente ao bem que lhe fosse conferido ${ }^{428}$.

Diante desse rico quadro doutrinário, parece-nos que a distinção entre a simulação, de um lado, e os negócios indireto e fiduciário, de outro, possa ser estabelecida

\footnotetext{
422 T. AsCARelli, Problemas... cit. (nota 413), p. 179.

${ }^{423}$ T. AsCARELli, Problemas... cit. (nota 413), p. 179.

${ }^{424}$ D. RUBINO, Il negozio giuridico indiretto cit. (nota 414), p. 76-77.

${ }^{425}$ G. STOLFI, Teoria del Negocio Jurídico cit. cit. (nota 20), p. 154, nota 3.

${ }^{426}$ M. A. Domingues De ANDRADE, Teoria Geral... cit. (nota 20), p. 175-179.

${ }^{427}$ L. CARIOTA FERRARA, I negozi fiduciari... cit. (nota 416), p. 43-51.

${ }^{428}$ N. DisTASO, La simulazione... cit. (nota 40), p. 127-131.
} 
com base naquele elemento que, segundo temos defendido, constitui a essência da simulação: a ilusão negocial.

A produção de efeitos indiretos por um negócio jurídico poderia bem implicar a atipicidade da sua causa concreta, ou, a depender da gravidade do desvio, justificar a requalificação. No primeiro caso, somente, caberia falar de negócio indireto, sendo certo que a denominação assim empregada não passaria de um rótulo dado a situações manejáveis mediante técnicas hermenêuticas. No segundo caso, a designação original do negócio jurídico perderia relevância em virtude da nova qualificação jurídica que lhe seria atribuída, razão pela qual seus resultados práticos já não se poderiam considerar indiretos. Dessa feita, em vista do atual estado da doutrina, pode-se dizer que o negócio indireto, propriamente dito, reduz-se a uma espécie de negócio atípico.

É de se notar que os autores que se debruçaram sobre o tema do negócio indireto, no passado, recorrentemente descreviam o fenômeno com base em uma incongruência entre o escopo prático e o negócio "adotado" pelas partes. Ora, o que seria o negócio "adotado"? Seria aquele indicado no título ou no preâmbulo do instrumento? Ainda que se pudesse crer, no passado, que a denominação do negócio jurídico, ou mais precisamente, a estipulação literal do tipo, realizada pelas partes, fosse suficiente para a "adoção" de um determinado esquema negocial, deve-se reconhecer que tal entendimento encontra-se superado pela civilística moderna. Como salienta Santoro-Passarelli, os fins ulteriores perseguidos pelas partes do negócio indireto não justificam o caracterização deste como categoria jurídica autônoma ${ }^{429}$. Com inatacável precisão, Bianca sublinha que os referidos fins ulteriores agem sobre a causa concreta, tornando-a incompatível com a causa abstrata eleita pelos contraentes. Esta incompatibilidade, porém, não dura muito tempo pois, como se sabe, a causa concreta orienta a qualificação da relação jurídica, logo, determina o seu enquadramento típico. Por conseguinte, é forçosa a conclusão de que, se o negócio indireto desempenha a função prático-individual de outro negócio jurídico típico, é ao tipo deste que deverá ser reconduzido; haveria, em tais circunstâncias, mera falsa qualificação. Por outro lado, se os resultados práticos buscados pelos particulares fossem absolutamente 
inovadores, o negócio indireto haveria de reputar-se simplesmente atípico, diante da denominação indicada no instrumento ${ }^{430}$.

Como se extrai da descrição precedente, o negócio indireto não é capaz de iludir a fé pública. Não há, aí, engano ou falta de recognoscibilidade. O mesmo, assinale-se, ocorre com o negócio fiduciário ${ }^{431}$. Enquanto o alienante simulado permanece titular do direito de que aparenta dispor, o alienante fiduciário efetivamente perde a condição de proprietário $^{432}$. A eficácia da transmissão efetuada pelo fiduciante é temperada por um componente obrigacional cuja operatividade compõe a causa concreta. O fiduciário é proprietário dos bens que lhe são transferidos; contudo, não pode usar, fruir, e gozar de tais bens, de maneira discricionária. Encontra-se obrigado a exercer tais faculdades segundo diretivas previamente definidas. $\mathrm{O}$ uso, gozo, e fruição, permanecem típicos; o que torna o negócio, como um todo, atípico, é o "pactum fiducice"433.

Vale registrar, por fim, que a despeito da distinção acima traçada, não é impossível que o negócio simulado tenha por fim dissimular o negócio indireto ou o negócio fiduciário. Isto ocorre sempre que os fins ulteriores ou o "pactum fiducice" não se tornem imediatamente recognoscíveis pelo público. Neste particular, Bianca ressalta que "é usual que as partes não qualifiquem abertamente a alienação como fiduciária, mas a mascarem sob o esquema da venda, simulando a prestação do preço"434. Quando isto sucede, a comunidade encontra-se fadada a identificar um negócio jurídico absolutamente típico, sem ter condições de identificar o pacto fiduciário dissimulado. Mutatis mutandis, é possível que o negócio indireto ou o negócio fiduciário sejam simulados, absoluta ou relativamente, bastando que as partes explicitamente formalizem o negócio jurídico sob tais roupagens, mantendo, contudo, em sigilo, a causa concreta de um negócio típico, ou atípico, que não coincida com a causa abstrata (indireta ou fiduciária) submetida à apreciação do público.

${ }^{430}$ C. M. BIANCA, Diritto Civile cit. (nota 63), p. 486.

${ }^{431}$ A. VON TuHR, Der allgemeine Teil des deutschen bürgerlichen Rechts, trad. esp. de T. Ravà, Derecho Civil - Teoria General del Derecho Civil Aleman (1910-1918), v. II - Los Hechos Jurídicos, Madrid, Marcial Pons, 2005, p. 506.

${ }^{432}$ C. M. BIANCA, Diritto Civile cit. (nota 63), p. 713.

${ }^{43}$ Observe-se, porém, que tal atipicidade não surge nos negócios fiduciários legalmente previstos, como, por exemplo, a alienação fiduciária em garantia (tipificada e regulada pelo Decreto-Lei $n^{\circ}$ 911/69); naqueles, a tipicidade é integral.

${ }^{434}$ C. M. BIANCA, Diritto Civile cit. (nota 63 ), p. 713, nota 68. 


\section{CAPÍTULO II - AS MANIFESTAÇÕES DA SIMULAÇÃO}

\section{§ 6. AS CLASSES DE SIMULAÇÃo}

Segundo uma abordagem classificatória, certos padrões são consagrados pela doutrina, relativamente à abrangência e à licitude do procedimento simulatório. Assentamse, deste modo, as bases das distinções entre a simulação absoluta e a relativa; a total e a parcial; a inocente e a nocente.

\section{Absoluta e relativa}

Dintingue-se a simulação absoluta da simulação relativa ${ }^{435}$.

A primeira surge quando a relação jurídica estabelecida entre as partes limita-se à simulação; as partes empregam o negócio simulado com o propósito único de criar uma aparência negocial capaz de sobrepor-se à inércia de suas posições jurídicas.

Se a simulação é relativa, algo diverso sucede. As partes estabelecem, entre si, uma relação jurídica complexa que, além da criação da aparência negocial, possui outro conteúdo. A ilusão negocial, neste contexto, não é um fim em si mesma, mas um instrumento para a ocultação de um regulamento de interesses distinto do aparente. Este último costuma-se denominar negócio dissimulado.

O negócio simulado e o negócio dissimulado não correspondem a relações negociais distintas e antagônicas, mas a faces de uma única relação jurídica. A ilusão negocial reveste o negócio dissimulado, recobre-o como um manto. Não seria correto, pois, pensar que as partes primeiro simulam para depois dissimularem; os contraentes, diversamente, fixam um regulamento de interesses normal o qual se torna dissimulado na medida em que - em momento logicamente ulterior - seja encoberto por uma aparência enganadora.

435 C. A. Mota PInTo, Teoria Geral do Direito Civil, atual. por A. Pinto Monteiro, e P. Mota Pinto, $4^{\mathrm{a}}$ ed., Coimbra, 2005, p. 467-468; M. A. Domingues DE ANDRADE, Teoria Geral... cit. (nota 20), p. 174-175. 


\section{Inocente e nocente}

Não se deve confundir a simulação inocente com a simulação fraudulenta ou nocente $^{436}$. Sempre que a simulação se destine exclusivamente a estabelecer uma aparência negocial, sem que disso decorra qualquer prejuízo a direitos de terceiros ou à aplicação da lei, aquela se diz inocente. Entretanto, se, além de criar o embuste, as partes objetivam lesar direitos de terceiros, ou infringir uma disposição legal imperativa, configura-se a simulação nocente, orientada pelo animus nocendi.

Esta distinção perdeu relevo com a entrada em vigor do Código Civil de 2002, o qual comina, indistintamente, a nulidade ao negócio simulado. Nada obstante, o animus nocendi ainda pode influenciar a verificação de determinados desdobramentos da declaração de nulidade, como, por exemplo, a necessidade de indenizar danos causados a terceiros de boa-fé.

\section{Total e parcial}

É total a simulação que abrange todos os elementos do negócio jurídico; parcial, quando engloba apenas um ou alguns destes elementos. Segundo o critério predominante na doutrina, a extensão da simulação é avaliada por uma perspectiva aritmética: é total quando atinge a soma dos elementos do negócio jurídico, parcial quando deixa de envolver qualquer daqueles. Seguindo este modo de raciocínio, dentre as hipóteses de simulação previstas no $\S 1^{\circ}$ do artigo 167, seriam parciais as indicadas nos incisos I (interposição de pessoa) e III (antedata e pós-data); poderiam ser parciais, ou totais, os casos de simulação reconduzidos à hipótese do inciso II (declaração não verdadeira).

Esta abordagem, no entanto, tem sofrido críticas. Gentili, por exemplo, defende que toda simulação seria parcial, pois, por definição, a relação decorrente da declaração simulada e aquela fundada na contradeclaração deveriam coexistir em um mesmo âmbito $^{437}$. Marani, por outro lado, sustenta que toda simulação seria total, pois as partes

${ }^{436}$ C. A. Mota Pinto, Teoria Geral... cit. (nota 435), p. 467; M. A. Domingues De AndRADE, Teoria Geral... cit. (nota 20), p. 172-174. A expressão "simulação nocente" foi empregada por F. C. PONTES DE MiRANDA (Tratado... cit., nota 220, p. 508-509).

${ }^{437}$ A. GENTILI, Il contratto simulato... cit. (nota 145), p. 531. Tradução livre; no original: "In concreto però una simulazione rigorosamente totale è impossibile, perché per definizione il rapporto emergente dalla 
não conseguiriam simular apenas uma parte do negócio jurídico (e.g. o preço, a data, o local da celebração etc.); ainda que pretendessem criar uma aparência relativa a um elemento em particular, teriam de simular o negócio como um todo ${ }^{438}$.

Mais consistente que o critério aritmético e, talvez, capaz de conciliar-se com as críticas antes expostas, mostra-se o parâmetro estrutural.

Considere-se que a distinção entre simulação total e parcial dependa de um pressuposto lógico consistente numa projeção daquilo que seria o negócio jurídico, se simulação não houvesse. A razão projetaria um modelo de completude negocial; para cada elemento simulado, uma peça do modelo seria retirada. Se alguma peça sobrasse, a simulação seria parcial; se nenhuma peça restasse, seria total. Poderia, contudo, ocorrer uma simulação tal que, embora abrangendo apenas uma das peças do modelo negocial, seria capaz de exclui-lo como um todo (como se um edifício fosse privado de um pilar fundamental, sem o qual não pudesse permanecer de pé). Isto se daria quando a simulação fosse capaz de alterar a identidade histórica do negócio jurídico. Neste caso, o modelo de completude negocial não se tornaria apenas quantitativa, mas qualitativamente diferente do negócio simulado.

Para melhor compreendermos estas ideias, vejamos um exemplo. Se a simulação criasse a aparência de um negócio jurídico celebrado entre "A" e "B", enquanto "A" e "C $C$ " o tivessem efetivamente firmado (artigo 167, $\S 1^{\circ}$, inciso I), aquela não se restringiria a um dos aspectos da relação jurídica. De fato, não existiria qualquer correspondência entre o "negócio aparente" (celebrado entre "A" e "B") e o modelo racional de completude consubstanciado no negócio dissimulado (celebrado entre "A" e "C"). A simulação

dichiarazione simulata e il rapporto emergente dalla controdichiarazione debbono in qualche modo coincidere, cioè essere rapporti esistenti nello stesso ambito".

${ }^{438}$ F. MARANI, La simulazione... cit. (nota 246), p. 33 ss. Esta conclusão decorre da premissa assumida pelo autor segundo a qual o negócio simulado não se destina a atender a qualquer finalidade negocial. O emprego do negócio para escopos não negociais significa, para o autor, a instrumentalização do negócio inteiro ao escopo simulatório, ainda que referida a apenas um dos seus elementos, ou a um dos seus modos de ser qualitativo ou quantitativo (p. 35). Para demonstrar a plausibilidade de suas ideias, o autor refere-se ao caso da simulação de preço, dizendo que "também o ocultamento de uma parte do preço, que pode parecer um caso não facilmente compatível com a tese acima defendida, não é uma simulação (de um elemento) isolado, um elemento do suporte fático em si, mas implica que com relação àquele o negócio inteiro seja utilizado com vistas à obtenção de efeitos estranhos ao momento negocial e, portanto, como ato diverso de um ato de autonomia privada" (p. 35-36). 
desempenharia, em tal cenário, o papel de aparentar, na totalidade, a relação jurídica dissimulada $^{439}$.

Raciocínio semelhante poderia ser desenvolvido quanto à hipótese de simulação de data (artigo 167, $\S 1^{\circ}$, inciso III). A declaração de vontade de 20/01/2010 poderia ser o suporte fático do negócio jurídico firmado entre "A" $\mathrm{e}$ " $\mathrm{B}$ " tendo por objeto o bem "X". A declaração de vontade de 21/01/2010, suporte fático do negócio jurídico firmado entre "A" e "B" tendo por objeto o bem " $X$ ", não se confundiria, de maneira alguma, com aquela produzida no dia anterior. Como se pode notar, a influência da data sobre a identidade do suporte fático tende a ser inevitável, porquanto atinge o âmago de sua historicidade ${ }^{440}$. Dessa feita, o negócio jurídico antedatado ou pós-datado é integralmente simulado, pois, no momento temporal a que ele se reporta, somente pode se concluir ter sido produzido o suporte fático simulado.

Seria possível conceber, ademais, um negócio jurídico que contivesse um conjunto de declarações não verdadeiras (artigo 167, $\S 1^{\circ}$, inciso II), a ponto de a sua própria natureza jurídica (i.e. sua qualificação) tornar-se simulada. Desta hipótese, cuja caracterização não requereria, necessariamente, a simulação de todas as declarações de que se constituísse o suporte fático, decorreria a simulação total. O contrato de compra e venda que dissimulasse um empréstimo, por exemplo, seria totalmente simulado. A simulação parcial ocorreria apenas no caso em que, extirpada a declaração simulada, a estrutura do negócio jurídico (aquele modelo racional a que acima nos referimos) pudesse subsistir, sem alteração da sua singular historicidade. Assim, por exemplo, no caso da simulação de preço, nada obstaria à conclusão de que, reconhecida a artificialidade do valor declarado, o negócio jurídico continuasse sendo uma compra e venda firmada no mesmo momento histórico em que teria surgido a contrapartida ilusória.

O parâmetro estrutural proposto baseia-se no exame da influência que a declaração simulada exerce sobre a consistência da estrutura negocial. Se a declaração simulada refere-se a um elemento cuja exclusão importa a exclusão do suporte fático por inteiro, é cabível identificar, na espécie, a simulação total. Se, diversamente, a estrutura

\footnotetext{
${ }^{439}$ F. MARANI, La simulazione... cit. (nota 246), p. 69.

${ }^{440}$ Antônio Junqueira DE Azevedo, Negócio Jurídico - Existência, Validade e Eficácia, $4^{\mathrm{a}}$ ed., São Paulo, Saraiva, 2010, p. 33-34.
} 
negocial mostra-se apta a sobreviver à exclusão ou substituição da declaração simulada, cuida-se de simulação parcial.

\section{§ 7. AS HIPÓTESES TÍPICAS DE SIMULAÇÃO}

Sob a perspectiva da materialidade do negócio simulado, os limites traçados se submetem ao raciocínio tipológico. Não há, no artigo 167, a descrição de caracteres capazes de elucidar, exaustivamente, as diversas manifestações da simulação. Aliás, como veremos, chega a existir uma sobreposição entre as hipóteses de simulação ventiladas nos incisos do $\S 1^{\circ}$ daquele dispositivo.

\section{O negócio simulado como tipo}

É característico, em uma norma inspirada pela jurisprudência de valoração, o recurso a categorias jurídicas com tessitura semântica aberta e conteúdo programático. $\mathrm{O}$ legislador de 2002, comprometido com a concretude e a operabilidade, elaborou diversos enunciados com estas características, ora valendo-se de tipos, ora prevendo cláusulas gerais. Nesse cenário, cabe indagar qual seria, dentre as técnicas normativas empregadas pelo legislador, a que melhor acomodaria os contornos categoriais do negócio simulado.

A circunstância de o $\S 1^{\circ}$ do artigo 167 trazer um rol de hipóteses em que o fenômeno simulatório deve reputar-se configurado exclui, por um lado, a possibilidade de associá-lo a uma cláusula geral ${ }^{441}$; por outro lado, fá-lo transitar entre o conceito e o tipo.

$\mathrm{O}$ conceito corresponde à categoria ideal cujos traços característicos estão descritos com riqueza de detalhes e precisão. O intérprete lança mão de um silogismo para enquadrar o fato concreto (rectius: o enunciado sobre o fato concreto) no conceito. Tal operação costuma-se designar subsunção. A membrana do tecido normativo constituída pelo conceito é impermeável a elementos estranhos. A norma estruturada com base nesta

441 A distinção entre a "casuística" e as cláusulas gerais é destacada por K. ENGISCH (Einführung in das Juristische Denken, 1983, trad. port. de J. Baptista Machado, Introdução ao Pensamento Jurídico, 10a ed., Lisboa, Calouste Gulbenkian, 2008, p. 230). 
categoria impõe ao intérprete uma solução jurídica unitária ("sim ou não"), com o consequente descarte de configurações alternativas ou mistas ${ }^{442}$.

O chamado conceito-geral abstrato é a unidade estrutural do sistema externo, assim entendido aquele no âmbito do qual as abstrações em que se fundamenta a regulação jurídica articulam-se logicamente. Um tal sistema garante não só a clareza, mas também a segurança, umas vez que, se ele fosse completo, poder-se-ia dar a toda questão jurídica uma resposta justificada por meio de uma simples operação lógica ${ }^{443}$. Quando se aplica um conceito-geral abstrato, a lógica formal substitui a teleologia e a ética jurídica ${ }^{444}$.

Os conceitos-gerais abstratos podem ser determinados ou indeterminados. Raros são os conceitos determinados; restringem-se, em grande medida, àqueles definidos por meio de valores, medidas, unidades: "20 quilômetros", "15 dias", "30 salários mínimos" etc. Por isto, os conceitos encontrados nas normas são predominantemente indeterminados, isto é, dotados de conteúdo e extensão incertos ${ }^{445}$. Os conceitos indeterminados são idênticos aos demais, com a diferença de que a aplicação da norma que os veicula deve ser precedida de uma etapa anterior, qual seja, a determinação conceitual. Esta tarefa, geralmente, incumbe ao juiz, não sendo escassos, contudo, os casos de regulamentação por meio de normas de escalão inferior ${ }^{446}$. Assim, quando, por exemplo, o artigo 944 alude à

${ }^{442}$ É o que K. LARENZ (Metodologia... cit., nota 8, p. 672) permite concluir: "A distinção entre direitos de crédito (relativos) e direitos reais (absolutos) é, sem dúvida, conceptual-abstrata. As notas conceptuais "relativo" e "absoluto" excluem-se reciprocamente. Em contrapartida, se virmos nos 'direitos de crédito' e 'direitos de senhorio' tipos jurídico, serão mais compreensíveis formas intermédias, como o direito de crédito garantido mediante registro prévio e, devido a isso, eficaz também perante terceiros. $\mathrm{O}$ direito garantido continua certamente a ser um direito, especialmente dirigido contra o devedor, a uma prestação que por ele deve ser realizada; não assegura ainda ao credor qualquer senhorio imediato sobre a própria coisa. Mas restringe o poder de disposição do devedor, e assim o seu poder jurídico-real, com eficácia perante terceiros, e garante ao titular do direito, em caso de insolvência do devedor, um privilégio face a outros credores. $\mathrm{O}$ titular do direito pode, por conseguinte, impedir que o terceiro frustre ou prejudique a realização da sua preensão mediante a aquisição de um direito à coisa. Este poder de exclusão foi caracterizado como 'direito negativo de senhorio'. No entanto, não se trata aí de um direito real autónomo em relação ao crédito, mas precisamente de um fortalecimento do direito de crédito mediante um dos traços que, no restante, são próprios apenas de um direito real".

${ }^{443}$ K. LARENZ, Metodologia... cit. (nota 8), p. 622.

${ }^{444}$ K. LARENZ, Metodologia... cit. (nota 8), p. 622-623.

${ }^{445}$ K. ENGISCH, Introdução... cit. (nota 441), p. 208.

${ }^{446} \mathrm{O}$ processo de determinação do conceito é bem exemplificado por Miguel REALE (História... cit., nota 4, p. 41): "São previstas, em suma, as hipóteses, por assim dizer, de 'indeterminação do preceito', cuja aplicação in concreto caberá, em cada caso, à luz das circunstâncias ocorrentes, tal como se dá, por exemplo, quando for indeterminado o prazo de duração do contrato de agência e uma das partes decidir resolvê-lo mediante aviso-prévio de noventa diasm fixando tempo de duração incompatível com a natureza e o vulto do investimento exigido do contratante, cabendo ao juiz decidir sobre sua razoabilidade e o valor devido, em havendo divergência entre as partes, consoante dispõe o art. 720 e seu parágrafo único". 
"extensão do dano" como diretriz para a fixação da indenização, vale-se de um conceito indeterminado cujo referencial semântico não se pode conhecer de antemão, embora seja determinável. Isto significa que, em última instância, surgirá uma única "extensão do dano" a ser considerada relevante, no caso concreto, para o arbitramento da reparação devida.

Já o tipo, "forma de ordenação da realidade em estruturas ou esquemas, representativos do que há de essencial entre os elementos de uma série de fatos ou de entes que nos interessa conhecer" ${ }^{\prime 47}$, é uma categoria fluida que oferece maior margem de flexibilidade ${ }^{448}$. Aflora nas situações em que uma determinada valoração não deve ser tida como excludente de outras, igualmente aplicáveis ao fato concreto mediante um juízo de "mais ou menos". As notas que caracterizam um tipo não precisam estar, todas elas, presentes em dada situação concreta para que esta se possa reconduzir àquele; importa que o dado da experiência corresponda à sua imagem global, isto é, à síntese essencial de suas características $^{449}$. O raciocínio tipológico permite a adoção de valorações graduais e ponderações; varia a intensidade da tipicidade. Os dois principais grupos de tipos são os

${ }^{447}$ M. REALE, Filosofia do Direito cit. (nota 279), p. 57.

${ }^{448}$ Neste contexto, surge a oportunidade para o preenchimento do conteúdo do tipo pela apreciação valorativa do intérprete. O que determina se um fato deve ser considerado típico - coordenado ao tipo - é a junção de (a) a presença das notas características típicas (plano do fenômeno); e (b) o enquadramento sob a perspectiva do vetor valorativo. Este segundo elemento refere-se ao juízo de valor, consubstanciado na norma, com base no qual o legislador teria solucionado o conflito de interesses subjacente à criação daquela. É fundamental, ainda, que tal valoração, refletida no caso concreto, tenha intensidade compatível com a que vem incorporada na norma jurídica; do contrário, essa valoração não passaria de um topo, um simples ponto de vista (Cf. K. LARENZ, Metodologia... cit., nota 8, p. 308).

A categoria dos tipos foi bem desenvolvida por Miguel REALE ( $O$ Direito... cit., nota 91, p. 162-164), por meio de sua teoria dos modelos jurídicos. Partindo do exame das estruturas sociais, o autor descreve os modelos jurídicos como "estruturação volitiva do sentido normativo dos fatos sociais". Os modelos jurídicos integram fatos e valores mediante normas postas em vigor por meio de um ato de escolha e de prescrição. Por sua vez, os modelos dogmáticos decorrem da Ciência do Direito, possuindo "estruturas teórico compreensivas do significado dos modelos jurídicos e de suas condições de vigência e de eficácia na sistemática do ordenamento jurídico". Os modelos não se diferenciam completamente dos tipos; isto, pois implicam uma "qualificação tipológica de comportamentos futuros, a que ligam determinadas conseqüências". A tipificação normativa não "obra cerebrina ou imaginosa, fruto de um querer arbitrário, mas sim o resultado de uma análise positiva de dados empíricos, análise essa que culmina sempre num ato decisório, na eleição de uma dentre duas ou mais soluções possíveis". Este ato decisório decorre de um embate dialético de forças efetivas, de natureza axiológica e fática, em razão da qual o fator axiológico converte-se em fator teleológico. "Nesse sentido particular será lícito afirmar que o modêlo jurídico é de natureza teleológica" pois o "fim não é senão a veste racional do valor".

${ }^{449}$ K. LAREnZ, Metodologia... cit. (nota 8) , p. 307: "São com frequência passíveis de gradação e até certo ponto comutáveis entre si. Consideradas isoladamente, só têm o significado de sinais ou indícios. O que é decisivo é, em cada caso, a sua conexão com a realidade concreta. Se uma determinada situação de facto se pode ou não ordenar ao tipo é algo que não pode, neste termos, ser decidido consoante contenha ou não todas as notas características tidas como imprescindíveis. Trata-se antes de se saber se as notas características tidas como 'típicas' estão presentes em tamanho grau e intensidade que a situação de facto 'no seu todo' corresponda à imagem fenoménica do tipo. O tipo não se define, descreve-se". 
dos tipos reais normativos e o dos tipos jurídico-estruturais. Enquanto os primeiros expressam a "imagem fenomênica" de fatos empíricos, os segundos prestam-se a caracterizar espécies de relações jurídicas ${ }^{450}$, tais como os contratos e as diversas espécies de direitos e deveres definidos em lei.

Ao examinar a dialética estabelecida entre conceitos e tipos ${ }^{451}$, Larenz admite que eles se mesclam no âmbito da experiência jusprivatística. A passagem da jurisprudência dos conceitos para a jurisprudência de valoração corresponde à transição do raciocínio subsuntivo (próprio dos conceitos) para o raciocínio tipológico ${ }^{452}$. Em razão disso, existe uma natural tendência a se associar as espécies de negócios simulado a tipos. Vejamos se esta intuição ultima-se confirmada.

Observe-se, em primeiro lugar, os suporte fáticos descritos nos incisos do $\S 1^{\circ}$ do artigo 167 remetem à imagem de relações jurídicas, muito semelhantemente ao modo como o fazem os dispositivos que definem os tipos contratuais. As espécies de negócio

${ }^{450}$ K. LARENZ, Metodologia... cit. (nota 8), p. 662.

${ }^{451}$ A distinção entre conceitos e tipos foi sumarizada com precisão por C. B. N. CiOfFI (Classe... cit., nota 62, p. 19-20): (a) os conceitos consubstanciam a somatória dos elementos que o compõem; os tipos configuram-se como quadros dotados de sentido total e unitário; (b) os conceitos são fechados e abstratos, porquanto definidos com rigidez e taxatividade; os tipos são abertos, pois referem-se a um aglomerado de notas em sua expressão concreta; (c) os confins dos conceitos são firmemente estabelecidos; os limites dos tipos são elásticos; e (d) os fatos concretos podem subsumir-se integralmente a conceitos, ou, alternativamente, não se subsumir; no caso dos tipos, a recondução pode ser total ou parcial, mais ou menos intensa; e

a aplicação de um conceito requer, quanto à situação de fato, a presença de todos os seus elementos; a caracterização do tipo requer, quanto à situação de fato, um certo grau de semelhança para com a síntese global de suas notas características.

Em sentido semelhante, A. KAUFMANn (Rechtsphilosophie, 1997, trad. port. de A. U. Cortês, Filosofia do Direito, 4a ed., Lisboa, Fundação Calouste Gulbenkian, 2010, p. 188) sustenta: “O tipo constitui o meio termo entre o geral e o particular, é comparativamente um concreto, um universale in re. Assim, o tipo distingue-se do conceito geral abstracto, que através dum número limitado de características isoladas 'define' (delimita) e, por isso, é - segundo Kant - contrário à intuição sensível. O tipo, na sua maior proximidade à realidade, à aparência, e à objectividade, pelo contrário, não é definível, mas apenas 'explicitável', ele tem na verdade um núcleo fixo, mas não fronteiras fixas, de tal modo que pode faltar um ou outro dos 'traços' característicos de um tipo sem que seja por isso necessário pôr em causa a tipicidade de uma determinada situação de facto. O conceito (aqui sempre entendido como conceito geral abstracto, como 'conceito género', 'conceito classificatório') é fechado; o tipo é aberto. O conceito conhece apenas o rígido 'sim ou não', o conceito separa, o pensamento conceptual é um 'pensamento que separa'. O tipo (o 'conceito ordenador', o 'conceito funcional', 'conceito de sentido') pelo contrário conforma-se com o 'mais ou menos' da realidade multifacetada e liga tornando conscientes as conexões de sentido, nele o geral é compreendido de forma sensível, 'integral'. Não se pode 'subsumir'sob o tipo como se faz sob o conceito, a ele apenas se pode, em maior ou menor medida, 'assimilar', 'fazer corresponder' uma concreta situação da vida. No tipo já não estamos pois perante um pensamento lógico-formal exacto. E aqui chegamos à Fuzzy Logic, que se baseia sobre esta distinção entre conceitos determinados e conceitos indeterminados e se move nas zonas cinzentas das transições graduais, do ainda-não-e-já-não".

${ }^{452}$ K. LARENZ, Metodologia... cit. (nota 8), p. 300 ss. 
simulado são definidas per genus et differentiam ${ }^{453}$, assim como sucede, por exemplo, com a doação. A semelhança que se pode verificar entre as formas proposicionais do $\S 1^{\circ}$ do artigo 167 e do artigo 538, por exemplo, é bastante eloquente. Por meio de uma simples paráfrase, incapaz de promover qualquer modificação de conteúdo, poder-se-ia redigir a primeira das citadas normas como segue: “considera-se simulado o negócio que: I aparenta conferir ou transmitir direitos a pessoas diversas daquelas às quais realmente se conferem, ou transmitem; II - contém declaração, confissão, condição ou cláusula não verdadeira; III - conste de instrumentos particulares antedatado, ou pós-datado; por seu turno, o artigo 538 dispõe: "[c]onsidera-se doação o contrato em que uma pessoa, por liberalidade, transfere do seu patrimônio bens ou vantagens para o de outra”.

Em segundo lugar, note-se que a circunstância de as espécies de negócio simulado corresponderem a relações jurídicas concilia-se com as conclusões a que chegamos linhas acima a respeito da associação entre o negócio simulado e a autonomia privada. Sendo aquele manifestação desta, não há como negar que as roupagens que a simulação pode assumir consistem em diferentes formatações de regulamentos de interesses.

E, em terceiro lugar, veja-se que um obstáculo intransponível opõe-se à conclusão de que os incisos do $\S 167$ definiriam conceitos, ainda que indeterminados: a amplitude da linguagem. O legislador valeu-se de termos amplos o suficiente para abranger variadas condutas. O inciso I, por exemplo, pode referir-se à interposição fictícia, à titulação de bem sob nome alheio, e à contratação sob nome falso, dentre outras hipóteses que a experiência pode revelar serem possíveis; o inciso II, por seu turno, empresa termos redundantes, como confissão e cláusula, que não deixam de ser exemplares de declaração; o inciso III, por fim,

\footnotetext{
${ }^{453} \mathrm{O}$ método mais comumente empregado para a definição legislativa de figuras e institutos jurídicos é o per genus et differentiam. Indica-se o nome de uma classe superior, e, na sequência, nomes de subclasses menos amplas, nas quais são enquadrados determinados objetos. O confronto entre a subclasse e a classe superior e a comparação entre as diversas subclasses permite identificar semelhanças e diferenças, e, deste modo, atribuir identidade a cada um dos objetos definidos. Há, como se vê, uma relação estreita entre a definição per genus et differentiam e a classificação. Por meio desta operação lógica, diversos objetos ou classes de objetos são agrupados em função de critérios de afinidade. O nome de uma subclasse pode ser obtido mediante a união do nome de uma classe superior (o genus) com a indicação das características que distinguem tal subclasse (ou species). A definição per genus et differentiam reflete, ao nível do nome, uma classificação dos objetos aos quais se refere o termo definido. Exemplos de definições per genus et differentiam constantes do Código Civil encontram-se nos dispositivos que descrevem os suportes fáticos dos diversos contratos típicos, tais como os artigos 481, 534, 538, 565, 579 etc. Cf., a propósito, A. BELVEDERE, Il problema delle definizione... cit. (nota 91), p. 73-74; 97-98; 169 ss.
} 
embora aluda à antedata e à pós-data, não é aplicável, como veremos, sempre que tais hipóteses sejam verificadas.

Em vista destas constatações, é válido atestar que o negócio simulado constitui um tipo jurídico-estrutural, cuja imagem global é constituída pela união dos três subtipos descritos nos incisos do $\S 1^{\circ}$ do artigo 167. Sobre a categoria dos tipos jurídico-estruturais, costuma-se afirmar que: apresentam importante valor cognoscitivo em ordem ao descobrimento de conexões jurídicas de sentido; derivam do tráfico jurídico, vale dizer, da experiência do direito; o legislador não os inventou, mas descobriu-os, porquanto os encontrou previamente na realidade da vida jurídica ${ }^{454}$. Tudo isto, sem hesitação, pode ser dito relativamente às espécies descritas nos incisos do $\S 1^{\circ}$ do artigo 167.

Nessa toada, o intérprete é levado a adentrar os rincões do sistema interno, cuja missão é a de tornar visível a unidade valorativa do ordenamento jurídico ${ }^{455}$. Isto, aliás, vem a calhar no curso do presente estudo, porquanto a simulação seja uma das categorias jurídicas mais sensíveis às variações axiológicas ocorridas no ambiente social. "Do ponto de vista político-legislativo o tratamento desta anormalidade deve remontar ao modo de ver e de sentir corrente e às condições dominantes na consciência social de um dado ambiente histórico: e a tais concepções é necessário reportar-se para ver se e até que ponto um negócio deva ser considerado empregado a um fim não seu, para se caracterizar como simulado (...) ${ }^{, 456}$.

Contra o entendimento acima defendido, poder-se-ia objetar que o raciocínio tipológico seria inadequado para guiar a aplicação de normas que cominam a nulidade ao negócio jurídico. Arguir-se-ia, diante do papel ordenante que a nulidade desempenha no sistema, que o juízo quanto à sua caracterização deveria ser binário: ou bem o negócio jurídico é nulo, ou bem é válido. Tal objeção perderia vigor, contudo, na medida em que se levasse em conta que a abordagem metodológica aqui defendida, a despeito de mostrar-se mais fluida e flexível, não prescinde de um juízo binário.

\footnotetext{
${ }^{454}$ K. LARENZ, Metodologia ... cit. (nota 8), p. 663-664.

${ }^{455}$ K. LARENZ, Metodologia... cit. (nota 8), nota, p. 623.

${ }^{456}$ E. BETTI, Teoria generale... cit. (nota 53), p. 394. Tradução livre; no original: "Dal punto di vista politicolegislativo il trattamento di questa anormalità deve rifarsi al modo di vedere e di sentire corrente e alle condizioni dominanti nella coscienza sociale di un dato ambiente storico: e a tali concezioni bisogna far capo per vedere se e fino a qual punto un negozio dia da considerare adibito ad un fine non suo, e da caratterizzare simulato (...)".
} 
É pertinente acentuar, neste passo, a distinção que se estabelece entre recondução (“Zuordnung") e ordenação ("Einordnung") ${ }^{457}$. A recondução ao tipo, posto que fundada na "imagem global" do enunciado normativo, dá-se mediante um júzo binário (i.e. sim ou não), em razão do qual se define a sujeição do fenômeno a um modelo regulativo estipulado em lei. Este juízo, de caráter análogo ao subsuntivo-conceitual, é denominado juizo secundário. Quando o juízo secundário resulta positivo, cumpre proceder à ordenação ao tipo, de modo a definir a intensidade com a qual há de incidir o modelo regulativo legalmente prescrito. Desta atividade surge o juizo primário, o qual identifica o grau de aderência (i.e. mais ou menos) do fato concreto às notas distintivas da categoria abstrata ${ }^{458}$.

Nesse estado de coisas, fatos concretos reconduzidos ao tipo "negócio simulado" (i.e. juízo secundário $=\operatorname{sim}$ ) podem-se ordenar, quanto àqueles, de diversas formas, conforme a simulação seja total ou parcial, inocente ou nocente, absoluta ou relativa etc. Não há, portanto, o risco de caracterizar-se um negócio jurídico "mais ou menos" nulo, pois a atipicidade implicaria, se fosse o caso, a "não simulação", logo, a ausência do pressuposto de nulidade previsto na norma.

Insta registrar, por fim, que a constatação da natureza típica do negócio simulado torna descabida qualquer elucubração em torno do caráter taxativo ou exemplificativo do rol de hipóteses constante do $\S 1^{\circ}$ do artigo 167. Tal discussão costuma ser suscitada com relação a definições denotativas ${ }^{459}$; todavia, como vimos acima ${ }^{460}$, o artigo 167 não contém uma definição dessa natureza. Cogitar-se do jaez exemplificativo dos subtipos do negócio simulado seria, com efeito, tão despropositado quanto pretender que ver na enumeração de contratos típicos presente no código civil uma lista em aberto. É claro que os particulares podem celebrar contratos atípicos (artigo 425); mas a atipicidade, conquanto admitida, se respeitadas as diretrizes informadoras da ordem jusprivatística, não implica o surgimento de novos tipos legais.

\footnotetext{
${ }^{457}$ P. PAis De VAsconcelos, Contratos Atípicos cit. (nota 353), p. 184. A palavra alemã Zuordnung é, geralmente, traduzida para o português como coordenação. A tradução não é feliz, pois deixa de transmitir a ideia, ínsita ao vocábulo, de recondução de algo a uma classe, conjunto ou pluralidade.

${ }^{458}$ P. PAis de VASCONCElOS, Contratos Atípicos cit. (nota 353), p. 184-187.

${ }^{459}$ A. BELVEDERE, Il problema delle definizione... cit. (nota 91), p. 93-94.

${ }^{460}$ V. tópico 7.
} 
Enfim, visto que o $\S 1^{\circ}$ do artigo 167 descreve tipos jurídico-estruturais, cumpre examinar quais são as notas características de cada um deles. Vejamos, em linha de partida, quais são os contornos típicos da denominada simulação subjetiva.

\section{Simulação subjetiva}

Segundo o inciso I do $\S 1^{\circ}$ do artigo 167, há simulação quando os negócios jurídicos aparentam "conferir ou transmitir direitos a pessoas diversas daquelas às quais realmente se conferem, ou transmitem". A abordagem tradicional ao tema funda-se na diferenciação entre a interposição real e interposição fictícia, a qual pode ser sintetizada nos seguintes termos ${ }^{461}$ :

(a) na interposição real, é necessário o efetivo concurso e três pessoas, o interponente, o interposto e o terceiro contratante; na interposição fictícia, basta a intervenção do interponente e do terceiro contratante, uma vez que o interposto limita-se a ceder o seu nome ou a atuar de maneira puramente mecânica, reproduzindo as palavras da declaração emitida pelo interponente, tal qual um núncio;

(b) na interposição real, não há acordo simulatório, mas um acordo real entre o interponente e o interposto, o qual pode ou não, indiferentemente ${ }^{462}$, ser de conhecimento do terceiro contratante; na interposição fictícia, existe um acordo simulatório trilateral, firmado entre o interponente, o interposto; e

${ }^{461}$ F. Ferrara, A simulação... cit. (nota 20), p. 321-322. Uma classificação dos casos de interposição é proposta por F. GAlgano, (Della simulazione in AAVv., Commentario del Codice Civile Scialoja-BrancaA cura di Francesco Galgano, Libro Quarto - Delle obbligazioni - Art. 1421, Bologna - Roma, Zanichelli Del Foro Italiano, 1998, p. 9) nos seguintes moldes: (a) interposição fictícia estática: o indivíduo aliena o próprio bem por meio de um contrato absolutamente simulado, de modo a celar a efetividade titularidade daquele;

(b) interposição fictícia dinâmica: o sujeito adquire um bem sob nome alheio, ocultando, assim, a aquisição aos olhos de terceiros; (c) interposição (real) fiduciária estática: o fiduciário, que já e proprietário do bem, obriga-se a administrá-lo conforme as instruções do fiduciante, e a transferi-lo, mediante uma ordem deste;

(d) interposição (real) fiduciária dinâmica: o titular do bem o transfere ao fiduciário para que o administre, com observância às suas instruções, e o restitua, em momento futuro; e (e) interposição (real) decorrente de mandato sem representação: o interposto adquire o bem em seu próprio nome, porém, agindo no interesse e por conta e ordem do interponente.

${ }^{462}$ Ressaltam este aspecto: C. A. Mota Pinto, Teoria Geral... cit. (nota 435), p. 470; F. MeSSINEO, Il contratto in genere cit. (nota 88), p. 541. 
(c) na interposição real, o interposto torna-se titular dos direitos e obrigações derivados do negócio em que intervém, assim como a obrigação (fiduciária ou mandatária) de transmitir os benefícios e os riscos assumidos ao interponente; na interposição fictícia, a esfera jurídica do interposto mantémse completamente alheia aos efeitos do negócio jurídico celebrado entre o interponente e o terceiro contratante.

$\mathrm{Na}$ interposição real, uma pessoa contrataria com outra apenas para que esta, depois, transferisse o bem ou direito ao destinatário efetivo; aqui, não haveria divergência entre a vontade e a declaração, pois todos os atos dão-se conforme definido pelas partes. $\mathrm{O}$ sujeito interposto atuaria em nome próprio, embora no interesse e por conta e ordem de outrem. Um exemplo pode ilustrar o que sucederia nesta instância: "A" está interessado na compra de certos bens (e.g. um lote de ações, uma quota social ou uma obra de arte) de "B", mas sabendo que este não os venderia diretamente ou só os venderia em condições muito onerosas, pede a "C" que os compre de "B", e depois os revenda a ele. Em tal caso, dir-se-ia que não há simulação, mas antes um mandato sem representação ${ }^{463}$.

No mais das vezes, a ação do interposto fictício é débil, limitando-se à aposição do nome do interposto no documento que formaliza a operação negocial ("presta-nome" ou "testa de ferro") ${ }^{464}$. Em outras situações, o interposto oferece cooperação material à simulação, embora não chegue a assumir, definitivamente, quaisquer direitos ou obrigações. Assuma-se, como exemplo, que “A” pretenda doar um prédio a "B", mas não quer que o negócio torne-se aparente; finge, então, doar a "C", para este, posteriormente, o doe a "B". Em tais circunstâncias, surgiria um conluio entre os três partícipes da operação $^{465}$.

A despeito da solidez das ideias acima expostas, não se tarda a notar que o fundamento da distinção entre a interposição real e a interposição fictícia não é dos mais $\operatorname{claros}^{466}$. Curiosamente, a interposição real enganaria não apenas o público, como, também, o próprio terceiro contratante. Do ponto de vista da criação da aparência e da

\footnotetext{
${ }^{463}$ C. A. Mota Pinto, Teoria Geral... cit. (nota 435), p. 469-470.

${ }^{464}$ F. FERrara, A simulação... cit. (nota 20), p. 314.

${ }^{465}$ C. A. Mota PinTo, Teoria Geral... cit. (nota 435), 469.

${ }^{466}$ F. ANELLI, Simulazione e interposizione cit. (nota 132), p. 637; G. MiRABELLI, Dei contratti in generale, $2^{\mathrm{a}}$ ed., Torino, UTET, 1967, p. 411.
} 
frustração da confiança, portanto, a interposição real seria mais grave que a interposição fictícia $^{467}$. Há, ainda, divergências sobre a imprescindibilidade do engano do terceiro contratante no caso da interposição real. Hörster, por exemplo, contrariando o entendimento majoritário, aduz que, na interposição real, o interposto deveria agir por conta de outrem, mas sem que a identidade do comitente ou fiduciante se tornasse recognoscível pelo terceiro contraente. $\mathrm{O}$ autor ressalta, ainda, que se o terceiro contratante soubesse que o interposto estaria a agir por conta e ordem de terceiro já não haveria interposição, mas representação ${ }^{468}$.

Nesse contexto, uma revisão dos termos com base nos quais se tem definido a interposição fictícia mostra-se necessária. Deve-se assinalar, a princípio, que a doutrina mais recente tem se insurgido contra a utilidade da distinção entre interposição real e interposição fictícia. Dubois-de Luzy, por exemplo, aduz que esta dicotomia seria impertinente $^{469}$. A dificuldade imposta pelo tema, ademais, levou diversos autores italianos a pretender excluir a interposição do terreno próprio da simulação ${ }^{470}$.

De nossa parte, não temos dificuldade em admitir que a interposição fictícia reconduz-se ao tipo descrito no inciso I do $\S 1^{\circ}$ do artigo 167. Cumpre assinalar, porém, que o referido tipo não se esgota na interposição fictícia, a qual, a bem se ver, sequer é mencionada explicitamente. A norma estatui que haverá simulação nos negócios jurídicos

${ }^{467}$ F. ANELLI, Simulazione e interposizione cit. (nota 132), p. 637.

${ }^{468}$ H. E. HÖRSTER, A parte Geral... cit. (nota 404), p. 541.

469 A. Dubois-DE LuZY, Interposition de personne, Paris, LGDJ, 2010, p. 47. Segundo a autora, tal diferenciação fora acolhida por uma doutrina que já ultrapassada, mas nunca contara com a adesão da jurisprudência francesa; em tais circunstâncias, “(...) [seria] certamente preferível reservar o termo ‘interposição de pessoa' para designar uma simulação por pessoa interposta”. Tradução livre; no original: “(...) il est certainement préférable de réserver les termes interposition de personne pour désigner une simulation par personne interposée". Em sua opinião, o agrupamento de situações geometricamente próximas, embora distintas, como a doação com encargo, a gestão de negócios, a estipulação em favor de terceiro, e o mandato sem representação, sob a alcunha da interposição, não traria nada além de confusão.

${ }^{470} \mathrm{Na}$ Itália, defende-se que a interposição fictícia seria uma simulação atípica. Segundo narra U. MAJELLO (Il contratto simulato... cit., nota 105, p. 651-652), diante da redação do artigo 1414 do Código Civil, a qual estabelece que "se le parti hano voluto concludere un contratto diverso da quello aparente, fa effetto tra esse il contratto dissimulato", no caso de simulação subjetiva, o negócio dissimulado não seria eficaz entre as partes do negócio simulado; seria, pois, impossível considerar a interposição de sujeito uma hipótese de simulação relativa. A diferença entre a interposição de pessoa e a simulação relativa residiria na autonomia estrutural do chamado "contrato interpositório". Surgiria, no caso da interposição de pessoa - ao lado do negócio simulado, e coligado a ele - um negócio jurídico, celebrado entre as partes do negócio simulado e o sujeito interposto (o autor diz que este contrato seria celebrado com o "interponente"; mas o interponente é já uma das partes do negócio simulado, precisamente, que dispõe do bem o direito), cujo objeto seria o estabelecimento da interposição. $\mathrm{O}$ autor, porém, argúi que conquanto não seja admissível afirmar que a interposição de pessoa cederia espaço à simulação relativa, não seria o caso de excluí-la, por completo, do âmbito da simulação; esta seria uma hipótese atípica de simulação. 
quando "aparentarem conferir ou transmitir direitos a pessoas diversas daquelas às quais realmente se conferem, ou transmitem". Em vista disso, a simulação subjetiva afigura-se uma maquinação, destinada a ocultar a imputação subjetiva dos efeitos derivados do negócio jurídico ${ }^{471}$, que abrange a interposição fictícia, mas a esta não se restringe.

A interposição fictícia configura caso típico de simulação relativa ${ }^{472}$; por detrás da ilusão negocial, estabelece-se uma relação jurídica plena, embora com sujeitos distintos dos que figuram, aparentemente, como contraentes. Trata-se de um mecanismo que permite aos figurantes, com o auxílio do interposto, ocultar a imputabilidade subjetiva dos efeitos de uma relação jurídica efetiva ${ }^{473}$. A estrutura da interposição fictícia pode ser ilustrada pelo seguinte esquema ${ }^{474}$ :

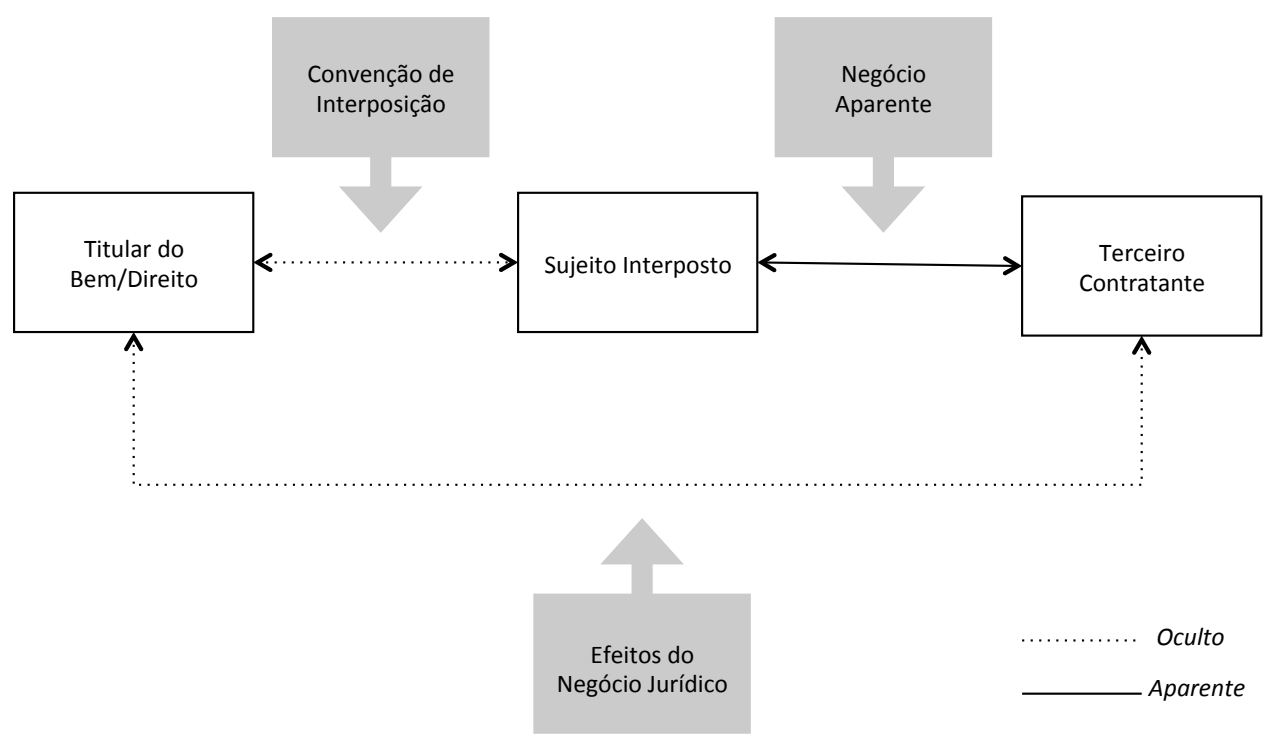

Evidentemente, a interposição fictícia também pode ter por objetivo a ocultação do adquirente, não do alienante. Isto geralmente ocorre quanto a negócios gratuitos, cuja demonstração esquemática seria a seguinte (considerando-se a doação de bens móveis) ${ }^{475}$ :

${ }^{471}$ G. FURGIUELE, Della simulazione... cit. (nota 144), 130.

${ }^{472}$ A impossibilidade da simulação subjetiva absoluta foi bem notada por F. MESSINEO (Il contratto in genere cit., nota 88, p. 533, nota 301).

${ }^{473}$ G. FURGIUELE, Della simulazione... cit. (nota 144), 125.

${ }^{474}$ A. DUBOIS-DE LUZY, Interposition de personne cit. (nota 469), p. 25.

${ }^{475}$ A. DuBOIS-DE LuZY, Interposition de personne cit. (nota 469), p. 27. 


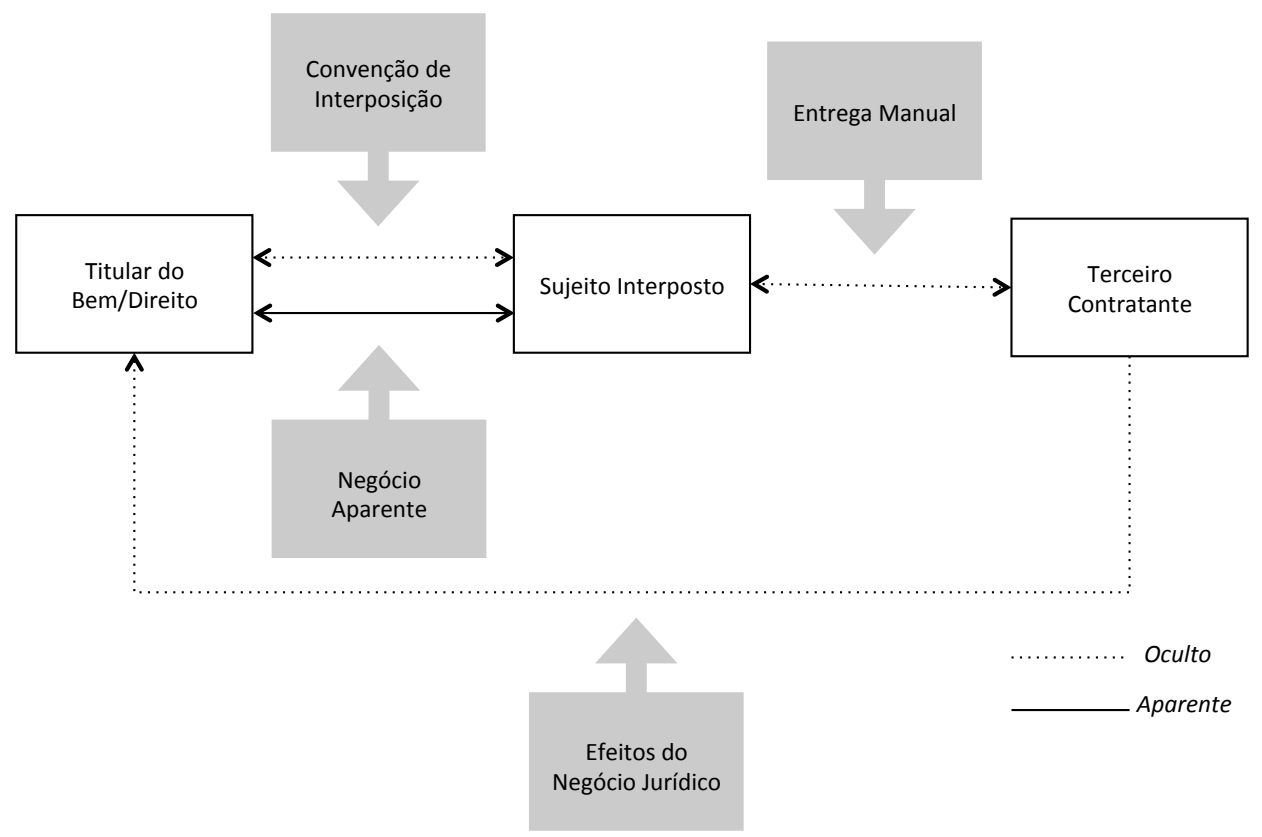

Para melhor captarmos a essência da simulação subjetiva, importa precisar a natureza da relação interna estabelecida entre o interponente e o interposto. O pacto interno firmado entre os figurantes colore a qualificação e a disciplina aplicáveis à interposição de pessoa; esta pressupõe uma relação de controle quanto ao exercício (per interpositum) de poderes dispositivos, a qual vem estabelecida pelo pacto interno entre o interposto e o dominus $^{476}$. Quanto à natureza do acordo de interposição, não há unanimidade. Há quem diga que este consistiria em um mandato com representação ${ }^{477}$ dissimulado. Para outros, o interposto agiria sob a égide de um mandato sem representação ${ }^{478}$ dissimulado. Há, ainda, os que entendem que as duas formatações seriam igualmente possíveis ${ }^{479}$.

${ }^{476}$ F. ANELLI, Simulazione e interposizione cit. (nota 132), p. 641.

${ }^{477}$ F. DeBOISSY, La simulation... cit. (nota 121), p. 231. Para A. DUBOIS-DE LUZY (Interposition de personne cit., nota 469, p. 93-94), o mandato outorgado ao interposto teria um objeto complexo. Por um lado, ele implica a realização de um ato oculto diretamente imputável ao interponente; por outro, também incumbe ao interposto manifestar um interesse pessoal quanto ao bem o direito objeto do contrato. Desse modo, apenas se a interposição de pessoa permanecesse oculta haveria, propriamente, a representação do interponente pelo interposto; porém, na medida em que a interposição de pessoa fosse desvelada, o mandato em questão mostraria toda a sua abrangência, tornando-se evidente que o interposto seria, a um só tempo, parte e terceiro quanto ao negócio jurídico. Nessa esteira, o mandato interpositório seria sui generis; não seria nem um madato com representação, nem um mandato com representação. Este entendimento, contudo, não leva em conta um dado elementar do procedimento simulatório: o acordo simulatório, entendido, conforme expusemos anteriormente, como o conteúdo convencional do ato, direcionado à criação da ilusão negocial. Desse modo, é evidente que o mandato interpositório é sui generis, pois a ele se adiciona o acordo simulatório. Por meio de tal programa de interesses, o interposto se obriga a realizar o ato em nome do interponente, e a manter em segredo a sua condição de representante. Não há como negar, contudo, que a representação existe, $a b$ initio, embora permaneça oculta.

${ }^{478}$ G. A. NuTI, La simulazione... cit. (nota 173), p. 251 ss. Para o autor, a simulação subjetiva implicaria o mascaramento da imputação jurídica; haveria a dissimulação de um mandato, mas não da procuração. Isto 
A nosso juízo, a melhor interpretação, dentre as referidas, é a que vislumbra, na interposição fictícia, a dissimulação de um mandato com representação. Nesse sentido, Deboissy explica que a tese segundo a qual haveria, entre interponente e interposto, uma relação de mandato sem representação, descuida, absolutamente, do vínculo que se estabelece entre a interposição fictícia e a teoria da simulação. Estruturalmente, a simulação é o fruto de uma divergência entre a aparência e a realidade. Partindo-se desta premissa, há de se concluir que, no plano da aparência, o interposto age em nome próprio, e em prol de seus interesses; no plano da realidade, contudo, aquele age como verdadeiro representante do interponente, pois os efeitos do negócio jurídico são produzidos diretamente na esfera de direitos deste. A representação existe ab initio, mas é oculta. Apenas a qualificação do mandato com representação mostra-se capaz de captar integralmente a especificidade da interposição fictícia, que combina a representação com a dissimulação ${ }^{480}$.

Ante o exposto, o diagnóstico da simulação subjetiva deve fundar-se sobre o exame das obrigações assumidas pelo interposto ${ }^{481}$. Na interposição real, o interposto assume, diretamente, a obrigação de transferir o bem ou direito ao terceiro ou ao interponente; a condição lógica desta atuação é a de que o interposto possua interesse próprio na aquisição, como o comitente; ele assume os riscos relativos à operação, mas também colhe os seus frutos, geralmente consistentes na remuneração pelos atos realizados por conta e ordem do interponente. Em contrapartida, na interposição fíctícia, as obrigações são assumidas exclusivamente pelo interponente (alienante ou adquirente dissimulado). Tal explicação, porém, não é capaz de superar a dificuldade de detecção da ilusão negocial, pois a simulação, nesta sede, incide exatamente sobre o arranjo obrigacional instituído pelos contraentes. Dessa feita, cumpre avaliar não apenas a direção

ocorreria porque o interposto produziria, por si, o fato histórico da declaração, que não seria a declaração de uma vontade alheia, mas a sua própria vontade. Por conseguinte, "a chamada interposição fictícia não é, pois, a dissimulação de uma procuração (que não foi conferida), mas o adimplemento de um mandato para declarar efetivamente uma vontade de contrair, dissimulando-se, ademais, que tal declaração é juridicamente imputável ao próprio interponente, no seu próprio nome e interesse, enquanto, com contrapartida, ao interposto não é juridicamente imputável nem a vontade de declarar, nem a vontade declarada, mas é apenas imputável o fato histórico de ter querido a própria declaração". A simulação subjetiva, nestes termos, fundarse-ia sobre uma dupla imputação aparente, seja da vontade de declarar, quanto do conteúdo da declaração, o que seria possível mediante a criação de um fato histórico destinado a ser mal qualificado pelo público.

${ }^{479}$ F. MESSINEO, Il contratto in genere cit. (nota 88), p. 535-536.

${ }^{480}$ F. DEBOISSY, La simulation... cit. (nota 121), p. 231

${ }^{481}$ U. MAJELLO, Il contratto simulato... cit. cit. (nota 105), p. 651. 
das obrigações assumidas pelo interposto, como também o modo como a posição jurídica que este ocupa vem identificada pelo terceiro contratante e pelo público.

Se o interponente outorga, ao interposto, um mandato com representação, e este é reconhecido por todos (terceiro contratante e demais terceiros), não há simulação, mas representação direta ${ }^{482}$. Se, no entanto, apenas os contratantes (adquirente e alienante) e o interposto sabem do mandato, há interposição fictícia. Vê-se, assim, como se forma o acordo trilateral na interposição fictícia: o interposto somente pode agir como representante oculto se esta condição for conhecida pelo terceiro contratante; do contrário, ele não estaria agindo como representante oculto, mas efetivamente contrataria em nome próprio. Neste caso, o negócio jurídico aparentaria "conferir ou transmitir direitos a pessoas diversas daquelas às quais realmente se conferem, ou transmitem".

A análise torna-se mais complicada quando o interponente outorga ao interposto um mandato sem representação. Se esta relação jurídica fosse recognoscível por todos, caracteriza-se a representação indireta. Agora, se mandato sem representação fosse dissimulado (isto é, conhecido apenas pelo interponente e pelo interposto), o negócio firmado entre o terceiro contratante e o interposto não poderia dizer-se simulado; logo, não haveria de reputar-se nulo. A interposição seria real, pois o interponente efetivamente assumiria direitos e obrigações. Assim sendo, caberia combater eventuais ilegalidades verificadas por meio de outras técnicas, como a da fraude à lei.

Nesse cenário, as distinções relevantes, no que tange à simulação subjetiva, são as seguintes:

(a) representação direta: o interposto age, às claras, em nome do interponente;

(b) representação indireta: o interposto age às claras como mandatário do interponente, mas sem poderes de representação; não se engana nem o terceiro contratante, nem o público;

(c) interposição real: o interposto age, veladamente, como mandatário do interponente, mas sem poderes de representação; enganam-se o terceiro interessado e o público; e

${ }^{482}$ F. DeBOISSY, La simulation... cit. (nota 121), p. 232. 
(d) interposição fictícia: o interposto atua como mandatário e representante do interponente; o terceiro contratante sabe disso, mas o público não.

A esta altura do discurso, cabe examinar os fundamentos com base nos quais haveria de ocorrer o diagnóstico da interposição fictícia. É que, na vida de relação, há situações limítrofes que impõem, ao jurista, notável dificuldade hermenêutica, em face das quais os esquemas abstratos acima esboçados podem mostrar-se insuficientes. Consideremse, para efeito de ulteriores investigações, as seguintes hipóteses:

(a) "A" e "B" celebram contrato de compra e venda, porém, "A" subscreve a escritura privada sob o nome de "C";

(b) “A" pede a "B" que compre bem de "C", provendo os recursos necessários ao pagamento do preço, diretamente a "C", ou mediante doação a "B"; e

(c) celebram-se, sucessivamente, dois contratos de compra e venda, um entre " $\mathrm{A}$ " e "B", e outro entre "B" e "C", mas as partes decidem documentar apenas uma transação, entre "A" e "C".

Na situação da letra (a), vislumbra-se uma contratação sob nome falso. A doutrina tem entendido que não haveria simulação neste caso ${ }^{483}$. Nada obstante, não se nos afigura sustentável a negativa de que, em tal hipótese, o negócio jurídico aparenta "conferir ou transmitir direitos a pessoas diversas daquelas às quais realmente se conferem, ou transmitem". Haveria uma relação de representação se o interposto concordasse com a utilização de seu nome; o caso seria, aí, de interposição fictícia. Não seria interposição fictícia, mas simples falsidade ideológica - ou melhor, contrafação - do instrumento se o interposto não concordasse com a utilização do seu nome. Esta, como observamos linhas acima $^{484}$, pode servir ao propósito de instrumentalizar a simulação. A solução dada pela doutrina, segundo a qual o falso nome daria azo à simulação apenas nos casos em que houvesse uma autorização do terceiro para que a parte se utilizasse do seu nome ${ }^{485}$, serve para definir os contornos da interposição fictícia, não para descaracterizar a simulação. Vale lembrar que o inciso $I$ do $\S 1^{\circ}$ do artigo 167 não se refere apenas à interposição de

${ }^{483}$ F. MESSINEO, Il contratto in genere cit. (nota 88), p. 542; G. BIANCHI, La simulazione... cit. (nota 264), p. 50-51.

${ }^{484} \mathrm{~V}$. tópico 18.

${ }^{485}$ G. BIANCHI, La simulazione cit. (nota 264), p. 47. 
pessoa, mas a qualquer arranjo negocial que possa transmitir uma imagem não verdadeira acerca da composição subjetiva da relação jurídica.

No exemplo da letra (b) depara-se com a chamada titulação de bens sob nome alheio ("intestazione di beni sotto nomi altrui"). Aqui, também, a doutrina afirma que não haveria simulação, pois o adquirente não agiria como interposto, mas legítimo interessado na aquisição dos bens ${ }^{486}$. Vale notar, porém, que esta estrutura negocial é empregada, no mais das vezes, com o objetivo de excluir certos bens do patrimônio de "A", de modo a protegê-los de eventuais pretensões de seus credores. Esta situação, por si, já sugere que ulteriores verificações devem ser processadas. De fato, se o dinheiro necessário ao pagamento do preço fosse provido por “A”, e - suponha-se - "B" disponibilizasse a posse, o uso e a fruição dos bens àquele, tornar-se-ia difícil defender que "B" nutriria um interesse próprio na aquisição. A consideração conjunta de todas estas circunstâncias poderia sugerir, sobretudo em vista do comportamento concludente das partes, que "B" teria agido como representante de "A". Se esta conclusão se tornasse possível, o diagnóstico da interposição fictícia poderia ser positivo.

Já no caso da letra (c), a primeira alienação não seria simulada, apenas sigilosa; mas, na segunda alienação, “A” seria o presta-nome de "B”, ou seja, agiria, dissimuladamente, como seu representante.

Nesse momento, poder-se-ia indagar sobre o que permitiria atestar, em um caso concreto, que o interposto teria agido como representante do interponente, não como mero mandatário deste. A solução desta questão, bem se vê, é crucial para a delimitação fenomenológica da interposição fictícia. A nosso juízo, a caracterização da representação dissimulada (a face reversa da interposição fictícia) deve levar em conta a causa concreta da operação negocial, ou seja, a precisa identificação da função prático-individual perseguida pelos figurantes. É imprescindível, para que se caracterize a interposição fictícia, que o terceiro contratante tenha conhecimento de que o interposto age em nome do

${ }^{486}$ F. MESSINEO, Il contratto in genere cit. (nota 88), p. 543-544; G. BIANCHI, La simulazione cit. (nota 264), p. 50 . 
interponente. Mais que isso, deve ficar claro, para o terceiro contratante, que o interponente assume os custos ${ }^{487}$ e os riscos ${ }^{488}$ relativos à aquisição da coisa.

Com base nisto tudo, torna-se viável diferenciar a hipótese de titulação de bens sob nome alheio da interposição fictícia. Se o terceiro contratante é capaz de notar que o contratante econômico é o interponente, e, ademais, adere à estrutura negocial que envolve a participação efêmera e transitória do interposto, não nos parece defensável (a despeito de eventual declaração escrita em sentido contrário) que este último agiria como verdadeiro mandatário (sem poderes de representação) do interponente. Tal conclusão afigurar-se-ia ainda mais consistente na situação em que o terceiro contratante concordasse em receber o preço diretamente do interponente, e se comprometesse a manter este estado de coisas em sigilo.

${ }^{487} \mathrm{O}$ pagamento do preço relativo ao bem ou direito importa à verificação da interposição fictícia. Se o sujeito interposto não pagasse o preço, recebesse o bem ou direito, e o revendesse ao terceiro, caberia investigar qual o destino reservado ao montante pago por este último. Se a quantia permanecesse com o interposto, não haveria simulação. Se, contudo, o preço fosse repassado ao interponente, dever-se-ia distinguir a situação em que isto ocorresse de maneira ostensiva (quando existisse esta previsão no contrato firmado com o terceiro), ou velada (quando não existisse esta previsão no contrato firmado com o terceiro). No primeiro caso, o sujeito interposto teria atuado, ostensivamente, como mandatário do interponente; ainda que esta posição jurídica não lhe tivesse sido atribuída expressamente, seria possível chegar-se a esta conclusão mediante a interpretação e a qualificação do conjunto das declarações emitidas pelas partes. Todavia, se a transferência do preço se desse em sigilo, tal circunstância indicaria o caráter simulado da interposição, em razão, precisamente, da dissimulação do mandato com representação. Vale registrar, porém, que o critério do pagamento do preço pode não ser suficiente para definir o tratamento a ser conferido a situações limítrofes, como, por exemplo, aquela em que o interponente ajusta, com o interposto, que a obrigação deste, de pagar o preço pela coisa, seja adimplida com o emprego dos recursos obtidos mediante a alienação do bem ou direito ao terceiro contratante ${ }^{487}$. Nesta hipótese, que se assemelha ao contrato estimatório, seria imperioso levar em conta outros índices de significação com vistas a se identificar a causa concreta do negócio jurídico. Se, por exemplo, o sujeito interposto fosse um comerciante que, habitualmente, realizasse esse tipo de operação, a tese da simulação subjetiva mostrar-se-ia frágil; por outro lado, se o sujeito interposto não apresentasse qualquer interesse comercial nesse tipo de atividade, e, ademais, agisse, em favor do interponente, a título gratuito, a referida tese tornar-se-ia mais consistente. De todo modo, contudo, a ocultação da transferência do preço pago pelo terceiro contratante poderia dissimular o contrato estimatório, o que, em última instância, conduziria à nulidade do negócio simulado.

${ }^{488}$ Acaso se constatasse que os riscos relativos à perda ou ao perecimento do bem ou direito permaneram ínsitos à esfera jurídica do interponente - embora, externamente, não fosse possível visualizar esta circunstância - reforçar-se-ia a convicção quanto a ter sido fictícia a interposição. Um exemplo de evidência da não transferência (dissimulada) de riscos consistiria no fato de, por exemplo, o interponente ter contratado, sob compromisso de confidencialidade, uma apólice de seguro com vistas a cobrir os riscos atinentes à preservação do bem ou direito. Outra situação que poderia tornar plausível a conclusão em favor da simulação seria aquela em que, tendo perecido a coisa antes da sua entrega ao terceiro, o interponente substituísse a coisa, ou restituísse, veladamente, o valor anteriormente pago pelo interposto. Se, eventualmente, não tivesse ocorrido o pagamento pelo interponente, chegar-se-ia a conclusão análoga, quando eventual penalidade prevista contratualmente fosse honrada, perante o terceiro, pelo interponente. 


\section{Declaração, confissão, condição ou cláusula não verdadeira}

A simulação por inserção, no negócio jurídico, de declaração, confissão, condição ou cláusula não verdadeira, prevista no inciso II do $\S 1^{\circ}$ do artigo 167 , costuma-se denominar simulação objetiva. A ilusão negocial recai sobre o conteúdo do regulamento de interesses estipulado pelas partes. Em geral, esta hipótese típica relaciona-se aos seguintes elementos ${ }^{489}$ :

(a) a existência do negócio jurídico, mormente nos casos de simulação absoluta;

(b) a natureza do negócio jurídico, quando o negócio ostensivo resulte de uma alteração do tipo correspondente ao negócio dissimulado;

(c) o valor da prestação, quando o quantum devido por um, ou ambos os contraentes, seja ilusório.

A rigor, confissão, condição, e cláusula, são espécies do gênero declaração. Isto poderia sugerir ter sido, a norma, redundante na enumeração dos fatos sobre os quais poderia incidir a simulação objetiva. A estrutura proposicional do dispositivo em comento põe em destaque o caráter típico desta; o legislador alude a expressões de alcance semântico distinto, como se estivesse desenhando a imagem global de um fenômeno. Não verdadeiras, a teor do inciso II do $\S 1^{\circ}$ do artigo 167, são as declarações, tais como a confissão, a condição e a cláusula.

O texto da norma ainda submete, à apreciação do intérprete, a delicada questão relativa à simulação da confissão. Segundo a doutrina hegemônica, a confissão não se prestaria a criar, extinguir, ou modificar uma relação jurídica, mas a atestar um estado de coisas relacionado a uma situação jurídica ${ }^{490}$. Seria uma declaração enunciativa ou representativa, desprovida de caráter negocial ${ }^{491}$.

Neste particular, Sacco defende que declarações como a confissão e a quitação, quando artificialmente emitidas, não seriam exatamente simuladas, mas irrealistas

\footnotetext{
${ }^{489}$ C. A. Mota Pinto, Teoria Geral... cit. (nota 435), p. 470-71.

${ }^{490}$ R. SACCO - G. DE NOVA, Il contratto cit. (nota 153), p. 650.

${ }^{491}$ E. BETTI, Teoria generale... cit. (nota 53), p. 151.
} 
("velleitarie"). O traço que as caracterizaria seria a falsidade ideológica ${ }^{492}$. Para exemplificar este comportamento negocial, Sacco descreve a situação em que Tício, querendo doar para além da parte disponível do seu patrimônio, celebra contrato de empréstimo com Caio, e, na sequência, dá-lhe quitação. Nesta situação, as partes quereriam os efeitos do ato cognoscitivo mentiroso ${ }^{493}$. O autor, na sequência, afirma que estas considerações conduziriam a um alargamento da noção de simulação, a qual passaria a englobar, também, as declarações de ciência ${ }^{494}$.

Em sentido contrário, Giorgianni aduz que confissão possuiria conteúdo negocial. Para o autor, o animus confitendi, subjacente à confissão, faria desta uma declaração de vontade, não de verdade. A intenção de quem confessa seria a de criar uma prova em favor do confitente, com vistas a eliminar incertezas atinentes a uma relação jurídica. Esta intenção corresponderia a um escopo negocial, em vista do qual a confissão assumiria o caráter de negócio declarativo ("negozio di accertamento") unilateral ${ }^{495}$.

A tese acima exposta seria, no entanto, duramente criticada por Pontes de Miranda. Para o autor, a concepção da confissão como negócio jurídico estaria definitivamente superada, uma vez que teria se fundado em grave confusão entre a confissão extrajudicial e o negócio jurídico declaratório ou recognoscitivo unilateral. A confissão, portanto, seria um meio de prova fundado numa declaração de verdade (=enunciado de fato $)^{496}$.

Com efeito, a doutrina italiana tem consolidado o entendimento de que a confissão seria produto de um ato não negocial ${ }^{497}$. Esclarece, a propósito, Mirabelli, que a presença do animus confitendi não seria suficiente para justificar o caráter negocial da confissão, pois muitos atos não negociais (e.g. fixação de domicílio) dependem de um ânimo psíquico dirigido a uma atividade de fato. Na realidade, quem confessa não dispõe e não se vincula; a lei limita-se a atribuir, ao ato praticado, a condição de prova plena ou prova legal. Na confissão, o confitente expressa sua própria representação sobre um fato.

\footnotetext{
${ }^{492}$ R. SACCO, Simulazione cit. (nota 141), p. 3

${ }^{493}$ R. SACCO, Simulazione cit. (nota 141), p. 3.

${ }^{494}$ Sobre a distinção, v. L. CARIOTA FERRARA, Il negozio giuridico... cit. (nota 34), p. 41.

${ }^{495}$ M. GiorgianNi, Il negozio di accertamento, Milano, Giuffrè, 1939, p. 153 ss.

${ }^{496}$ F. C. Pontes DE Miranda, Tratado de Direito Privado, v. 3, atual. por M. Bernardes de Melo e Marcos Ehrhardt Jr., São Paulo, Revista dos Tribunais, 2012, p. 551.

${ }^{497}$ L. CARIOTA FERRARA, Il negozio giuridico... cit. (nota 34), p. 47.
} 
Nesse estado de coisas, a confissão configura uma participação de representação ${ }^{498}$, para cuja produção tem importância a orientação volitiva do sujeito ${ }^{499}$.

O tema afeito à simulabilidade da confissão ocupou muitas páginas da doutrina italiana, tendo prevalecido o entendimento de que as declarações de ciência em geral (dentre as quais se destaca a quitação) não seriam simuláveis ${ }^{500}$. Sacco, quando abriu divergência em face da opinião dominante, viu-se na contingência de ampliar a abrangência da noção de simulação ${ }^{501}$. No direito brasileiro, porém, não há necessidade de se alargar a noção de simulação, como se, sob a guarida de uma só denominação, fossem congregados eventos heterogêneos.

Segundo a opção do nosso legislador, as declarações simuláveis são tanto as dispositivas (negociais, ou de vontade) como as enunciativas ou representativas (de ciência, ou de verdade). Em vista disso, a confissão pode ser simulada, embora por intermédio da falsidade. Isto, a bem se ver, confirma o nosso entendimento de que a simulação decorre da criação da ilusão negocial; a aparência de adimplemento, ou de débito, pode ser criada por meio da falsa confissão. Esta compreensão, ademais, lança luz sobre a proximidade, admitida pelo nosso direito, entre a simulação e a falsidade ideológica $^{502}$.

Indo adiante, insta assinalar que não são apenas as declarações geneticamente não verdadeiras que podem dar azo à simulação; esta também pode decorrer da superveniente inveracidade da relação jurídica. Considere-se, por exemplo, que Caio e Tício tenham celebrado contrato de locação, o qual permaneça em vigor por um ano; ao final deste período, as partes decidem resili-lo, mas mantêm este ato em sigilo, de maneira que, aos olhos de terceiros, o contrato continue em vigor, e os pagamentos realizados por Tício sejam vistos como relacionados a aluguéis. Diante deste cenário, Sacco - De Nova diriam que não haveria simulação, pois esta não surgiria quando as partes ocultassem uma declaração verdadeira ${ }^{503}$; seriam, contudo, desmentidos por Furgiuele $^{504}$, o qual,

\footnotetext{
${ }^{498}$ Ver tópico 33 .

499 G. MirabelLI, L'atto non negoziale nel diritto privato italiano, Napoli, Eugenio Jovene, 1955, p. 354356.

${ }^{500}$ T. MONTECCHIARI, La simulazione del contratto, Milano, Giuffrè, 1999, p. 18-23.

${ }^{501}$ R. SACCO, Simulazione cit. (nota 141), p. 3

${ }^{502}$ V. tópico 18.

${ }^{503}$ R. SACCO - G. DE NOVA, Il contratto cit. (nota 153), p. 655-656.
} 
perspicazmente, reconhece que a ilusão negocial não pressupõe, necessariamente, a exposição de uma declaração nova (não verdadeira), mas qualquer ato, inclusive a simples ocultação de uma alteração da relação jurídica original, que seja capaz de induzir o público ao engano.

Situações como esta, ademais, mostram o quão equivocada é a concepção de que o acordo simulatório seria sempre anterior, ou, quando muito, contemporâneo à celebração do negócio simulado ${ }^{505}$. O acordo simulatório é anterior, ou contemporâneo, à simulação ${ }^{506}$; mas esta bem pode se instalar a partir de um negócio que, de início, não era simulado. Isto denota, ainda, que o negócio simulado, isto é, aquele que estabelece o regulamento de interesses entre as partes com vistas à criação da ilusão negocial, não se confunde com o "negócio aparente"; porquanto, como evidencia o exemplo acima colacionado, o negócio simulado entraria em vigor exatamente no momento em que o negócio não simulado, anterior, fosse resolvido, e passasse, a partir de então, a ser mera aparência.

\section{Antedata e pós-data}

A terceira das hipóteses típicas enunciadas pelo $\S 1^{\circ}$ do artigo 167 é a antedata ou pós-data de instrumentos particulares.

Cuida-se de simulação relativa, pois, a despeito da data aparente, há outra que demarca o início da vigência da relação jurídica estabelecida entre as partes ${ }^{507}$.

A data é veiculada por meio de uma declaração de ciência ${ }^{508}$; trata-se de um elemento extrínseco do negócio jurídico, do qual depende a definição de sua identidade histórica $^{509}$. Esta afirmação dá ensejo a uma intrigante indagação: se as declarações de

\footnotetext{
${ }^{504}$ G. FURGIUELE, Della simulazione... cit. (nota 144), p. 68 ss.

${ }^{505}$ F. MESSINEO, Il contratto in genere cit. (nota 88), p. 453.

${ }^{506}$ G. Furgiuele, Della simulazione... cit. (nota 144), p. 84-85.

${ }^{507}$ F. C. PONTES DE MiRANDA, Tratado... cit. (nota 220), p. 519-521.

${ }^{508}$ R. SACCO, Simulazione cit. (nota 141), p. 3. Contra: F. FERRARA, A simulação... cit. (nota 20), p. 282, nota 3.

${ }^{509}$ Antônio JunQueIRA DE AZEVEDO, Negócio Jurídico... cit. (nota 440), p. 33-34: "Se o fato jurídico é um fato do mundo real sobre o qual a norma jurídica incide, torna-se intuitiva a evidência que não há fato jurídico sem data e lugar. $\mathrm{O}$ que tem confundido esse assunto é a circunstância de que não é muito comum o legislador estabelecer um requisito para os elementos tempo e lugar do negócio jurídico; segue-se daó que, na hipótese normativa do fato jurídico (isto é, no seu 'suporte fático'), os elementos tempo e lugar ficam, em geral, apenas implícitos. Por outras palavras, se todo fato jurídico tem data e lugar, isso significa que ambos
} 
ciência podem ser simuladas, nos termos do que dispõe o inciso II do $\S 1^{\circ}$ do artigo 167 , por qual motivo teria, o legislador, reiterado esta possibilidade, no inciso III, especificamente no que tange à data?

À evidência, o inciso III do $\S 1^{\circ}$ do artigo 167 não tem por objetivo prever a simulabilidade da data, pois esta previsão positiva já consta do inciso anterior. De fato, o inciso II do $\S 1^{\circ}$ do artigo 167 reputa simulados os negócios jurídicos que contenham tanto declarações dispositivas como declarações de ciência, como a data e o local da contratação. $\mathrm{Na}$ verdade, o dispositivo relativo à antedata e à pós-data ventila uma prescrição de caráter negativo: o papel desta não é o de reconhecer a simulabilidade da data, mas o de restringila aos negócios jurídicos formalizadas por instrumentos particulares. Por certo, o legislador viu que não seria necessário prever a impossibilidade de se simular o local da celebração indicado em instrumentos públicos (pois este somente poderia ser aquele em que se situasse o tabelionato responsável pela lavratura da escritura), mas a data, ao menos em princípio, poderia ser simulada mesmo em escritos públicos. Isto, obviamente, demandaria a participação do oficial público no acordo simulatório; é exatamente esta hipótese que o comando normativo em questão vem excluir.

$\mathrm{O}$ inciso III do $\S 1^{\circ}$ do artigo 167 cria uma presunção iure et de iure quanto à lisura do comportamento dos oficiais públicos que intervenham nas relações privadas. Por conta dessa presunção, a escritura pública jamais será acometida pela simulação; quando muito, admitindo-se que os tabeliães possam cometer erros, configurar-se-á a falsidade.

Deve-se observar, contudo, que nem sempre a antedata ou pós-data deve justificar a qualificação do negócio como simulado. É necessário atentar à ratio que subjaz à previsão do inciso III do $\S 1^{\circ}$ do artigo 167: o negócio, ali referido, cujo instrumento particular encontra-se antedatado ou pós-datado é, antes de tudo, um negócio simulado. Logo, serve de instrumento para a perpetração de uma ilusão atinente à vigência do negócio jurídico. Portanto, acaso se verificasse o simples fato objetivo da antedata ou pós-

são elementos de todo fato jurídico (inclusive do negócio jurídico), ainda que raramente a eles se imponham requisitos. Entretanto, a importância de ambos esses elementos é, ainda assim, não pequena; mesmo quando não há qualquer requisito a seu respeito, eles servem inegavelmente para a exata identificação do negócio; isto é evidente diante do costume jurídico notório de se datar e colocar o lugar de feitura em todos os documentos". 
data, sem, contudo, poder-se concluir que este tivesse servido como índice de significação artificialmente criado pelos simuladores, não caberia atestar-se a simulação.

Esclareça-se este ponto por meio dos seguintes exemplos:

(a) Caio e Tício celebram um contrato de compra e venda no dia 03/04/2006; objetivando beneficiar-se de um regime tributário favorecido, cuja norma instituidora houvera sido revogada em 30/03/2006, as partes resolvem antedatar o instrumento particular relativo ao negócio jurídico realizado; e

(b) Caio e Tício celebram um contrato de compra e venda no dia 03/04/2006; por comum deliberação das partes, o negócio jurídico é celebrado sob a forma oral. Em 05/09/2009, Caio precisa apresentar, a determinada autoridade pública, prova quanto à celebração do referido contrato. Nesta data, assinam as partes, então, instrumento particular, o qual resolvem antedatar.

Em ambos os exemplos, observa-se a assinatura de instrumento particular antedatado. Há, pois, a presença da hipótese descrita no artigo $167, \S 1^{\circ}$, inciso III. Isto significaria, necessariamente, que, nas duas situações, haveria simulação?

A resposta afigura-se negativa. Apenas no exemplo (a) o instrumento particular antedatado teria servido aos desígnios de criar a ilusão negocial. No exemplo 2, a antedata seria, quando muito, uma inadequada forma de ratificar a vigência da relação jurídica pretérita (melhor seria que as partes assinassem um instrumento particular em 05/09/2009, com a indicação, nos "consideranda", de que o contrato houvera sido concluído oralmente em 03/04/2006; e com a determinação, em cláusula específica, de que os termos ali pactuados aplicar-se-iam à disciplina das relações entre as partes a partir de 03/04/2006); contudo, não haveria engano nem traição da boa-fé do público, pois a relação jurídica efetivamente vigorava desde a data apontada no instrumento particular.

\section{§ 8. OS LIMITES DA SIMULAÇÃo}

Apesar de a simulação ser um fenômeno amplamente difundido, presente nos mais variados rincões da vida de relação, nem todos os atos particulares podem ser simulados. 
Como vimos, em geral, a difusão da ilusão negocial pressupõe a criação de uma "forma de realidade", ou seja, a produção de índices de significação relacionados à forma do negócio jurídico (e.g. escritura pública ou instrumento particular). Apenas em um menor número de ocasiões é possível que a simulação seja concretizada por meio do simples comportamento concludente (i.e. quanto aos negócios jurídicos "de fato", como a procuração e a sociedade, por exemplo). Isto posto, deve-se notar que, não raramente, a forma negocial criada é considerada, pelo direito, como fato bastante ao estabelecimento da relação jurídica correlata. Em tais instâncias, a forma exaure o suporte fático, excluindo a possibilidade de se levar em consideração quaisquer outras condutas das partes para a definição da "realidade" deste.

Quando isto sucede, a simulação torna-se inviável, pois não é possível a segregação entre o plano da aparência e o da realidade. Sobretudo quando as partes não dispõem de controle sobre a eficácia de seus atos, e quando o negócio jurídico encontra-se sujeito a requisitos de forma interna, a aparência e a realidade se fundem, sendo, assim, impossível a criação da aparência negocial.

\section{A "disponibilidade dos efeitos" e a "forma interna"}

Esta questão sempre chamou a atenção da doutrina, sendo notável a evolução do modo como ela tem sido enfrentada. O debate remonta à formulação de Messina, o qual sustentava que a declaração simulada seria emitida como um fato jurídico em sentido estrito; as partes conseguiriam cindir o movimento volitivo que anima o agir negocial, querendo produzir, não exatamente a declaração, mas o fato da declaração, como execução de um secreto acordo simulatório ${ }^{510}$. Essa concepção seria criticada por Ferrara, para quem a emissão da declaração deflagraria consequências inevitáveis: acolher o pensamento contrário seria como jogar um corpo para o alto e desejar, em meio ao movimento ascendente, que ele jamais caísse ${ }^{511}$ Mais tarde, Cariota Ferrara retomaria a

\footnotetext{
${ }^{510}$ G. MESSINA, La simulazione assoluta cit. (nota 40), p. 92.

${ }^{511}$ F. FERRARA, A simulação... cit. (nota 20), p. 65: "O efeito jurídico produz-se não por arbítrio das partes, mas em virtude da lei: aquelas podem, certamente, dar o impulso, criar as condições necessárias para que tal efeito se produza, mas não podem detê-lo ou impedi. O efeito jurídico é como o efeito físico ou químico: pode-se ou não deixar cair um corpo duma altura, pode-se ou não chegar um fósforo aceso à pólvora inflamável, mas feito isto, não pode impedir-se a queda ou a explosão: o efeito dá-se por si, irrevogavelmente, necessariamente. Do mesmo modo, pois, as partes podem não querer o negócio e, por falta de consentimento, determinar a sua ineficácia, mas não podem querer um negócio sem efeitos jurídicos".
} 
discussão, propondo uma solução com base na distinção entre vontade de declaração e vontade de conteúdo ${ }^{512}$.

Um pouco mais adiante, Romano chamaria atenção para o fato de que, uma vez emitida a declaração negocial, configurar-se-ia a indisponibilidade dos efeitos (ou seja, esta seria a regra); os particulares não conseguiriam voltar atrás quanto à criação do negócio jurídico, pois esta seria uma consequência puramente normativa, sobre a qual aqueles não exerceriam qualquer influência. Poderiam, quando muito, provocar a desnaturação a posteriori da causa, por meio da adoção de um comportamento executivo que com ela conflitasse ${ }^{513}$.

Foi Auricchio, porém, o responsável por atribuir contornos dogmáticos mais claros ao debate. Segundo o autor, a principal barreira com a qual o intento simulatório se defrontaria seria indisponibilidade dos efeitos. A caracterização da simulação não se daria com base em um simples comportamento psicológico dos simuladores, mas resultaria do modo como este comportamento influenciaria a eficácia do ato aparente ${ }^{514}$. Haveria certos negócios jurídicos que assumiriam relevância exclusivamente por força da criação da forma prevista na lei. Nestas situações, não haveria espaço para a investigação de outros materiais interpretativos, como, por exemplo, as tratativas, as condutas sucessivas, e as circunstâncias negociais. Em tais casos, os efeitos seriam produzidos independentemente da intenção das partes de paralisá-los; bastaria a criação do suporte fático previsto em lei para que a eficácia jurídica viesse à tona ${ }^{515}$.

Auricchio acreditava que o suporte fático do negócio jurídico resumir-se-ia ao aglomerado de essentialia descrito na lei: uma declaração feita por sujeitos capazes, munida de objeto, causa (abstrata), e revestida da forma legalmente prescrita ou não defesa. Este conjunto de fatos prestar-se-ia a justificar a validade ou invalidade do negócio jurídico. A eficácia, por sua vez, derivaria diretamente do regulamento de interesses, uma espécie de pacto $n u$, ou seja, não formalizado, que expressaria a funcionalidade do acordo firmado. Com base nestas premissas, o autor sustenta que o suporte fático poderia carecer

\footnotetext{
${ }^{512}$ L. CARIOTA FERRARA, Il negozio giuridico... cit. (nota 34), p. 524.

${ }^{513}$ S. RomAnO, Contributo esegetico... cit. (nota 53), p. 36.

${ }^{514}$ A. AURICCHIO, La simulazione... cit. (nota 19), p. 72.

${ }^{515}$ A. AURICCHIO, La simulazione... cit. (nota 19), p. 76.
} 
de um regulamento de interesses operativo; o suporte fático, portanto, reportar-se-ia a um regulamento de interesses meramente aparente.

Deparando-se com o tema, Marani ratifica o entendimento de que a disponibilidade dos efeitos seria um pressuposto da simulação. Em vista disso, o autor considera excluída, de antemão, a possibilidade de simularem-se os atos não patrimoniais assim como os atos não negociais ${ }^{516}$. A disponibilidade dos efeitos, entendida como uma relação entre ato e efeito determinada pela relevância que a norma atribuiria ao regulamento de interesses predisposto pelas partes, seria uma decorrência da autonomia $\operatorname{privada}^{517}$.

Tendo-se em mente a concepção instrumental da simulação, à qual aderimos, a dialética instalada em torno da operatividade da simulação, e dos limites desta, induz-nos a dar um passo além. Ao que nos parece, a querela não se refere unicamente à disponibilidade dos efeitos - pois, quanto a isto, concordamos com Romano: a indisponibilidade dos efeitos é a regra - mas à possibilidade de os particulares criarem elementos do suporte fático legalmente prescrito como índices de significação, isto é, como imagens parciais que, embora comuniquem uma mensagem quando observadas a partir de um particular ponto de vista, não chegam a formar um quadro unitário - apenas aparentam fazê-lo.

É necessário prestar reforçada atenção aos pressupostos de incidência da norma, que, por vezes, pode atribuir relevância jurídica exclusiva a um específico ato ou fato. Em tal hipótese, toda a substância jurídica do ato ultima-se absorvida por determinada forma. Nenhum valor assume, portanto, o complexo de atos e condutas dos particulares; apenas um aspecto fático é levado em conta para que se dê a incidência do modelo regulativo correlato.

A vinculação entre a forma e o conteúdo do ato jurídico é mais intensa, a ponto de ambos praticamente se confundirem, nos casos em que a norma prescreve uma forma interna. Conforme salienta Pais de Vasconcelos, a forma interna participa do ser e da existência do ato. É algo que faz parte dele e sem ela o ato ou não é qualificável como tal,

\footnotetext{
${ }^{516}$ F. MARANI, La simulazione... cit. (nota 246), p. 118; 120.
}

${ }^{517}$ F. MARANI, La simulazione... cit. (nota 246), p. 122. 
ou é mesmo juridicamente inexistente" ${ }^{, 518}$. Os exemplos mais claros desta ocorrência são os títulos de crédito, em especial, a letra de câmbio e o cheque, cujas formas internas são detalhadamente descritas nas respectivas Leis Uniformes, e em outros dispositivos legais correlatos.

Em contrapartida, a forma externa é aquela de que o ato se veste; seja ad substantiam ou ad probationem, é algo que lhe acresce, mas que não participa da sua essência, do seu ser. É exemplo claro de forma externa a escritura pública no contrato de compra e venda de imóvel ${ }^{519}$.

A distinção entre forma interna e forma externa fora proposta já por Manuel de Andrade, o qual distinguiu "a forma necessária para a validade ou para a prova do negócio" da "forma que constitui elemento do próprio conceito de um certo tipo negocial, por maneira que a sua falta produza a inexistência do respectivo negócio - forma que pode qualificar-se como constitutiva",520.

A forma interna é absoluta, vale por si própria, porque pertence ao próprio tipo do ato ou do negócio, e, portanto, não permite redução teleológica. A forma externa, ao contrário, é funcional, finalisticamente determinada; por isso, pode ser objeto de redução teleológica se assim justificar, designadamente, a boa-fé ou o fim social ou econômico que tenha determinado a sua exigência ${ }^{521}$.

Para concretizarem a simulação, as partes devem dispor da liberdade de criar suportes fáticos complexos, não atrelados a uma determinada forma interna, de modo que os índices de significação ostentados aos olhos do público não encerrem a totalidade do pressuposto de incidência da norma. Com isto, torna-se viável aquela atividade hermenêutica que, como na hipótese da falsa demonstratio, busca extrair, do complexo comportamental dos indivíduos, a substância jurídica do regulamento de interesses.

Num negócio falsamente qualificado, o nomen juris é ignorado em vista do teor das cláusulas que contêm a regulação convencionada entre as partes. Se, porém, a lei

\footnotetext{
${ }^{518}$ P. PAis De VASCONCElos, Teoria Geral... cit. (nota 103), p. 705.

${ }^{519}$ P. PAIS DE VASCONCELOS, Teoria Geral... cit. (nota 103), p. 705-706.

${ }^{520}$ M. A. Domingues De Andrade, Teoria Geral... cit. (nota 20), p. 142. V. também F. C. Pontes DE MiRANDA, Tratado... cit. (nota 496), p. 444.

${ }^{521}$ P. PAis DE VASCONCELOS, Teoria Geral... cit. (nota 103), p. 706.
} 
dispusesse que o nomen juris deveria determinar a natureza da relação jurídica, isto se daria independentemente de aquele contrastar com os demais termos firmados pelos contraentes; seria o caso de negar vigência a algumas cláusulas, ou integrar, por meio da interpretação, o conjunto de cláusulas constantes do instrumento, mas a qualificação jurídica pautada no nomen juris seria definitiva.

Analogamente, quando a norma atribui, à declaração negocial contida num instrumento, a condição de suporte fático exclusivo, de nada adianta, aos contraentes, ocultar intenções, comportamentos, declarações; é impossível a simulação, pois a juridicização do suporte fático é inexorável e indelével.

A simulação pressupõe a possibilidade de uma relação jurídica constituir-se com base em elementos que não se integram a um único instrumento. Naquela, assim como na falsa demonstratio, o índice de significação ostensivo remete a termos que não refletem a efetiva situação jurídica das partes - com a diferença de que não é apenas o título que se mostra equivocado. Em caso contrário, isto é, se a forma ostensiva encerra a integralidade do suporte fático valorado pela norma como pressuposto de um dado modelo regulativo, a simulação se torna impensável.

\section{Atos formais}

O princípio do consensualismo, segundo o qual a declaração de vontade não requer forma especial, encontra-se positivado no artigo 107. Mas o próprio dispositivo ressalva a possibilidade de a lei requerer a adoção de forma especial, a qual pode prestar-se tão somente a fins probatórios (ad probationem), ou integrar a substância do ato (ad substanciam).

A dúvida sobre a possibilidade de dar-se a simulação surge no que tange aos negócios formais. Neste caso, poder-se-ia supor que a forma especial (externa), sobretudo o instrumento público, faria o negócio inevitavelmente assumir plena relevância jurídica.

O negócio celebrado mediante instrumento público não pode, certamente, ser considerado simulado em virtude de antedata ou pós-data (artigo 167, § $1^{\circ}$, inciso III). Contudo, no que se refere às demais manifestações do fenômeno simulatório, não se vislumbra empecilho à simulação. 
Como bem frisa Carresi, no caso da simulação, a realidade do negócio jurídico deve investigar-se para além de qualquer limitação formal ${ }^{522}$. Isto significa que o conteúdo convencional que notabiliza a substância do negócio jurídico pode extrapolar a forma especial criada; consequentemente, a forma criada pelas partes pode ser convertida em mero índice de significação.

\section{Títulos de crédito}

A doutrina é praticamente unânime ao asseverar a impossibilidade de simular-se o título de crédito. Variam as justificativas: alguns dizem que isto decorreria da abstração do título de crédito $^{523}$; outros entendem que a circunstância de o título de crédito ser espécie de negócio unilateral não receptício impediria a formação do acordo simulatório ${ }^{524}$.

Consoante expusemos acima, o simples fato de o negócio jurídico ser unilateral não constitui óbice à simulação. Sendo o título de crédito um documento (constitutivo) destinado à circulação, nesta consiste a causa de sua emissão, e, em vista dela, aquele deve responder, para a justa tutela do tráfico jurídico, a inderrogáveis exigências de certeza e segurança. $O$ atendimentos de tais exigências é assegurado através de um processo de simplificação do suporte fático, mediante o qual o documento adquire uma função de legitimação no exercício do direito; a promessa se desvincula do destinatário e o direito incorporado no título de crédito torna-se autônomo no confronto com a relação fundamental. O formalismo jurídico dos títulos ${ }^{525}$ de crédito expressa-se em razão de seus caracteres fundamentais: a literalidade, a autonomia e a abstração ${ }^{526}$.

Tem prevalecido, atualmente, o entendimento de que o título de crédito surge por força da sua criação. A declaração cambiária é perfeita com a simples criação do título; que ele saia das mão do devedor é simples fator de eficácia da obrigação, mas o negócio é perfeito desde a criação do documento, e, portanto, as exceções relativas à emissão não podem ser opostas ao terceiro possuidor de boa-fé. Nesse sentido, o artigo 16 do Anexo I da Lei Uniforme em matéria de Letras de Câmbio e Notas Promissórias (incorporada ao

\footnotetext{
${ }^{522}$ F. CARRESI, Apparenza e realtà... cit. (nota 305), p. 499-500.

${ }^{523}$ T. AsCARElli, Teoria Geral dos Títulos de Crédito, $2^{\mathrm{a}}$ ed., São Paulo, Saraiva, 1969, p. 108.

${ }^{524}$ S. PugliatTi, La simulazione... cit., (nota 53), p. 580-583.

${ }^{525}$ Fran MARTins, Títulos de Crédito, $15^{\mathrm{a}}$ ed., Rio de Janeiro, Forense, 2010, p. 12-13.

${ }^{526}$ N. DisTASO, La simulazione... cit. (nota 40), p. 309.
} 
direito brasileiro por meio do Decreto $\left.\mathrm{n}^{\mathrm{o}} 57.663 / 1966\right)$, reconhece que mesmo quando ocorra extravio o furto da letra ou da nota, o portador considera-se seu legítimo proprietário: “(...) Se uma pessoa foi por qualquer maneira desapossada de uma letra, o portador dela, desde que justifique o seu direito pela maneira indicada na alínea precedente, não e obrigado a restitui-la, salvo se a adquiriu de má-fé ou se, adquirindo-a, cometeu uma falta grave".

Pode-se dizer, nesta toada, que a criação do título de crédito implica uma "duplicação" da declaração, em virtude da qual a declaração fundamental separa-se da declaração cartular, a qual assume plena autonomia ${ }^{527}$. A obrigação se materializa, enquanto fato juridicamente relevante, pelo simples fato da sua consubstanciação no documento previsto e descrito na lei (pelo que, ademais, deixa de coincidir com a obrigação resultante da relação fundamental ${ }^{528}$ ). Tal documento é o suporte fático suficiente e, mais que isto, exclusivo, do ato jurídico que representa. O título de crédito não se mostra apto a servir como índice de significação de uma situação jurídica que lhe seja distinta. A simulação do conteúdo do título de crédito é inviabilizada pela exigência de forma interna ${ }^{529}$ para a própria existência daquele ${ }^{530}$. A natureza abstrata e formal dos negócios cambiais cria uma realidade única; logo, não há simulação possível ${ }^{531}$.

Nessa linha de ideias, tem-se reconhecido que as chamadas "firmas e favor" não implicam a simulação da letra. Muito frequentemente são apostas assinaturas em cambiais não tendo, quem assina, a menor intenção de pagar no vencimento. O objetivo da assinatura consiste, no mais das vezes, apenas em facilitar a circulação da cambial no interesse de um outro obrigado, que se compromete, perante ao signatário de favor, a evitar que este - apesar da sua assinatura - ultime-se compelido a efetivar o pagamento. $\mathrm{O}$ favor consiste justamente na aposição da firma como um fim em si mesmo (a "relação de favor").

Em tais circunstâncias, o negócio cambiário não é simulado; quem assina por favor assume, exata e conscientemente, o risco de pagar a cambial; o caráter de favor da

\footnotetext{
${ }^{527}$ T. AsCARELLI, Teoria Geral... cit. (nota 523), p. 30; 44.

${ }^{528}$ T. AsCARELLI, Teoria Geral... cit. (nota 523), p. 57.

${ }^{529}$ Ver tópico 30.

${ }^{530}$ T. ASCARELLI, Teoria Geral... cit. (nota 523), p. 23.

${ }^{531}$ N. DisTASO, La simulazione... cit. (nota 40), p. 320.
} 
firma decorre de uma convenção extracartular, cujos sujeitos não são os da relação cartular. As partes se propõem a criar uma realidade jurídica, a obrigação cambiária, que deve valer e operar no mundo externo com todos os efeitos próprios da obrigação que nela se expressa e se incorpora. Assim, longe de criar uma aparência contrária à realidade, a subscrição de favor desenvolve todas as funções normais ${ }^{532}$. Fosse o caso de se identificar, na espécie, a ocorrência da interposição fíctícia, seria necessário que o credor tivesse originário conhecimento da relação de favor; mesmo assim, contudo, não caberia falar-se de simulação, pois a cambial continuaria apta a circular como consequência da definitiva validade resultante de sua criação.

Cumpre registrar, por oportuno, que a aposição de assinatura falsa (falsidade material ou contrafação) não prejudica a validade da letra ou nota, nem causa a insubsistência das demais obrigações cartulares incorporadas no mesmo documento. $\mathrm{O}$ sujeito que tiver a assinatura falsificada não será compelido a efetuar o pagamento simplesmente por não ter participado da relação cambial. A propósito, o artigo $7^{\circ}$ do Anexo I da Lei Uniforme em matéria de Letras de Câmbio e Notas Promissórias estatui que "[s]e a letra contém assinaturas de pessoas incapazes de se obrigarem por letras, assinaturas falsas, assinaturas de pessoas fictícias, ou assinaturas que por qualquer outra razão não poderiam obrigar as pessoas que assinaram a letra, ou em nome das quais ela foi assinada, as obrigações dos outros signatários nem por isso deixam de ser válidas”. A falsidade da assinatura pode surgir de maneiras diversas, por exemplo: pode o primus (sacador) assinar com o nome de terceiro, com ou sem o consentimento deste; pode, ainda, o primus a apor a assinatura de aceita, com vistas a obrigar o secundum (aceitante); o pode, por último, o secundum (aceitante) adulterar o documento, para que a assinatura do primus (sacador) pareça ser de tertius (beneficiário-endossante). Em todo caso, o último signatário da cadeia de endossos permanecerá obrigado perante o portador, a despeito da eventual falsidade das assinaturas e figurantes anteriores. Dessa feita, se a assinatura viciada for a do primus (sacador), e o título tiver de ser aceito e circulado, o portador, conquanto não possa exigir o pagamento daquele que tiver a assinatura falsificada, poderá fazê-lo em face do avalista, dos eventuais endossantes e dos respectivos avalistas; mutatis mutandis, se a assinatura falsificada for a do secundum (aceitante), o título de crédito não terá devedor

${ }^{532}$ T. ASCARELLI, Teoria Geral... cit. (nota 523), p. 107-108; N. DiSTASO, La simulazione... cit. (nota 40), p. 319-320. 
principal, embora todos os demais que nele tenham comparecido continuem vinculados pela obrigação; e, por fim, se o endossante tiver a assinatura falsificada, apenas contra ele o portador não poderá demandar o pagamento ${ }^{533}$.

Também não induz a simulação do título de crédito a antedata ou pós-data. Neste mister, a Lei do Cheque (Lei $n^{\circ} 7.357 / 1985$ ) assinala, no parágrafo único do artigo 32, que “[o] cheque apresentado para pagamento antes do dia indicado como data de emissão é pagável no dia da apresentação" ${ }^{, 534}$. Nessa direção, o Superior Tribunal de Justiça já decidiu que "[a] emissão de cheque pós-datado, popularmente conhecido como cheque prédatado, não o desnatura como título de crédito, e traz como única consequência a ampliação do prazo de apresentação" ${ }^{\text {535 }}$.

Por fim, uma advertência mostra-se pertinente: tudo o que acima foi dito sobre a simulação do título de crédito não deve conduzir à conclusão, que seria errada, de que a relação fundamental não pode ser simulada. Como salienta Ascarelli, o título de crédito pode ser criado com vistas a difundir a percepção de que a relação fundamental existiria ${ }^{536}$. Tal situação, em regra, produziria consequências apenas entre os figurantes da relação fundamental, mas poderia implicar a nulidade do próprio título de crédito acaso este fosse causal. Nos títulos causais, o direitos cartulares são decorrentes de um negócio declaratório; por conseguinte, na valoração destes, deve-se levar em conta, dentre as exceções cartulares, as derivadas de vícios da relação objeto da declaração, assim como eventuais divergências entre a relação fundamental e o que é manifestado com a declaração cartular $^{537}$.

Nesta sede, é importante notar que a simulação da relação fundamental prejudicaria indiretamente a validade do título de crédito, pois este mostrar-se-ia, em última instância, carente de causa. Costuma-se considerar um exemplo deste tipo de ocorrência a emissão da chamada "duplicata simulada". Tal denominação, no entanto, tem sido empregada indiscriminadamente aos casos em que a relação fundamental inexista ${ }^{538}$

\footnotetext{
${ }^{533}$ L. E. F. Rosa JR., Títulos de Crédito, $5^{\mathrm{a}}$ ed., Rio de Janeiro, Renovar, 2007, p. 161-165.

${ }^{534}$ Fran MARTins, Títulos de Crédito cit. (nota 525), p. 306-307.

${ }_{535}$ Recurso Especial no 612.423, Nancy Andrighi (relatora), DJ de 26/06/2006.

${ }^{536}$ T. AsCARELLI, Teoria Geral... cit. (nota 523), p. 108.

${ }^{537}$ T. ASCARELLI, Teoria Geral... cit. (nota 523), p. 129.

${ }^{538}$ V., por exemplo, o acórdão do Superior Tribunal de Justiça relativo ao Recurso Especial $n^{0} 774304 / \mathrm{MT}$, de 05/10/2010, assim ementado: "DIREITO COMERCIAL. DUPLICATA DE PRESTAÇÃO DE
} 
(e.g. "A" saca duplicata em face de "B" sem que qualquer operação comercial tenha ocorrido) e àqueles em que a relação fundamental seja efetivamente simulada (e.g. "A" e "B" celebram simuladamente contrato de fornecimento de mercadorias, e, com base nisto, "A" saca a duplicata em face de "B"). Em qualquer dos casos, a executoriedade da duplicata ultimar-se-ia excluída; porém, apenas na segunda das referidas haveria simulação ${ }^{539}$, e, ainda assim, não seria da duplicata, mas da relação fundamental.

\section{Atos não negociais}

A questão referente à simulabilidade dos atos não negociais torna-se relevante em vista do artigo 185, segundo o qual “[a]os atos jurídicos lícitos, que não sejam negócios jurídicos, aplicam-se, no que couber, as disposições do Título anterior”. O “Título anterior" a que se refere este dispositivo, é o "Título I" (do "Livro III"), dedicado ao negócio jurídico. Neste se inclui o artigo 167, que faz referência, apenas, ao negócio simulado.

Muito já se discutiu sobre os fatores que diferenciariam o negócio jurídico dos atos não negociais. Em geral, afirma-se que enquanto a eficácia do negócio jurídico seria

SERVIÇOS. EMISSÃO IRREGULAR. SIMULAÇÃO. INOPONIBILIDADE DAS EXCEÇÕES PESSOAIS A ENDOSSATÁRIOS DE BOA-FÉ. NÃO-APLICAÇÃO. VÍCIO FORMAL INTRÍNSECO. 1. O que o ordenamento jurídico brasileiro veda - e isso desde o Decreto $\mathrm{n}^{\circ} 2.044 / 1908$, passando-se pelo Código Civil de 1916 e, finalmente, chegando-se à Lei Uniforme de Genebra - é a oposição de exceȩões de natureza pessoal a terceiros de boa-fé, vedação que não abarca os vícios de forma do título, extrínsecos ou intrínsecos, como a emissão de duplicata simulada, desvinculada de qualquer negócio jurídico e, ademais, sem aceite ou protesto a the suprir a falta. 2. Em relação à Duplicata - é até ocioso ressaltar -, a Lei ${ }^{\circ}$ 5.474/68 condiciona a sua emissão à realização de venda mercantil ou prestação de serviços, bem como a aceitação do sacado ou, na ausência, o protesto acompanhado de comprovante da realização do negócio subjacente, sem os quais estará configurado o vício de forma intrínseco, o qual poderá ser oposto pelo sacado a qualquer endossatário, ainda que de boa-fé. 3. Recurso especial conhecido e improvido".

No voto condutor do aresto, o relator, Ministro Luis Felipe Salomão, assevera: "Deveras, o que o ordenamento jurídico brasileiro veda - e isso desde o Decreto $\mathrm{n}^{\circ}$ 2.044/1908, passando-se pelo Código Civil de 1916 e, finalmente, chegando-se à Lei Uniforme de Genebra - é a oposição de exceções de natureza pessoal a terceiros de boa-fé, vedação que não abarca os vícios de forma do título, extrínsecos ou intrínsecos, como a emissão de duplicata simulada, desvinculada de qualquer negócio jurídico e, ademais, sem aceite ou protesto a the suprir a falta. Em realidade, tal prática foi erigida há muito a ilícito penal (Art. 172 do Código Penal - Emitir fatura, duplicata ou nota de venda que não corresponda à mercadoria vendida, em quantidade ou qualidade, ou ao serviço prestado).

Em relação à Duplicata - é até ocioso ressaltar -, a Lei no 5.474/68 condiciona a sua emissão à realização de venda mercantil ou prestação de serviços, bem como a aceitação do sacado ou, na ausência, o protesto acompanhado de comprovante da realização do negócio subjacente, sem os quais estará configurado o vício de forma intrínseco, o qual poderá ser oposto pelo sacado a qualquer endossatário, ainda que de boa-fé.

(...)

No caso ora em exame, a toda evidência, cuida-se de duplicatas simuladas, sem lastro em nenhuma venda mercantil ou prestação de serviços, constituindo tal vício óbice à própria perfectibilização do título como cambiariforme"

${ }^{539}$ I. GAINO, A Simulação... cit. (nota 122), p. 170-171. 
autônoma (pois surgiria já no tráfico social, e seria tão somente reconhecida ou recepcionada pela ordem jurídico-positiva), a eficácia dos atos não negociais seria heterônoma, pois decorreria exclusivamente da juridicização do respectivo suporte fático $^{540}$.

Segundo Mirabelli, os atos não negociais podem ser de três espécies ${ }^{541}$ :

(a) atos exteriores: são atos captados, pela ordem normativa, como meros fatos, isto é, com total desprezo a qualquer inclinação psicológica que possa estar à sua base; são exemplos, dentre outros: a especificação, a invenção de tesouro, a instauração da posse, a presença, a ausência, e a convivência;

(b) atos de expressão de um elemento interior: são atos apreciados, pela lei, não somente como fatos, mas como expressão de um elemento psíquico interior; são exemplos, dentre outros: a fixação e a transferência de domicílio, a apreensão, o ato devido (adimplemento), e a gestão de negócios; e

(c) atos de participação: são atos que comunicam um pensamento do declarante a outrem; bipartem-se entre as participações de representação (que expressam eventos passados) e as participações de vontade (que veiculam eventos futuros); são exemplos, dentre outros: a notificação, a oferta, o convite, e a confissão.

Para Mirabelli, a simulação não seria compatível com os atos não negociais. No que tange aos atos exteriores, um acordo tendente a modificar os efeitos previstos em lei seria plenamente operante, independentemente da aplicação da disciplina própria da simulação. Quanto aos atos que expressam um elemento interior, o acordo simulatório implicaria, simplesmente, a ausência do conteúdo psíquico do ato, e, portanto, o desnaturaria por completo. Nas participações, se estas fossem inexatas, reputar-se-iam ineficientes, razão pela qual um acordo que tivesse por escopo assinalar uma aparência diversa àquelas não seria concebível.

\footnotetext{
${ }^{540}$ Sobre o tema, v. A. FALZEA, L'atto negoziale nel sistema dei comportamenti giuridici in Rivista di diritto civile, Padova, $1^{\text {a }}$ parte, 1996, p. 1-55.

${ }^{541}$ G. MiRABELLI, L'atto non negoziale... cit. (nota 499), p. 18 ss.
} 
Poderia, contudo, admitir-se que as partes convencionassem atribuir, à participação, um efeito diverso do legal; a tal acordo não caberia negar eficácia, embora este implicasse (semelhantemente ao que ocorreria no caso dos atos exteriores) a modificação direta dos efeitos (e da natureza) do ato, não a criação de uma dissociação entre o aparente e o real. "Dizer, por exemplo, que é simulado um ato de constituição em mora, no caso em que o credor acorde com o devedor no sentido de que ele emitirá a intimação para fazer crer, aos terceiros, que ele provoca a atuação do seu direito, mas considerará não verificados, no que diga respeito a este último, os efeitos da mora, significa dizer que ao ato falta a intenção do agente de dar a conhecer a outrem uma própria exigência (...) ${ }^{, 542}$.

Diversamente, Dagot defende que a simulação de "fatos jurídicos", desde que se tratem de fatos jurídicos voluntários. Para reforçar sua convicção, o autor se vale do elucidativo exemplo da fixação da sede de uma sociedade: "[u]ma sociedade, para afastar a jurisdição de um tribunal, ou para adquirir uma nacionalidade, ou ainda para se beneficiar de reduções fiscais concedidas pelo governo a empresas cuja sede estava nas colônias, pode usar dois procedimentos jurídicos: realmente instalar sua sede social no lugar e nos países listados nos estatutos, e a operação será irrepreensível; ou instalar um conjunto mínimo de corpos administrativos, mantendo a gestão da empresa em outro lugar, onde então será a sede social real, não passando, o lugar especificado nos estatutos, de uma sede social fictícia" ${ }^{543}$.

No mesmo sentido, Pontes de Miranda entende que os atos não negociais podem ser simulados. Aduz, o autor, que a comunicação da outorga de poder, a denúncia, a

\footnotetext{
542 G. MirabelLi, L'atto non negoziale... cit. (nota 499), p. 433-435. Tradução livre; no original: "Dire, ad esempio, che viene simulato un atto di costituzione in mora, nel caso che il creditore si accordi con il debitore nel senso che egli emetterà l'intimazione per far credere ai terzi che egli provoca l'attuazione del suo diritto, ma riterrà non verificatisi, per quanto lo concerne, gli effetti della mora, significa dire che nell'atto manca l'intenzione dell'agente di far conoscere all'altro una propria esigenza (...)".

${ }^{543}$ M. DAGOT, La simulation... cit. (nota 50), p. 230-231. Tradução livre; no original: "Une société, pour écarter la compétence d'un tribunal, ou pour acquérir telle nationalité, ou encore pour bénéficier des réductions d'impôt accordées par le gouvernement aux sociétés dont le siège social était aux colonies, peut utiliser deux procédés juridiques : soit installer effectivement son siège social au lieu, et dans le pays indiqués par les statuts, et l'opération est irréprochable, soit n'y installer qu'un minimum d'organes d'administration, les organes de direction de la société se trouvant en un autre lieu ou se trouve alors le vrai siège social; le lieu indiqué dans les statuts comme siège social n'est plus alors qu'un siège social fictif'.
} 
derrelição ${ }^{544}$ e a transmissão da posse longa manu poderiam ser anuladas por conta da simulação ${ }^{545}$.

Diante desse embate doutrinário, quid juris, à luz do artigo $167 ?$

Para solucionar este dilema, ao que nos parece, não precisamos fazer grande esforço: a resposta que buscamos encontra-se na literalidade da lei. Como demonstramos acima $^{546}$, a confissão é ato não negocial, e, explicitamente, vem prevista como um dos possíveis alvos da simulação. Portanto, concluímos, ao lado de Pontes de Miranda, que, no direito brasileiro, os atos não negociais podem ser simulados.

Neste passo, é oportuno retomar uma passagem da obra de Mirabelli em que ele reconhece que a formação de um acordo tendente a modificar a natureza, e consequentemente a eficácia, dos atos não negociais, poderia induzir o público ao engano. Ao tratar da voluntária modificação das participações, o autor afirma que os terceiros que extraíssem conclusões inexatas da conclusão do ato poderiam ser tutelados apenas nos limites da eventual relevância da sua boa-fé ${ }^{547}$. O engano decorrente da manipulação da eficácia de um ato não negocial poderia ser esclarecido por um exemplo dado pelo próprio autor: Caio é proprietário de um terreno no qual se encontram materiais de construção de propriedade de Tício; Caio acorda com Tício que utilizará os referidos materiais de construção, e que, uma vez concluída a obra, a propriedade desta não lhe seja transferida, mas permaneça sob a titularidade de Tício. Eles acordam, ainda, que este pacto deve ser mantido em segredo, para que terceiros possam acreditar que Caio tenha se tornado proprietário do prédio ${ }^{548}$.

Nesta hipótese, as partes conseguiriam modificar a eficácia de um ato exterior transformando-o em um ato material contratualmente disciplinado. Os efeitos que a lei prevê somente seriam produzidos enquanto o ato não tivesse formado objeto de uma contratação entre os sujeitos interessados. Quando o ato fosse precedido de um acordo que regulasse os seus efeitos, este perderia a natureza de ato com efeitos legais e se

\footnotetext{
${ }^{544}$ Atualmente disciplinada pelo artigo 1276.

${ }^{545}$ F. C. PONTES DE MiRANDA, Tratado... cit. (nota 220), p. 522-523.

${ }^{546} \mathrm{~V}$. tópico 28.

${ }^{547}$ G. MiRABELLI, L'atto non negoziale... cit. (nota 499), p. 343-435.

${ }^{548}$ G. MiRABELLI, L'atto non negoziale... cit. (nota 499), 147-148.
} 
transformaria em ato material, ao qual se coligariam efeitos contratuais ${ }^{549}$. Mirabelli reconhece, nestes termos, que a autonomia privada possuiria força determinante também em um campo do qual parecia ter sido absolutamente excluído, isto é, aquele dos atos com eficácia legal ${ }^{550}$. A despeito da consistência de suas formulações, o autor nega que haveria, na espécie, simulação.

Tal conclusão, no entanto, somente poderia ser acolhida com base em uma concepção do fenômeno simulatório diversa da que defendemos. Uma vez que se entenda que a simulação é fruto de uma operação negocial voltada a iludir a confiança do público, não há como deixar de vislumbrar, numa situação como a acima referida, o acima demonstrado, o engano que constituiria o escopo do negócio simulado.

Demais disso, torna-se ainda mais evidente a distinção que traçamos, em diversas passagens deste trabalho, entre o negócio simulado e ao "negócio aparente" (i.e. aparência que reveste o primeiro). O contrato que, segundo aduz Mirabelli no excerto acima reproduzido, altera a natureza do ato não negocial, é o próprio negócio simulado; aquele que, como diz a lei, "aparenta", afigura-se "não verdadeiro". O negócio simulado, com seu peculiar conteúdo convencional, converte o ato não negocial em mero índice de significação, induzindo, deste modo, o público a formar uma equivocada representação da realidade.

Bem se vê, portanto, que a proteção que o legislador de 2002 buscou conferir às vítimas da ilusão criada pela simulação do ato não negocial vai além daquela reconhecida por Mirabelli. Estes podem, com efeito, pleitear a declaração de nulidade do ato, ou, se lhes for conveniente, a manutenção dos efeitos derivados da aparência criada.

\section{Negócios unilaterais}

É controversa a possibilidade de configurar-se a simulação quanto a negócios unilaterais.

Na Alemanha, o $§ 117$ do Código Civil estabelece que somente são simuláveis os atos unilaterais receptícios, isto é, aqueles em que a declaração de vontade seja direcionada

${ }^{549}$ G. MiRABELLI, L'atto non negoziale... cit. (nota 499), p. 148.

${ }^{550}$ G. MirabelLI, L'atto non negoziale... cit. (nota 499), p. 149. 
a um sujeito específico, a despeito da caracterização deste como parte. Em vista disso, a doutrina alemã tem uniformemente restringido o âmbito da simulação dos negócios unilaterais àqueles que possuam destinatário determinado ${ }^{551}$.

Na Itália, o terceiro parágrafo do artigo 1414 estatui que as disposições ali contidas também se aplicam "aos atos unilaterais destinados a uma pessoa determinada, que sejam simulados por acordo entre o declarante e o destinatário". A despeito da aparente univocidade do texto normativo, diversas teorias têm surgido a respeito de sua aplicação. A posição doutrinária majoritária, fiada na literalidade da norma, defende, assim como os alemães, que apenas os negócios unilaterais receptícios seriam simuláveis.

Ainda sob a vigência do Código Civil italiano de 1865, Ferrara sustentava que seria impossível a simulação de todo e qualquer ato unilateral. "Como a simulação requer o concurso de várias partes contratantes, está excluída do campo dos actos unilaterais, e, se o declarante tem uma vontade oposta ao que declara, isto constitui reserva mental e não simulação" $" 552$.

Para Pugliatti, esta posição seria um tanto intransigente ${ }^{553}$. Contudo, assinala o autor, as críticas que foram formuladas à opinião de Ferrara não se mostravam convincentes. Afirmava-se que, no negócio unilateral receptício, o terceiro destinatário da declaração colaboraria com o seu aperfeiçoamento; a recepção tornar-se-ia, assim, parte da declaração de vontade. Mas esta formulação teria sido rebatida pelo próprio Ferrara, o qual acentuava que a declaração de vontade seria fruto exclusivo da atividade do declarante, e, a despeito da recepção, o terceiro não se tornava parte do negócio jurídico ${ }^{554}$.

Diante disso, Pugliatti sublinha que a discussão pautada nestes termos necessariamente seria infrutífera. Cumpria verificar, no que se referisse aos negócios unilaterais, qual seria o efeito de um acordo simulatório firmado entre o declarante e o terceiro destinatário da declaração.

\footnotetext{
${ }^{551}$ ENNECCERUS - H. C. NiPPERdey (Derecho Civil... cit., nota 43), p. 319, nota 6; W. Flume, El negocio jurídico cit. (nota 43), p. 483; e A. Von TuHR, Derecho Civil... cit. (nota 431), p. 503.

${ }^{552}$ F. Ferrara, A simulação... cit. (nota 20), p. 143.

${ }^{553}$ S. PUGLIATTI, La simulazione... cit., (nota 53), p. 568;

${ }^{554}$ S. Pugliatti, La simulazione... cit., (nota 53), p. 569.
} 
O autor adota, como ponto de partida, a diferença entre os negócios unilaterais receptícios e não receptícios. No caso dos primeiros, pressupor-se-ia a individualização do destinatário; já os segundos produziriam efeitos em face de uma esfera larga de interessados. Desse modo, relativamente aos atos receptícios, apenas, seria concebível um acordo simulatório, firmado entre o emitente da declaração negocial e o sujeito preventivamente individualizado como seu destinatário ${ }^{555}$. Na hipótese de um negócio não receptício, ainda que não fosse o caso de excluir-se completamente a existência de um acordo entre o declarante e um destinatário em especial, o fato de este não figurar como parte do negócio simulado faria com que a sua colaboração com a simulação não tivesse o mesmo valor que nos negócios receptícios ${ }^{556}$.

A opinião de Pugliatti, acima descrita, é uma decorrência direta de sua concepção do acordo simulatório como negócio nominado, dotado da causa típica consistente em destruir ou modificar a causa do negócio simulado ${ }^{557}$. Causa certa apreensão, ao leitor do ensaio deste magnífico jurista, a aparente contradição entre a autonomia conferida ao acordo simulatório e a conclusão de que apenas nos negócios receptícios o terceiro poderia figurar como parte da simulação. Tudo indica que isto decorreria do fato de o terceiro ser predeterminado como destinatário da declaração; contudo, há de se convir que o critério não se mostra isento de críticas. Se o acordo simulatório e o negócio simulado são "congruentes", como quer fazer crer Pugliatti, o que impossibilitaria que um terceiro fosse designado a figurar como parte, exclusivamente, do acordo simulatório?

Este aspecto não escapou à arguta percepção de Giampiccolo, o qual defendeu, contrariamente à literalidade do artigo 1414 do Código Civil italiano, que também os negócios unilaterais não receptícios poderiam ser simulados.

Este autor defende que, mais do que se apegar à literalidade do texto normativo, o intérprete deveria perseguir a ratio que subjaz ao seu sentido ${ }^{558}$. A mens legis por detrás da norma em apreço poderia ser investigada a partir de um trecho da Relazione ao Código Civil italiano segundo o qual, no que tange à simulação de atos unilaterais destinados a pessoa determinada, ter-se-ia levado em consideração a possibilidade de se formar um

\footnotetext{
${ }^{555}$ S. PugliatTi, La simulazione... cit., (nota 53), p. 570.

${ }^{556}$ S. Pugliatti, La simulazione... cit., (nota 53), p. 570

${ }^{557}$ S. PUGLIATTI, La simulazione... cit., (nota 53), p. 571-572.

${ }^{558}$ G. GiamPICCOLO, La dichiarazione recettizia (1959), Napoli, Edizioni Scientifiche Italiane, 2011, p. 247.
} 
acordo dirigido a simular o ato ${ }^{559}$. Ao assim se expressar - explica Giampiccolo - o legislador italiano não teria concebido o terceiro destinatário da declaração como colaborador da atividade negocial, mas como contrainteressado na repercussão que a simulação poderia surtir sobre a sua posição jurídica; o terceiro, portanto, não seria partícipe da produção do efeito, mas destinatário do efeito ${ }^{560}$.

Além disso, o autor enfatiza que o critério da recepticiedade da declaração houvera sido mal compreendido pela doutrina ${ }^{561}$. Não seria correto dizer que o terceiro destinatário da declaração cooperaria com o aperfeiçoamento do ato. Uma colaboração do gênero, acaso se insistisse em identificá-la, seria meramente passiva, logo, não penetraria no processo formativo da declaração. Assentada esta premissa, seria idêntica a posição do destinatário de toda declaração emitida, fosse receptícia ou não receptícia ${ }^{562}$. O paradigma da recepticiedade não apresentaria perfeita correspondência com a hipótese de uma determinação subjetiva do terceiro interessado no ato: do mesmo modo que se dariam declarações receptícias in incertam personam, bem poderia ser não receptícia uma declaração a contrainteressado determinado (ex. reconhecimento de débito, convalidação de contrato etc. $)^{563}$.

Em vista disso, a tomada de posição quanto ao problema da simulação dos negócios unilaterais repousaria, sim, sobre a relevância atribuída ao acordo simulatório; este, contudo, não seria obra do querer exclusivo das partes do negócio aparente, mas de todos que nutrissem interesse sobre o "acordo de ficção" que caracteriza a relação jurídica criada com a simulação ${ }^{564}$. Para Giampiccolo, portanto, o discrímen da recepticiedade não desempenharia um papel decisivo e a norma do terceiro parágrafo do artigo 1414 deveria

\footnotetext{
${ }^{559}$ G. GIAMPICCOLO, La dichiarazione recettizia cit. (nota 558), p. 253.

${ }^{560}$ G. GIAMPICCOLO, La dichiarazione recettizia cit. (nota 558), p. 253.

561 Segundo G. GIAMPICCOLO (La dichiarazione recettizia cit., nota 558, p. 43 ss.), o caráter receptício de uma declaração deveria ser investigado a partir da natureza e do conteúdo desta. Com base nesta aproximação, seria possível identificar dois grupos de declaração receptícias. O primeiro deles englobaria aquelas declarações quanto às quais o conhecimento do terceiro seria condição necessária a que aquelas pudessem exercer sua função prática; a exigência de uma direção ao terceiro seria interna à estrutura do ato. No segundo dos referidos grupos estariam compreendidas as declarações que, embora possam ser produzidas solitariamente, em virtude de serem destinadas a influir sobre a esfera de direitos de terceiros, devem chegar ao conhecimento destes; aqui a direção ao terceiro exerce uma função instrumental. No primeiro dos mencionados grupos estariam, por exemplo, a oferta de contrato e a notificação; já no segundo encontrar-seiam a declaração de escolha do devedor, a revogação de proposta comercial e as instruções do contratante de transporte. Seriam não receptícias, por outro lados, as declarações de ciência, como a confissão.

${ }^{562}$ G. GIAMPICCOLO, La dichiarazione recettizia cit. (nota 558), p. 249.

${ }^{563}$ G. GIAMPICCOLO, La dichiarazione recettizia cit. (nota 558), p. 255.

${ }^{564}$ G. GIAMPICCOLO, La dichiarazione recettizia cit. (nota 558), p. 251.
} 
ser interpretada, segundo a melhor técnica, de maneira extensiva, considerando-se aplicável a todo negócio unilateral (receptícia ou não receptícia) que tivesse um contrainteressado subjetivamente determinado ${ }^{565}$.

Também para Marani, o parâmetro segundo o qual deveria ser verificada a simulabilidade dos negócios unilaterais não haveria de consistir na recepticiedade da declaração. O papel deste requisito seria circunscrito ao episódio da formação do negócio, em que o destinatário é considerado passivamente como termo estático do procedimento declarativo. Na simulação, ao invés, seria requerida a participação ativa do terceiro destinatário da declaração, de modo a configurar-se a formação positiva do acordo, excluindo-se a hipótese de este se materializar com o simples conhecimento das intenções simulatórios manifestadas pelo declarante. "Diria, para concluir o ponto, que a expressa postulação do requisito do acordo tem o significado de retirar toda a importância que a recepticiedade ocupa no caso" ${ }^{\circ 66}$.

De acordo com o autor, a simulação caracterizar-se-ia pela exclusão da vinculatividade mediante o emprego do aparato negocial para fins não negociais. Em vista disso, o acordo entre o declarante e o contrainteressado no negócio unilateral seria condição da eliminação do vínculo negocial. Se não houvesse uma conexão entre o terceiro destinatário da declaração e a parte substancial do negócio jurídico, seria impossível, a despeito do acordo, concretizar-se a simulação. Daí o autor entender, como Giampiccolo, que o terceiro parágrafo do artigo 1414 do Código Civil italiano ter-se-ia referido, ao disciplinar a simulação dos negócios unilaterais, às declarações emitidas em direção a um contrainteressado subjetivamente determinado ${ }^{567}$.

Enfatiza, contudo, Marani, que a possibilidade de simular-se negócios unilaterais encontrar-se-ia subordinada à preventiva identificação do terceiro interessado na simulação. Com base neste parâmetro, o autor defende que alguns atos unilaterais não seriam simuláveis, ou pela ausência de terceiro contrainteressado, ou pela impossibilidade de sua preventiva identificação. Refere-se, neste particular, aos exemplos da renúncia, do

\footnotetext{
${ }^{565}$ G. GIAMPICCOLO, La dichiarazione recettizia cit. (nota 558), p. 251.

${ }^{566}$ F. MARANI, La simulazione... cit. (nota 246), p. 177-178.

${ }^{567}$ F. MARANI, La simulazione... cit. (nota 246), p. 178
} 
testamento, da promessa ao público, e dos títulos de crédito ${ }^{568}$. Para compreendermos melhor a posição do autor, e colocarmo-nos em posição propícia a examiná-la criticamente, vejamos como ele aborda a impossibilidade de simular-se a promessa ao público.

Segundo Marani, a promessa unilateral endereçada ao público criaria uma obrigação, ao declarante, sem a prévia identificação de um sujeito ativo. Desse modo, o declarante assumiria a condição de sujeito passivo ao passo que o credor somente tornarse-ia conhecido em momento futuro, quando da realização de um ato ou da verificação de um fato previsto no regulamento negocial. Em tais circunstâncias, seria impossível a formação de um acordo simulatório, em sentido próprio $^{569}$.

Apenas para ilustrar o debate que se poderia instalar quanto ao posicionamento que acabamos de descrever, vale trazer à colação a opinião de Pontes de Miranda, segundo a qual a promessa ao público poderia ser simulada, absoluta ou relativamente: "[o] que simula promessa de recompensa para doar está exposto a que o interessado no objeto da recompensa, que satisfaça o que se exigiu, promova a anulação; e.g., trata-se do executor testamentário que tinha de fazer promessa ao público em que a recompensa seria quadro célebre, e em verdade doou a alguém que instruiu para se utilizar da simulação, ou apenas, sem acôrdo, fêz ser o único beneficiável"570.

A contraposição entre os entendimentos acima referidos suscita nossa reflexão, a qual, como não poderia deixar de ser, conduziremos à luz de nosso entendimento sobre a configuração e a operatividade do fenômeno simulatório.

Conforme já assinalamos ${ }^{571}$, não se mostra logicamente consistente assumir os contornos substanciais do "negócio aparente" como fatores limitantes da simulação, mormente porque aquele, entendido como produto da ilusão negocial, consiste tão somente na representação ideal que os terceiros são capazes de formular a partir dos índices de significação criados pelos simuladores. A questão que se deve enfrentar, portanto,

\footnotetext{
${ }^{568}$ F. MARANI, La simulazione... cit. (nota 246), p. 179-180; 190 ss.; 202 ss.; 228 ss.

${ }^{569}$ F. MARANI, La simulazione... cit. (nota 246), p. 228-229.

${ }^{570}$ F. C. PONTES DE MiRANDA, Tratado... cit. (nota 220), p. 521.

${ }^{571} \mathrm{~V}$. tópico 44.
} 
relaciona-se às restrições que se imporiam à criação de uma aparência que remetesse o público à imagem de um negócio unilateral.

A simulação funda-se sobre um comportamento negocial instrumental. $O$ regulamento de interesses estabelecido entre as partes não consiste, ainda que se trate de simular um negócio unilateral, num invólucro oco, desprovido da natural vinculatividade, mas num programa negocial complexo e pleno de conteúdo, pelo qual as partes coordenam esforços para a produção da ilusão negocial.

Evidentemente, um simulador não seria capaz de se valer de uma declaração negocial unilateral, como mero índice de significação, se agisse sozinho; quando muito, haveria, na espécie, reserva mental, a qual, se desconhecida do público, não assumiria qualquer relevância jurídica. Porém, se o declarante ajustasse com um terceiro - o qual, neste contexto, dever-se-ia reputar preventivamente identificado - o estabelecimento de um programa simulatório, disto poderia surgir uma ruptura no plano da realidade jurídica, permanecendo, no plano levado ao conhecimento do público, a simples aparência.

Nessa ordem de ideias, é de se notar que o negócio simulado é sempre bilateral. Ainda que ele crie uma ilusão negocial consistente num negócio unilateral, será um negócio bilateral sob as vestes de um negócio unilateral; um negócio jurídico que não deixa entrever a dimensão da bilateralidade, induzindo o público, equivocadamente, a qualificá-lo como unilateral, logo, precisamente, o instrumento de que se valem as partes para a consecução de desígnios simulatórios.

A adoção deste modo de pensar submete o tema da simulabilidade do negócio unilateral aos pressupostos que lhe são pertinentes, os quais nos permitem apreender o sentido concreto da tese de Giampiccolo, assim sintetizado pelo autor ${ }^{572}$ :

Se o elemento central da simulação é, de fato, o acordo simulatório com o contrainteressado, é evidente que a hipótese é por si concebível tanto no negócio bilateral ou plurilateral, como no negócio unilateral; depende,

\footnotetext{
${ }^{572}$ G. GIAMPICCOLO, La dichiarazione recettizia cit. (nota 558), p. 251-252. Tradução livre; no original: "Se l'elemento centrale della simulazione è infatti l'intesa simulatoria col controinteressato, è evidente che l'ipotesi è per se concepibile tanto nel negozio bilaterale o plurilaterale quanto nel negozio unilaterale; dipende semmai dal fatto che un accordo idoneo a coprire l'intera area degli interessi in gioco si possa in concreto realizzare, se una simulazione sarà, poi, o meno, configurabile: finché non si raggiunge, infatti, l'intesa fra tutti gli interessati, l'atto di autonomia conserva integra la sua funzione e, per conseguenza, il negozio non può definirsi apparente o, se si vuole, simulato".
} 
sobretudo do fato de um acordo idôneo a cobrir a inteira área dos interesses em jogo poder-se concretamente realizar se uma simulação será, ou não, configurável: até que seja alcançado, de fato, o acordo entre todos os interessados, o ato de autonomia conserva íntegra a sua função e, por consequência, o negócio não se pode definir aparente ou, caso se queira, simulado.

Valha-se, pela simplificação do discurso, do exemplo, já abordado, da promessa ao público. Considere-se que o declarante ajuste com um terceiro a simulação absoluta do negócio jurídico. Entre o declarante, e este terceiro, estaria claro que a declaração emitida não deveria implicar qualquer consequência jurídica. Apesar disso, nenhum outro sujeito teria acesso a esta informação, e se qualquer deles viesse a cumprir a condição para o pagamento da recompensa, poderia, sem dúvida alguma, exigi-lo perante o promitente. A simulação não surgiria, neste caso, porque o acordo sobre a simulação não teria atingido toda a área dos interesses em jogo. Dessa feita, para que se pudesse cogitar da simulação absoluta de uma promessa de recompensa, todos os terceiros destinatários da declaração deveriam figurar como parte do negócio simulado. Se, por exemplo, a promessa fosse endereçada aos associados de um clube de campo, todos deveriam assentir com a não vinculação do declarante, e, ademais, comportar-se como se a promessa fosse genuína, de modo a instaurar-se a aparência que poderia enganar outros terceiros que não se incluíssem neste hipotético grupo.

Muito diferente seria aquela situação, tal qual a imaginada por Pontes de Miranda, em que o declarante pretendesse doar o bem a um sujeito específico. Como se vê, a identificação preventiva deste sujeito não seria determinada pelo negócio simulado, mas pelo negócio dissimulado. Para atingir seus objetivos, os simuladores fariam constar, do instrumento negocial, uma condição tal que somente pudesse ser atendida pelo pretenso donatário. O negócio jurídico assim celebrado, a despeito de sua bilateralidade, afigurar-seia, aos olhos do público, como um negócio unilateral.

Deve-se notar, neste último caso, que a dissimulação limitaria a área dos interesses em jogo, pois os demais destinatários da promessa passariam a figurar como terceiros enganados pela ilusão negocial. Assim, a declaração unilateral ostentaria a condição de índice de significação na medida em que a realidade negocial subjacente - a doação -, a um só tempo, ditaria o teor da relação global estabelecida entre os simuladores, assim como tornaria inócua (desprovida de potencial eficacial) a promessa endereçada ao público, em razão da eleição de uma condição que somente pudesse ser atendida por um 
sujeito, não coincidentemente, o pretenso donatário da recompensa; ou, alternativamente, se todos os potenciais contrainteressados na declaração soubessem da doação em curso.

À luz de todas estas ponderações, somos da opinião de que a simulação de negócios unilaterais, receptícios ou não receptícios, depende da adesão dos terceiros contrainteressados na declaração, assim como da preventiva identificação destes. Esta identificação, contudo, não se pauta, pelo aspecto substancial do "negócio aparente", uma vez que, sendo este o produto da ilusão negocial, não é mais que a aparência enganadora que se comunica ao público. Assim, a individualização dos contrainteressados dá-se com base no aspecto substancial da simulação, ou seja, no engajamento quanto ao estabelecimento dos índices de significação que remetem à situação jurídica fictícia (o “negócio aparente"). É assim que se justifica a possibilidade de simular-se a promessa ao público antes mesmo de se conhecer o sujeito ativo da obrigação; posição jurídica que, de mais a mais, também é abrangida pelo procedimento simulatório.

Nada obstante, Marani tem razão ao dizer que somente poderiam ser contrainteressados aptos a participarem da simulação - substancialmente legitimados - os terceiros em face dos quais fosse emitida a declaração unilateral, ou seja, aqueles que se encontrassem no raio de eficácia do negócio unilateral. Assim não fosse, seria impossível tornar a declaração negocial um índice de uma relação jurídica meramente aparente. Pensese, novamente, na promessa de recompensa endereçada aos associados de um clube um clube de campo; de que adiantaria o declarante compartilhar, por exemplo, com um tio seu, a intenção de simular, se este não fosse associado ao clube de campo? Não haveria, neste caso, espaço para o que acima denominamos "ruptura no plano da realidade jurídica", porquanto, considerando-se todos os interesses em jogo (i.e. os interesses do declarante, assim como aqueles dos associados ao clube de campo), a promessa realizada figuraria como firme, válida e eficaz, não como índice de uma ilusão negocial.

Observadas estas premissas, perfilhamos o entendimento de Pontes de Miranda ${ }^{573}$ segundo o qual é possível simular não apenas a promessa ao público, como, também, o testamento, a outorga de poder e a revogação $0^{574}$. A simulabilidade de declarações não

${ }^{573}$ F. C. POnTES De MiRAnda, Tratado... cit. (nota 220), p. 522.

${ }^{574}$ No mesmo sentido: L. B. GERI, Appunti in tema di simulazione del testamento in Rivista trimestrale di diritto e procedura civile, Milano, 1962, p. 1278-1280; S. RoMANO, Contributo esegetico... cit. (nota 53), p. 
receptícias é, ainda, confirmada pelo direito positivo, na medida em que este prevê, explicitamente, a simulação da confissão, que é ato não negocial derivado de uma declaração não receptícia ${ }^{575}$.

\section{Sociedade: o debate em torno da simulabilidade}

A simulação da sociedade tem suscitado acirrados debates.

Na Itália, a doutrina se divide. Parte dos autores entende que a sociedade não poderia ser simulada pois a criação da pessoa jurídica pressuporia a intervenção de uma autoridade pública. "[M]esmo supondo que os contraentes não tenham a intenção de realizar o acto e queiram simplesmente produzir a sua aparência, o oficial público ignora as suas secretas resoluções e a elas se conserva extranho, pelo que o acto tem plena eficácia, existindo somente uma dupla reserva mental, não uma simulação, que exigiria um acordo de todas as partes na ficção posta em prática"576. Diante do conflito entre a vontade de praticar a simulação e a vontade de praticar o ato societário, esta última preponderaria, razão pela qual, com a completude do ato constitutivo da sociedade, mediante os trâmites requeridos à sua publicidade, o seu surgimento seria inevitável ${ }^{577}$.

Segundo esta vertente teórica, o direito positivo consideraria necessária e suficiente, a integrar a causa típica do contrato de sociedade a declaração de dois ou mais sujeitos de querer exercitar uma atividade econômica com fim de lucro. Em contrapartida, não se requereria que a declaração correspondesse, na realidade concreta, à realização da referida causa. A intervenção da autoridade pública no procedimento complexo de constituição da sociedade seria determinante para a sua existência. A criação de um novo sujeito de direito, à qual daria ensejo o registro dos atos constitutivos da sociedade, não poderia ser eliminada por um pacto extra-social, como o acordo simulatório. Deveras, a autoridade não teria condições de verificar, no ato da inscrição, se efetivamente o quanto declarado pelos sócios fundadores poderia ser desnaturado pela existência de uma contradeclaração dirigida em sentido oposto, com a consequência que, privilegiando os

60-61. Contra: F. FERrara, A simulação... cit. (nota 20), p. 143 ss; N. DistASO, La simulazione... cit. (nota 40), p. 301 ss.

${ }^{575}$ G. GIAMPICCOLO, La dichiarazione recettizia cit. (nota 558), p. 54-58.

${ }^{576}$ F. FERRARA, A simulação... cit. (nota 20), p. 125-127.

${ }^{577} \mathrm{P}$. GRECO, Le società di "comodo"e il negozio indiretto in Rivista del diritto commerciale e del diritto generale delle obbligazioni, Milano, v. XXX, $1^{\mathrm{a}}$ parte, 1932, p. 766-767. 
ideais de certeza e previsibilidade, o direito preferiria excluir a priori uma semelhante eventualidade $^{578}$. As partes não poderiam simular a vontade de constituir a sociedade senão querendo efetivamente a sua conclusão formal e aparente. No caso de simulação do ato constitutivo, a situação jurídica aparente seria precisamente representada pela constituição a sociedade ${ }^{579}$.

Por outro lado, uma respeitável parcela da doutrina italiana sustenta a possibilidade da simulação da sociedade, tanto a de pessoas, como a de capital. Segundo

${ }^{578}$ L. SANTA MARIA, Società e simulazione, società e comunione di godimento in Rivista trimestrale di diritto e procedura civile, Milano, n.1, Marzo, 1995, p. 212.

${ }^{579}$ L. SANTA MARIA, Società e simulazione... cit. (nota 578), p. 213ss. Para ilustrar seu ponto de vista, L. SANTA MARIA lança mão de dois exemplos. O primeiro deles é o da chamada "sociedade de prateleira": duas secretárias de um escritório de comercialistas constituem uma sociedade, com a observência de todas as formalidades pertinentes, para que possa acolher, como futuros e efetivos sócios, clientes do mencionado escritório $^{579}$. O segundo exemplo a que alude o autor é o da chamada "sociedade de deleite": duas ou mais pessoas constituem uma sociedade que adquire a titularidade de bens imóveis entregues, por um dos sócios, a título de integralização de capital, e limita-se a dá-los em locação ao referido sócio, o mais das vezes sem prestar quaisquer serviços complementares.

De acordo o autor, tais situações não dariam azo à simulação, pois, quando duas pessoas concordassem em dar vida, segundo as disposições da lei, a uma sociedade, tornar-se-ia totalmente inócua a vontade de que isto não ocorresse. Uma vez constituída, a sociedade concretamente existiria, e se os sócios quisessem extinguila, deveriam deliberar a sua dissolução. No exemplo da sociedade de deleite, as partes pretenderiam realizar a gestão de um bem sob a forma de sociedade, logo, quereriam os efeitos desta. Haveria, aí, uma espécie de negócio indireto, pois o contrato de sociedade resultaria querido, e, consequentemente, não poderia ser tachado de aparente.

O autor assinala, ainda, que a divergência entre a atividade declarada e a atividade desempenhada não obstaria à validade do registro. O que interessaria, para a existência e a validade da sociedade, seria o objeto indicado no estatuto, não aquele efetivamente exercitado. Desse modo, apenas a atividade declarada perante o registro de comércio que importaria para a constituição da sociedade.

A divergência entre a atividade declarada e a atividade desempenhada não obstaria à validade do registro. $\mathrm{O}$ que interessaria, para a existência e a validade da sociedade, seria o objeto indicado no estatuto, não aquele efetivamente exercitado. Desse modo, apenas a atividade declarada perante o registro de comércio que importaria para a constituição da sociedade.

$\mathrm{Na}$ obstante, o fato de a sociedade ter sido legalmente constituída não impediria que o intérprete procedesse à superação da personalidade jurídica em particulares condições. Quando a sociedade fosse constituída instrumentalmente, com o fim precípuo (não declarado) de eludir direitos de terceiros, a sua existência não seria obstáculo a que o intérprete procurasse uma solução alternativa, capaz de privilegiar os interesses de terceiros.

Para explicar como isto se daria, o autor se vale de outro exemplo. Um tal Sr. White seria titular de $94 \%$ das ações da sociedade de capital "X" (a qual teria capital social de 5 milhões de dólares), e da totalidade das ações da sociedade de capital "Z\&B" (cujo capital social remontaria a 200 mil dólares) As duas sociedades teriam como presidente e administrador o Sr. White, seriam sediadas no mesmo endereço, e contariam com o mesmo grupo de empregados. A sociedade " $X$ " teria adquirido um lote edificável, e sucessivamente, teria contratado a sociedade "Z\&B" para construir o prédio. Todos os pagamentos devidos a fornecedores de materiais para a obra seria realizados com recursos disponibilizados pela sociedade " $X$ ", sem que surgisse a necessidade, da sociedade "Z\&B", de recorrer a empréstimos bancários. Por fim, uma parte dos débitos da sociedade "Z\&B" não seria paga, e um dos credores pretenderia que a sociedade " $\mathrm{X}$ " arcasse com a dívida inadimplida, sustentando que, na realidade, a sociedade "Z\&B" teria sido constituída com o objetivo de limitar a sujeição patrimonial da sociedade "X".

Neste caso, a fraude perpetrada pela sociedade " $X$ " autorizaria a desconsideração da personalidade jurídica da sociedade "Z\&B". Não seria possível alegar-se a simulação, pois a desconsideração da personalidade jurídica seria a solução cabível diante do abuso da constituição da sociedade. 
esta linha de raciocínio, a participação da autoridade pública no processo de criação da pessoa jurídica teria caráter meramente declaratório, e como tal, não passaria de um requisito imposto à regularidade do contrato de sociedade. A sociedade surgiria em virtude da manifestação da vontade dos sócios fundadores, razão pela qual o registro dos seus atos constitutivos teria mero caráter declarativo. Por conseguinte, seria possível a simulação, sendo certo que o registro do contrato social, ou do estatuto, não sanaria eventuais vícios que ele apresentasse ${ }^{580}$.

Nesse sentido, Schermi assevera que não haveria razões que impedissem o reconhecimento da simulação da sociedade. Poder-se-ia aduzir, perante o juízo, que, simuladamente, teria sido constituída a organização ordenante societária - ou, até mesmo, um grupo de sociedades. Seria possível demonstrar, se fosse o caso, que a atividade empreendedora, indicada no ato constitutivo, seria exercitada por uma única pessoa (empresário individual), o qual haveria de responder ilimitadamente pelas obrigações assumidas no exercício daquela atividade. Seria cabível, ainda, atestar que sócios aparentes não exerceriam qualquer atividade empresarial em comum, sendo, porém, coproprietários de um direito real sobre um ou mais bens Diante desse quadro, não haveria razões que impedissem o reconhecimento da simulação da sociedade. Poder-se-ia aduzir, perante o juízo, que, simuladamente, teria sido constituída a organização ordenante societária - ou, até mesmo, um grupo de sociedades. Seria possível demonstrar, se fosse o caso, que a atividade empreendedora, indicada no ato constitutivo, seria exercitada por uma única pessoa (empresário individual), o qual haveria de responder ilimitadamente pelas obrigações assumidas no exercício daquela atividade. Seria cabível, ainda, atestar que sócios aparentes não exerceriam qualquer atividade empresarial em comum, sendo, porém, coproprietários de um direito real sobre um ou mais bens ${ }^{581}$.

\footnotetext{
${ }^{580}$ A. BUterA, Della simulazione... cit. (nota 20), p. 136 ss.; N. Distaso, La simulazione... cit. (nota 40), p. 283 ss.

${ }_{581}$ A. SCHERMI, Simulazione e gruppi di società in Giustizia civile, Milano, v. XLVII, Giugno, 1997, p. 335 ss. Para o autor, não seria correto dizer que os sujeitos que estipulassem um contrato de sociedade pretenderiam realizar e conservar ao menos um dos seus efeitos - a constituição de uma pessoa jurídica -, ainda que por um limitado arco de tempo.O contrato seria um acordo voltado ao desempenho de uma função concreta; uma autorregulamentação de interesses divergentes ou convergentes caracterizado $\mathrm{e}$ individualizado pela sua causa concreta. A causa concreta do ato constitutivo de uma sociedade seria a criação de uma organização que, efetivamente, proporcionasse o exercício de uma atividade empreendedora. Apenas se esta causa concreta se tornasse operativa entre as partes poder-se-ia atribuir, ao contrato, a qualificação e a disciplina jurídica típicas do contrato de sociedade. Em suas palavras:
} 
Na França, a doutrina majoritária ${ }^{582}$ reconhece a possibilidade da simulação da sociedade, tanto a de pessoas como a de capital. Segundo Dagot, uma vez admitida a natureza contratual da sociedade, a simulação deve reputar-se viável; demais disso, a opinião contrária não poderia ser defendida com base na necessidade de proteger os direitos de terceiros, pois o regime próprio da simulação seria suficiente para preservar as posições jurídicas baseadas na aparência maliciosamente criadas pelos pretensos sócios. A hipótese mais frequente de "société fictive" seria aquela em que falta a affectio societatis $^{583}$. Sobre o tema, são esclarecedoras as palavras de Dubois-de Luzy ${ }^{584}$ :

Mesmo que a realidade seja diferente, a sociedade fictícia apresenta-se à plena luz jurídica como real: as formalidades de constituição, incluindo e publicidade, foram concluídas, o nome e a sede foram selecionados, os órgãos da sociedade agem em seu nome. No entanto, a empresa fictícia na verdade não existe (...) Nestes fantasmas legais, a vontade de participar de uma empreitada comum para compartilhar os benefícios que disto podem resultar é completamente ausente: não há affectio societatis.

A sociedade seria simulada com vistas a, artificialmente, proporcionar a separação de parte do patrimônio dos sócios, ou, ainda, para dissimular a presença de um outro contrato, como o contrato de prestação de serviços ou de trabalho ${ }^{585}$. Segundo Abeille, a simples exteriorização, desacompanhada da materialização, tornaria a sociedade instrumento de um ilusão de ótica. Haveria de se distinguir, de um lado, a constituição legal, e, de outro, a constituição real da sociedade; se faltasse a segunda, a sociedade seria apenas aparente. Isto implicaria a conclusão de que a realidade do contrato, como do ente moral, seria distinta da sua validade ${ }^{586}$.

\footnotetext{
“A mim parece, porém, que o ordenamento jurídico opera na realidade social, sobre posições e vicissitudes humanas: operatividade, do ordenamento jurídico, receptiva (prévia valoração positiva), qualificadoras e regulamentadoras das posições e vicissitudes humanas. E então a gênese, no âmbito social, de uma organização ordenanente efetivamente existente, é pressuposto necessário da operatividade qualificadora do ordenamento jurídico consistente na atribuição de personalidade jurídica à oganização ordenante complexa. Então, se a organização não surge na vida social, é mera aparência, logo, pode haver simulação".

${ }^{582} \mathrm{O}$ testemunho disso nos é dado por M. DAGOT, La simulation... cit. (nota 50), p. 64; 260.

${ }^{583}$ J. ABEILle, De la simulation... cit. (nota 374), p. 165.

584 A. DUBOIS-DE LUZY (Interposition de personne cit., nota 469, p. 93-94). Tradução livre; no original: "Alors même que la réalité est autre, la société fictive se présente à pleine lumière juridique comme réelle : les formalités de constitution, e compris de publicité, ont été accomplies, l'appellation et le siège social ont été choisis, les organes de la société agissent en son nom. Pourtant, la société fictive n'existe pas réellement (...) Dans ces fantômes juridiques, la volonté de s'associer à une œuvre commune en vue de partager le bénéfice qui pourrait en résulter fait complément défault : il n'y a aucune affectio societatis".

${ }^{585}$ M. DAGOT, La simulation... cit. (nota 50), p. 64 ss.

${ }^{586}$ J. ABEILle, De la simulation... cit. (nota 374), p. 165 ss.
} 
A ilusão fundada na aparência da sociedade poderia derivar simplesmente nos atos constitutivos, devidamente publicizados e registrados, assim como em outros índices, como, por exemplo, a existência de escritórios e a contratação de colaboradores. A sociedade simulada, ademais, deveria revestir-se da aparência de validade, pois seria contrário ao objetivo dos simuladores que a sociedade pudesse ser impugnada com base na invalidade exterior de sua constituição. Comprovada a simulação, a sociedade fictícia seria declarada inexistente, ao passo que a relação jurídica dissimulada seria tida como existente $^{587}$. As principais manifestações da sociedade simulada seriam:

(a) sociedade unipessoal: uma sociedade apresenta todas as características de uma sociedade real e regular, mas, na verdade, todas as suas atividades são voltadas à satisfação de um único associado ${ }^{588}$; e

(b) grupo de sociedades fictícias: uma sociedade holding pode tornar-se titular de uma ou mais "subsidiárias de fachada"; isto sucede quando inexiste qualquer "conflito de interesses" entre a sociedade controladora e a sociedade controlada, ou seja, esta não dispõe de qualquer autonomia, econômica ou jurídica $^{589}$.

A sociedade simulada - defende Deboissy - não possuiria qualquer substância; seria simples aparência destinada a enganar os terceiros ${ }^{590}$. Além do caso da falta de pluralidade de sócios, implicaria a simulação da sociedade a falta de exploração efetiva do objeto social e a ausência de autonomia patrimonial. Existiria uma relação entre a simulação e a racionalidade econômica da sociedade; sempre que esta faltasse, aquela poderia manifestar-se ${ }^{591}$. No terreno societário, a aparência enganadora poderia também referir-se a certos atributos da sociedade, como, por exemplo, a composição do quadro de

\footnotetext{
${ }^{587}$ J. ABEILle, De la simulation... cit. (nota 374), p. 179 ss.

${ }^{588}$ J. ABEILle, De la simulation... cit. (nota 374), p. 187 ss.

589 J. ABEILle, De la simulation... cit. (nota 374), p. 211 ss. O autor lança mão do seguinte exemplo para ilustrar o caso: uma sociedade imobiliária foi criada em 1920, e, anos mais tarde, entrou em processo de falência. A insolvência decorria do fato de quase todo o ativo da referida sociedade ter sido transferido a subsidiárias, as quais desempenhavam a mesma atividade que sua controladora, e era administrada por uma pessoa de confiança escolhida pelos sócios desta.

${ }_{590}^{5}$ F. DEBOISSY, La simulation... cit. (nota 121), p. 86.

${ }^{591}$ F. DEBOISSY, La simulation... cit. (nota 121), p. 94 ss.
} 
quotistas ou acionistas (na hipótese de interposição fictícia), a atividade econômica explorada como objeto social, e a fixação de sedes e escritórios ${ }^{592}$.

Dentre os autores portugueses, a possibilidade de simular-se a sociedade também é acolhida. Para Ferrer Correia, o especial interesse do pretenso sócio, na constituição da sociedade, deveria, além do desejo de constitui-la, importar a vontade específica de assumir a condição de sócio. Esta intenção pressuporia "a consciência de se ficar juridicamente vinculado, ante a própria sociedade, ao cumprimento dos deveres estatutários de sócio" "593. Ademais, seria "da essência de toda relação associativa o constituir-se para perdurar o seu desenvolvimento no tempo. Querer constituir uma sociedade e querer simultaneamente a instauração posterior imediata de uma situação de fato que é a negação da mesma ideia de sociedade, seriam termos antitéticos" ${ }^{\text {"594 }}$. Nestes termos, a constituição de uma sociedade que não viesse a explorar uma atividade econômica, à qual se voltassem os interesses comuns dos sócios, ou que tivesse existência efêmera, haveria de reputar-se simulada.

O autor não nega que a sociedade viesse a constituir-se efetivamente. Do contrato de sociedade decorreria uma série de efeitos, tais como a autonomização do complexo patrimonial formado pelas contribuições dos sócios e a entrada em vigor de um regulamento aplicável às relações entre os sócios. Tais efeitos seriam queridos pela totalidade dos subscritores. Isto, contudo, não excluiria a simulação nos casos em que um ou mais sócios não quisessem sujeitar-se ao regime jurídico societário; não se trataria, pois, de verificar o emprego da sociedade para fins atípicos, mas de identificar, no caso da sociedade simulada, um particular conflito entre a vontade real e a vontade declarada ${ }^{595}$.

$\mathrm{Na}$ Argentina, Mosset Iturraspe também opina favoravelmente à simulabilidade do contrato de sociedade. Ele distingue, porém, os casos de simulação da sociedade, daqueles em que há simulação na sociedade ${ }^{596}$.

\footnotetext{
${ }_{592}^{592}$ F. DURAND, L'apparence... cit. (nota 104), p. 99-100.

${ }^{593}$ A. Ferrer Correia, Sociedades Fictícias e Unipessoais, Coimbra, Atlântida, 1948, p. 163.

${ }^{594}$ A. FERrer CORREIA, Sociedades Fictícias... cit. (nota 593), p. 146.

${ }^{595}$ A. FERRER CORREIA, Sociedades Fictícias... cit. (nota 593), p. 158-151.

596 J. Mosset Iturraspe, Contratos Simulados y Fraudulentos, t. I - Contratos Simulados, Santa Fé, Rubinzal-Culzoni, 2008, p. 137.
} 
A simulação da sociedade corresponderia ao fenômeno da sociedade fictícia. A própria constituição do ente personificado seria simulada. Tal situação poderia configurarse sob as seguintes roupagens, tais como: a falta de pluralidade real de sócios; a irrealidade de elementos da sociedade: abrangeria a organização, a atividade comum, ou o fim comum para uma pluralidade; ou a ocultação, sob a relação societária aparente, de outro contrato, como uma locação, um mútuo, ou um contrato de trabalho; a ocultação do tipo societário; a ocultação do objeto; e a ocultação da sede, designação de matriz, e da criação de fíliais ou sucursais $^{597}$. No que tange à simulação na sociedade, a ficção não surgiria no momento da constituição, mas durante a vida da sociedade. Neste contexto, poderia dar-se a eliminação da pluralidade de sócios, ou, ainda, ocorrerem operações societárias que não seriam verdadeiras, como a transformação, a fusão e a cisão ${ }^{598}$.

\section{Sociedade: simulação e desconsideração}

Em vista do intrincado quadro doutrinário descrito no tópico anterior, quid juris, à luz do Código Civil?

Na doutrina produzida no Brasil, a questão praticamente não foi examinada. Dentre as poucas manifestações existentes, encontram-se as de Ascarelli ${ }^{599}$, Pontes de Miranda $^{600}$ e Gaino ${ }^{601}$, segundo as quais seria possível a simulação de sociedade; e a de Carvalhosa $^{602}$, que, em sentido contrário, nega que a legislação societária admita a sociedade simulada.

O enfrentamento do tema não pode prescindir de um exame sistemático da legislação vigente. Isto se deve ao fato de que, nas últimas duas décadas, normas foram editadas com vistas a prover acolhimento à teoria da desconsideração da personalidade jurídica $^{603}$. Desde as suas origens, esta teoria dialoga intensamente com as dogmáticas da

\footnotetext{
597 J. MOSSET ITURRASPE, Contratos Simulados... cit. (nota 596), p. 139-142.

${ }^{598}$ J. Mosset ITURRASPe, Contratos Simulados... cit. (nota 596), p. 147-150..

${ }^{599}$ T. ASCARELli, Problemas... cit. (nota 413), p. 195-196.

${ }^{600}$ F. C. Pontes De Miranda, Tratado de Direito Privado, v. 50, atual. por A. A. Gonçalves Neto, São Paulo, Revista dos Tribunais, 2012, p. 222; 229.

${ }^{601}$ I. GAINO, A Simulação... cit. (nota 122), p. 130.

${ }^{602}$ M. Carvalhosa, Comentários à Lei de Sociedades Anônimas, vol. 2, 4 a ed., São Paulo, Saraiva, 2008, p. 74.

${ }^{603}$ Um esboço do confronto entre a simulação e a desconsideração da personalidade jurídícia pode ser encontrado em: J. Mosset ItURRASPe, Contratos Simulados... cit. (nota 596), p. 189-190; E. O. ANDRADE FILHO, Desconsideração da Personalidade Jurídica no Novo Código Civil, São Paulo, MP, 2005, p. 94-97.
} 
simulação, da fraude à lei e do abuso de direito, razão pela qual tornaram-se muito fluidas as fronteiras que demarcam o campo específico de aplicação de cada um destes institutos.

Não é este o espaço para dissertarmos sobre o rico desenvolvimento teórico atinente à desconsideração da personalidade jurídica ${ }^{604}$. Cumpre, entretanto, distinguir a chamada teoria maior, da denominada teoria menor da desconsideração, de modo a delimitar-se o confronto entre a desconsideração da personalidade jurídica e a simulação da sociedade.

Com base na teoria maior da desconsideração, a autonomia patrimonial da pessoa jurídica pode ser superada em virtude da caracterização de abuso, o qual deve decorrer de desvio de finalidade ou confusão patrimonial. Nestes termos, dispõe o artigo 50: “[e]m caso de abuso da personalidade jurídica, caracterizado pelo desvio de finalidade, ou pela confusão patrimonial, pode o juiz decidir, a requerimento da parte, ou do Ministério Público quando lhe couber intervir no processo, que os efeitos de certas e determinadas relações de obrigações sejam estendidos aos bens particulares dos administradores ou sócios da pessoa jurídica". Por outro lado, a teoria menor da desconsideração fundamenta a mitigação da eficácia da personalidade jurídica na hipótese de insolvência do ente moral. Nestes moldes, o artigo 28 do Código de Defesa do Consumidor estabelece que "[o] juiz poderá desconsiderar a personalidade jurídica da sociedade quando, em detrimento do consumidor, houver abuso de direito, excesso de poder, infração da lei, fato ou ato ilícito ou violação dos estatutos ou contrato social. A desconsideração também será efetivada quando houver falência, estado de insolvência, encerramento ou inatividade da pessoa jurídica provocados por má administração"; e o artigo $4^{\circ}$ da Lei $n^{\circ} 9.605 / 98$ determina que “[p]oderá ser desconsiderada a pessoa jurídica sempre que sua personalidade for obstáculo ao ressarcimento de prejuízos causados à qualidade do meio ambiente”.

Como se pode notar facilmente, a teoria menor da desconsideração emposta-se sobre um terreno claramente distinto daquele em que se depara com a simulação. No entanto, a teoria maior da desconsideração tende a aplicar-se em casos aos quais poderia,

${ }^{604}$ V. a respeito: R. REQUIÃO, Abuso de direito e fraude através da personalidade jurídica in Revista dos Tribunais 416, São Paulo, 1969, p. 12 ss.; J. L. CORRÊA DE OlIVEIRA, A Dupla Crise da Pessoa Jurídica, São Paulo, Saraiva, 1979, passim; S. E. C. Koury, A Desconsideração da Personalidade Jurídica (disregard doctrine) e os Grupos de Empresas, Rio de Janeiro, Forense, 1993, p. 63-96; P. H. T. BIANQUI, Desconsideração da personalidade jurídica no processo civil, São Paulo, Saraiva, 2011, p. 23-86. 
com igual consistência, cogitar-se da simulação. É costumeira a afirmação de que a personalidade jurídica poderia ser superada nos casos em que a sociedade opera em favor de interesses que se confundem com os dos sócios, como se fizesse as vezes deles ${ }^{605}$. Lamartine Corrêa chega a dizer, nesse sentido, que a desconsideração dependeria da resposta à seguinte indagação: "no caso em exame, foi realmente a pessoa jurídica que agiu, ou foi ela mero instrumento nas mão de outras pessoas, físicas ou jurídicas?"606. Ora, não poderia esta mesma pergunta orientar o diagnóstico da interposição fictícia, da interposição real em fraude à lei, ou, quiçá, da simulação da própria constituição do ente societário?

Para entender-se a relação existente entre os artigos 167 e 50, mostra-se útil examinar, sucintamente, o desenvolvimento teórico observado no campo de estudo da desconsideração da personalidade jurídica. Nesta sede, é interessante relembrar os moldes segundo os quais foram elaboradas as teorias unitarista e pluralista da desconsideração.

A teoria unitarista tende a identificar, na personalidade jurídica, um fenômeno homogêneo caracterizado por uma essência pré-jurídica, análoga à da pessoa física; ou pela autonomização do patrimônio da sociedade com relação ao patrimônio dos sócios. Esta corrente dogmática divide-se, assim, em subgrupos que se inclinam a conceber a desconsideração por um viés subjetivo ou objetivo-institucional. Dentre os subjetivistas encontra-se Serick, para quem a desconsideração dever-se-ia operar segundo o sistema regra-exceção: a regra seria a autonomia patrimonial da pessoa jurídica, e a exceção, fundamentada no intento fraudulento ou abusivo, seria a extensão da sujeição patrimonial da pessoa jurídica aos bens de titularidade dos sócios ${ }^{607}$. Para os objetivistas, como Immenga, a desconsideração deveria fundar-se sobre dados concretos, independentes do ânimo pessoal dos sócios, como, por exemplo, a utilização contrária aos estatutos e a desvirtuação da função da pessoa jurídica ${ }^{608}$.

${ }^{605}$ A. Couto Silva, Desconsideração da Personalidade Jurídica - Limites para sua aplicação in Revista dos Tribunais 780, São Paulo, 2000, p. 54; C. RAmALHETE, Sistema de Legalidade na "Desconsideração da Personalidade Jurídica" in Revista dos Tribunais 586, São Paulo, 1984, p. 14.

${ }^{606}$ J. L. CORRÊA DE OliveIRA, A Dupla Crise... cit. (nota 604), p. 613.

${ }^{607}$ R. SERICK, Rechtsform und Realität juristischer Personen - Eins rechtsvergleichender Beitrag zur Frage des Durchgriffs auf die Personen oder Gegestände hinter der juristischen Person (1955), trad. it. de M. Vitale, Forma e realtà della persona giuridica, Milano, Giuffrè, 1966, p. 275 ss.

${ }^{608}$ C. SAlomão Filho, O Novo Direito Societário, $4^{\mathrm{a}}$ ed., São Paulo, Malheiros, 2011, p. 235. 
A teoria unitarista seria considerada insuficiente para explicar o fenômeno da desconsideração, uma vez que se mostraria aplicável apenas aos casos de falência. Somente nestas circunstâncias seria possível estender a responsabilidade societária aos sócios, diante da escassez do patrimônio do ente coletivo. Seria, contudo, insustentável, sob uma perspectiva teleológica, restringir a desconsideração aos casos de falência, pois desconsideração e falência são institutos antagônicos: enquanto esta presta-se a pôr fim à pessoa jurídica, aquela objetiva perpetuá-la ${ }^{609}$. Nessa ordem de ideias, abre-se espaço ao desenvolvimento de uma teoria pluralista (ou antiunitarista) da desconsideração, capaz de acomodar a desconsideração atributiva, a desconsideração para fins de responsabilidade, a desconsideração inversa e a desconsideração em favor do sócio.

A teoria pluralista da desconsideração, hoje dominante na Alemanha, ancora-se na concepção da pessoa jurídica como centro de imputação. Nessa esteira, a desconsideração passa a não se limitar apenas aos casos de fraude, podendo abranger aquelas situações em que, à luz da importância e do objetivo da norma aplicável, mostre-se conveniente mitigar a eficácia da personalidade jurídica. Justifica-se, desse modo, a atribuição de determinadas relações jurídicas diretamente à pessoa dos sócios, mormente quando características, comportamentos, ou conhecimentos pessoais destes sejam confundidas com as da sociedade. Pode, outrossim, a personalidade ser desconsiderada para fins de responsabilidade, sobretudo quando exista confusão de esferas (i.e. quando a denominação, a organização ou o patrimônio da sociedade e dos seus membros não seja claramente distinguível), subcapitalização (i.e. a insuficiência do capital social, que pode ser evidente - subcapitalização qualificada - ou culposa - subcapitalização simples). Admite-se, ainda, a desconsideração em sentido inverso, notabilizada pela atribuição, à sociedade, de certas relações jurídicas formalmente estabelecidas por seus membros. E, por fim, torna-se possível cogitar a desconsideração em favor do sócio, especialmente nos casos em que apenas este possui legitimidade para pleitear um direito formalmente detido pela sociedade (um exemplo da adoção deste raciocínio, no direito brasileiro, extrai-se da súmula $\mathrm{n}^{\mathrm{o}} 486$ do Supremo Tribunal Federal, a qual permite o despejo, para uso da sociedade, de um imóvel do sócio único) ${ }^{610}$.

${ }^{609}$ C. SAlOMÃo Filho, O Novo Direito Societário cit. (nota 608), p. 237-240.

${ }^{610}$ C. SAlOMÃo Filho, O Novo Direito Societário cit. (nota 608), p. 241-251. 
O artigo 50 prevê a desconsideração da personalidade jurídica exclusivamente para fins de responsabilidade patrimonial ${ }^{611}$. A lei acolhe a possibilidade da desconsideração tanto por fundamentos objetivos, como subjetivos ${ }^{612}$. Os pressupostos da desconsideração da personalidade jurídica, nos termos deste dispositivo, são o desvio de finalidade e a confusão patrimonial. Vale observar, no entanto, que a aplicação da teoria da desconsideração da personalidade jurídica não se limita as casos de responsabilidade, porquanto alcança, também, os casos de imputação (desconsideração atributiva) e de aplicação da teoria da aparência.

O desvio de finalidade não se confunde com a prática de atos ultra vires. Estes consistem naqueles atos praticados pelos administradores da sociedade com inobservância aos limites impostos pelo objeto social e desrespeito aos poderes designados no contrato social. No caso dos atos ultra vires os terceiros de boa-fé têm como válidos os atos praticados; a sociedade responde perante aqueles com quem contrata, e os administradores respondem perante a sociedade ${ }^{613}$. O método da desconsideração da personalidade jurídica não diz respeito a atos, mas a atividades ${ }^{614}$. A organização societária é posta a serviço de um objetivo anormal. O desvio de finalidade, portanto, se caracteriza pela disfunção da pessoa jurídica, ou seja, o exercício, pelos sócios e administradores, de atos previstos pelo contrato social de maneira incompatível com os fins perseguidos pelo ente coletivo ${ }^{615}$.

Toda pessoa jurídica é criada para o desempenho de funções determinadas. A função geral da personalização consiste na criação de um núcleo de interesses autônomo. A causa, na constituição da sociedade, equivale ao estabelecimento de esferas patrimoniais distintas, cujos ativos e passivos não devem confundir-se. Tal segregação justifica-se pela

${ }^{611}$ C. SAlomão Filho, O Novo Direito Societário cit. (nota 608), p. 258.

${ }^{612}$ A. Pagani De SouZA, Desconsideração da Personalidade Jurídica - Aspectos Processuais, $2^{\mathrm{a}}$ ed., São Paulo, Saraiva, 2011, p. 93: "Por fim, é importante observar que atualmente não se atribui à teoria da desconsideração da personalidade jurídica caráter exclusivamente objetivista ou subjetivista. Ou seja, para se configurar a hipótese necessária para a aplicação da teoria, não se exige que ocorra a confusão patrimonial, o que seria um enfoque exclusivamente objetivista. Assim, se não houver confusão patrimonial, mas se verificarem outras hipóteses de aplicação da teoria (tais como a intenção de fraudar, o abuso de direito etc.), a desconsideração da personalidade jurídica deve ser decretada. Em suma, as formulações objetiva e subjetiva da teoria da desconsideração da personalidade jurídica são compatíveis entre si e devem conviver harmoniosamente".

${ }^{613}$ A. COUTO SIlva, O Novo Direito Societário cit. (nota 605), p. 49.

${ }^{614}$ C. SAlomão FilHo, O Novo Direito Societário cit. (nota 608), p. 262. Sobre a noção de atividade, v. T. Ascarelli, Corso di diritto commerciale, Cap. VII (1962), trad. port. de E. V. Azevedo e Novaes França, $A$ atividade do empresário in Revista de Direito Mercantil, São Paulo, 2003, p. 132 ss.

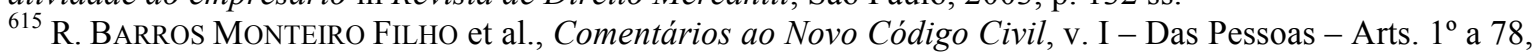
Rio de Janeiro, Forense, p. 788-799. 
necessidade de atender ao objeto social; por conseguinte, a personalidade jurídica somente se mantém enquanto se mostre útil à consecução do escopo representado pelo objeto social. Quando o comportamento do sócio ou a relação estabelecida tornam inútil ou ineficaz a organização societária, anômala se torna a função desempenhada pela pessoa jurídica ${ }^{616}$.

A confusão patrimonial, a seu turno, caracteriza-se pela impossibilidade de distinguir se o uso e a disposição de determinados bens dá-se pela sociedade ou pelos seus membros; ou, melhor dizendo, se o patrimônio é empregado de modo a satisfazer interesses de uma, ou de outros. Configura-se, por exemplo, nas situações em que a sociedade utiliza imóveis pertencentes aos sócios, emprega veículos destes para o desempenho de suas atividades operacionais, ou paga suas contas pessoais ${ }^{617}$. A confusão patrimonial pode, ademais, relacionar-se a uma situação de controle, especialmente nos grupos econômicos de subordinação (quando inexista convenção grupal, nos moldes do artigo 266 da Lei $\mathrm{n}^{\circ} 6.404 / 76$ ), em que as sociedades controladas perdem grande parte de sua autonomia de gestão empresarial em razão da atuação "soberana" da sociedade holding $^{618}$.

Nesse passo, é lícito constatar que o direito positivo veicula uma gama de juízos de valor que delineia a própria pessoa jurídica. Como se sabe, diversas teorias já foram propostas com o objetivo de sintetizar a essência categorial da pessoa jurídica ${ }^{619}$. No artigo 981 ("Celebram contrato de sociedade as pessoas que reciprocamente se obrigam a contribuir, com bens ou serviços, para o exercício de atividade econômica e a partilha, entre si, dos resultados") encontram-se presentes todos os traços do contratualismo

\footnotetext{
${ }^{616}$ F. K. COMParato - C. SAlomão Filho, O Poder de Controle na Sociedade Anônima, $4^{\mathrm{a}}$ ed., Rio de Janeiro, Forense, 2005, p. 351; 356-357.

${ }^{617}$ A. PagAni De SouZa, Desconsideração... cit. (nota 612), p. 92.

${ }^{618}$ F. K. Comparato - C. SAlomão Filho, O Poder de Controle... cit. (nota 616), p. 355-361: “Ora, essa perda da autonomia de gestão empresarial traduz-se, frequentemente, senão sempre, pelo sacrifício dos interesses de cada sociedade ao interesse global do grupo. Os patrimônios sociais tendem a confundir-se, e tudo se passa nesse campo, como frisou um autor, analogamente ao princípio dos vasos comunicantes".

${ }^{619}$ Segundo a teoria da ficção ou da entidade, pessoa somente seria a natural; a pessoa jurídica nada mais seria que uma arbitrária criação da lei, simples ficção legal. De acordo com a teoria do parimônio de afetação, a pessoa jurídica consistiria em um patrimônio destacado e destinado à persecução de um determinado objetivo; seria realidade, não ficção, porque esta nada cria. Nos quadros da teoria orgânica ou da realidade, não apenas a pessoa natural seria sujeito de direito; haveria organismos sociais e entes coletivos reais capazes de manifestar vontade e agir nas diversas esferas da vida de relação. A teoria institucional ou da organização contesta o paralelismo entre pessoa natural e pessoa jurídica; a pessoa jurídica, diferentemente da natural, seria uma instituição, uma organização voltada à realização de fins públicos ou privados (Cf. a respeito, R. SzTAJn, Sobre a Desconsideração da Personalidade Jurídica in Revista dos Tribunais 762, São Paulo, 1999, p. 85-88).
} 
tradicional: a pluralidade de pessoas unidas em prol do exercício de uma atividade econômica e a reciprocidade das obrigações entre os sócios, e entre estes e a sociedade ${ }^{620}$. Nada obstante, o interesse da sociedade não pode mais ser identificado com o interesse dos sócios (como no contratualismo), nem à autopreservação (como no institucionalismo). A visão moderna da pessoa jurídica assenta-se sobre a noção de contrato organização. É no valor da organização (entendida como coordenação de atos que exerçam influência recíproca) - não mais na coincidência dos interesses dos sócios - que se passa a identificar o elemento distintivo do contrato social. É esta concepção que fundamenta, e, ao mesmo tempo, é ratificada, pela previsão de uma metodologia de desconsideração da personalidade jurídica baseada no aspecto funcional da sociedade ${ }^{621}$.

É importante noticiar, adicionalmente, que o desenvolvimento da teoria da desconsideração da personalidade jurídica não é fato isolado ou arbitrário, mas resultado de uma tendência, manifestada no decorrer das últimas décadas, de desvinculação da disciplina dos institutos societário do regime geral aplicável aos negócios jurídicos. Reflexo desta tendência é a restrição da despersonalização à hipótese de dissolução. A despersonalização implica o desaparecimento do ente coletivo; a desconsideração, por outro lado, não altera a substância das esferas envolvidas, pois permanece intacta a personalidade jurídica ${ }^{622}$.

O surgimento de um subsistema societário tem afastado a possibilidade de se aplicar a disciplina da nulidade dos negócios jurídicos ao contrato de sociedade. A tendência é, hoje, a de excluir a pessoa jurídica do campo de incidência da nulidade, sujeitando-se as situações problemáticas ao regime da desconsideração da personalidade jurídica ou da dissolução da sociedade ${ }^{623}$. A consequência disso resultante é dupla: de um lado, a disciplina legal torna-se mais coerente, uma vez que evita a aplicação do regramento geral dos negócios jurídicos à atividade societária; de outro, amplia-se o âmbito de pertinência da desconsideração da personalidade jurídica ${ }^{624}$.

\footnotetext{
${ }^{620}$ Sobre as teorias contratualistas e institucionalistas, v. C. SALOMão FILHO, O Novo Direito Societário cit. (nota 608), p. 27 ss.

${ }^{621}$ C. SAlOMÃo Filho, O Novo Direito Societário cit. (nota 608), p. 38 ss.

${ }^{622}$ C. SAlomão Filho, O Novo Direito Societário cit. (nota 608), p. 263.

${ }^{623}$ C. ANGELICI, La società nulla, Milano, Giuffrè, 1975, p. 256.

${ }^{624}$ F. K. COMPARATO - C. SAlOMÃo FILHO, O Poder de Controle... cit. (nota 616), p. 353-354.
} 
Pois bem. A solução do dilema quanto à simulabilidade da sociedade pressupõe, mais que o recurso a fórmulas abstratas fundadas no simples raciocínio doutrinário, o exame da valoração legal a que se submete a relação societária. É este, precisamente, o mérito do raciocínio orientado a valores, o qual, desprendendo-se da "genealogia dos conceitos", busca colocar o intérprete em contato direto com a concretude que a norma pode assumir na solução de conflitos intersubjetivos.

É salutar reconhecer que a constituição da sociedade não é valorada, pela norma, como ato, mas como procedimento. Não importa, para a existência e para a validade da sociedade, o valor individual dos atos (contrato social, inscrição etc.) que compõem o procedimento da constituição daquela, mas o valor emanado do nexo de funcionalidade que se estabelece entre tais atos. A conclusão do referido procedimento, com a inscrição e o registro da sociedade, demarca o início da sua existência enquanto organização societária. O que seria um vício do ato, sob a perspectiva negocial, transforma-se em vício da organização, sob a ótica societária. Referido vício não é normativamente captado no momento genético, mas tão somente em um momento ulterior, quando a sociedade se encontra em operação ${ }^{625}$. Não por outro motivo, o Código Civil prevê que, diante da anulação da "constituição", a sociedade deve dissolver-se, para, então, sujeitar-se à liquidação (artigo 1034, inciso I c/c artigo 1036). Como se vê, não há menção à anulação do "ato constitutivo"; do mesmo modo, os artigos 206, inciso III, alínea "a", e 285, da Lei $n^{\text {o }}$ 6.404/76 referem-se tão somente à anulação da "constituição", com idêntica determinação de que, em tais circunstâncias, proceda-se à dissolução e à liquidação da companhia.

Em vista destas considerações, a simulação do ato constitutivo da sociedade não se mostra viável ${ }^{626}$; tal inviabilidade não se coloca no plano ontológico, mas na dimensão valorativa. A pretensa simulação do contrato social pode acarretar consequências práticas, mas estes desdobramentos já não serão suficientes para tornar não verdadeiro o juízo sobre a existência da sociedade (artigo 167, $\S 1^{\circ}$, inciso II), pois repercutirão no plano da 
organização, justificando a desconsideração da personalidade jurídica e, eventualmente, a dissolução ${ }^{627}$.

Tome-se, por exemplo, o caso da sociedade unipessoal dissimulada. O fato de um ou mais sócios comparecerem como testas de ferro no ato constitutivo, ou de estes se comprometerem a transferir a totalidade das cotas ou ações a um único sócio não será causa de nulidade da sociedade, mas de dissolução (artigo 1033, inciso IV). A lei não permite que a sociedade seja reputada ilusória ${ }^{628}$, pois " $[n]$ os casos de dissolução da pessoa jurídica ou cassada a autorização para seu funcionamento, ela subsistirá para os fins de liquidação, até que esta se conclua" (artigo 51) ${ }^{629}$.

Do mesmo modo, a suposta falta de affectio societatis (elemento que importa tão somente à estabilidade das sociedades de pessoas) não autoriza a conclusão de que a sociedade seria fictícia. Registre-se, neste passo, que os artigos 1001 a 1009, ao tratarem dos direitos e das obrigações dos sócios, mal chegam a tangenciar a questão da affectio societatis. O artigo 1001 estabelece que “[a]s obrigações dos sócios começam imediatamente com o contrato, se este não fixar outra data, e terminam quando, liquidada a sociedade, se extinguirem as responsabilidades sociais"; e o artigo 1004, o único a tratar, explicitamente, dos deveres dos sócios, limita-se a dispor que "[o]s sócios são obrigados, na forma e prazo previstos, às contribuições estabelecidas no contrato social, e aquele que deixar de fazê-lo, nos trinta dias seguintes ao da notificação pela sociedade, responderá perante esta pelo dano emergente da mora”. A vontade de assumir a condição de sócio, nos quadros do Código Civil, apresenta feição eminentemente objetiva; em razão disso, a falta grave cometida pelo sócio (que poderia consistir, eventualmente, em retirar-se, de fato, da sociedade, deixando de adotar medidas necessárias à manutenção da organização societária) não implicaria a simulação, mas a dissolução parcial, conforme preceitua o artigo 1030: “[r]essalvado o disposto no art. 1.004 e seu parágrafo único, pode o sócio ser excluído judicialmente, mediante iniciativa da maioria dos demais sócios, por falta grave

${ }^{627}$ C. ANGELICI, La società nulla cit. (nota 623), p. 261-262, nota 270.

${ }^{628}$ Registre-se a opinião contrárias de F. C. PONTES DE MIRANDA (Tratado de Direito Privado, v. 49, atual. por A. A. Gonçalves Neto, São Paulo, Revista dos Tribunais, 2012, p. 149), a qual, contudo, foi emitida em momento histórico diferente do presente, à luz de outras premissas dogmáticas: "O contrato social é nulo se infringe regra jurídica cogente, ou se, por ser nulo ou anulado o ato de participação de algum sócio, deixou de haver o mínimo de sócios, que a lei exige".

${ }^{629}$ Assinale-se que, precisamente porque não haveria simulação, nem nulidade, não caberia cogitar-se da extraversão de uma pressuposta empresa individual de responsabilidade limitada - EIRELI (artigo 980-A). 
no cumprimento de suas obrigações, ou, ainda, por incapacidade superveniente"; e do artigo 1085: "ressalvado o disposto no art. 1.030, quando a maioria dos sócios, representativa de mais da metade do capital social, entender que um ou mais sócios estão pondo em risco a continuidade da empresa, em virtude de atos de inegável gravidade, poderá excluí-los da sociedade, mediante alteração do contrato social, desde que prevista neste a exclusão por justa causa";

Diga-se o mesmo quanto à duração da sociedade. A lei não requer que a sociedade tenha duração mínima; muito pelo contrário: o parágrafo único do artigo 981 estabelece que "[a] atividade pode restringir-se à realização de um ou mais negócios determinados". Assim sendo, uma sociedade que seja constituída em um determinado dia, para a prática de um único negócio, e dissolvida no mesmo dia, após a realização do referido negócio, deve ser tida como válida e eficaz, inexistindo fundamento para a impugnação de sua substância jurídica em razão da sua duração. É importante assinalar que a lei refere-se à realização de um ou mais negócios determinados, sem especificar a natureza destes; desta feita, a sociedade que seja constituída exclusivamente para realizar um negócio societário (e.g. recebimento de bens e dinheiro como realização de capital, aportados, respectivamente, pelos sócios "A" e "B"; e posterior cisão, com a versão dos bens à sociedade resultante desta operação de que participe o sócio "B”) não pode ser considerada simulada.

É de se ressalvar, no entanto, que a criação de uma sociedade de pessoas da qual um ou mais sócios deixem de manifestar affectio societatis, ou de qualquer organização societária que tenha duração efêmera, pode servir a propósitos elusivos ou fraudulentos, ou ocasionar a confusão patrimonial. Se tal suceder, sem prejuízo da dissolução, que, quando cabível, depende da iniciativa do sócio para requerê-la (artigo 1034, em se tratando de dissolução judicial), ou para requerer a liquidação (artigo 1033 c/c artigo 1036, parágrafo único, no caso de dissolução de pleno direito), podem eventuais credores pleitear a desconsideração da personalidade jurídica, com fulcro no artigo $50^{630}$.

\footnotetext{
${ }^{630}$ Dentre estes credores encontra-se, por óbvio, a Fazenda Pública, mas exclsuivamente no que diz respeito a obrigações tributárias constituídas independentemente da desconsideração da personalidade jurídica, e desde que sejam observadas as regras dispostas na legislação específica (e.g. artigo 124; 134, inciso VII; 135, inciso I; e 137 do Código Tributário Nacional). Nada obstante, se a desconsideração da personalidade é pressuposto da caracterização do fato gerador da obrigação tributária, esta somente pode dar-se com fundamento no artigo 116, parágrafo único, do Código Tributário Nacional, o qual, por ora, não pode ser aplicado por carecer de regulamentação.
} 
Também pode ensejar a desconsideração da personalidade jurídica a inatividade da sociedade, ou a exploração de um objeto distinto daquele descrito no contrato social. Deveras, se a atividade não desempenha atividade econômica, ou desempenha atividade econômica diversa daquela para o exercício da qual foi constituída, a organização societária não mais se mostrará capaz de atender à sua função própria, e, neste caso, somente poderá satisfazer interesses dos próprios sócios. Outrossim, pode dar-se a desconsideração da personalidade jurídica diante do estabelecimento de subsidiárias que careçam de autonomia gerencial ou econômica; em casos como este, pode-se constatar a confusão patrimonial a que faz referência o artigo 50 .

Em suma, a simulação da sociedade não é possível porque a criação da organização societária não é produto de um ato, mas de uma atividade ${ }^{631}$. Isto não impede, porém, que sejam simulados determinados atos praticados pela sociedade. Considere-se, a título de exemplo, que um dos sócios tenha resolvido, de comum acordo com os demais, tornar-se empregado da sociedade: passa a receber, mensalmente, a título de dividendos, uma quantia fixa (que faz as vezes do salário ou da remuneração pelos serviços prestados); não participa de quaisquer assembleias convocadas pela sociedade; passa, enfim, a sujeitarse às normas ordinariamente impostas, pela sociedade, aos demais prestadores de serviço (e.g. horários de trabalho, hierarquia, risco de dispensa etc.). Embora não seja possível dizer, diante desse contexto, que a sociedade seria simulada, não haveria obstáculos que se opusessem à conclusão de que a condição formalmente ostentada pelo "sócio-empregado" seria simulada, e que, consequentemente, as distribuições de dividendos realizadas em seu favor seriam nulas, por dissimularem o pagamento de salários ou remunerações. Nessa esteira, podem ainda ser simulados outros atos, como a eleição de domicílio ${ }^{632}$ e aportes de capital realizados pelos sócios, mormente quando o bem não exista ou não tenha o valor atestado pelos laudos de avaliação ${ }^{633}$.

Não podem, contudo, ser simuladas as deliberações de órgãos da pessoa jurídica.

A deliberação é negócio jurídico coletivo. Embora a sua produção dependa da manifestação de diversas vontades, ela encerra uma vontade única, atribuível, em última

\footnotetext{
${ }^{631}$ F. K. COMPARATO - C. SAlomão Filho, o Poder de Controle... cit. (nota 616), p. 445.

${ }^{632} \mathrm{~V}$. tópico 33.

${ }^{633}$ M. DAGOT, La simulation... cit. (nota 50), p. 81-82.
} 
instância, à sociedade. O ato colegial é responsável pela formação da vontade do ente personificado; é um "dialogo" da sociedade consigo própria ${ }^{634}$. O exame da simulabilidade do ato colegial deve dar-se em dois planos distintos: no primeiro destes, insta verificar se o próprio ato, formado pelo concurso de múltiplas vontades amalgamadas sob o princípio majoritário seria simulado; no segundo, cabe analisar se cada manifestação de vontade, individualmente considerada, poderia ser simulada (hipótese de "vício do voto").

No que se refere à simulação da deliberação social, apreendida enquanto ato coletivo, Ascarelli defende que ela não seria simulável, pois configuraria negócio unilateral não receptício ${ }^{635}$. No mesmo sentido, Distaso ${ }^{636}$ assevera que, quanto a tal ato, somente seria possível configurar-se a reserva mental. Tendo-se em mente, porém, as ponderações acima aduzidas acerca da simulação dos negócios unilaterais ${ }^{637}$, parece-nos que a deliberação social não seja simulável porque não existe a possibilidade de se definir um contrainteressado interessado na declaração diferente da própria sociedade.

Não convém, pois, deixar-se enganar pelo que dispõem o artigos 48 (que estabelece o prazo decadencial de três anos para a anulação de decisões de órgão colegiais, quando restar caracterizada simulação) e o $\S 3^{\circ}$ do artigo 1078 (segundo o qual a aprovação do balanço patrimonial e do de resultado econômico exonera de responsabilidade os membros da administração e do conselho fiscal, salvo erro, dolo ou simulação). A simulação a que se referem tais dispositivos não se materializa no plano do ato colegial, mas ao nível das manifestações de vontade individuais que o compõem ${ }^{638}$. Nem seria

${ }^{634}$ T. Ascarelli, Problemas... cit. (nota 413), p. 532-534; E. V. AzEVEdo E FranÇA, Invalidades das Deliberações de Assembléia das S.A., São Paulo, Malheiros, 1999, p. 41 ss.

${ }^{635}$ T. ASCARELLI, Sulla simulazione in materia di società e sulla simulazione di modificazione statutaria (trasformazione di società) in Studi in Tema di Società, Milano, Giuffrè, 1952, p. 215-221.

${ }^{636}$ N. DisTASO, La simulazione... cit. (nota 40), p. 249.

${ }^{637} \mathrm{~V}$. tópico 34.

${ }^{638}$ A distinção entre vícios da assembleia, vícios da deliberação e vícios do voto foi bem traçada por E. V. AZEVEDO E NOVAES FrANÇA (Invalidades... cit., nota 634, p. 85), como segue: "Impende distinguir agora, por amor à clareza, aquilo que, na defeituosa redação do art. 286, aparece indevidamente confundido. Repitase a dicção do mencionado dispositivo: 'Art. 286. A ação para anular as deliberações tomadas em assembléia geral ou especial, irregularmente convocada ou instalada, violadoras da lei ou do estatuto, ou eivadas de erro, dolo, fraude ou simulação, prescreve em 2 (dois) anos, contados da deliberação'. Logo se verifica que o legislador confundiu, na referida disposição legal, três espécies diversas de vícios, a saber:

a) vícios da própria assembléia - que pode ter sido irregularmente convocada (ou mesmo não convocada) ou instalada, por força de violação da lei ou do estatuto, hipótese em que o vício, obviamente, atingirá todas as deliberações que nela forem tomadas;

b) vícios das deliberações - nessa hipótese, os vícios dizem respeito às próprias deliberações assemblares, que podem ter sido tomadas, todas ou algumas delas apenas, com violação da lei ou do estatuto; 
possível conjecturar, nesta sede, de inexistência da deliberação simulada ${ }^{639}$. Trata-se, destarte, de simulação do voto, o qual, conquanto unilateral e não receptício, pode direcionar-se a contrainteressados interessados, a saber, os demais membros do colegiado; demais disso, não há como descartar a hipótese de o voto ser manifestado por meio de documento antedatado ou pós-datado, ou, ainda, mediante o expediente da interposição fictícia. Desse modo, não há que se confundir a simulação da deliberação social, que, se fosse possível, atingiria diretamente o ato colegial, com a simulação do voto ${ }^{640}$, que apenas mediatamente pode macular a deliberação social, na medida em que venha a desqualificar a maioria formada por meio do conclave. Vê-se, pois, que a aplicação do regime da anulabilidade, prevista no artigo 48, não é simples exceção, assistemática e caprichosa, ao regime instituído pelo artigo 167, mas uma decorrência da descaracterização da maioria formada com o cômputo de votos simulados.

Mencione-se, por último, que as ponderações acima apresentadas relacionam-se à sociedade personificada. Relativamente à sociedade em comum (artigos 986 a 990), pode haver simulação: dois ou mais indivíduos apresentam-se, perante o público, como se fossem sócios, todavia, secretamente, ajustam a segregação de suas atividades de tal modo a atuarem, na realidade, como empresários individuais ${ }^{641}$. A ilusão negocial assim criada seria fruto da inveracidade do contrato de sociedade, o qual existiria apenas na mente do público. Não há simulação, contudo, no caso da sociedade em conta de participação (artigos 991 a 996), que não apenas é prevista e disciplina em lei, como, ademais, não passa de um dissimulação pura, da qual não se ocupa o artigo 167.

Ante todo o exposto, concluímos que a sociedade não pode ser simulada; a disciplina legal vigente em matéria societária cuida dos casos de desvio de finalidade e confusão patrimonial com base no método da desconsideração da personalidade jurídica e no mecanismo da dissolução. Diversamente, podem ser simulados determinados atos da sociedade, como, por exemplo, a distribuição de dividendos realizada em favor de um "sócio-empregado".

c) vícios do voto - nessa hipótese, um ou alguns dos votos que concorreram para a formação da deliberação (ou mesmo todos eles, em alguns casos), podem ter sido viciados em razão de erro, dolo, fraude ou simulação $(\ldots)$.

${ }^{639}$ J. H. C. P. Furtado, Deliberações de Sociedades Comerciais, Coimbra, Almedina, 2005, p. 506.

${ }^{640}$ T. AsCARELli, Problemas... cit. (nota 413), p. 551, nota 1180.

${ }^{641}$ F. Galgano, Della simulazione... cit. (nota 461), p. 26-30. 


\section{Atos familiares}

No que tange aos atos não patrimoniais, como, por exemplo, os atinentes ao direito de família, a autonomia privada encontra limitada expressão. A lei atribui relevância precípua à declaração consubstanciada na forma legalmente prevista - forma interna, no caso. Assim ocorre, por exemplo, com o casamento, o divórcio e a adoção, que não são simuláveis.

Conforme destaca Santoro-Passarelli, "há uma esfera de aplicação da autonomia privada no direito de família, mas é reduzida, em razão dos 'interesses superiores' que são tutelados" ${ }^{\prime 642}$. Por isso, os negócios familiares, quando admitidos, são personalíssimos, formais, nominados, e legítimos ${ }^{643}$.

Ao dizer que os negócios familiares são legítimos, Santoro-Passarelli refere-se ao fato de que a autonomia privada não pode modificar os seus efeitos, nem mesmo nos limites assinalados pela causa. "Os efeitos são em tudo e por tudo predeterminados pela lei, de acordo com o tipo de negócio, de modo que a margem da autonomia privada se reduz à iniciativa e à produção destes efeitos". Apenas no caso dos negócios familiares patrimoniais poderia existir uma alteração dos efeitos; contudo, ressalva o autor, isto jamais poderia ocorrer para além da causa que os caracteriza ${ }^{644}$. Nesse estado de coisas, a simulação reputar-se-ia inoperante quanto aos negócios familiares ${ }^{645}$.Vale ressaltar que, após a reforma do direito de família italiano, pela Lei de 19 de maio 1975, nº 151, alguns autores passaram a admitir a simulação do casamento ${ }^{646}$. O fundamento desta opinião consistiria na nova redação que a referida lei teria dado ao artigo 123 do Código Civil italiano, o qual passou a aludir, expressamente, ao casamento simulado ${ }^{647}$. Outros, porém,

\footnotetext{
${ }^{642}$ F. SANTORo-PASSARELl, L'autonomia privata nel diritto di famiglia in Saggi di diritto civile, Napoli, Jovene, 1961, p. 381-382.

${ }^{643}$ F. SANTORO-PASSARELLI, L'autonomia ... cit. (nota 642), p. 384.

${ }^{644}$ F. SANTORO-PASSARELLI, L'autonomia... cit. (nota 642), p. 385.

${ }^{645}$ F. SANTORO-PASSARELLI, L'autonomia... cit. (nota 642), p. 386-387.

${ }^{646}$ O. T. SCOZZAFAVA, Il matrimonio simulato nell'ordinamento civile in Rivista di diritto civile, Padova, $\mathrm{n}$. 5, Settembre-Ottobre, 1990, p. 657-664.

647 “Art. 123. Simulação. O casamento pode ser impugnado por qualquer dos cônjuges quando os nubentes convencionaram não adimplir as obrigações e não exercitar os direitos daquele decorrentes. A ação não pode ser proposta se decorrido um ano da celebração do casamento ou então no caso em que os contraentes conviveram como cônjuges sucessivamente à referida celebração. Tradução livre; no original: "Art. 123. Simulazione. Il matrimonio può essere impugnato da ciascuno dei coniugi quando gli sposi abbiano convenuto di non adempiere agli obblighi e di non esercitare i diritti da esso discendenti. L'azione non può
} 
defenderam que a simulação a que teria feito menção o citado artigo, em sua nova dicção, não seria a mesma disciplinada pelo artigo 1414, também do Código Civil italiano, mas um peculiar modelo normativo, uma vez que o casamento não teria deixado de ser um negócio constitutivo de um status, cuja eficácia não se encontraria à disposição das partes ${ }^{648}$.

O regime da simulação do casamento, previsto no artigo 123 do Código Civil italiano, em sua versão reformada, tenderia a satisfazer a duas exigências: a valorização do consenso quanto à celebração do casamento, e a certeza do vínculo conjugal. A simulação, ali referida, decorreria de uma vontade convergente dos cônjuges, anterior ao rito matrimonial, voltada à criação de um status conjugal deficitário, correlato ao intento de recusar o adimplemento dos deveres conjugais ${ }^{649}$. Caracterizar-se-ia pela instrumentalidade do casamento com vistas à consecução de fins não conjugais ${ }^{650}$. De todo modo, este desvio, ou abuso, do instituto do casamento, não impediria que o vínculo conjugal surgisse. Por isso, não seria possível reconduzir a simulação do casamento à disciplina ordinária do negócio simulado, prescrita no artigo 1414 do Código Civil italiano ${ }^{651}$.

No direito brasileiro, esta hipótese não é sequer cogitada. Não há, em norma alguma, referência ao casamento simulado. Em vista disso, podemos aderir, sem maiores delongas, à opinião unânime da doutrina anterior à reforma do direito de família italiano, no sentido de que o casamento civil não pode ser simulado ${ }^{652}$. Conclusões análogas, em nosso sentir, são aplicáveis a outros negócios familiares não patrimoniais, como o reconhecimento de filho e a adoção ${ }^{653}$. Diversa, porém, é a situação do contrato de união estável, o qual, por não se submeter às estritas exigências formais previstas para o casamento, afigura-se simulável.

essere proposta decorso un anno dalla celebrazione del matrimonio ovvero nel caso in cui i contraenti abbiano convissuto come coniugi successivamente alla celebrazione medesima".

${ }^{648}$ F. PARENTE, Il ruolo della simulazione nel sistema delle patologie matrimoniali in Rassegna di diritto civile, Napoli, n. 4, Dicembre, 2006, p. 1103-1104.

${ }^{649}$ F. PARENTE, Il ruolo della simulazione... cit. (nota 648), p. 1107.

${ }^{650}$ F. PARENTE, Il ruolo della simulazione... cit. (nota 648), p. 1104-1105.

${ }^{651}$ F. PARENTE, Il ruolo della simulazione... cit. (nota 648), p. 1107.

${ }^{652}$ F. FERrarA, A simulação... cit. (nota 20), p. 128 ss.

${ }^{653}$ A. VON TuHr, Derecho Civil... cit. (nota 431), p. 505. 


\section{CAPÍTULO III - O REGIME JURÍDICO DA SIMULAÇÃO}

\section{§ 9. A NULIDADE DO NEGÓCIO SIMULADO}

O negócio simulado é nulo. Di-lo, explicitamente, o caput do artigo 167. Apesar disso, dúvidas ainda persistem sobre a eventual inexistência do negócio simulado, assim como sobre as justificativas dogmáticas e os desdobramentos da referida nulidade.

Vejamos, com maior vagar, como o artigo 167, com sua singela e econômica redação, acomoda os variados aspectos da disciplina conferida ao negócio simulado.

\section{A existência do negócio simulado}

O Código Civil de 1916 disciplinava a simulação nos artigos 102 a $105^{654}$. Enquanto a simulação nocente figurava como causa de anulabilidade (simulação invalidande $e^{655}$ ), o artigo 103 estabelecia tratamento diferenciado para a simulação inocente, que não deveria ser considerada defeito do negócio jurídico ${ }^{656}$. A dicotomia

${ }^{654}$ A seguir transcritos:

“Art. 102. Haverá simulação nos atos jurídicos em geral:

I. Quando aparentarem conferir ou transmitir direitos a pessoas das a quem realmente se conferem, ou transmitem.

II. Quando contiverem declaração, confissão, condição, ou cláusula não verdadeira.

III. Quando os instrumentos particulares forem antedatados, ou posdatados.

Art. 103. A simulação não se considerará defeito em qualquer dos casos do artigo antecedente, quando não houver intenção de prejudicar a terceiros, ou de violar disposição de lei.

Art. 104. Tendo havido intuito de prejudicar a terceiros, ou infringir preceito de lei, nada poderão alegar, ou requerer os contraentes em juízo quanto à simulação do ato, em litígio de um contra o outro, ou contra terceiros.

Art. 105. Poderão demandar a nulidade dos atos simulados os terceiros lesados pela simulação, ou representantes do poder publico, a bem da lei, ou da fazenda".

${ }^{655}$ F. C. PONTES DE MIRANDA, Tratado... cit. (nota 220), p. 521.

${ }^{656}$ No Projecto primitivo, inexistia uma previsão equivalente à que viria a plasmar-se no referido artigo 103. Os dispositivos do Projecto primitivo que tratavam da matéria eram os seguintes:

"Da Simulação e Da Reserva Mental

Art. 102. Haverá vício de simulação nos actos entre vivos:

1. ${ }^{\circ}$ Quando as partes praticarem um acto sem intenção de dar-lhe efficiencia, ou para annullarem-no em seguida.

2. ${ }^{\circ}$ Quando o acto apparente occultar um outro que as partes não queiram.

3. ${ }^{\circ}$ Quando não fôr verdadeira a data do instrumento comprobatorio do acto.

Art. 103. A simulação não póde ser invocada por nenhuma das partes coniventes, para eximir-se de obrigação que tenha assumido no acto simulado; mas qualquer terceiro prejudicado poderá promover a sua anullação, em tanto quanto baste para ressarcir o seu direito. 
estabelecida pelo legislador daria origem a debates sobre a condição jurídica do negócio simulado, sobretudo na hipótese de simulação inocente.

Clóvis Beviláqua defendia que o negócio inocentemente simulado seria existente e válido, apesar da simulação ${ }^{657}$. Espínola, conquanto conhecesse bem a categoria da inexistência, afirmava, enigmaticamente, que o negócio licitamente simulado "se annulla, se considera inexistente" ${ }^{958}$. A inusitada cópula de anulação e declaração de inexistência não permite identificar, com segurança, qual teria sido a opinião defendida pelo autor; de todo modo, em outra passagem, ele dizia que a simulação, fosse inocente ou nocente, deveria acarretar a anulação do negócio simulado ${ }^{659}$.

Art. 104. Se a simulação tiver sido commettida exclusivamente em fraude da lei prohibitiva ou fiscal, cabe ao ministerio publico promover a annullação do acto, no primeiro caso, e, no segundo, a cobrança dos impostos devidos.

Art. 105. A declaração de vontade subsiste valida, ainda que o declarante haja feito a reserva mental de não querer o que declara, salvo se a pessoa, a quem fôr dirigida, tiver conhecimento da reserva".

Quando submetido à apreciação da comissão revisora, o capítulo dedicado à simulação sofreu importantes alterações. Em reunião ocorrida em 7 de maio de 1900, os membros da Comissão, então presidida pelo Dr. Epitácio Pessoa, concluíram que a seção constante do Projecto primitivo era omissa, em razão de abordar apenas a simulação dos atos entre vivos, e não disciplinar, especificamente, a simulação lícita. Diante disso, propôs, o Dr. Barradas, a substituição dos artigos do Projecto primitivo pelos artigos 521 a 527 do Esbôço de Teixeira de Freitas (v. Código Civil Brasileiro - Trabalhos Relativos à Sua Elaboração, Rio de Janeiro, Imprensa Nacional, 1918).

${ }^{657}$ C. Beviláqua, Código Civil dos Estados Unidos do Brasil, v. 1, Rio de Janeiro, Francisco Alves, 1916, p. 381: "Esta disposição não se encontrava no Projecto primitivo, porque se as partes recorrem aos expedientes da simulação, o acto não tem a seriedade exigida pelo direito, e faz presumir intenção maliciosa. Prevaleceu a opinião contrária, que se apoia no direito romano, por se entender que, não havendo prejuízo de terceiro, nem offensa á lei, nem erro de uma das partes, o acto, embora simulado, é innocente, E DEVE PRODUZIR EFFEITO. Teixeira de Freitas dava ações ás partes para o acto ser annullado, ou valer com o seu caracter verdadeiro (Consol., nota 17 ao art. 358). O Código não considera defeito a simulação inocente; PORTANTO, DEVE SUBSISTIR O ACTO, APEZAR DELLA".

Opinião semelhante foi defendida por Silvio RodRigues (Curso... cit., nota 37, p. 301): "Dispunha o art. 103 que se não considerava defeito a simulação quando inocente. Ora, se a simulação inocente não representava defeito, o ato jurídico dela oriundo não podia ser infirmado, porque era perfeito. Parece evidente que se um negócio não apresenta qualquer vício, não pode ser desfeito, a não ser pelo consenso das partes. Disso decorre que, se inocente o fingimento, o ato simulado prevalece ainda que revelada a simulação".

Embora sustentasse este ponto de vista, o autor concederia à posição doutrinária majoritária, concluindo ser possível o desfazimento do negócio licitamente simulado pelas próprias partes, com base numa interpretação a contrario sensu do artigo 104 do Código Civil de 1916.

${ }^{658}$ E. Espínola, Manual do Código Civil Brasileiro, v. III - Parte Geral - Dos Factos Jurídicos, Parte 1, Rio de Janeiro, Jacintho Ribeiro dos Santos, 1923, p. 504: "Não nos parece admissivel a interpretação do egregio Dr. Clovis Bevilaqua, ao affirmar que ao acto simulado innocente 'deve produzir effeito', 'deve subsistir, apezar da simulação'. Se assim fosse, teríamos que, de accôrdo com o art. 104, não poderiam os contrahentes allegar a simulação, porque fraudulenta; e, de acordo com o art. 103, também o não poderiam porque, sendo inocente o acto simulado, deveria subsistir”. (...) Era presunção de que fosse sempre intuito das partes, ao empregar a simulação, illudir a lei ou prejudicar a terceiro. Condemnava-se, desse modo, a simulação sem indagar do intuito dos contrahentes. Praticaram um acto simulado, soffram-lhe as consequencias".

${ }^{659}$ E. EsPínOLA, Manual... cit. (nota 658), p. 504. 
A divergência doutrinária tornar-se-ia mais acirrada com a publicação do Tratado de Pontes de Miranda. Para este autor, no caso de simulação inocente, não haveria ato jurídico pois somente o suporte fático que embutisse a intenção de prejudicar terceiros ou frustrar a aplicação da lei entraria no mundo jurídico ${ }^{660}$. Existente, válido e anulável seria o ato simulado com animus nocendi, o qual daria azo à simulação invalidante ${ }^{661}$. A simulação inocente seria, por seu turno, preexcludente de juridicidade ${ }^{662}$, ainda que se tratasse de simulação relativa ${ }^{663}$. Os artigos 102 a 105 somente disciplinariam a simulação invalidante pois o legislador não teria repetido a regra da simulação preexcludente de juridicidade que existia no artigo 524 do Esbôço de Teixeira de Freitas ${ }^{664}$.

O cenário normativo acima descrito transformou-se com a entrada em vigor do Código Civil de 2002. O artigo 167 estabelece que o negócio simulado é nulo, sem prever qualquer exceção a esta cominação. Nem todos, porém, entenderam que este marco normativo imporia o abandono à tese da inexistência do negócio simulado.

Marcos Bernardes de Mello, que concebe a simulação como um vício ligado à vontade enquanto elemento cerne do negócio jurídico ${ }^{665}$, sustenta que não seria justificável lançar na "vala comum" da nulidade todas as espécies de negócio simulado. Na simulação relativa inocente, o negócio jurídico deveria ser considerado válido, em vista do princípio da conservação dos negócios jurídicos (a extraversão proporcionaria simples desconsideração do negócio simulado, para que se passasse a considerar a validade do negócio dissimulado; daí cogitar o autor, em tais circunstâncias, de nulidade putativa). Todavia, tratando-se de simulação absoluta inocente, estar-se-ia diante de inexistência, por falta de elemento essencial à formação do fato jurídico (=manifestação consciente de

${ }^{660}$ F. C. PONTES DE MIRANDA, Tratado... cit. (nota 220), p. 500.

${ }^{661}$ F. C. PONTES DE MiRANDA, Tratado... cit. (nota 220), p. 521.

${ }^{662}$ F. C. Pontes De Miranda, Tratado... cit. (nota 220), p. 500: "Entre os figurantes, o ato aparente, sem ofensa, não existe. Aparece, porém não entrou no mundo jurídico. Para qualquer dêles fazer ressaltar a pura aparência, isto é, para mostrar que não houve ato jurídico, basta alegar que só se trata de ato jurídico aparente (=não ato jurídico). A decisão, a respeito, é declarativa negativa”.

${ }^{663}$ F. C. PONTES DE MiRANDA, Tratado... cit. (nota 220), p. 532: “O ato jurídico é, ex hypothesi, inexistente, pois a simulação foi inocente; e o ato jurídico dissimulado talvez satisfaça os pressupostos de existência e de validade. De modo que a vinda à tona depende de poder ser e valer o ato dissimulado: não basta que seja; é preciso que valha. Os pressupostos de validade são elevados a pressupostos de existência".

${ }^{664}$ F. C. PONTES DE MiRANDA, Tratado... cit. (nota 220), p. 500.

${ }^{665}$ M. B. Mello, Teoria do Fato Jurídico - Plano da Validade, $12^{\text {a }}$ ed., São Paulo, Saraiva, 2012, p. 56. 
vontade). A nulidade, propriamente dita, somente teria lugar nas hipóteses de simulação nocente $^{666}$.

No mesmo sentido, Humberto Theodoro Júnior defende que, no caso de simulação absoluta inocente, prevaleceria a autonomia da vontade. A aparência negocial teria sido criada voluntariamente pelos figurantes, mas não chegaria a repercutir na esfera jurídica. A inexistência premeditada do "negócio aparente" não seria mais que um reflexo da intenção das partes. Na hipótese de simulação relativa inocente, não haveria nulidade mormente porque, afora as partes, ninguém mais nutriria interesse quanto à declaração da simulação. O que entraria no mundo jurídico seria tão somente o negócio dissimulado, cuja validade não seria influenciada, em qualquer medida, pelo "negócio aparente". Por conseguinte, somente haveria nulidade nas hipóteses de simulação nocente ${ }^{667}$.

Gaino, a seu turno, entende que o fato de o negócio ser simulado não impederia que este fosse considerado inexistente, em razão da ausência de elementos considerados essenciais pela lei. Isto sucederia, por exemplo, no caso de falsificação do traslado de escritura pública relacionada a contrato de compra e venda, uma vez que faltaria a forma e o consentimento expresso perante o tabelião. Segundo o autor, quando o negócio fosse inexistente, nenhum dos seus efeitos poderia prevalecer, sendo inaplicável a garantia conferida aos terceiros pelo $\S 2^{\circ}$ do artigo $167^{668}$.

A despeito do inegável mérito das opiniões acima expostas, a elas não podemos aderir. Em nossa opinião, a clareza e a univocidade do comando ventilado no caput do artigo 167 não abrem margens a construções alternativas. O negócio simulado é nulo sempre, independentemente da classe de simulação com a qual se depare em determinado caso concreto. O pensamento contrário incorreria naquele vício do qual, segundo a opinião prevalecente nos quadros da Ciência do Direito, padeceria a jurisprudência dos conceitos: a pretensão de extrair-se normas de concepções puramente dogmáticas. À doutrina cumpre racionalizar o sentido da norma, não ditá-lo a partir de arbitrárias abstrações.

A cominação da nulidade implica um juízo de valor por parte do legislador, notadamente o de que o negócio simulado existe enquanto negócio jurídico. $\mathrm{O}$ afastamento

\footnotetext{
${ }^{666}$ M. B. Mello, Teoria do Fato Jurídico... cit. (nota 665), p. 174-175.

${ }^{667}$ Humberto THEODORO JÚNIOR, Comentários... cit. (nota 38), p. 485-487.

${ }^{668}$ I. GAINO, A Simulação... cit. (nota 122), p. 110.
} 
desta conclusão, fundado em uma perspectiva que poderia justificar-se à luz do Código Civil de 1916, não se mostra oportuno nem adequado no presente; é inoportuno porque diminui a relevância da novidade trazida pelo Código Civil de 2002, e inadequado porque divorcia-se do texto legal sem qualquer justificativa legal plausível.

A doutrina produzida durante a vigência do Código Civil de 1916 não negligenciou a peculiaridade com a qual o direito brasileiro disciplinava a simulação, em completa dissonância com os padrões observados nos principais ordenamentos jurídicos europeus. Era inusitada a inserção, no suporte fático da simulação (invalidante), do animus nocendi ${ }^{669}$ (artigo 103 do Código Civil de 1916). Este específico dado normativo permitia conjecturar-se acerca da inexistência do negócio simulado, sobretudo quando não estivesse presente a intenção de causar prejuízos ou desafiar o império da lei. Ocorre, porém, que o artigo 167 não considera o animus nocendi integrante do suporte fático da simulação; pelo contrário, reconhece a existência, ou seja, a relevância jurídica do negócio simulado independentemente daquele elemento. Isto somente pode significar que o objeto da regulação prescrita na norma dedicada à simulação passou a ser uma atividade em si negocial: um regulamento de interesses que deve reputar-se completo pelo simples fato de aparentar conferir ou transmitir direitos a pessoas diversas daquelas às quais realmente se conferem, ou transmitem; expressar declaração, confissão, condição ou cláusula não verdadeira; ou encontrar-se formalizado em instrumento particular antedatado ou pósdatado.

A aproximação do padrão brasileiro àquele do direito europeu confirma o acerto desta interpretação. Houve, de fato, autores europeus que defenderam a inexistência do negócio simulado. Tal vertente teórica, no entanto, é claramente minoritária, sobretudo na Itália, na Alemanha e em Portugal. Há quem defenda a nulidade ${ }^{670}$, e até mesmo a simples

669 T. AsCARELli, Problemas... cit. (nota 413), p. 72 ss. Em vista da peculiar configuração da disciplina atribuída à simulação pelo Código Civil de 1916, Vicente RÁo (Ato Jurídico, 4ª ed., São Paulo, RT, 1997, p. 186-187) chegou a defender que não haveria conflito entre vontade e declaração se não houvesse animus nocendi. Entenda-se bem: o autor não defende que haveria simulação, porém, está não invalidaria o infirmaria o negócio jurídico; diz, diversamente, que sequer se configuraria o fenômeno simulatório, pois "conflito verdadeiro e próprio não pode causar a discordância consensual e consciente entre a vontade de um lado e a declaração de outro lado, sem enganar ou causar dano ao direito alheio e sem violar a lei". Interessantemente, o autor, conquanto se fiasse nas lições de Ferrara para desenvolver seu raciocínio, chega à singular conclusão de que, na simulação inocente, sequer haveria conflito entre vontade e declaração.

${ }^{670}$ G. D. Kallimopoulos, Die Simulation... cit. (nota 124), p. 109 ss.; K. LARENZ, Derecho Civil... cit. (nota 123), p. 500; W. Flume, El negocio jurídico cit. (nota 43), p. 482-485; M. A. DomingueS DE ANDRADE, Teoria Geral... cit. (nota 20), p. 181; 189; C. A. MotA PINTO, Teoria Geral... cit. (nota 435), p. 468; M. C. 
ineficácia relativa ${ }^{671}$, mas menos numerosos são os que insistem com a tese da inexistência ${ }^{672}$.

Deve-se atentar, ademais, ao fato de que, como salienta Moreira Alves, o Código Civil de 2002 não contempla a tripartição dos planos do negócio jurídico (existência, validade e eficácia $)^{673}$. Em vista disso, assim como o Código Civil revogado, o vigente não veicula a norma sobre a simulação preexcludente de juridicidade do Esbôço de Teixeira de Freitas, na qual se inspirou Pontes de Miranda para defender a inexistência do negócio inocentemente simulado. A tese da inexistência do negócio inocentemente simulado mostrava-se plausível, sob a égide do Código Civil de 1916, porque este disciplinava, separadamente, a simulação inocente e a simulação nocente, determinando que somente esta última considerar-se-ia invalidante. Sendo certo que apenas a simulação nocente configuraria vício do negócio jurídico, surgia o impasse quanto à relevância jurídica do negócio eivado de simulação inocente. Com a entrada em vigor do Código Civil de 2002, todavia, a porta de acesso à tese da inexistência do negócio simulado se fecha. $\mathrm{O}$ artigo 167 considera invalidante toda e qualquer simulação. Este dispositivo apresenta abrangência maior que a do artigo 103 do Código Civil de 1916, cobrindo a totalidade do fenômeno simulatório $^{674}$.

DIENER, Il contratto in generale... cit. (nota 40), p. 728-729; R. SACCO, Simulazione cit. (nota 141), p. 5; dentre outros.

${ }^{671}$ C. M. BIANCA, Diritto Civile cit. (nota 63), p. 696; A GenTILI, Simulazione cit. (nota 145), pp 606-608.

${ }^{672}$ L. CAGNETA, Simulazione (verbete) in Digesto italiano, v. 21, Torino, UTET, 1902, p. 411; F. CARRESI, Il contratto cit. (nota 64), p. 394; F. Del Bono, Dichiarazione riproduttiva... cit. (nota 233), p. 17-19; D. Ferreira, Negócio Jurídico Condicional, Coimbra, Almedina, 1998, p. 126-127. Seguindo raciocínio semelhante, G. MESSINA (La simulazione assoluta cit., nota 40, p. 92-95) e M. DAGOT (La simulation... cit., nota 50, p. 57-58) afirmam que o negócio simulado seria um fato jurídico em sentido estrito.

${ }^{673}$ J. C. Moreira Alves, A Parte Geral... cit. (nota 237), p. 105.

${ }^{674}$ É nulo o negócio simulado mesmo no caso em que a ilusão negocial deriva de uma contratação sob nome falso ("nome fantástico"). A dúvida sobre a existência do negócio simulado, nesta hipótese, foi levantada por G. A. NuTI (La simulazione... cit., nota 173, p. 221 ss.; 269 ss.), segundo o qual, se um ou ambos os contraentes contratassem fazendo constar, do instrumento, um nome fictício, seria impossível a conclusão formal do negócio jurídico, uma vez que faltariar-lhe-ia um dos elementos do suporte fático.

Para o autor, a indicação de um sujeito inexistente interromperia o nexo de coligação com a imputação jurídica sem o qual o figurante não poderia ser considerado titular nem mesmo da vontade de declarar. É de se assinalar, neste mister, que fosse impossível atribuir a declaração prestada sob nome alheio a qualquer sujeito, então, por coerência, dever-se-ia concluir que o negócio jurídico celebrado em data não verdadeira não se vincularia, como fato histórico, a qualquer data. Essa elaboração, contudo, não se afiguraria promissora. Assim como soaria absurdo estatuir que o negócio jurídico não pertence a qualquer momento temporal, seria dificilmente sustentável a suposição de que uma declaração socialmente recognoscível não possui autor (como se fosse possível uma declaração surgir por obra do acaso, como fenômeno da natureza). A existência de um autor da declaração é um corolário da cognição realizada pelo público; logo, precisar a sua identidade em nada difere da descoberta do efetivo conteúdo da declaração (no caso de declaração não 
Dessa feita, não persiste aquela lacuna que, ao tempo do Código Civil revogado, induzia parte da doutrina a considerar inexistente o negócio inocentemente simulado. Dizendo de outro modo: seria possível cogitar-se do reconhecimento de lege ferenda da simulação preexcludente de juridicidade se, dentre todos os negócios simulados possíveis, algum deixasse de submeter-se à disciplina da simulação invalidante contida no caput do artigo 167; como, porém, isto não ocorre, a adoção, no presente momento, da lógica da inexistência análoga à sustentada à luz do Código Civil de 1916 seria não apenas errada, como, sobretudo, contra legem.

Nesse passo, não é demais recobrar que, como demonstramos acima ${ }^{675}$, o negócio simulado é estruturalmente perfeito. Não lhe falta, como sugere Marcos Bernardes de Mello, uma "manifestação consciente de vontade": a uma, porque a simulação não se confunde com a coação ou o erro obstativo, na presença dos quais poder-se-ia cogitar da ausência da exteriorização de uma vontade efetiva; a duas, porque o suporte fático do negócio jurídico consiste na declaração de vontade, sendo-lhe estranho o fato psicológico $^{676}$ (é, ainda, o que se extrai do artigo 112, o qual alude à vontade “consubstanciada" na declaração); e, por derradeiro, a três, porque o negócio simulado é fruto da expressão de uma específica vontade de simular, uma vez que não há simulação por erro ou por obra de um fenômeno da natureza.

Nesse passo, insta esclarecer que a constatação da existência do negócio simulado não impede que se considere inexistente a relação jurídica de cuja aparência ele se reveste. Se a compra e venda, por exemplo, se reveste da aparência de locação, a locação é inexistente; ou, então, se a absoluta inércia jurídica se reveste da aparência de um empréstimo, este é inexistente. Advirta-se, contudo, que a predicação da ilusão negocial como inexistente seria imprópria, pois, sendo esta o (pretenso) efeito da simulação, não se

verdadeira de que trata o inciso II do $\S 1^{\circ}$ do artigo 167), ou do efetivo titular do bem ou direito objeto do negócio jurídico (no caso da interposição fictícia).

Enfim, constatar a verdadeira identidade do declarante inclui-se no trâmite de desvelamento da simulação ou melhor dizendo, de evidenciação da dissimulação, a que pode sujeitar-se todo e qualquer negócio relativamente simulado.

${ }^{675} \mathrm{~V}$. tópico 10.

${ }^{676}$ E. BETTI, Teoria generale... cit. (nota 53), p. 54 ss. Antônio JUNQUEIRA DE AzEVEDO, Negócio Jurídico... cit. (nota 440), p. 82: "Em resumo, analisando o negócio jurídico no plano da existência, vê-se logo que a vontade não faz parte dele; o que ocorre é que a declaração deve resultar de um processo volitivo, sob pena de não valer ou de não produzir efeitos (planos da validade ou da eficácia). Com esta visão, o problema muda completamente de figura. Será, apenas, uma questão de grau saber até que ponto o direito positivo admite o até que ponto deve ele de lege ferenda admitir as influências da vontade sobre a declaração". 
mostra idônea a ser qualificada como existente ou inexistente. Deveras, deve-se considerar simulado, como dita a lei, o negócio jurídico que "aparenta" ou "contém" uma inverdade; trata-se, pois, de um regulamento de interesses segundo o qual as partes criam a ilusão negocial. O negócio simulado é a causa eficiente da ilusão negocial. Aquele é existente (em sentido técnico), mas nulo; esta, a rigor, também é existente (em sentido lato), mas enquanto aparência, ou seja, como incorreta representação da realidade formada pela razão do público.

Para concluir o exame desta complexa questão, vem a calhar, por encorajar a defesa das opiniões que acima emitimos, a feliz intuição de Gentili ${ }^{677}$ : o fato de a norma rejeitar determinada manifestação negocial exclui a inexistência desta; com efeito, fosse inexistente o negócio simulado, qual seria a utilidade e o sentido do artigo 167? Se considerou necessária a sua intervenção, o legislador viu motivo suficiente para tanto.

\section{A nulidade especial prevista no artigo 167}

Durante a vigência do Código Civil de 1916, a simulação figurava como causa de anulabilidade do negócio jurídico (artigo 147, inciso II). Com a entrada em vigor do Código Civil de 2002, a disciplina da simulação foi deslocada do capítulo dos defeitos para o capítulo das invalidades do negócio jurídico.

Defendemos, no Capítulo I, que o negócio simulado é um ato de autonomia privada. Deve, porém, ficar claro que, com esta ponderação, pretendemos tão somente atestar que a simulação surge em virtude de um fenômeno de natureza negocial. O negócio simulado existe enquanto negócio jurídico; corresponde ao regulamento de interesses, instaurado entre os simuladores, cuja finalidade consiste na perpetração da ilusão negocial.

Considerar que o negócio simulado é uma manifestação de autonomia privada não implica, contudo, atestar a sua validade. Esta, entendida como a potencialidade de produzir efeitos jurídicos regulares, depende do processamento de um juízo de mérito (ou melhor, de uma valoração ${ }^{678}$ ) por parte da ordem normativa. No direito brasileiro atual, a valoração do negócio simulado é-nos dada explicitamente. Ao tipificar a causa simulatória, o

${ }^{677}$ A GENTILI, Simulazione cit. (nota 145), p. 602.

${ }^{678}$ G. B. FERri, Causa e tipo... cit. (nota 66), p. 255. 
legislador tomou uma posição sobre o desvalor dos interesses que a caracterizam. $\mathrm{O}$ negócio simulado é nulo porque o legislador, formulando o juízo axiológico ínsito a uma norma inspirada pela jurisprudência de valoração, concluiu serem indignos de tutela jurídica os interesses dos simuladores.

A doutrina produzida após a entrada em vigor do Código Civil de 2002 tem associado a nulidade, cominada no artigo 167, a um defeito estrutural do negócio simulado. Ao abordar o tema, Rizzardo sustenta que o negócio simulado seria nulo em razão da falta de $_{\text {objeto }}{ }^{679}$. Já Gaino afirma que nulidade resultaria da falta de correspondência entre a vontade e a declaração ${ }^{680}$. Já tivemos oportunidade de expor as razões que nos levam a rejeitar estas opiniões ${ }^{681}$. Cumpre, assim, examinarmos os contornos característicos da categoria da nulidade para, então, buscarmos uma justificativa para o regime jurídico previsto no artigo 167.

A invalidade costuma ser associada ao vício de algum dos elementos essenciais do negócio jurídico ou de algum dos pressupostos constitutivos do tipo a que este pertence $^{682}$. Esta classe abrange duas distintas categorias: a nulidade e a anulabilidade. Em termos gerais, as características da nulidade são as seguintes ${ }^{683}$ :

(a) tutela interesses gerais, aplicando-se a situações que a ordem pública reputa perniciosas;

(b) opera de pleno direito; não é necessária uma sentença judicial para desconstituir o negócio jurídico, o qual é nulo desde a sua formação;

(c) pode ser alegada por qualquer interessado, assim entediado o titular de toda relação jurídica que pudesse ser afetada se nulidade não houvesse; pode,

\footnotetext{
${ }^{679}$ A. Rizzardo, Parte Geral do Código Civil, $7^{\mathrm{a}}$ ed., Rio de Janeiro, Forense, 2011, p. 493-494.

${ }^{680}$ I. GAINO, A Simulação... cit. (nota 122), p. 45. Em idêntico sentido, R. SENISE LiSBOA (Manual... cit., nota 122 , p. 468) associa a nulidade do negócio simulado a um descompasso entre a vontade e a declaração: "[a] simulação não se restringe mais à falsidade da declaração negocial como meio de acarretar prejuízos a terceiros. Deixou-se de lado a imprescindibilidade do intuito de causar prejuízo. Na nova codificação, basta que a declaração não corresponda à vontade real das partes, à aparência não verdadeira da declaração".

${ }^{681} \mathrm{~V}$. tópico 10.

${ }^{682}$ E. BETTI, Teoria generale... cit. (nota 53), p. 457.

${ }^{683}$ Custódio da Piedade Ubaldino MiRAndA, Teoria Geral... cit. (nota 51), p. 154; Z. Veloso, Invalidade do Negócio Jurídico - Nulidade e Anulabilidade, Belo Horizonte, 2a ed., Del Rey, 2005, p. 313-314.
} 
ainda, ser reconhecida ex officio, em processo judicial que envolva o negócio jurídico viciado (artigo 168);

(d) previne que o negócio jurídico produza quaisquer dos seus efeitos típicos; e

(e) não é suprível, sanável pelo decurso do tempo, ou passível de confirmação pelos interessados; o pleito da declaração da nulidade não se sujeita à decadência (artigo 169).

Por outro lado, a anulabilidade se notabiliza, genericamente, pelos seguintes $\operatorname{traços}^{684}$ :

(a) protege interesses individuais de uma das partes do negócio jurídico;

(b) não opera ipso jure; é indispensável a ação judicial voltada à decretação da anulação, a qual, ademais, não pode ser reconhecida ex officio;

(c) somente pode ser alegada pelos sujeitos em benefício e no interesse dos quais foi prevista;

(d) somente aproveitar ao interessado que a alega, salvo nos casos de solidariedade e indivisibilidade (artigo 177);

(e) não impede que o negócio jurídico produza efeitos enquanto não for anulado; e

(f) é sanável pelo decurso do tempo (artigo 179) ou pela confirmação dos interessados (artigos 172 a 176).

Vale aqui registrar que algumas das diferenças entre a nulidade e a anulabilidade têm sido relativizadas pela doutrina mais recente. Nesse contexto, afirma-se que o direito brasileiro não teria acolhido a figura da nulidade de pleno direito; na realidade, tanto a nulidade quanto a anulabilidade somente poderiam operar-se mediante sentença judicial. Além disso, questiona-se a eficácia ex nunc que parte da doutrina atribui à decretação da anulabilidade; defende-se, contrariamente a este entendimento, que o artigo 182 aplicar-se-

${ }^{684}$ Custódio da Piedade Ubaldino MiRAndA, Teoria Geral... cit. (nota 51), p. 155. 
ia indistintamente aos negócios nulos e anuláveis, de modo que também a anulabilidade desconstituiria a relação jurídica desde o início ${ }^{685}$.

Outro aspecto que tem sido destacado pela doutrina refere-se ao fato de que a enumeração das hipóteses de nulidade e de anulabilidade não possuiria inspiração científica $^{686}$. A distinção entre nulidades e anulabilidades não poderia ser colhida do cotejo entre as consequências que delas decorrem, pois não haveria uniformidade quanto aos respectivos regimes jurídicos; diversamente, caberia reportar-se à enunciação de hipóteses, contida na lei, para identificar-se aquelas que seriam reconduzíveis a cada uma das referidas categorias ${ }^{687}$. Configurar-se-ia, em princípio, a nulidade, quando o negócio jurídico encontra-se gravemente viciado; a anulabilidade, por sua vez, caracterizar-se-ia na hipótese de o negócio simulado encontrar-se inquinado de vícios leves. Contudo, a definição dos vícios mais graves e menos graves não se daria com precisão. Nulo e anulável seriam somente "nomes". O legislador sentir-se-ia livre para, vez ou outra, denominar "nulo" um negócio jurídico, mas submetê-lo a um regime jurídico semelhante ao da anulabilidade, sendo certo que o contrário também poderia acontecer. $\mathrm{O}$ sistema das invalidades do Código Civil seria, na verdade, um "não sistema", motivo pelo qual a delimitação das fronteiras entre o válido, o nulo e o anulável não poderia ter explicação que não fosse de natureza político-legislativa ${ }^{688}$.

Nesse estado de coisas, é difícil atestar categoricamente, com base em ilações conceituais abstratas, a razão da nulidade cominada ao negócio simulado pelo artigo 167. O exame sistemático da legislação confirma, a princípio, que a simulação não depõe contra a capacidade das partes (artigo 166, inciso I), não vicia nem torna ilícito o objeto (artigo 166, inciso II), não acarreta a ilicitude do motivo comum determinante (artigo 166, inciso III), nem pressupõe a preterição de formalidades ou solenidades previstas em lei (artigo 166, incisos IV e V). A solidez destas constatações deriva do simples fato de que, fosse o negócio simulado inquinado por uma das referidas imperfeições, não seria necessário que o artigo 167 lhe cominasse a nulidade. Não tem razão, portanto, Humberto Theodoro Júnior

\footnotetext{
${ }^{685}$ L. Mattietto, Invalidade dos atos e negócios jurídicos in G. TePedino (coord.), A Parte Geral do Código Civil - Estudos e Perspectivas do Direito Civil Constitucional, Rio de Janeiro, Renovar, 2007, p. 343-348; Humberto THEODORO JúNIOR, Comentários... cit. (nota 38), p. 425; 618.

${ }^{686}$ Orlando GOMES, Introdução... cit. (nota 78), p. 532 ss.

${ }^{687}$ L. MATTIETTO, Invalidade... cit. (nota 685), p. 345.

${ }^{688}$ Antônio JunQUEIRA DE AZEVEDO, Negócio Jurídico e Declaração Negocial... cit. (nota 279), p. 111-112.
} 
quando defende que a simulação ensejaria uma ilicitude do objeto ${ }^{689}$; ora, fosse este o caso, a nulidade decorreria da regra geral ventilada no inciso II do artigo 166. Não nos parece, com efeito, adequado supor que o legislador tenha descuidado da sistematicidade ao prescrever a disciplina jurídica do negócio simulado, ainda mais quando inexistam fundamentos autônomos capazes de justificar uma redundância desse tipo. A tarefa racionalizadora que incumbe ao jurista conduz, nesta sede, à percepção de que a nulidade do negócio simulado não decorreria, naturalmente, da aplicação do artigo 166; disso teria surgido a necessidade de estabelecê-la em dispositivo específico.

Dessa feita, parece-nos que o artigo 167 ventila hipótese de nulidade especial. O artigo 166, inciso VII, alude a esse tipo de nulidade, ao prever que também será nulo o negócio jurídico que a lei taxativamente declarar como tal.

A nulidade especial é geralmente prevista como forma de tutela de determinados interesses que não seriam protegidos com base nas regras gerais da nulidade. São exemplos claros deste expediente as chamadas nulidades de proteção previstas na legislação consumeirista, especialmente no que tange às cláusulas abusivas. A especialidade da nulidade, porém, não exclui os traços característicos desta categoria, como a decretabilidade de ofício, a insuscetibilidade à decadência e a definitividade da consequente ineficácia. Demais disso, ainda que a nulidade fosse prevista com vistas a prover maior justiça a um grupo de posições jurídicas, ela não deixaria de se referir a situações de danosidade social generalizada ${ }^{690}$.

Consequentemente, a nulidade do negócio simulado não decorre de qualquer imperfeição estrutural, mas de uma pontual valoração empreendida pelo legislador. O conteúdo desta valoração pode tornar-se melhor compreensível a partir de um paralelo entre o direito brasileiro e o alemão. Como se sabe, o $§ 117$ do Código Civil alemão também estabelece a nulidade do negócio simulado. Em vista deste dispositivo, a doutrina sustenta que a nulidade seria uma decorrência do sentido jurídico do comportamento negocial das partes. Estas não desejariam a produção de efeitos capazes de alterar a sua posição jurídica; buscariam, deliberadamente, a inércia. A nulidade, portanto, resultaria do

\footnotetext{
${ }^{689}$ Humberto THEODORO JÚNIOR, Comentários... cit. (nota 38), p. 470.

${ }^{690}$ C. M. BianCA, Diritto Civile cit. (nota 63), p. 623-625.
} 
reconhecimento, pelo ordenamento jurídico, da situação jurídica inoperante predisposta pelos contraentes ${ }^{691}$.

É de se assinalar, todavia, que se o negócio simulado visa à disseminação do engano generalizado, então não é verdade que os simuladores buscam a absoluta inércia jurídica. Pretendem, sim, que suas esferas individuais de direitos e obrigações permaneçam inalteradas; contudo, na medida em que a causa simulandi em sentido estrito é associativa, as partes empenham esforços para que suas condutas gerem, ao menos, um resultado: a ilusão negocial. Isto significa que, se fosse válido o negócio simulado, os terceiros não poderiam alegar terem sido enganados, pois a ilusão negocial seria tutelada pela ordem jurídica. Quando, então, o artigo 167 diz que o negócio simulado é nulo, exclui a produção daquele resultado, em particular. Nega, aos simuladores, a possibilidade de ludibriar a razão alheia mediante a perpetração de uma situação jurídica apenas aparente.

Ante o exposto, a nulidade especial prevista no artigo 167 afigura-se como instrumento de proteção da confiança do público; é uma medida normativa que visa a "valorizar a verdade" $" 692$. Não há, no direito brasileiro, uma regra que vede o sigilo das relações particulares; aliás, em alguns casos, o segredo se mostra digno de específica proteção, como ocorre, por exemplo, com o segredo industrial. O ordenamento jurídico não permite, todavia, que o segredo prevaleça de modo a iludir a comunidade, levando esta a crer em aparências que não correspondem à essência dos negócios privados ${ }^{693}$. A confiança do público não pode ser traída; eis um importante contraponto à garantia fundamental da

\footnotetext{
${ }^{691}$ K. LARENZ, Metodologia... cit. (nota 123), p. 500-501; W. FluME, El negocio jurídico cit. (nota 43), p. 482. Esclarecedoras, nesse sentido, são as ponderações de G. D. KALlimopoulos, Die Simulation... cit. (nota 124), p. 109: "Diferentemente se mostra a situação no caso de um negócio aparente puro: não se quer, desde o começo, originar qualquer consequência jurídica, que corresponde às declarações externalizadas. Quer-se permanecer na situação antiga e se age 'jurídico-negocialmente' por almejar outros objetivos, os quais podem ser alcançados apenas ou ao menos mediante o engano de terceiros. Essas intenções das partes, que não se podem assumir sempre oriundas de motivos ilícitos, é considerada pelo ordenamento jurídico, vez que ele, como as partes almejam, confere ao negócio aparente todo efeito jurídico no sentido das declarações entregues pelas partes, encarando-o como nulo". Tradução livre; no original: "Anders gestaltet sich die Lage bei den reinen Scheingeschäften: Man will von Anfang an keine Rechtsfolgen bewirken, die den geäußerten Erklärungen entsprechen. Man will beim alten bleiben und betätigt sich 'rechtsgeschäftlich', um anderer Zwecke willen, die sich nur oder zumindest leichter durch Täuschung Dritter erreichen lassen. Diesen Parteiabsichten, die nicht immer aus unlauteren Gründen $\mathrm{zu}$ erklären sind, trägt die Rechtsordnung Rechnung, indem sie, wie von den Parteien gewünscht, dem Scheingeschäft jede Rechtswirkung im Sinne der abgegebenen Erklärungen abspricht und es als nichtig betrachtet”.

${ }^{692}$ Humberto THEODORO JÚNIOR, Comentários... cit. (nota 38), p. 490.

${ }^{693}$ L. MATTIETTO, Invalidade... cit. (nota 685), p. 348. O autor, contudo, afirma que a simulação privaria o negócio jurídico de sua causa; a improcedência desta tese encontra-se demonstrada no tópico 9.
} 
privacidade, cuja aplicabilidade irrestrita poderia levar a situações de injustificável insegurança, sobretudo nos âmbito da atividade negocial.

É interessante notar, em sintonia com os ensinamentos da doutrina alemã, acima colacionados, que a nulidade do negócio simulado não constitui uma penalização aos simuladores $^{694}$. A caracterização da nulidade como sanção já é, por si, controversa ${ }^{695}$. No caso do negócio simulado, contudo, mostra-se acima de dúvidas o papel que desempenha a nulidade: menos que uma sanção aos simuladores, ela atua como ferramenta de composição dos conflitos de interesses instaurados em torno do negócio simulado. Com a nulidade, as expectativas das partes são atendidas, ao menos em parte, pois se assegura a ineficácia da relação jurídica aparente e elimina-se a incerteza sobre a alegabilidade da simulação. Do ponto de vista dos terceiros, a nulidade prestigia os interesses que tenham sido preteridos pela ilusão negocial, embora a norma preveja que os direitos de terceiros de boa-fé não possam ser prejudicados em virtude do desvelamento da aparência enganadora (artigo 167, $\S 2^{\circ}$ ). Esta multifacetada composição reforça a constatação de que a nulidade do negócio simulado é especial, produto de uma valoração preocupada com a mitigação dos efeitos negativos que a simulação pode ocasionar em diversos planos: o das partes, o dos terceiros interessados na nulidade e o dos terceiros interessados na eficácia da aparência negocial.

Vale esclarecer, por fim, que as ponderações precedentes não levam ao esvaziamento da distinção entre simulação inocente e simulação nocente. Com efeito, esta dicotomia pouco importa para a aplicação do regime da nulidade ao negócio simulado ${ }^{696}$. Não há de se ignorar, no entanto, que o negócio simulado não é necessariamente ilícito ${ }^{697}$; desse modo, o negócio eivado de simulação nocente é nulo por mais de um fundamento

\footnotetext{
${ }^{694}$ Na Itália: A. LuMINOSO, Il mutuo dissenso cit. (nota 118), p. 218 ss.

${ }^{695}$ Sobre a discussão relativa ao tema, v., E. A. ZANNONI, Ineficacia y nulidad de los actos jurídicos, Buenos Aires, Astrea, 1986, p. 160-162; M. B. Mello, Teoria do Fato Jurídico... cit. (nota 665), pp 86 ss.

${ }^{696}$ P. S. Gagliano - R. PAmplona Filho, Novo Curso de Direito Civil... cit. (nota 241) , p. 419. Isto, aliás, já observava J. C. Moreira Alves (A Parte Geral... cit., nota 237, p. 118-119), ao comentar a direção que seguia o anteprojeto do Código Civil de 2002: “Ao disciplinar a simulação, apartou-se o Projeto inteiramente do sistema observado pelo Código vigente (...). Não mais se distingue a simulação inocente da fraudulenta; ambas conduzem ao mesmo resultado: nulidade do negócio simulado, e subsistência do dissimulado, se for o caso. Essa, aliás, a conseqüência - segundo a melhor doutrina - que resulta do art. 103 do Código em vigor, que não considera defeito a simulação inocente". Mas o fato de ambas as simulações, a inocente e a nocente, conduzirem à nulidade do negócio jurídico, não significa, em absoluto, que elas sejam equiparáveis.

${ }^{697}$ L. CARIOTA FERRARA, Il negozio giuridico... cit. (nota 34), p. 525; N. Distaso, La simulazione... cit. (nota 40), p. 213-215; G. A. NUTI, La simulazione... cit. (nota 173), p. 17-18; F. CARRESI, Il contratto cit. (nota 64), p. 392.
} 
(como também seria, por exemplo, o negócio formal que tivesse objeto indeterminável), pois, além de simulado, pode ser ilícito.

Ademais, a nocência pode ser relevante para a constatação do interesse na declaração de nulidade do negócio simulado, e para a definição de ulteriores desdobramentos desta, como, por exemplo, a possibilidade de um dos simuladores obter a reparação por danos sofridos em virtude da simulação, aos quais corresponda um injustificado enriquecimento da contraparte. Por conseguinte, não deve reputar-se o animus nocendi completamente desprovido de importância. Como observa Ceroni ${ }^{698}$, é possível que a simulação seja manejada com vista à persecução de objetivos (motivos) legítimos. Há, nesta hipótese, um fim digno de aprovação, o qual, porém, não justifica o meio consistente na simulação. Não necessariamente os simuladores buscam prejudicar direitos de terceiros. Pense-se no caso de uma compra e venda simulada com o objetivo de dissimular a doação realizada a indivíduo que, por convicções morais ou filosóficas, sentirse-ia humilhado pelo fato de sua comunidade conhecer da liberalidade realizada em seu favor. Evidentemente, o negócio simulado seria nulo, mas nem por isso poder-se-ia dizer ilícito. O negócio simulado sempre será nulo; apenas eventualmente, contudo, pode surgir a pretensão de um ou mais terceiros à reparação de danos eventualmente experimentados em virtude da simulação.

\section{Os desdobramentos da nulidade do negócio simulado}

Declarada a nulidade do negócio jurídico, restituem-se partes ao estado em que antes dele se achavam, e, não sendo possível restituí-las, serão indenizadas com o equivalente. É o que dispõe o artigo 182.

O negócio simulado não deve acarretar qualquer alteração na condição jurídica dos simuladores; isto, porém, pode eventualmente ocorrer, na medida em que a criação dos índices de significação sobre os quais repousa a ilusão negocial implique a transferência de bens ou direitos. A compra e venda simulada pode vir acompanhada da entrega da coisa vendida e do pagamento do preço, ainda que em aparência; o mútuo simulado pode acarretar a disponibilização dos montantes emprestados e a restituição destes, adicionados dos juros pactuados, posto que ilusoriamente. Nesse estado de coisas, a principal

${ }^{698}$ C. CERONI, Autonomia privata ... cit. (nota 115), p. 22-24. 
consequência da declaração de nulidade do negócio simulado consiste na imposição, aos simuladores, da obrigação de desconstituir os índices de significação criados, mormente quando estes tenham envolvido a transferência, entre si, de bens ou direitos.

É bem verdade que nem todos os desdobramentos fáticos e jurídicos do negócio simulado serão desfeitos quando se trate de simulação relativa; com efeito, parte deles pode corresponder, precisamente, ao cumprimento do negócio dissimulado que venha a extraverter-se. Tratando-se, contudo, de simulação absoluta, a reconstituição do statu quo ante deverá ser integral.

Nesse cenário, dúvidas podem surgir sobre a possibilidade de repetição de valores eventualmente pagos por um simulador ao outro, uma vez que os artigos 882 e 883 vedam a devolução do pagamento de prestação judicialmente inexigível e de coisas dadas com vistas à obtenção de fimm ilícito, imoral, ou proibido por lei. Tais normas, porém, não devem aplicar-se no caso de pagamentos aparentes. Não havendo seriedade nos pagamentos efetuados, estes não devem receber esta qualificação, mantendo-se, portanto, à margem do âmbito de incidência dos artigos 882 e 883 .

Problemas, ainda, podem ser enfrentados relativamente a eventual pleito de indenização em circunstâncias diversas daquela aludida no artigo 182. Considere-se que por conta da titularidade aparente assumida em virtude da simulação, um dos contraentes incorra, perante terceiros, em despesas relacionadas, por exemplo, à preservação do bem ou ao pagamento de impostos. Declarada a nulidade do negócio simulado, teria, o sujeito que arcasse com tais custos, o direito de ser ressarcido dos montantes despendidos?

Como se sabe, o artigo 150 veda que uma das partes peça indenização em face da outra na hipótese do dolo concorrente. Mas a analogia com a simulação não se mostra cabível, pois, como veremos ${ }^{699}$, os simuladores podem alegá-la, o que já não se faculta na hipótese de dolo.

A nosso ver, a indenização acima referida pode ser concedida pelo juiz nos casos de simulação inocente. Em tais circunstâncias, não tendo havido a intenção de prejudicar direitos alheios, nem o intuito de frustrar a aplicação de normas imperativas, a restituição 
dos simuladores ao statu quo ante deve abranger, igualmente, os "custos da simulação", assim entendidos os gastos que uma das partes tenha assumido exatamente por conta da titularidade aparente em que se funda a ilusão negocial. A rigor, tais custos deveriam ter sido honrados pelo efetivo titular do bem ou direito que os teria gerado, e a negativa ao direito de indenização do simulador que os tivesse circunstancialmente assumido fatalmente acarretaria uma nova ilegalidade, consistente no enriquecimento sem causa da contraparte do negócio simulado. A aplicação do artigo 182, nestes termos, representa uma concretização do princípio da vedação ao enriquecimento sem causa ${ }^{700}$.

No que se refere aos casos de simulação nocente, a questão mostra-se mais complexa. Permaneceria, nestas situações, a potencialidade do enriquecimento sem causa de um dos simuladores; contudo, a simulação poderia ter sido adotada exatamente com o propósito de elidir o pagamento do custo que, em última instância, viesse a dar origem ao pedido de indenização.

Tome-se, como exemplo, uma transação comercial realizada entre duas empresas, "A" e "B". Com vistas a oferecer o seu produto por um preço mais competitivo, "A" resolve concluir a operação mediante a interposição fictícia da empresa "C", que integra o seu grupo econômico e goza de um incentivo fiscal consistente na isenção do Imposto sobre Produtos Industrializados. De modo que, em aparência, "B" adquire mercadorias fornecidas por " $C$ ", enquanto, efetivamente, tais mercadorias são fornecidas por "A". Em virtude desta triangulação, "B" logra adquirir os produtos de seu interesse por um preço menor; em contrapartida, "C" não sofre qualquer perda econômica com a venda assim processada, pois a redução no preço praticado equivale ao montante do imposto que deixaria de recolher. Pois bem: algum tempo depois, o fisco federal instaura uma auditoria tendo por objeto esta negociação. Após a colheita de evidências e a condução de detalhada investigação, constata a presença de índices que permitiriam concluir ter havido simulação por interposição de pessoa. Consequentemente, exige, em face de "A", o interponente, o pagamento do imposto não recolhido por "C", o interposto.

Se a transação comercial do exemplo não tivesse sido simulada, "A" recolheria o imposto normalmente e o embutiria no preço da mercadoria. Com o rumo que os

${ }^{700}$ G. E. NANNI, Enriquecimento Sem Causa, $3^{\mathrm{a}}$ ed., São Paulo, Saraiva, 2012, p. 392. 
acontecimentos tomaram, porém, nada obstante " $\mathrm{B}$ " tenha se valido da economia correspondente ao não recolhimento do imposto, "A" terá de pagá-lo aos cofres públicos, arcando, portanto, com o custo que deveria ter sido repassado ao seu cliente. Diante desse cenário, caberia perguntar se a restituição das partes ao statu quo ante não consentiria que "A" fosse ressarcida do custo tributário decorrente do desvelamento do esquema simulatório.

A solução, a nosso juízo deve ser afirmativa. Ainda que a simulação tenha sido manejada pelas partes com vistas a lesar o fisco - ou, talvez, exatamente por isso -, não seria adequado negar-se o direito à indenização pleiteada por " $\mathrm{A}$ " na medida em que isto implicaria a perpetuação do locupletamento gozado por "B". Uma das principais preocupações da doutrina, de longa data, tem sido a de que o exaurimento da simulação não pode dar azo a vantagens para qualquer dos simuladores. A restituição ao statu quo ante deve significar tão somente o desfazimento dos atos praticados no curso do procedimento simulatório, sendo certo que disto não pode derivar o favorecimento de qualquer das partes. Se assim não fosse, se o benefício buscado por um dos partícipes da simulação ultimasse-se consolidado, a nulidade não desempenharia com plenitude o seu papel; a ilusão negocial teria servido para alguma coisa, pois, ao menos um dos mentores do estratagema simulatório se safaria com as benesses perseguidas por meio de sua atuação ilícita.

Em se tratando de simulação tributária, "A" sofreria a imposição de penalidade pela evasão fiscal, a qual, obviamente, não haveria de ser indenizada. Seria sua pena por ter-se metido com a artimanha. O benefício econômico gozado por "B", às custas do empobrecimento de "A" - correspondente ao imposto devido - deveria, porém, ser indenizado. Não apenas porque o enriquecimento de "B" careceria de causa, mas, sobretudo, porque teria causa ilícita.

O princípio que há de reger a resolução de discussões como estas, a nosso juízo, é o da eliminação das vantagens decorrentes da simulação quanto a todos que dela participam. 


\section{A nulidade parcial do negócio simulado}

Uma questão desafiadora que costuma surgir quando se analisa a nulidade do negócio simulado diz respeito à extensão dos efeitos da sua declaração. Tratando-se de caso de simulação parcial, deveria ser também parcial a declaração de nulidade?

A nulidade parcial do negócio jurídico encontra-se, atualmente, disciplinada no artigo 184. Segundo este dispositivo, a invalidade parcial de um negócio jurídico não o prejudicará na parte válida, se esta for separável. Há quem entenda que nos casos em que apenas um dos elementos do negócio jurídico é simulado (e.g. o preço, uma condição, a data etc.), somente a parcela viciada deveria ser tida como nula ${ }^{701}$. Têm razão os que assim pensam.

Em vista disso, tendemos a concordar com a possibilidade de um negócio parcialmente simulado ser parcialmente nulo. No entanto, para que se possa considerar a parte simulada "separável" do restante do negócio jurídico, a simulação parcial deve ser aferida com base no parâmetro estrutural que propusemos acima. Se assim não fosse, correr-se-ia o risco de considerar válido o esquema negocial que teve de ser inteiramente simulado, ainda que com vistas a criar uma ilusão negocial atinente a um único aspecto (como, por exemplo, o caso da antedata ou pós-data). Remetemos o leitor, neste passo, ao tópico 25 , onde explicamos com maior riqueza de detalhes os critérios para a identificação da simulação parcial.

\section{§ 10. A LEgITIMIDAde PARA ALEGaR A NULIDADE do NEGócio SIMULAdo}

Durante a vigência do Código Civil de 1916, os artigos 103 e 104 daquele diploma suscitaram discussões sobre a possibilidade de a simulação ser alegada pelas partes. Não havia dúvidas de que os terceiros poderiam pleitear a anulação do negócio simulado, quando este lhes causasse prejuízo; era obscuro, no entanto, se as partes poderiam fazê-lo.

Com a entrada em vigor do Código Civil de 2002, um novo cenário se descortina. O negócio simulado, nulo que é, passa a sujeitar-se à regra do artigo 168, segundo o qual

${ }^{701}$ I. GAINO, A Simulação... cit. (nota 122), p. 114. 
as invalidades podem ser alegadas por "qualquer interessado". Este dispositivo, por se referir à alegabilidade das nulidades, tende a ser interpretado de maneira ampla: qualquer interessado seria sinônimo de "qualquer pessoa". Este entendimento, porém, deve ser evitado.

A norma é muito precisa ao estabelecer que a legitimidade para deduzir a nulidade do negócio jurídico em juízo depende do interesse; mais precisamente, do interesse de agir. Vejamos, então, como e sob quais condições pode-se ter como presente o interesse de dos contraentes e dos terceiros quanto à declaração de nulidade do negócio simulado.

\section{O debate sob a vigência do Código Civil de 1916}

Sob a vigência da legislação revogada, um acalorado debate se desenrolou em torno deste assunto. Dois tópicos ocuparam a agenda da doutrina, neste particular:

(a) a possibilidade de se alegar a simulação inocente, diante da previsão contida no artigo 103 do Código Civil de 1916; e

(b) a possibilidade de a simulação nocente ser alegada pelas partes, em vista da vedação veiculada no artigo 105 do Código Civil de 1916.

Quanto à possibilidade de se alegar a simulação inocente, alguns autores buscavam extrair uma solução a partir do próprio artigo 104, realizando uma leitura $a$ contrario sensu; outros, porém, buscavam um fundamento no artigo 103.

San Tiago Dantas, por exemplo, entendia que o ato simulado podia ser anulado sempre, em qualquer situação, fosse pelas partes ou por terceiros ${ }^{702}$.

Clóvis Beviláqua, por seu turno, defendia que, como decorrência do que dispunha o artigo 103 do Código Civil de 1916, nada poderia ser alegado a respeito do ato inquinado

\footnotetext{
702 San Tiago DANTAS (Programa... cit., nota 37, p. 283) afirmava, nesse sentido: "Em primeiro lugar o negócio simulado aparente é sempre anulável. Não existe aí uma declaração séria da vontade, porque ao mesmo tempo em que se está manifestando a vontade conducente a certo ato jurídico, sabe-se que o que existe é uma vontade diversa dirigida num outro sentido".
} 
de simulação inocente; com efeito, aduz o autor, esta não configuraria vício do ato jurídico; logo, o negócio simulado inocentemente deveria subsistir, apesar da simulação ${ }^{703}$.

Espínola, após uma investigação percuciente do processo legislativo que teria dado origem aos artigos 102 a 105 do Código Civil de 1916, sustentava que as partes poderiam sempre alegar a simulação inocente, pois como esta seria admitida pelo direito, tal faculdade resultaria normalmente assegurada aos contraentes do ato simulado. Para o ajuizamento da demanda, não seria necessária uma autorização especial; inexistindo vedação expressa, nada obstaria ao exercício desse direito ${ }^{704}$.

Para Pontes de Miranda, a questão se resolveria a partir da distinção entre a simulação preexcludente de juridicidade e a simulação invalidante. Qualquer das partes, assim como qualquer terceiro, poderia requerer a declaração de inexistência do negócio jurídico inocentemente simulado. Esta conclusão derivaria da natureza do pedido (declaratório), adequado a casos em que não se desse a entrada do suporte fático do negócio jurídico no mundo jurídico ${ }^{705}$.

Segundo Antônio Junqueira de Azevedo, conquanto o artigo 104 do Código Civil de 1916 vedasse a alegação da simulação nocente de maneira expressa, uma leitura $a$ contrario sensu do seu enunciado revelaria que a simulação inocente poderia ser sempre alegada (o início do artigo colocaria em destaque o caráter ilícito da simulação cuja alegabilidade seria limitada: "Tendo havido intuito de prejudicar a terceiros").

No que tange à alegabilidade da simulação nocente, Clóvis Beviláqua defendia que apenas os terceiros prejudicados, ou o Ministério Público, quando admitido a intervir, poderiam alegá-la. Os simuladores não poderiam fazê-lo "porque ninguém pode alegar o próprio dolo, nemo auditur turpitudinem suam allegans, e na simulação, se o ato é bilateral, ambas as partes são conhecedoras do artifício fraudulento; se é unilateral, o agente é também autor do dolo"706. No mesmo sentido, Pontes de Miranda dizia que a

\footnotetext{
${ }^{703}$ Clóvis BeviláQua, Código Civil... cit., nota 657, p. 381.

${ }^{704}$ E. ESPÍNOLA, Manual... cit. (nota 658), p. 504.

${ }^{705}$ F. C. PONTES DE MIRANDA, Tratado... cit. (nota 220), p. 529-530.

${ }^{706}$ Clóvis BevilÁQuA, Teoria Geral... cit. (nota 35), p. 311-312. V., no mesmo sentido, M. GARCEZ, Nulidades dos Actos Jurídicos, $2^{\mathrm{a}}$ ed., v. 1, Rio de Janeiro, Jacintho Ribeiro dos Santos, 1910, p. 244 ; A. Chaves, Tratado de Direito Civil, v. I - Parte Geral, t. II, $3^{\text {a }}$ ed., São Paulo, Revista dos Tribunais, 1982, p. $1.445-1.446$.
} 
regra do artigo 104 do Código Civil de 1916 não comportaria exceções: os simuladores não poderiam, de modo algum, alegar a simulação nocente, uns em face dos outros ${ }^{707}$.

Espínola reconhecia que, já em seu tempo, a doutrina dominante contrariava a posição acolhida pelo Código Civil de 1916. Consolidava-se, em Portugal, na França e até na Argentina, a compreensão de que o adágio nemo auditur turpitudinem suam allegans não seria plenamente compatível com a simulação; sendo a simulação um instrumento utilizado para a prática de atos fraudulentos, vedar às partes a possibilidade de se arrependerem implicaria a perpetuação da violação à lei e a confirmação do locupletamento decorrente do ato reprovado pelo direito. Nada obstante, resignando-se, o autor conclui que, no caso do direito brasileiro, "a lei fecha as portas dos tribunaes ás partes que simularam um negócio jurídico, com a intenção de fraudar-lhe uma das disposições ou proporcionar damno a terceiro" ${ }^{\text {,708. }}$.

Antônio Junqueira de Azevedo apresentava uma profunda crítica ao artigo 104 do Código Civil de 1916. Chamava a atenção do autor, inicialmente, a circunstância de que a jurisprudência, muitas vezes, simplesmente ignorava o dispositivo ${ }^{709}$ :

Ora, aí, em primeiro lugar, ao ser movida a ação de anulação e ao alegar o autor que o ato de alienação foi simulado, põe-se um difícil problema de opção para o réu, ou seja, invocar ou não o art. 104. Embora esse artigo aparentemente o favoreça, sente-se ele em posição processualmente fraca, ao pedir sua aplicação; parece-lhe que o fato de querer impedir a discussão, levantada na inicial, sobre a simulação, poderá futuramente pesar contra ele; de certa forma (pensa) fugir da acusação de simulação utilizando o art. 104 poderá parecer uma confissão de que realmente ocorreu simulação (ato socialmente censurado) (...). Adota, pois, o réu, em geral, a solução contrária; opta pela política do silêncio, finge não saber da existência do art. 104 (ou, então, o lembra, mas sem muita ênfase) e defende-se pelo mérito, afirmando que não houve simulação (...). Assim, todos, autor, réu e juiz, fingem que não vêem o art. 104.

\footnotetext{
${ }^{707}$ F. C. PONTES DE MiRANDA, Tratado... cit. (nota 220), p. 526-527.

${ }^{708}$ E. EsPínOLA, Manual... cit. (nota 658), p. 550. A justificativa dessa vedação (certa ou errada; superada, ou não, pela doutrina mais moderna) residiria, segundo o autor, nem tanto na vedação ao comportamento contraditório, mas no raciocínio segundo o qual o ato simulado ilícito representaria uma violação consumada (como um cristal quebrado, cujos cacos já não seria possível reunir); permitir o seu desfazimento não beneficiaria de qualquer modo a lei violada, apenas os próprios simuladores, que poderiam livrar-se de um problema (i.e. do ato que teriam servido para o único propósito de proporcionar a elusão da aplicação da norma), e, desse modo, cumprir o ciclo da simulação da mais proveitosa possível: com todos os bônus e nenhum ônus.

${ }^{709}$ Antônio JUNQUEIRA DE AZEVEDo, Negócio Jurídico... cit. (nota 440), p. 94.
} 
Seria acertada, na opinião do autor, a conclusão a que chegavam as decisões que vinham proferindo os tribunais, as quais permitiam, aos simuladores, alegar a simulação, uns contra os outros; contudo, tais julgados, na medida em que divergiam da literalidade de um dispositivo legal, deveriam vir acompanhados de uma fundamentação material mais bem elaborada. Esta deveria pautar-se pelo fato de que, no âmbito da simulação nocente, nem sempre o animus nocendi seria compartilhado por todos os contraentes do negócio jurídico. O autor refere-se, a título de exemplo, a negócios de compra e venda ou compromisso de compra e venda simulados com o propósito de encobrir empréstimos usurários. Desse modo, existindo, no negócio simulado, um contraente agindo de boa-fé e outro agindo de má-fé, aplicar-se-ia a este a interpretação da forma proposicional direta derivada do enunciado do artigo 104 do Código Civil de 1916 (i.e. a vedação à alegação da simulação), e, ao primeiro, o entendimento a contrario sensu, (i.e. a permissão à alegação, diante da inexistência de animus nocendi por parte deste contraente do negócio jurídico) $)^{710}$.

Esta solução seria criticada por Custódio da Piedade Ubaldino Miranda. O autor defende que quando a lei falava do intuito de prejudicar terceiros ou de violar disposição de lei, não poderia ter querido contentar-se com o elemento subjetivo, sendo indispensável que ocorresse também o resultado. Em razão disso, não seria adequado inferir, da disciplina legal da simulação, a aplicação de um tratamento jurídico "liberal" a quem simulasse "sem intuito malévolo", porquanto a cooperação da chamada "parte inocente" seria indispensável para se alcançar o resultado acima referido, isto é, a criação de uma aparência negocial capaz de viabilizar o prejuízo a terceiros ou a violação da lei. Consistindo a simulação num procedimento complexo, a cooperação de ambas as partes em prol do resultado ilícito não permitiria, aos olhos da norma, cindir as intenções das partes, para o efeito de seu autorizar a uma o que seria vedado à outra. Demais disso, o que deveria ser levado em conta para a interpretação do negócio jurídico é a intenção comum das partes, objetivada na declaração ${ }^{711}$.

Prosseguindo com sua construção, Custódio da Piedade Ubaldino Miranda destaca que os julgados que admitiam, excepcionalmente, a alegação da simulação por um dos contraentes, revelavam duas constantes: por um lado, restringiam-se aos casos de violação oculta da lei e, por outro lado, tinham em mira a nulidade do negócio dissimulado ou de

\footnotetext{
${ }^{710}$ Antônio JunQueIRA DE AZEVEdo, Negócio Jurídico... cit. (nota 440), p. 95.

${ }^{711}$ Custódio da Piedade Ubaldino MirandA, A Simulação... cit. (nota 149), p. 129.
} 
uma cláusula acessória (e.g. a do pacto comissório), ou a de ambos. Em vista disso, as referidas decisões não vinham inspiradas, propriamente, pela preocupação de anular o negócio simulado, mas tinham por escopo declarar a nulidade do negócio dissimulado. A invalidade do negócio simulado, que também se decretava, não passaria de uma consequência daquelas outras nulidades, uma vez que a simulação seria um todo unitário, enquanto procedimento ${ }^{712}$.

A conciliação das referidas decisões com o artigo 104 do Código Civil, segundo o autor, deveria dar-se com atenção à finalidade perseguida pelas partes mediante o procedimento simulatório. Se numa simulação nocente as partes viessem a juízo para pleitear a anulação do negócio jurídico, seria preciso apurar se tivera sido intenção comum das partes a de causar prejuízo a terceiros ou violar a lei. Diante desta constatação, haverse-ia de conferir prevalência não à letra, mas ao espírito do artigo 104. Com base neste, tornar-se-ia possível entender que se a proibição da arguição da simulação tivesse o objetivo de prevenir a que prejudica terceiros ou viola a lei, nada impediria que tal proibição sofresse atenuações na medida em que com elas pudesse vir a atender-se aos fins da proibição ${ }^{713}$.

Consistindo o desiderato último da norma em tutelar a integridade do ordenamento jurídico, a simulação não poderia ser alegada pelas partes com vistas à obtenção de vantagens derivadas da anulação do negócio simulado; este seria o fim imediato da proibição. Haveria, porém, outros resultados possíveis que poderiam ser considerados compatíveis com a eliminação das vantagens decorrentes da simulação. Assim sucederia sempre que o resultado final de eventual demanda envolvendo uma simulação nocente implicasse o "restabelecimento do império da lei". A unidade do fenômeno simulatório acarretaria, diante da ilicitude do negócio dissimulado, a anulabilidade do negócio simulado. Como não seria possível anular apenas o negócio dissimulado, admitir-se-ia a alegação da própria simulação de modo a dar-se a restauração da eficácia do direito posto. Custódio da Piedade Ubaldino Miranda adverte, por fim, que

\footnotetext{
${ }_{712}^{71}$ Custódio da Piedade Ubaldino MiRAndA, A Simulação... cit. (nota 149), p. 130-131.

${ }^{713}$ Custódio da Piedade Ubaldino MiRAndA, A Simulação... cit. (nota 149), p. 131-132.
} 
não lhe pareceria possível qualquer interpretação que buscasse flexibilizar o artigo 104 do Código Civil de 1916 com base em parâmetros diferentes destes ${ }^{714}$.

\section{Interesse e legitimidade}

Todo o rico debate acima relatado não mais se justifica à luz do Código Civil de 2002. Este, com efeito, não repetiu a vedação que constava do artigo 104 do Código Civil de 1916. No cenário que se descortina, a doutrina tem se manifestado no sentido de que seria amplamente admissível a alegação da simulação, pelas partes ou por terceiros. Em um estudo sobre a disciplina que o anteprojeto do Código Civil de 2002 dispensava ao negócio jurídico, Moreira Alves afirma que, "ressalvados os direitos de terceiros de boa-fé em face dos contraentes do negócio jurídico simulado, [o anteprojeto] admite, como decorrência mesma da nulidade, que a simulação possa ser invocada pelos simuladores em litígio de um contra o outro, ao contrário do que reza o art. 104 da Codificação atual" ${ }^{\text {715 }}$. O entendimento contido neste trecho remete, evidentemente, à norma que viria a plasmar-se no artigo $168^{716}$.

A propósito, Nobre Júnior assevera que negar-se aos contraentes do negócio simulado a faculdade de alegá-la representaria, por parte da nova legislação, um “inegável retrocesso". O autor aduz uma série de argumentos para evidenciar que não permaneceria, no Código Civil de 2002, qualquer restrição à legitimidade das próprias partes para alegar a simulação nocente. Alude, neste mister, a debates doutrinários e jurisprudenciais havidos em Portugal, destacando que, ali, o Código Civil de 1966 teria expressamente acolhido a tese de que a simulação poderia ser alegada pelos contraentes do negócio simulado ainda que houvesse intuito ilícito no seu proceder; menciona, ademais, que a legislação argentina

\footnotetext{
${ }_{714}^{714}$ Custódio da Piedade Ubaldino Miranda, A Simulação... cit. (nota 149), p. 132-134.

715 J. C. Moreira Alves, A Parte Geral... cit. (nota 237), p. 119.

716 “Art. 168. As nulidades dos artigos antecedentes podem ser alegadas por qualquer interessado, ou pelo Ministério Público, quando lhe couber intervir.

Parágrafo único. As nulidades devem ser pronunciadas pelo juiz, quando conhecer do negócio jurídico ou dos seus efeitos e as encontrar provadas, não lhe sendo permitido supri-las, ainda que a requerimento das partes". A matéria era objeto dos artigos 104 e 105 do Código Civil de 1916, a seguir reproduzidos:

Art. 104. Tendo havido intuito de prejudicar a terceiros, ou infringir preceito de lei, nada poderão alegar, ou requerer os contraentes em juízo quanto à simulação do ato, em litígio de um contra o outro, ou contra terceiros.

Art. 105. Poderão demandar a nulidade dos atos simulados os terceiros lesados pela simulação, ou representantes do poder publico, a bem da lei, ou da fazenda.
} 
ter-se-ia submetido a evolução semelhante. Para Nobre Júnior, a inexistência de óbice à alegação da nulidade pelos simuladores fundar-se-ia nos seguintes pressupostos ${ }^{717}$ :

(a) a ausência de norma proibitiva, nos moldes do artigo 104 do Código Civil de 1916 ;

(b) a qualificação da simulação como causa de nulidade do negócio jurídico; e

(c) o repúdio que causaria, à comunidade jurídica, a possibilidade de os simuladores locupletarem-se do ato simulado.

O tema foi também debatido durante a IV Jornada de Direito Civil do Conselho da Justiça Federal, em que foi aprovado o enunciado n” 294, pelo qual "[s]endo a simulação uma causa de nulidade do negócio jurídico, pode ser alegada por uma das partes contra a outra". No texto elaborado como justificativa deste verbete ${ }^{718}$, o seu proponente destaca que, mesmo ao albergue do Código Civil de 1916, a jurisprudência já permitia que os contraentes do negócio simulado alegassem a simulação, em litígio de um contra o outro. Tal posicionamento decorreria do fato de que "por não ser a simulação um vício do consentimento, não poderia haver uma solução de base puramente subjetiva, como se o defeito fosse daqueles que estampam a incongruência entre a vontade e a declaração". Sustenta, ainda, que, sob o regime da nulidade, seria indiferente, para fins de alegabilidade, a circunstância de tratar-se de simulação inocente ou nocente.

A despeito das eminentes manifestações doutrinárias acima referidas, temos a impressão de que o artigo 168 ainda requer um exame mais acurado.

Em geral, admite-se que as próprias partes do negócio nulo aleguem a nulidade; porém, é necessário, em todo caso, que elas demonstrem dispor de interesse relativamente à declaração de nulidade. "O poder ser argüida pelo próprio causador do nulo a nulidade não dispensa que se lhe inquira do interêsse. Se não há interêsse na decretação, inclusive o de evitar multa ou outras penas, excluído está o causador do nulo (...)"719. Não se trata

${ }^{717}$ E. NOBRE JÚNIOR, Simulação e sua argüição pelos simuladores in Revista da Escola de Magistratura Federal da $5^{a}$ Região, n. 18, Recife, 2008, p. 11-26.

718 Disponível em <http://columbo2.cjf.jus.br/portal/publicacao/download.wsp?tmp.arquivo=2016>; consultado em 23/03/2013.

${ }^{719}$ F. C. PONTES DE MiRANDA, Tratado... cit. (nota 220), p. 307. 
aqui, obviamente, de qualquer interesse, mas de interesse jurídico, o qual somente se materializa quando litigante demonstra a necessidade de proteção jurídica ${ }^{720}$.

Poder-se-ia arguir que tal linha de raciocínio não seria admissível quanto à nulidade; que o interesse somente seria relevante no caso da anulabilidade. Tal raciocínio, no entanto, não seria procedente. É bem verdade que a anulabilidade somente pode ser alegada pelos sujeitos cujo interesse seria tutelado com a anulação ${ }^{721}$. Sem prejuízo disso, também a alegação da nulidade deve ser amparada por um interesse legítimo, ou seja, um interesse que não seja frívolo ou abusivo ${ }^{722}$. "A redação da lei exige que se dê alguma atenção ao interesse que funda a legitimidade" ${ }^{, 723}$.

$\mathrm{O}$ interesse requerido para a alegação da nulidade surge na medida em que o sujeito obtenha alguma utilidade ou remova alguma desvantagem com a declaração daquela $^{724}$. Coincide, aquele, com o interesse de agir que a lei processual descreve como condição da demanda ${ }^{725}$.

$\mathrm{O}$ interesse de agir pode ser decomposto em interesse-adequação e interessenecessidade. O primeiro destes componentes refere-se ao acerto, pelo postulante, da espécie de provimento por meio do qual buscará obter a tutela jurisdicional atinente ao bem da vida que pretende atingir. O segundo, por sua, vez, surge na situação em que, sem o processo, e, logo, sem o exercício da jurisdição, o indivíduo ver-se-ia desprovido do bem da vida almejado ${ }^{726}$.

\footnotetext{
${ }^{720}$ Humberto THEODORO JÚNIOR, Comentários... cit. (nota 38), p. 514: "Uma empresa, por exemplo, não pode pretender a declaração de nulidade por simulação de um contrato de terceiro, apenas com o propósito de afastar concorrente ou de melhorar sua posição na concorrência. $\mathrm{O}$ seu interesse, in casu, seria puramente conômico, porque os autores da pretensa simulação não teriam violado relação laguma mantida com o demandante, cuja eficácia pudesse ser afetada ou lesada. Mesmo aquele que tenha um vínculo contratual com o simulador não pode restringir-se a invocá-lo; terá de comprovar que, in concreto, a simulação causou prejuízo jurídico à referida relação de direito material (...)”.

721 P. PAIS DE VASCONCELOS, Teoria Geral... cit. (nota 103), p. 744.

722 P. PAIS DE VASCONCELOS, Teoria Geral... cit. (nota 103), p. 744.

${ }^{723}$ P. PAIS DE VASCONCElos, Teoria Geral... cit. (nota 103), p. 744.

${ }^{724}$ P. PAIS DE VASCONCELOS, Teoria Geral... cit. (nota 103), p. 744.

${ }^{725}$ P. PAis DE VASCONCElos, Teoria Geral... cit. (nota 103), p. 745; M. A. Domingues DE ANDRADE, Teoria Geral... cit. (nota 20), p. 417; M. B. MELLO, Teoria do Fato Jurídico... cit. (nota 665), p. 289.

${ }^{726}$ C. R. Dinamarco, Instituições de Direito Processual Civil, v. II, $5^{\text {a }}$ ed., São Paulo, Malheiros, 2005, p. 302-303.
} 
O Código de Processo Civil de 1939 previa, em seu artigo $2^{\mathrm{o}^{727}}$, que o interesse requerido para a propositura ou contestação da demanda deveria ser de natureza econômica ou moral. O Código de Processo Civil vigente, por seu turno, quando descreve o interesse e agir, não lhe apõe quaisquer adjetivações; um acerto que seria louvado pela doutrina processualista. São preciosas, neste capítulo, as lições de Dinamarco ${ }^{728}$ :

Constitui objeto do interesse de agir a tutela jurisdicional e não o bem da vida a que ela se refere. O demandante terá ou não direito a obter esse bem - e isso é uma questão de direito material, a ser resolvida em conformidade com as normas deste e sem influência sobre o interesse de agir. É inadequado falar em interesse econômico ou moral como condição da ação, como fazia o art. $2^{\circ}$ do Código de 1939 , porque essa adjetivação é própria do interesse ao bem e não à tutela jurisdicional. Haverá o interesse processual sempre que o pedido for o único caminho para tentar obtê-lo e tiver aptidão a propiciá-lo àquele que o pretende.

Nessa esteira, o interesse de agir não se identifica com uma motivação econômica ou moral qualquer, mas consiste, mais propriamente, na vinculação entre o resultado prático (bem da vida) que interessa ao autor e a tutela jurisdicional postulada. Esta deve ser necessária a obtenção daquele, no sentido de que o resultado prático mirado pelo autor não possa ser atingido de outra maneira que não pela intervenção do judiciário. Ademais, descaracterizaria o interesse de agir a circunstância de o resultado prático perseguido pelo autor ter sido, eventualmente, alcançado anteriormente à propositura da demanda.

Assentadas estas premissas, cumpre perquirir a respeito da relação entre o interesse e a legitimidade.

Peccenini explica que o interesse é aquele estado de fato que qualifica a posição jurídica sobre a qual o sujeito buscará o provimento jurisdicional; a legitimidade, por seu turno, é a titularidade da relação jurídica em si, que por seus próprios méritos, autoriza o sujeito a demandar perante o juízo ${ }^{729}$. Enquanto a legitimidade decorre de uma adequação abstrata entre o sujeito e a causa, o interesse corresponde à face concreta da causa, isto é, à

\footnotetext{
727 “Art. $2^{\circ}$ Para propor ou contestar ação é necessário legítimo interesse, econômico ou moral”.

${ }^{728}$ C. R. DinAMARCO, Instituições... cit. (nota 726), p. 303.

${ }^{729}$ F. PECCENInI, Della nullità del contratto in AAVv., Commentario del Codice Civile Scialoja-Branca-A cura di Francesco Galgano, Libro Quarto - Delle obbligazioni - Art. 1421, Bologna - Roma, Zanichelli Del Foro Italiano, 1998, p. 165 ss..
} 
utilidade que o sujeito espera obter por meio da demanda. É, por isso, salienta Dinamarco, que não raramente a parte possui legitimidade, mas não tem interesse de $\operatorname{agir}^{730}$.

Advirta-se, neste passo, que a legitimidade de que ora tratamos é a processual, e com ela não se deve confundir a legitimidade substantiva. A legitimidade processual corresponde à de exercer determinada ação perante o juízo. Já a legitimidade substantiva consiste na qualidade da posição do sujeito que o torna apto a exercícios jurídicos materiais, como, por exemplo, a prática de um ato negocial. São exemplos de legitimidade processual a de alegar a prescrição (artigo 193), a de requerer a interdição (artigo 1768), e a de alegar a nulidade do negócio jurídico (artigo 168). Por outro lado, são exemplos de legitimidade substantiva a de renunciar à prescrição (artigo 191), a de gerir negócios alheios sem autorização (artigo 861), a de exercer o poder familiar (artigo 1634), a de administrar e dispor dos bens próprios sujeitos ao regime de comunhão parcial (artigo 1665), dentre outras ${ }^{731}$.

Numa situação normal, as partes do negócio nulo seriam os únicos legitimados a ajuizar a demanda buscando a declaração da nulidade ${ }^{732}$ (pois o negócio nulo não produziria efeitos perante terceiros e, desse modo, somente as próprias partes seriam atingidas pela relação jurídica, posto que nula). Por isso, o legislador estende a legitimidade não apenas àqueles que são titulares da relação jurídica, mas, também, aos que, de algum modo, possuam o interesse (possam obter alguma utilidade com a declaração da nulidade $)^{733}$. O resultado consiste em elevar o interesse legítimo à condição de fator determinante da legitimidade ativa ad causam: as partes do negócio nulo a possuem naturalmente, mas perdem-na se não apresentarem o interesse de agir; os terceiros, por seu turno, não a possuem naturalmente, mas a adquirem, na medida em que passam a demonstrar o interesse de agir.

\footnotetext{
${ }^{730}$ C. R. DiNAMARCO (Instituições... cit., nota 726, p. 304; 307) explica a diferença entre tais noções aludindo à hipótese do indivíduo que impetra um mandado de segurança contra a banca organizadora de um concurso público pretendendo que esta o admita no certame; contudo, fá-lo após a realização dos exames. Ainda que o autor pudesse ser considerado, neste exemplo, parte legítima (porque haveria adequação abstrata entre o sujeito e a causa), ele haveria de ser tido por carecedor da ação, diante da falta de interesse de agir (porquanto o provimento postulado se mostraria inapto a proporcionar, ao autor, o bem da vida pedido).

${ }^{731}$ A. MENEZES CORDEIRO, Tratado... cit. (nota 402), p. 15 ss.

${ }^{732}$ C. R. Dinamarco, Instituições... cit., (nota 726), p. 307.

${ }^{733}$ F. PECCENINI, Della nullità del contratto cit. (nota 729), p. 165 ss.
} 
O artigo 168, portanto, autoriza aos interessados alegar a nulidade, inclusive a do negócio simulado. Resta, em vista disso, verificar em quais circunstâncias poder-se-ia atestar a presença do interesse voltado à declaração de nulidade do negócio simulado.

\section{O interesse dos simuladores}

Parece incontestável o interesse dos simuladores nos casos em que a simulação seja alegada pela via da exceção. O provimento jurisdicional seria, nestas circunstâncias, necessário a que o demandado não sofresse as consequências da ilusão negocial, a qual, não fosse reconhecida como tal, poderia justificar a efetividade da pretensão aduzida pelo autor.

O exame torna-se um pouco mais complexo, porém, quando se trata de casos em que a simulação venha invocada pela via direta, ou seja, como objeto da demanda manejada pelo autor. No que tange a tais situações, parece-nos ser necessário distinguir as hipóteses de simulação nocente e simulação inocente.

Se a simulação é nocente, o interesse do autor sempre deve ser considerado presente. Valem, neste contexto, as críticas formuladas durante a vigência do Código Civil de 1916, segundo as quais privar o simulador da liberdade de invocar a simulação significaria a perpetuação da ilicitude e a definitividade da locupletação indevida. Dessa feita, o arrependimento de um dos contraentes autoriza-o a deduzir a nulidade em face da contraparte, não havendo, a nosso aviso, justificativa plausível para se negar o reconhecimento do interesse de agir assim manifestado. A utilidade do provimento jurisdicional consistiria, neste caso, precisamente em permitir que o sujeito cesse a ilicitude, prevenindo a aplicação de uma penalidade; ou a sane, sujeitando-se às sanções legalmente estabelecidas.

Tratando-se, entretanto, de simulação inocente, pensamos que o autor da demanda deva demonstrar, de maneira pontual e específica, a utilidade que obteria com a movimentação da máquina judiciária em prol da declaração da nulidade, pois, em regra, aqueles que celebram o negócio com simulação inocente não possuem interesse na decretação de nulidade ${ }^{734}$. Se o juiz constata que o único resultado útil da demanda, se

\footnotetext{
${ }^{734}$ Humberto THEOdORO JúNIOR, Comentários... cit. (nota 38), p. 486.
} 
provida, seria a confirmação de um estado de coisas já assegurado pelo conteúdo convencional do negócio simulado (a plena ineficácia da ilusão negocial entre os simuladores), ou a simples causação de um prejuízo ao réu, não haveria como concluir-se favoravelmente à presença do interesse de agir, logo, da legitimidade.

Não se caia no equívoco de cogitar que o arrependimento do simulador teria o mérito, neste caso, de contemplar o interesse da coletividade, cuja confiança teria sido traída pela ilusão negocial. A relação processual, no âmbito em que se discute a nulidade do negócio privado, não visa a tutelar imediatamente o interesse público, sendo certo que mesmo o seu delegatário, o Ministério Público, somente pode alegar a simulação quando autorizado a intervir no curso da demanda, como se extrai da literalidade do artigo 168. Para precisar-se o interesse do simulador quanto à declaração de nulidade, é absolutamente irrelevante indagar sobre a utilidade que a declaração de nulidade ocasionaria para quaisquer terceiros estranhos ao processo; importa verificar, isto sim, a utilidade que o provimento jurisdicional traria para o autor da demanda.

\section{5. $O$ interesse dos terceiros}

Com relação à legitimidade dos terceiros, a verificação do interesse requer um olhar ainda mais atento.

Para pleitear a nulidade do negócio simulado, o terceiro não precisa cumprir o requisito da boa-fé, a qual é pressuposto apenas da excepcional eficácia do "negócio aparente". Não há norma que exija a boa-fé para que se considere caracterizado o interesse de terceiros acerca da declaração de nulidade do negócio simulado. Como salienta Carvalho Fernandes, seria incoerente exigir, dos terceiros, algo que não se requer nem mesmo dos simuladores; nada justificaria a previsão de tal tratamento mais gravoso ${ }^{735}$.

O interesse dos terceiros relativamente à declaração de nulidade do negócio simulado pode depender de fatores diversos.

No que se refere aos credores, por exemplo, chegou-se a afirmar, a esse propósito, que apenas aqueles que fossem levados à insolvência nutririam interesse concreto em

${ }^{735}$ L. A. CARVAlHO FERNANDES, Estudos sobre a simulação, Lisboa, Quid Juris, 2004, p. 80. 
postular a nulidade. Numa posição intermediária, defendeu-se que os credores que houvessem sofrido prejuízo efetivo, por conta da simulação, poderiam exercer o direito potestativo de requerer a declaração de nulidade do negócio simulado. Mais razoável e acertada, contudo, parece ser a opinião daqueles que defendem que o interesse dos credores na nulidade do negócio simulado surge na medida em que isso possa representar uma utilidade prática calcada na preservação da garantia representada pelo patrimônio do simulador $^{736}$.

Se o negócio simulado implicasse o esvaziamento do patrimônio do devedor, teria, o credor, todo o interesse em ver o seu restabelecido, para que sobre ele pudesse fazer recair a pretensão em caso de eventual inadimplemento obrigacional. Tal interesse, vale esclarecer, nutririam quaisquer credores, independentemente do momento em que tivesse ocorrido a constituição do crédito (i.e. antes ou após a simulação). Daquele interesse não careceriam, ademais, os credores beneficiados por garantias reais, porquanto estas constituiriam mero reforço das obrigações contraídas pelo devedor e não assegurariam o efetivo pagamento ${ }^{737}$.

Outra classe de terceiros digna de nota é a que congrega os subadquirentes de direitos do alienante simulado. Estes terceiros poderiam figurar em dois distintos cenários:

(a) negócio simulado anterior à aquisição ajustada com o alienante simulado: isto ocorreria se, por exemplo, "A" e "B" celebrassem negócio de compra e venda simulado tendo por objeto o bem " $\mathrm{X}$ ", e, posteriormente, " $\mathrm{A}$ " alienasse o bem "X" a "C"; e

(b) negócio simulado posterior à aquisição ajustada com o alienante simulado: isto ocorreria se, por exemplo, "D" alienasse o bem "Y" a "E", mas, procurando frustrar a posição jurídica de "E”, "D” simulasse, posteriormente, uma compra e venda antedatada com "F".

No primeiro cenário, "C" teria interesse em ver declarada a nulidade para que o negócio simulado este não viesse a afetar a eficácia do negócio jurídico do qual decorreria

\footnotetext{
${ }^{736}$ C. A. Mota Pinto, Teoria Geral... cit. (nota 435), p. 479; M. A. Domingues De Andrade, Teoria Geral... cit. (nota 20), p. 204-205.

${ }^{737}$ L. A. CARVALHO FERNANDES, Estudos sobre a simulação cit. (nota 735), p. 92-95.
} 
a aquisição do seu direito sobre o bem $X$. No segundo cenário, "E" teria interesse em demonstrar a nulidade de um negócio jurídico que, se fosse tido como válido, poderia prevalecer sobre aquele que daria origem ao direito que adquirira sobre o bem Y.

O subadquirente, todavia, não teria interesse em ver declarada a nulidade do negócio simulado, num e noutro caso, se, em razão de outras regras, o seu direito fosse considerado naturalmente prevalecente sobre o do adquirente simulado. Isto ocorreria, em ambos os casos, tratando-se de bem imóvel, se o negócio jurídico celebrado com o subadquirente fosse levado a registro antes do negócio simulado; ou, sendo móvel o bem, ocorresse a tradição ao subadquirente, não ao simulado adquirente ${ }^{738}$.

Dúvidas poderiam surgir, ademais, a respeito da legitimidade de herdeiros para alegar a nulidade do negócio simulado, por serem sucessores de um dos simuladores. A despeito da simulação perpetrada pelo de cujus, os herdeiros continuariam sendo titulares de expectativas próprias quanto à herança e, por isso, não seria adequado considerá-los privados do interesse, que em nada diferiria daquele que teriam se houvessem conhecido a simulação ainda enquanto o simulador estivesse vivo ${ }^{739}$. Em tal contexto, os herdeiros do alienante simulado possuiriam natural interesse em postular a nulidade do negócio simulado do qual tenha resultado a diminuição da herança. Por coerência, os herdeiros do adquirente simulado não ostentariam esse interesse, já que a aquisição, conquanto simulada, teria acrescido à herança.

Outro grupo de terceiros que ocupa posição de destaque é o dos preferentes, os quais teriam interesse em requerer a declaração de nulidade quando a simulação excluísse ou prejudicasse o exercício do seu direito. Este interesse pressuporia que a simulação fosse relativa, pois, sendo absoluta, não haveria como se exercer a preferência ${ }^{740}$. A referida simulação relativa teria por objeto o preço do negócio jurídico ou a caracterização de uma liberalidade aparente, com vistas a encobrir uma alienação onerosa. Nestas hipóteses, o preferente obteria uma utilidade por meio da declaração de nulidade do negócio simulado, tornando-se apto a exercer a preferência pelo preço dissimulado.

\footnotetext{
${ }^{738}$ L. A. CARVAlHO FERNANDES, Estudos sobre a simulação cit. (nota 735), p. 91.

${ }^{739}$ L. A. CARVALHO FERNANDES, Estudos sobre a simulação cit. (nota 735), p. 95-101.

${ }^{740}$ L. A. CARVALHO FERNANDES, Estudos sobre a simulação cit. (nota 735), p. 102.
} 
Pelo exposto, constata-se existir amplo espaço para a caracterização do interesse de terceiros quanto à decla1ração de nulidade do negócio simulado. Este interesse, porém, somente pode ser considerado legítimo se constatado o potencial, da referida declaração, de proporcionar uma utilidade ao autor da demanda.

\section{Declaração ex officio}

Todo o discurso que acima desenvolvemos sobre a legitimidade perderia sentido acaso não se identificassem os pressupostos da declaração de nulidade ex officio, prevista no artigo 168. A bem da verdade, este dispositivo tornar-se-ia contraditório se não fosse possível conciliar as duas previsões que enceta: de um lado, a de que apenas os interessados podem alegar a invalidade, e, de outro, a de que o juiz pode, quando conheça do negócio jurídico e dos seus efeitos, pronunciar de ofício a invalidade que encontrar provada. Sem uma explicação capaz de tornar compatíveis os comandos veiculados no artigo 168, concretizar-se-ia a premonição de Pais de Vasconcelos: as orientações restritivas em matéria de legitimidade para a arguição da nulidade perderiam o seu sentido $^{741}$.

Galgano salienta ser necessário conciliar a previsão legal da declaração de nulidade ex officio com o princípio da demanda, que impõe limites à atuação do juiz no processo. Para tanto, sugere a adoção dos seguintes parâmetros ${ }^{742}$ :

(a) o juiz deve reconhecer a nulidade de ofício se a validade do negócio jurídico integrar o objeto da demanda e se as partes instalarem um debate sobre a aplicação ou a execução daquele;

(b) o juiz não pode declarar a nulidade ex officio se a parte interessada tiver formulado um pedido voltado a um remédio diverso, como a anulação ou a resolução;

(c) o juiz pode declarar a nulidade oficiosamente apenas se a nulidade manifestar-se imediatamente a partir do ato, ou a ulterior prova que aquela requeira tiver sido já produzida; e

${ }^{741}$ P. PAIS DE VASCONCELOS, Teoria Geral... cit. (nota 103), p. 745.
${ }^{742}$ F. GALGANO, Il negozio giuridico cit. (nota 119), p. 342. 
(d) a nulidade pode ser reconhecida de ofício em qualquer fase do processo ou grau de jurisdição desde que o juiz de grau inferior não tenha se pronunciado sobre a validade do negócio jurídico, disso decorrendo a preclusão para uma posterior reavaliação ex officio do tema.

De acordo com o primeiro parâmetro, acima enunciado, reconhece-se a possibilidade de o juiz declarar a nulidade ex officio quando a própria validade do negócio jurídico esteja em discussão, no âmbito de uma controvérsia relativa à aplicação ou à execução do negócio jurídico. Nesse contexto, a declaração de nulidade levaria à conclusão de que a aplicação ou a execução do negócio jurídico não seriam exigíveis em face do réu. A atribuição desta utilidade a uma das partes do processo permitiria presumir a presença do interesse na declaração de nulidade, assim como integraria o pedido formulado na defesa, sem, com isto, discrepar do princípio da demanda. No caso da simulação, isto ocorreria naqueles casos em que um simulador exigisse do outro a prestação prevista no negócio simulado; o reconhecimento de ofício de uma exceção de simulação necessariamente atenderia a um legítimo interesse do réu.

Não pensamos, porém, que seja aceitável o segundo dos parâmetros propostos por Galgano. Somente poderíamos concordar com ele se a declaração de nulidade produzisse, para as partes do processo, resultados idênticos à anulação ou à resolução, o que de fato não sucede. Na realidade, a nulidade não contraria o interesse voltado à impugnação ou à cessação da vigência do negócio jurídico; ela, na verdade, atribui maior alcance a este interesse, sem com ele conflitar, na medida em que faz com que a declaração judicial apresente eficácia ex tunc e erga omnes.

Quanto ao terceiro dos parâmetros acima citados, podemos acolher a necessidade de prova da nulidade, pois esta decorre da própria literalidade do artigo 168. Por seu turno, a conclusão de que a manifestação sobre a validade do negócio jurídico tornaria a matéria preclusa, conforme consta do último dos parâmetros propostos pelo autor italiano, mostrase tecnicamente correta. Se uma das partes do processo tivesse alegado a nulidade e o juiz a apreciasse, pela via da declaração incidental, concluindo pela sua improcedência, o tribunal não poderia debruçar-se sobre a matéria ex officio, pois tratar-se-ia de questão definitivamente julgada. Vale notar, porém, que, se o recurso apresentado versasse exatamente sobre a questão da nulidade, posto que declarada de ofício, não haveria 
preclusão, pois o efeito devolutivo permitiria o reexame da questão (que já não mais seria ex officio).

Inobstante o valor da construção jurídica acima examinada, não podemos ignorar que a tradição do direito brasileiro tem sido a de atribuir ampla abrangência ao poder-dever do juiz de declarar, de ofício, a nulidade do negócio jurídico. Em vista disso, parece-nos que uma solução menos ousada, porém igualmente eficaz, poderia ser concebida. A correta interpretação do artigo 168, a nosso aviso, não pode fazer com que qualquer dos seus termos perca vigência, ou seja, torne-se dispensável.

Considere-se, por exemplo, que o Ministério Público interviesse em um processo sem autorização para tanto e, ao fazê-lo, trouxesse elementos suficientes para demonstrar a simulação do negócio jurídico objeto do litígio. Poderia, o juiz, declarar a sua nulidade ex officio? Ora, se assim o fizesse, o juiz converteria em letra morta o comando, ventilado no próprio artigo 168, segundo o qual o Ministério Público não possui legitimidade para alegar a nulidade quando não esteja autorizado a intervir no curso do processo.

Contudo, poderia suceder que uma das partes do processo efetivamente nutrisse interesse na declaração de nulidade do negócio simulado; neste caso, ao aproveitar-se da indevida intromissão do Ministério Público, o juiz não estaria subvertendo completamente as regras do jogo processual, pois, em última instância, o provimento jurisdicional exarado geraria uma utilidade para, ao menos, um dos envolvidos na lide.

Pensando assim, torna-se possível supor que, ao elaborar o artigo 168, o legislador teria assumido a premissa de que a nulidade do negócio jurídico necessariamente interessaria a uma das partes. Com isto, o $\S 1^{\mathrm{o}}$ não conflitaria com o conjunto das disposições contidas no artigo 168, pois ainda que sobreviesse uma situação absurda (e.g. um terceiro completamente estranho à relação processual "atravessasse" uma petição contendo evidências hábeis a comprovar a nulidade do negócio jurídico em discussão), o juiz poderia (ou melhor, deveria) declarar a nulidade conhecida e provada, com a certeza de que esta solução atenderia ao interesse de pelo menos uma das partes.

Mas, é claro, o legislador histórico não seria capaz de imaginar a infinidade de situações que a experiência jurídica poderia submeter à incidência da norma abstratamente concebida. Em vista disso, sobressai a essencialidade da atividade da doutrina, tendente a 
racionalizar o teor abstrato da lei em vista da riqueza de fatos e situações com base em que se desenrola a vida de relação.

Nem sempre, como vimos, as partes de um negócio jurídico terão interesse na declaração de nulidade de um negócio simulado. Esta afirmação mostra-se particularmente verdadeira nos casos de simulação inocente. A ausência de interesse poderia configurar-se ainda em processos envolvendo apenas terceiros, no curso dos quais o negócio simulado fosse discutido apenas subsidiariamente, como um fundamento remoto do direito alvo de controvérsia. Sob tais condições, ausentes partes interessadas na declaração de nulidade do negócio simulado, o juiz deveria abster-se de declarar, de ofício, a nulidade fundada na simulação, ainda que contasse com elementos que dessem conta de sua inequívoca configuração.

O poder-dever do juiz de declarar a nulidade do negócio simulado ex officio, portanto, deve ser entendido como supletivo da legitimidade. O magistrado deve mover-se pelo interesse que, conquanto esteja presente no seio da relação processual, não tenha sido exercitado por omissão da parte. Somente esta linha de pensamento, ao que nos parece, permite racionalizar o conteúdo do artigo 168, primando, ainda, pela preservação de princípios tão caros à lei e à ciência processuais, sobretudo, a condição da demanda consistente no interesse de agir.

\section{§ 11. Prescrição E deCAdÊnCIA}

O artigo 169 estabelece que o "negócio jurídico nulo não é suscetível de confirmação, nem convalesce pelo decurso do tempo". Em vista desta dicção, a doutrina tem sustentado que a ação declaratória de nulidade do negócio jurídico seria imprescritivel $^{743}$.

Embora a questão pareça singela, ela requer especial atenção pois, a bem se ver, o lapso temporal em questão não é propriamente o de prescrição, mas o de decadência. Quem alega a nulidade do negócio jurídico, e requer a sua declaração em juízo, não exerce pretensão, mas um direito potestativo.

${ }^{743}$ F. FerrarA, A simulação... cit. (nota 20), p. 457. 
Além disso, consta do artigo 48 um prazo decadencial específico, aplicável às deliberações de órgãos de entes coletivos. Esta previsão, à primeira vista, parece destoar do regime geral instaurado pelo artigo 169.

\section{A inaplicabilidade da regra de decadência}

A questão do prazo disponível para a alegação das nulidades já suscitou diversos debates no cenário jurisprudencial brasileiro. Sob a vigência do Código Civil de 1916, a jurisprudência chegou a adotar o entendimento de que as nulidades "prescreveriam" no maior prazo previsto em lei (vinte anos) ${ }^{744}$. Acolhendo este entendimento já à luz do Código Civil de 2002, Mattietto sustenta que "[n]ão parece correto insistir, como faz parte da doutrina, sobretudo a menos recente, que as nulidades sejam imprescritíveis, ficando as situações em aberto por mais de dez anos, que é o prazo prescricional geral, podendo ser agitadas a qualquer tempo",745.

O ponto de vista do autor, embora consentâneo com uma antiga tendência jurisprudencial, deve ser analisado com ponderação, porquanto esbarre em um obstáculo de ordem técnica já antecipado: o prazo a que se sujeitam as nulidades é o de decadência, não o de prescrição; logo, não é possível aplicar-lhes o prazo "prescricional geral” de dez $\operatorname{anos}^{746}$.

\footnotetext{
${ }^{744}$ Um retrospecto da jurisprudência sobre o tema pode ser encontrado em Y. S. CAHALI, Prescrição e Decadência, $2^{\mathrm{a}}$ ed., São Paulo, Revista dos Tribunais, 2012, p. 75 ss. Especificamente sobre a prescrição aplicada à declaração de simulação, v. a resenha jurisprudencial apresentada por L. MATTIETTO, Negócio jurídico simulado... cit. (nota 83), p. 478-479.

${ }_{745}$ L. MATTIETTO, Negócio jurídico simulado... cit. (nota 83), p. 478.

${ }^{746}$ Ao descrever a diretriz da operabilidade, uma das mais importantes a inspirar o Código Civil de 2002, Miguel ReAle utiliza-se do seguinte exemplo (História... cit., nota 4, p. 40): "Nessa ordem de idéias, o primeiro cuidado foi eliminar as dúvidas que haviam persistido durante a aplicação do Código anterior. Exemplo disso é o relativo à distinção entre prescrição e decadência, tendo sido baldados os esforços no sentido de se verificar quais eram os casos de uma ou de outra, com graves conseqüências de ordem prática. Para evitar esse inconveniente, resolveu-se enumerar, na Parte Geral, em numerus clausus, sendo as hipóteses de decadência previstas em imediata conexão com a disposição normativa que a estabelece. Assim, por exemplo, após o artigo declarar qual a responsabilidade do construtor de edifícios pela higidez da obra, é estabelecido o prazo de decadência para ela ser exigida. As hipóteses taxativas de prescrição são aquelas do artigo 206. Em contrapartida, a decadência encontra-se prevista de modo esparso no Código, como, por exemplo, no artigo 178, em que se estabelece que "[é] de quatro anos o prazo de decadência para pleitear-se a anulação do negócio jurídico". Em vista disso, estender às nulidades o prazo geral de prescrição, conquanto possa afigurar-se uma interpretação imbuída de "boas intenções", corromperia a coerência que o legislador deliberadamente procurou imprimir ao sistema composto pelas regras que disciplinam prescrição e decadência. Não se pode ignorar o dado objetivo de que, em sua configuração vigente, o Código Civil, de um lado, separa claramente as hipóteses de prescrição (as quais se encontram enumeradas em numerus clausus) e
} 
Nesse cenário, a conclusão que se afigura mais correta, do ponto de vista da técnica normativa, é a de que a nulidade do negócio simulado pode ser alegada a qualquer momento $^{747}$. Se há, contudo, resistência quanto a aceitar-se uma indefinição perene sobre a questão da simulação, no lugar de buscar-se uma saída assistemática, talvez seja razoável, e não agrida a organicidade do ordenamento jurídico, recorrer à solução que, ainda sob a vigência do Código Civil de 1916, propunha Custódio da Piedade Ubaldino Miranda. Este autor afirmava que a imprescritibilidade da ação declaratória de simulação (agora diríamos: a não sujeição ao prazo de decadência) deve ser entendida cum grano salis. "É que a ação só pode ser proposta enquanto perdurar o interesse de agir do autor,"748.

Quem quer que alegue a nulidade do negócio simulado deve demonstrar o interesse de agir. Em circunstâncias nas quais tenha transcorrido longo período de tempo, é possível - embora não seja mandatório - que o interesse de agir não persista. $\mathrm{O}$ aspecto temporal ligado à inércia do autor da demanda, geralmente relacionado ao instituto da decadência, poderá, portanto, manifestar-se aos olhos do juiz, evidenciando, de maneira concreta - mediante o desaparecimento do interesse de agir - o perecimento do direito potestativo que se pretenderia exercer.

Nessa linha de raciocínio, é importante identificar as situações em que o interesse de agir do autor funda-se sobre uma pretensão derivada do negócio simulado ou do negócio dissimulado. O credor, por exemplo, justifica o seu interesse na declaração de nulidade do negócio simulado com base em um débito que, ao tempo da propositura da demanda, já se encontraria prescrito. Em tais situações, deve ser extinta, sem julgamento

decadência, e, de outro, não contempla, expressamente, um prazo decadencial aplicável ao pleito de declaração de nulidade do negócio jurídico; não há, além disso, um prazo geral de decadência.

747 Nesse sentido tem se pronunciado a jurisprudência: Agravo de Instrumento $\mathrm{n}^{\mathbf{0}}$ 200798887.2013.8.26.0000, Tribunal de Justiça de São Paulo, Walter Barone (relator), julgamento em 11/12/2013; Apelação $n^{0}$ 0001925-89.2011.8.26.0246, Tribunal de Justiça de São Paulo, Miguel Brandi (relator), julgamento em 25/09/2013; Apelação $n^{\circ}$ 0030709-43.2011.8.26.0451, Tribunal de Justiça de São Paulo, Donegá Morandini (relator), julgamento em 15/01/2013; Apelação nº 0020016-09.2009.8.26.0309, Tribunal de Justiça de São Paulo Pereira Calças (relator), julgamento em 06/12/2011; Apelação no 70048919468, Tribunal de Justiça do Rio Grande do Sul, Angelo Maraninchi Giannakos (relator), julgamento em 22/08/2012; Apelação no 70022565782, Tribunal de Justiça do Rio Grande do Sul, José Aquino Flores de Camargo (relator), julgamento em 26/03/2008; Apelação no 2008.001.09277, Tribunal de Justiça do Rio de Janeiro, Carlos Santos de Oliveira (relator), julgamento em 01/04/2008.

${ }^{748}$ Custódio da Piedade Ubaldino MiRANDA, A Simulação... cit. (nota 149), p. 150. 
de mérito, a demanda declaratória de simulação, não porque se encontra prescrita (rectius: decaída), mas porque faltaria o interesse de agir ${ }^{749}$.

\section{O regime excepcional do artigo 48}

O artigo 48, parágrafo único, estabelece prazo de decadência de três anos para a anulação das decisões da administração da pessoa jurídica, quando configurada a simulação. Regra semelhante pode ser encontrada no artigo 286 da Lei no 6.404/76: "[a] ação para anular as deliberações tomadas em assembléia-geral ou especial, irregularmente convocada ou instalada, violadoras da lei ou do estatuto, ou eivadas de erro, dolo, fraude ou simulação, prescreve em 2 (dois) anos, contados da deliberação" ${ }^{\text {"750 }}$.

A previsão de um prazo decadencial para a anulação de atos simulados parece contrastar com a previsão do artigo 169. A antinomia, contudo, é apenas aparente.

A doutrina comercialista acentua, a propósito, que os vícios da vontade apontados como fundamentos para a anulação da deliberação de órgão de ente coletivo não se referem, propriamente, ao ato colegial, mas aos atos individuais que o formam. Cabe, portanto, diferenciar o vício da deliberação do vício do voto ${ }^{751}$.

Assim como os vícios da vontade, os vícios sociais podem macular o voto. Assim, fraudulentos ou simulados podem ser os votos que concorrem com a formação do ato de vontade unitário emanado do ato colegial. Compreende-se, nestes termos, que a deliberação se torna anulável em razão de o vício de um ou mais votos desqualificar a maioria previamente formada, alterando, consequentemente, o resultado da deliberação.

Esta interpretação permite, como se nota, conciliar o teor do artigo 48 com os artigo 167 e 169. A deliberação não é anulável porque simulada, mas porque, eventualmente, fundada numa maioria que não se mantém, em razão da simulação de um ou mais votos.

\footnotetext{
${ }^{749}$ Humberto THEODORO JÚNIOR, Comentários... cit. (nota 38), p. 517.

750 Esse dispositivo possui ampla aplicabilidade, pois são inúmeros os atos societários dependentes de deliberações assembleares, tais como, por exemplo, a constituição da companhia, exceto no caso de constituição por escritura pública (artigos 87, 88, 95, da Lei $n^{0}$ 6.404/76); a reforma do estatuto, eleição de administradores, autorização de emissão de debêntures, e aprovação de operações de transformação, fusão, incorporação e cisão (artigo 122 da Lei n ${ }^{\circ}$ 6.404/76).

${ }^{751}$ V. tópico 201 , in fine.
} 
Isto significa que se a simulação de votos não for suficiente para alterar a maioria formada entre os integrantes do órgão, não se torna anulável a deliberação, mantendo-se, pois, hígido o ato de vontade que ela consubstancia. Diversamente, se a imprestabilidade do voto simulado for suficiente para alterar o resultado do conclave, a anulabilidade se configura, dispondo, os interessados, do prazo decadencial de três anos para aduzi-la em juízo.

\section{Prescrição e decadência quanto ao negócio dissimulado}

Pouco estudada é a questão da aplicação dos prazos de prescrição e decadência relativamente ao negócio dissimulado. Pode ocorrer de um negócio dissimulado dar origem a uma pretensão, ou, então, encontrar-se maculado por um vício sujeito a prazo de decadência (e.g. erro). Qual seria o termo inicial dos prazos dentro dos quais tais situações deveriam ser aduzidas perante o Judiciário?

Duas respostas mostram-se plausíveis:

(a) o termo inicial do prazo de prescrição ou decadência seria a data do surgimento da pretensão, ainda que não tenha ocorrido a extraversão do negócio dissimulado; ou

(b) o termo inicial dos prazos de prescrição e decadência seria a data de extraversão do negócio dissimulado, ou a data do surgimento da pretensão, se posterior à primeira.

A dificuldade que se enfrenta, ao examinar a questão, liga-se ao entendimento, defendido por alguns, de que, antes da extraversão, o negócio dissimulado não possuiria relevância jurídica autônoma. Esta questão será examinada com maior vagar no $\S 12$. Por ora, insta assinalar que, sem dúvidas, uma pretensão pode surgir antes de processada a extraversão. De igual maneira, um vício da relação jurídica dissimulada poderia ser identificado antes daquela.

É evidente que, para exercer uma pretensão, sanar um vício, ou anular o negócio dissimulado, as partes teriam de pleitear a declaração de nulidade do negócio simulado e a extraversão do negócio dissimulado. Conquanto a declaração de nulidade do negócio simulado, em si, não se submeta a prazo decadencial (dependendo apenas da perseverança 
do interesse de agir), o exercício da pretensão, ou do direito de anular o negócio dissimulado, deve dar-se dentro dos respectivos lapsos legais, contados, no caso de prescrição, da data do surgimento da pretensão; e no caso de decadência, da data de celebração do negócio dissimulado, a qual, normalmente, coincide com o momento de constituição da relação jurídica simulada.

Somente haveria razão para diferir o início do cômputo dos prazos prescricional e decadencial para a data da extraversão se, enquanto esta não sobreviesse, não se pudesse considerar atendido o princípio da actio nata ${ }^{752}$. Tal fundamento, de fato, poderia ser adotado quanto a pretensões eventualmente nutridas por terceiros; contudo, ele não se mostra adequado para orientar o cômputo do prazo prescricional ou decadencial a cuja observância se sujeitam os simuladores, uma vez que a extraversão em nada altera a capacidade das próprias partes de tomarem ciência de pretensões ou vícios relativos ao negócio dissimulado.

\section{§ 12. A VALIDAde do NEGócio disSimulado}

A simulação relativa encontra-se expressamente disciplinada no artigo 167, o qual estabelece que, a despeito da nulidade do negócio simulado, subsiste o que se dissimulou, se válido for em substância e em forma.

A primeira questão com a qual se depara o intérprete, ao examinar este comando normativo, refere-se à relação, ou vínculo, que se estabelece entre o negócio simulado e o dissimulado. Assume-se que seria esta relação com o negócio simulado que atribuiria ao negócio dissimulado a sua natureza peculiar. A questão é das mais complexas, uma vez que a sua solução pressupõe que se enfrente, antes de mais, o dilema afeito à autonomia do negócio dissimulado.

Precisada a natureza e a autonomia do negócio dissimulado, deve-se investigar quais seriam os requisitos de substância e de forma a que a norma subordina a validade do negócio dissimulado. O tema apresenta maior complexidade quando se tem em vista negócios dissimulados formais: seriam estes nulos, por defeito de forma, ou poderiam

\footnotetext{
${ }^{752}$ Sobre o tema, v. G. PUGLIESE, La prescrizione nel diritto civile, Parte Seconda - La prescrizione estintiva, $4^{\mathrm{a}}$ ed., Torino, UTET, 1924, p. 98 ss.
} 
valer-se da forma do "negócio aparente"? Para responder esta pergunta, cumprirá analisar com maior vagar o funcionamento do mecanismo da extraversão.

\section{A unidade da simulação relativa}

O artigo 167, ao disciplinar o negócio dissimulado, estatui, especificamente quanto à simulação relativa, que "subsistirá o que se dissimulou, se válido for na substância e na forma”. Antes de aderirmos a uma posição categórica sobre qual a melhor interpretação a ser dada a este enunciado normativo, é oportuno conhecermos, no quanto essencial, o teor dos debates que a doutrina tem travado a respeito do tema.

Segundo uma parte dos autores, negócio simulado e negócio dissimulado seriam distintos. O negócio dissimulado seria dotado de completa autonomia, não devendo ser identificado, nem mesmo, com o acordo simulatório.

Para Messineo, haveria razões de ordem técnica e legal que justificariam a conclusão de que, no contexto da simulação relativa, o negócio simulado deveria ser considerado independente. Algumas destas razões seriam as seguintes ${ }^{753}$ :

(a) o artigo 1414 do Código Civil italiano ressalta a separação dogmática entre negócio simulado e negócio dissimulado, ao estabelecer uma clara antinomia entre os dois;

(b) a lei reserva disciplinas jurídicas totalmente diferentes ao negócio simulado e ao negócio dissimulado; e

(c) como consequência da dualidade de regimes jurídicos, acima destacada, reforça-se a necessidade de se considerarem os negócios simulado e dissimulado autônomos entre si; "se há uma doação mascarada sob a forma de contrato oneroso (venda), não se pode, sem incoerência, fazer uma só coisa do contrato dissimulado (doação) e do contrato simulado (venda)".

${ }^{753}$ F. MESSINEO, Il contratto in genere cit. (nota 88), p. 479-481. 
A dualidade dos negócios simulado e dissimulado aperfeiçoar-se-ia por meio de uma coligação negocial ${ }^{754}$, levada a efeito pelo acordo simulatório. Disto resultaria, ademais, a alteridade entre o negócio dissimulado e o acordo simulatório ${ }^{755}$.

Perfilhando a corrente dualista, Nuti desenvolve uma intrincada teoria sobre a simulação relativa, baseada na ideia de cisão da vontade. O autor entende que o negócio jurídico não suportaria uma dupla causalidade, isto é, não poderia ser, ao mesmo tempo, simulado e dissimulado - sob pena de rompimento de sua integridade estrutural. Disso decorreria a distinção ontológica entre o negócio simulado e o dissimulado ${ }^{756}$.

Diante desse cenário, o autor busca demonstrar que, ao contrário do que ocorre na simulação absoluta - em que as partes não quereriam o negócio simulado, pura e simplesmente - na simulação relativa, as partes buscariam simular a eficácia do negócio simulado. Entre as partes, contudo, deveria ser eficaz o negócio dissimulado, o qual se prestaria a produzir quaisquer efeitos perante terceiros. Desse modo, a simulação relativa envolveria a celebração de um negócio dissimulado, eficaz entre as partes, e de um negócio não dissimulado, eficaz perante terceiros ${ }^{757}$.

Nuti insiste quanto à circunstância de que o negócio não dissimulado seria, em verdade, um negócio jurídico querido, ou seja, estrutural e funcionalmente íntegro, ao menos no confronto com o público. $\mathrm{Na}$ aparência do negócio não dissimulado permaneceria implícita uma simulação imprópria e parcial, uma vez que tal negócio seria necessariamente querido para poder simular apenas a eficácia relevante entre as partes; não se simularia, porém, a eficácia perante terceiros ${ }^{758}$. O negócio não dissimulado seria, portanto, perfeitamente eficaz perante terceiros (como se não fosse simulado), mas

${ }^{754} \mathrm{~F}$. MESSINEO, Il contratto in genere cit. (nota 88), p. 475.

${ }^{755}$ F. MESSINEO, Il contratto in genere cit. (nota 88), p. 477-478. Para justificar seu ponto de vista, o autor aponta quatro justificativas, a seguir sintetizadas:

(a) acordo simulatório poderia valer por si (no período que precedesse a celebração do negócio simulado);

(b) o acordo simulatório pode ser anterior ao negócio dissimulado - aliás, seria comum que assim ocorresse;

(c) se o acordo simulatório e o negócio dissimulado fossem uma só coisa, a invalidade do último acarretaria a do primeiro; isto, contudo, não aconteceria; e

(d) seria possível existir o acordo simulatório sem o negócio dissimulado, como bem demonstraria a hipótese de simulação absoluta.

${ }^{756}$ G. A. NUTI, La simulazione... cit. (nota 173), p. 183.

${ }^{757}$ G. A. NUTI, La simulazione... cit. (nota 173), p. 184-185.

${ }^{758}$ G. A. NUTI, La simulazione... cit. (nota 173), p. 193. 
deliberadamente inerte no âmbito da relação entre os simuladores - já que celebrado com esta finalidade -, pois disto dependeria a relevância interpartes do negócio dissimulado.

Haveria uma interdependência entre os dois negócios. Segundo Nuti, o negócio dissimulado seria o pressuposto da celebração do negócio não dissimulado. Não se deveria equiparar o pressuposto ao motivo, ou a uma condição. Seria, mais precisamente, o evento natural ou jurídico subjacente à determinação volitiva, implícito ao negócio jurídico, como potencialidade de eficácia. $\mathrm{O}$ acordo simulatório coligaria o negócio não dissimulado ao pressuposto da dissimulação; assim, as partes poderiam paralisar a eficácia daquele, com a certeza de que o negócio dissimulado supriria a ausência de efeitos decorrente desta deliberação ${ }^{759}$.

O acordo simulatório, portanto, estabeleceria a interface entre o não dissimulado e o dissimulado, determinando uma interdependência recíproca. As partes quereriam um negócio entre si ineficaz com vistas a que este fosse indiretamente eficaz perante terceiros; paralelamente, celebrariam um negócio oculto, de cuja eficácia pretenderiam excluir os terceiros. A distribuição dos efeitos destes negócios, do ponto de vista subjetivo, seria uma tarefa atribuída ao acordo simulatório ${ }^{760}$.

A interdependência negocial acarretaria relevantes consequências na hipótese de falta do negócio dissimulado. Se isto ocorresse - diz Nuti - o negócio não dissimulado perderia o fundamento de sua ineficácia relativamente às partes, e, por isso, tornar-se-ia plenamente eficaz. Entenda-se bem a hipótese que o autor imaginou: acordado o negócio não dissimulado, as partes decidiriam postergar a efetivação do negócio dissimulado, o qual, por quaisquer razões, não viria a ser celebrado; diante dessas circunstâncias, o negócio não dissimulado recuperaria a sua eficácia, de pleno direito ${ }^{761}$. Diverso, porém, seria o resultado observado na hipótese de nulidade do negócio dissimulado: se as partes chegassem a celebrar o negócio dissimulado, mas este não se tornasse eficaz diante de um vício próprio, o negócio não dissimulado dever-se-ia considerar resolúvel, ante a insubsistência do seu pressuposto ${ }^{762}$.

\footnotetext{
${ }^{759}$ G. A. NuTI, La simulazione... cit. (nota 173), p. 208-212.

${ }^{760}$ G. A. NUTI, La simulazione... cit. (nota 173), p. 212.

${ }^{761}$ G. A. NUTI, La simulazione... cit. (nota 173), p. 213.

${ }^{762}$ G. A. NUTI, La simulazione... cit. (nota 173), p. 213.
} 
Auricchio criticaria fortemente o entendimento de que, na simulação relativa, o suporte fático do negócio dissimulado seria diferente daquele do negócio simulado. Para este autor, tal concepção seria insustentável pois não satisfaria à necessidade dogmática de diferenciar a simulação relativa da simulação absoluta; a ocultação da relação jurídica dissimulada dar-se-ia - acaso esta contasse com um suporte fático independente - em virtude de um fato absolutamente externo à simulação. Contudo, para o autor, o negócio jurídico tornar-se-ia simulado como resultado das peculiaridades da sua estrutura e do seu perfil funcional, e isto ocorreria de maneira idêntica, fosse a simulação absoluta ou relativa $^{763}$.

Para elucidar a sua posição, Auricchio vale-se do exemplo em que as partes celebram um negócio de compra e venda, por instrumento particular, e paralelamente celebram um negócio jurídico de doação, por instrumento público. Neste caso - diz ele existiria simulação absoluta. "Seria, de fato, carente de fundamento a pretensão de negar qualquer direito ao donatário com base na consideração de que o contrato de compra e venda não teria a forma requerida para o negócio de doação; é, enfim, muito óbvio que, neste caso, o ato de liberalidade teria, em si, todos os requisitos de validade e eficácia para produzir os seus efeitos"

Em vista destas ponderações, o autor nega ser possível diferenciar o suporte fático do negócio dissimulado daquele do negócio simulado. Segundo ele, o negócio dissimulado consistiria em um regulamento de interesses instituído pelas partes sem que ocorresse a correspondente declaração negocial. Seria uma espécie de "vontade nua", um núcleo de eficácia pura que somente seria alocado ao suporte fático do negócio simulado - o único criado pelas partes - diante da declaração de simulação pelo juiz ${ }^{765}$.

Esta mesma questão houvera sido examinada por Romano, o qual igualmente concluíra que, na simulação, absoluta ou relativa, não se poderia cogitar da existência de outra declaração negocial além daquela atinente ao negócio simulado. Fosse o caso de pressupor que o negócio dissimulado implicaria a criação de elementos extrínsecos ao

\footnotetext{
${ }^{763}$ A. AURICCHIO, La simulazione... cit. (nota 19), p. 165.

${ }^{764}$ A. AURICCHIO, La simulazione... cit. (nota 19), p. 165. Tradução livre; no original: "Sarebbe infatti priva di fondamento la pretesa di negare ogni diritto al donatario in base alla considerazione che il contratto di compravendita non ha la forma richiesta per il contratto di donazione; è fin troppo ovvio che in questo caso l'atto di liberalità ha in sé tutti i requisiti di validità e di efficacia per produrre i suoi effetti'.

${ }^{765}$ A. AURICCHIO, La simulazione... cit. (nota 19), p. 170-177.
} 
negócio simulado, estes somente poderiam formar outro negócio jurídico. A simulação relativa, em tais circunstâncias, caracterizar-se-ia como um fenômeno negocial plúrimo, uma parte do qual estaria em evidência, outra parte oculta. Isto, porém, não seria compatível com o conteúdo do artigo 1414 do Código Civil italiano, de acordo com o qual o negócio dissimulado teria efeito entre as partes desde que lhe subsistissem os requisitos de substância e de forma. Nessa linha de raciocínio, Romano defende que a simulação relativa seria um fenômeno unitário no qual a relação jurídica dissimulada seria extraída do comportamento executivo das partes ${ }^{766}$.

Considerando-se o modelo dogmático proposto no Capítulo I, inclinamo-nos a considerar que a tese dualista, concebida por parte da doutrina como justificativa da autonomia do negócio dissimulado, não se amolda ao artigo 167.

É importante atentar-se, como temos advertido no decorrer deste trabalho, ao juízo de valor expresso pela norma. O legislador, que não estabeleceu uma norma inútil ou contraditória, comunica, na segunda parte do caput do artigo 167, uma tomada de posição a respeito do tema. Assume que o negócio dissimulado integra-se ao negócio simulado de tal forma que, se não existisse a previsão normativa ali instituída, a nulidade de um acarretaria, naturalmente, a nulidade do outro. Por isso viu a necessidade de ressalvar a validade do negócio dissimulado ${ }^{767}$.

\footnotetext{
${ }_{767}^{766}$ S. Romano, Contributo esegetico... cit. (nota 53), p. 53.

${ }^{767}$ Raciocínio análogo tem prevalecido nos mais recentes estudos sobre a exegese do segundo parágrafo do artigo 1414 do Código Civil italiano, cuja semelhança com a segunda parte do caput do artigo 167 não diríamos tratar-se de mera coincidência. O referido dispositivo da lei italiana estabelece que "[s]e as partes quiseram concluir um contrato diferente daquele aparente, tem efeito entre estas o contrato dissimulado, desde que subsistam os seus requisitos de substância e de forma" ("[s]e le parti hanno voluto concludere un contratto diverso da quello apparente, ha effetto tra esse il contratto dissimulato, purché ne sussistano i requisiti di sostanza e di forma"). Ao se debruçar sobre o assunto, F. ANELLI (Simulazione e interposizione cit., nota 132, p. 605-606) afirma: "Em efeito, falar do negócio simulado e do dissimulado como realidades contrapostas - e extrair disso rigorosas consequências sobre o plano da disciplina - não parece respeitar autenticamente o programa perseguido pelas partes, que não é aquele, simplesmente, de simular um negócio e, contextualmente aperfeiçoar um diverso. Se assim fosse, o mesmo artigo 1414, par. 2, acabaria tendo um valor preceitual incerto: este não explicitaria mais que uma consequência de qualquer modo resultante da ineficácia, autonomamente cominada pelo primeiro parágrafo, do negócio simulado, e da validade - se e enquanto por conta, precisamente, da perfeição estrutural - do contrato dissimulado. Não se compreenderia, em outros termos, por qual motivo o legislador teria expressamente afirmado a eficácia de um contrato em si completo, cuja única característica seria aquela de manter-se em segredo pelas partes; segredo que de nenhum modo obsta à validade e eficácia inter partes do contrato, incidindo, quando muito, sobre a oponibilidade do contrato aos terceiros (mais ainda neste caso por efeito da aplicação ordinária das regras em tema de oponibilidade das operações de circulação, restando estranham ao problema as normas em tema de simulação). Uma eficácia, portanto, que não precisaria ser reafirmada". Tradução livre; no original: "In
} 
Tal equivalência de regimes jurídicos não seria verificável se o negócio dissimulado fosse dotado de autonomia. Ainda que o negócio simulado e o negócio dissimulado fossem coligados, a nulidade do primeiro não induziria a do segundo, porquanto os seus escopos negociais (abrangendo os respectivos objetos e causas) não seriam coincidentes ${ }^{768}$. Enquanto o negócio simulado teria por objeto o agir simulado, e como causa a criação da ilusão negocial, o negócio dissimulado destinar-se-ia ao estabelecimento de uma relação jurídica distinta, não ilusória, embora secreta. Vale ressaltar, ainda, que, embora se pudesse admitir que o negócio simulado figura como pressuposto do negócio dissimulado, a ilusão negocial não seria condição para a concretização dos desígnios perseguidos por este último, o qual, como negócio autônomo, de todo modo vincularia as partes nos limites do seu conteúdo.

Nessa ordem de ideias, há de se reconhecer a unidade estabelecida pela lei entre o negócio simulado e o negócio dissimulado. O tratamento jurídico da simulação relativa resume-se à reconstrução da relação jurídica dissimulada a partir da estrutura do negócio “aparente". Tendo havido uma manifestação dissimulada do intento das partes, esta não precisa exprimir-se, originariamente, por meio da forma necessária à sua validade. $\mathrm{O}$ negócio dissimulado, portanto, não é um centro separado e independente de produção de efeitos jurídicos ${ }^{769}$.

O negócio simulado é aquele que possui a aptidão de disseminar a ilusão negocial. Sendo relativa a simulação, o conteúdo convencional consubstanciado no regulamento de interesses que notabiliza o negócio jurídico abrange, além da causa simulatória, a causa de outra relação jurídica. A ilusão negocial, criada em virtude de uma deliberação adjeta ao

effetti, parlare del negozio simulato e del dissimulato come realtà contrapposte - e trarne rigorose conseguenze sul piano della disciplina - non sembra rispecchiare autenticamente il programma perseguito dalle parti, che non è quello, semplicemente, di simulare un negozio e, contestualmente perfezionarne uno diverso. Se così fosse, lo stesso art. 1414, c. 2, finirebbe per avere una valenza precettiva incerta: esso non espliciterebbe altro che una conseguenza comunque risultate dall'inefficacia, autonomamente sancita dal primo comma, del contratto simulato, e da validità - se ed in quanto per conto proprio strutturalmente perfetto - del contratto dissimulato. Non si comprenderebbe, in altri termini, per quale motivo il legislatore avrebbe dovuto espressamente affermare l'efficacia di un contratto in sé compiuto, la cui sola caratteristica sarebbe quella di essere tenuto segreto dai contraenti; segretezza che in alcun modo osta alla validità ed efficacia inter partes del contratto, incidendo, semmai, sulla sola opponibilità del contratto ai terzi (ma anche in questo caso per effetto dell'operare delle ordinarie regole in tema di opponibilità delle vicende circolatorie, restando estranee al problema le norme in tema di simulazione), e che pertanto non vi sarebbe necessità di riaffermare".

768 Sobre a nulidade de contratos coligados, v. F. P. DE C. MARINO, Contratos Coligados no Direito Brasileiro, São Paulo, Saraiva, 2010, p. 189 ss.

${ }^{769}$ F. MARANi, La simulazione... cit. (nota 246), p. 46-52. 
negócio dissimulado, reveste-o, sobrepondo-se à sua normal aparência. É por isso que, em última instância, na simulação relativa, o "negócio aparente" e o negócio dissimulado são duas faces de um único fenômeno (o negócio simulado), se bem que encarados por perspectivas distintas: a do público, no que toca ao primeiro; a das partes, no que tange ao segundo.

Mostra-se correto, pois, o ponto de vista de Distaso, segundo o qual não seria possível estabelecer uma rígida divisão entre os diversos momentos da simulação ${ }^{770}$. As partes não estabelecem, mesmo na simulação relativa, algo além do negócio simulado e do acordo simulatório - os quais, entre si, já se confundem. $\mathrm{O}$ intento simulatório reage sobre o negócio simulado estabelecendo a realidade da relação entre os contraentes ${ }^{771}$. Em vista disso, o negócio dissimulado não é mais que o próprio negócio simulado reinterpretado à luz do complexo procedimento do qual resulta a sua celebração ${ }^{772}$.

\section{A extraversão do negócio dissimulado}

O artigo 167, ao estatuir que o negócio dissimulado subsiste, se "válido" for em substância e forma, não estabelece uma obviedade. Disciplina o mecanismo da extraversão, assim batizado por Pontes de Miranda, sob a vigência do Código Civil de 1916.

Não se deve - esclareça-se logo de início - associar a extraversão à conversão substancial ${ }^{773}$. O artigo 170 prevê, a propósito desta, que quando "o negócio jurídico nulo contiver os requisitos de outro, subsistirá este quando o fim a que visavam as partes permitir supor que o teriam querido, se houvessem previsto a nulidade". A lei permite que o intérprete atribua, às partes, uma vontade que presumivelmente teriam manifestado se conhecessem da nulidade. Opera-se, aí, uma requalificação do negócio nulo, com eficácia retroativa, sob o fundamento de que tal qualificação somente não teria sido preferida pelos

\footnotetext{
${ }^{770}$ N. Distaso, La simulazione... cit. (nota 40), p. 341.

${ }^{771}$ N. DisTASO, La simulazione... cit. (nota 40), p. 345-346.

772 N. Distaso, La simulazione... cit. (nota 40), p. 342; F. C. PonTES DE MiRANDA, Tratado... cit. (nota 220), p. 534.

${ }^{773}$ T. L. SoARES, A Conversão do Negócio Jurídico, Coimbra, Almedina, 1986, p. 74-75; J. A. S. DeL Nero, Conversão Substancial... cit. (nota 142), p. 396 ss.; F. MARANI, La simulazione... cit. (nota 246), p. 66-68.
} 
particulares porque não tinham a consciência da nulidade da relação jurídica originalmente criada $^{774}$.

$\mathrm{Na}$ extraversão, a situação com a qual se depara é muito distinta. Em primeiro lugar, descabe supor a ignorância das partes quanto à nulidade do negócio simulado, porquanto, a bem da verdade, tal nulidade consiste, ela própria, no objeto da deliberação dos contraentes ${ }^{775}$, porquanto a decisão de celebrar um negócio meramente aparente traz consigo a certeza do resultado desta conduta. Em segundo lugar, o negócio dissimulado não é aquele que as partes teriam celebrado se conhecessem da nulidade; trata-se, na realidade, de uma relação jurídica constituída apesar da nulidade. Isto, aliás, é decorrência imediata da unidade do procedimento simulatório, de que tratamos acima. Em vista destas precisões, não se sustenta a crítica de Álvaro Villaça Azevedo segundo a qual o caput do artigo 167 sobrepor-se-ia, assistematicamente, ao artigo $170^{776}$; na realidade, extraversão e conversão não se confundem, razão pela qual a norma do caput do artigo 167 desempenha um particular papel no sistema do direito privado.

Na opinião de Pontes de Miranda, a extraversão seria responsável por trazer o negócio dissimulado à tona. Por conta disso, os requisitos de validade do negócio dissimulado se identificariam com os seus elementos de existência; apenas no momento da extraversão poder-se-ia dizer que o negócio dissimulado efetivamente teria entrado no mundo jurídico. Se o negócio dissimulado fosse, por si, nulo, não haveria extraversão; se fosse apenas anulável, a extraversão equivaleria a uma confirmação ${ }^{777}$.

Dessa feita, enquanto não ocorresse a extraversão, a eficácia da relação jurídica dissimulada fundar-se-ia sobre um estado de fato, porquanto a forma criada pelos particulares abrangeria tão somente o "negócio aparente", fruto da ilusão negocial. Nesta fase, o negócio dissimulado não seria mais que um negócio virtual. Pensando deste modo, compreende-se por que Auricchio defendia que o negócio dissimulado corresponderia a uma "vontade nua", um núcleo de "eficácia pura", que somente seria alocado ao suporte

774 J. A. S. Del Nero, Conversão Substancial... cit. (nota 142), p. 333-334.

${ }^{775}$ K. LARENZ, Derecho Civil... cit. (nota 123), p. 500-501; W. FluME, El negocio jurídico cit. (nota 43), p. 482 .

${ }_{776}$ Álvaro Villaça Azevedo, Teoria Geral do Direito Civil-Parte Geral, São Paulo, Atlas, 2012, p. 343.

${ }^{777}$ F. C. PONTES DE MiRANDA, Tratado... cit. (nota 220), p. 532. 
fático do negócio simulado - o único criado pelas partes - diante da declaração da simulação pelo juiz ${ }^{778}$.

A extraversão levanta o véu da ilusão negocial; revela, ao público, a natureza da operação global posta em prática pelas partes. O intento simulatório, julgado nulo, é eliminado do negócio jurídico. Dizendo de outro modo, a extraversão combina a interpretação corretiva e a requalificação com a exclusão de parcela do regulamento de interesses (referente à causa simulatória), tal qual se dá no caso de nulidade parcial. Num contexto em que, a rigor, não seria possível separar o simulado do dissimulado, intervém o legislador para estabelecer um regime especial que assegura a possibilidade de persistir a parcela não ilusória do comportamento negocial dos contraentes.

No que se refere aos requisitos de substância do negócio dissimulado, há quem defenda que aqueles somente seriam atendidos se entre o "negócio aparente" e o negócio dissimulado houvesse uma relação de continência. Romano assevera, nesse sentido, que o “negócio aparente" conteria não apenas os requisitos (de validade), mas até mesmo os elementos (de existência) do negócio dissimulado ${ }^{779}$ :

Isto significa - para maior esclarecimento da hipótese legislativa - que o contrato simulado contém "quantitativamente" todos os elementos executivos, e os contém em uma medida maior com relação ao negócio dissimulado. Normalmente este subtrai do primeiro uma parte, deixando cair aquele ligado à causa do negócio simulado. Assim, na hipótese de uma compra e venda que dissimule uma doação, cai o preço indicado no contrato simulado, não exigível segundo a intenção das partes e efetivamente não pago no comportamento executivo destas.

Argumentação semelhante apresenta-nos Anelli. O autor refere-se ao exemplo do particular que, buscando preservar um bem de seu patrimônio do possível exercício de uma pretensão executória, por parte de um credor, celebra um contrato de compra e venda simulado, entregando o bem em questão ao adquirente simulado; paralelamente, os simuladores firmam, entre si, um contrato de locação, em virtude do qual o adquirente

${ }^{778}$ A. AURICCHIO, La simulazione... cit. (nota 19), p. 170-177.

${ }^{779}$ S. Romano, Contributo esegetico... cit. (nota 53), p. 54. Tradução livre; no original: "Questo significa - a maggior chiarimento dell'ipotesi legislativa - che il contratto simulato contiene "quantitativamente" tutti gli elementi esecutivi, e li contiene in una misura maggiore rispetto a quelli richiesti dal contratto dissimulato. Normalmente questo sottrae al primo solo una parte, lasciando cadere quelli legati alla causa del contratto simulato. Così, nell'ipotesi di una compra-vendita che dissimuli una donazione, cade il prezzo indicato nel contratto simulato non esigibile nell'intento delle parti ed effettivamente non pagato nel comportamento esecutivo delle stesse". 
simulado compromete-se a remunerar o alienante simulado pelo gozo do bem transferido. Em tal contexto, haveria dois suportes fáticos distintos: o de uma compra e venda absolutamente simulada e aquele de uma locação (oculta), cada qual destinado a seguir a própria sorte; em tais circunstâncias - diz Anelli - seria difícil identificar uma vontade de dissimular a locação por detrás de uma aparente compra e venda ${ }^{780}$.

Diversa seria a situação - prossegue o autor - da compra e venda celebrada com o intuito de dissimular uma doação. Neste caso, a eficácia atribuída ao negócio ostensivo prestar-se-ia, em alguma medida, a justificar movimentação jurídica pretendida pelas partes; de fato, tanto a compra e venda como a doação implicariam a efetiva transferência de um bem, do patrimônio de um sujeito, para o patrimônio do outro. O caráter ilusório da avença emergiria em virtude do ajuste quanto ao pagamento apenas aparente do preço. No complexo programa estabelecido entre as partes, estas buscariam realizar uma operação dispositiva mediante a combinação dos efeitos, produzidos entre si e perante terceiros, do "negócio aparente" e do negócio oculto ${ }^{781}$.

Adotando estas premissas em parte, Marani prega que o negócio dissimulado poderia adquirir relevância própria, independentemente de encontrar-se "contido" no "negócio aparente", quando a simulação fosse relacionada à causa. Esta poderia ser reconstruída com base no "pacto nu" firmado pelos contraentes, à margem da forma negocial ostensivamente criada. A referida reconstrução do negócio dissimulado, porém, não seria possível quando se tratasse de simulação relativa afeita ao objeto ou aos sujeitos contratantes. Nestas hipóteses, seria impossível extrair, do próprio "negócio aparente”, um suporte fático diverso, inspirado por elementos extratextuais, como o aludido "pacto nu". Dessa feita, excepcionalmente, a validade do negócio dissimulado requereria a formação de um suporte fático separado, capaz de abranger o objeto dissimulado ou conferir titularidade autônoma ao contratante dissimulado ${ }^{782}$.

Embora compartilhasse da visão de que, na simulação relativa, existiria apenas uma declaração negocial, Auricchio se opõe a este entendimento, defendendo ser inconcebível que o "negócio aparente" contenha, quantitativamente, os elementos do

\footnotetext{
${ }^{780}$ F. ANELLI, Simulazione e interposizione cit. (nota 132), p. 606.

${ }^{781}$ F. ANELLI, Simulazione e interposizione cit. (nota 132), p. 607.

${ }^{782}$ F. MARANI, La simulazione... cit. (nota 246), p. 52 ss.
} 
negócio dissimulado. Ele aponta, como exemplo, a situação, não rara, em que se dissimula um preço maior que aquele indicado no "negócio aparente". Nesta situação, não se poderia dizer que o preço maior estaria contido no preço menor declarado. Do mesmo modo, quando a simulação se desse mediante interposta pessoa, a relação jurídica com a parte dissimulada não se extrairia daquela estabelecida entre as partes do "negócio aparente". Mais gritante, ainda, seria o caso da simulação do tipo negocial: "como poder-se-ia sustentar que uma compra e venda contém a causa de uma locação?” - indaga, em tom provocador $^{783}$.

Seguindo semelhante tendência, Carresi nega que haveria, entre o "negócio aparente" e o negócio dissimulado, uma necessária coincidência entre aspectos substanciais, de modo que o último poderia ser deduzido do outro. Nada impediria, por exemplo, que um contrato de compra e venda fosse dissimulado sob a aparência de um contrato de compra e venda, sendo certo que, entre tais negócios jurídicos não haveria qualquer nexo de continuidade psicológica. A contradeclaração deveria servir como fonte dos elementos necessários à reconstrução do negócio dissimulado, precisamente porque a efetiva intenção das partes seria em vão pesquisada na aparência enganadora produzida pela simulação. E, uma vez que o negócio simulado fosse concebido como produto do emprego de uma linguagem convencional ou alusiva, não haveria razões para se acreditar que entre a aparência, e a realidade, devesse existir uma necessária vinculação substancial, o que, aliás, seria confirmado pelas hipóteses de simulação subjetiva ${ }^{784}$.

A solução do dilema doutrinário acima assinalado, segundo nos parece, deve ter como ponto de partida a constatação de que não é a dissimulação que se adiciona à simulação, como um elemento adjeto, mas bem o contrário. O negócio jurídico torna-se dissimulado porque passa a ostentar uma aparência que não é a sua; as partes primeiro deliberam os termos em que querem vincular-se, para, em momento logicamente ulterior, decidirem modificar, mediante a criação da ilusão negocial, o aspecto externo da relação jurídica. Fica, assim, evidente o descabimento da busca da totalidade dos elementos do negócio dissimulado no "negócio aparente".

${ }^{783}$ A. AURICCHIO, La simulazione... cit. (nota 19), p. 169.

${ }^{784}$ F. CARRESI, Apparenza e realtà cit. (nota), p. 494 ss. 
Os particulares poderiam convencionar a celebração do contrato de locação, bem como a manutenção de seus desdobramentos executivos (principalmente o pagamento dos alugueres) em segredo. Adicionalmente, poderiam pactuar atribuir, a este contrato, a aparência de um contrato de compra e venda, mediante a criação de índices de significação que remetessem à eficácia deste contrato. Neste contexto, a compra e venda simulada teria, em comum com a locação dissimulada, apenas a transferência da posse do bem. Todos os demais índices, ocultos ou ostensivos, seriam evidências ou bem da criação da ilusão negocial, ou bem da relação jurídica dissimulada, criadas em razão do complexo programa negocial posto em prática pelos particulares.

Pelo exposto, somos da opinião de que o negócio simulado, em sua dimensão socialmente recognoscível (o “negócio aparente”), não conterá a materialidade da relação jurídica dissimulada, sendo certo que a extraversão pode envolver - e normalmente envolverá - a consideração de um conjunto de índices ocultos positivos, não coincidentes com a ilusão negocial disseminada, os quais hão de ser, sem dúvidas, relevantes para a interpretação e a qualificação do comportamento negocial total dos particulares.

Assentada a unidade entre o negócio simulado e o negócio dissimulado, surge a interessante questão acerca da possibilidade de extraverter-se o negócio dissimulado para cuja validade a lei imponha forma especial. Nesta sede, cabe indagar se os requisitos de forma, mencionados na parte final do caput do artigo 167, deveriam estar presentes no "negócio aparente" ou no negócio dissimulado.

Vale esclarecer, em linha de partida, que a forma a que ora nos referimos é a externa $^{785}$. Com efeito, conforme assinalamos anteriormente ${ }^{786}$, os negócios jurídicos submetidos a exigência de forma interna sequer podem ser simulados.

Em Portugal, o debate anterior ao Código Civil de 1966 polarizava-se com as opiniões de Beleza dos Santos e Manuel de Andrade. Para o primeiro, a forma do negócio dissimulado deveria, ela própria, atender às respetivas exigências formais dispostas em lei ${ }^{787}$. Em contrapartida, o segundo defendia a possibilidade de a forma aparente, da qual se revestiria o negócio simulado, ser aproveitada para conferir validade ao negócio

\footnotetext{
${ }^{785}$ P. PAIS DE VASCONCELOS, Teoria Geral... cit. (nota 103), p. 691-692.

${ }^{786} \mathrm{~V}$. tópico 30.

${ }^{787}$ J. BELEZA DOS SANTOS, A Simulação... cit. (nota 20), p. 273 ss.
} 
dissimulado $^{788}$. A forma do "negócio aparente", portanto, se atendesse às exigências de forma a que se submetesse o negócio dissimulado, poderia justificar a validade deste.

O Supremo Tribunal de Justiça de Portugal, por meio do Assento de 23 de julho de 1952, consagrou a doutrina restritiva de Beleza dos Santos: "Anulados os contratos de compra e venda de bens imóveis e de cessão onerosa de créditos hipotecários, que dissimulavam doações, não podem estas considerar-se válidas" ${ }^{\text {,799. }}$.

Nos trabalhos preparatórios do Código Civil português, o Projeto de Rui de Alarcão seguiu a tese de Manuel de Andrade e propôs a seguinte redação: "Sendo o negócio dissimulado de natureza formal, a sua validade supõe, na falta de uma contradeclaração com a forma legalmente requerida para o negócio, que as razões do seu formalismo se mostrem satisfeitas com a observância das formalidades revestidas pelo negócio simulado". No final das contas, contudo, o Código Civil português adotou uma fórmula ambígua, que não poderia fím aos debates sobre o tema. No $\mathrm{n}^{\mathrm{o}} 2$ do artigo $241^{\circ}$, ficou a constar que "se, porém, o negócio dissimulado for de natureza formal, só é válido se tiver sido observada a forma exigida por lei" ${ }^{, 790}$.

Nesse cenário, Mota Pinto concebe o negócio dissimulado como um "negócio latente"791 o qual haveria de revestir-se de forma própria, se a lei assim o requeresse. Segundo o autor, haveria um argumento racional em favor da tese mais restritiva: os preceitos sobre a forma visariam a finalidades específicas, sendo duvidoso que elas sejam asseguradas com a simples observância das solenidades do "negócio aparente". Em razão disso, no caso de negócios dissimulados formais, dever-se-ia reputá-los nulos por vício de forma $^{792}$.

Segundo Hörster, a ideia da falsa demonstratio não serviria para solucionar o problema, pois, afinal de contas, todas as simulações seria falsœe demonstrationes. Para o autor, a figura da falsa demonstratio teria lugar no plano da interpretação, sobretudo no contexto em que a obscuridade da declaração negocial não fosse capaz de acarretar o

\footnotetext{
${ }^{788}$ M. A. Domingues De ANDRADE, Teoria Geral... cit. (nota 20), p. 192-194.

${ }^{789}$ P. PAIS DE VASCONCELOS, Teoria Geral... cit. (nota 103), p. 686.

${ }^{790}$ P. PAIS DE VASCONCELOS, Teoria Geral... cit. (nota 103), p. 686-687.

${ }^{791}$ C. A. Mota PinTo, Teoria Geral... cit. (nota 435), p. 473-474.

792 C. A. Mota Pinto, Teoria Geral... cit. (nota 435), p. 474-476. No mesmo sentido, F. GALGANO, Il negozio giuridico cit. (nota 119), p. 371-372.
} 
dissenso entre os contraentes. "A 'falsa demonstratio' tem a ver com a eventual dificuldade das partes em exprimir-se bem; no negócio dissimulado, porém, as partes sabem exprimirse muito bem, tão bem que até simulam para enganar terceiros..." ${ }^{\text {793 }}$. A avaliação acerca da validade, ou invalidade, do negócio dissimulado sujeito a forma especial, teria que ver com a compatibilidade da declaração negocial, assim como consta do instrumento, com a forma de que, segundo a lei, ele deveria se revestir. "É este o resultado da avaliação da declaração negocial, feita de acordo com os interesses públicos, legitimadores da forma legal. Não está em causa a satisfação da vontade real das partes, mas sim a vontade da lei em ver respeitadas as suas normas imperativas" ${ }^{\text {,794. }}$.

Seguindo uma direção oposta, Pais de Vasconcelos aduz que a exigência legal de forma para os negócios jurídicos, sob cominação de nulidade (forma ad substantiam), não seria arbitrária; responderia a uma específica intencionalidade. A forma legal destinar-se-ia a assegurar a ponderação das partes, a titularidade do ato e a respectiva publicidade. No caso da simulação relativa, a ponderação das partes e a titularidade do ato seriam asseguradas pelo respeito à forma do "negócio aparente". Apenas as necessidades de cognoscibilidade do ato por terceiros restariam frustradas. Mas os simuladores pretenderiam isto mesmo: enganar o público ${ }^{795}$.

No Brasil, Pontes de Miranda defende a impossibilidade extraversão do negócio dissimulado sujeito a exigência de forma especial. Para o autor, seria possível provar-se a simulação por qualquer meio, mas não se admitiria a prova, por instrumento particular, do negócio dissimulado que devesse formalizar-se mediante escritura pública ${ }^{796}$.

Ora, em vista de tão discrepantes opiniões, quid juris, à luz do artigo $167 ?$

É importante salientar, neste passo, que a opinião de Pontes de Miranda, acima descrita, foi concebida à luz do Código Civil de 1916, o qual sujeitava o negócio simulado ao regime da anulabilidade. Neste contexto normativo, o autor não podia vislumbrar contemporaneidade entre o negócio simulado e o negócio dissimulado pois, enquanto não ocorresse a extraversão, somente o negócio simulado existiria; tanto assim, que se viesse a

\footnotetext{
${ }^{793}$ H. E. HÖRSTER, A parte Geral... cit. (nota 404), p. 546. V. também L. A. CARVALHO FernANDES, Estudos sobre a simulação cit. (nota 735), p. 36-38.

${ }^{794}$ H. E. HÖRSTER, A parte Geral... cit. (nota 404), p. 546-747.

${ }^{795}$ P. PAIS DE VASCONCELOS, Teoria Geral... cit. (nota 103), p. 689.

${ }^{796}$ F. C. PONTES DE MiRANDA, Tratado... cit. (nota 220), p. 532-533.
} 
tornar-se impossível a anulação deste, em razão da decadência, o negócio dissimulado jamais assumiria qualquer relevância. Por conta disso, a extraversão implicaria uma espécie de substituição do negócio simulado, que, sendo anulado, cederia lugar ao negócio dissimulado. A nulidade cominada ao artigo 167, no entanto, altera o cenário em consideração do qual a questão deve ser analisada. O direito positivo, ademais, não faz referência a uma substituição, mas à subsistência, ou seja, à continuidade ou manutenção de algo que já existia.

A opção pela invalidade do negócio dissimulado, quando este carecesse de forma autônoma, pareceria, à primeira vista, assegurar melhor a publicidade e, com ela, os interesses dos terceiros. Todavia, em concreto, tal não sucederia necessariamente. Assim, no caso, por exemplo, de uma simulação para enganar e prejudicar preferentes, em que se manifestasse uma doação para ocultar uma compra e venda, a solução da nulidade obstaria ao exercício da preferência e acabaria por beneficiar os simuladores. Mais justo seria admitir a validade formal e proteger os terceiros através da responsabilidade civil, nos moldes gerais: a simulação seria ilícita e os danos causados a terceiros pela falta de publicidade ou pela falsa publicidade emergente intencionalmente da simulação seriam ressarcíveis de acordo com as regras da responsabilidade civil ${ }^{797}$.

Somos da opinião de que o legislador brasileiro, embora não tenha sido explícito, admite a suficiência da forma aparente para assegurar a validade do negócio dissimulado. Com efeito, a forma adotada no negócio jurídico, tal como os simuladores lhe dão aparência, jamais pode revelar a totalidade do negócio dissimulado. Tal exteriorização seria incompatível com a simulação ${ }^{798}$. Se assim não fosse, não apenas cairia por terra a concepção unitária da simulação relativa, como, ademais, mostrar-se-ia inviável a dissimulação da maioria dos negócios formais, sobretudo aqueles dependentes de escritura pública. $\mathrm{O}$ texto legal, contudo, não dá a entender que os negócios formais não poderiam ser dissimulados; pelo contrário, tanto admite esta possibilidade que disciplina o trâmite da extraversão relativamente ao requisito de forma.

A bem se ver, se a dissimulação do negócio formal não fosse possível, careceria de todo sentido a menção, na parte final do caput do artigo 167 , ao requisito de forma. $\mathrm{O}$ 
simples fato de a norma referir-se aos requisitos de forma do negócio dissimulado indica que o pressuposto desta é a possibilidade de dissimular-se negócios formais. Ademais, sendo certo que a formalização do negócio jurídico por meio de escritura pública excluiria o mecanismo da ilusão negocial, então a norma admite que o negócio dissimulado poderia ser formalizado por meio de instrumento particular, ou consistir tão somente em produto do comportamento concludente das partes, e, ainda assim, atender ao requisito de forma a que estivesse sujeito. Em vista disso, à norma somente pode ser atribuído um sentido: o que de é possível que o negócio dissimulado venha a aproveitar-se da forma do "negócio aparente", uma vez que se processe a extraversão. O artigo 167, portanto, ao ressalvar a validade do negócio dissimulado, autoriza que o negócio oculto encarne na forma utilizada na criação da aparência ${ }^{799}$.

Com a extraversão, veiculada por meio da competente sentença judicial, dá-se a integração entre o conteúdo dissimulado e a forma simuladora. Os elementos do contrato dissimulado que não estejam cobertos pela forma do "negócio aparente" tornam-se expressos na sentença que declara a simulação (e a dissimulação), cuja certidão pode ser averbada para fins de retificação do registro do ato ${ }^{800}$. A extraversão supre a lacuna resultante da simulação, afigurando-se, por conseguinte, como um fato jurídico suplementar à declaração de nulidade do negócio simulado, capaz de imputar o conteúdo dissimulado à forma simuladora.

Vale registrar, por pertinente, que esta solução se compatibiliza com o princípio da conservação do negócio jurídico ${ }^{801}$. O que se dissimulou subsiste se a extraversão mostrar-se viável, isto é, se, integrado o conteúdo dissimulado à forma simuladora, esta satisfizer as exigências formais legalmente previstas à validade do regulamento de interesses remanescente após a extirpação do intento simulatório. $\mathrm{O}$ requisito de validade relativo à forma, portanto, deve ser verificado no próprio "negócio aparente", posto que em confronto com a norma aplicável ao negócio dissimulado, sem que seja necessária a produção de um suporte fático independente para o negócio dissimulado.

\footnotetext{
${ }^{799}$ Tese semelhante foi defendida por F. CARRESI, Apparenza e realtà... cit. (nota 305), p. 494.

${ }^{800}$ P. PAIS DE VASCONCELOS, Teoria Geral... cit. (nota 103), p. 691.

${ }^{801}$ P. PAIS DE VASCONCELOS, Teoria Geral... cit. (nota 103), p. 691.
} 
Às conclusões acima expostas poder-se-ia opor um argumento baseado em pretensa interpretação sistemática do caput do artigo 167. Dir-se-ia que seria razoável, senão mandatório, assumir que o legislador, ao se referir aos requisitos de substância e de forma, o teria feito de maneira homogênea. Ainda que substância e forma não fossem confundíveis, ambas as espécies de requisitos seriam igualmente importantes para a subsistência do negócio dissimulado. Como a substância do negócio dissimulado não poderia ser encontrada no "negócio aparente", então ela deveria ser investigada diretamente no negócio dissimulado. Coerentemente, a forma requerida para a validade do negócio dissimulado, tal qual a substância, haveria também de ser perscrutada diretamente no negócio dissimulado.

$\mathrm{O}$ argumento acima, embora pudesse impressionar o intérprete menos atento, em razão de sua consistência lógica, não seria determinante para a formação de um juízo acerca da interpretação do comando relativo à excepcional validade do negócio dissimulado. Valhamo-nos, para refutar a argumentação acima descrita, do mesmo rigor lógico que a notabiliza: se o negócio dissimulado fosse julgado pela própria forma, ou seja, constituísse um suporte fático autônomo com relação ao negócio simulado, a ausência de qualquer dos seus requisitos de validade implicaria, diretamente, a sua invalidade, independentemente da sorte do negócio simulado. Logo, se faltasse uma forma autônoma, capaz de atender às exigências legais correspondentes, o negócio dissimulado necessariamente não subsistiria, pois seria, ab initio, nulo. Por isso, o artigo 167, quando se refere à forma necessária à validade do negócio dissimulado, não faria algo mais que repetir a regra do artigo 166, incisos IV e V.

Ao intérprete, porém, não é dado reduzir a norma à inutilidade quando existe uma interpretação que preserva a sua importância ao sistema. $\mathrm{O}$ artigo 167 , mais que repetir o comando do artigo 166, incisos IV e V, veicula um fato de novidade, consistente na previsão de uma exceção à regra: a forma a ser valorada não é aquela que normalmente seria, se o negócio dissimulado fosse considerado destacadamente do negócio simulado; tal forma passa a ser, em razão da mencionada exceção, a do próprio "negócio aparente", a qual não importaria à validade do negócio dissimulado se fosse aplicada diretamente a norma geral do artigo 166, incisos IV e V.

Nada obstante, a norma em exame não requer que o "negócio aparente" seja o único levado em consideração, pois, se assim fosse, não haveria qualquer sentido em se 
exigir a validade substancial do negócio dissimulado, a qual, no mais das vezes, não se pode abstrair do teor da aparência de negócio criada pelos simuladores. O artigo 167 também não remete exclusivamente à substância do negócio dissimulado, pois, assim fosse, tal norma estaria apenas repetindo o teor dos incisos I, II, III e VI do artigo 166. A substância necessária à validade do negócio dissimulado, na realidade, é aquela decorrente da integração entre este e o "negócio aparente". O legislador, como se vê, confirma que a simulação e a dissimulação são faces de um fato jurídico único.

É essencial perceber, neste ponto, que o negócio dissimulado pode ser, em si substancialmente ilegítimo (e.g. negócio com objeto ilícito), mas é bem possível, outrossim, que aquele seja substancialmente irrepreensível, sendo, contudo, substancialmente reprováveis tão somente os desdobramentos da dissimulação. A título de exemplo, considere-se a simulação de preço direcionada à obtenção de uma economia fiscal: não haveria, em tal instância, qualquer mácula acerca da substância do negócio dissimulado, mas a simulação relativa (i.e. a causa simulandi em sentido amplo) visaria a perpetrar um dano ao erário. Fosse o caso de se considerar, unicamente, a substância do negócio dissimulado (como se autônomo fosse), não haveria nada que obstasse à extraversão. No entanto, como foi bem observado ${ }^{802}$, a extraversão não pode processar-se quando se trate de simulação nocente. Nesta sede, a ilicitude não seria, propriamente, relacionada à substância do negócio dissimulado, mas macularia o fenômeno simulatório como um todo.

Esta comunicação entre a substância do negócio dissimulado, isoladamente considerada, e a substância de todo o aparato da simulação relativa, comprova que o legislador não se refere ao negócio dissimulado, nem à sua substância e à forma, como se este fosse um fenômeno estranho ao negócio simulado. A consideração unitária do fenômeno simulatório, no caso da dissimulação, justifica a conclusão de que a extraversão pode ser denegada ainda que o negócio dissimulado seja, em si, substancialmente perfeito; e, em contrapartida, a extraversão pode ocorrer sempre que a simulação e a dissimulação, consideradas como fato jurídico unitário, atendam aos requisitos de forma e de substância legalmente previstos.

${ }^{802}$ F. C. Pontes de Miranda, Tratado... cit. (nota 220), p. 533; M. B. Mello, Teoria do Fato Jurídico... cit. (nota 665), p. 169-170. 


\section{§ 13. OS DIREITOS DE TERCEIROS DE BOA-FÉ}

A admissão da simulação como manifestação de autonomia privada pode ocasionar efeitos colaterais, sobretudo, prejuízos às posições jurídicas ostentadas por terceiros. Atento a potenciais conflitos de interesses entre estes e os simuladores, o legislador tratou de estabelecer critérios segundo os quais as tensões eventualmente surgidas deveriam ser apaziguadas.

Elemento fundamental da simulação, como se demonstrou acima, é a ilusão negocial, cuja característica é a capacidade de incutir em terceiros a crença, fundada na confiança, quanto à efetividade da relação jurídica estabelecida entre as partes. Com base nesta confiança, podem os terceiros realizar atos jurídicos ulteriores, assim como considerar terem adquirido certos direitos ou assumido determinadas obrigações.

Nesse contexto, descoberta a simulação, dois interesses distintos podem levar os terceiros a insurgir-se contra os simuladores: (a) podem objetivar a declaração de nulidade do negócio simulado, para que prevaleça o cenário jurídico dissimulado; ou (b) podem pretender que, a despeito da simulação, o negócio simulado persista, a fim de que permaneçam hígidos os direitos que tenham adquirido em razão da sua celebração. A satisfação do primeiro grupo de interesses depende das regras relativas à legitimidade dos terceiros para alegar e pleitear a decretação de nulidade do negócio simulado ${ }^{803}$. O atendimento ao segundo grupo de interesses depende, por sua vez, da observância dos critérios fixados no $\S 2^{\circ}$ do artigo 167.

Este dispositivo, que põe a salvo os direitos de terceiros de boa-fé em face dos simuladores, será examinado no decorrer deste parágrafo. Antes de abordá-lo diretamente, contudo, é oportuno tecer breves comentários sobre a classe de sujeitos a que tal norma se dirige: os terceiros com relação ao negócio simulado.

\section{A condição de terceiro}

Partes do negócio simulado são os sujeitos que o estipulam, isto é, os simuladores. Dentre estes se incluem as interpostas pessoas, no caso de o negócio simulado vir a ser

${ }^{803}$ V. tópico 45. 
concluído nos moldes do que preconiza o $\S 1^{\circ}$, inciso $\mathrm{I}$, do artigo 167 . O critério que orienta esta conclusão é o de que as partes do negócio simulado devem coincidir com as partes do acordo simulatório, sob pena de não se concretizar o "mecanismo técnico" da simulação ${ }^{804}$.

Ao contrário de outras legislações, o Código Civil não dispensa tratamento específico para casos individuais de terceiros, os quais são aludidos, de maneira genérica, no $\S 2^{\circ}$ do artigo 167 . Terceiros são aqueles que não tomam parte do negócio simulado. Não adquire relevância, inicialmente, a questão acerca do conhecimento que eles possam adquirir a respeito da simulação. Esta circunstância possibilitará distinguir os terceiros de boa-fé dos terceiros de má-fé; de todo modo, todos devem ser considerados alheios ao esquema simulatório. São espécies relevantes de terceiros: os credores das partes do negócio simulado, o adquirente de bens alienados pela parte do negócio simulado, o fisco, o cônjuge da parte do negócio simulado, os herdeiros e legatários da parte do negócio simulado, etc.

Uma questão de certa complexidade neste tópico refere-se à definição das partes do negócio simulado em negócios plurilaterais; acaso um dos contraentes não participasse do acordo simulatório, fosse este o critério para identificar as partes do negócio simulado, a solução logicamente aplicável tenderia a um cenário de difícil sustentação: considerar-se-ia o negócio simulado nulo entre aqueles que houvessem pactuado a simulação, porém válido apenas quanto a uma das partes, por não ter se envolvido com o esquema simulatório.

A nosso ver, tal solução não se mostra aceitável. Uma solução alternativa seria a adoção da ideia, proposta no direito alemão, do procedimento simulado falido ${ }^{805}$. Se as partes buscassem colocar em prática um esquema simulatório, mas não conseguissem a adesão de um sujeito específico, a parcela do negócio jurídico relativa a este sujeito que não aderisse à simulação deveria ser considerada inexistente. Tal entendimento baseia-se

\footnotetext{
${ }^{804}$ F. MESSINEO, Il contratto in genere cit. (nota 88), p. 447.

${ }^{805}$ Segundo W. Flume (El negocio jurídico cit., nota 43, p. 483; 492), há falência da simulação quando o declarante espera que o declaratário se dê conta do caráter simulatório da declaração, porém, este não reconhece tal circunstância; em casos como este, não se alcança nenhum acordo sobre a celebração do negócio jurídico, sobretudo quanto ao seu conteúdo simulatório. O negócio jurídico assim celebrado equiparar-se-ia ao intercâmbio de declarações não sérias (§ 118 do Código Civil alemão), tais como as declarações jocandi gratia ou docendi causa. O negócio jurídico seria, então, não negócio (inexistente), ressalvada a possibilidade de o declaratário requerer, em face do declarante, a indenização dos danos sofridos em razão de ter crido na seriedade da declaração.
} 
na pressuposição de que a parte em questão teria compreendido de maneira equivocada o contexto negocial que teria diante de si (como se as contrapartes dissessem "A", e ela entendesse "B"), o que justificaria a insubsistência do vínculo jurídico estabelecido entre ela e os demais sujeitos.

Afirma-se, ademais, que os herdeiros das partes do negócio simulado tomariam, em regra, o seu lugar ${ }^{806}$. Também com isto não se pode concordar. Somente seria possível a sucessão causa mortis das partes do negócio sucessório acaso se admitisse que o acordo simulatório não contivesse estipulações de caráter personalíssimo; ora, a própria estrutura negocial sigilosa do acordo simulatório aponta que, por natureza, o seu conteúdo não convive com qualquer hipótese de sucessão. Disso decorre, por consequência, a impossibilidade de se cogitar da sucessão quanto ao negócio simulado, cujo conteúdo convencional, como já demonstramos, se identifica com o acordo simulatório.

Vale citar, por fim, a discussão doutrinária instalada em torno do caso do representante da parte do negócio simulado em relação ao qual, segundo nos parece, o tratamento jurídico aplicável pode ser definido com razoável facilidade, porquanto, embora do ponto de vista formal se possa dizer que ele ocupe o papel de parte, do ponto de vista material caracteriza-se como terceiro ${ }^{807}$.

\section{As bases dogmáticas da tutela aos direitos de terceiros de boa-fé}

No debate acerca da proteção dos direitos de terceiros de boa-fé, uma das justificativas dogmáticas mais comumente relacionadas à disciplina que a lei confere ao tema consiste na inoponibilidade da simulação.

Ferrara mostra certo desconforto ao examinar a questão, recorrendo, a princípio, a uma justificativa de ordem política. "Se a lei permite a simulação por parte dos contratantes para não violar a liberdade contratual, esta concessão deve ter, no entanto, um limite e uma medida, na protecção da boa-fé de terceiros e na segurança do comércio. Esta solução impõe-se como uma necessidade política"808. Apesar de dar a entender que a eficácia do negócio simulado seria fruto de uma arbitrária opção legislativa, o autor

\footnotetext{
${ }^{806}$ F. MESSINEO, Il contratto in genere cit. (nota 88), p. 447.

${ }^{807}$ F. MESSINEO, Il contratto in genere cit. (nota 88), p. 449.

${ }^{808}$ F. FERrARA, A simulação... cit. (nota 20), p. 337.
} 
desenvolve a tese da inoponibilidade da simulação com fundamento na teoria $d a$ responsabilidade.

Como a reserva mental seria ineficaz para o contratante que a ignorasse, assim também a simulação, reserva comum e consensual de ambos os contraentes, deveria ser ineficaz quanto a terceiros. Os simuladores formariam, agrupados, uma unidade diante do público e emitiriam uma declaração mentirosa, reservada na sua mente, e até fariam constar em documento uma vontade oposta. Em tal caso, dever-se-ia aplicar, por analogia, o princípio da irrelevância da reserva mental. Valendo-se desta construção, o autor submeteria a disciplina externa da simulação ao princípio da responsabilidade. Com base no qual assegurar-se-ia mínima segurança e proteção ao tráfico jurídico, na medida em que se atribuísse, aos simuladores, o ônus de suportar os efeitos da relação jurídica tornada nula por sua culpa.

Esta construção teórica seria aprimorada, sobretudo a partir da obra de Cariota Ferrara. Para este autor, uma restrição atinente à legitimidade passiva acarretaria a inoponibilidade da própria nulidade ${ }^{809}$. Também pensa assim Santoro-Passarelli, para quem a nulidade do negócio simulado poderia fazer-se valer em face das partes por todos os terceiros interessados, em prejuízo dos quais a simulação tivesse sido realizada (e.g. os subadquirentes, os credores, os herdeiros legítimos do alienante simulado), mas tal nulidade ser oposta a estes terceiros, em virtude da confiança que teriam depositado sobre o negócio celebrado pelos simuladores ${ }^{810}$.

Vê-se, pois, que a inoponibilidade da simulação, independentemente de qual fosse a sua matriz principiológica - a teoria da responsabilidade ou a tutela da confiança corresponderia a uma limitação da abrangência subjetiva dos efeitos da nulidade cominada ao negócio simulado. Tal expediente não deixaria de aproximar-se de uma ficção normativa, pela qual o ordenamento jurídico conferiria, a certas classes de sujeitos, tratamento jurídico análogo àquele que seria aplicável se a simulação nunca houvera sido praticada e, portanto, a nulidade não houvera maculado o negócio jurídico.

${ }^{809}$ L. CARIOTA FERRARA, Il negozio giuridico... cit. (nota 34), p. 328.

${ }^{810}$ F. SANTORO-PASSARELli, Dottrine... cit. cit (nota 40), p. 154-156. 
Contra esta linha de pensamento, defendeu-se que os terceiros seriam protegidos das consequências da simulação em razão do caráter relativo da nulidade do negócio simulado.

Para Betti, não se poderia afirmar que o negócio simulado seria absolutamente nulo; haveria, aí, apenas nulidade relativa. Tal conclusão decorreria do fato de que a invalidade não poderia jamais prejudicar a titularidade de direitos de terceiros de boa-fé, e, por isso, o negócio simulado somente poderia ser qualificado como nulo dentro dos limites da relação estabelecida entre as partes ${ }^{811}$. Haveria dois tipos de nulidade relativa: aquela que não poderia ser alegada por certos sujeitos e aquela que não se faria efetiva em face de certos sujeitos. "A relatividade decorre da diferença e independência das respectivas relações jurídicas e pode referir-se a uma limitação não apenas da legitimidade ativa, mas também da legitimidade passiva ${ }^{\$ 812}$. O negócio simulado, portanto, seria relativamente nulo na medida em que a nulidade sofreria uma limitação quanto à legitimidade passiva.

Como se percebe, tanto a tese da nulidade relativa como a da inoponibilidade, embora por vias diversas, levam à conclusão de que o negócio simulado seria válido, no que tange à esfera jurídica dos terceiros. Tal situação poderia induzir o intérprete a debruçar-se sobre a questão referente à possibilidade de o negócio nulo produzir efeitos, relativamente a um grupo de sujeitos.

A doutrina, de fato, tem admitido a relevância de certos efeitos do negócio nulo. $\mathrm{O}$ negócio nulo não poderia atingir todos os escopos ou o escopo principal que os contraentes tivessem em mira, mas poderia alcançar objetivos parciais ou secundários ${ }^{813}$. Estes efeitos, ademais, poderiam chegar a apresentar natureza negocial: de uma compra e venda nula não derivaria a válida transmissão da propriedade do bem nem o válido pagamento do preço; contudo, a disponibilidade dos objetos das prestações intercambiadas, para que as partes pleiteassem as respectivas restituições, poderia ser considerada, mais que uma simples contingência fática, um resultado derivado do próprio negócio de compra e venda, conquanto nulo, ou melhor, porque nulo ${ }^{814}$. Nos casos em que o ordenamento jurídico

\footnotetext{
${ }^{811}$ E. BETTI, Teoria generale... cit. (nota 53), p. 409.

${ }^{812}$ E. BETTI, Teoria generale... cit. (nota 53), p. 409, nota 13.

${ }^{813}$ L. RATTIN, Sugli effetti dei negozi nulli, Bolgna, Pàtron, 1983, p. 51.

${ }^{814}$ L. RATTIN, Sugli effetti... cit. (nota 813), p. 61.
} 
respeitasse, ao menos, a eficácia derivada do adimplemento voluntário do negócio nulo, a invalidade seria apenas parcial ${ }^{815}$.

A despeito disso, a explicação da proteção dos direitos de terceiros de boa-fé a partir de uma excepcional validade do negócio simulado (resultante da relatividade ou da inoponibilidade da nulidade) apresenta fragilidades.

Como ressalta Betti, a oponibilidade é um fenômeno pertencente ao campo da ineficácia em sentido estrito ${ }^{816}$. Ela se manifesta nas situações em que uma posição jurídica dos terceiros se mostra incompatível com dada relação negocial pelo fato de os contraentes não terem observado um dever de legalidade que lhes incumbia, como o de publicidade dos atos para os quais a lei a requeresse (e.g. registro de atos societários junto ao órgão competente) $)^{817}$.

Em vista disso, não se mostra sólida a proposição de que a nulidade poderia ser tachada de inoponível. Cogitar da inoponibilidade da nulidade implicaria pressupor que o negócio jurídico, a princípio válido, tornar-se-ia insubsistente por efeito da nulidade. Nessa ordem de ideias, a ineficácia, entendida como efeito da nulidade, não seria oponível aos terceiros de boa-fé. Ocorre, contudo, que a ineficácia do negócio jurídico, assim como a sua inaptidão de integrar o sistema jurídico positivo, não é um efeito da nulidade, mas a própria nulidade, enquanto estado de coisas. Com efeito, falar-se de "efeito da nulidade" não faz sentido, tanto quanto não cabe cogitar-se de "existência da nulidade" e, muito menos, da "validade da nulidade". Desse modo, a tese da inoponibilidade da nulidade mostra-se claramente artificiosa, porquanto o negócio nulo não nasce válido; a rigor, sequer se reveste da juridicidade - eficiência, como diria Pontes de Miranda - necessária à regular produção de consequências jurídicas.

Houvesse, no direito brasileiro, um dispositivo como o artigo $291^{\circ}$ do Código Civil português ${ }^{818}$, seria defensável a aplicação da inoponibilidade da nulidade como ficção

\footnotetext{
${ }^{815}$ L. RATTIN, Sugli effetti... cit. (nota 813), p. 71.

${ }^{816}$ E. BETTI, Teoria generale... cit. (nota 53), p. 457.

${ }^{817}$ E. BETTI, Teoria generale... cit. (nota 53), p. 457.

818 “Artigo $291^{\circ}$ (Inoponibilidade da nulidade e da anulação)

1. A declaração de nulidade ou a anulação do negócio jurídico que respeite a bens imóveis, ou a bens móveis sujeitos a registo, não prejudica os direitos adquiridos sobre os mesmos bens, a título oneroso, por terceiro de boa fé, se o

registo da aquisição for anterior ao
} 
jurídica. Mas, veja-se bem: tratar-se-ia de uma ficção jurídica e, por decorrer do agir criativo do legislador, não caberia censurá-la. Nada obstante, não se identifica, no Código Civil, uma menção sequer à inoponibilidade da nulidade. Nesse cenário, a inoponibilidade deve limitar-se, como bem salientava Betti, aos efeitos da simulação, isto é, à situação jurídica dissimulada ou à ausência de quaisquer efeitos (acaso se trate de simulação absoluta $^{819}$. Tal conclusão, ressalte-se, amolda-se com perfeição à concepção da simulação como programa negocial de caráter instrumental, capaz de elidir o reconhecimento social das posições jurídicas efetivamente ocupadas pelos contraentes.

A compreensão da nulidade como radical aversão entre o ato de autonomia privada e as diretrizes regentes da ordem jurídica também justifica a dificuldade com a qual a doutrina tem lidado com a ideia de nulidade relativa. Para Fedele, um de seus mais sagazes críticos, a nulidade relativa seria tecnicamente inconsistente, pois a nulidade, por definição, deveria acarretar a insubsistência do negócio jurídico perante todo e qualquer sujeito $^{820}$. Já Cariota Ferrara sublinha o grave equívoco em que consistiria relativizar a nulidade com base na legitimidade passiva ${ }^{821}$. Segundo o autor, a nulidade que existisse para um e não para outro seria conceito falso ou absurdo. O ser e o não ser seriam termos contrapostos; o negócio não poderia produzir efeitos, embora estes devessem valer como produzidos para todos, se a parte que sozinha tivesse o direito à pronúncia de nulidade não decidisse requerê-1a ${ }^{822}$.

As dificuldades enfrentadas para aderir às teses da inoponibilidade e da nulidade relativa suscitam a busca de uma via alternativa. Esta, reconheça-se, vem sendo explorada pela doutrina já há algum tempo, com fundamento na teoria da aparência.

Referida teoria desenvolveu-se, sobretudo, graças à ação criativa da jurisprudência, diante de casos em que situações jurídicas aparentes induziam particulares

registo da acção de nulidade ou anulação ou ao registo do acordoentre as partes acerca da invalidade do negócio.

2. Os direitos de terceiro não são, todavia, reconhecidos, se a acção for proposta e registada dentro dos três anos posteriores à conclusão do negócio.

3. É considerado de boa fé o terceiro adquirente que no momento da aquisição desconhecia, sem culpa, o vício do negócio nulo ou anulável".

${ }^{819}$ E. BETTI, Teoria generale... cit. (nota 53), p. 460.

${ }^{820}$ A. FeDELE, La invalidità del negozio giuridico di diritto privato, Torino, Giappichelli, 1983, p. $111 \mathrm{ss}$.

${ }^{821}$ L. CARIOTA Ferrara, Il negozio giuridico... cit. (nota 34), p. 330. No mesmo sentido: F. MeSSINEO, Il contratto in genere cit. (nota 88), p. 494.

${ }^{822}$ L. CARIOTA FERRARA, Il negozio giuridico... cit. (nota 34), p. 330-331. 
a julgamentos equivocados sobre a realidade dos fatos e, por consequência, ao estabelecimento de relações jurídicas levando em consideração esses julgamentos.

Nessa ordem de ideias, Dagot defende que a disciplina da simulação seria um dos casos, previstos legislativamente, que se amoldariam à teoria da aparência. Segundo o artigo 1321 do Código Civil francês, as contre-lettres não seriam eficazes em face de terceiros de boa-fé. Em vista desse comando normativo, os terceiros poderiam, segundo a conveniência dos seus interesses, valer-se da relação jurídica aparente ou da contradeclaração ${ }^{823}$.

O autor narra que parte da doutrina francesa teria pretendido explicar esta solução legal a partir da teoria da "pena privada". A maioria dos autores, contudo, teria adotado a teoria da aparência. A razão, segundo Dagot, estaria com a maioria. A única condição imposta pela lei para a proteção dos interesses dos terceiros seria a boa-fé que seria, ademais, a condição essencial para a incidência de toda a teoria da aparência. Na contramão da previsão legal, a ideia de pena privada implicaria a formação de um juízo de valor sobre o "estado de espírito" dos simuladores, o que, em última instância, significaria negligenciar a posição jurídica ocupada pelos terceiros ${ }^{824}$. Além disso, a ideia de pena privada não permitiria explicar a situação - já admitida pela jurisprudência - em que um terceiro invocasse a aparência do negócio simulado contra outro terceiro. Também não ofereceria um critério seguro para a solução de um conflito entre terceiros, um dos quais buscasse se valer do negócio oculto. Conclui, por fim, Dagot, que "a simulação, em seu primeiro elemento constitutivo, o elemento aparente, se apresenta, portanto, como uma aplicação da teoria da aparência" ${ }^{, 825}$.

Danis-Fatôme relata que outros autores teriam tentado negar a aplicação da teoria da aparência afirmando que, na simulação, a aparência seria criada propositalmente e, adicionalmente, tal aparência não implicaria o erro comum dos terceiros. Todavia, a circunstância de a aparência ter sido criada propositalmente, ou ter surgido por acaso, seria irrelevante para a aplicação da teoria. Em todo caso, estar-se-ia diante de um contratante sendo enganado quanto à realidade do direito de um particular, o qual, por seu turno,

${ }^{823}$ M. DAGOT, La simulation... cit. (nota 50), p. 129.

${ }^{824}$ M. DAGOT, La simulation... cit. (nota 50), p. 130.

${ }^{825}$ M. DAGOT, La simulation... cit. (nota 50), p. 131. 
continuaria a agir como legítimo titular do direito em questão ${ }^{826}$. Para rebater o argumento de que a concretização da simulação não dependeria do erro comum dos terceiros, DanisFatôme destaca que quando os terceiros não incorressem em erro algum - isto é, não fossem enganados pela simulação - já não se mostraria aplicável o artigo 1321 do Código Civil francês; demais disso, a simulação tornaria o erro dos terceiros escusável, na medida em que lhes permitiria valer-se da eficácia do ato aparente ${ }^{827}$.

A teoria da aparência, no âmbito do estudo da simulação, foi também acolhida na Itália. Bianca, por exemplo, afirma que a regra do artigo 1415 do Código Civil italiano ${ }^{828}$ decorre do princípio da aparência, "que não deve entender-se como equivalência entre aparência e realidade, mas, diversamente, no sentido de que quem cria uma situação negocial aparente não pode fazer valer a situação real a prejuízo de terceiros de boa-fé” ${ }^{829}$.

A adoção da teoria da aparência como fundamento dogmático da norma inserta no $\S 2^{\circ}$ do artigo 167 amolda-se à ótica segundo a qual o fenômeno simulatório deve ser captado. Como temos repetido, no decorrer deste estudo, o "negócio aparente" apenas existe enquanto representação ideal suscitada pela ilusão negocial à perspectiva do público. O negócio jurídico existente, em que se consubstancia o arranjo de interesses dos simuladores, é instrumental na medida em que objetiva a disseminação de uma eficácia aparente. Bem por isso, a discussão em torno da nulidade relativa ou da inoponibilidade não se mostra plenamente capaz de explicar como a pura aparência poderia justificar a manutenção das posições jurídicas que os terceiros passassem a assumir com base nela.

A temática da proteção dos terceiros de boa-fé, no contexto da simulação, é impertinente ao plano da validade. Uma coisa é a aparência de vontade, da qual decorre a

\footnotetext{
${ }^{826}$ A. DANis-FATÔME, Apparence et contrat, Paris, LGDJ, 2004, p. 49-50.

${ }^{827}$ A. DANIS-FATÔME, Apparence et contrat cit. (nota 826), p. 50.

828 “Art. 1415. Efeitos da simulação com respeito a terceiros. A simulação não pode ser oposta nem pelas partes contraentes, nem pelos seus subadquirentes ou pelos credores do alienantes simulado, aos terceiros que de boa-fé adquiriram direitos do titular aparente, ressalvados os efeitos da transcrição da demanda de simulação. Os terceiros podem fazer valer a simulação em confronto com as partes, quando esta prejudique os seus direitos". Tradução livre; no original: "Art. 1415 Effetti della simulazione rispetto ai terzi. La simulazione non può essere opposta né dalle parti contraenti, né dagli aventi causa o dai creditori del simulato alienante, ai terzi che in buona fede hanno acquistato diritti dal titolare apparente, salvi gli effetti della trascrizione della domanda di simulazione. I terzi possono far valere la simulazione in confronto delle parti, quando essa pregiudica i loro diritti".

${ }^{829}$ C. M. BIANCA, Diritto Civile cit. (nota 63), p. 706. Em igual direção, G. DE FERRA, I contratti simulati del fallito, Milano, Giuffrè, 1957, p. 4-8.
} 
nulidade do negócio simulado; outra, completamente diferente, é a legitimidade aparente que os terceiros de boa-fé atribuem aos simuladores ${ }^{830}$.

Sendo nulo o negócio simulado, os simuladores não chegam a ocupar as posições jurídicas que, segundo a aparência, deveriam ocupar. $\mathrm{O}$ fato de terceiros de boa-fé assumirem como válida aquela aparência não excepciona a nulidade do negócio simulado. Para que isto ocorresse, seria necessário que a aparência substituísse os elementos do suporte fático que estivessem ocasionando a nulidade. A aparência, porém, por ser um fato jurídico alheio à estrutura negocial, não pode agir sobre o plano da validade; pode, contudo, influenciar a manifestação do negócio simulado no plano da eficácia ${ }^{831}$.

A aparência é um instrumento elástico, capaz de não só penetrar nos campos em que o formalismo jurídico não se aplica, mas também de proporcionar a proteção do interesse dos terceiros sempre que sejam induzidos a erro por uma situação de fato que tenha manifestado como existente uma realidade jurídica inexistente. Ela faz gravitar o suporte fático do negócio jurídico em torno da tutela dos terceiros de boa-fé. De modo que, por exemplo, o efeito liberatório do pagamento ao credor aparente não decorre da legitimação deste último para receber o pagamento, mas da legitimação do devedor para pagar a quem por circunstâncias unívocas parece ser o verdadeiro credor ${ }^{832}$.

Em vista da perpetração da ilusão negocial, a aparência criada assume relevância própria, vinculando-se apenas juridicamente, não logicamente, à boa-fé ${ }^{833}$. Por outras palavras, a ilusão negocial e a boa-fé unem-se, formando um suporte fático complexo ${ }^{834}$, do qual decorre a relevância dos direitos de terceiros de boa-fé em face dos contraentes do negócio simulado. A aparência, associada à boa-fé do terceiro, ao invés de substituir o elemento viciado do suporte fático, exerce uma ação paralisante da ineficácia derivada da nulidade. A boa-fé do terceiro, portanto, ao tomar por efetiva a legitimidade aparente do simulador, é detectada, pela norma, como uma negação da negação. O resultado deste mecanismo técnico é a eficácia do ato de disposição do non dominus; portanto,

\footnotetext{
${ }^{830}$ L. Mengoni, L'acquisto “a non domino”, Milano, Vita e Pensiero, 1949, p. 110-111.

${ }^{831}$ L. MENGONI, L'acquisto “a non domino” cit. (nota 830), p.111.

${ }^{832}$ A. FALZEA, Apparenza cit. (nota 298), p. 690-692.

${ }^{833}$ A. FALZEA, Apparenza cit. (nota 298), p. 693.

${ }^{834}$ A. FALZEA, Apparenza cit. (nota 298), p. 694.
} 
precisamente, e sem rebarbas, aquilo que previu a lei: a preservação do direito do terceiro de boa-fé ${ }^{835}$.

É, pois, esta interação entre a aparência e a boa-fé que o $§ 2^{\circ}$ do artigo 167 eleva à condição de fonte produtiva de efeitos jurídicos, e sobre a qual funda a tutela do público, ali disciplinada.

\section{O requisito da boa-fé}

$\mathrm{O} \S 2^{\circ}$ do artigo 167 estabelece que estão a salvo os direitos dos terceiros de boafé.

Do ponto de vista subjetivo, a boa-fé resume-se à ignorância acerca da não titularidade do simulador ${ }^{836}$. Mengoni observa, com relação a este aspecto, que o ônus da prova recai sobre a parte adversária; isto, pois, no âmbito da teoria da aparência, não é a boa-fé um pressuposto constitutivo do direito, mas a má-fé um fato impeditivo da sua aquisição $^{837}$. A se admitir este ponto de vista, por consequência, conclui-se que a boa-fé a que se refere a norma legal em exame - esta sim, elemento do suporte fático correspondente - deve ser apreendida objetivamente.

Pelo ângulo objetivo, pode-se atestar a boa-fé do terceiro quando demonstrada a confiança na legitimidade aparente, ou seja, quando concretizada a consumação do engano $^{838}$ perante a generalidade dos terceiros ${ }^{839}$.

Compreendida nesse giro dúplice a boa-fé do terceiro, torna-se superável a crítica de Carvalho Fernandes segundo a qual a teoria da aparência seria insuficiente para justificar a tutela dos terceiros. Diz o autor que "[a] aparência que o acto simulado cria é apenas um dos elementos em que se assenta aquela protecção do interesse do terceiro. Para que essa protecção se dê, necessário se torna que o terceiro confie na aparência, o que implica que ele ignore a realidade que o acto simulado encobre" ${ }^{\$ 40}$.

${ }^{835}$ L. MengOni, L'acquisto “a non domino” cit. (nota 830), p. 113.

${ }^{836}$ C. A. Mota PinTo, Teoria Geral... cit.. (nota 435), p. 480.

${ }^{837}$ L. Mengoni, L'acquisto "a non domino" cit. (nota 830), p. 117.

${ }^{838}$ G. MESSINA, La simulazione assoluta cit. (nota 40), p. 95-98.

${ }^{839}$ L. MENGONI, L'acquisto "a non domino" cit. (nota 830), p. 116.

${ }^{840}$ L. A. CARVALHO FERNANDES, Estudos sobre a simulação cit. (nota 735), p. 106. 
O trecho destacado no parágrafo anterior dá a entender que, do modo como interpretada por Carvalho Fernandes, a teoria da aparência seria capaz de conferir tutela ao interesse do terceiro em virtude do simples fato (i.e. fato jurídico em sentido estrito) da legitimidade aparente do simulador. Isto seria correto se fosse considerado tão somente o aspecto subjetivo da boa-fé, que, melhor dizendo, corresponderia à ausência de má-fé, enquanto fato impeditivo da aplicação da tutela da aparência. Contudo, a boa-fé do terceiro corresponde também à confiança que ele deposita na legitimidade aparente; não individualmente, mas como integrante da coletividade de terceiros à qual se destinou a ilusão negocial criada pela simulação. Esta boa-fé objetiva do terceiro é imanente ao contexto da simulação, vale dizer, irradia-se da própria aparência criada. Se assim não fosse, ou seja, se esta boa-fé estivesse excluída, a própria aparência estaria excluída, e, portanto, não caberia cogitar-se nem mesmo da presença da simulação.

Neste particular, uma questão interessante que se coloca diz respeito ao grau de diligência que o terceiro haveria de manter com relação à simulação para mostrar-se digno da proteção prevista em lei. Menezes Cordeiro defende que a simples cognoscibilidade da simulação seria suficiente para afastar a boa-fé do terceiro ${ }^{841}$. Discordando, Carvalho Fernandes sustenta que a má-fé dos simuladores justificaria um tratamento mais favorável aos terceiros, os quais, mesmo que desconhecessem a simulação culposamente, seriam dignos da proteção legal ${ }^{842}$.

Volvendo o olhar para o Código Civil, parece-nos que a culpabilidade de um determinado terceiro quanto ao reconhecimento da simulação não seria suficiente para excluir a boa-fé. Em primeiro lugar, isto decorre da ambivalência valorativa da boa-fé (objetiva/subjetiva) no caso da tutela da confiança do público diante da legitimidade aparente do simulador. Em segundo lugar, isto vem confirmado pelo fato de o legislador brasileiro, de maneira sistemática, ter atribuído primazia à dimensão objetiva da boa-fé, nas diversas normas do Código Civil que se lhe dedicaram; de fato, quando se pretendeu dar destaque ao aspecto subjetivo da boa-fé, ou seja, à cognoscibilidade de determinada circunstância, fez-se expressa referência ao grau de diligência exigido do sujeito (e.g. artigo 138) e à possibilidade concreta de tomar-se conhecimento da situação em questão (e.g. artigos 898 e 1009). Desse modo, se o negócio simulado é capaz de, objetivamente,

${ }^{841}$ A. Menezes Cordeiro, António, Da Boa Fé no Direito Civil, Coimbra, Almedina, 2007, p. 484.

${ }^{842}$ L. A. CARVALHO FERNANDES, Estudos sobre a simulação cit. (nota 735), p. 109. 
enganar a generalidade dos terceiros, mas um terceiro que circunstancialmente poderia não ser enganado o é, por culpa, ainda assim este deveria reputar-se de boa-fé em face dos contraentes do negócio simulado.

\section{Os direitos assegurados aos terceiros de boa-fé}

$\mathrm{O} \S 2^{\circ}$ do artigo 167 ressalva os direitos de terceiros de boa-fé, sem opor qualquer qualificação ou restrição ao objeto da proteção aí estabelecida. Algumas dúvidas, porém, têm ocupado a atenção da doutrina que estudou, de modo geral, a tutela dos interesses de terceiros no âmbito da simulação.

Uma primeira indagação enfrentada pelos autores relaciona-se à necessidade de prejuízo para a concessão, aos terceiros de boa-fé, da tutela legal. Por outras palavras, poderia, o terceiro de boa-fé, buscar amparo na aparência negocial se disto ele extraísse apenas vantagens?

A nosso ver, a resposta afirmativa não seria compatível com a ratio subjacente ao texto legal. $\mathrm{O} \S 2^{\circ}$ do artigo 167 protege os direitos de terceiros de boa-fé. O que explica tal regime jurídico é a necessidade de impedir que a invalidade do negócio simulado ponha em risco as posições jurídicas legítimas assumidas com base na confiança. Entre a má-fé do simulador e a boa-fé do terceiro, deve esta prevalecer de modo a prevenir-se que o primeiro invoque a própria torpeza. Mas isto já não se aplica nos casos em que a preservação da eficácia do "negócio aparente" pudesse levar a um injustificado enriquecimento do terceiro ${ }^{843}$.

Como bem salienta Mota Pinto a propósito do artigo $243^{\circ}$ do Código Civil português $^{844}$, a salvaguarda legal conferida aos terceiros de boa-fé tem como objeto, tão somente, a prevenção de prejuízos injustos. "Em conformidade com o exposto, feita uma venda por 100 e tendo-se declarado simuladamente um preço de 30 , um preferente não

\footnotetext{
${ }^{843}$ L. A. CARVAlHO FERNANDES, Estudos sobre a simulação cit. (nota 735), p. 204-205.

844 “ARTIGO $243^{\circ}$

(Inoponibilidade da simulação a terceiros de boa fé)

1 - A nulidade proveniente da simulação não pode ser arguida pelo simulador contra terceiro de boa fé. 2 - A boa fé consiste na ignorância da simulação ao tempo em que foram constituídos os respectivos direitos. 3 Considera-se sempre de má fé o terceiro que adquiriu o direito posteriormente ao registo da acção de simulação, quando a este haja lugar".
} 
pode invocar a sua qualidade de terceiro de boa-fé para preferir pelo preço declarado; é-lhe oponível a nulidade do negócio simulado, sendo admitido a preferir pelo preço real" ${ }^{\prime 845}$.

Este entendimento tornar-se-ia ainda mais bem fundamentado em vista da formulação de Menezes Cordeiro segundo o qual a conclusão de que a proteção concedida aos terceiros de boa-fé se restringiria aos casos de potencial prejuízo seria justificada pela tutela da confiança. "[A] tutela da confiança só se justifica quando haja um investimento de confiança, isto é: quando o confiante adira à aparência e, nessa base, erga um edifício jurídico e social que não possa ser ignorado sem dano injusto. Ora, o preferente por valor simulado inferior ao real não fez qualquer investimento de confiança. A sua posição não pode invocar a tutela dispensada à aparência, pela boa-fé" ${ }^{846}$.

Diante do exposto, mostra-se mais condizente com as diretrizes regentes do sistema normativo do direito privado brasileiro, as quais incluem, dentre outras, a proteção da boa-fé objetiva e a proibição do abuso de direito, o entendimento de que a tutela dos direitos de terceiros de boa-fé somente pode autorizar a excepcional eficácia da aparência enganadora, perpetrada pelos simuladores, quando isto venha a poupá-los de um dano injusto. Consequentemente, não se mostra adequado admitir que os terceiros de boa-fé possam valer-se da aparência negocial com vistas, unicamente, a obter vantagens que, se prevalecesse a relação jurídica dissimulada, não seriam sustentáveis.

Dificuldades também são enfrentadas no que tange à proteção de supostos direitos de credores quirografários do adquirente simulado. Há ordenamentos jurídicos, como o italiano, que estabelecem regras específicas para a proteção dos interesses dos credores das partes do negócio simulado (artigos 1415 e 1416 do Código Civil italiano ${ }^{847}$ ). Este não é, contudo, o caso do direito brasileiro.

\footnotetext{
${ }^{845}$ C. A. Mota Pinto, Teoria Geral... cit. (nota 435), p. 481

846 Menezes Cordeiro, Tratado de Direito Civil Português, v. I - Parte Geral, t. I, $3^{\text {a }}$ ed., Coimbra, Almedina, 2005, p. 848-850.

847 “Art. 1415. Efeitos da simulação com respeito a terceiros. A simulação não pode ser oposta nem pelas partes contraentes, nem pelos seus subadquirentes ou pelos credores do alienantes simulado, aos terceiros que de boa-fé adquiriram direitos do titular aparente, ressalvados os efeitos da transcrição da demanda de simulação. Os terceiros podem fazer valer a simulação em confronto com as partes, quando esta prejudique os seus direitos". Tradução livre; no original: "Art. 1415 Effetti della simulazione rispetto ai terzi. La simulazione non può essere opposta né dalle parti contraenti, né dagli aventi causa o dai creditori del simulato alienante, ai terzi che in buona fede hanno acquistato diritti dal titolare apparente, salvi gli effetti
} 
O legislador de 2002 certamente levou em consideração o dado, colhido da experiência jurídica, de que uma manifestação comum da simulação seria aquela praticada contra interesses de credores. Nada obstante, optou por estabelecer uma regra única e genérica para a proteção dos direitos de terceiros de boa-fé.

Os credores do adquirente simulado realmente nutririam a expectativa de valer-se da garantia representada pelo patrimônio do devedor, ao qual se teria acrescido um bem em virtude do negócio simulado. Esta garantia poderia sujeitar-se à execução, no caso de inadimplemento por parte do devedor. Fosse possível caracterizar a relação estabelecida entre o credor quirografário e o bem acrescido ao patrimônio do simulado adquirente como um vínculo de natureza jurídica definitivamente constituído - tal qual o que surge em virtude da outorga de uma garantia real, em razão da qual o credor torna-se titular de direito real sobre coisa alheia - não haveria grandes dificuldades para justificar-se a aplicação do $\S 2^{\circ}$ do artigo 167 em tais circunstâncias. Nada obstante, tais credores ostentam, quando muito, uma expectativa de fato quanto a poderem, na eventualidade de futuro descumprimento obrigacional, valer-se de determinado bem para verem seu direito de crédito satisfeito. Não há, aí, portanto, “direito" de terceiro de boa-fé a tutelar ${ }^{848}$.

O curioso a se notar é que, acaso o adquirente simulado alienasse o bem objeto do negócio simulado antes de revelada a simulação e, por conta desta alienação, viesse à tona a sua insolvência, os seus credores quirografários poderiam demandar a anulação do negócio jurídico praticado com fundamento na fraude contra credores configurada. Contudo, anulado o negócio simulado, sendo a nulidade a causa do esvaziamento do patrimônio do adquirente simulado, e ausente, no Código Civil de 2002, uma regra

della trascrizione della domanda di simulazione. I terzi possono far valere la simulazione in confronto delle parti, quando essa pregiudica i loro diritti”.

“Art. 1416. Relações com os credores. A simulação não pode ser oposta pelos contraentes aos credores do titular aparente que de boa-fé concluíram atos de execução sobre bens que foram objeto do contrato simulado. Os credores do alienante simulado podem fazer valer a simulação que prejudique os seus direitos e, no conflito com os credores quirografários do adquirente simulado, preferem a estes, se o seu crédito é anterior ao ato simulado". Tradução livre; no original: "Art. 1416 Rapporti con i creditori. La simulazione non può essere opposta dai contraenti ai creditori del titolare apparente che in buona fede hanno compiuto atti di esecuzione sui beni che furono oggetto del contratto simulato. I creditori del simulato alienante possono far valere la simulazione che pregiudica i loro diritti, e, nel conflitto con i creditori chirografari del simulato acquirente, sono preferiti a questi, se il loro credito è anteriore all'atto simulato".

Sobre o tema, G. GIAMPICCOLO, In tema di tutela del creditore chirografario del simulato acquirente, in Studi in onore di Francesco Santoro-Passarelli, Napoli, Jovene, p. 607-631.

${ }^{848}$ F. SANTORO-PASSARELli, Dottrine... cit. (nota 40), p. 156. Conclusão análoga pode ser sustentada quanto aos herdeiros do simulado adquirente. 
equitativa $^{849}$ como a do artigo 1415 do Código Civil italiano, ou uma regra ampla como a do artigo $243^{\circ}$, número 1 , do Código Civil português ${ }^{850}$, ficaria o credor na incômoda situação de depender da assiduidade do devedor, até porque voluntariamente assumira a condição de credor quirografário.

\section{Conflitos entre terceiros de boa-fé?}

Um tema recorrentemente abordado nos textos relativos à simulação é a possível instauração de conflitos entre terceiros de boa-fé ${ }^{851}$. São examinadas diversas situações em que, concomitantemente, um terceiro pretenderia obter a declaração de nulidade, enquanto a outro importaria a preservação da eficácia atribuída à relação jurídica aparente. Dentre os possíveis conflitos vislumbrados pela doutrina, vale citar os seguintes:

(a) credores dos simuladores: o credor do alienante simulado teria interesse na declaração de nulidade do negócio simulado, ao passo que o credor do adquirente simulado preferiria a sua preservação;

(b) herdeiros dos simuladores: de um lado, o herdeiro do alienante simulado buscaria a desconstituição da ilusão negocial porque dela teria decorrido diminuição da herança; de outro lado, o herdeiro do adquirente simulado pretenderia aproveitar-se da eficácia aparente, porquanto dela resultaria aumento da herança;

(c) subadquirentes dos simuladores: o subadquirente do alienante simulado pleitearia a declaração de nulidade do negócio simulado, enquanto, ao subadquirente do adquirente, interessaria a subsistência dos seus efeitos; e

(d) credor do alienante simulado e subadquirente do adquirente simulado: o primeiro teria interesse na nulidade do negócio simulado, ao passo que o segundo pretenderia a sua validade.

\footnotetext{
${ }^{849}$ F. SANTORO-PASSARELli, Dottrine... cit. (nota 40), p. 156.

${ }^{850}$ L. A. CARVAlHo FERNANDES, Estudos sobre a simulação cit. (nota 735), p. 119-120.

${ }^{851}$ Por exemplo: L. A. CARVAlho Fernandes, Estudos sobre a simulação cit. (nota 735), p. 130 ss.; M. A. Domingues DE ANDRADE, Teoria Geral... cit. (nota 20), p. 208 ss. No Brasil, já sob a vigência do Código Civil de 2002 : H. C. BADINE JúNIOR, Efeitos do Negócio Jurídico Nulo, São Paulo, Saraiva, 2010, p. 51-55.
} 
Antes mesmo de passar ao exame de cada uma dessas situações, deve-se responder uma fundamental pergunta: há, segundo o direito brasileiro, a possibilidade de surgirem tais conflitos? A resposta, em nosso sentir, deve ser identificada numa sutil, mas precisa indicação do legislador.

O $\S 2^{\circ}$ do artigo 167 deve ser lido com atenção. Este dispositivo não confere ampla proteção aos direitos de terceiros de boa-fé; protege, tão somente, os direitos de terceiros de boa-fé "em face dos contraentes do negócio jurídico simulado". O que isto significa? Simplesmente isto: o legislador brasileiro resolveu os potenciais conflitos entre terceiros de boa-fé da maneira mais simples possível, qual seja, excluindo toda a conflituosidade. Eliminou o mal pela raiz: sempre que um terceiro tiver interesse na nulidade, e outro na validade do negócio simulado, prevalece a primeira pretensão. A nulidade se sobrepõe à validade, exceto se a divergência surgir entre um terceiro de boa-fé e os simuladores.

A esta conclusão já chegava Hörster, com base no $\mathrm{n}^{\circ} 1$ do artigo $291^{\circ}$ do Código Civil português ${ }^{852}$. Diz, aquele autor, que diante de dois males, a preservação do negócio simulado, de um lado, com a consequente proteção de terceiros que tivessem confiado na estabilidade aparente; e a declaração de nulidade do negócio simulado, de outro lado, com a resultante desproteção dos terceiros, a lei teria adotado uma solução de compromisso em favor da proteção dos terceiros de boa-fé, restrita, contudo, às estreitas relações entre estes e o simulador ${ }^{853}$. Mais explicitamente, Mota Pinto afirma ${ }^{854}$ :

Apesar das justificadas dúvidas que a questão suscita, tendemos a considerar que a proteção conferida pelo artigo $243^{\circ}$ se restringe às situações em que a nulidade da simulação é invocada pelos simuladores ou por quem ocupe a sua posição (os herdeiros, desde logo, salvo quando intervenham como terceiros). Além da letra da lei, parece que só se

852 “ARTIGO $291^{\circ}$

(Inoponibilidade da nulidade e da anulação)

1. A declaração de nulidade ou a anulação do negócio jurídico que respeite a bens imóveis, ou a bens móveis sujeitos a registo, não prejudica os direitos adquiridos sobre os mesmos bens, a título oneroso, por terceiro de boa fé, se o registo da aquisição for anterior ao registo da acção de nulidade ou anulação ou ao registo do acordo entre as partes acerca da invalidade do negócio.

2. Os direitos de terceiro não são, todavia, reconhecidos, se a acção for proposta e registada dentro dos três anos posteriores à conclusão do negócio.

3. É considerado de boa fé o terceiro adquirente que no momento da aquisição desconhecia, sem culpa, o vício do negócio nulo ou anulável".

${ }^{853}$ H. E. HÖRSTER, A parte Geral... cit. (nota 404), p. 538.

${ }^{854}$ C. A. MOTA PINTO, Teoria Geral... cit. (nota 435), p. 481. 
justificará esta proteção especial quando a nulidade for invocada por quem intencionalmente criou a situação que agora pretende destruir: os simuladores, precisamente. Neste caso, perante uma tão reprovável dos simuladores (e na mesma linha, aliás, das restrições de que eles já sofrem quanto aos meios de prova a utilizar), a proteção dos terceiros é altamente facilitada. Já nos outros casos, porém, quando a nulidade for invocada por terceiros, parece que a proteção do terceiro adquirente somente deverá colher nos termos gerais do art. $291^{\circ}$.

No direito brasileiro não vigora regra semelhante à do artigo $291^{\circ}$ do Código Civil português, o qual disciplina a excepcional inoponibilidade da nulidade. Também não há, entre nós, dispositivo que regule, em geral, a solução de conflitos de interesses, como o faz o $\operatorname{artigo} 335^{\circ}$ do Código Civil português ${ }^{855}$. Nem por isso, todavia, há de se precipitar a dizer que, especificamente no caso de conflitos de terceiros de boa-fé enganados pela simulação, haveria uma lacuna normativa. Muito pelo contrário.

Nos termos do $\S 2^{\circ}$ do artigo 167 , o direito de terceiro de boa-fé é preservado em face dos simuladores, ou seja, quando estes busquem fazer valer a nulidade em prejuízo de posições jurídicas ocupadas por aqueles. Se, diversamente, surge um choque entre direitos de terceiros de boa-fé, sendo tais direitos o de obter a desconstituição do negócio simulado, e o de se amparar na eficácia da relação jurídica aparente, a solução somente pode ser, nos termos dispostos na lei, a que dá prevalência à nulidade.

Em vista das considerações precedente, não se deve pensar que o terceiro de boafé que tivesse o seu direito preterido ficaria totalmente desamparado. Sem dúvidas este poderia pleitear a condenação dos simuladores ao pagamento de indenização, com vistas a recompor os danos que viesse a sofrer em razão da declaração de nulidade do negócio simulado. Esta solução mostra-se plenamente compatível com o direito positivo brasileiro, uma vez que a reparação das perdas e danos não deixa de ser um direito do terceiro de boafé "em face dos contraentes do negócio jurídico simulado". Haveria, in casu, responsabilidade civil extracontratual, à qual deveriam sujeitar-se ambos os simuladores, solidariamente.

\footnotetext{
855 “ARTIGO $335^{\circ}$
}

(Colisão de direitos)

1. Havendo colisão de direitos iguais ou da mesma espécie, devem os titulares ceder na medida do necessário para que todos produzam igualmente o seu efeito, sem maior detrimento para qualquer das partes.

2. Se os direitos forem desiguais ou de espécie diferente, prevalece o que deva considerar-se superior". 


\title{
CONCLUSÕES
}

\author{
Mit Flügeln, die ich mir errungen, \\ In heißem Liebesstreben, \\ Werd'ich entschweben \\ Zum Licht, zu dem kein Aug' gedrungen! \\ Sterben werd' ich, um zu leben! \\ Aufersteh'n, ja aufersteh'n \\ wirst du, mein Herz, in einem $\mathrm{Nu}$ ! \\ Was du geschlagen \\ zu Gott wird es dich tragen! \\ (Gustav Mahler)
}

Diante de tudo o que se expôs no decorrer deste trabalho, concluímos os seguinte:

(a) por meio do negócio simulado, as partes conferem eficaz regulamentação aos seus interesses, ajustando a conjugação de esforços em prol da criação de uma aparência enganadora ; trata-se, pois, de ato de autonomia privada do qual as partes se valem para alcançar um determinado resultado jurídico;

(b) o escopo dos contraentes do negócio simulado consiste, além de explorar o lado negativo da autonomia privada, em determinar a exterioridade de uma operação negocial que a qualquer observador possa parecer produtiva de efeitos conforme o declarado, perpetrando, desse modo, uma incorreta representação da realidade; nesta empreitada, os simuladores definem metas que pretendem implementar mediante condutas logicamente $\mathrm{e}$ finalisticamente articuladas; o negócio simulado assume uma feição instrumental, na medida em que serve como ferramenta à disseminação de um engano;

(c) o negócio simulado, entendido como ato de autonomia privada voltado à criação de uma aparência enganadora, enceta um regulamento de interesses querido e declarado pelas partes (ainda que sigilosamente); desempenha uma bem definida função prático-individual (causa concreta), a qual, captada e disciplinada in abstracto pelo artigo 167, remete a uma causa típica específica (a causa simulandi em sentido estrito); 
(d) a simulação é convencional, ou seja, fruto de uma peculiar convenção; o acordo simulatório, conquanto possua natureza negocial, não é autônomo: consiste no enlace volitivo dos simuladores, ínsito ao negócio simulado;

(e) a compreensão do fenômeno simulatório pressupõe a consideração do ponto de vista do público; a aparência, por óbvio, não surge entre as partes, tornando-se visualizável, apenas, sob a perspectiva dos terceiros; na simulação, divergem os sentidos que as partes e o público atribuem à relação negocial; os simuladores permitem que a generalidade dos terceiros tenha acesso a apenas parte do seu comportamento negocial, e, desse modo, induzem a formação de um inadequado julgamento sobre a realidade do negócio jurídico;

(f) denominamos ilusão negocial a aparência enganadora criada por intermédio do negócio simulado; a criação voluntária da ilusão negocial torna-se possível em vista da consideração, pelas partes e pelos terceiros, respectivamente, de materiais interpretativos mais amplos (os quais aderem com maior intensidade aos fatos históricos e às circunstâncias concretas que subjazem ao estabelecimento da relação jurídica) e mais restritos (declarações e comportamentos dotados de maior aderência ao aspecto formal); o suporte fático ostensivo constitui-se de um conjunto de índices de uma realidade inexistente; tomados em conjunto, tais índices formam um signo cujo sentido isolado contrasta com o sentido global do agir negocial; a característica da simulação, precisamente, é esta dúplice e separada relevância da aparência que ilude e da aparência (que se mantém velada) do real;

(g) a ilusão negocial pode instalar-se por dois modos distintos: a relação jurídica aparente pode expressar-se exclusivamente por meio de circunstâncias fáticas colaterais ou sucessivas à celebração do (presumido) negócio jurídico (e.g. atos de execução de obrigações e comportamento concludente), tal qual ocorre com a simulação da sociedade de fato; ou a relação jurídica aparente pode expressar-se por meio de uma declaração formalizada (e.g. um instrumento escrito, ou uma declaração oral feita perante testemunhas); no primeiro caso, a ilusão negocial surge em razão do complexo comportamental das partes, sendo necessário que os índices de significação criados pelos 
simuladores aludam à eficácia do regulamento de interesses cuja existência se pretende comunicar ao público; no segundo caso, a simples criação da forma negocial (e.g. declaração escrita) é suficiente para despertar a confiança do público, que somente poderia questionar a substância do negócio jurídico acaso se pusessem a investigar a causa concreta para além do disposto na declaração levada a termo;

(h) segundo a opção do nosso legislador, as declarações simuláveis são tanto as dispositivas (negociais, ou de vontade) como as enunciativas ou representativas (de ciência, ou de verdade); em vista disso, a confissão (declaração de ciência; ato não negocial) pode ser simulada, embora por intermédio da falsidade; nada obstante, nem todos os negócios jurídicos podem ser simulados; sobretudo aqueles que se sujeitem a exigência de forma interna não podem ser simulados, pois o conteúdo se confunde com a forma, o que significa que a aparência forçosamente torna-se real (i.e. revestida de um único sentido possível, o que exclui a possibilidade do engano);

(i) o negócio simulado é existente, posto que nulo; ele entra no mundo jurídico, embora seja valorado negativamente pela norma; a estrutura do negócio simulado é perfeita, pois que engloba um complexo regulamento de interesses, querido, declarado, e dotado de causa concreta reconduzível a uma causa típica (a causa simulandi em sentido estrito);

(j) o artigo 167 cria hipótese de nulidade especial; a causa do negócio simulado, portanto, é ilegal, mas não necessariamente ilícita; continua sendo relevante, portanto, diferenciar a simulação inocente da simulação nocente;

(k) a principal consequência da declaração de nulidade do negócio simulado consiste na imposição, aos simuladores, da obrigação de desconstituir os índices de significação criados, mormente quando estes tenham envolvido a transferência, entre si, de bens ou direitos (restituição ao statu quo ante); é bem verdade que nem todos os desdobramentos fáticos do negócio simulado serão desfeitos quando se trate de simulação relativa, pois parte deles pode corresponder, precisamente, ao cumprimento do negócio dissimulado que 
venha a extraverter-se; tratando-se, contudo, de simulação absoluta, a reconstituição da condição de fato dos simuladores deve ser integral;

(1) a nulidade do negócio simulado não é uma sanção aos simuladores, pois, a rigor, acarreta uma situação jurídica idêntica à buscada por meio da simulação (a completa ineficácia interpartes da relação jurídica aparente); desse modo, a nulidade cominada no artigo 167 serve como ferramenta de composição de conflitos intersubjetivos, pois assegura que as partes possam alegar a simulação uma contra a outra (sempre que nutram interesse legítimo), e, ao mesmo tempo, confere ampla proteção à confiança e aos direitos dos terceiros;

(m) os simuladores podem alegar a simulação, um contra o outro, desde que possuam interesse de agir; esta condição também se impõe à legitimidade dos terceiros; o interesse de agir deve considerar-se caracterizado quando a declaração de nulidade ensejar uma utilidade para quem a alega; a nulidade do negócio simulado pode ser alegada a qualquer momento, não se the aplicando qualquer prazo de decadência, e, muito menos, o mais longo prazo prescricional; decadência e prescrição não se confundem;

(n) o negócio dissimulado forma, com o negócio simulado, um fenômeno jurídico unitário; se o legislador viu a necessidade de ressalvar a validade do negócio dissimulado, isto somente pode significar que, na ausência desta ressalva, a nulidade do negócio simulado implicaria a nulidade do negócio dissimulado; o negócio simulado é aquele que possui a aptidão de disseminar a ilusão negocial; sendo relativa a simulação, o conteúdo convencional consubstanciado no regulamento de interesses que notabiliza o negócio jurídico abrange, além da causa simulatória, a causa de outra relação jurídica;

(o) a excepcional validade do negócio simulado decorre da extraversão, por meio do qual a forma aparente se integra com o conteúdo dissimulado; os requisitos de substância e forma necessários à subsistência do negócio dissimulado são aqueles presentes no produto da extraversão, isto é, no fruto da integração antes referida; por conseguinte, o negócio dissimulado (se formal) pode aproveitar-se da forma aparente, e, em contrapartida, a 
substância dissimulado lícita pode ser maculada pelo caráter nocente da simulação;

(p) os terceiros de boa-fé têm os direitos relativos ao negócio simulado protegidos com base na proteção da confiança e na eficácia autônoma da aparência criada pelos simuladores; tal proteção não se presta a conferir vantagens, mas a prevenir danos injustos; assim, o potencial prejuízo do terceiro, ao lado da boa-fé, é um requisito para a excepcional eficácia da relação jurídica aparente; e

(q) no caso de conflito entre terceiros de boa-fé, em que um pretendesse obter a declaração de nulidade do negócio simulado, e outro pleiteasse a eficácia da relação jurídica aparente, deve prevalecer a posição fundada na nulidade do negócio simulado, pois o legislador ressalvou apenas os direitos de terceiros de boa-fé "em face dos contraentes do negócio simulado". 


\section{REFERÊNCIAS}

ABEILle, Jean, De la simulation dans le droit des sociétés, Paris, LGDJ, 1938.

Albaladejo GarcíA, Manuel, La simulación, Madrid, Edisofer, 2005.

Almeida, Carlos Ferreira de, Texto e Enunciado na Teoria do Negócio Jurídico, Coimbra, Almedina, 1992.

Amaral, Francisco, Direito Civil - Introdução, $7^{\mathrm{a}}$ ed., Rio de Janeiro, Renovar, 2008.

Andrade, Manuel A. Domingues de, Teoria Geral da Relação Jurídica, v. II, Coimbra, Almedina, 2003 (reimpressão).

Andrade Filho, Edmar Oliveira, Desconsideração da Personalidade Jurídica no Novo Código Civil, São Paulo, MP, 2005.

ANDRIOLI, Virgilio, Profili processuali della nuova disciplina della simulazione in Studi in onore di Enrico Redenti, v. II, Milano, Giuffrè, 1951.

Anelli, Franco, Simulazione e interposizione in CostanZA, Maria (cur.), Vincenzo Roppo - Trattato del contrato, v. III - Effeti, Milano, Giuffrè, 2006, pp. 560-773.

Arruda Alvim, A Função Social dos Contratos no Novo Código Civil in Revista dos Tribunais 815, São Paulo, 2003, pp. 11 ss.

Ascarelli, Tullio, Corso di diritto commerciale, cap. VII (1962), trad. port. de E. V. Azevedo e Novaes França, A atividade do empresário in Revista de Direito Mercantil, São Paulo, 2003, pp. 132 ss.

, Problemas das Sociedades Anônimas e Direito Comparado (1945), Campinas, Bookseller, 2001.

, Sulla simulazione in materia di società e sulla simulazione di modificazione statutaria (trasformazione di società) in ASCARELLI, Tullio, Studi in Tema di Società, Milano, Giuffrè, 1952, pp. 215-221.

, Teoria Geral dos Títulos de Crédito, 2a ed., São Paulo, Saraiva, 1969.

AURICCHIO, Alberto, La simulazione nel negozio giuridico - Premesse generali, Napoli, Eugenio Jovene, 1957.

Azevedo e Novaes FrançA, Erasmo Valladão, Invalidades das Deliberações de Assembléia das S.A., São Paulo, Malheiros, 1999. 
BADINE JÚnIOR, Hamid Charaf, Efeitos do Negócio Jurídico Nulo, São Paulo, Saraiva, 2010.

Barros Monteiro, Washington de, Curso de Direito Civil, v. 1 - Parte Geral, Curso de Direito Civil, v. 1 - Parte Geral, atual. por A. C. B. M. França Pinto, 44a ed., São Paulo, Saraiva, 2012.

Barros Monteiro Filho, Raphael, et al., Comentários ao Novo Código Civil, v. I - Das Pessoas - Arts. $1^{\circ}$ a 78, Rio de Janeiro, Forense, 2010.

BAudrillard, Jean, Simulacres et simulation (1981), trad. port. de M. J. Costa Pereira, Simulacros e Simulação, Lisboa, Relógio d’Água, 1991.

Beleza dos Santos, José, A Simulação em Direito Civil (1955), 2a ed., São Paulo, Lejus, 1999.

Belvedere, Andrea, Il problema delle definizione nel codice civile, Milano, Giuffrè, 1977.

BETTI, Emilio, Interpretazione della legge e degli atti giuridici (teoria generale e dogmatica), $2^{\mathrm{a}}$ ed., Milano, Giuffré, 1971.

, Teoria generale del negozio giuridico, $3^{\mathrm{a}}$ ed. (1960), Napoli, Edizioni Scientifiche Italiane, 2002.

Bernardes de Mello, Marcos, de, Teoria do Fato Jurídico - Plano da Validade, $12^{\mathrm{a}}$ ed., São Paulo, Saraiva, 2012.

Bevilaqua, Clóvis, Código Civil dos Estados Unidos do Brasil, v. 1, Rio de Janeiro, Francisco Alves, 1916.

, Direito das Obrigações, $5^{\text {a }}$ ed. (1940), Rio de Janeiro, Rio, 1977.

, Teoria Geral do Direito Civil, 2ª ed. (1928), Campinas, Servanda, 2007.

Bianca, Cesare Massimo, Diritto Civile, v. III - Il Contratto, 2a ed. (2000), Milano, Giuffrè, 2007.

BIANCHI, Giorgio, La Simulazione, Padova, CEDAM, 2003.

Bianqui, Pedro Henrique Torres, Desconsideração da personalidade jurídica no processo civil, São Paulo, Saraiva, 2011.

Bierwagen, Mônica Yoshizato, Princípios e Regras de Interpretação dos Contratos no Novo Código Civil, $3^{\mathrm{a}}$ ed., São Paulo, Saraiva, 2007.

BobBIo, Norberto, Il positivismo giuridico - Lezioni di filosofia del diritto, 1996, trad. port. de M. Pugliesi, E. Bini e C. Rodrigues, O Positivismo Jurídico - Lições de Filosofia do Direito, São Paulo, Ícone, 2006. 
, Teoria della norma giuridica (1993), trad. port. de F. Pavan Baptista e A. Bueno Sudatti, Teoria da Norma Jurídica, $2^{\mathrm{a}}$ ed., São Paulo, Edipro, 2003.

Bodin de Moraes, Maria Celina, A Causa dos Contratos in Revista Trimestral de Direito Civil, Rio de Janeiro, v. 21, 2005, pp. 95-119.

Bonnet, David, Cause et condition dans les actes juridiques, Paris, LGDJ, 2005.

Boulos, Daniel M., Abuso do Direito no novo Código Civil, São Paulo, Método, 2006.

Branco, Gerson Luiz Carlos, Função Social dos Contratos - interpretação à luz do Código Civil, São Paulo, Saraiva, 2009.

BRIGHT, Susan, Avoiding tenancy legislation: Sham and contracting out revisited in The Cambridge Law Journal, n. 61, Cambridge, 2002, pp. 146-168.

Bueno De Godoy, Claudio Luiz Função Social do Contrato, $4^{\mathrm{a}}$ ed., São Paulo, Saraiva, 2012 .

Bulhões Carvalho, Francisco Pereira de, Falhas do Anteprojeto de Código Civil, $2^{\mathrm{a}}$ ed., Rio de Janeiro, 1974.

1981. , Sistema de Nulidades dos Atos Jurídicos, $2^{\mathrm{a}}$ ed., Rio de Janeiro, Forense,

Butera, Antonio, Della simulazione nei negozi giuridici e degli atti "in fraudem legis", Torino, UTET, 1936.

CAenegem, R. C. van, Introduction historique au droit privé, 1988, trad. port. de Carlos Eduardo Lima Machado, Uma Introdução Histórica ao Direito Privado, $2^{\mathrm{a}}$ ed., São Paulo, Martins Fontes, 1999.

Cagnetta, Luigi, Simulazione (verbete) in Digesto italiano, v. 21, Torino, UTET, 1902, pp. 411-449.

CAhali, Yussef Said, Prescrição e Decadência, $2^{\mathrm{a}}$ ed., São Paulo, Revista dos Tribunais, 2012

CÁmARA, Héctor, Simulación en los actos jurídicos, Buenos Aires, Depalma, 1944.

Carcaba Fernandez, Maria, La simulación en los negocios jurídicos, Barcelona, Bosch, 1986.

CARIOTA FERrara, Luigi, I negozi fiduciari - trasferimento cessione e girata a scopo di mandato e di garanzia. Processo fuiduciario (1933), Padova, CEDAM, 1978. , Il negozio giuridico nel diritto privato italiano, Napoli, Morano, 1949. 
CARnelutti, Francesco, Sistema del diritto processuale civile, v. II, Podova, CEDAM, 1938 .

, Teoria del falso, Padova, CEDAM, 1935.

, Teoria generale del Diritto (1951), trad. port. de A. C. Ferreira, Teoria Geral do Direito, São Paulo, LEJUS, 1999.

CARRESI, Franco, Apparenza e realtà del contratto in Rivista trimestrale di diritto e procedura civile, Milano, 1963, pp. 479-500.

, Il contratto, t. 1, Milano, Giuffrè, 1987.

CARVAlho Fernandes, Luís A., Estudos sobre a simulação, Lisboa, Quid Juris, 2004.

Carvalhosa, Modesto, Comentários à Lei de Sociedades Anônimas, vol. 2, $4^{\mathrm{a}}$ ed., São Paulo, Saraiva, 2008.

Casella, Mario, Simulazione (diritto privato) (verbete) in Enciclopedia del diritto, v. XLII, Milano, Giuffrè, 1990, pp. 593-615.

Castanheira Neves, António, Metodologia jurídica: problemas fundamentais, Coimbra, Coimbra, 1993.

CERONI, Cristina, Autonomia privata e simulazione, Padova, CEDAM, 1990.

Chaves, Antônio, Tratado de Direito Civil, v. I - Parte Geral, t. II, $3^{\text {a }}$ ed., São Paulo, Revista dos Tribunais, 1982.

CiOfFI, Carmine B. N., Classe, concetto e tipo nel percorso per l'individuazione del diritto applicabile ai contratti atipici, Torino, Giappichelli, 2005.

CiPriAni, Nicola, La simulazione di effeti giuridici. Appunti sulla fattispecie, 2012, disponível em $<$ http://www.giurisprudenza.unisannio.it $>$.

Coderch, Pablo Salvador, SÁnchez, Jesús Maria Silva, Simulación e deberes de veracidad - Derecho civil e derecho penal: dos estudios de dogmática jurídica, Madrid, Civitas, 1999.

Colmet-DaÂge, Felix, Des Contre-Lettres, Paris, M. Giard \& E. Brière, 1913.

Comparato, Fábio Konder, Salomão Filho, Calixto, O Poder de Controle na Sociedade Anônima, $4^{\mathrm{a}}$ ed., Rio de Janeiro, Forense, 2005.

Conaglen, Matthew, Sham Trusts in The Cambridge Law Journal, n. 67, Cambridge, 2008, pp. 176-207. 
CONTE, Giuseppe, La simulazione del matrimonio nella teoria del negozio giuridico, Padova, CEDAM, 1999.

CorrêA de Oliveira, José Lamartine, A Dupla Crise da Pessoa Jurídica, São Paulo, Saraiva, 1979.

CorreIA, António Arruda Ferrer, Sociedades fictícias e unipessoais, Coimbra, Atlântida, 1948.

CORTÉs, Hernan, La simulación como vicio jurídico, Buenos Aires, Araujo, 1939.

Couto Silva, Alexandre, Desconsideração da Personalidade Jurídica in Revista dos Tribunais 780, São Paulo, 2000, pp. 47 ss.

Coviello, Nicola, Manuale di diritto civile italiano - Parte generale, $3^{\mathrm{a}}$ ed., Milano, Società Editrice Libraria, 1924.

CRICENTI, Giuseppe, Frode alla lege, 2a ed., Milano, Giuffrè, 2008.

DAGOT, Michel, La simulation en droit privé, Paris, LGDJ, 1965.

Danis-Fatôme, Anne, Apparence et contrat, Paris, LGDJ, 2004.

Dantas, San Tiago, Programa de Direito Civil - Aulas Proferidas na Faculdade Nacional de Direito, Rio de Janeiro, Rio, 1979.

DANZ, Erich, Die Auslegung der Rechtsgeschäfte: Zugleich ein Beitrag zur Rechts- und Thatfrage (1897), trad. esp. de W. Roces, La interpretacion de los negocios jurídicos Estudio sobre la cuestion de derecho e la cuestion de hecho, Madrid, Victoriano Suarez, 1926.

DE FERRA, Giampaolo, I contratti simulati del fallito, Milano, Giuffrè, 1957.

DeBoISSY, Florence, La simulation en droit fiscal, Paris, LGDJ, 1997.

Del Bono, Fabrizio, Dichiarazione riproduttiva - Contributo alla dottrina del documento contrattuale, Milano, Giuffrè, 1948.

Del Nero, João Alberto Schützer, Conversão Substancial do Negócio Jurídico, Rio de Janeiro, Renovar, 2001.

Delgado, Mário Luiz, Codificação Descodificação Recodificação do direito civil brasileiro, São Paulo, Saraiva, 2011.

DIENER, Maria Cristina, Il contratto in generale - Manuale e applicazioni pratiche dalle lezioni di Guido Capozzi, Milano, Giuffrè, 2002. 
Di MARZIO, Fabrizio, Interposizione reale di persona, simulazione, frode alla lege nei contratti in Giustizia civile, Milano, v. LI, Ottobre, 2001, pp. 422-456. , La nullità del contratto, Padova, CEDAM, 1999.

Distaso, Nicola, La simulazione dei negozi giuridici, Torino, UTET, 1960.

DuBoIs-De LuZY, Agnès, Interposition de personne, Paris, LGDJ, 2010.

Dumont-Kisliakoff, Nadia, La simulation en droit romain, Paris, Cujas, 1970.

ENGISCH, Karl, Einführung in das Juristische Denken, 1983, trad. port. de J. Baptista Machado, Introdução ao Pensamento Jurídico, $10^{\mathrm{a}}$ ed., Lisboa, Calouste Gulbenkian, 2008 .

EnnecCerus, Luwig, NipPerdey, Hans Carl, Allgemeiner Teil des Bürgerlichen Rechts, trad. esp. de Blas Péres González e José Alguer, Derecho Civil (Parte General), v. II, Primeira Parte, Barcelona, 1981.

Espínola, Eduardo, Manual do Código Civil Brasileiro, v. III - Parte Geral - Dos Factos Jurídicos, Parte 1, Rio de Janeiro, Jacintho Ribeiro dos Santos, 1923.

FAlzEA, Angelo, Apparenza in Enciclopedia del diritto, v. II, Milano, Giuffrè, 1958, pp. 682-701.

, L'atto negoziale nel sistema dei comportamenti giuridici in Rivista di diritto civile, Padova, $1^{\mathrm{a}}$ parte, 1996, pp. 1-55.

FEDELE, Alfredo, La invalidità del negozio giuridico di diritto privato, Torino, Giappichelli, 1983.

Ferrara, Francesco, Della simulazione dei negozi giuridici, 1922, trad. port. de A. Bossa, A Simulação dos Negócios Jurídicos, São Paulo, Saraiva, 1939.

Ferraz Junior, Tércio Sampaio, Introdução ao estudo do direito: técnica, decisão, dominação, $4^{\mathrm{a}}$ ed. São Paulo, Atlas, 2003.

, Simulação e negócio jurídico indireto: no direito tributário e à luz do novo Código civil in Revista Fórum de Direito Tributário, v. 48, 2010, pp. 9-26.

Ferreira, Durval, Negócio Jurídico Condicional, Coimbra, Almedina, 1998.

FERRI, Giovanni B., Causa e tipo nella teoria del negozio giuridico, Milano Giuffrè, 1966. , Il Negozio Giuridico, 2a ed., Padova, CEDAM, 2004.

Flavian, C. L., Des Contre-Lettres, Paris, Sirey, 1929. 
FLuME, Werner, Allgemeiner Teil des Bürgerlichen Rechts. Zweiter Band, Das Rechtsgeschäft. Vierte, unveränderte Auflage Enzyklopädie der Rechts-und Staatswissenschaft, 1992, trad. esp. de J. M. M. González e E. G. Calle, El negocio jurídico, Madrid, Fundación Cultural Del Notariado,1998.

Freud, Sigmund, Die Zukunft einer Illusion (1927), trad. port. de J. Salomão (dir.), O Futuro de Uma Ilusão in Edição Standard Brasileira das Obras Psicológicas Completas de Sigmund Freud, v. XXI, São Paulo, Imago, 2006, pp. 15-63.

FurgiUele, Giovanni, Della simulazione di effetti negoziali, Padova, CEDAM, 1992.

Furtado, Jorge Henrique da Cruz Pinto, Deliberações de Sociedades Comerciais, Coimbra, Almedina, 2005, p. 506.

GABrielli, Enrico, Il contratto e le sue classificazioni in Rescigno, Pietro, GABRIELli, Enrico (cur.), Tratatto dei contratti, t. I - I contratti in generale, $2^{\mathrm{a}}$ ed., Torino, UTET, 2008 .

GADAMER, Hans-Georg, Wahrheit und methode, 1960, trad. port. de F. P. Meurer, Verdade e Método, v.1, 12ª ed., Petrópolis, Vozes, 2012.

, Wahrheit und methode, 1986/1993, trad. port. de E. P. Giachini, Verdade e Método, v.2, 6 ed., Petrópolis, Vozes, 2011.

Gagliano, Pablo Stolze, Pamplona Filho, Rodolfo, Novo Curso de Direito Civil, v. 1 Parte Geral, 14a ed., São Paulo, Saraiva, 2012.

GaIno, Itamar, A Simulação dos Negócios Jurídicos, 2ª ed., São Paulo, Saraiva, 2012.

Galgano, Francesco, Della simulazione in AaVv., Commentario del Codice Civile Scialoja-Branca - A cura di Francesco Galgano, Libro Quarto - Delle obbligazioni - Art. 1421, Bologna - Roma, Zanichelli - Del Foro Italiano, 1998. , Il negozio giuridico, 2a ed., Milano, Giuffrè, 2002.

Garcez, Martinho, Nulidades dos Actos Jurídicos, $2^{\mathrm{a}}$ ed., v. 1, Rio de Janeiro, Jacintho Ribeiro dos Santos, 1910.

García MÁynez, Eduardo, Introducción a la Lógica Jurídica, Ciudad de México, Fondo de Cultura Económica, 1951, pp. 201-202

GeNTILI, Aurelio, Il contratto simulato - Teorie della simulazione e analisi del linguaggio, Milano, Giuffrè, 1982.

, Simulazione in Bessone, Mario (dir.), Trattato di diritto privato, t. V - Il contratto in generale, Torino, Giappichelli, 2002, pp. 469-697. 
, Simulazione dei negozio giuridi in Digesto delle Discipline Privatistiche Sezione Civile, v. XVIII, Torino, UTET, 1998, pp. 511-524.

GERI, Lina Bigliazzi, Appunti in tema di simulazione del testamento in Rivista trimestrale di diritto e procedura civile, Milano, 1962, pp. 1274-1290.

GHESTIN, Jacques, Causa de l'engagement et validité du contrat, Paris, LGDJ, 2006.

GiAmPiCCOLO, Giorgio, In tema di tutela del creditore chirografario del simulato acquirente, in Studi in onore di Francesco Santoro-Passarelli, Napoli, Jovene, pp. 607631.

, La dichiarazione recettizia (1959), Napoli, Edizioni Scientifiche Italiane, 2011.

Giorgianni, Michele, Il negozio di accertamento, Milano, Giuffrè, 1939.

Gomes, Orlando, Introdução ao Direito Civil, 6a ed., Rio de Janeiro, Forense, 1979.

Goodman, Nelson, Languages of Art, 2a ed., Indianapolis, Hackett, 1976.

Gonçalves, Carlos Roberto, Direito Civil Brasileiro, v. 1 - Parte Geral, São Paulo, $10^{\mathrm{a}}$ ed., 2012.

Gorla, Gino, Il Contratto, v. I - Lineamenti generali, Milano, Giuffrè, 1954.

GRAU, Eros Roberto, Ensaio e discurso sobre a interpretação/aplicação do direito, $5^{\mathrm{a}}$ ed., São Paulo, Malheiros, 2009.

GRECO, Paolo, Le società di "comodo"e il negozio indiretto in Rivista del diritto commerciale e del diritto generale delle obbligazioni, Milano, v. XXX, 1ª parte, 1932, pp. 757-808.

Hegel, Gerog Wilhelm Friedrich, Wissenschaft der Logik (1816), trad. port. de M. A. Werle, Ciência da Lógica (excertos), São Paulo, Barcarolla, 2011.

Hörster, Heinrich Ewald, A Parte Geral do Código Civil Português - Teoria Geral do Direito Civil, Coimbra, Almedina, 1992.

Hume, David, A Treatise of Human Nature (1739), trad. port. de D. Danowiski, Tratado da Natureza Humana - Uma tentativa de introduzir o método experimental de raciocínio nos assuntos morais, $2^{\mathrm{a}}$ ed., São Paulo, UNESP, 2009.

IRTI, Natalino, Letture bettiane sul negozio giuridico, Milano, Giuffrè, 1991.

Josserand, Louis, De l'esprit des droits et leur relativitè - Théorie dite de l'abus des droits (1939), $2^{\mathrm{a}}$ ed., Paris, Dalloz, 2006. 
Junqueira de Azevedo, Antônio, Negócio Jurídico - Existência, Validade e Eficácia, $4^{\mathrm{a}}$ ed., São Paulo, Saraiva, 2010.

, Negócio Jurídico e Declaração Negocial (Noções gerais e formação da declaração negocial), Tese (Titularidade) - Faculdade de Direito da Universidade de São Paulo, São Paulo, 1986.

KALINOWSKI, Georges, La logique des normes (1972), trad. esp. de J. R. Capella, Logica del discurso normativo, Madrid, Tecnos, 1975.

Kallimopoulos, Von Georgios D., Die Simulation im bürgerlichen Recht - Eine rechtsdogmatische Untersuchung, München, Verlag, 1966.

Kant, Imannuel, Grundlegung zur Metaphysik der Sitten, trad. port. de G. A. Almeida, Fundamentação Metafísica dos Costumes, São Paulo, Discurso/Barcarolla, 2009.

, Kritik der reinen Vernunft (2 $2^{\mathrm{a}}$ ed., 1787), trad. port. de V. Rohden e U. B. Moosburger, Crítica da Razão Pura, São Paulo, Nova Cultural, 1999, p. 231.

, Logik - Ein Handbuch zu Vorlesungen, trad. port. de F. Castilho, Manual dos cursos de Lógica Geral, 2a ed., Campinas, Unicamp, 2002.

, Versuch den Begriff der negativen Grössen in die Weltweisheit eizuführen, 1763, trad. port. de Jair Barboza, Ensaio para introduzir a noção de grandezas negativas em filosofia in Ensaios pré-críticos, São Paulo, UNESP, 2005.

Kaufmann, Arthur, Hassemer, Winfried (orgs.), Einfürung in Rechtsphilosophie und Rechtstheorie der Gegenwart, 1994, trad. por. de M. Keel - M. S. Oliveira, Introdução à Filosofia do Direito e à Teoria do Direito Contemporâneas, Lisboa, Calouste Gulbenkian, 2002.

Kelsen, Hans, Allgemeine Theorie der Normen (1979), trad. port. de J. F. Duarte, Teoria Geral das Normas, Porto Alegre, Sergio Antonio Fabris, 1986.

, Reine Rechslehre, 1960, trad. port. de João Baptista Machado, Teoria Pura

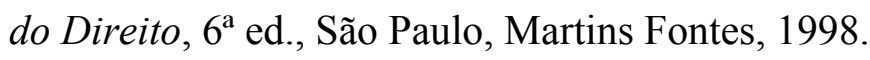

Koury, Suzy Elizabeth Cavalcante, A Desconsideração da Personalidade Jurídica (disregard doctrine) e os Grupos de Empresas, Rio de Janeiro, Forense, 1993.

LA PORTA, Ubaldo, Il problema della causa del contratto - I. La causa ed il trasferimento dei dirrito, Torino, Giapicchelli, 2000.

LARENZ, Karl, Allgeimeiner Teil des deutschen Bürgerlichen Rechts, 1975, trad. esp. de M. Izquierdo y Macías-Picavea, Derecho Civil-Parte General, Madrid, EDERSA, 1978. 
LARENZ, Karl, Methodenlehre der Rechtswissenschaft, 1991, trad. port. de José Lamego, Metodologia da Ciência do Direito, $5^{\mathrm{a}}$ ed., Lisboa, Calouste Gulbenkian, 2009.

Lehman, Heinrich, Allgemeiner Teil des Bürgerlichen Gesetzbuches, 1922, trad. esp. de J. M. Navas, Parte General, v. 1, Madrid, Revista de Derecho Privado, 1956.

LIPARI, Nicolò, Il negozio fiduciario, Milano, Giuffrè, 1971.

LisboA, Roberto Senise, Manual de Direito Civil, v. 1 - Teoria Geral do Direito Civil, $6^{\mathrm{a}}$ ed., São Paulo, Saraiva, 2010.

Luminoso, Angelo, Il mutuo dissenso, Milano, Giuffrè, 1980.

BAPTISTA MACHADO, João, Introdução ao direito e ao discurso legitimador, Coimbra, Almedina, 1983.

Majello, Ugo, Il contratto simulato: aspetti funzionali e strutturali in Rivista di Diritto Civile, Padova, n. 5, Settembre-Ottobre, 1995, pp. 641-656.

MARANI, Francesco, La simulazione negli atti unilaterali, Padova, CEDAM, 1971.

MARCHI, Eduardo C. Silveira, Guia de metodologia jurídica, 2a ed., São Paulo: Saraiva, 2009.

Marino, Francisco Paulo De Crescenzo, Contratos coligados no direito brasileiro, São Paulo, Saraiva, 2009.

, Interpretação e Integração do Negócio Jurídico, São Paulo, Saraiva, 2011.

Martins-Costa, Judith, A Boa-Fé no Direito Privado - sistema e tópica no processo obrigacional, São Paulo, Revista dos Tribunais, 1999.

, Reflexões sobre o Principio da Função Social do Contrato in Revista Direito GV, v. 1, n.1, São Paulo, maio-2005, pp. 41-66.

, Branco, Gerson, Diretrizes Teóricas do Novo Código Civil Brasileiro, São Paulo, Saraiva, 2002.

Martins, Fran, Títulos de Crédito, 15ª ed., Rio de Janeiro, Forense, 2010.

Mattietto, Leonardo, Invalidade dos atos e negócios jurídicos in TePedino, Gustavo, (coord.), A Parte Geral do Código Civil - Estudos e Perspectivas do Direito Civil Constitucional, Rio de Janeiro, Renovar, 2007, pp. 325-360.

, Negócio jurídico simulado (notas ao art. 167 do Código Civil) in Delgado, Mario Luiz, Alves, Jones Figueirêdo (coords.), Questões Controvertidas Parte Geral do Código Civil, Série Grandes Temas de Direito Privado - v. 6, São Paulo, Método, 2007, pp. 466-480. 
MaZZARESE, Tecla, Logica deontica e linguaggio giuridico, Padova, CEDAM, 1989.

Menezes Cordeiro, António, Da Boa Fé no Direito Civil, Coimbra, Almedina, 2007. , Tratado de Direito Civil, v. V, Coimbra, Almedina, 2011. , Tratado de Direito Civil Português, v. I - Parte Geral, t. I, $3^{\mathrm{a}}$ ed., Coimbra, Almedina, 2011.

Mengoni, Luigi, L'acquisto “a non domino”, Milano, Vita e Pensiero, 1949.

Messina, Giuseppe, La simulazione assoluta in Scritti giuridici (1907-1908), v. V, Milano, Giuffrè, 1948, pp. 69.141.

Messineo, Francesco, Il contratto in genere, t. 2º, Milano, Giuffrè, 1972.

Mirabelli, Giuseppe, Dei contratti in generale, 2a ed., Torino, UTET, 1967. , L'atto non negoziale nel diritto privato italiano, Napoli, Eugenio Jovene, 1955.

Miranda, Custódio da Piedade Ubaldino, A Simulação no Direito Civil Brasileiro, São Paulo, Saraiva, 1980.

, Comentários ao Código Civil, v. 5 - Dos Contratos em Geral (Arts. 421 a 480), São Paulo, Saraiva, 2013. , Teoria Geral do Negócio Jurídico, 2ª ed., São Paulo, Atlas, 2009. , Interpretação e Integração dos Negócios Jurídicos, São Paulo, Revista dos Tribunais, 1989.

MONTECCHIARI, Tiziana, La simulazione del contratto, Milano, Giuffrè, 1999.

Moreira Alves, José Carlos, A Parte Geral do Projeto de Código Civil (Subsídios Históricos para o Novo Código Civil Brasileiro), 2a ed., São Paulo, Saraiva, 2003.

Morello, Umberto, Frode alla legge, Milano, Giuffrè, 1969.

Moschella, Raffaele, Contributo alla teoria dell'apparenza giuridica, Milano, Giuffrè, 1973.

Mosset ItUrRaspe, Jorge, Contratos Simulados y Fraudulentos, tt. I-II, Santa Fe, Rubinzal-Culzoni, 2008.

Mota Pinto, Carlos Alberto da, Teoria Geral do Direito Civil, atual. por A. Pinto Monteiro, e P. Mota Pinto, $4^{\mathrm{a}}$ ed., Coimbra, 2005. 
Nanni, Giovanni Ettore, Enriquecimento Sem Causa, 3ª ed., São Paulo, Saraiva, 2012.

NARDI, Sandro, Frode alla legge e collegamento negoziale, Milano, Giuffrè, 2006.

NERY JúNIOR, Nelson, Vícios do Ato Jurídico e Reserva Mental, São Paulo, Saraiva, 1983.

NOBRE JÚNIOR, Edílson, Simulação e sua argüição pelos simuladores in Revista da Escola de Magistratura Federal da $5^{a}$ Região, n. 18, Recife, 2008, pp. 11-26.

NuTi, Giuseppe Attilio, La simulazione del contratto nel sistema del diritto civile, Milano, Giuffrè, 1986.

Oliveira Ascenção, José de, Direito Civil - Teoria Geral, Direito Civil - Teoria Geral, v. 3 - Relações e Situações Jurídicas, 2a ed., São Paulo, Saraiva, 2010.

Pais de Vasconcelos, Pedro, Contratos Atípicos, Coimbra, Almedina, 1995. , Teoria Geral do Direito Civil, $6^{\mathrm{a}}$ ed., Coimbra, Almedina, 2010.

PARENTE, Ferdinando, Il ruolo della simulazione nel sistema delle patologie matrimoniali in Rassegna di diritto civile, Napoli, n. 4, Dicembre, 2006, pp. 1093-1122.

Peccenini, Flavio, Della nullità del contratto in AaVv., Commentario del Codice Civile Scialoja-Branca - A cura di Francesco Galgano, Libro Quarto - Delle obbligazioni - Art. 1421, Bologna - Roma, Zanichelli - Del Foro Italiano, 1998.

PelliCANÒ, Aldo, Il problema della simulazione nei contratti, Padova, CEDAM, 1988.

Pinto Duarte, Rui, Tipicidade e Atipicidade dos Contratos, Coimbra, Almedina, 2000.

Plasman, L. C., Des Contre-Lettres, Paris, Librarie de la Cour de Cassation, 1822.

Platão, O Sofista, trad. port. de J. D. Rodrigues, UFB, 1980 (disponível em $<$ http://www.ebooksbrasil.org/eLibris/sofista.html $>$.

Pontes de Miranda, Francisco Cavalcanti, Tratado de Direito Privado, v. 3, atual. por M. Bernardes de Melo e Marcos Ehrhardt Jr., São Paulo, Revista dos Tribunais, 2012.

, Tratado de Direito Privado, v. 3, atual. por M. Bernardes de Melo e Marcos Ehrhardt Jr., São Paulo, Revista dos Tribunais, 2012.

, Tratado de Direito Privado, v. 49, atual. por A. A. Gonçalves Neto, São Paulo, Revista dos Tribunais, 2012.

, Tratado de Direito Privado, v. 50, atual. por A. A. Gonçalves Neto, São Paulo, Revista dos Tribunais, 2012. 
PestalozzA, Filippo, La simulazione nei negozi giuridici, Milano, Società Editrice Libraria, 1919.

Pugliatti, Salvatore, La simulazione dei negozi giuridici unilaterali in Diritto civile Metodo - Teoria - Pratica, Milano, Guffrè, 1951, pp. 539-585.

Pugliese, Giovanni, La simulazione nei negozi giuridici - Studio di diritto romano, Padova, CEDAM, 1938.

Pugliese, Giuseppe, La prescrizione nel diritto civile, Parte Seconda - La prescrizione estintiva, $4^{\mathrm{a}}$ ed., Torino, UTET, 1924.

Ramalhete, Clóvis, Sistema de Legalidade na "Desconsideração da Personalidade Jurídica" in Revista dos Tribunais 586, São Paulo, 1984, pp. 9 ss.

RÁo, Vicente, Ato Jurídico, 4ª ed., São Paulo, Revista dos Tribunais, 1997.

RATtin, Livio, Sugli effetti dei negozi nulli, Bolgna, Pàtron, 1983.

Reale, Miguel, Direito Natural/Direito Positivo, São Paulo, 1984.

, Filosofia do direito, São Paulo, Saraiva, 2002.

, História do Novo Código Civil, São Paulo, Revista dos Tribunais, 2005.

, Nova Fase do Direito Moderno, 2a ed., São Paulo, Saraiva, 1998.

, O Direito como Experiência (Introdução à Epistemologia Jurídica), São

Paulo, Saraiva, 1968.

, Verdade e Conjetura, São Paulo, Nova Fronteira, 1983.

REQUIÃO, Rubens, Abuso de direito e fraude através da personalidade jurídica in Revista dos Tribunais 416, São Paulo, 1969, pp. 12 ss.

Rodrigues, Silvio, Curso de Direito Civil, v. 1 - Parte Geral, 32a ed., São Paulo, Saraiva, 2002.

Romano, Salvatore, Contributo esegetico allo studio della simulazione (L'art. 1414 c.c.) in Rivista trimestrale di diritto e procedura civile, Milano, 1954, pp. 15-61.

ed., Napoli, Morano, s.d.

, Ordinamento sistematico del diritto privato, v. II - L'azione - Il potere, $3^{\mathrm{a}}$

Roppo, Enzo, Il contratto, trad. port. de A. Coimbra e M. Gomes, O Contrato, Coimbra, Almedina, 2009. 
Rosa JR., Luiz Emygdio Franco da, Títulos de Crédito, 5a ed., Rio de Janeiro, Renovar, 2007.

Ross, Alf, Directives and Norms, trad. esp. de J. S.-P. Hierro, Lógica de las normas, Madrid, Tecnos, 1971.

, On law and justice (1958), trad. port. de E. Bini, Direito e Justiça, São Paulo, Edipro, 2003.

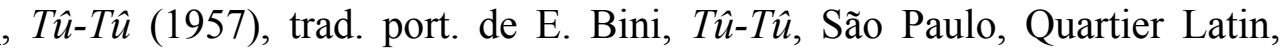
2004, pp. 13-14.

RouBIER, Paul, Droits subjectifs et situations juridiques (1963), Paris, Dalloz, 2005.

RuBINO, Domenico, Il negozio giuridico indiretto, 1937, trad. esp. de L. Rodriguez-Arias, El negocio jurídico indirecto, Madrid, Revista de Derecho Privado, 1953.

SACCO, Rodolfo, Simulazione (verbete) in Enciclopedia giuridica, v. XXXIII, Roma, Istituto della Enciclopedia Italiana, 1992, pp. 1-11.

, De Nova, Giorgio, Il contratto, t. 1, $3^{\mathrm{a}}$ ed., Torino, UTET, 2004.

SAlomão Filho, Calixto, A Sociedade Unipessoal, São Paulo, Malheiros, 1995. , Função Social - Primeiras Anotações in Revista dos Tribunais 823, São Paulo, 2004, pp. 67 ss.

, O Novo Direito Societário, $4^{\mathrm{a}}$ ed., São Paulo, Malheiros, 2011.

SANTA MARIA, Luigi, Società e simulazione, società e comunione di godimento in Rivista trimestrale di diritto e procedura civile, Milano, n.1, Marzo, 1995, pp. 205-245.

Santoro-Passarelli, Francesco, Dottrine generali del diritto civile, 9 $9^{\mathrm{a}}$ ed. (1966), Napoli, Eugenio Jovene, 1983.

, L'autonomia privata nel diritto di famiglia in SANTORO-PASSARELLI, Francesco, Saggi di diritto civile, Napoli, Eugenio Jovene, 1961, pp. 381-388.

SAntos Cifuentes, Negocio jurídico, 2ª ed., Buenos Aires, ASTREA, 2004.

SAVIGNY, Friedrich Carl von, System des heutigen römischen Rechts (1840 a 1849), trat. it. de V. Scialoja, Sistema del diritto romano atuale, v. 3, Torino, UTET, 1900.

SCHAPP, Jan, Einführung in das Bürgeliche Recht (2003), trad. port. de M. G. L. Rurack e K.-P. Rurack, Introdução ao Direito Civil, Porto Alegre, Sergio Antonio Fabris, 2006.

SCHERMI, Aldo, Simulazione e gruppi di società in Giustizia civile, Milano, v. XLVII, Giugno, 1997, pp. 335-350. 
Scognamiglio, Renato, Contributo ala teoria del negozio giuridico, $2^{\mathrm{a}}$ ed. (1969), Napoli, Jovene, 2008.

Scozzafava, Oberdan Tommaso, Il matrimonio simulato nell'ordinamento civile in Rivista di diritto civile, Padova, n. 5, Settembre-Ottobre, 1990, pp. 625-668.

SCHREIBER, Rupert, Logik des Rechts (1962), trad. esp. de E. Valdés, Lógica del Derecho, Fontamara, Ciudad de México, 1991

SEGRÈ, Gino, In materia di simulazione nei negozi giuridici (1924) in Scritti giuridici, v. I, Arezzo, Cortona, 1930, pp. 422-434.

Serpa Lopes, Miguel Maria de, Curso de Direito Civil, v. I - Introdução, Parte Geral e Teoria dos Negócios Jurídicos, $8^{\text {a }}$ ed., Rio de Janeiro, Freitas Bastos, s.d.

SERICK, Rolf, Rechtsform und Realität juristischer Personen - Eins rechtsvergleichender Beitrag zur Frage des Durchgriffs auf die Personen oder Gegestände hinter der juristischen Person (1955), trad. it. de M. Vitale, Forma e realtà della persona giuridica, Milano, Giuffrè, 1966.

Silva Pereira, Caio Mário da, Instituições de Direito Civil, v.1 - Introdução ao Direito Civil e Teoria Geral de Direito Civil, atual. por M. C. Bodin Moraes, 25 a ed., Rio de Janeiro, Forense, 2012.

SoAres, Teresa Luso, A Conversão do Negócio Jurídico, Coimbra, Almedina, 1986.

Stolfi, Giuseppe, Teoria del negozio giuridico, 1947, trad. esp. de Jaime Santos Briz, Teoria del Negocio Jurídico, Madrid, Revista de Derecho Privado, 1959.

Sztajn, Rachel, Sobre a Desconsideração da Personalidade Jurídica in Revista dos Tribunais 762, São Paulo, 1999, pp. 81 ss.

Theodoro Júnior, Humberto, Comentários ao Novo Código Civil, v. III, t. I (arts. 138 a 184), $4^{\mathrm{a}}$ ed., Rio de Janeiro, Forense, 2008.

, O Contrato e sua Função Social, $3^{\mathrm{a}}$ ed., Rio de Janeiro, Forense, 2008, pp.

$73 \mathrm{ss}$

TôRres, Heleno Taveira, Simulação de Atos e Negócios Jurídicos - Pactos Simulatório e Causa do Negócio Jurídico in JunqueIra De AzEVEdo, Antônio, TôRres, Heleno Taveira, Carbone, Paolo (coords.), Princípios do Novo Código Civil Brasileiro e Outros Temas Homenagem a Tullio Ascarelli, 2a ed., São Paulo, Quartier Latin, 2010, pp. 283-354.

TRABUCCHI, Alberto, Istituzioni di diritto civile, 8 ed., Padova, CEDAM, 1954.

VAlEnte, Arnaldo, Nuovi profili della simulazione e della fiducia - Contributo ad un superamento della crisi della simulazione, Milano, Giuffrè, 1961. 
Veloso, Zeno, Invalidade do Negócio Jurídico - Nulidade e Anulabilidade, $2^{\mathrm{a}}$ ed., Belo Horizonte, Del Rey, 2005.

Villaça Azevedo, Álvaro, Teoria Geral do Direito Civil - Parte Geral, São Paulo, Atlas, 2012.

Von TuHr, Andreas, Der allgemeine Teil des deutschen bürgerlichen Rechts, trad. esp. de T. Ravà, Derecho Civil - Teoria General del Derecho Civil Aleman (1910-1918), v. II Los Hechos Jurídicos, Madrid, Marcial Pons, 2005.

WIEACKer, Franz, Privatrechtsgeschchte der Neuzeit Unter Besonderer Berücksichtigung der Deutschen Entwicklung, 1967, trad. port. de A. Botelho Hespanha, História do Direito Privado Moderno, 4a ed., Lisboa, Calouste Gulbenkian, 2010. 